\author{
UNIVERSIDADE DE SÃO PAULO \\ FACULDADE DE FILOSOFIA LETRAS E CIÊNCIAS HUMANAS \\ DEPARTAMENTO DE GEOGRAFIA
}

\author{
Matheus Hoffmann Pfrimer
}

\title{
A GUERRA DA ÁGUA EM COCHABAMBA, BOLÍVIA: desmistificando os conflitos por água à luz da geopolítica
}

São Paulo 
UNIVERSIDADE DE SÃO PAULO

FACULDADE DE FILOSOFIA LETRAS E CIÊNCIAS HUMANAS

DEPARTAMENTO DE GEOGRAFIA

Matheus Hoffmann Pfrimer

\title{
A GUERRA DA ÁGUA EM COCHABAMBA, BOLÍVIA: desmistificando os conflitos por água à luz da geopolítica
}

\begin{abstract}
Tese apresentada ao Programa de PósGraduação em Geografia como parte dos requisitos para a obtenção do título de Doutor em Ciências pelo Departamento de Geografia da Faculdade de Filosofia, Letras e Ciências Humanas da Universidade de São Paulo. Área de Concentração: Geografia Humana.
\end{abstract}

Orientador: Prof. Dr. André Roberto Martin

São Paulo 


\section{Matheus Hoffmann Pfrimer}

\section{A GUERRA DA ÁGUA EM COCHABAMBA, BOLÍVIA: desmistificando os conflitos por água à luz da geopolítica}

Tese apresentada ao Programa de Pós-Graduação em Geografia como parte dos requisitos para a obtenção do título de Doutor em Ciências pelo Departamento de Geografia da Faculdade de Filosofia, Letras e Ciências Humanas da Universidade de São Paulo. Área de Concentração: Geografia Humana.

São Paulo

BANCA EXAMINADORA 
À minha esposa, Linda, e aos meus filhos, Luca e Luigi, que me mostraram a alegria que a vida pode nos oferecer. 


\section{Agradecimentos}

Essa tese não teria se concretizado sem a participação de inúmeras pessoas que estiveram sempre presentes durante essa longa caminhada. Mais do que um trabalho individual, esse trabalho se transmutou ao contar com inúmeras "mãos amigas". Assim, quero registrar meus agradecimentos especiais:

- A todos os cochabambinos e cochabambinas, bolivianos e bolivianas que direta ou indiretamente, participaram deste estudo, e que, sobretudo, me ensinaram a simplicidade da vida.

- À Profa. Amalia Inés Geraiges de Lemos, pela orientação e conselhos no início desta pesquisa.

- Aos centros de pesquisa bolivianos CERES e CEDIB, pela atenção e ajuda no fornecimento de dados.

- À CAPES pela bolsa de estudo

- Aos meus colegas Fernando, Eduardo e Antônio Marcos, pelos momentos de discussões e debates sobre este assunto tão instigantes que é a geopolítica.

- À tia Dalva e às irmãs Elizete, Janete, Cananea e Angélica, que me acompanharam durante as atividades do trabalho de campo na nossa querida Llajta. Sem a dedicação e o apoio de vocês, a Bolívia teria sido para mim apenas mais um país entre tantos.

- À Suzana e ao Binho, pelo trabalho desbravador de revisão, comentários e organização deste trabalho. Mais do que isso, vocês são uma lição de vida, de companheirismo, de amizade e de união. 
- À Profa. Rosa Ester Rossini, pela ajuda nos momentos difíceis. A gênese dessa pesquisa pode ser atribuída à sua persistência, assim como ao seu trabalho pioneiro na geografia.

- Ao meu orientador, Prof. André Martin, não apenas pelos conselhos e discussões, mas sobretudo por acreditar em mim e pelo companheirismo nessa caminhada. Mais do que orientador e orientando, hoje somos amigos. Espero algum dia poder retribuir o seu apoio.

- Aos meus cunhados, Roger e Álvaro, e à minha sogra, Julieta, pela convivência e ajuda monumental prestada, desde que nos conhecemos e, particularmente, durante os 4 anos desta pesquisa.

- Aos meus pais, Amadeus e Araci, e aos meus irmãos, Pollyanna e André, pelo apoio incondicional e presença nos momentos mais cruciais da minha vida. Sem o carinho e a atenção de vocês, tudo teria sido muito mais difícil.

- À minha esposa Linda, por compartilhar comigo as dificuldades e me proporcionar tantos momentos felizes. Te agradeço não apenas pela ajuda prestada durante a tese, mas por tudo o que você já fez por mim.

- $\quad$ Aos meus filhos, Luca e Luigi, que trazem a certeza de que nada na vida é em vão. Vocês são a prova mais certa de que tudo de mais belo na vida está nas coisas mais simples e singelas. Agradeço a cooperação de vocês dois e pelos momentos de carinho.

- A Deus, pelo privilégio de viver a vida e de aprender as suas mais belas lições. 


\section{RESUMO}

PFRIMER, Matheus Hoffmann. A Guerra da Água em Cochabamba, Bolívia: desmistificando os conflitos por água à luz da geopolítica. 2009. xxx f. Tese (Doutorado em Geografia Humana)-Faculdade de Filosofia, Letras e Ciências Humanas, Universidade de São Paulo, São Paulo, 2009.

A geopolítica vem apresentando várias contribuições ao estudo da relação entre recursos naturais e conflito. Entre esses recursos, a água é um dos que mais vem sendo apontado como suscetível de desencadear conflitos. Na visão geopolítica, a relação entre tensões e recursos hídricos é estruturada a partir da multicausalidade, e, portanto, há inúmeros fatores de diferentes escalas geográficas que se coadunam com a gestão dos recursos hídricos engendrando conflitos. Nesse contexto, a Guerra da Água, em Cochabamba, Bolívia, constitui um evento bastante estudado pela comunidade acadêmica, sendo retratado como a vitória da sociedade civil local sobre a empresa multinacional Aguas del Tunari, responsável pelo abastecimento de água naquela cidade boliviana. Entretanto, outros fatores nas escalas nacional, sulamericana e global influenciaram a deflagração das tensões, tendo seus efeitos repercutido em escalas mais amplas que apenas a local. No presente estudo, visamos avaliar a atuação das diferentes territorialidades na área metropolitana de Cochabamba, bem como os fatores estruturantes e estruturados desse conflito nos âmbitos nacional, sul-americano e global. Esta pesquisa consistiu em um estudo de caso de características analítica, descritiva e qualitativa. A pesquisa analítica se desenvolveu a partir de três dimensões: 1) a caracterização do objeto de pesquisa; 2) a dimensão espacial; 3) a dimensão temporal. O processo descritivo baseou-se em entrevistas com os líderes dos movimentos sociais atuantes durante a Guerra da Água, além de abranger estudos avaliativos de documentos, dados estatísticos e bibliográficos. Já o caráter qualitativo desenvolveu-se por meio da coleta de dados e observação longa e extensiva in loco. Concluímos que a caracterização da Guerra da Água apenas como um conflito relacionado aos recursos hídricos é incompleta e reducionista, já que diferentes tensões de várias escalas se materializam na região.

Palavras-chave: Geopolítica. Segurança ambiental. Guerra da Água. Cochabamba. 


\section{ABSTRACT}

PFRIMER, Matheus Hoffmann. The Water War in Cochabamba, Bolivia: demystifying the conflicts related to water resources through geopolitics. 2009. xxx f. Thesis (Doctoral in Human Geography)-Faculdade de Filosofia, Letras e Ciências Humanas, Universidade de São Paulo, São Paulo, 2009.

Geopolitics has presented many contributions to study the relation between natural resources and conflicts. Among these resources, water has been pointed out as the most susceptible to motivate conflicts. According to the geopolitical perspective, the relationship between tensions and water resources is structured on the multicausality, and, therefore, there are countless factors from different scales that together with the management of water resources can engender conflicts. In this context, the Water War in Cochabamba, Bolivia, is an event which is highly investigated by the academic community and is portrayed as the victory of local civil society over the multinational company Aguas del Tunari, responsible for the water supply in that Bolivian city. However, other agents in the national, south-American, and global spheres influenced the factors that triggered tensions and had their effects reflecting on broader scales than the local one. In the present study, we aimed to evaluate the action of different territorialities in the metropolitan area of Cochabamba, as well as the structuring and structured factors of the Water War in the national, south-American, and global spheres. This research consisted of a case study with analytical, descriptive, and qualitative characteristics. The analytical research was developed taking into account three dimensions: 1) the characterization of the research object; 2) the spatial dimension; 3) the temporal dimension. The descriptive process was based on interviews with the social movements' leaders that acted during the Water War, and also included the evaluation of documents, statistical and bibliographic data. The qualitative characteristic of this study was developed by means of data collection and long and extensive observations in loco. After analyzing the facts, data, and context of the Water War, we concluded that the characterizing this conflict as related only to water resources is incomplete and reductionist, since different tensions of many scales influence that region.

Key words: Geopolitics. Environmental security. Water War. Cochabamba. 


\section{RESUMEN}

PFRIMER, Matheus Hoffmann. La Guerra del Agua en Cochabamba, Bolivia: desmitificando los conflictos por los recursos hídricos en la luz de la geopolítica. 2009. xxx f. Tese (Doutorado em Geografia Humana)-Faculdade de Filosofia, Letras e Ciências Humanas, Universidade de São Paulo, São Paulo, 2009.

La geopolítica presenta diversas contribuciones al estudio de la relación entre los recursos naturales y los conflictos, entre estos recursos, el agua es uno de los más mencionados como probables para desencadenar conflictos. De acuerdo con la visión de la geopolítica, la relación entre las tensiones y los recursos hídricos es estructurada desde la multi-causalidad, y por lo tanto, existen muchos factores de diferentes escalas geográficas que juntamente con la gestión de los recursos hídricos son generadores de conflictos. En este contexto, la Guerra del Agua en Cochabamba, Bolivia, es un acontecimiento muy investigado por la comunidad académica, siendo presentada como la victoria de la sociedad civil local sobre la multinacional Aguas del Tunari, responsable por el abastecimiento del agua en esa ciudad. Sin embargo, otros factores en la escala nacional, sudamericana y global determinaran el comienzo de las tensiones, y sus efectos afectaran escalas más amplias que sólo la local. En el presente estudio pretendemos evaluar el desempeño de diferentes territorialidades en el área metropolitana de Cochabamba, así como los factores estructurantes y estructurados de ese conflicto a nivel nacional, sudamericano y mundial. Esta investigación consistió en un estudio de caso con características analítica, descriptiva y cualitativa. El estudio analítico ha desarrollado a partir de tres dimensiones: 1) caracterización del objeto de la investigación, 2) la dimensión espacial, 3) la dimensión temporal. El proceso descriptivo se basó en entrevistas con los líderes de los movimientos sociales actuantes durante la Guerra del Agua, e incluye también estudios de evaluación de documentos, datos estadísticos y bibliográficos. El carácter cualitativo se desarrolla a través de la recopilación de datos y una larga y extensa observación in loco. Se concluye que la caracterización de la guerra del agua sólo como un conflicto relacionado con los recursos hídricos es incompleta y reduccionista, ya que diferentes tensiones de diferentes escalas se manifestaran en la región.

Palabras clave: Geopolítica sudamericana. Seguridad ambiental. Guerra del Agua. Cochabamba. 


\section{LISTA DE ESQUEMAS}

Esquema 1. Matriz de análise fatorial entre as variáveis dependente (ocorrência de conflito) e independente (existência de escassez), de acordo com Homer-Dixon.

Esquema 2. As duas fases do processo causal de um conflito ambiental de acordo com Homer-Dixon.

Esquema 3. Teoria das relações causais entre escassez ambiental e conflitos violentos de acordo com Homer-Dixon.

Esquema 4. Relação entre fatores inibidores e desencadeadores de conflitos de acordo com o modelo do ENCOP.

Esquema 5. Modelo relacionando mudanças ambientais e falência do Estado de acordo com State Failure Task Force (SFTF).

Esquema 6. Relação entre pressão ambiental e segurança nacional de acordo com o modelo da OTAN.

Esquema 7. O efeito duplo da democracia sobre os conflitos.

Esquema 8. Perfil básico do relevo do Departamento de Cochabamba. ..... 188

Esquema 9. Complementaridade climática no Departamento de Cochabamba.

Esquema 10. Circulação aproximada dos ventos provenientes da vertente norte no Vale Central de Cochabamba.

Esquema 11. Situação hidrogeológica do Vale Central de Cochabamba. .....

Esquema 12. Terras comunitárias de origem no Vale Central de Cochabamba antes de 1825.

Esquema 13. Estrutura institucional do Estado boliviano após as reformas estruturais de 1994.

Esquema 14. Rede de movimentos sociais ligados à Coordinadora del Agua. 


\section{LISTA DE FOTOGRAFIAS}

Fotografia 1. Imagem de satélite do Vale Central de Cochabamba com sobreposição da área da bacia hidrográfica do rio Rocha.

Fotografia 2. Expansão da área urbana no Vale Central de Cochabamba, no período entre 1962 e 2000.

Fotografia 3. Principais fontes e objetos técnicos utilizados na captação de água pelo SEMAPA.

Fotografia 4. Infraestrutura do Projeto Múltiplo Misicuni para o Vale Central de Cochabamba e suas três fases.

Fotografia 5. Infraestrutura existente e planejada para a implantação do Projeto Corani. 


\section{LISTA DE GRÁFICOS}

Gráfico 1. Síntese das sociedades propensas a entrar em colapso: benefícios reduzidos para alto nível de complexidade.

Gráfico 2. Distribuição pluviométrica mensal nas quatro regiões fisiográficas do Departamento de Cochabamba de 1961 a 2003.

Gráfico 3. Comparação da população total do município de Cercado, na região metropolitana de Cochabamba, e do Departamento de Cochabamba durante o período entre 1900 e 2001.

Gráfico 4. Taxa de desemprego da PEA na Bolívia no período entre 1990 e 1999.

Gráfico 5. Média do preço para o consumo de $10 \mathrm{~m} 3$ nos três maiores centros urbanos bolivianos entre 1992 e 2000.

Gráfico 6. Média do número de conflitos por mês para cada governo da Bolívia no período entre 1994 e 2005.

Gráfico 7. Formas de adesão a conflitos na Bolívia no período entre 1994 e 2005.

Gráfico 8. Principais motivos para o desencadeamento de conflitos na Bolívia no período entre 1994 e 2005.

Gráfico 9. Ocorrência de conflitos sociolaborais na Bolívia no período entre 1994 e 2005. 


\section{LISTA DE MAPAS}

Mapa 1. Relevo do Departamento de Cochabamba. .................................. 183

Mapa 2. Bolívia no contexto fisiográfico sul-americano. .............................. 184

Mapa 3 Cobertura vegetal do Departamento de Cochabamba. .................. 186

Mapa 4. Distribuição espacial da taxa pluviométrica para os períodos entre 1961 e 1990 (à esquerda) e entre 1998 e 2003 (à direita) no Departamento de Cochabamba.

Mapa 5. Uso do solo na bacia hidrográfica do rio Rocha no Vale Central de Cochabamba.

Mapa 6. Bacia hidrográfica do rio Rocha no Vale Central de Cochabamba. .. 193

Mapa 7. Densidade demográfica da região metropolitana de Cochabamba em 2001.

Mapa 8. Região metropolitana de Cochabamba: complexos industriais e localização das indústrias.

Mapa 9. Indivíduos do município de Cercado, região metropolitana de Cochabamba, que se autoidentificam com alguma etnia indígena, de acordo com as zonas de recenseamento em 2001.

Mapa 10. Indivíduos do município de Cercado, região metropolitana de Cochabamba, que se autoidentificam com a etnia quéchua, de acordo com as zonas de recenseamento em 2001.

Mapa 11. Indivíduos do município de Cercado, região metropolitana de Cochabamba, que se autoidentificam com a etnia aymara, de acordo com as zonas de recenseamento em 2001.

Mapa 12. Indivíduos do município de Cercado, região metropolitana de Cochabamba, que não se autoidentificam com qualquer etnia indígena, de acordo com as zonas de recenseamento em 2001.....

Mapa 13. Expectativa de vida ao nascer (anos) nos diferentes distritos municipais do município de Cercado, região metropolitana de Cochabamba, em 2000.

Mapa 14. Taxa de alfabetização (\%) nos diferentes distritos municipais do município de Cercado, região metropolitana de Cochabamba, em 2000. 
Mapa 15. Distribuição dos recursos provenientes dos mecanismos de coparticipação popular (\%) nos diferentes distritos municipais do município de Cercado, região metropolitana de Cochabamba, em 2000.

Mapa 16. População pobre (\%) nos diferentes distritos municipais do município de Cercado, região metropolitana de Cochabamba, em 2000.

Mapa 17. Habitações abastecidas com água proveniente de caminhões-pipa (\%), de acordo com as zonas de recenseamento, nos diferentes distritos municipais do município de Cercado, região metropolitana de Cochabamba, em 2000.

Mapa 18. Habitações abastecidas com água pela rede do SEMAPA (\%), de acordo com as zonas de recenseamento, nos diferentes distritos municipais do município de Cercado, região metropolitana de Cochabamba, em 2000

Mapa 19. Habitações abastecidas com água proveniente de rio, lago ou vertente (\%), de acordo com as zonas de recenseamento, nos diferentes distritos municipais do município de Cercado, região metropolitana de Cochabamba, em 2000.

Mapa 20. Habitações abastecidas com água proveniente de poço (\%), de acordo com as zonas de recenseamento, nos diferentes distritos municipais do município de Cercado, região metropolitana de Cochabamba, em 2000.

Mapa 21. Habitações não servidas pela rede de energia elétrica (\%), de acordo com as zonas de recenseamento, nos diferentes distritos municipais do município de Cercado, região metropolitana de Cochabamba, em 2000.

Mapa 22. Habitações não servidas pela rede de esgoto (\%), de acordo com as zonas de recenseamento, nos diferentes distritos municipais do município de Cercado, região metropolitana de Cochabamba, em 2000. 
Mapa 23. Habitações sem banheiro ou latrina (\%), de acordo com as zonas de recenseamento, nos diferentes distritos municipais do município de Cercado, região metropolitana de Cochabamba, em 2000.

Mapa 24. Habitações não servidas pela rede de água do SEMAPA (\%), de acordo com as zonas de recenseamento, nos diferentes distritos municipais do município de Cercado, região metropolitana de Cochabamba, em 2000.

Mapa 25. Qualidade dos serviços básicos, de acordo com as zonas de recenseamento, na região metropolitana de Cochabamba, em 2003.

Mapa 26. Distribuição espacial da clientela de Aguas del Tunari no município de Cercado, de acordo com categorias de tarifação.

Mapa 27. Município de Cercado, região metropolitana de Cochabamba, rede de abastecimento de água potável do SEMAPA em 2003.

Mapa 28. Município de Cercado, região metropolitana de Cochabamba, número de medidores de água segundo ciclos em 2003.

Mapa 29. Município de Cercado, região metropolitana de Cochabamba, número de medidores de água segundo ciclos em 2004.

Mapa 30. Município de Cercado, região metropolitana de Cochabamba, número de habitações servida pela rede Semapa de abastecimento de água potável em 2001.

Mapa 31. Município de Cercado, região metropolitana de Cochabamba, frequência da distribuição de água pela rede de abastecimento do SEMAPA segundo zonas de recenseamento em 2006. 


\section{LISTA DE QUADROS}

Quadro 1. Estudos sobre a Guerra da Água e suas abordagens metodológicas a partir das dimensões temporal e espacial utilizadas até o momento atual.

Quadro 2. Pessoas entrevistadas, sua conexão com o conflito da água em Cochabamba e tópico principal abordado durante as entrevistas, realizadas entre os dias 15 e 30 de janeiro de 2006 .

Quadro 3. Relação entre a distribuição geográfica do recurso e a natureza do conflito, de acordo com Le Billon.

Quadro 4. Pesquisas quantitativas sobre recursos naturais e guerras civis. .. 103

Quadro 5. Natureza das territorialidades na região metropolitana de Cochabamba.

Quadro 6. Polarização política em torno dos dois representantes da Sociedade Civil durante a Guerra da Água. 


\section{LISTA DE TABELAS}

Tabela 1. Probabilidade de ocorrência de guerras civis quando fatores de risco são acrescentados (período entre 1980 e 1992).

Tabela 2. Probabilidade de ocorrência de conflitos armados quando fatores de risco são acrescentados (período entre 1980 e 1992).

Tabela 3. Produção média de água a partir de neblina em quatro países diferentes.

Tabela 4. Comparação do consumo médio de água virtual para produzir algumas commodities em países desenvolvidos e nos países do BRIC.

Tabela 5. Propriedades privadas no Vale Central de Cochabamba e de Sacaba em quatro décadas.

Tabela 6. População urbana e rural em vários municípios da região metropolitana de Cochabamba em 1992 e 2001.

Tabela 7. Composição do PIB de acordo com a atividade econômica, no Departamento de Cochabamba, Bolívia, entre 1965 e 2007.

Tabela 8. PEA por setor de atividade nos municípios da região metropolitana de Cochabamba em 1992 e 2001.

Tabela 9. Investimentos públicos da Lei no 2.235 (BOLIVIA, 2001) e da Lei no 1.551 (BOLIVIA, 1994c) na região metropolitana de Cochabamba em 2002.

Tabela 10. Distribuição de recursos dos investimentos municipais (em \%) por setor entre 1996 e 2000.

Tabela 11. Oferta líquida de água potável de diferentes fontes para o município de Cercado entre 1825 e 1950.

Tabela 12. Poços perfurados pelo SEMAPA no Vale Central de Cochabamba entre 1979 e 1992.

Tabela 13. Síntese dos principais investimentos internacionais no SEMAPA entre 1970 e 1992.

Tabela 14. Produção das principais fontes de água utilizadas pelo SEMAPA em 2001. 
Tabela 15. Comparação dos indicadores econômicos, sociais e técnicos do serviço de abastecimento de água em diferentes categorias de habitações no município de Cercado em 1996.

Tabela 16. Comparação entre o Projeto Múltiplo Misicuni e o Projeto Corani. 258

Tabela 17. Comparação entre o Projeto Múltiplo Misicuni original e o Projeto "Misicunito".

Tabela 18. Tarifação pelo serviço de abastecimento de água e esgoto no município de Cercado, de acordo com categorias de tarifação. .....

Tabela 19. Comparação entre a Rede do SEMAPA, poços comunitários e distribuidores de água (aguateros) em 2004.

Tabela 20. Distribuição populacional na Bolívia de acordo com regiões ecológicas, áreas e regiões metropolitanas de residência no período entre 1900 e 2001.

Tabela 21. População migrante interdepartamental e taxa de migração líquida, de acordo com o departamento de residência habitual, no período entre 1997 e 2001.

Tabela 22. Preço do lance de compra das maiores empresas bolivianas capitalizadas por setor de atividade.

Tabela 23. Comparação entre o desempenho das empresas SAMAPA em 1997 e Aguas del Illimani (AISA) em 2003.

Tabela 24. Comparação da expansão do serviço de abastecimento de água nas três maiores regiões metropolitana da Bolívia por quintilhos. ..

Tabela 25. Síntese das categorias tarifárias e volume de água consumido em La Paz, durante a gestão de AISA, no período entre 1997 e 2001. 


\section{LISTA DE ABREVIATURAS E SIGLAS}

Asicasur Asociación de Sistemas Comunitarios de la Zona Sur, Associação de Sistemas Comunitários da Zona Sul

BID Banco Interamericano de Desenvolvimento

BRIC Brasil, Rússia, Índia e China, formando um grupo de países em desenvolvimento

CAF Corporación Andina de Fomento, Corporação Andina de Fomento

CAN Comunidad Andina de Naciones, Comunidade Andina de Nações

CEDIB Centro de Documentación e Información Bolivia, Centro de Documentação e Informação Bolívia

CERES Centro de Estudios de la Realidad Económica y Social, Centro de Estudos da Realidade Econômica e Social

CIADI Centro Internacional para Arbitragem de Disputas sobre Investimentos

CIPCA Centro de Investigación y Promoción del Campesinado, Centro de Investigação e Promoção do Campesinato

CNUMAD Conferência da Organização das Nações Unidas sobre Meio Ambiente e Desenvolvimento

COB Central Obrera Boliviana, Central de Trabalhadores Boliviana

CODAEP Comité de Defensa del Agua y la Economía, Comitê de Defesa da Água e da Economia

COMIBOL Corporación Minera de Bolivia, Corporação Mineira da Bolívia

CONDESAN Consorcio para el Desarrollo Sostenible de la Ecorregión Andina, Consórcio para o Desenvolvimento Sustentável da Ecoregião Andina

DEA Drug Enforcement Administration, Força Administrativa de Narcóticos

ENCOP Environment and Conflicts Project, Projeto Ambiente e Conflitos

FEDECOR Federación Departamental Cochabambina de Organizaciones de Regantes, Federação Departamental Cochabambina de Organizações de Irrigadores

FOCOMADE Fórum Cochabambino del Médio Ambiente y Desarrollo, Fórum Cochabambino do Meio Ambiente e Desenvolvimento

FONPLATA Fondo Financiero para el Desarrollo de la Cuenca del Plata, Fundo Financeiro para o Desenvolvimento da Bacia do Prata 
FTC Fuerza de Tarea Conjunta, Força Tarefa Conjunta

GASBOL Gasoduto Brasil-Bolívia

IBT Increasing Block Tariff, tarifa que aumenta por bloco de consumidores

IBTA Instituto Boliviano de Tecnologia Agropecuaria, Instituto Boliviano de Tecnologia Agropecuária

ICSID International Center for Settlement of Investment Disputes, Centro Internacional para Arbitragem de Disputas sobre Investimentos CIADI

IDH Índice de Desenvolvimento Humano

IIRSA Iniciativa para la Integración de la Infraestructura Regional Suramericana, Iniciativa para a Integração da Infraestrutura Regional Sul-americana

INE Instituto Nacional de Estadísticas, Instituto Nacional de Estatística

IPCC Intergovernmental Panel on Climate Change, Comitê Intergovernamental sobre Mudanças Climáticas

LPP Ley de Participación Popular, Lei de Participação Popular

MDSMA Ministério do Desenvolvimento Sustentável e Meio Ambiente

MNR Movimiento Nacionalista Revolucionário, Movimento Nacionalista Revolucionário

NATO North Atlantic Treaty Organization, Organização do Tratado do Atlântico Norte - OTAN

ONG organização não-governamental

OTAN Organização do Tratado do Atlântico Norte

OTB Organización Territorial de Base, Organização Territorial de Base

PEA População economicamente ativa

PIB Produto interno bruto

PRIO Peace Research Institute of Oslo, Instituto de Pesquisa da Paz de Oslo

PRODES Proyecto de Desarrollo Chapare-Yungas, Projeto de Desenvolvimento Chapare-Yungas

SEMAPA Servicio Municipal de Agua Potable y Alcantarillado, Serviço Municipal de Água Potável e Rede de Esgotos

SFTF State Failure Task Force, Força de Trabalho sobre a Falência Estatal 
SIG Sistema de Informações Geográficas

SIRESE Ley del Sistema de Regulación Sectorial, Lei do Sistema de Regulação Setorial

UMOPAR Unidad Móvil de Patrullaje Rural, Unidade Móvel para o Patrulhamento Rural

USAID United States Agency for International Development, Agência Norteamericana para o Desenvolvimento Internacional

USEPA U. S. Environmental Protection Agency Agência de Proteção Ambiental Norte-americana

VIDA Red Vigilancia Interamericana para la Defensa y Derecho al Agua, Rede de Vigilância Interamericana para a Defesa e Direito à Água 


\section{SUMÁRIO}

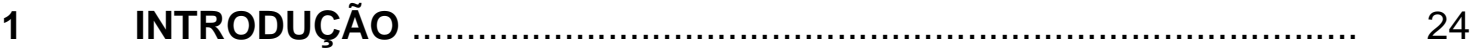

2 A HIDRA DE LERNA: QUANDO CORTES E RECORTES EPISTEMOLÓGICOS NÃO RESOLVEM A QUESTÃO ...................... 30

2.1 Geografia: a mãe muitas vezes esquecida pelos "estudos ambientais"

2.2 "Ambientalização" dos conflitos sociais ou "socialização" dos conflitos: por uma ontologia do confronto de territorialidades ....... 56

2.3 Escalas, temporalidades e conceitos: refletindo sobre o curso a ser navegado

3 INDRA: DEUS DA GUERRA OU DA ÁGUA?

3.1 Histórico dos estudos sobre a relação entre conflitos sociais e recursos naturais

3.1.1 O primeiro enfoque: conflitos violentos - escassez ou abundância de recursos naturais?

3.1.2 O segundo enfoque: revisando conflitos por meio da história das sociedades e do meio ambiente

3.1.3 O terceiro enfoque: sociologia ambiental - sobrepondo os conflitos sociais aos problemas ambientais?

4 MARTE OU MINERVA: QUANDO A GUERRA DA ÁGUA É MENOS LETAL QUE AS RELAÇÕES DE PODER

4.1 Da guerra da água aos conflitos sociais relacionados a recursos hídricos

4.2 Geopolítica da água: ampliando as concepções do hidrokratos ....

4.3 Por uma geopolítica voltada à instabilidade

5 PACHAMAMA OU CHINA SUPAY: A GUERRA DA ÁGUA COMO VITÓRIA E DERROTA QUE COEXISTEM

5.1 Da segurança cultural e natural ao território do risco

5.2 Vale Central de Cochabamba: o ditado de Tupac Katari se faz presente

5.3 Estrutura e função do Vale de Cochabamba: planificando territórios de risco 
5.4 A LPP e os talleres zonales: segmentando ainda mais territórios já fragmentados

5.5 Histórico das políticas hídricas no Vale Central de Cochabamba ... 237

5.6 Processo e dinâmica dos conflitos: água e polarização territorial . 260

5.6.1 Antecedentes do conflito à luz da instrumentalização dos recursos hídricos para a política

5.6.2 Atores e conflitos: da velha ordem territorial a uma nova ordem territorial

5.6.3 Fases do conflito: a lógica do amigo e inimigo

5.6.4 Consequências pós-guerra da água: ganhou-se a guerra, mas perdeuse a água

6 PACHACUTI E COCHABAMBA: A GUERRA DA ÁGUA E A TRANSMUTAÇÃO DA NAÇÃO BOLIVIANA

6.1 Transformações territoriais na Bolívia: um equilíbrio às avessas ..

6.2 Das novas políticas econômicas à crise: quando o Estado sai de cena

6.3 Guerra da água e política nacional: quando a questão nacional se volta para a regional

6.4 Políticas hídricas na Bolívia: públicas ou privadas?

6.5 Da Guerra da Água à Guerra do Gás: a gota d'água

7 Inkarrí: Cochabamba e as tensões no espaço sul-americano e global

7.1 Cochabamba: entre a contenção e a integração no espaço sulamericano

7.2 Guerra da Água no espaço global: materializando tensões da maior escala na região

7.2.1 A influência norte-americana: Plan Dignidad (Plano Dignidade), recursos naturais e água

7.2.2 Um conflito de redes: empresas transnacionais e movimentos sociais 353

8 ÁGUA PURA OU ABIGARRADA? 
APÊNDICE A Questionário aplicado aos membros da Coordinadora del Agua ................................................ 403

APÊNDICE B Legendas das siglas na tabela que se segue com os resultados do questionário .......................................................... 404

APÊNDICE C Resultados obtidos após aplicação do questionário 405 APÊNDICE D DVD - "La Guerra del Agua" na Bolívia ................ 408 


\section{INTRODUÇÃO}

Desde a Antiguidade, a água tem sido objeto de disputa entre homens, sociedades e civilizações. Por ser um elemento essencial à vida de forma geral, pode ser tanto objeto como sujeito de grandes tensões. Com o desenvolvimento técnico e científico, a relação entre recursos hídricos e conflitos vem se tornando cada vez mais complexa, porquanto, além do próprio fluxo natural, redes de objetos interferem na natureza natural. Assim sendo, cada vez mais, outros fatores passam a exercer influência nessa relação.

Um dos fatores que tem influenciado cada vez mais a relação água-conflito é o território. Em um período no qual a implantação de diferentes objetos técnicos e científicos tem a capacidade de mudar completamente a configuração natural dos lugares, diversos pontos do território tornam-se estratégicos. Então, lugares que originalmente não se conectavam entre si, a partir da implantação da malha hídrica passam a manter profundas relações. Nesse contexto, o controle, a gestão e o uso do território tornam-se instrumentos de poder, influenciando o binômio água-conflito.

Da mesma forma que a relação entre água e conflito se torna ontologicamente mais complexa, o caminho metodológico e lógico para apreendê-la também se configura como intrincado. O seu reflexo sobre a água turva e revolta da contemporaneidade se torna ainda mais distorcido, em uma representação fidedigna da realidade. Em meio a esse contexto instável, a geografia se apresenta como importante instrumento para a reflexão, vez que os conflitos não podem ser mais apreendidos adotando-se apenas uma determinada escala espacial, devendo os pesquisadores se debruçar sobre a temática usando uma lente multidimensional.

Tendo isso em mente, buscamos no presente trabalho apresentar novos conceitos e construtos a serem empregados como ferramentas para compreender esse novo cenário. Porém, em meio a águas revoltas, não se pode descartar completamente os referenciais antigos, pois, sem eles, facilmente se tomaria um norte equivocado. Consequentemente, a geopolítica clássica não pode ser completamente ignorada, como defendem alguns autores mais afoitos. 
Um dos aspectos que incentivou esta pesquisa leva em conta justamente esse argumento, uma vez que a complexidade do momento em que vivemos acaba confundindo muitos intelectuais. Ainda quando cursava uma disciplina como aluno especial de pós-graduação no Departamento de Ciência Política, houve uma ocasião interessante que bem expressa isso. No primeiro dia de aula, o professor pediu aos alunos que se apresentassem e falassem sobre o tema que pretendiam desenvolver em sua dissertação ou tese de pós-graduação. Ao me apresentar como mestre em relações internacionais e afirmar que desejava desenvolver um estudo sobre a Guerra da Água na Bolívia, o professor se espantou e imediatamente me advertiu: "Isso é um conflito regional, que diz muito mais respeito a questões internas do país andino e tem pouco a ver com as relações internacionais. Um exemplo de conflito com o qual as relações internacionais lidam seria o imbróglio entre Brasil e Argentina pela construção de Itaipu". Nesse dia, nada respondi; porém, essa colocação muito me intrigou por um bom tempo. Após longa e cuidadosa ponderação, tornou-se claro que, em boa medida, a geografia, campo por excelência das escalas espaciais, é uma das poucas ciências que pode responder com grande maestria a essa questão.

Mas por que a escolha recaiu sobre a Bolívia? Desde o começo de sua conturbada experiência republicana, aquela nação vem passando por guerras, revoluções, conflitos, crises e rebeliões de toda ordem. Por isso, ela constitui um laboratório social para aqueles que se dedicam a estudar esse assunto, principalmente quando se quer entender a relação entre recursos naturais e conflitos. Outro fator que coaduna os interesses deste estudo com a opção pela Bolívia é o fato de o país andino ser, do ponto de vista geopolítico, um caso à parte. Como concluiu o grande geógrafo Whitlesey (1944, p. 565), a Bolívia é um "país deficiente" (handicapped state), devido às inúmeras pressões de forças políticas dos seus vizinhos. Não obstante, para outros geógrafos, o país andino seria o coração do continente sul-americano, como bem atesta o conceito de "triângulo mágico boliviano" nas teorias do subimperialismo brasileiro e do Plano Alpaca do General Augusto Pinochet. Nessa perspectiva, a Bolívia foi um campo de prova para os postulados geopolíticos e, portanto, muitos de seus aspectos na atualidade são explicáveis a partir do arcabouço dessa disciplina. 
Também devemos destacar a existência de poucos estudos sobre a Bolívia no Brasil, para não citar os livros sobre aquela nação quase em extinção em nossas bibliotecas. Quando muito, se fala em integração sul-americana, pouco se conhecendo acerca dos países com os quais pretendemos formar um ente político supranacional. Destarte, a escolha do país andino como objeto desta pesquisa visou ocupar uma lacuna há muito existente na academia.

Finalmente, não podemos deixar de considerar a pressão política internacional pela qual tem passado a Bolívia em relação aos seus recursos naturais. Inicialmente a prata, depois o estanho, posteriormente o gás, o petróleo e os recursos hídricos, e agora já se colocando em pauta o lítio. Aquele país encontra grandes dificuldades para explorá-los da melhor maneira em seu proveito, em decorrência da falta de tecnologia para exploração e extração dessas riquezas. Daí advém a grande tensão entre conceder a exploração desses recursos a empresas transnacionais ou tentar fazê-lo ineficientemente empregando suas próprias forças. A Guerra da Água não foi uma exceção a esse modelo.

Desde o período colonial, a cidade de Cochabamba vem passando por sucessivas crises de provimento de água potável. Em um primeiro momento, o problema se traduziu por controle e posse dos recursos hídricos. Posteriormente, foram se interpondo a essa situação inicial diversos fatores, como a falta de infraestrutura, a diminuição dos índices pluviométricos, as disputas políticas e a má gestão territorial. Desde então, o abastecimento de água naquela cidade se tornou um caso crônico para a segurança ambiental.

Após a revolução de 1952, o governou do Movimiento Nacionalista Revolucionário (MNR, Movimento Nacionalista Revolucionário) propôs uma série de medidas visando a modernização de Cochabamba como polo geopolítico de expansão para o oriente boliviano. A fixação de diferentes redes de objetos técnicos e a expansão urbana desordenada intensificaram ainda mais a crise, dando origem, na microescala, a uma série de embates entre diversas territorialidades (índios versus criollos, urbano versus rural, Estado versus movimentos sociais), a fim de controlar locais estratégicos do território que facilitassem o acesso aos recursos hídricos.

Embora a questão remonte a séculos anteriores, os microconflitos relacionados aos recursos hídricos tiveram pouca repercussão além da escala local 
antes da Guerra da Água. Porém, sedimentos sociais (políticos, culturais, jurídicos, entre outros) foram se decantando, juntamente com a temática da água, ao longo desse período, formando uma espessa camada no imaginário popular. Todavia, assim que o problema da água veio à tona novamente com maior intensidade, durante a Guerra da Água, logo se determinou que os recursos hídricos deveriam ser tratados como prioritários no rol dos conflitos. Contudo, aquela camada recôndita de sedimentos sociais, que se acumulou ao longo de tanto tempo no fundo do imaginário social, ficou completamente em suspensão pelo turbilhão provocado nas águas revoltas do conflito, tendo sido poucos os analistas que conseguiram visualizar a matéria em sua forma mais complexa. Rapidamente, muitos acharam os culpados: Foi a água! Foi a privatização da gestão da água! Foi a atuação da empresa transnacional Águas del Tunari!

O contexto no qual o conflito em torno dos recursos hídricos se insere acaba sendo negligenciado. A contingência da água já era um problema antigo em Cochabamba. Naturalmente, novos fatos vieram acentuar o que já era, por si só, questão de grande monta, como a privatização da empresa municipal de abastecimento de água e o aumento das tarifas de água. No entanto, na maioria das vezes, o contexto histórico no qual se insere a Guerra da Água passa despercebido: graves crises política e econômica que coincidiram com o período do conflito.

A maioria das investigações sobre a Guerra da Água leva em conta apenas a água propriamente dita, se esquecendo de uma série de outros aspectos, escalas e atores que intervieram no conflito. Correntemente, se caracteriza a Guerra da Água como o confronto entre a sociedade civil local e a empresa multinacional Aguas del Tunari, fazendo-se referência à batalha entre Davi e Golias. A partir desse foco, o conflito se tornou um ícone no discurso altermundialista. Entretanto, muitos deixam de levar em consideração o fato de que, mesmo após a "vitória popular" contra a gigante transnacional, a cidade de Cochabamba continuou enfrentando grave déficit hídrico. Assim, alguns autores chegaram a afirmar que a "pseudovitória" trouxe implicações negativas para as áreas mais pobres da cidade. Portanto, no percurso para a consecução do presente trabalho houve necessidade de confrontar as duas visões: Guerra da Água ou contra a água?

Diante desse cenário, diferentes questionamentos vêm à tona: De que forma a geopolítica e a noção de segurança poderiam contribuir para a melhor 
compreensão da Guerra da Água? Como o embate entre as diferentes territorialidades teria influenciado o conflito? A Guerra da Água teria sido um conflito pela privatização da companhia de abastecimento de água e esgoto em Cochabamba ou outras causas mais profundas estariam ocultas nessa primeira causa? Quais são os fatores geopolíticos estruturantes e estruturados da Guerra da Água na região metropolitana de Cochabamba, na Bolívia, no espaço nacional, na esfera sul-americana e no âmbito global?

Visando responder a todos esses questionamentos, neste trabalho avaliam-se a atuação das diferentes territorialidades na área metropolitana de Cochabamba e, a partir disto, a conformação de diferentes arranjos territoriais, os quais implicam a materialização do poder sobre o espaço. Ademais, investigam-se os fatores estruturantes e estruturados do conflito nos espaços nacional e sul-americano, vez que este embate não pode ser totalmente compreendido apenas levando em conta a escala da região, porquanto fatores das escalas maiores fizeram refletir seus efeitos na escala regional.

Didaticamente, esta pesquisa pode ser dividida em duas partes. A primeira, diz respeito a discussões teóricas e ontológicas acerca do trabalho efetuado, englobando os itens 2, 3 e 4 . A segunda parte refere-se diretamente às reflexões sobre a Guerra da Água, as quais são desenvolvidas nos tópicos 5, 6 e 7.

No item 2, intitulado A Hidra de Lerna: quando cortes e recortes epistemológicos não resolvem a questão, traçamos as diretrizes teóricometodológicas e os questionamentos que um fenômeno tão complexo requer para que não nos percamos em divagações ao longo do caminho.

O tópico 3, denominado Indra: deus da guerra ou da água?, traz reflexões a respeito da relação entre recursos naturais e conflitos a partir dos novos paradigmas que vieram à tona após o fim da Guerra Fria, levando-se em conta as suas implicações para a área ambiental. Adicionalmente, apresentam-se as contribuições que a geopolítica pode oferecer a essa discussão.

O tópico 4, chamado Marte ou Minerva: quando a guerra da água é menos letal que as relações de poder, se caracteriza pela construção de um arcabouço teórico relacionando conflito, território e recursos hídricos. Assim sendo, apresentamos os principais enfoques dos estudos sobre conflito relacionados a 
recursos hídricos, demonstrando a importância de se refletir sobre os arranjos territoriais quando se deseja compreender a dinâmica de conflitos e suas consequências para a segurança.

No item 5, denominado Pachamama ou China Supay: a Guerra da Água como vitória e derrota que coexistem, apresentamos 0 arranjo territorial conformado pela ação das territorialidades na região metropolitana de Cochabamba e suas implicações para a materialização do poder e da dinâmica do conflito na escala regional. Para tanto, buscamos os elementos estruturantes e estruturados do conflito de modo a diferenciar os fatores ativadores dos elementos de fundo da dinâmica conflitiva.

A dimensão multiescalar passou, então, a ser desenvolvida ao longo do tópico 6, intitulado Pachacuti e Cochabamba: a Guerra da Água e a transmutação da nação boliviana, e do tópico 7, chamado Inkarrí: Cochabamba e as tensões no espaço sul-americano e global, de forma a unir diferentes fatores das escalas maiores (nacional, sul-americana e global) que se materializam na região metropolitana de Cochabamba, juntamente com as questões locais. Da mesma maneira, a escala temporal (estrutura e conjuntura) foi construída visando apresentar os diferentes matizes que compõem esse conflito. 


\section{A HIDRA DE LERNA: QUANDO CORTES E RECORTES EPISTEMOLÓGICOS NÃO RESOLVEM A QUESTÃO}

$\mathrm{Na}$ epopéia mitológica grega, Hércules foi obrigado a desenvolver 12 trabalhos. Em um deles, o herói grego encontrava-se diante da Hidra, um horrendo monstro com várias cabeças e um bafo venenoso, que chacinava qualquer criatura que estivesse diante dela. O maior paradoxo dessa figura mitológica consiste na regeneração de suas cabeças todas as vezes que elas eram decepadas. $O$ confronto com a criatura mitológica fez com que Hércules necessitasse de novas estratégias para vencer a Hidra, uma vez que as convencionais não eram mais eficientes. Da mesma forma, os problemas da contemporaneidade não podem ser mais solucionados apenas com as táticas anteriores, sendo requeridos novos estratagemas para compreender os problemas em maior profundidade.

A partir da Idade Moderna, o pensamento científico instituiu suas bases metodológicas (REALE; ANTISSERI, 1990). Nesse contexto, o pensamento cartesiano se implantou como um modelo a ser seguido. Em sua famosa obra, intitulada Discurso sobre o método, Descartes (1973) traçou quatro regras a serem cumpridas para que se chegasse ao correto uso da razão. Na segunda delas, o pensador afirmava a necessidade de "dividir cada uma das dificuldades que eu examinasse em tantas parcelas quantas possíveis e quantas necessárias para melhor resolvê-las" (HELFERICH, 2006, p. 163). Surgiu, assim, a defesa do corte analítico. Ademais, o filósofo francês traçou a distinção entre res extensae e res cogitans a partir da diferença entre "coisas pensantes" e "coisas não-pensantes". Segundo Helferich (2006, p. 165), "formula-se assim o traço determinante do pensamento moderno, o dualismo entre o eu e o mundo exterior". Justamente essa distinção provoca o dualismo entre sujeito e objeto do conhecimento, homem e natureza.

Baseando-se nesses princípios, a ciência moderna se instituiu, dividindo o conhecimento em diferentes objetos de estudo e racionando cada vez mais a realidade a partir de cortes epistemológicos. A maior desvantagem desse procedimento ocorreu pela radicalização e especialização desse projeto de ciência 
enquanto estudo de objetos fragmentados e fora de seu contexto. Para Morin (1995, p. 1, tradução nossa):

Sem dúvida, a instituição das disciplinas corre ao mesmo tempo um risco de hiperespecialização do investigador e um risco de coisificação do objeto de estudo, donde se corre o risco de esquecer que este é extraído ou construído. O objeto da disciplina será, então, percebido como uma coisa em si; as relações e solidariedades deste objeto com outros, tratados por outras disciplinas, serão deixadas de lado, assim como também as ligações e solidariedades com o universo do qual o objeto é parte. ${ }^{1}$

Assim, quando recortamos radicalmente a realidade (o todo) em várias partes, acabamos perdendo as ligações e as relações entre elas quando tentamos fazer o processo inverso ao reconstruir o todo. Daí decorre o famoso estratagema de que o todo não pode se constituir a partir da soma de suas partes. Dessa forma, o todo reconstruído acaba sendo um arcabouço artificial. A esse respeito, Morin (2003, p. 14) ainda afirmou:

Vivemos numa realidade multidimensional, simultaneamente econômica, psicológica, mitológica, sociológica, mas estudamos estas dimensões separadamente, e não umas em relação com as outras. O princípio de separação torna-nos talvez mais lúcidos sobre uma pequena parte separada do seu contexto, mas nos torna cegos ou míopes sobre a relação entre a parte e o seu contexto.

Além disso, o método experimental, que permite tirar um "corpo" do seu meio natural e colocá-la num meio artificial, é útil, mas tem os seus limites, pois não podemos estar separados do nosso meio ambiente; o conhecimento de nós próprios não é possível, se nos isolarmos do meio em que vivemos. Não seríamos seres humanos, indivíduos humanos, se não tivéssemos crescido num ambiente cultural onde aprendemos a falar, e não seríamos seres humanos vivos se não nos alimentássemos de elementos e alimentos provenientes do meio natural.

Evidentemente, a divisão do conhecimento em ciências foi inicialmente uma medida necessária. Seria retrógrado achar que o homem poderia estudar eficientemente todo o universo, em suas mais diferentes manifestações, sem a divisão disciplinar. Porém, o que mais agravou e distorceu o conhecimento foi o fato de as ciências, aos poucos, terem se afastado umas das outras e, consequentemente, perdido a noção do todo que é a expressão da realidade, terminando por se especializar em excesso nos seus temas. O movimento anterior, que era de análise e cortes de objetos, seguido posteriormente da síntese, de forma

\footnotetext{
1 "Sin embargo la institución disciplinaria entraña a la vez un riesgo de hiperespecialización del investigador y un riesgo de cosificación del objeto de estudio donde se corre el riesgo de olvidar que este es extraído o construido. El objeto de la disciplina será entonces percibido como una cosa en sí; las relaciones y solidaridades de este objeto con otros, tratados por otras disciplinas, serán dejadas de lado, así como también las ligazones y solidaridades con el universo del cual el objeto es parte."
} 
a reconstruir a realidade, aos poucos foi se perdendo e se tornando uma análise excessiva.

Por outro lado, a separação entre sujeito e objeto de conhecimento, implica, assim como toda a ideologia moderna, a separação entre homem e natureza, como se o homem não fizesse parte da natureza e a natureza não fosse cada vez mais humanizada. Essa escolha metodológica redundou, cada vez mais, na visão do natural como algo atrasado. Em sua Gramática da civilização, logo no primeiro capítulo (A variação do vocabulário), Braudel (2004) fez uma análise do significado de civilizado e civilização em diversas línguas, chegando à conclusão de que os civilizados são aqueles que não são mais dominados por uma natureza selvagem, mas pertencem a uma "alta cultura". Adorno e Horkheimer (2006) também demonstraram que essa separação entre homem e natureza expressa o ideal de dominação da natureza pela ciência como estratégia para a dominação do homem pelo homem.

Esse dois movimentos epistemológicos de separação e constante especialização do conhecimento trouxeram algumas consequências para as ciências no momento atual. Uma delas é uma visão segmentada e compartimentalizada. Diante de uma realidade cada vez mais dinâmica e globalizada, decorrente da implantação de sistemas técnicos e informáticos sobre a superfície terrestre, esse conhecimento segmentado impõe sérias dificuldades para a compreensão dos fatos contemporâneos. Ademais, a segmentação das ciências provocou a construção de uma gama de conceitos e metodologias específicas para cada objeto, tornando difícil a integração entre os conhecimentos disciplinares, sob pena de cair no ecletismo epistemológico. Houve, no entanto, algumas raras tentativas bem-sucedidas de integração das ciências a partir da segunda metade do século $X X$, como a cibernética.

Outra consequência importante surgiu com a chamada "crise de civilização", provocada pelo atual modo de produção capitalista, que se materializa em uma sociedade de consumo intensivo e na superexploração dos recursos naturais, engendrando o esgotamento da base natural. Com a dicotomia homem-natureza, a maioria das ciências não se preocupou em operacionalizar seus conceitos, teorias e métodos levando em conta o fato de natureza e homem formarem uma segunda natureza. Nas ciências humanas, somente a sociedade é considerada. Nas ciências 
naturais, apenas a natureza pura e desumanizada é levada em conta. Entretanto, como bem apontou o geógrafo Reclus (1993) no século XIX, a crise provocada pelo desgaste e a degradação natural causou também a degradação humana, uma vez que o homem, enquanto elemento da natureza, também termina por ser lesado.

Devido à complexidade da questão, na contemporaneidade tenta-se, então, voltar a integrar ciências humanas e físico-naturais ou, seguindo por outro caminho, tenta-se colocar a questão da degradação natural no rol das ciências humanas e a da degradação humana no campo das ciências naturais, explorando as características específicas de cada disciplina. Contudo, na maior parte das vezes, ambos os caminhos resultam na formação de uma colcha de retalhos; daí o surgimento de tantos neologismos a instar o socioambiental, o sociobiológico, entre outros termos. O ímpeto de resolver os dualismos a partir de um holismo generalizado vem, frequentemente, carregado de uma série de equívocos epistemológicos, como bem afirma Moraes (2005, p. 31):

É interessante observar que variedade e diversidade são qualificadas, na maioria dos comentaristas do tema, como um valor negativo. Os cursos de especialização do setor (mesmo uma boa parte dos envolvidos com a capacitação pessoal da área pública) ou são hiperespecializados quando técnicos, ou marcadamente homogeneizadores quando visam formar "o especialista em meio ambiente". Esse afã homogeneizador acaba por se traduzir em generalismo. Assim como o desejo de tudo gerir pode resultar numa gestão ineficaz.

Claramente, existe dificuldade para fazer uma "soldadura" entre ciências humanas e ciências naturais, estabelecendo as relações entre os processos. A maioria das tentativas tem se dado por meio da Teoria Geral dos Sistemas e pela Teoria da Complexidade, como bem atestam as teorias de Capra (1982), Maturana e Varela (2001) e Morin (2008). Embora essas iniciativas apresentem caminhos que devem ser seguidos, ainda precisam ser mais bem trabalhadas, principalmente no que concerne aos conceitos e às categorias interdisciplinares.

Frente aos desafios que encontramos no percurso, há necessidade de compor novos instrumentos para pensar essa realidade, que se torna paulatinamente mais complexa, pois cada vez mais (res-)surgem novas e velhas formas de interação entre as mais diferentes dimensões e objetos de sua constituição. Todavia, não devemos nos precipitar criando e construindo objetos, novas ciências ou mesmo unificando as ciências já existentes sem rigor e critérios 
epistemológicos bem fundamentados. Para tal, é necessário trilhar ainda um longo caminho, que gradativamente poderá levar à interdisciplinaridade entre as ciências. Por isso, nem sempre o holismo exagerado e rasteiro, várias vezes elaborado a partir da simplificação da Teoria Geral dos Sistemas, é o melhor caminho. Como expressa Moraes (2005, p. 32):

O abandono do exclusivismo holístico permite que se acate a variedade de ações e consequente necessidade de formações diversificadas para uma boa atuação. $O$ abandono da ética uniformizadora da interdisciplinaridade permitiria um rico equacionamento da questão ambiental num patamar multidisciplinar, o qual poderia fornecer as bases para a definição dos efetivos campos transdisciplinares.

Os caminhos da interdisciplinaridade precisam ainda ser mais bem trabalhados. Mas, então, como proceder? Não queremos neste trabalho apresentar uma nova forma de interdisciplinaridade ou resolver as laboriosas questões que se referem aos processos de integração entre as ciências, uma vez que ainda há um longo caminho a ser percorrido. Porém, pretendemos tratar da questão levantada de forma mais integral, abordando a multidimensionalidade da Guerra da Água na Bolívia. Então, não estaríamos diante de um grande paradoxo? No nosso entender não, se optarmos por fazer uso da geografia apostando em sua reflexão sintetizante, integrando diversas dimensões de reflexão tanto escalares (lugar, micro e macro regiões) quanto em relação aos conteúdos (político, natural, econômico, antropológico). Essa postura não significa considerar a geografia como a síntese de todas as ciências, mas como a síntese das ciências que estudam a sociedade em um lócus específico: a região. Ao tratar do tema ambiental, Becker e Gomes (1993 apud CUNHA; GUERRA, 2003, p. 27) revelaram o aspecto multidimensional com o qual a geografia pode contribuir:

\begin{abstract}
O tema vem cercado de novas indagações e de um contexto efetivamente diverso. Afinal, uma das considerações mais atuais se refere exatamente ao papel da ciência e da técnica na produção de conceitos, no uso e na gestão do ambiente e na incontrolável política do problema. [...] Sem dúvida, não é possível contar com muitas certezas, mas pelo menos, a Geografia pode contribuir para revelar algumas das múltiplas dimensões do problema, reconhecendo, assim, a complexidade do tema atualmente.
\end{abstract}

Ao apostar nas contribuições da geografia para a temática ambiental, Mendonça (1998, p. 23) ressaltou que:

Observando-se a história da evolução da ciência moderna percebe-se que a Geografia é a única ciência de cunho ambientalista lato sensu desde sua origem, sendo que as outras são mais específicas no tratamento da referida temática. [...] Contudo, não se pretende dizer que a Geografia é a única 
ciência que sozinha consegue dar conta de toda a problemática que envolve o conhecimento do meio ambiente.

Desse modo, a geografia é uma das poucas disciplinas que, desde o início, tem procurado trabalhar seus conceitos e métodos a partir da integração de uma realidade natural e social, como na tradição regional. Evidentemente, cuidados devem ser tomados para não se partir para naturalismos ou determinismos. E nem tampouco considerar que a geografia vá fazer a síntese de todas as ciências. O natural deve ser refletido a partir de sua apropriação pelo social. Na situação de não se contar "com muitas certezas" em relação a reflexões interdisciplinares, acreditamos que a geografia possa contribuir sobremaneira para uma reflexão mutidimensional e integralizante da questão.

Levando-se em conta que uma das bases desta pesquisa é justamente compreender o que foi a Guerra da Água, acreditamos que cortes epistemológicos rígidos pudessem tirar toda a riqueza do trabalho. Nessa perspectiva, o trabalho reconstitui o que foi o conflito. Para contribuir com o debate sobre a relação entre os recursos hídricos e os conflitos, utilizamo-nos da geografia política, que nos forneceu o embasamento para lidar com conceitos tais como conflito, território, segurança e recursos hídricos, além de suas interações. Subscrever a geografia política como ponto de reflexão para este debate significa adotar o poder em seus mais variados espectros, não apenas como poder do Estado, mas em todas as suas dimensões.

Por outro lado, este estudo pode ser caracterizado como multidisciplinar, vez que discute assuntos relacionados a outras disciplinas, como sociologia, relações internacionais, antropologia e ciências ambientais. No entanto, isso não significa submeter a geografia aos objetivos e procedimentos das outras ciências, desde que ela possui seus próprios métodos e propósitos (HARTSHORNE, 1966).

Embora o presente estudo se enquadre dentro da geografia política, não se vale da geografia pura e tão-somente como ciência auxiliar para a investigação acerca de política e poder (conceitos originalmente da ciência política). Portanto, a geografia política se preocupa com o espaço geográfico e a materialização do poder a partir dele, quer este poder emane do Estado ou de outros atores não-estatais. Como bem demonstrou Jones (1954), a geografia política não se preocupa apenas com a espacialização dos conceitos e fenômenos da ciência política, mas possui um campo próprio de atuação. 
Assim, neste trabalho analisamos a materialização do poder a partir das territorialidades e investigamos de que forma a configuração destas garante a certos atores o controle ou o acesso aos recursos hídricos. Ademais, a configuração territorial expressa relações de poder que são suscetíveis de se transformar em conflitos violentos relacionados a esses recursos. Destarte, para compreender a gênese de um conflito social e sua interrelação com os recursos hídricos, não podemos caracterizar o objeto de estudo desta pesquisa somente a partir da categoria conflito, sendo imprescindível considerar igualmente a categoria relações de poder. Além disso, ao utilizarmos um conceito de segurança que procura apresentar uma posição intermediária entre os conceitos de segurança nacional e segurança humana, seria uma incongruência o emprego apenas da categoria conflito, pois ela contemplaria tão-somente a segurança nacional.

Embora a relação entre conflito social e recursos hídricos necessite das contribuições da geografia física e das ciências ambientais e naturais, não é nosso intuito principal refletir em profundidade as questões físicas acerca dos recursos hídricos no plano central deste estudo, porquanto esta tarefa foge ao objetivo capital do trabalho, especialmente porque já há vários estudos de geomorfologia, hidrologia e áreas afins que exploram esta questão com maior propriedade no que se refere à Guerra da Água. Inclusive, é a partir desses trabalhos e de dados estatísticos que exploramos o aspecto físico para as nossas discussões. A mesma precaução foi tomada em relação aos aspectos técnico e hidráulico. Destacamos que, do contrário, essa tarefa se tornaria longa e árdua para ser explicitada em uma única tese de doutorado. Como bem aponta George (1986, p. 111):

[...] a especialização se tornou inevitável: o problema principal consiste em fazer com que esta especialização se harmonize com uma unidade de pensamento. Hoje em dia, é totalmente inútil obstinar-se em esperar que o mesmo indivíduo produza obras-primas simultaneamente em geomorfologia, em economia e em urbanismo; é indispensável, entretanto, que, tendo optado por este ou por aquele dentre esses vários setores, os pesquisadores geógrafos não se descuidem de agir como geógrafos, permanecendo continuamente integrados numa equipe e num mesmo modo de pensar, de forma que lhes seja sempre possível passar de um campo para outro, sem que isto Ihes acarrete a obrigação de se manterem cientes de tudo que ocorre ao nível da pesquisa fundamental.

Ao desenvolver a concepção de geografia socioambiental, Mendonça (2001, p. 124) seguiu a mesma linha de pensamento: 
Na concepção aqui defendida, um estudo elaborado em conformidade com a Geografia socioambiental deve emanar de problemáticas em que situações conflituosas, decorrentes da interação entre a sociedade e a Natureza, explicitem degradação de uma ou de ambas. A diversidade das problemáticas é que vai demandar um enfoque mais centrado na dimensão natural ou mais na dimensão social, atentando sempre para o fato de que a meta principal de tais estudos e ações vai na direção da busca de soluções do problema, e que este deverá ser abordado a partir da interação entre estas duas componentes da realidade.

Levando-se em conta que o aspecto fulcral desta tese é o conflito denominado Guerra da Água, nosso enfoque deve estar mais centrado na dimensão social, embora a dimensão física deva também ser abordada. Isso significa que, neste trabalho, a dimensão física tem por tarefa apresentar subsídios para a melhor compreensão das relações entre os processos sociais e os recursos naturais como "trunfos do poder" no território, utilizando uma expressão tão cara a Raffestin (1993).

Por outro lado, não se justifica um aprofundamento vertical excessivo na avaliação das dimensões de reflexão (política, econômica, social), uma vez que várias pesquisas anteriores sobre a Guerra da Água já realizaram essa empreitada levando em conta apenas uma dessas dimensões. Então, no presente trabalho procuramos, ao contrário, maior aprofundamento horizontal da reflexão, verificando tanto as relações quanto as interligações entre essas dimensões.

Outro aspecto, que justifica o fato de não centralizarmos esta pesquisa na discussão detalhada sobre as questões físicas relacionadas aos recursos hídricos, reside na caracterização da categoria conflito aqui utilizada. Para os fins deste estudo, não utilizamos a categoria conflitos socioambientais, tampouco conflitos ambientais, porquanto estas não contribuem para a correta interpretação de todas as dimensões envolvidas em um conflito social, impedindo a compreensão teórica mais ampla das características essenciais do conflito ora analisado (BARBANTI JÚNIOR, 2002; BAUMAN, 2001; TOURAINE, 1989). Assim, além dos aspectos físicos, há outros, tais como os fatores econômicos, políticos e culturais que se relacionam ao conflito e que igualmente devem ser explicitados. Com isso, centrar nossa análise somente nos aspectos ambientais seria uma medida simplista e reducionista, bem como contraditória às escolhas metodológicas aqui tomadas.

Entendemos que o conflito se relaciona às diversas dimensões e não apenas ao aspecto natural. Existem inúmeras outras relações que se somam àquelas dos recursos hídricos, levando, então, à deflagração do conflito social (BARNETT, 2001; 
LACOSTE, 2001). A questão hídrica pode ser somente um fator de sublimação de tensões entre atores, causadas por outros fatores muito mais profundos, como sugere o conceito de ambivalência de Freud (BAECHLER, 1999; COSER, 1956).

Naturalmente, no trabalho aqui proposto utilizamo-nos das contribuições de geógrafos como Claude Raffestin, da França, e Bertha Becker, do Brasil. No entanto, também fazemos uso de algumas propostas (com várias ressalvas de nossa parte) oriundas de uma nova corrente que se denomina geopolítica crítica ou geopolítica pós-moderna. Trata-se de um grupo de autores de origem britânica, radicados nos Estados Unidos e Canadá, que a partir de 1990 ressaltaram um enfoque geopolítico baseado na análise do discurso e na ênfase do uso de escalas menores que a do Estado, enfatizando com mais força o poder com "p" minúsculo, expressão tão conhecida de Raffestin. Por outro lado, essa corrente tem sido criticada por apenas desconstruir o arcabouço teórico clássico da geopolítica sem apresentar proposta mais palpável.

Ao realizar uma nova proposta para a geopolítica, Becker (1988) destacou a importância de um resgate da geopolítica clássica. Costa (2008) também salientou a importância desse resgate, o mesmo se podendo afirmar acerca de Martin (1992). Procurando avançar neste propósito, propomo-nos a resgatar alguns conceitos, não somente da geopolítica clássica, mas particularmente da geopolítica sul-americana. Assim sendo, debruçamo-nos sobre conceitos como triângulo estratégico boliviano, forças centrípetas e centrífugas, puncti dolens, ${ }^{2}$ entre outros, que não podem deixar de ser discutidos quando se estuda a Bolívia. Procuramos, ainda, reequilibrar a análise das relações de poder analisando as escalas dos protagonistas não-estatais juntamente com as dos Estados. Sob esta perspectiva, a adoção da geografia regional se tornou crucial, a partir da análise em diferentes escalas, o que, no caso dos estudos sobre a Guerra da Água, foi raras vezes utilizado.

De maneira geral, esta pesquisa consiste em um estudo de caso avaliativo, uma vez que procura fornecer subsídios para a compreensão dos conflitos relacionados aos recursos hídricos e às suas outras dimensões, a partir de um estudo em profundidade da Guerra da Água em Cochabamba, cidade localizada na Bolívia. Para tanto, realizamos uma pesquisa com características ontológica, descritiva e qualitativa.

\footnotetext{
${ }^{2}$ pontos de confrontação entre Brasil e Argentina na América do Sul.
} 


\subsection{Geografia: a mãe muitas vezes esquecida pelos "estudos ambientais"}

O grande expoente da geografia, Santos (2004), nomeou um capítulo de seu livro de "Geografia: a viúva do espaço", chamando a atenção para o fato de que os geógrafos se esquecem que o espaço geográfico é, por excelência, o objeto da geografia. Aqui, queremos frisar que não apenas os geógrafos deixam de lembrar do espaço como também uma boa parte dos "estudos ambientais" tem se olvidado da geografia e da importância de seus conceitos. Não queremos criar mais polêmicas, porquanto o que menos precisamos no atual momento é instigar uma competição acadêmica entre as disciplinas. Pelo contrário, necessitamos de um debate rigoroso e crítico entre as diferentes ciências, buscando integrá-las. Porém, o chamado debate "ambiental" tem, muitas vezes, negligenciado a geografia se apropriando de seus conceitos sem considerá-la nos estudos interdisciplinares.

Por conta da ansiedade em resolver questões práticas da degradação natural, estudiosos de diferentes domínios do saber têm se precipitado em organizar uma nova ciência a partir da construção de um objeto de estudo interdisciplinar, o ambiente ou o meio ambiente, como se ele constituísse uma nova dimensão de estudo, ao lado das dimensões econômica, cultural e política. Tal objeto seria de domínio da ciência ambiental. Um exemplo disso é o discurso do conhecido ecologista Odum (2006, p. 261, tradução nossa) sobre o desenvolvimento da ecologia:

A ciência ambiental está sendo convidada agora para ajudar a determinar um nível realístico da densidade populacional humana e da taxa de uso dos recursos e poder que são os ideais em termos de qualidade de vida humana, a fim de que "o retorno societal" possa ser colocado em prática antes que haja sérios enganos. Isto requer o estudo diligente dos ecossistemas e, fundamentalmente, um julgamento a respeito da capacidade de sobrecarga da biosfera. Se os estudos das populações naturais levarem em conta esse problema, nós podemos estar certos que a densidade ideal em termos de opções individuais para a liberdade e a busca pela felicidade é algo menor que o número máximo de "animais" domésticos que pode ser sustentado em um nível de subsistência em um pasto para alimentação poluído! ${ }^{3}$

\footnotetext{
3 "Environmental science is now being called upon to help determine a realistic level of human population density and rate of use of resources and power that are optimum in terms of the quality of human life, in order that 'societal feedback' can be applied before there are serious overshoots. This requires diligent study of ecosystems, and, ultimately, a judgment on the carrying capacity of the biosphere. If studies of natural populations have any bearing on the problem, we can be quite certain that the optimum density in terms of the individual's options for liberty and the pursuit of happiness is something less than the maximum number that can be sustained at a subsistence level, as so many domestic 'animals' in a polluted feed lot!"
} 
Colin (2004, p. 75, tradução nossa), em seu dicionário sobre o meio ambiente e ecologia, traz a seguinte definição: "Ciência ambiental: substantivo, o estudo da relação entre o humano e o ambiente, os problemas causados pela poluição ou perda de habitats e soluções propostas."

Outro exemplo pode ser comprovado pelo que postula Manahan (2000, p. 1, itálico e negrito do autor, grifo nosso, tradução nossa) quando caracteriza a ciência ambiental da seguinte forma:

A ciência ambiental em seu sentido mais amplo é a ciência das interações complexas que ocorrem entre os ambientes terrestre, atmosférico, aquático, vivente e antropológico. Inclui todas as disciplinas, tais como química, biologia, ecologia, sociologia e governo, que afetam ou descrevem estas interações. Para as finalidades deste livro, a ciência ambiental será definida como o estudo da terra, do ar, da água, e dos ambientes viventes e os efeitos da tecnologia sobre eles. Em um grau significativo, a ciência ambiental evoluiu a partir das investigações sobre os meios pelos quais e os lugares nos quais os organismos vivos realizam seus ciclos de vida. Esta é a disciplina da história natural, que em épocas recentes se transformou na ecologia, o estudo dos fatores ambientais que afetam os organismos e como os organismos interagem com estes fatores e entre si. ${ }^{5}$

Na primeira parte da conceituação, o autor define ciência ambiental como o conjunto das interações entre sociedade e natureza por intermédio do conceito de ecossistema da ecologia. O mesmo se pode perceber na segunda parte da definição, quando ele afirma que a ciência ambiental nada mais é que a evolução da história natural e da ecologia. Além disso, ele enumera várias outras disciplinas, porém nunca citando a geografia, o que tacitamente implica que, no seu entender, esta ciência não tem o que acrescentar a este campo. Esse tipo de conceituação procura afirmar a ciência ambiental enquanto ciência objetivada pelos conceitos da ecologia, o que causa uma "ecologização" da atual crise por que passamos. Nessa perspectiva, Tomasoni e Tomasoni (2002, p. 304) afirmaram que:

O sentido dado à ecologia permitiu a sua consagração e visibilidade como a "ciência do ambiente", mesmo que pautada numa visão parcial da totalidade

\footnotetext{
4 "Environmental Science: noun, the study of the relationship between human and the environment, the problems caused by pollution or loss of habitats, and proposed solutions."

5 "Environmental science in its broadest sense is the science of the complex interactions that occur among the terrestrial, atmospheric, aquatic, living, and anthropological environments. It includes all the disciplines, such as chemistry, biology, ecology, sociology, and government that affect or describe these interactions. For the purposes of this book, environmental science will be defined as the study of the earth, air, water, and living environments, and the effects of technology thereon. To a significant degree, environmental science has evolved from investigations of the ways by which, and places in which, living organisms carry out their life cycles. This is the discipline of natural history, which in recent times has evolved into ecology, the study of environmental factors that affect organisms and how organisms interact with these factors and with each other."
} 
das relações sociedade-natureza, forjando, portanto, uma inversão (proposital ou não) da questão ambiental em questão ecológica.

Mais à frente, ao discutir a concretização da ideia de equilíbrio ambiental, os dois geógrafos enunciaram que:

A crise de valores pela qual a humanidade passa torna-a cada vez mais angustiada, pois a técnica que nos permitiu chegar a avançados mecanismos de "leitura" instantânea do planeta, parece não ser bastante eficaz na resolução dos problemas concretos da humanidade. Devemos ter em mente, sobre estes temas, que nossa percepção do tempo é muito limitada, pois a predições baseiam-se em escalas espaço-temporais reduzidas, limitando a compreensão dos ritmos e alternâncias dos sistemas naturais. Isto é fundamental para que não reduzamos a questão ambiental a simples terminologias como meio ambiente ou ecologia (TOMASONI; TOMASONI, 2002, p. 311-312).

Nas duas últimas definições, nota-se tanto a presença do chamado "ecletismo" epistemológico como a falta de teorização mais rigorosa. Em sua análise acerca do aparecimento da questão ambiental, o epistemólogo Leff (2006, p. 72, grifo nosso) postulou a impossibilidade de se criar uma "ciência ambiental":

\begin{abstract}
O ambiental aparece como um campo de problematização do conhecimento que induz um processo desigual de "internalização" de certos princípios, valores e saberes "ambientais" dentro dos paradigmas tradicionais das ciências. Este processo tende a gerar especialidades ou disciplinas ambientais, métodos de análise e diagnóstico, assim como novos instrumentos práticos para normatizar e planejar 0 processo de desenvolvimento econômico sobre as bases ambientais. Entretanto, esta orientação "interdisciplinar" referente a objetivos ambientais não autoriza a constituição de um novo objeto científico - o ambiente - como domínio generalizado das relações sociedade-natureza.
\end{abstract}

Dessa forma, não havendo o objeto científico "ambiente", não há como se falar em uma ciência ambiental. Ainda em relação à última definição, não se pode conceder exclusividade à ciência ambiental como aquela que estuda as relações entre sociedade e natureza, uma vez que há várias outras ciências já consolidadas e dedicadas justamente a esta temática, como a antropologia, a geografia, a economia, entre outras. Em adição a isso, a relação entre homem e natureza não pode ser reduzida tão-somente a temas como poluição e perda de habitats.

Outro aspecto relevante para esta discussão é o próprio conceito de meio ambiente. Muitas críticas vêm sendo feitas a ele, porque é, na verdade, uma aproximação ao conceito de meio proposto pela ecologia e apresenta uma série de complicações epistemológicas. Conforme o filósofo francês Canguilhem (1985), a definição de meio ambiente surgiu a partir do conceito de meio, inicialmente criado 
pelos enciclopedistas franceses na segunda metade do século XVIII, a partir da ideia de fluido, cujo arquétipo único seria o éter da mecânica newtoniana. Para Newton, o fluido era um veículo da ação, não apenas intermediário entre os corpos, mas também os penetrando.

Canguilhem (1985) observou que desde Galileu, passando por Descartes e Pascal, podiam ser identificadas pelo menos três concepções de meio na ciência moderna: 1) situação mediana; 2) fluido de sustentação; 3) ambiente vital. Também asseverou que Lamarck retomou o pensamento newtoniano e a ideia de meio; para o biólogo, havia fluidos (no plural) - água, ar e luz -, designando um conjunto de ações engendradas por esses elementos sobre os seres vivos ou circunstâncias influentes. Na concepção lamarckiana, as noções de circunstâncias e ambiência tinham significados diferentes dos utilizados na linguagem atual. Para Canguilhem (1985), esses conceitos remetem à ideia de uma disposição esférica, na qual a Terra retorna à sua posição central, em conformidade com uma cosmologia tipicamente aristotélico-ptolomaica.

Como indicou Canguilhem (1985), um avanço decisivo dado ao conceito de meio foi aplicado por Auguste Comte. Para esse filósofo francês, não importava somente o fluido no qual o corpo se encontrava imerso, mas sim o complexo total das circunstâncias exteriores, necessário à existência de cada organismo. Apesar de Comte enfatizar a ideia da relação entre organismos e meio, em sua obra, a visão mecanicista também pode ser notada quando ele afirma que a relação do organismo apropriado e do meio favorável é um conjunto de potências cujo ato é construído pela função matemática (CANGUILHEM, 1985).

O conceito de meio como um sistema de relações entre organismos e entre estes e o seu entorno precedeu a ideia de ecossitema, objeto de estudo da ecologia (LEFF, 2006). No entanto, a "ecologização" dessa matéria torna-se evidente quando se verifica que não há grandes distinções entre os conceitos de meio e de meio ambiente.

Tomasoni e Tomasoni (2002, p. 304) apresentaram várias definições de meio ambiente que encontraram em suas pesquisas:

1. Ação de situar-se no entorno; arredores de um local. 2. Conjunto das condições naturais (físicas, químicas, biológicas), culturais (sociológicas) suscetíveis de influenciar os organismos vivos e as atividades humanas. 3. Conjunto dos elementos do meio que um animal pode perceber. 
Conforme Ferreira (2004, p. 546), o conceito de meio aparece inclusive como sinônimo de meio ambiente: "meio [...] 10. meio ambiente [...]". Na língua francesa, o vocábulo meio é expresso por duas palavras: milieu (no sentido de entorno) e moyen (no sentido de recurso empregado para alcançar um objetivo). Para nós, interessa apenas o vocábulo milieu, definido no dicionário da língua francesa Le Robert micro como: "1. aquilo que cerca, aquilo em que uma coisa ou um ser se encontra [...]. 2. Conjunto de objetos materiais, de circunstâncias físicas que cercam ou influenciam um organismo vivo $\rightarrow$ ambiente. Adaptação ao meio. 3. O entorno material e moral (de uma pessoa)" (REY, 1998, p. 836, tradução nossa). ${ }^{6}$ Destarte, percebe-se que meio ambiente e meio querem dizer praticamente a mesma coisa.

Expondo a temática "ambiental", Christofoletti (1994, p. 132) ressaltou duas abordagens principais do problema:

A primeira possui a significância biológica e social e valor antropocêntrico, evidenciando o contexto e as relações que envolvem o ser vivo; a segunda considera a funcionalidade interativa da geosfera-biosfera, com enfoque sobre as "unidades de organização" com ou sem a presença humana. Esta idéia remete ao geosistema como unidade que espelha certa organização e particularidades.

Não estaria, ainda, a primeira abordagem nos remetendo à concepção de espaço geográfico? Este ponto será tratado mais adiante.

A discussão relativa ao conceito de meio ambiente não é somente etimológica, pois se refere também às esferas epistemológica e teórica. Segundo Tomasoni e Tomasoni (2002, p. 305), “o conceito de 'meio ambiente' é insuficiente para tratar da ampla gama de questões envolvidas na pesquisa sobre as relações entre sociedade e natureza". Jollivet e Pavé (2002) também levantam uma série de discussões epistemológicas sobre o conceito. Esses autores indagaram se seria possível delimitar um campo de pesquisa específica sobre o meio ambiente e se haveria um paradigma norteador deste campo. Além disso, argumentaram que a assertiva de que o ambiente é aquilo que circunda os indivíduos em um momento e local determinados remete, invariavelmente, a um objeto central que variará de acordo com a subjetividade de seu observador:

\footnotetext{
6 "1. Ce qui entoure, ce dans quoi une chose ou um être se trouve [...] 2. Ensemble des objets matériels, des circonstances physiques qui entourent et influencent un organisme vivant $\rightarrow$ environnement. Adaptation au milieu. 3. L'entourage matériel et moral (d'une personne)."
} 
[...] para um biólogo de populações, o objeto central é a população que ele investiga, e o meio ambiente equivaleria àquilo que circunda essa população. Para um especialista em fisiologia, o objeto central é um organismo ou órgão, e o meio ambiente constituiria aquilo que circunda esse organismo (o milieu cellulaire). Para um sociólogo, o meio ambiente pode ser o meio familiar, o grupo social, o ambiente de trabalho, o habitat [...] (JOLLIVET; PAVÉ, 2002, p. 57).

Esses mesmos autores ainda asseveraram que o conceito de meio ambiente é polissêmico, implicando uma multiplicidade de significados, o que permite que seja apropriado de modo diverso por vários setores científicos e tecnológicos. Para dar um exemplo disso, os autores se referiram à noção de meio ambiente no campo da informática, que significa "um conjunto de dispositivos e programas de aplicação necessários ao desempenho de certas tarefas, especialmente aquelas consideradas de alto nível" (JOLLIVET; PAVÉ, 2002, p. 59). Portanto, a interdisciplinaridade entre as ciências se torna difícil, uma vez que com definições tão diferentes para um mesmo conceito serão alcançados resultados metodologicamente pouco consistentes.

Continuando suas críticas ao conceito de meio ambiente, Jollivet e Pavé (2002, p. 60) ainda apontaram que a dificuldade em se estabelecer uma concepção única a respeito do termo é originada a partir da complexidade de se "distinguir, por um lado, as flutuações e a variabilidade dos sistemas naturais e, por outro lado, os efeitos induzidos pela ação humana", o que, necessariamente, leva à investigação acerca da complexidade de escalas espaço-temporais e dos diversos planos de organização dos seres vivos. Assim, os autores acabaram por afirmar que compreender essas relações do "nível local ao global, do intervalo de um segundo até a era geológica, da macromolécula aos ecossitemas, às paisagens, ou mesmo à biosfera vista como um todo" é uma tarefa extremamente complexa (JOLLIVET; PAVÉ, 2002, p. 62). Consequentemente, outro grande problema do conceito de meio ambiente se refere à escala. Até onde vai o meio ambiente? Que extensão possui o entorno dos homens? Somente até onde alcança a sua percepção? Ademais, os fenômenos se materializam em um determinado lugar sob a interferência de vários outros fenômenos em diversas escalas Nesse sentido, os próprios conceitos de meio ambiente e de ecossistema são frágeis e insuficientes, porquanto podem se referir desde a microescala até a macroescala, utilizando-se dos mesmos conceitos para escalas tão díspares. 
Mesmo em outras áreas, como nas ciências jurídicas, o conceito de meio ambiente não é pacífico. O jurisconsulto Milaré (2001, p. 63) sustentou a tese de que o termo é "camaleão", uma vez que os vocábulos meio e ambiente trazem significados divergentes:

[...] Meio pode significar: aritmeticamente, a metade de um inteiro; um dado contexto físico e social; um recurso ou insumo para se alcançar ou produzir algo. Já ambiente pode representar um espaço geográfico ou social, físico, físico ou psicológico, natural ou artificial [...]

Destacando esse mesmo problema, Moraes (2005, p. 51) apontou que:

[...] meio para um geógrafo ou um biólogo, é um habitat, para um economista, refere-se a um instrumento ou fator (de produção, de circulação etc). Os exemplos poderiam ser multiplicados, mostrando que a questão da linguagem não é secundária. Uma ação comum entre diferentes áreas, ciência e pesquisas, pede, como patamar elementar, uma relação comunicativa.

Jollivet e Pavé (2002) concluíram que o conceito de meio ambiente juntou-se aos termos natureza e meio natural e, de certa maneira, os generalizou. Essa generalização pode ser evidenciada em Ribeiro (1991, p. 29, grifo nosso), quando este conceituou meio ambiente afirmando que: "[...] a 'natureza', o 'meio ambiente', ou qualquer outro nome que se queira dar àquilo que na concepção moderna foi delimitado (pelos homens) como exterior ao próprio homem, criando a ideia de um recurso disponível [...]". Evidentemente, o conceito pode se tornar flexível para os fins a que se propõem o pesquisador e a investigação. A esse respeito, BaylissSmith e Owens (1996, p. 126) ponderaram que o termo ambiente é multidimensional e que se pode distinguir "interpretações de cunho antropocêntrico das interpretações que se baseiam na bioética". Porém, a questão do conceito de meio ambiente não é apenas ideológica. Quando um mesmo conceito com acepções diferentes começa a se sobrepor em uma reflexão, qualquer movimento de avaliação se torna confuso. Portanto, faz-se necessário refletir sobre algumas definições de meio ambiente mais recentes.

Leff (2001) afirmou que o ambiente não deve ser simplificado simplesmente àquilo que circunda os indivíduos e as espécies biológicas, porque este tipo de reducionismo disfarça o fato de o meio ambiente ser também uma construção humana, desse modo sendo o produto resultante de processos que têm origem tanto na ordem física quanto na social. 
Jollivet e Pavé (2002, p. 63) definiram meio ambiente como:

[...] o conjunto de meios naturais ou artificializados da ecosfera onde o homem se instala e que ele explora e que ele administra, bem como o conjunto dos meios que são submetidos à ação antrópica e que são considerados necessários à sua sobrevivência [...]

Reigota (1998, p. 14), por seu turno, apresentou o meio ambiente como um:

[...] lugar determinado ou percebido, onde os elementos naturais e sociais estão em relações dinâmicas e em interação. Essas relações implicam processos de criação cultural e tecnológica e processos históricos e sociais de transformação do meio natural construído.

As definições tanto de Jollivet e Pavé (2002) quanto de Reigota (1998) procuram salientar que o meio ambiente não pode ser definido somente pela relação entre seres biológicos e o seu entorno ou meio, pois a ação humana também se faz presente construindo uma segunda natureza. Na primeira definição, Jollivet e Pavé (2002) mencionaram meios naturais e artificializados sobre os quais o homem atua, cabendo perguntar se a atuação do homem sobre o meio natural já não seria motivo suficiente para que este deixasse de ser natureza natural? Já na outra definição, Reigota (1998) ainda chamou a atenção para a percepção e a ação consciente sobre o meio, talvez querendo diferenciar o agir humano do agir meramente instintivo dos animais. Nas duas definições, os autores remetem a um espaço sujeito à apropriação humana: na primeira, a "meios naturais ou artificializados", e na segunda, a "um lugar determinado".

Ao discorrer sobre a ciência natural enquanto ciência da natureza, o grande filósofo Whitehead (1920, p. 3, tradução nossa) se perguntou: "mas - o que é natureza?". ${ }^{7}$ Para nós, a pergunta vem a calhar justamente para comparação com o conceito de natureza e meio ambiente. Whitehead (1920, p. 4, tradução nossa) mesmo respondeu que a "natureza é aquilo que nós observamos na percepção por meio dos nossos sentidos. Nessa percepção sensorial temos consciência de algo que não é pensamento e é independente para o pensamento". ${ }^{8}$ Sob essa perspectiva, o filósofo enfatizou o fato de que a natureza não está contida no homem por intermédio de seus pensamentos, mas que ela abrange tudo o que é externo ao homem, ou seja, que pertence ao seu meio, do qual ele toma conhecimento

\footnotetext{
7 "But - what is nature?"

8 "Nature is what we observe in perception through the senses. In this sense perception we are aware of something which is not thought and which is self-contained for thought."
} 
utilizando seus sentidos. Naturalmente, tal definição é muito ampla que o nosso propósito. Todavia, fazendo um paralelo com o conceito de meio ambiente, o conceito de natureza de Whitehead (1920) não se encontra muito distante da noção de meio ambiente dada por Einstein como "tudo aquilo que não seja eu" (BAYLISSSMITH; OWENS, 1996, p. 126).

No Dictionary of human geography, de Johnston, Gregory e Smith (1994, p. 408, tradução nossa), o termo natureza possui três acepções:

1. A essência de algo [...] 2. Áreas não afetadas ou não alteradas pela ação humana. 3. O mundo físico em geral, como a totalidade dos seus fenômenos ou processos ou como um tópico de estudo [...] Em qualquer desses sentidos, a "natureza" pode ser usada normativamente como um padrão de valores; o que é mais "natural" é considerado melhor, um padrão ao qual não têm faltado críticas desde pelo menos o tempo de John Stuart Mill (1873). ${ }^{9}$

Os autores salientaram um importante ponto quando apontaram que a natureza pode ser utilizada como um "padrão de valor". Se há um padrão de valor, sinal de que ela é valorizada por alguém - o homem -, o conceito de natureza, qualquer que seja ele - mesmo aquele mais radical de "natureza intocada" - está, portanto, vinculado à própria existência humana.

A primeira das três definições não é desenvolvida pelos autores, porquanto se refere muito mais a uma acepção filosófica do conceito, no mesmo sentido da definição oferecida por Whitehead (1920). Em relação ao segundo sentido, Johnston, Gregory e Smith (1994, p. 408, tradução nossa) explicaram que ele "é afim ao significado de natureza selvagem". ${ }^{10}$ Após discorrer sobre essa concepção, McKibben (1989 apud JOHNSTON; GREGORY; SMITH, 1994, p. 408, tradução nossa) afirmou que, nesse contexto, a natureza é uma construção irreal, vez que: "Os contínuos e generalizados impactos humanos têm sido tão propagados, porém, que (do mesmo modo que natureza selvagem), natureza nesse sentido é frequentemente mais um construto imaginativo que uma realidade histórica ou física."11 Naturalmente, trata-se de um conceito de natureza já em desuso, que

\footnotetext{
9 "1. The essence of something [...] 2. Areas unaffected or unaltered by human action. 3. The physical world in general, as the totality of its phenomena or process or as a topic of study [...] In any of these senses, 'nature' can also be used normatively as a standard of value; what is most 'natural' is judged to be best, a standard that has not lacked critics since at least the time of John Stuart Mill (1873)."

10 "[...] is akin to the notion of wilderness."

11 "Long-term and pervasive human impacts have been so widespread, however, that (like wilderness), nature in this sense is often more an imaginative construct than an historical or physical reality."
} 
predominou até a metade do século passado, influenciando a institucionalização do preservacionismo e o mito da natureza intocada, como aponta Diegues (2001). A esse respeito, Ribeiro (1991, p. 30) informou que:

[...] falar de um ambiente natural, ou melhor, um ambiente cuja dinâmica pode ser explicada a partir dos processos inerentes aos elementos constituintes do seu próprio sistema, é praticamente impossível desconsiderando-se a ação humana (cuja escala planetária é evidente aos nossos olhos), é negar um dos componentes do sistema.

Em relação à última acepção de natureza segundo Johnston, Gregory e Smith (1994, p. 408, tradução nossa), os autores declararam que:

O terceiro sentido é o mais significativo e também o mais amplo sobre as questões que ele aponta a respeito da relação humana com a natureza. Um prolongado debate focaliza-se no grau em que os enfoques das ciências naturais [...] são apropriados para o estudo da vida social. ${ }^{12}$

Conti (2002, p. 10) pareceu ser favorável a essa terceira acepção do conceito de natureza apresentada por Johnston, Gregory e Smith (1994) quando postulou que "a natureza é, na mais genérica das definições, o conjunto dos elementos bióticos e abióticos que compõem o universo. Portanto, o ser humano faz parte desse todo". Aqui, o conceito de universo pode tanto se referir ao cosmos como um todo quanto somente à Terra e aos seus habitantes. ${ }^{13}$ Porém, como bem expressou Conti (2002), esse conceito de natureza é uma definição genérica e acaba englobando "tudo" (o universo) e fazendo com que o conceito perca a sua função: delimitar um determinado conteúdo. Maturana e Varela (2001, p. 47) destacaram que "o ato de designar qualquer ente, objeto, coisa ou unidade, está ligado a um ato de distinção que separa o designado e o distingue de um fundo". Por conseguinte, essa acepção de natureza, por ser muito abrangente, reiteradas vezes abarca algo (o universo inteiro) que em sua maior parte não está em relação direta com o homem.

Buscando uma delimitação menos abrangente de natureza, nos apoiamos na conceituação de Santos (1992 apud CONTI, 2002, p. 10), para quem:

\footnotetext{
12 "The third sense is the most significant, and also the broadest in the questions it raises regarding the human relation to nature. A long-standing debate centers on the extent to which the approaches of the natural sciences $[\ldots]$ are appropriate to the study of social life."

13 "Universo. 1 conjunto de tudo quanto existe (incluindo a Terra, os astros, as galáxias e toda a matéria disseminada no espaço); o cosmo. 2. A Terra e os seus habitantes." (FERREIRA, 2004, p. 802).
} 
A natureza é o continente e o conteúdo do homem, incluindo os objetos, as ações, as crenças, os desejos e as perspectivas [...] Com a presença do homem sobre a Terra, a natureza está sendo sempre redescoberta [...] com a criação da Natureza Social.

Nesse sentido, o homem faz parte da natureza, apesar de ser contido por ela e, portanto, ela também dá sentido à vida do homem. Assim, homem e natureza tornaram-se conceitos indissociáveis e a separação deles somente aconteceu por influência do pensamento cartesiano. Ainda a esse respeito, Santos (2004, p. 162163, itálico do autor, grifo nosso) reiterou que:

Tem cabimento a afirmação de Sportelli (1974, p. 91) quando diz que a objetividade social é frequentemente reduzida a uma objetividade natural. Isso equivale a dizer que natureza é objeto de permanente transformação por causa da atividade humana, daí porque a natureza é uma realidade social e não exclusivamente natural. Nesse sentido, a palavra natural deve ser tomada como um sinônimo de social, da mesma forma que podem ser assimilados os vocábulos natureza e espaço [...] Nessa expressão, natureza socializada, deve-se identificar aquilo que os geógrafos chamam normalmente de espaço ou espaço geográfico.

Ao conceituar o espaço geográfico, Beaujeu-Garnier (1971, p. 56, itálico da autora, tradução nossa) ressaltou que:

A primeira noção que se destaca é, portanto, aquela de um duplo sistema: das relações de formas diversas, na qual os elementos de natureza muito diferente são amplamente disseminados sobre a superfície do globo; a inscrição materializada e localizada em tal ou tal etapa, de um momento característico dessas relações dentro de um quadro bem determinado. Essas relações podem fazer intervir elementos físicos, biológicos, sociológicos e econômicos $[\ldots]^{14}$

Silva (1986, p. 32) também seguiu na mesma direção ao externar seu conceito acerca de espaço geográfico:

O espaço, primeira categoria do pensamento geográfico, é, portanto, categorialmente concebido como resultado do ato da produção. Mas há aqui uma particularidade: o espaço produzido o é a partir do espaço existente, ou seja, da transformação do espaço anterior. Este último pode ser a própria natureza ou o espaço já humanizado; retransformado [ou seja, natureza transformada pelo homem].

Levando-se essas conceituações em consideração, pode-se, então, entender a "segunda natureza" como o espaço geográfico. Dessa forma, aquele aspecto que

\footnotetext{
14 "La première notion que si dégage est donc celle, d'un double système: des relations de formes diverses, dont les éléments de nature trés differénte sont largement disséminés à surface du globe; l'inscription matérialisée et localisée a telle ou telle étape, d'un moment caractéristique de ces rapports dans un cadre bien déterminé. Ces rapports peuvent faire intervenir des éléments biologiques, physiques, sociologiques et economiques [...]"
} 
Leff (2001) tanto procurou enfatizar do meio ambiente como entorno, não somente físico, mas produzido pelo humano, e que tanto Jollivet e Pavé (2002) como Reigota (1998) retrataram como um conjunto de meios em que se dá a interação entre os "elementos social e natural", se refere nada mais e nada menos que ao espaço geográfico.

Não obstante, o conceito de espaço geográfico abrangeria apenas parte ou todo o globo terrestre? Ainda no final do século XIX, Reclus (1993, p. 171, tradução nossa) constatou que: "[...] está próximo o dia em que não restará mais uma só região dos continentes que não tenha sido visitada pelo pioneiro civilizado, e cedo ou tarde o trabalho humano será exercido sobre todos os pontos do globo [terrestre]". ${ }^{15}$ Esse fato já se concretizou, como bem constatou Santos (2008, p. 99, itálico do autor):

A sociedade humana tem como seu domínio a Terra; o planeta, todo ele, é habitat da sociedade humana, na verdade habitat e ecúmeno são agora, sinônimos, cobrindo igualmente toda a superfície da Terra, pois o planeta e a comunidade humana se confundem num todo único. A presença do homem é um fato em toda a face da Terra e a ocupação que não se materializa é, todavia, politicamente existente.

Essa mudança também traz consequências para as ciências e seus conceitos. Anteriormente, se poderia falar que não havia coincidência entre os conceitos de habitat e ecúmeno em relação à sociedade humana; entretanto, as transformações atuais criam um novo contexto, tornando esta coincidência possível, como bem apontou Santos (2008). Além disso, os próprios conceitos de meio ambiente e natureza vêm sendo redefinidos, na busca de sua adequação a esse contexto, embora essa nova redefinição tenha feito esses conceitos coincidir com os de outras ciências, daí advindo a sobreposição das concepções de meio ambiente, natureza e espaço geográfico.

Certamente, ao longo do desenvolvimento histórico humano, o conceito de natureza passou por diferentes moldes, desde a phisis grega até o organicismo romântico dos idealistas alemães. Desse modo, Cidade (2001, p. 116) ponderou que, ao longo da história da geografia, "diferentes visões de mundo e de natureza têm se apresentado de forma clara como parte constituinte do saber geográfico". Gomes (1996) afirmou que os antagonismos na geografia abundam e que nada mais

\footnotetext{
15 “[...] le jour est proche oú il ne restera plus une seule région des continents qui n’ait été visitée par le pionnier civilisé, et tôt ou tard le travail humain se sera exercé sur tous les points du globe."
} 
são que expressão de uma dualidade fundamental entre dois polos epistemológicos característicos da modernidade e correspondentes a duas concepções diferentes da atividade científica.

Ao mesmo tempo em que conceitos coincidentes podem facilitar a interdisciplinaridade, também têm a possibilidade de servir como armadilha e jogo de poder para afirmar qual disciplina deve cuidar de determinado campo ou assunto do saber. Infelizmente, muitas vezes essa tem sido a prática. Diante dessa questão, o geógrafo Gonçalves (1989) postulou que o conceito de meio ambiente deveria ser abandonado, vez que poderia até mesmo significar um ambiente pela metade. Não queremos partir para um fundamentalismo epistemológico e conceitual, porquanto para os nossos propósitos, a geografia possui outros conceitos que podem abordar o tema de forma menos problemática. Evidentemente, o termo "questão ambiental", entre outros, já foi apropriado pelas práticas sociais no cotidiano; portanto, querer abandoná-los na linguagem do senso comum seria como abandonar a palavra sanduíche para adotar a expressão duas metades de pão com um recheio no meio.

Ainda complementando essa questão, Fazenda (1994, p. 30, grifo nosso) relatou que, no fim do século $\mathrm{XX}$, a interdisciplinaridade tem sido levada adiante a partir de quatro caminhos: "1. reter ou reinstalar a idéia de unidade e sínteses; 2. emergência de programas organizados de pesquisa e ensino; 3. alargamento das disciplinas da ecologia; 4. surgimento de movimentos de identificação interdisciplinar."

Esse "alargamento das disciplinas da ecologia" faz referência justamente ao processo de "ecologização" dos estudos da relação entre o homem e natureza, que várias vezes é expresso pelo olvido da geografia, apesar de utilizar alguns de seus conceitos sob outros rótulos. Odum (2006, p. 261, tradução nossa) apontou que "para muitos, a 'ecologia' agora significa 'a totalidade do homem' e o ambiente". 16 Um exemplo disso pode ser notado na obra de Leff (2006, p. 74), na qual o autor indicou que: "O conceito de meio está implícito, desta forma, no objeto da biologia evolutiva, da antropologia estrutural e da economia política" - apenas no objeto dessas três ciências. Embora Leff (2006) tenha mostrado ser contra uma "ecologização", por outro lado, apesar de não ter afirmado explicitamente, pretendeu justificar a não vinculação da geografia e seu objeto de estudo ao conceito de meio a

16 "To many, 'ecology' now stands for 'the totality of man' and environment." 
partir das conclusões a que chegou o filósofo Canguilhem (1971 apud LEFF, 2006, p. 74):

A partir daí podemos compreender o prestígio da noção de meio para o pensamento científico moderno. O meio transforma-se num instrumento universal de dissolução das sínteses orgânicas individualizadas no anonimato dos elementos e movimentos universais [...]. O meio é, na verdade, um puro sistema de relações sem suportes.

A última frase da citação chama a atenção: "O meio é, na verdade, um puro sistema de relações sem suportes". O significado dado ao conceito de meio, nesses termos, o torna tão abstrato a ponto de fossilizá-lo, inclusive para a biologia e a ecologia, porquanto, até o momento, somente temos conhecimento de vida no planeta Terra. Assim, não há uma biologia e uma ecologia extraterrestres e isso já envolve a existência de um suporte. ${ }^{17}$ Claval (1984, p. 149, tradução nossa) ponderou que "toda vida humana repousa sobre um suporte material do qual ela toma emprestado aquilo que lhe é indispensável". ${ }^{18}$ Consequentemente, essa acepção de meio a torna inaplicável para o estudo das relações entre os homens e o meio. De fato, a noção de meio dada por Canguilhem (1971 apud LEFF, 2006) serve muito mais ao estudo de microorganismos que ao estudo das relações entre homem e meio.

Por fim, para a garantia de sua existência, essas relações necessitam de um espaço que não é bidimensional (enquanto suporte), mas multidimensional, tanto em termos absolutos (há ainda uma terceira dimensão) como em termos relativos, em decorrência de seus diferentes conteúdos sociais, para poder dar conta das relações entre sociedade e natureza.

Com base nessa acepção de meio, Leff (2006, p. 74) chegou à seguinte conclusão:

\begin{abstract}
Esta concepção de meio como um sistema de relações entre os organismos e entre estes e seu entorno precedeu o conceito de ecossistema, objeto da ecologia. Por sua vez, a noção de meio tem estado associada com as análises sistêmicas aplicadas ao estudo das inter-relações de um conjunto de objetos, variáveis, fatores e processos. Contudo, o meio não constitui propriamente o objeto de nenhuma ciência, e nem é o campo de articulação das ciências centradas em seus objetos de conhecimento, organizadores de processos materiais específicos. Por isso, as pretendidas ciências ambientais são inexistentes.
\end{abstract}

${ }^{17}$ De acordo com Ferreira (2004, p. 758), o conceito do substantivo "suporte" é: "1. que suporta algo; 2. aquilo em que algo se firma ou se assenta".

${ }_{18}$ "Toute vie humaine repose sur un support matériel auquel elle emprunte ce qui lui est indispensable." 
Assim, a partir do conceito de meio exposto por Canguilhem (1971 apud LEFF, 2006), Leff (2006) justificou o fato de não haver nenhuma ciência que o utiliza como objeto de estudo, nem mesmo a ecologia, vez que esta já se sustenta no conceito de ecossistema. Contudo, o autor somente pôde chegar a essa conclusão partindo do princípio que a geografia estuda o meio enquanto superfície terrestre, espaço absoluto, "teatro da humanidade" na acepção dada por Herder (1863 apud MORAES, 1989). Perroux (1961 apud BEAUJEU-GARNIER, 1971, p. 57, tradução nossa), por sua vez, advertiu que "[...]o espaço geográfico não é puramente este espaço físico no qual seu papel seria mais ou menos determinista". ${ }^{19}$ Ou seja, Canguilhem (1971 apud LEFF, 2006) levou em conta uma noção de geografia bastante incompleta, já que existem várias tradições nesta ciência e, portanto, direta ou indiretamente, essas correntes acabam participando das discussões acerca desta questão.

Podemos distinguir pelo menos três concepções de geografia ao longo da história do pensamento geográfico. Uma delas se sustenta no estudo das relações entre homem e meio geográfico. Moraes (2007, p. 6), ao analisar essa concepção, informou que ela "expressa o mais intenso debate do pensamento geográfico". Levando-se em consideração essa tradição bastante consolidada na geografia, a partir de Alexander Von Humboldt, Friedrich Ratzel, Vidal de La Blache, Maximillien Sorre entre outros, e adotando uma acepção diferente de meio que não a utilizada por Leff (2006), pode-se afirmar que esta ciência possui como objeto de estudo não somente o meio (físico) como também o meio geográfico apropriado e socializado pelo homem, que é a acepção buscada pelos significados mais recentes de meio ambiente apresentados anteriormente. Claval (1984, p. 149, tradução nossa) apontou que "[...] a geografia contemporânea parte de uma análise das relações de grupos e de seu meio, mas ela vai ainda mais longe, uma vez que ela acrescenta os modelos de sociedade e de homem aos modelos ecológicos". ${ }^{20}$

Ademais, a afirmação anterior de Leff (2006, p. 74) de que "[...] a noção de meio tem estado associada com as análises sistêmicas aplicadas ao estudo das inter-relações de um conjunto de objetos, variáveis, fatores e processos", também se

\footnotetext{
19 “[...] l'espace geographique n'est pas purement cet espace physique dont le role serait plus ou moins deterministe."

20 "[...] la géographie contemporaine part d'une analyse des relations de groupes et de leur environment, mais elle va plus loin, puisqu'elle ajoute aux modèles écologique des modèles de la société et des modèles de l'homme."
} 
relaciona ainda a uma segunda corrente, que parte de uma geografia enquanto ciência do espaço. Note-se, por exemplo, a semelhança entre esse conceito de meio ressaltado por Leff (2006) e a definição de espaço de Santos (1999), que a trata como um conjunto indissociável de sistemas de objetos e sistemas de ações. Porém, a definição de espaço do geógrafo brasileiro vai ainda mais adiante, como ele mesmo advertiu:

Não se trata de sistemas de objetos, nem sistemas de ações tomados separadamente. Nem tampouco se trata de reviver a proposta de Berry \& Marble (1968) fundada na teoria de sistemas então em moda e segundo a qual "todo espaço consiste em um conjunto de objetos, os caracteres desses objetos e suas inter-relações" [...] (SANTOS, 1999, p. 51).

Embora não se possa falar em ciências ambientais no sentido apresentado por Leff (2006), em pelo menos uma das três correntes do pensamento geográfico se pode apontar a geografia como a ciência que estuda o meio geográfico a partir dos conceitos interdisciplinares trabalhados pelas ciências auxiliares. Isso não significa submeter a geografia a qualquer conceito de outras disciplinas e muito menos a métodos e propósitos que não os seus, mesmo porque a geografia realiza uma síntese das regiões e não das ciências. Assim, essa interdisciplinaridade deve se dar de forma consciente e crítica e não de forma radical e generalizada, pois isso levaria a uma "não-geografia" e a uma "posição perigosa" para esta ciência (BEAUJEU-GARNIER, 1971, p. 10), bem como a patologias epistemológicas, como o ecletismo (OLIVEIRA FILHO, 1995).

Ao apontar essas considerações, não queremos desconsiderar a ecologia; aliás, ela é necessária e sempre esteve em profundo contato com a geografia, vez que essas duas ciências sempre caminharam juntas. $\mathrm{Na}$ primeira edição do conhecido Journal of Political Ecology, Greenberg e Park (1994, p. 2, tradução nossa) ressaltaram que a

A ecologia começou como um tipo de geografia com algumas discussões gerais e inocentes sobre clima, temperatura ou altitude nos sistemas biológicos. Autores alemães, como Humboldt e Haeckel, foram os primeiros a desenvolver essas ideias. ${ }^{21}$

Claval (1984, p. 155) esclareceu que o desenvolvimento do conceito de biocenose por Tamsley, a partir de 1935, possibilitou também o maior

21 "Ecology began as a form of geography with somewhat general and naïve discussions of the role of climate, temperature, or altitude on biological systems. German writers, such as Humboldt and Haeckel, were the first to develop these ideas." 
desenvolvimento da geografia no estudo das relações entre homem e meio. Odum (2006, p. 261, tradução nossa) observou que:

Antropólogos e geógrafos há muito tempo se preocupam com o impacto do homem sobre o seu ambiente e desde cedo vêm debatendo a questão: até que ponto o contínuo problema do homem com ambientes deteriorados derivou do fato de a cultura humana tender a se desenvolver independentemente do ambiente natural? ${ }^{22}$

No entanto, o que percebemos atualmente é uma tendência em diminuir ou mesmo substituir o papel da geografia pela ecologia nos chamados estudos ambientais. Nesse sentido, Mendonça (1993, p. 23) expôs o seguinte:

Observando-se a história da evolução da ciência moderna, percebe-se que a geografia é a única ciência de cunho ambientalista lato sensu desde a sua origem, sendo que as outras são mais específicas no tratamento da referida temática. Para se ter uma idéia, duas das ciências mais ligadas ao estudo da natureza, desde sua origem e em função de suas especificidades, desenvolveram seus estudos de maneira bastante diferenciada do que hoje se entende por meio ambiente: a biologia, por exemplo, embora produza inúmeros e valiosos conhecimentos para a compreensão do meio natural, jamais envolveu o homem como ser social em sua análise, e a ecologia, proposta enquanto ciência somente nos anos 30 de nosso século, está muito mais próxima do estudo da natureza dissociada do homem até porque seu pressuposto metodológico básico - o ecossistema - é de cunho eminentemente naturalista. Mesmo mais recentemente, introduzindo abordagens como a ecologia humana ou a ecologia urbana, ainda assim ela deixa muitas lacunas enquanto ciência que sozinha englobaria todo o tratamento do ambiente.

Evidentemente, a responsabilidade é nossa também, pois, como bem advertiu Seabra (1984), o surgimento da ecologia e a desconsideração em relação à geografia se deram pela própria fragmentação das disciplinas dentro desta ciência, pois cada vez mais estamos diante de geomorfologia, climatologia - em separado e não de uma abordagem sintetizadora de algo ainda mais complexo com o fito de incorporar o homem. À vista disso, a própria geografia também oscilou em seu desenvolvimento teórico-metodológico, titubeando entre um enfoque geral ou regional, nomotético ou idiográfico.

Apesar dessas incongruências, não se justifica a negligência em relação às contribuições da geografia. Afinal, não habitamos a grande mãe Terra, Gaia, Pacha Mama? Levar em conta os subsídios proporcionados pela geografia é (re)conhecer a

\footnotetext{
22 "Anthropologists and geographers have long been concerned with the impact of man on his environment and early debated the question: To what extent has man's continuing trouble with deteriorated environments stemmed from the fact that human culture tends to develop independently of the natural environment?"
} 
nossa grande mãe, que nos acolhe a cada instante. Nesse contexto, a geografia é de fundamental importância para a discussão das relações entre sociedade e natureza.

\section{2 "Ambientalização" dos conflitos sociais ou "socialização" dos conflitos: por uma ontologia do confronto de territorialidades}

Essa "ecologização" excessiva da crise de civilização por que temos passado ocasionou algumas patologias na forma de pensar e compreender alguns problemas. Talvez uma dessas patologias seja a criação de uma nova semântica em profusão dentro das ciências. Alguns termos ainda pouco desenvolvidos nem sempre dão origem a novos objetos e conceitos com conteúdos diferentes, mas simplesmente dão nomes diferentes a conceitos e objetos com conteúdos iguais. Por exemplo, o que anteriormente era um conflito social visando melhores condições de trabalho, hoje semanticamente se "transformou" em conflito ambiental ou socioambiental, dependendo das posições ideológicas dos participantes.

Fala-se em socioambientalismo como um paradigma pleiteando não apenas

[...] sustentabilidade estritamente ambiental - ou seja, a sustentabilidade das espécies, ecossistemas e processos ecológicos - como também a sustentabilidade social - ou seja, contribuir para a redução da pobreza e das desigualdades sociais e promover valores como justiça social e equidade (GUIMARÃES, 2001 apud SANTILLI, 2005 p. 34).

No entanto, isso não prova necessariamente a existência de um novo tipo de conflito. Como bem exprimiu Barbanti Júnior (2002, p. 7):

O problema é que uma chamada questão "ambiental", por exemplo, a extração ilegal de madeira numa reserva indígena por ex-trabalhadores rurais sem terra, pode envolver questões agrárias, trabalhistas e de gênero, além de outras várias. Mas este é um conflito agrário ou um conflito ambiental?

Por outro lado, ao se preocupar também com a redução da pobreza, o paradigma socioambiental implica conflitos sociais de classe. Abordando, a degradação natural e os conflitos sociais, o geógrafo Gonçalves (1989, p. 117-118) indicou que: 
Antes de qualquer outra coisa, é preciso dizer bem claramente que este não é um problema recente. Em 1844, F. Engels já abordava a questão em seu excelente livro $A$ situação da classe trabalhadora na Inglaterra. Assim, enquanto o problema do ar poluído, do barulho, da água infectada, das casas insalubres foi sentido exclusivamente pela classe operária, poucos foram os que se levantaram para o apontar e combater. Hoje, quando o capitalismo se aprofundou e a poluição já não atinge somente a classe operária, mas também os segmentos da pequena-burguesia - a chamada classe média - a degradação da natureza ganha espaço nos jornais, nas emissoras de rádio e televisão. Em síntese, invade, através do discurso, todos os cantos. Eis aí a primeira razão para tanto estardalhaço sobre o tema. Se tivéssemos visitado as favelas e os bairros periféricos de nossas cidades há cerca de 20 ou 30 anos atrás [sic], veríamos que o problema, de fato, não é novo, nem é simplesmente um problema ecológico [...]

Esse tema também foi abordado por Gleick (2008) em sua análise sobre o surgimento de tensões sociais e o uso dos recursos hídricos ao longo da história humana. O geógrafo norte-americano relatou a ocorrência de centenas de conflitos nos quais a água esteve envolvida, seja como arma de guerra, seja como objeto de poder a ser conquistado. Lasserre e Descroix (2005) também se referiram a vários conflitos em que os recursos hídricos estiveram envolvidos desde 1913 até 2005. Desse modo, percebe-se que tensões envolvendo, de alguma forma, os recursos hídricos não são recentes e, portanto, não estamos falando de um novo tipo de conflito. Tampouco os dois estudos mencionados constataram mudanças substanciais na forma como os recursos hídricos se relacionam a tensões, porquanto, desta feita, estamos falando de relações ontologicamente novas.

Atualmente, vem se comentando a respeito de uma "ambientalização" dos conflitos. Como os próprios autores citados colocaram, a palavra "ambientalização" está escrita entre aspas porque somente se refere a um novo tipo de percepção, porquanto ontologicamente, os conflitos atuais são de mesma natureza que aqueles de tempos passados. Para Lopes et al. (2004, p. 17):

O termo "ambientalização" é um neologismo semelhante a alguns outros usados nas ciências sociais para designar novos fenômenos ou novas percepções de fenômenos. Assim, os termos industrialização ou proletarização (este último usado por Marx) foram indicativos de novos fenômenos no século XIX, como se poderia também falar de tendências de "desindustrialização" e de "sub-proletarização" desde o final do século XX. Ou ainda, num sentido estrito, os termos usados por Norbert Elias para caracterizar processos históricos passados percebidos de forma nova como importantes, tais como "curialização" - designativo da formação de sociedades de corte européias entre os séculos XIV e XVIII - ou "esportificação" - ganharam o mundo no século XX a partir da Inglaterra do século XIX [...] O sufixo comum a todos esses termos indicaria um processo histórico de construção de novos fenômenos, associado a um processo de interiorização pelas pessoas e pelos grupos sociais [...] 
Nessa perspectiva, muitos autores vêm tentando construir um novo tipo de conflito sob o rótulo de socioambiental. Como afirmamos anteriormente, o conceito de ambiente ou de meio ambiente é problemático e o próprio termo socioambiental implica formas de tentar remediar aquilo que já nasceu deficiente. Isso fica evidente na explicação do termo por Mendonça (2001, p. 117):

\begin{abstract}
Ainda que tendo sido ampliado e se tornado mais abrangente, o termo meio ambiente, ou ambiente (estes sim podendo ser tomados como sinônimos), parece não conseguir desprender-se de uma gênese e uma história fortemente marcadas por princípios naturalistas, o que leva a crer que tenha sido gerada uma concepção cultural do meio ambiente que exclui a sociedade da condição de componente/sujeito, mas a inclui como agente/fator. Inserir na abordagem ambiental a perspectiva humana portanto social, econômica, política e cultural - parece ser um desafio para toda uma geração de intelectuais, cientistas e ambientalistas que se encontram vinculados a tais discussões no presente, e certamente também no futuro próximo. Observa-se assim, na atualidade, diante de tão importante desafio, uma forte tendência à utilização, de forma ampla, do termo socioambiental, pois tornou-se muito difícil e insuficiente falar de meio ambiente somente do ponto de vista da Natureza quando se pensa na problemática interação sociedade-natureza do presente [...] o termo sócio aparece, então, atrelado ao termo ambiental para enfatizar o necessário envolvimento da sociedade enquanto sujeito elemento, parte fundamental dos processos relativos à problemática ambiental contemporânea.
\end{abstract}

A utilização do termo também não é consensual, pois pesquisadores franceses e anglo-saxões não utilizam os termos socioenvironemental e socioenvironmental, respectivamente, mas sim socio-écologique e socio-ecological. A utilização do hífen separando o social do ecológico tem gerado certo desconforto para os próprios criadores do termo, uma vez que transmite a ideia de que o âmbito social estaria separado do ecológico. O economista Veiga (2007) comentou que o termo socioambiental, como uma gíria, veio para ficar, sendo comumente empregado por pesquisadores de língua portuguesa, assim como pelos de língua espanhola, com exceção da Bolívia.

Então, surge a pergunta: mas, por que a Bolívia não adota esse termo? O que o autor não explica é que para a maior parte dos bolivianos, em sua maioria indígenas, nunca existiu uma dicotomia entre sociedade e ambiente, como claramente expôs o geógrafo Moreira (1982, p. 105):

É fato que a unidade homem-meio só existe como dicotomia nas condições concretas do modo capitalista de produção. Inexiste na consciência dos homens nos modos de produção anteriores por não fazer parte da sua existência real. Para estes homens, o homem e a natureza compõem perceptivelmente uma identidade. Enquanto "ente exterior", a natureza não passa de uma abstração cuidadosamente cultivada pelo capital, com a preciosa ajuda da geografia. Só é uma realidade concreta sob as 
determinações do modo capitalista de produção. Se não basta a evidência de que o homem é um "animal social" ou de que é "o estágio superior da escala da evolução natural", pode-se lembrar ainda que a força de trabalho com que o homem erige a civilização e produz o capital é ela mesma natureza.

Embora o capitalismo venha se embrenhando de forma crescente na Bolívia, - imaginário popular e a forte cultura andina marcam continuamente a Weltanshaung (visão de mundo) dos bolivianos. Corroborando essa concepção, e mesmo adicionando mais um aspecto contrário à utilização do termo conflito socioambiental, é fato que na língua nativa boliviana - aymara -, a palavra conflito (ch'axwa) significa desarmonia tanto com a comunidade como com a natureza (NICOLAS; FERNÁNDEZ; FLORES, 2007). Dessa forma, o próprio significado de conflito (ch'axwa) em aymara já denota a ideia que o termo socioambiental quer designar no conceito de conflito socioambiental em português. Portanto, na cosmovisão andina, seria uma redundância desnecessária a aplicação do termo conflito socioambiental, sendo, dessa forma, não muito aceito pelos pesquisadores bolivianos.

A questão é ainda mais complexa do que apenas um problema etimológico. Ao discorrer acerca do conceito de conflito ambiental, Alonso e Costa (2002, p. 47) esclareceram que:

A definição do termo é em si mesma um problema, com usos polissêmicos na literatura. Alguns autores relacionam tais conflitos ao modelo de desenvolvimento econômico (Frota, 2001). Outros ressaltam que um conflito ambiental emerge toda vez que dada atividade econômica produz um "efeito perverso" sobre o estoque de recursos naturais ou sobre a "qualidade de vida" de dado grupo social (Braga, 2000).

O que vem a ser um conflito ambiental ou socioambiental? A concepção de conflito socioambiental ou ambiental é fortemente discutível no meio acadêmico, uma vez que ontologicamente não se trata de um novo tipo de conflito. Trata-se, então, de uma forma diferente de percepção do conflito? Entretanto, somente uma percepção diferente de algo que sempre esteve latente não é suficiente para criar uma nova categoria de conflito. Se assim fosse, teríamos tantos diferentes tipos de conflitos quantas fossem as diversas percepções sobre eles. E, muitas vezes, as percepções e suas versões do conflito são conflitantes. Todas essas questões serão mais bem discutidas no tópico 4 desta tese, intitulado "Marte ou Minerva: quando a guerra da água é menos letal que as relações de poder". 
Como decorrência desses pontos discutidos, a Guerra da Água está sendo estudada neste trabalho a partir de um recorte que não visou destacar apenas a abordagem ambiental, mas que procurou compreender como a temática ambiental e outras dimensões (política, econômica, cultural) se relacionam com este fato social. Porém, para estudar a Guerra da Água a partir da nova concepção de segurança ambiental e do enfoque da geopolítica crítica, não podemos inseri-la tão-somente na categoria conflito, já que este termo não abrange os objetivos daqueles dois conceitos em sua totalidade. Por isso, utilizamos o vocábulo conflito aliado à categoria relações de poder. Dessa forma, a Guerra da Água passou a ser caracterizada por um conjunto de relações de poder manifestado a partir das territorialidades, podendo ser contestadas por meio dos conflitos. Privilegiamos, assim, um corte ontológico, em detrimento de um corte epistemológico do objeto de estudo.

A partir das considerações anteriores, surgiu o impasse sobre como harmonizar os conceitos relações de poder e conflito. Na verdade, os dois conceitos são complementares, porque representam fases distintas das relações entre as diferentes territorialidades. É possível compreender essa complementaridade a partir do estratagema de Clausewitz (2005), autor que defendeu a ideia de que a guerra é a continuação da política por outros meios, isto é, quando as relações de poder não são mais suficientes para manter "silenciosamente" o status quo vigente até aquele momento, então elas são contestadas e desafiadas. Assim, quando os atores tomam consciência das relações de adversidade, surge o conflito social, que pode desencadear o confronto violento entre as partes. Por outro lado, Foucault (2005) demonstrou que a recíproca também é verdadeira ao inverter o enunciado e postular que a política é a continuação da guerra por outros meios. Essas relações de poder e conflitos se materializam no território a partir de configurações territoriais e de suas formas (BECKER, 1983).

Nessa perspectiva, Raffestin (1993) foi bem explícito ao afirmar que os sistemas de tessituras, de nós e de redes organizadas hierarquicamente permitem assegurar o controle sobre aquilo que pode ser distribuído, alocado e/ou possuído. Permitem, ainda, impor e manter uma ou várias ordens. Assim, enquanto a manutenção da ordem territorial for possível por meio do uso das ideologias geográficas, as relações de poder seriam mantidas. Evidentemente, as 
territorialidades são dinâmicas e estão em transformação, e quando as relações de poder não são suficientes para manter a ordem vigente e são desafiadas por outros atores, a configuração territorial existente sofre mudanças profundas por meio do consenso ou de conflitos violentos. Portanto, os confrontos violentos significam uma ordem rígida territorial entre dois períodos com configurações territoriais diferentes e flexíveis, o que Raffestin (1993, p. 170) denominou "mudança de tessitura".

Ademais, não visamos separar ou isolar a questão ambiental das outras dimensões do conflito e das relações do poder, uma vez que, ao se separar essas dimensões e mesmo ao isolá-las, não se poderá obter como resultado final a compreensão da interação entre as dimensões do conflito. Frisamos, outrossim, que considerando a definição tão difundida de Foucault (2005) sobre a multidimensão do poder, seria inconsistente de nossa parte optar por um recorte epistemológico e reducionista do objeto de estudo.

Mais do que simplesmente caracterizar o conflito como multidimensional, o conflito é um momento não apenas de transformação social, mas também de transformação do confronto entre territorialidades. Dessa forma, o conflito traduz um momento de reestruturação das forças que agem sobre o território, originando novo arranjo territorial. Nesse sentido, refletimos a respeito da ontologia do conflito a partir do confronto de territorialidades e redes.

\subsection{Escalas, temporalidades e conceitos: refletindo sobre o curso a ser navegado}

Com o fito de trabalhar o objeto de estudo em sua totalidade, sugerimos alguns conceitos que nos auxiliarão nesta árdua tarefa. A proposição desses conceitos visa confrontá-los entre si e discuti-los mais profundamente nos itens 3 , "Indra: deus da guerra ou da água?", e 4, "Marte ou Minerva: quando a guerra da água é menos letal que as relações de poder". Após a discussão, eles serão enfrentados pelo caso estudado (Guerra da Água). Essa medida tem o intuito de propiciar a realização de um processo heurístico ao final do trabalho, quando as contribuições teóricas serão comparadas com as particularidades da região e do caso estudado. 
Nos últimos anos, tem havido uma tendência dos estudos securitários em resgatar a geopolítica como base para se estudar a relação entre recursos naturais e conflitos. Para autores como Deudney (1999), Matthew (2002b) e Brown (2008), a geopolítica foi a disciplina precursora do que hoje se procura estabelecer como segurança ambiental. Naturalmente, esses estudiosos ressaltaram que o resgate da geopolítica não significa retomar todos os conceitos e métodos desta ciência, mas resgatar alguns conceitos de forma crítica, uma vez que, após o surgimento do nazismo, houve tendência em vulgarizar a geopolítica clássica como ciência do mal que deveria ser esquecida.

Evidentemente, esse reconhecimento da importância da geopolítica por parte de cientista políticos e de outros acadêmicos não surgiu do nada. Em primeiro lugar, foi necessária uma rearticulação dos seus conceitos e conhecimentos, levada a cabo inicialmente na França no final da década de 1970 e no Brasil no começo dos anos 80, o que ficou conhecido como geopolítica crítica. O grande atributo dessa corrente foi chamar a atenção para as relações pacíficas e conflitivas entre Estados, bem como levar em conta tanto as relações de poder, como os conflitos que vinculam atores em diferentes escalas.

Dessa forma, o conceito de segurança foi rearticulado como proteção não apenas do Estado, das instituições governamentais e do território nacional, mas também da vida humana e do estoque de recursos naturais, de forma que pudessem ser garantidos alimento, água, saúde e segurança pessoal tanto aos indivíduos como às comunidades (MYERS, 1993; OPSCHOOR, 1996). Por consequência, a segurança ambiental se refere também às condições ambientais necessárias a uma vida digna, aludindo não somente a confrontos violentos (agressão física), mas igualmente à agressão estrutural (GALTUNG, 1980), representada pelas relações de poder que afetam a vida das pessoas "ocultadas" pelas práticas sociais no cotidiano.

Porém, ao lidar com a segurança de indivíduos e de comunidades, o território se torna um aspecto importante, porque é apropriado a partir das práticas sociais e, assim, nele estão materializadas inúmeras relações de poder. Levando em consideração tanto essas transformações do conceito de segurança e suas implicações para as questões ambientais como a escala de análise, a nova geopolítica contribuiu muito para a melhor compreensão do problema. A geopolítica, como grade analítica da estratégia territorial de diversos atores em diferentes 
escalas, propicia melhor compreensão das relações de poder e seus efeitos acerca da "nova" segurança ambiental dos cidadãos.

Entendendo territorialidade como a face vivida do poder e a representação da oposição do local ao global (BECKER, 1983; RAFFESTIN, 1993), fica claro que este termo apresenta, de forma mais explícita, as relações de poder com as quais o conceito atual de segurança ambiental visa trabalhar em determinado território. Diante disso, destituem-se também a visão apenas unidimensional baseada no Estado e a visão individualista centrada nos cidadãos. Assim, evita-se o embate entre o holismo (segurança nacional) e o individualismo metodológico (segurança humana) e busca-se uma visão mais completa do problema, compreendendo a relação entre o local e o global (DALBY, 2002). Outra vantagem proporcionada pela análise territorial é a melhor compreensão dos fluxos, não só dos naturais como também daqueles modificados pela implantação de diferentes objetos e redes técnicas sobre o território, significando uma relação entre lugares que anteriormente não existia.

Utilizando-se a geopolítica crítica vinculada aos recursos hídricos, pode-se refletir sobre as relações entre tensões e recursos hídricos das quais diferentes atores fazem parte. À vista disso, uma geopolítica voltada a refletir sobre os recursos hídricos não se limita aos conflitos violentos entre Estados, mas engloba também as relações de poder entre diferentes protagonistas em suas diferentes escalas de atuação. Esse enfoque evita o discurso apocalíptico de que os conflitos internacionais relacionados à água seriam os de maior impacto. Na verdade, tanto os conflitos da escala intranacional como os da internacional devem ser considerados, pois afinal estas duas escalas não possuem uma fronteira rígida entre si, vez que em um conflito local, agentes que atuam na escala internacional, como as empresas multinacionais, podem estar em litígio com atores da escala local, tais como os movimentos sociais. Assim, os conceitos de conflito internacional e intranacional se perderam, o que pode ser considerado uma das contribuições da geopolítica crítica (GIBLIN, 2003; LACOSTE, 2001; PIRES DO RIO, 2006; REUBER, 1999).

Quando discorremos acerca de geopolítica crítica, que pode ser utilizada para refletir sobre os recursos hídricos, não pretendemos inferir que os conflitos, as tensões e as relações de poder versam exclusivamente sobre o tema água. É fato 
que existem inúmeras outras relações além daquelas ligadas aos recursos hídricos que podem realmente contribuir para o conflito social (BARNETT, 2001; LACOSTE, 2001). A água pode ser apenas um fator de sublimação de tensões entre protagonistas de crises muito mais profundas, como sugere o conceito de ambivalência de Freud (BAECHLER, 1999; COSER, 1956). Por essa razão, recortes dos tipos conflito ambiental ou socioambiental não contribuem para a correta interpretação de todas as dimensões envolvidas em um conflito social, impedindo a compreensão teórica mais ampla das características essenciais desses embates (BARBANTI JÚNIOR, 2002; BAUMAN, 2001; TOURAINE, 1989). Foucault (1976) fez a mesma ressalva ao afirmar que as relações de poder não estão em posição de exterioridade no que diz respeito a outros tipos de relações (econômicas, sociais, culturais), mas são imanentes a elas. Sendo assim, grande parte dos estudos sobre conflito e recursos naturais tem evitado o recorte conflitos por recursos naturais (HOMER-DIXON, 1999; LE BILLON, 2001b).

Faz-se necessário lembrar, a partir do método regional, que para refletir sobre a atuação dos diferentes protagonistas em um dado lugar, precisamos visualizar o contexto em que a interação entre eles se dá. Por isso, a região se torna um conceito importante, sobretudo porque existem várias tensões "locais" e em escalas maiores que se materializam na região. Por isso mesmo, várias tensões de escalas maiores se cristalizam na região a partir das condições ali existentes, sendo uma interação entre aspectos de diferentes escalas. Isso é justamente o que o conceito de shatterbelt procura enfatizar, ou seja, a escalada de tensões pela sobreposição de disputas entre atores de diferentes escalas (KELLY, 1986).

O presente estudo se desenvolveu a partir de três dimensões relacionadas entre si: 1) a caracterização do objeto de pesquisa; 2) a dimensão espacial; 3) a dimensão temporal. A primeira dimensão já foi devidamente explicitada no tópico anterior.

A segunda dimensão, que é a espacial, foi realizada a partir de uma reflexão multiescalar.

A terceira dimensão, que é a temporal, enfocou tanto as questões conjunturais (a curto prazo), como as estruturais (a longo prazo). A utilização dessas duas categorias pretende isolar os fatores estruturalmente peremptórios, que continuam ao longo do tempo, dos fatores conjunturais, decisivos a curto prazo. E, 
dessa forma, poderemos analisar se as questões conjunturais não teriam sublimado as tensões provocadas por dissensões estruturais, abordando, assim, a ambivalência. Acreditamos que, na Bolívia, os fatores conjunturais se iniciaram a partir de 1997, quando Hugo Banzer venceu as eleições para a presidência da república. Na ocasião, uma série de políticas públicas para a região metropolitana de Cochabamba foi delineada por seu governo, gerando grande insatisfação em diversas camadas da população. Após a Guerra da Água, esses fatores foram extintos a partir de 2001, quando o impulso ocasionado pela insatisfação com as políticas hídricas foi desviado para a nacionalização de outros setores, como os hidrocarbonetos. Já os fatores estruturais, como as políticas territoriais e a transição política na Bolívia, tiveram início a partir da revolução de 1952 e permanecem latentes até o presente momento.

Os fatores intervenientes na Guerra da Água, quer sejam econômicos, culturais ou políticos, ainda podem ser divididos quanto à sua atuação conforme uma escala temporal relacional em: 1) os que tiveram influência sobre a Guerra da Água; 2) e os que surgiram como efeito da Guerra da Água. Para não utilizar os vocábulos causas e consequências, porque implicam dicotomia, no presente trabalho empregamos os termos fatores estruturantes e fatores estruturados, respectivamente, porquanto se trata de uma relação dialética. Adicionalmente, muitos fatores que influenciaram a deflagração do conflito pela água acabaram se tornando também efeitos ocasionados por ele, por meio dos processos de estruturação.

De forma a compreender as mudanças territoriais entre esses dois períodos, novos estudos têm procurado fazer uma análise a longue durée, assim como no sentido dado por Braudel (1976), a fim de que se possa compreender não somente as variáveis conjunturais, mas também o fenômeno a partir das variáveis estruturais e das mudanças que ocorrem nas relações entre os agentes (BAECHLER, 1999; GIZEWSKI; HOMER-DIXON, 1998; HOMER-DIXON; BLITT, 1998; HOWARD; HOMER-DIXON, 1998; KELLY; HOMER-DIXON, 1998; LE BILLON, 2005; PERCIVAL; HOMER-DIXON, 1998). Além disso, os estudos em profundidade temporal visam compreender as tensões passadas com o intuito de evitar falsas conclusões produzidas por meio da ambivalência (BAECHLER, 1999; MATTHEW; FRASER, 2002). 
Em relação à dimensão espacial, até há pouco tempo, os estudos nas áreas de ecologia política e ciências ambientais tinham a tendência de enfocar principalmente a escala local, enquanto os estudiosos das relações internacionais e áreas afins relacionavam a escala global como prioridade para o estudo, sobretudo em relação às possíveis "guerras por água" (KAPLAN, 2000; KLARE, 2002; ESTY et al., 1999). Outras pesquisas ainda focalizaram uma dada dimensão, tal como uma região, de forma rígida, como se entre as diferentes escalas geográficas houvesse fronteiras rígidas (HOMER-DIXON, 1999; LIETZMANN; VEST, 1999). Interessante notar que as diferentes escalas se relacionam pela atuação das redes e, desse modo, não há distinção inflexível (FONT; RUFI, 2001; HARTMANN, 2001; SANTOS, 2005). No sentido de proporcionar uma visão mais global, a geografia pode trazer uma de suas melhores contribuições aos estudos nessa área.

Naturalmente, a escolha das escalas é uma decisão que pode influenciar no resultado final de uma reflexão e, por isso, é de fundamental importância para o presente estudo. A utilização de diferentes escalas não significa um enfoque rígido entre elas, até porque elas se complementam - como Ritter já havia afirmado acerca da relação dialética entre as escalas, de acordo com Moraes (1989). Dessa forma, escolhemos a escala da região metropolitana de Cochabamba com a finalidade de estudar a atuação das diferentes territorialidades e, principalmente, os contrastes entre o urbano e o rural, bem como entre os espaços modernos e os ditos atrasados. Em adição a isso, as escalas nacional, sul-americana e global ganham importância como forma de complementar a compreensão do conflito, principalmente porque inúmeros outros protagonistas dessas escalas atuaram em nível local, influenciando na transformação da configuração territorial.

Dessa forma, o objeto de estudo foi trabalhado a partir de quatro escalas: a área metropolitana de Cochabamba, o espaço nacional boliviano, o espaço de integração sul-americana e o espaço global. $\mathrm{Na}$ região metropolitana de Cochabamba, o estudo visou precipuamente compreender quais fatores contribuíram para o conflito e quais "mudanças de tessitura" o conflito ocasionou, alterando, assim, as várias territorialidades. Para compreender essas diferentes territorialidades, foi necessário analisar o uso do território, bem como a forma pela qual a adição de redes e objetos técnicos transformou as territorialidades e suas relações, formas e funções, especialmente em relação ao acesso aos recursos 
hídricos e ao âmbito étnico e cultural. Com o intuito de abordar essas questões, estudos sobre os fluxos migratórios para Cochabamba, as políticas territoriais bolivianas e a gestão do território, considerados essenciais, foram realizados por meio de pesquisa da literatura especializada, dados estatísticos, fontes bibliográficas e documentais coletadas no trabalho de campo, mapas e entrevistas nãoestruturadas feitas in loco pelo autor em janeiro de 2006.

No espaço nacional, a análise objetivou compreender quais processos se instalaram nessa escala e quais fatores se estruturaram em Cochabamba, constituindo-se em causas da Guerra da Água. Por outro lado ainda, foi necessário determinar quais foram os fatores estruturados da Guerra da Água no âmbito nacional, que efeitos eles ocasionaram sobre a "morfologia do território nacional", mormente em relação às esferas política, econômica e ambiental.

Em relação ao espaço da integração sul-americana, o problema foi abordado com enfoque na posição geopolítica estratégica de Cochabamba dentro do chamado triângulo boliviano (heartland sul-americano). Em decorrência desse fator, Cochabamba tem sido objeto de uma série de projetos de integração e "jogos geopolíticos", sobretudo entre Brasil e Argentina. Além disso, uma série de organismos de integração e atores internacionais, como a Corporación Andina de Fomento (CAF, Corporação Andina de Fomento), a Corani (empresa norteamericana), a Astaldi S. A. (multinacional), o Banco Interamericano de Desenvolvimento (BID), entre outros, investiram ou financiaram projetos de exploração ou abastecimento de água em Cochabamba. Assim, foi nosso intento compreender de que forma a ação desses financiadores influenciou na Guerra da Água, bem como em outras tensões relacionadas aos recursos naturais. Foi necessário, ainda, estudar se a atuação dos protagonistas das escalas maiores teria contribuído para o aumento das tensões em Cochabamba e em escala nacional. Por outro lado, foi preciso abordar os fatores estruturados após a Guerra da Água no espaço de integração sul-americana, levando-se em conta o aumento das tensões. Desse modo, avaliamos se os efeitos dos projetos da integração sul-americana contribuíram para que o conflito fosse desencadeado. Por último, na escala global, verificamos de que forma as redes globais e a implementação do regime neoliberal atuam sobre um determinado lugar, provocando o aumento de tensões. Nesse sentido, muitas vezes o postulado de que as democracias (principalmente as 
liberais) não travam guerras entre si esconde 0 fato de que as tensões internacionais, que eram travadas anteriormente entre Estados, agora podem ser empreendidas por indivíduos pertencentes às escalas maiores contra outros das escalas menores, bem como entre grupos étnicos e transnacionais, assim aumentando o número de guerras civis e conflitos ditos "intranacionais".

A Guerra da Água tem sido o foco de várias pesquisas conduzidas até o momento, havendo considerável acervo de literatura a ser consultado. Porém, a nosso ver, uma boa parte dos estudos apresentados no Quadro 1 falha nas formas de abordar o objeto de estudo.

A primeira falha está em utilizar somente a escala local (região metropolitana de Cochabamba), porquanto é pequena demais para se visualizar as origens e as consequências desse fenômeno, por conta da atuação de uma série de outros protagonistas de escalas maiores que esta. Ao utilizar uma escala menor para analisar o objeto de estudo, não se consegue compreender a ligação desse fato social com outras lutas em outros locais e seus possíveis efeitos em diferentes escalas.

A segunda falha ocorre na caracterização da Guerra da Água como conflito ambiental, o que realmente prejudica o entendimento de outros fatores que estariam na origem ou nos resultados deste fato social. Além disso, construiu-se o sofisma de que a Guerra da Água teria sido apenas um conflito entre a sociedade civil local e a multinacional Aguas del Tunari, responsável pelo saneamento e a distribuição de água. Essa falsa concepção deixa de considerar outras relações de poder no tocante ao acesso aos recursos hídricos em Cochabamba (LASERNA, 2000b; LE BILLON, 2005).

A terceira falha presente na maior parte das pesquisas sobre a Guerra da Água conduzidas até o momento está relacionada a um horizonte temporal muito estreito, o que cria um viés nos estudos, porquanto consideram apenas os aspectos conjunturais e não se ocupam dos aspectos estruturais demonstrados. Não se pode ignorar que a Guerra da Água é o desenlace de uma série de outras tensões e conflitos do passado relacionados aos recursos hídricos. Portanto, uma compreensão profunda desse fato se torna impossível se não forem valorizados os problemas de segurança ambiental pelos quais a cidade de Cochabamba vem passando há tempos. Em contraste, o objeto de estudo não pode ser entendido só 
como um conflito casual, devendo também ser considerado como ponto de ruptura a partir do qual um novo processo se instaura, resultando em aumento substancial do número de conflitos sociais na Bolívia (KOHL, 2006; LASERNA, 2004).

Quadro 1. Estudos sobre a Guerra da Água e suas abordagens metodológicas a partir das dimensões temporal e espacial utilizadas até o momento atual.

\begin{tabular}{|c|c|c|c|}
\hline \multirow{2}{*}{$\begin{array}{l}\text { Dimensão } \\
\text { temporal }\end{array}$} & \multicolumn{3}{|c|}{ Dimensão espacial } \\
\hline & $\begin{array}{c}\text { Escala local (região } \\
\text { metropolitana de } \\
\text { Cochabamba) }\end{array}$ & $\begin{array}{l}\text { Escalas maiores } \\
\text { (departamental, } \\
\text { nacional, sul- } \\
\text { americana, global) }\end{array}$ & $\begin{array}{l}\text { Diversas escalas } \\
\text { integradas }\end{array}$ \\
\hline $\begin{array}{l}\text { A curto prazo } \\
\text { (enfoque } \\
\text { conjuntural) }\end{array}$ & $\begin{array}{c}\text { Assies (2003) } \\
\text { Peredo Beltrán } \\
(2004) \\
\text { Bustamante (2002) } \\
\text { Ceceña (2005) } \\
\text { Ceres (2000) } \\
\text { Crespo e Fernández } \\
\text { (2001) } \\
\text { De la Fuente (2000) } \\
\text { Laserna (2000b) } \\
\text { Daroca Oller (2001) } \\
\text { Peredo Beltrán } \\
\text { (2004) } \\
\text { Maldonado Rojas } \\
\text { (2004) }\end{array}$ & $\begin{array}{l}\text { Courivaud (2005) } \\
\text { Crespo, Fernández e } \\
\text { Peredo (2004) }\end{array}$ & $\begin{array}{l}\text { Kruse e Ramos } \\
\qquad(2003) \\
\text { Kruse e Vargas } \\
\qquad(2001) \\
\text { Laserna (2000a) }\end{array}$ \\
\hline $\begin{array}{l}\text { A longo } \\
\text { prazo } \\
\text { (enfoque } \\
\text { estrutural) }\end{array}$ & $\begin{array}{l}\text { García, García e } \\
\text { Quitón (2003) } \\
\text { Salazar Ortuño } \\
(2000)\end{array}$ & $\begin{array}{c}\text { Kohl (2006) } \\
\text { Laserna (2006) }\end{array}$ & $\begin{array}{l}\text { Herbas Camacho } \\
\qquad(2001)\end{array}$ \\
\hline $\begin{array}{l}\text { Ambos } \\
\text { (enfoques } \\
\text { conjuntural e } \\
\text { estrutural) }\end{array}$ & $\begin{array}{l}\text { Orellana Aillón } \\
\qquad(2004) \\
\text { Crespo (2000a) } \\
\text { Stoehr (2004) }\end{array}$ & $\begin{array}{l}\text { Rocha (2006) } \\
\text { Tapia (2000) }\end{array}$ & $\begin{array}{c}\text { Crespo, Fernández e } \\
\text { Peredo (2004) } \\
\text { Laserna (2004) }\end{array}$ \\
\hline
\end{tabular}

Fonte: Organizado pelo autor. 
Os projetos de integração regional e a implantação do regime neoliberal na Bolívia têm se relacionado a uma série de tensões e conflitos envolvendo os recursos naturais (GRUENBERGER, 1999; MOLINA, 2005; VILLEGAS, 2005). Dessa forma, nossa proposta de estudo da Guerra da Água pode auxiliar no entendimento da relação entre tensões e conflitos e os recursos naturais. Além disso, entendemos que esse fenômeno social ocorrido em Cochabamba pode propiciar novas formas de estudo da relação entre violência e recursos hídricos, uma vez que se trata de um conflito com repercussão internacional e que produziu uma mudança na estrutura de poder até então vigente, estando ainda relacionado ao aumento de embates na Bolívia (LASERNA, 2006).

Propusemos, assim, um exame da Guerra da Água que abranja as escalas local, nacional, sul-americana e global, pois acreditamos que este trabalho poderá oferecer elementos para a análise dos efeitos da implantação do regime neoliberal em países da América do Sul. Consequentemente, a presente pesquisa poderá contribuir para a melhor compreensão dos resultados dos projetos de integração regional sul-americana, vez que a cidade de Cochabamba se encontra no corredor econômico boliviano e, portanto, tem sido alvo da implantação de vários objetos e redes técnicas.

Por essas razões, o presente trabalho apresenta contribuições a partir de uma abordagem pouco explorada do problema. Enfocando a integração das dimensões temporais a curto (conjuntura) e longo (estrutura) prazos, assim como a integração das escalas geográficas, com esta pesquisa visamos apresentar entendimento mais completo do objeto de estudo. Em relação aos dois únicos trabalhos publicados na literatura mundial que já seguiram esse caminho, de Crespo e Fernández (2004) e de Laserna (2004), apenas este último caracterizou o objeto de estudo como conflito social. Entretanto, Laserna (2004) não explorou as escalas da integração sul-americana e global e, então, acabou não explicando vários outros fatores estruturantes e estruturados da Guerra da Água. Por sua vez, Crespo e Fernández (2004) pecaram ao caracterizar o objeto de estudo como conflito ambiental, o que prejudica a compreensão do problema pelas razões apresentadas anteriormente.

Decorridos oito anos da Guerra da Água, acreditamos haver transcorrido tempo suficiente para que uma análise, não somente dos aspectos conjunturais, 
como também das consequências estruturais, possa ser feita a partir de um conjunto de dados inéditos colhidos in loco, em janeiro de 2006, pelo próprio autor desta pesquisa.

No presente estudo de geopolítica, adotamos o enfoque estruturacionista, a partir do qual procuramos invocar os fatores estruturantes e estruturados da configuração territorial, levando em conta precipuamente a atuação das territorialidades. Exatamente por levar em conta essencialmente a estruturação e a reestruturação, a dimensão temporal não pode aqui ser olvidada, como pretenderam os estruturalistas e funcionalistas mais radicais. Ademais, acreditamos que a categoria função deva ser acrescida às nossas considerações, tendo em mente principalmente o papel ou o efeito do conflito na (re)estruturação do arranjo territorial. Nesse sentido, a reflexão funcional defendida por Hartshorne (1950) pode nos trazer uma série de contribuições. Evidentemente, algumas modificações foram feitas em decorrência do contexto e dos objetivos a que este estudo se dedica. $O$ enfoque funcional na geografia política enfatiza principalmente a atuação de forças, tanto internas quanto externas, na organização do território nacional, levando em conta a relação entre as diferentes regiões de um país (COHEN, 1964; HARTSHORNE, 1950). Todavia, para o presente estudo, buscamos englobar a função do conflito necessária para a reestruturação de um novo arranjo territorial levando em conta as territorialidades de diferentes agentes das quatro escalas enfocadas, quais sejam: regional, nacional, sul-americana e global. Ao adotar essa postura, acreditamos que outros fatores, além do fator água, despontam como intervenientes no conflito.

Contudo, o enfoque funcional tradicional de Hartshorne (1950) considera estritamente apenas a relação entre Estados e unidades federativas, ou seja, atores estatais. Naturalmente, no contexto pós-Guerra Fria, essas relações não se restringem aos entes estatais, estendendo-se a diversos protagonistas em escalas menores e maiores, que também influenciam na organização do território como um todo. Nessa perspectiva, acrescentam-se algumas contribuições do estruturacionismo, que ressalta o fato de que agente e estrutura se constituem mutuamente, não havendo precedência ontológica de um elemento sobre o outro. Essa proposta, por sua vez, associa-se ao intenso debate agente-estrutura entre os 
teóricos de sociologia, política internacional e geografia (FLINT, 2006; GIDDENS, 2000; WENDT, 2006).

Levando em consideração a dinâmica dessa reflexão, outras categorias como forma e processo também ganham certa importância. A forma se relaciona ao aspecto visível, ao arranjo ordenado de objetos, redes e, principalmente, dos arranjos territoriais procurando o controle e o acesso aos recursos hídricos. A categoria processo explicita esse movimento objetivando a (re-)estruturação que ocorre por etapas concatenadas. Assim, a mudança de tessitura ocasionada pelo conflito se constitui em um processo. Portanto, para o presente enfoque, as categorias estrutura e função serão salientadas com maior ímpeto, porquanto este estudo objetiva compreender a estruturação e a construção das relações de poder e do conflito por meio da análise territorial.

Tendo em mente essas diretrizes, buscamos, em um momento inicial, retrabalhar o conceito de geopolítica relacionada aos recursos hídricos, especialmente porque nele existe uma tensão clara no que se refere à aplicação de meios militares para questões muitas vezes de cunho civil ou multilateral. Diante disso, por meio das contribuições da geopolítica crítica, procuramos acrescentar novos elementos ao debate sobre a existência de conflitos socioambientais. Deve-se destacar a importância do território e de seu arranjo na compreensão da estruturação de conflitos e tensões, reiteradas vezes não muito latentes.

Em um momento seguinte, utilizamo-nos da geografia regional a fim de verificar as particularidades da região metropolitana de Cochabamba em relação aos outros espaços do território nacional boliviano. Analisando de que formas essas peculiaridades se relacionaram com o conflito, ponderamos, primeiramente, a respeito do arranjo e da densidade territorial - mormente em relação aos recursos hídricos - na área metropolitana de Cochabamba. Outro ponto importante foi a verificação das transformações da tessitura durante a passagem das relações de poder para o conflito e vice-versa.

Após essa apreciação, o movimento de reflexão se dirigiu às escalas maiores, visando analisar de que forma as territorialidades e os fatores dessas escalas influenciaram ou se relacionaram com as transformações territoriais em Cochabamba. Por ter igual relevância, buscamos relacionar a intencionalidade dessas transformações, para o que, tornou-se essencial verificar os fatores que 
levaram Cochabamba a se constituir no locus para a materialização do conflito e de que forma as forças territoriais de outros lugares se fizeram presentes e contribuíram para este evento. Note-se que se trata de uma região estratégica para a integração tanto nacional como sul-americana.

Finalmente, a partir da dimensão temporal, isolamos os fatores estruturalmente peremptórios, os quais continuam ao longo do tempo, dos fatores conjunturais, que são decisivos a curto prazo. E, dessa forma, procuramos analisar se os elementos conjunturais não teriam sublimado as tensões provocadas por tensões estruturais, abordando, assim, a questão já mencionada da ambivalência.

A parte teórica, descrita anteriormente, não pode, contudo, ficar isenta no confronto com a realidade. Portanto, a pesquisa de campo foi realizada com o propósito de colocar a construção teórica frente a frente com a construção empírica. Além de tornar possível a análise de algumas proposições a respeito da Guerra da Água por meio de questionários e entrevistas, o intuito principal da pesquisa de campo foi propiciar familiarização mais profunda com a região estudada. Nesse sentido, ela pode ser caracterizada como exploratória e descritiva (MARCONI; LAKATOS, 2007).

Desenvolvemos a pesquisa de campo entre 18 de janeiro e 8 de fevereiro de 2006. Apenas três dias foram passados fora da região metropolitana de Cochabamba, para coleta de dados bibliográficos e estatísticos no Instituto Nacional de Estadísticas (INE, Instituto Nacional de Estatística) e no Centro de Investigación y Promoción del Campesinado (CIPCA, Centro de Investigação e Promoção do Campesinato) em La Paz, entrevista com o antropólogo Xavier Albó em El Alto e visita a Tihuanako durante a posse do presidente Evo Morales.

Utilizamos diferentes técnicas de pesquisa, como observação nãoparticipante, aplicação de questionário, realização de entrevistas, coleta de dados estatísticos, cartográficos, bibliográficos e documentais. A observação nãoparticipante teve como principais propósitos a observação, a análise e a descrição das diferentes territorialidades no espaço metropolitano de Cochabamba. Também participamos de reuniões da Coordinadora de Defensa del Agua y de la Vida (Coordenadoria de Defesa da Água e da Vida) - que passaremos a chamar aqui de Coordinadora del Agua -, de Associações de Bairros (Juntas Vecinales) e Sistemas de Aguas. Outro aspecto qualitativo da pesquisa foi a produção de fitas de áudio e 
vídeo, as quais utilizamos para a elaboração do documentário em formato DVD, intitulado La Guerra del Agua.

As entrevistas não-estruturadas foram realizadas com os líderes de movimentos sociais, tais como os da Coordinadora del Agua, da Junta Vecinale de Cochabamba, dos Sistemas de Aguas, da Federación Departamental Cochabambina de Organizaciones de Regantes (FEDECOR, Federação Departamental Cochabambina de Organizações de Irrigadores), membros da Asociación de Estudiantes Universitarios de Cochabamba (Associação de Estudantes Universitários de Cochabamba), pesquisadores do conflito, assim como da cúpula da Igreja Católica, que mediou o conflito com a prefeitura e o governo nacional. Durante as entrevistas, procuramos trazer à luz novos fatos, de modo a ensejar reflexão mais profunda para a consecução deste trabalho.

Por intermédio dessas entrevistas, procuramos compreender as diferentes territorialidades no que tange ao acesso e à apropriação dos recursos hídricos e suas motivações em relação à participação nas manifestações da Guerra da Água. Buscamos, ainda, compreender as nuances dessas diversas relações de poder e o que estava sendo desafiado e contestado por intermédio do conflito: somente o conflito da água ou outras questões? Após a realização e a análise das entrevistas não-estruturadas, estas foram divididas de acordo com o seu conteúdo principal (Quadro 2). Optamos pela aplicação de entrevistas não-estruturadas porque as consideramos uma forma espontânea de as pessoas darem o seu relato sobre o conflito.

Os questionários estruturados foram aplicados durante nosso encontro com os representantes da Coordinadora del Agua em Cochabamba, em 3 de fevereiro de 2006, ocasião em que vários participantes deste movimento social estiveram presentes na sede da Federación de Trabajadores Fabriles de Cochabamba (Federação dos Trabalhadores Fabris de Cochabamba) (Apêndice A, B e C). O intuito precípuo dos questionários foi verificar a origem dos recursos hídricos aos quais os participantes da Coordinadora del Agua tinham acesso e a motivação para participar das manifestações. Acredita-se que muitos membros tinham outros interesses no conflito, que iam além da nacionalização da empresa transnacional Aguas del Tunari. 
Quadro 2. Pessoas entrevistadas, sua conexão com o conflito da água em Cochabamba e tópico principal abordado durante as entrevistas, realizadas entre os dias 15 e 30 de janeiro de 2006.

\begin{tabular}{|c|c|c|}
\hline Nome & Ligação com o conflito & Conteúdo \\
\hline Abraham Grandidier & $\begin{array}{l}\text { Presidente da Asociación de } \\
\text { Sistemas Comunitarios de la Zona } \\
\text { Sur (Asicasur, Associação de } \\
\text { Sistemas Comunitários da Zona } \\
\text { Sul) }\end{array}$ & $\begin{array}{l}\text { Motivos da participação no conflito } \\
\text { (zona sul) }\end{array}$ \\
\hline Adalid & $\begin{array}{c}\text { Presidente de Sistema de Água em } \\
\text { Quillacollo }\end{array}$ & $\begin{array}{l}\text { Motivos da participação no conflito } \\
\text { (Quillacollo) }\end{array}$ \\
\hline Amadeo Choque & $\begin{array}{c}\text { Presidente da Organización } \\
\text { Territorial de Base (OTB, } \\
\text { Organização Territorial de Base) } \\
\text { Taquiña }\end{array}$ & $\begin{array}{l}\text { Motivos da participação no conflito } \\
\text { (zona norte) }\end{array}$ \\
\hline Amadeus Peredo & $\begin{array}{c}\text { Líder do Sistema de Água de } \\
\text { Marquina }\end{array}$ & $\begin{array}{l}\text { Motivos da participação no conflito } \\
\text { (zona rural) }\end{array}$ \\
\hline Bautista Lopez & Líder da Junta Vecinal de La Chulla & $\begin{array}{l}\text { Motivos da participação no conflito } \\
\text { (zona rural) }\end{array}$ \\
\hline Carlos Mendoza & Líder da OTB Pacata & Motivos da participação no conflito \\
\hline Flora Condori & $\begin{array}{l}\text { Líder do Sistema de Água de } \\
\text { Ironcollo }\end{array}$ & $\begin{array}{l}\text { Motivos da participação no conflito } \\
\text { (zona rural) }\end{array}$ \\
\hline Franz Taquichiri & Membro da Coordinadora del Agua & $\begin{array}{l}\text { Motivos da participação no conflito } \\
\text { (Coordinadora del Agua) }\end{array}$ \\
\hline Herbert Arce & Guerreros del Água & Motivos da participação no conflito \\
\hline Isidro Ascoy & Líder de Palca Parta & $\begin{array}{l}\text { Motivos da participação no conflito } \\
\text { (zona rural) }\end{array}$ \\
\hline Juan Camargo & $\begin{array}{c}\text { Engenheiro chefe do Servicio } \\
\text { Municipal de Agua Potable y } \\
\text { Alcantarillado (SEMAPA, Serviço } \\
\text { Municipal de Água Potável e Rede } \\
\text { de Esgotos) }\end{array}$ & $\begin{array}{c}\text { Abastecimento de água em } \\
\text { Cochabamba }\end{array}$ \\
\hline Juan Carlos Cabrerizo & Engenheiro do Projeto Misicuni & $\begin{array}{c}\text { Aporte de água e conclusão do } \\
\text { Projeto Misicuni }\end{array}$ \\
\hline Juan Carlos Vilka & Líder da OTB Siglo XX & $\begin{array}{l}\text { Motivos da participação no conflito } \\
\text { (zona sul) }\end{array}$ \\
\hline Marcelo Bandeiras & Guerreros del Água & $\begin{array}{l}\text { Motivos da participação no conflito } \\
\text { (centro) }\end{array}$ \\
\hline
\end{tabular}

Continua 
Conclusão

Quadro 2. Pessoas entrevistadas, sua conexão com o conflito da água em Cochabamba e tópico principal abordado durante as entrevistas, realizadas entre os dias 15 e 30 de janeiro de 2006.

\begin{tabular}{|c|c|c|}
\hline Nome & Ligação com o conflito & Conteúdo \\
\hline Mirta Condori & $\begin{array}{l}\text { Líder do Sistema de Água de } \\
\text { Ironcollo }\end{array}$ & $\begin{array}{c}\text { Motivos da participação no conflito } \\
\text { (zona rural) }\end{array}$ \\
\hline Monsenhor Tito Solari & Mediador no conflito & Mediação e Negociação no conflito \\
\hline Oscar Oliveira & Líder da Coordinadora del Agua & $\begin{array}{c}\text { Motivos da participação no conflito } \\
\text { (Coordinadora del Agua) }\end{array}$ \\
\hline Padre Gregório Iriarti & Mediador no conflito & Mediação e negociação no conflito \\
\hline Padre Moreno & Religioso & Mediação no conflito \\
\hline Ramiro Balderrama & $\begin{array}{l}\text { Estudante da Universidad Mayor de } \\
\text { San Simon (Universidade Maior de } \\
\text { San Simon) }\end{array}$ & $\begin{array}{l}\text { Motivos da participação no conflito } \\
\text { (centro) }\end{array}$ \\
\hline Ricardo Ayala & Diretor do SEMAPA & $\begin{array}{c}\text { Abastecimento de água em } \\
\text { Cochabamba }\end{array}$ \\
\hline Roberto Laserna & $\begin{array}{c}\text { Sociólogo, diretor do Centro de } \\
\text { Estudios de la Realidad Económica y } \\
\text { Social (CERES, Centro de Estudos } \\
\text { da Realidade Econômica e Social) e } \\
\text { mediador }\end{array}$ & Origem e efeitos do conflito \\
\hline Rogelio Cruz & $\begin{array}{l}\text { Presidente da OTB Alto } \\
\text { Cochabamba }\end{array}$ & $\begin{array}{l}\text { Motivos da participação no conflito } \\
\text { (zona sul) }\end{array}$ \\
\hline Ruben Mena & Religioso & $\begin{array}{l}\text { Motivos da participação no conflito } \\
\text { (centro) }\end{array}$ \\
\hline Sandro Aranda & $\begin{array}{c}\text { Pesquisador da Universidad Mayor } \\
\text { San Andres (Universidade Maior de } \\
\text { San Andres) }\end{array}$ & Origem e efeitos do conflito \\
\hline Wilder Bautista & $\begin{array}{l}\text { Líder do Sistema de Água de } \\
\text { Quillacollo }\end{array}$ & $\begin{array}{l}\text { Motivos da participação no conflito } \\
\text { (zona urbana) }\end{array}$ \\
\hline Xavier Albó & Antropólogo & $\begin{array}{l}\text { Contraste entre o urbano e o rural } \\
\text { em Cochabamba }\end{array}$ \\
\hline
\end{tabular}

Ressalta-se, ainda, que a aplicação dos questionários visou somente o universo dos membros da Coordinadora del Agua, obtendo-se uma amostra de 61 indivíduos. Levando-se em conta que o número de participantes dessa organização social atualmente não chega a 2.000, acreditamos que o número de questionários aplicados é significativo. Porém, como não há números precisos sobre a quantidade de participantes durante as fases mais turbulentas do conflito, alertamos que nossa 
amostragem possa não ser significativa para proceder a generalizações. Por isso, ressaltamos que com os questionários e as entrevistas não buscamos generalizar resultados, sendo a função de ambos servir de parâmetro para confronto com as reflexões e as conclusões que possamos tirar por outros meios.

Ainda durante o trabalho de campo, uma série de fontes bibliográficas, hemerográficas, cartográficas e documentais foram coletadas em instituições como CIPCA, SEMAPA, CERES, Coordinadora del Agua, Fundação ABRIL, Prefeitura Municipal de Cochabamba (alcaldia), empresa de abastecimento de água Misicuni, FEDECOR e Centro de Documentación e Información Bolivia (CEDIB, Centro de Documentação e Informação Bolívia).

Finalmente, por meio da coleta de dados estatísticos sobre etnias, acesso aos recursos hídricos e localização (rural/urbana) no INE e pela utilização do sistema de informação geográfica para a construção de cartografias temáticas, intentamos compreender as diferentes territorialidades, bem como de que forma elas se interrelacionam.

No presente trabalho, a empiria foi construída a partir de fontes bibliográficas, fontes documentais, entrevistas, dados estatísticos, questionários e observaçãodescrição do autor. Para conferir maior veracidade a esta construção, os resultados que essas técnicas de pesquisa aportam foram confrontados uns com os outros, pesando-se, para cada caso, não apenas o número dessas técnicas que apontam para um mesmo resultado, mas primordialmente o peso dos fatos e dos argumentos empíricos trazidos por elas. 


\section{INDRA: DEUS DA GUERRA OU DA ÁGUA?}

Na mitologia hindu, o deus Indra representa a deidade do clima, da água e também da guerra. Em certa ocasião, o dragão Vritra roubou toda a água da Terra, levando as civilizações a passar por grave período de seca. Indra andava à procura do dragão quando encontrou vários raios dentro de um baú. Após esse achado, ainda continuou sua saga em busca de Vritra. Quando finalmente o encontrou, Indra o atingiu com os raios encontrados em sua jornada, fazendo jorrar água novamente sobre a Terra. Reza a lenda que, posteriormente, Indra empreendeu várias outras batalhas, sendo por isto comumente invocado em orações antes de grandes batalhas pela civilização hindu. Assim como Indra não pode ser considerado apenas o deus da água, os conflitos sociais também não podem ser considerados exclusivamente ambientais ou por recursos hídricos. Eles são, antes de mais nada, conflitos que envolvem diversas variáveis, entre elas a ambiental.

Alguns autores vêm afirmando a emergência de um novo tipo de conflito: 0 socioambiental. Porém, esquecem-se eles que os homens fazem parte do ambiente. Afinal, o filósofo Blaize Pascal (1887, tradução nossa) não afirmou que "l'homme est le milieu" (o homem é o meio, tradução nossa)? Os seres humanos fazem parte da natureza, assim como também fazem do mundo cultural. Dessa forma, todo conflito social poderia, em essência, ser enquadrado no que se procura salientar com o adjetivo socioambiental. Quando alguns homens divergem entre si, estão em jogo tanto forças culturais como sociais, embora simultaneamente forças naturais também entrem neste conflito.

O objetivo desta parte do presente trabalho é apresentar os diferentes enfoques acerca da relação entre recursos naturais e conflitos sociais. A partir daí, discutimos as propostas para conceituações de novos tipos de conflitos, tais como ambiental e socioambiental. Em seguida, analisamos a relação entre os recursos hídricos e os conflitos sociais sob a perspectiva da guerra por recursos hídricos. Finalmente, propomos uma visão dos conflitos a partir da geografia, com o intuito de melhor compreendê-los. 


\subsection{Histórico dos estudos sobre a relação entre conflitos sociais e recursos naturais}

A origem dos estudos que se preocupam com a relação entre conflitos e recursos naturais pode ser datada desde o século XVIII, com as contribuições de Thomas Malthus e os trabalhos do Marquês de Condorcet. Posteriormente, Karl Marx abordou a questão por meio da economia política. Entrementes, essas visões podem ser consideradas enfoques que ainda não tinham como prioridade a segurança ambiental, mas antes o progresso humano, assim como todo o pensamento iluminista e seus posteriores desdobramentos o fizeram. Dessa forma, nos concentramos nos enfoques que se centram sobre a segurança ambiental após os anos 70 do século $\mathrm{XX}$.

De acordo com o relato de Matthew (2002a), esses estudos se dividem em dois enfoques. O primeiro se fundamenta nos efeitos imediatos da ação antrópica sobre o meio ambiente, particularmente da escassez, e suas implicações para a segurança. De acordo com os seus proponentes, as crescentes mudanças ambientais "[...] já se apresentam como ameaças diretas aos interesses nacionais, à estabilidade regional e ao bem-estar da humanidade" (MATTHEW, 2002a, p. 7, tradução nossa). ${ }^{23}$ Também alertam eles para o risco de conflitos relacionados aos recursos naturais, o que afetará ainda mais a segurança das comunidades. Esses estudos partem de uma base empírica calcada no método comparativo, bem como na análise estatística. Ademais, esse primeiro enfoque se dividiu historicamente em duas subcorrentes: uma, que se preocupou com a relação causal entre escassez de recursos naturais e conflitos, partindo do princípio de que a escassez ambiental ocasiona contendas; e outra, mais recente que a anterior, que emana da economia política dos conflitos e sua relação com os recursos naturais. Esta última tem como seu preceito principal que os conflitos também podem exercer pressões sobre os recursos naturais, especialmente quando estes podem financiar ações. Para compreender essa ligação, os adeptos dessa subcorrente traçaram uma classificação geográfica dos recursos naturais e chegaram à conclusão de que tanto a escassez como a abundância de recursos estão relacionadas a conflitos.

23 "[...] already pose direct threats to national interests, regional stability, and the welfare of humankind." 
O segundo enfoque parte de estudos de paleoantropologia e da história ambiental, assim como de seus efeitos sobre a segurança ambiental em determinados contextos ao longo do tempo. São exemplos dessa abordagem os trabalhos de Crosby (1993), Fagan (1999), Diamond (1999; 2005) e McNeill (2000). A partir de casos históricos, esses estudos buscaram demonstrar como os fatores ambientais retroagem sobre as sociedades, criando novas formas de se organizar, as quais podem determinar tanto sua falência como sua continuidade. Apresentamos aqui as conclusões às quais essas teorizações chegaram a respeito da relação entre conflitos e recursos naturais para, posteriormente, revelar uma visão do conflito a partir de um enfoque territorial.

A esses dois enfoques anteriores, acrescentaríamos ainda um terceiro. Tratase daquele levado adiante pela sociologia ambiental, partindo essencialmente da hermenêutica e da análise de discurso, embora haja dissidentes que partam do realismo. $O$ que se nota nessa corrente é uma crescente motivação para cunhar novos conceitos.

3.1.1 O primeiro enfoque: conflitos violentos - escassez ou abundância de recursos naturais?

Desde que a questão ambiental ganhou ênfase em escala internacional, a partir do final da década de 1960, a relação entre conflitos e recursos naturais vem sendo retratada como uma grande ameaça à humanidade. A partir de então, surgiram vários trabalhos abordando as consequências dramáticas que o aquecimento global e a devastação gerada pelo homem poderiam ocasionar. Uma boa parte deles partia do pressuposto que a degradação dos recursos naturais, juntamente com o aumento populacional mundial - ainda pujante naquele período -, poderia gerar grandes conflitos e tensões em um sistema internacional instável. Naturalmente, tratavam-se de estudos feitos somente a partir de conclusões filosóficas de caráter metafísico, sem uma verdadeira comprovação por meios científicos utilizando provas. Autores como Brown (1977), Falk (1971), Ophuls e Boyan (1992) e Westing (1984) apontaram as primeiras conclusões e considerações a esse respeito, as quais puderam ser utilizadas como hipóteses de pesquisa em outros estudos subsequentes, de base empírica. 
Sob a influência da publicação do documento que veio a ser popularmente conhecido como Relatório Brundtland (WCED, 1987) e, posteriormente, da Conferência da Organização das Nações Unidas sobre Meio Ambiente e Desenvolvimento (CNUMAD), realizada no Rio de Janeiro em 1992, também conhecida como ECO-92, vários grupos de pesquisa se instituíram de forma a verificar o nexo causal entre recursos naturais e conflitos. A maior parte deles baseou-se na premissa de que a escassez de recursos naturais podia desencadear graves conflitos, tendo o já citado grupo de Toronto sido o primeiro a ser instituído para este fim. A partir de um plano de pesquisa apresentado à American Academy of Arts and Sciences (Academia Americana de Artes e Ciências) em 1990, o cientista político Thomas Homer-Dixon, da Universidade de Toronto, traçou as diretrizes do que veio a ser a primeira teoria nessa área de investigação.

Em seu plano de pesquisa, Homer-Dixon (1990, p. 5, tradução nossa) ressaltou que as leis de causa e efeito nos processos conflitivos envolvendo pressões ambientais são indiretas, isto é:

[...] há várias etapas causais entre uma pressão ambiental específica e um tipo específico de conflito. Entretanto, a influência oculta de fatores ambientais, embora talvez não-quantificável, pode ser grande. [...] Muitos problemas ambientais diferentes estão ocorrendo simultaneamente, e é difícil para os pesquisadores avaliar as complexas interações ou estimar os seus múltiplos efeitos. ${ }^{24}$

Por outro lado, o pesquisador criticou a postura reducionista que outros estudos até então haviam adotado. Afinal, os problemas ambientais e seus efeitos sociais - entre eles os conflitos - não podem ser analisados fora de sua contextualização com vários outros processos que ocorrem conjuntamente em uma mesma realidade, como o crescimento populacional, a cultura, o arranjo institucional e as relações sociais em dada sociedade (HOMER-DIXON, 1990). A partir desse argumento, Homer-Dixon (1990) partiu do princípio que não existem conflitos ambientais propriamente ditos, já que se torna difícil articular o conceito de conflito por recursos naturais como categoria particular, como alguns pesquisadores têm feito, uma vez que múltiplas variáveis, além da ambiental, influenciam o processo como um todo.

\footnotetext{
24 "[...] there are many causal steps between a specific environmental stress and a specific kind of conflict. However, the underlying influence of environmental factors, although perhaps not quantifiable, may be great. [...] Many different environmental problems are occurring simultaneously, and it is difficult for researchers to evaluate their complex interactions or estimate their multiple effects."
} 
Seguindo esses passos metodológicos, o grupo de Toronto pesquisou a dinâmica da escassez de recursos renováveis e suas ligações com processos conflitivos, a partir de 16 estudos de caso e aplicação do método comparativo, por meio de análise fatorial entre as variáveis dependente (ocorrência de conflito) e independente (existência de escassez) (Esquema 1).

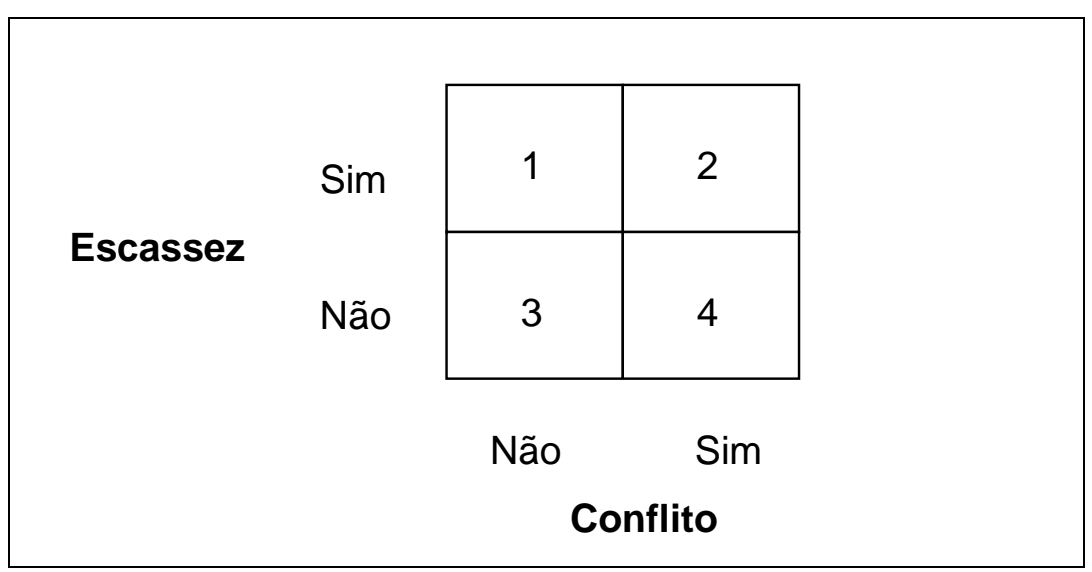

Esquema 1. Matriz de análise fatorial entre as variáveis dependente (ocorrência de conflito) e independente (existência de escassez), de acordo com Homer-Dixon.

Fonte: Homer-Dixon (1999, p. 173, tradução nossa).

A partir daí, comparações foram feitas entre os casos que se situavam nos diferentes quadrantes, analisando os processos desenvolvidos por cada caso dentro do mesmo quadrante, assim como entre quadrantes. Nessa análise, tanto as generalizações como as particularidades são importantes para que se possa compreender como o todo e suas partes dialogam entre si e, em seguida, entender o funcionamento dos padrões determinados pela totalidade nas suas diferentes partes. Resta claro que cada caso é único, porquanto constitui a materialização do padrão desenvolvido pela totalidade em uma dada realidade particular; todavia, não se pode afirmar que cada caso não siga padrões determinados pela totalidade e, justamente por isso, generalizações entre os casos são desenvolvidas. Essa foi a posição adotada pelo autor canadense quando enfatizou que:

Naturalmente, inúmeros fatores contextuais têm se combinado com as pressões ambientais e demográficas para produzir esses resultados. A escassez ambiental nunca é uma causa única ou suficiente para grandes migrações, pobreza ou violência; ela sempre se junta a outros fatores 
econômicos, políticos e sociais para produzir seus efeitos (HOMER-DIXON, 1999, p. 16, tradução nossa). ${ }^{25}$

Embora o contexto seja importante, os analistas devem evitar mudar para o outro extremo, no qual o papel causal da escassez ambiental está inteiramente subordinado ao dos fatores contextuais (HOMER-DIXON,1999, p. 17 , tradução nossa). ${ }^{26}$

Homer-Dixon (1999) afirmou que os casos estudados foram escolhidos a partir de critérios subjetivos, tendo sido selecionados aqueles em que havia evidências de que a questão ambiental havia influenciado, de alguma forma, a dinâmica conflitiva. Também relatou que sua pesquisa representava um esforço inicial de desenvolvimento de uma nova área de pesquisa e que, portanto, muitos passos ainda precisariam ser dados para conseguir algo mais concreto. Para o cientista político canadense, os países mais propensos a enfrentar problemas com escassez são os que se encontram em desenvolvimento, vez que suas economias dependem, em grande parte, da exportação de recursos naturais.

A preocupação com a escassez de recursos renováveis se deu justamente porque estaria vinculada a conflitos com interações complexas dentro dos Estados. Além disso, havia raras evidências empíricas de que a escassez de recursos renováveis ocasionaria conflitos entre Estados. Estudando as relações entre escassez de recursos naturais e conflitos, Westing (1986) comprovou que nos 50 anos anteriores à sua pesquisa, os Estados vinham lutado muito mais por recursos não-renováveis, como petróleo e minerais, que por recursos renováveis, embora isto não signifique que lutem apenas por recursos não-renováveis. Na tipologia traçada por Homer-Dixon (1990), os conflitos que provavelmente se tornarão mais frequentes e mais sérios serão aqueles por privação relativa. Por outro lado, os que surgem entre Estados, denominados conflitos por simples escassez (simple scarcity conflicts), são os que possivelmente menos acontecerão, uma vez que os Estados não podem facilmente convertê-los em aumento de poder estatal, ao contrário do que ocorre em relação aos recursos não-renováveis, como o petróleo (HOMERDIXON,1999).

\footnotetext{
25 "Of course, numerous contextual factors have combined with environmental and demograhic stress to produce these outcomes. Environmental scarcity is never a sole or sufficient cause of large migrations, poverty, or violence; it always joins with other economic, political, and social factors to produce its effects."

26 "Although context is important, analysts should avoid swinging to the opposite extreme, in which the causal role of evironmental scarcity is entirely subordinated to that of contextual factors."
} 
No entanto, apenas a escassez não é suficiente por si só para dar origem a conflitos. Para o grupo de Toronto, a escassez não se caracteriza como algo necessariamente negativo, pois pode ser um incentivo para que a sociedade se aprimore e crie práticas sociais mais justas. Entrementes, em decorrência do impacto da degradação humana, o conceito de escassez expandiu-se para incluir o esgotamento de "metarrecurso", entendido como o efeito multiplicador da degradação dos serviços ambientais e do potencial produtivo dos ecossistemas (HOMER-DIXON, 1999).

Dessa forma, Homer-Dixon (1999) salientou a importância da capacidade de engenhosidade (ingenuity) das sociedades para se adaptar a diferentes tipos de escassez. Por engenhosidade, o autor não somente se referiu à adaptação técnica, mas também à adaptação social a partir de novas formas de organização social. Nem sempre a escassez pode ser totalmente evitada, dando origem a perturbações sociais, entre as quais, o grupo de Toronto apontou a migração e a expulsão de grande contingente populacional, além da redução da produtividade agrícola e econômica. Esses efeitos sociais negativos podem ocasionar a instabilidade tanto política como econômica nos Estados, que reunidas a diferentes clivagens sociais, étnicas e políticas, podem dar origem a conflitos (Esquemas 2 e 3 ).

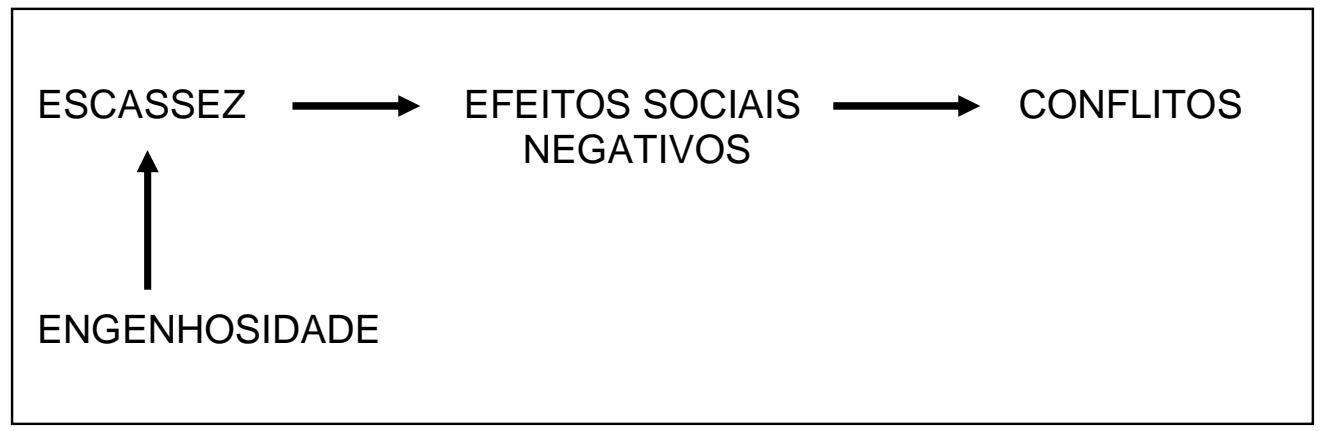

Esquema 2. As duas fases do processo causal de um conflito ambiental de acordo com HomerDixon.

Fonte: Baseada em Homer-Dixon (1999, p. 7, tradução nossa).

Por outro lado, a temática espacial e geopolítica não é tão abordada por esse grupo de pesquisa. Homer-Dixon (1999) afirmou que embora a violência interna aos Estados não seja tão conspícua ou dramática como ao ocasionar conflitos entre países, pode, no entanto, ter vastas implicações. Uma delas é que alguns dos 
países mais afetados internamente pela escassez ambiental são pivôs (pivotal), ou seja, sua estabilidade e bem-estar afetam profundamente a segurança regional e mundial, estando incluídos nesta categoria a África do Sul, o México, o Paquistão, a Índia e a China (HOMER-DIXON, 1999).

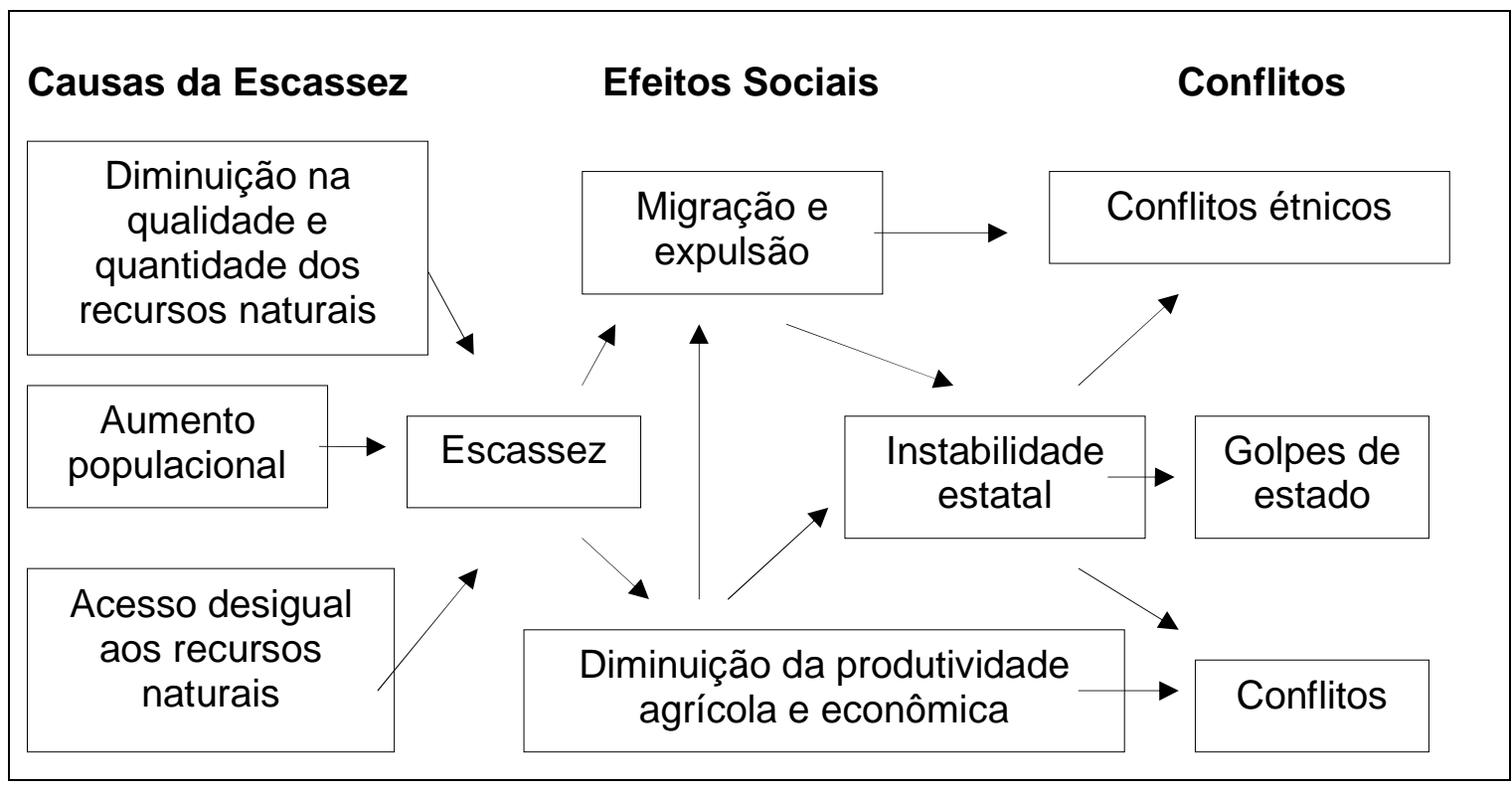

Esquema 3. Teoria das relações causais entre escassez ambiental e conflitos violentos de acordo com Homer-Dixon.

Fonte: Homer-Dixon (1999, p. 134, tradução nossa).

O paradigma do grupo de Toronto recebeu diferentes críticas (HARTMANN, 2001; LE PRESTRE, 2000; LEVY, 1995; PELUSO; WATTS, 2001), principalmente no que se refere à escolha dos casos, porquanto não houve a preocupação em definir as circunstâncias em que a ocorrência de escassez não desencadearia conflitos, casos que se localizariam no quadrante 1 da Figura 1. Outro aspecto muitas vezes criticado se refere aos dados coletados e ao processo de construção da teoria, vez que para alguns autores estes são inconsistentes para engendrar uma teoria empírica que comprove o fato de que a escassez pode gerar conflito. Ainda há alguns autores que asseveram que as conclusões positivistas do grupo de Toronto deixam de levar em conta que as decisões humanas não ocorrem de forma tão mecanicista, como postulou Homer-Dixon (1999). Embora as críticas tenham fundamento, e posteriormente tenham sido respondidas pelo autor canadense, essa teoria recebeu grande aceitação por parte da comunidade acadêmica, sendo 
inclusive citada pelos relatórios do Intergovernmental Panel on Climate Change (IPCC, Painel Intergovernamental sobre Mudanças Climáticas).

Outras equipes logo procuraram avançar nas pesquisas realizadas pelo grupo de Toronto. Um dos grandes institutos europeus de pesquisa na área de segurança a se interessar pela temática foi o Swiss Peace Institute (Instituto da Paz Suíço), que a partir do início dos anos 90 instaurou um grupo de pesquisadores envolvidos na investigação sobre a relação entre recursos naturais e conflitos, denominado Environment and Conflicts Project (ENCOP, Projeto Ambiente e Conflitos) e liderado pelo cientista político Günther Baechler (LEVY, 1995).

Esse grupo de pesquisa suíço iniciou seus estudos com 40 casos distribuídos pelo globo, caracterizados por degradação ambiental, subdesenvolvimento e conflitos violentos (BAECHLER, 1999; PELUSO, WATTS, 2001). Libisewsky (1992), um dos membros do grupo, apontou que o conceito de escassez deve incluir excesso na utilização dos recursos naturais, sobrecarga na capacidade de sustentabilidade e empobrecimento do espaço de vida. Os pesquisadores do ENCOP procuraram estabelecer os fatores que atuam como forças inibidoras ou desencadeadoras de conflito, sendo os principais encontrados por seu estudo de caso os seguintes:

Condições ambientais inevitáveis - a sobrevivência do grupo é dependente de recursos degradados para os quais não há substitutos aparentes; escassez de mecanismos regulatórios e reduzido desempenho do Estado um sistema político é incapaz de produzir certas condições sociais e políticas, enquanto o uso dos recursos sustentáveis está longe de ser alcançado; instrumentalização do meio ambiente - usando o ambiente (e sua destruição) de modo a satisfazer interesses específicos do grupo, de tal modo que a discriminação ambiental se torna um assunto (ideológico) de identidade do grupo; oportunidades para construir organizações e encontrar aliados - atores se organizam e se armam a partir de arranjos políticos, frequentemente seguindo um líder forte, e ganham aliados. Os atores rurais que são capazes de desencadear conflitos necessitam de parceiros fortes em sua coalizão de diferentes níveis sociais para apoiar os seus objetivos, como por exemplo, parte da inteligência, membros da classe média ou um líder carismático de uma minoria étnica que esteja em risco; efeito de conflitos históricos - a discriminação ambiental ocorre dentro do contexto de uma estrutura (histórica) de conflitos preexistente e, como resultado, o conflito recebe novo ímpeto (BAECHLER, 1999, p. xvi-xvii, tradução nossa). ${ }^{27}$

\footnotetext{
27 "Inevitable environmental conditions - group survival is dependent on degraded resources for which no substitutes are apparent; scarcity of regulatory mechanisms and poor state performance - a political system is incapable of producing certain social and political conditions, whereas sustainable resource use is far from being attainable; instrumentalizing the environment - using the environment (and its destruction) in order to pursue specific group interests, so that environmental discrimination becomes as (ideological) issue of group identity; opportunities to build up organization and find allies actors organize and arm themselves in political settings, often behind a strong leader, and gain allies.
} 
O ENCOP também apontou dois fatores como inibidores dos problemas ambientais, dessa forma resultando na redução do subdesenvolvimento. O primeiro é a estruturação de instituições legais e civis, tais como pluralismo político, mecanismos regulatórios, mecanismos legais bem estabelecidos e habilidade dos movimentos oposicionistas em pleitear interesses. O segundo se refere à capacidade do Estado de programar políticas públicas com a finalidade de resolver os problemas gerados pela modernização (Esquema 4).

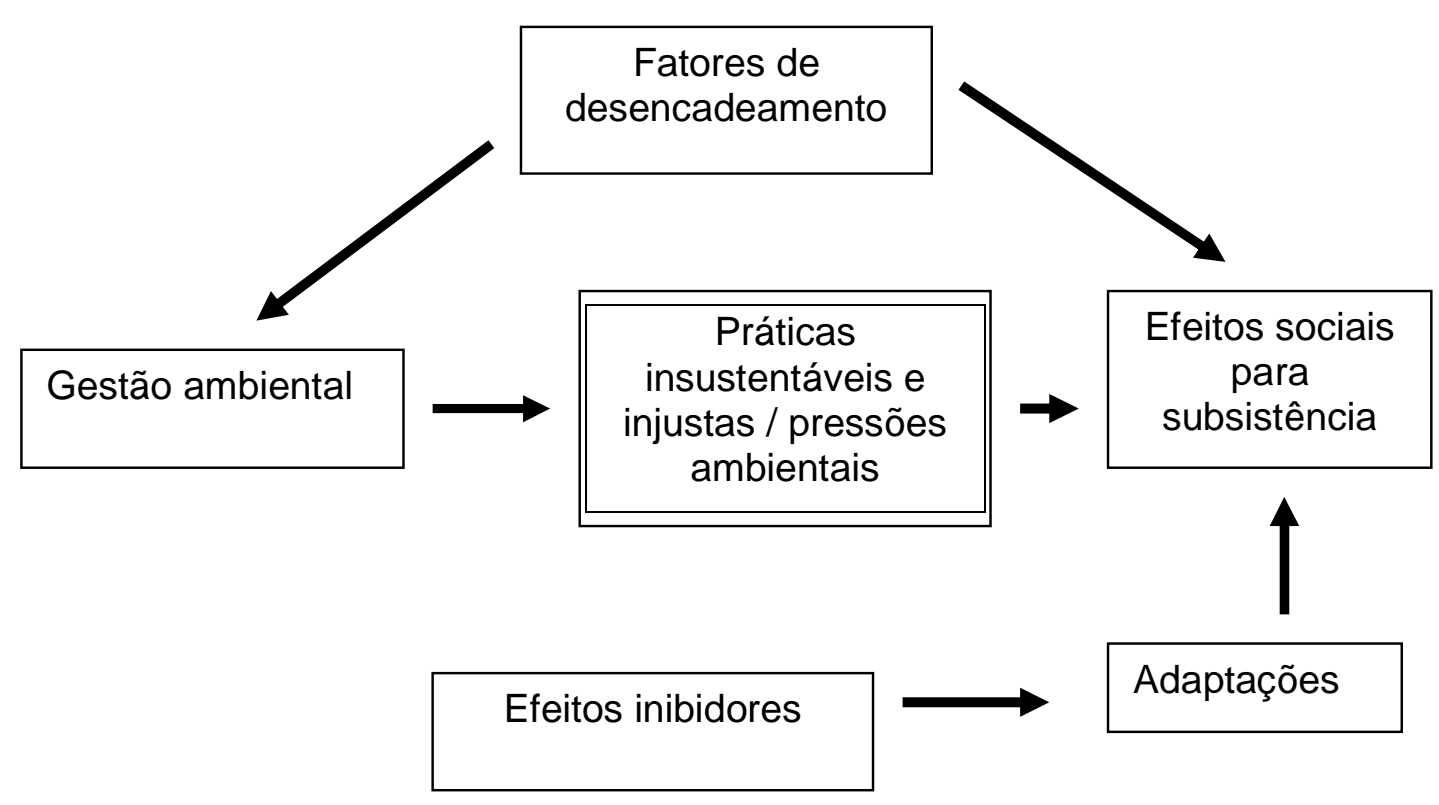

Esquema 4. Relação entre fatores inibidores e desencadeadores de conflitos de acordo com o modelo do ENCOP.

Fonte: Organizada a partir de Baechler (1999).

Baechler (1999, p. xvi-xvii, (tradução nossa) ponderou que a partir do estudo empírico:

[...] o recurso à violência somente ocorre SE e quando alguns dos cinco fatores de desencadeamento de conflito coincidem [...] Esses cinco

Rural actors capable of waging conflict need powerful coalition partners from different social levels to support their goals, for instance, part of the intelligencia, members of the middle class, or a charismatic leader of an ethic minority at risk; spill-over from a historic conflict - environmental discrimination occurs within the context of an existing (historic) conflict structure and, as a result, the conflict receives new impetus." 
contextos constituem a arena para atores que escolhem a violência como sua melhor alternativa às atividades não-violentas. ${ }^{28}$

Com base no trabalho de Karl Polanyi, Baechler (1999) procurou desenvolver a concepção de que a violência e o subdesenvolvimento estão relacionados à degradação ambiental, causada principalmente pelo avanço da modernização imperfeita nos países em desenvolvimento. Partindo de uma premissa "ecogeográfica" e "sociopolítica", o grupo suíço procurou analisar aspectos fisiográficos que poderiam se relacionar a esses conflitos. Chegaram à conclusão de que as situações geográficas nas quais esses conflitos são passíveis de acontecer incluem áreas semi-áridas, áridas, de montanhas, de bacias hidrográficas que cruzam Estados, de mineração ou construção de barragens, florestas tropicais e bolsões de pobreza em áreas urbanas. Porém, como bem enfatizou o líder do grupo ENCOP, isso não significa seguir pelo caminho do determinismo, porque "ultrapassar o limiar da violência definitivamente depende dos fatores sociopolíticos e não do nível de degradação ambiental propriamente dito" (BAECHLER, 1999, p. 100 , tradução nossa). ${ }^{29}$

Por outro lado, o grupo suíço não se preocupou com uma definição teórica de conflito ambiental, apesar de usar o termo livremente. Assim é que Baechler (1999, p. 18, tradução nossa) alertou que "em vez de sugerir uma definição abrangente e, portanto, sem sentido de conflito ambiental, pode-se apenas formular uma estratégia plausível de investigação aplicada a esses problemas considerados relevantes". ${ }^{30} \mathrm{O}$ autor ainda criticou diversos pesquisadores por caírem nos mais variados tipos de vieses ao tentar conceituar os conflitos ambientais. Do mesmo modo que o grupo de Toronto, Baechler (1999) declarou que os conflitos em escala nacional são os que mais se relacionam com a degradação ambiental.

Não obstante, deve-se lembrar que Baechler e seus colegas também receberam críticas, tal como a feita por Fraser (2002, p. 20, tradução nossa):

\footnotetext{
28 "[...] the resort to violence only occurs IF and when some of the five key situations coincide [...] These fie contexts constitute the arena for actors who choose violence as their best alternative to nonviolent activities."

29 "[...] passing the threshold of violence definitely depends on sociopolitical factors and not on the degree of environmental degradation as such."

${ }^{30}$ "Instead of suggesting a comprehensive and therefore meaningless definition of environmental conflict, one can do no more than formulate a plausible research strategy applied to these problems considered relevant."
} 
O amplo modelo teórico de Baechler propicia um insight no debate da segurança ambiental. No entanto, sua definição de pressão ambiental é ampla, levando em conta qualquer tipo de pressão no sistema ambiental. Suas tipologias, embora interessantes, podem ser muito restritas e podem não considerar aqueles conflitos que não pertencem às distinções selecionadas ou incluir mais de uma tipologia. A verificação promovida por Baechler dos fatores de desencadeamento e inibição é também problemática, uma vez que eles não são inteiramente mutuamente exclusivos. $^{31}$

O impacto provocado pelas conclusões dos grupos canadense e suíço impulsionou a implantação de diferentes agências estatais de pesquisa na busca para compreender as implicações das mudanças climáticas e seus efeitos sobre a estabilidade política nacional. Uma delas foi a State Failure Task Force (SFTF, Força de Trabalho sobre a Falência Estatal), instituída em 1994 nos Estados Unidos, durante o primeiro governo do Presidente William Clinton. Essa agência teve como seu objetivo principal a investigação dos principais fatores relacionados diretamente com as crises políticas denominadas de falência do Estado nos 40 anos anteriores. Goldstone et al. (2000, p. 3, tradução nossa) definiram a falência do Estado como:

[...] um termo novo para um tipo de séria crise política exemplificada pelos eventos ocorridos na década de 1990 na Somália, Bósnia e Herzegovina, Libéria e Afeganistão. Observadores estrangeiros caracterizaram um Estado falido como aquele "absolutamente incapaz de se sustentar como membro da comunidade internacional", e eles geralmente atribuem a falência estatal a condições tais como a guerra civil, o colapso do governo e a privação econômica. Estritamente definidas, as falências do Estado consistem em instâncias nas quais a autoridade central do Estado entra em colapso por vários anos. ${ }^{32}$

O enfoque adotado pela SFTF era, evidentemente, quantitativo e estatístico, diferenciando-se dos anteriores, pois seu escopo principal era descobrir as principais causas da falência dos Estados. Os estudos desse grupo basearam-se na análise de mais de 1.000 variáveis coletadas de 127 casos de falência dos Estados. Os autores partiram da hipótese de que não encontrariam correlação direta entre

\footnotetext{
31 "Baechler's largely theory-driven model provides insight into the environmental security debate. However, his definition of environmental stress is broad, accounting for nearly any type of stress on the environmental system. His typologies, although interesting, may be too narrow and may not account for those conflicts that may lie outside the chosen distinctions or include more than one typology. Baechler's examination of triggering and inhibiting factors is also problematic insofar as they are not entirely mutually exclusive."

32 " [...] a new term for a type of serious political crisis exemplified by events that occurred in the 1990s in Somalia, Bosnia and Herzegovina, Liberia, and Afghanistan. Foreign-policy observers have characterized a failed state as one "utterly incapable of sustaining itself as a member of the international community", and they generally attribute state failure to conditions such as civil strife, government breakdown, and economic privation. Narrowly defined, state failures consist of instances in which central state authority collapses for several years."
} 
mudança ambiental e falência do Estado. Por outro lado, esperavam que a mudança ambiental pudesse ter impacto significativo e negativo em um dos fatores diretamente associados com a falência dos Estados (ESTY et al., 1999).

Ao final da pesquisa, os autores concluíram que a falência do Estado está correlacionada diretamente com a mortalidade infantil, a abertura comercial e a democratização. Segundo Esty et al. (1999, p. 24 e 26, negrito e itálico dos autores, tradução nossa):

A mudança ambiental não parece estar diretamente correlacionada à falência do Estado. [...] Para determinar se seria possível encontrar uma correlação estatística entre mudança ambiental e falência do Estado, nós testamos variáveis que mensuravam o desmatamento e o abastecimento de água, mas ambos falharam na geração de resultados significativos. Isso estava de acordo com a nossa hipótese de que os efeitos mais diretos da democratização, da abertura comercial e da qualidade de vida - medida pela mortalidade infantil - tinham um impacto tão substancialmente forte na falência do Estado que mascaravam qualquer impacto da deterioração ambiental. ${ }^{33}$

No entanto, a relação entre qualidade de vida e falência pode ser ainda atenuada ou intensificada pela atuação dos Estados, bem como por sua capacidade de solucionar a questão. Então, com base no modelo da SFTF, o grupo de trabalho chegou a conclusões semelhantes às da teoria do grupo de Toronto. O conceito de capacidade do Estado assemelha-se ao conceito de engenhosidade (ingenuity), embora este último seja ainda mais amplo, pois não se restringe tão-somente à capacidade do Estado, abarcando também os diversos atores sociais.

No que concerne ao enfoque, nota-se que a preocupação da SFTF centrou-se especialmente na falência do Estado e não estritamente nos conflitos, tratando-se, assim, de uma perspectiva mais abrangente (Esquema 5). Embora conflitos possam causar a falência do Estado, mais comumente são um dos efeitos desta. Pesquisas posteriores desse grupo apresentaram também forte correlação entre conflitos relacionados a diferenças étnicas e falência do Estado. Um dos pontos fortes dessa abordagem está em apontar que não apenas a relação entre conflito e recursos naturais é relevante para a segurança ambiental, mas também a influência da

33 "Environmental change does not appear to be directly linked to state failure. To determine whether it was possible to find a statistical correlation between environmental change and state failure, we tested variables that measured deforestation and freshwater supply, but both failed to generate significant results. This was consistent with our hypothesis that the more direct effects of democratization, trade openness and quality of life - measured by infant mortality - had such a strong impact on state failure that they masked any impact of environmental deterioration." 
mudança ambiental sobre outros fenômenos, nesse caso, especificamente, a mortalidade infantil, podendo desencadear a falência do Estado.

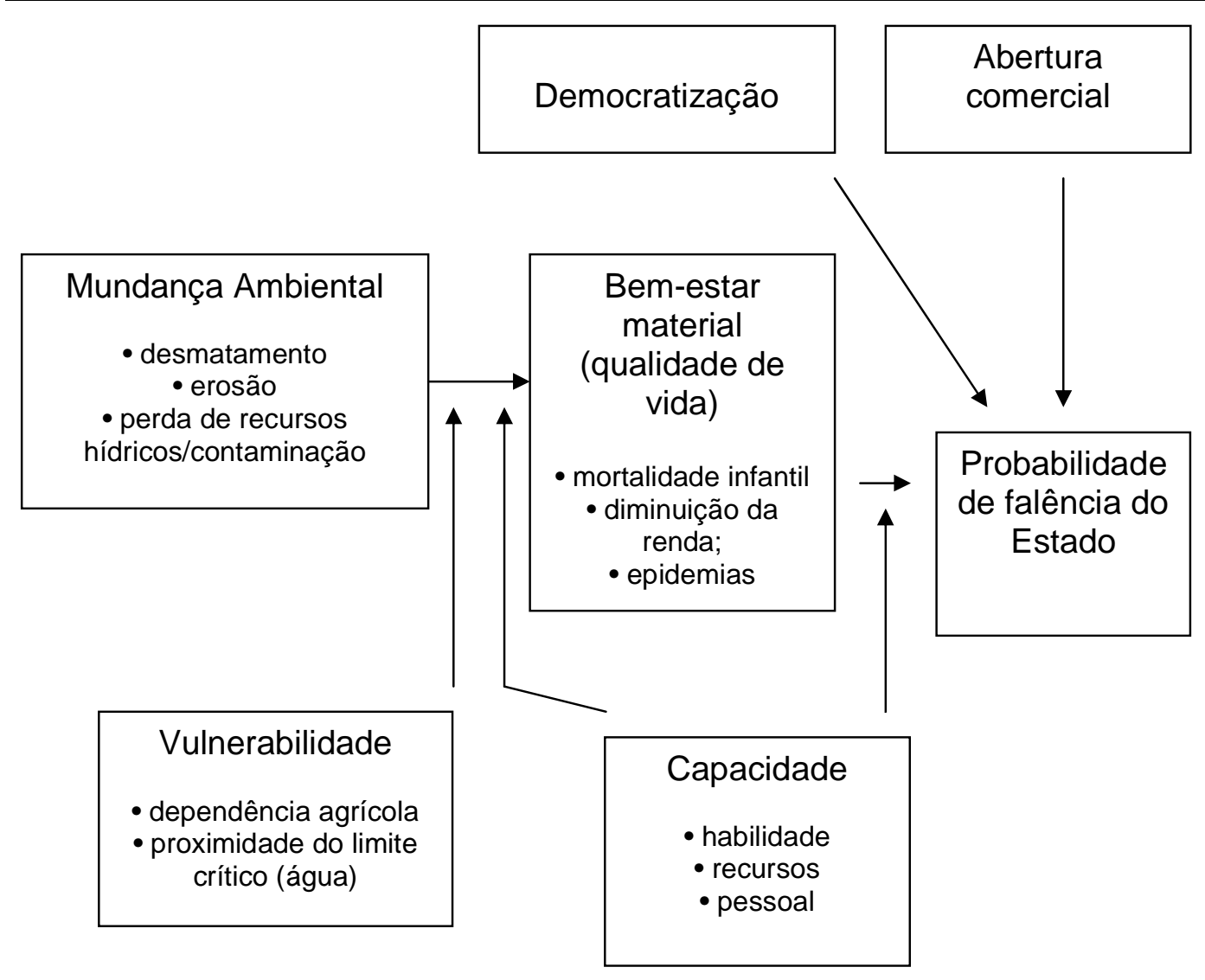

Esquema 5. Modelo relacionando mudanças ambientais e falência do Estado de acordo com State Failure Task Force (SFTF).

Fonte: Esty et al. (1999, p. 27).

Apesar de bastante ambicioso, esse tipo de pesquisa recebeu várias críticas. A exemplo do que fez com o ENCOP, Fraser (2002) igualmente criticou a posição metodológica da SFTF, uma vez que determinando a variável dependente em termos tão dramáticos, os pesquisadores negligenciaram uma série de outras pressões ambientais. Também criticou o fato de os pesquisadores se concentrarem exclusivamente em um fenômeno não muito comum - a falência do Estado. Por último, Fraser (2002) destacou que assumir um enfoque tão abrangente como o da 
agência norte-americana acaba por esconder os verdadeiros efeitos sociais das pressões ambientais.

Todavia, não só a agência governamental norte-americana SFTF despertou seu interesse para pesquisas sobre segurança ambiental, mas várias outras agências governamentais e internacionais também o fizeram. Entre uma das mais conhecidas, podemos citar a North Atlantic Treaty Organization (NATO, Organização do Tratado do Atlântico Norte - OTAN), que no final dos anos 90 procurou analisar os efeitos que a mudança ambiental poderia ter em suas atividades. Os pesquisadores dessa instituição adotaram o escopo de criar um modelo de aplicação global para identificar a relação entre pressão ambiental e conflito, considerando o meio ambiente como "interesse nacional crítico", da forma mais operacional e pragmática possível, tentando identificar áreas em que a política poderia atenuar conflitos (LIETZMANN; VEST, 1999).

Seguindo as diretrizes traçadas, o modelo da OTAN se baseou em dois conceitos principais: pressão ambiental (environmental stress) e segurança (security). Dentro da teorização do grupo, este último conceito pode ser avaliado a partir de três dimensões: a integridade do território nacional, a independência política em relação à proteção da soberania e, por fim, a estabilidade internacional. Por sua vez, o conceito de pressão ambiental se fundamenta em dois pressupostos: redução percebida da quantidade e da disponibilidade de recursos naturais renováveis (LIETZMANN; VEST, 1999).

Em seu relatório, os pesquisadores da OTAN concluíram que as "[...] pressões ambientais podem atuar como uma fonte estrutural de conflitos, fator catalisador de conflitos ou fator desencadeador de conflitos" (LIETZMANN; VEST, 1999, p. 93, tradução nossa). ${ }^{34}$ Esses autores ainda destacaram a importância do contexto em que se dão as pressões ambientais, porquanto segundo este enfoque, há vários fatores contextuais importantes, como a percepção, a vulnerabilidade econômica, a capacidade tecnológica, o potencial para a violência, as estruturas de segurança nacional, a instabilidade política, os mecanismos de resolução de conflitos, entre tantos outros (Esquema 6).

\footnotetext{
34 "[...] environmental stress can act as a structural source of conflict, catalyst for conflict or trigger for conflict."
} 


\section{Contexto}

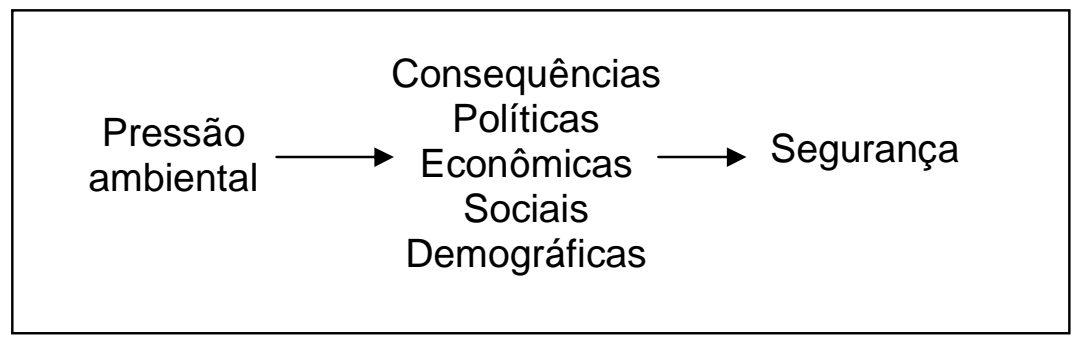

Esquema 6. Relação entre pressão ambiental e segurança nacional de acordo com o modelo da OTAN.

Fonte: Lietzmann e Vest (1999, p. 41, tradução nossa).

Lietzmann e Vest (1999) chegaram à conclusão de que a relação entre pressão ambiental e falência do Estado possui três lógicas causais possíveis. $\mathrm{Na}$ primeira delas, a multicausalidade, as pressões ambientais se relacionam com diversos outros fatores políticos, econômicos e sociais, intensificando inúmeras tensões antes de desencadear conflitos. A segunda lógica causal engloba a reciprocidade e os mecanismos de retroalimentação em uma situação na qual a relação entre pressão ambiental e conflitos é cíclica, pois a pressão ambiental pode levar a conflitos, assim como esses podem gerar ainda mais pressão ambiental, não havendo prevalência de um sobre o outro. $O$ terceiro tipo se refere às consequências das pressões ambientais, entre as quais são consideradas como principais a pobreza, a insegurança alimentar, as condições precárias de saúde, a migração e o deslocamento de refugiados, a desestabilização das instituições políticas e sociais, todas consequências das pressões ambientais que podem se combinar a um contexto desfavorável e dar início a conflitos.

Embora as pressões ambientais possam ser resolvidas sem o recurso à violência, Lietzmann e Vest (1999) traçaram uma tipologia de quatro conflitos diferentes relacionados aos fatores ambientais: conflitos etnopolíticos, conflitos migratórios, conflitos internacionais relacionados a recursos e conflitos resultantes das mudanças climáticas globais.

As principais críticas feitas ao modelo da OTAN dizem respeito, sobretudo, ao conceito de segurança adotado, porquanto, evidentemente, se trata de um modelo baseado no conceito de segurança nacional stricto sensu. Por outro lado, os 
pesquisadores daquele grupo se referem muito ao contexto em que as condições de pressão ambiental podem ocorrer, sem, no entanto, proceder a uma regionalização do espaço mundial ou algo do tipo, para cuja finalidade a geografia poderia trazer boas contribuições. Outra crítica comum feita ao modelo em questão é o foco exclusivo dos autores nos Estados-nação, assim olvidando uma série de outros atores que podem influir na segurança e nos conflitos. A esse respeito, Dalby (2002, p. 58) comentou que:

A utilidade política de tais indicadores pode ser óbvia para os funcionários da OTAN, ansiosos por acompanhar as tendências que causam turbulência política, mas o que elas podem significar para as populações que são monitoradas é muito menos claro. Evidentemente, a segurança que é da maior preocupação aqui é a da estabilidade política do sistema mundial. A possibilidade que ela possa estar gerando insegurança não é inteiramente descartada nesta discussão das diversas síndromes de mudança, mas uma reflexão mais dramática sobre a segurança não é levada adiante nesta discussão. ${ }^{35}$

Ainda outro aspecto que se pode discutir no enfoque da OTAN é a falta de qualquer esforço de regionalização do espaço mundial, a ser empreendida buscando apresentar os fatores que poderiam representar essas causas contextuais. As admoestações de Fraser (2002, p. 23) apontaram nessa direção:

O modelo desenvolvido pela OTAN é talvez a maior de todas as tentativas em larga escala para definir a ligação entre escassez ambiental e conflitos. Embora ela levante pontos interessantes, é demasiado vaga para oferecer qualquer valor analítico ou prescritivo. O modelo da OTAN também tem alguns problemas metodológicos que restringem sua utilidade $[\ldots]^{36}$

Os enfoques até aqui apresentados baseiam-se no princípio que as mudanças ambientais apresentam grande potencial para gerar conflitos e tensões. No entanto, o Peace Research Institute of Oslo (PRIO, Instituto de Pesquisa da Paz de Oslo), da Noruega, adotou uma abordagem que parte de outra premissa. Para os pesquisadores noruegueses, na maioria das vezes, as mudanças ambientais incitam

\footnotetext{
35 "The political utility of such indicators might be obvious to NATO officials anxious to monitor the trends that cause political turmoil, but what they might mean to the populations so monitored is much less clear. Of course, the security that is of most concern here is the political stability of world system. The possibility that it might be engendering insecurities is not entirely dismissed in this discussion of the various syndromes of change, but a more dramatic rethinking of security is not countenanced in this discussion."

${ }^{36}$ "The model developed by NATO is perhaps the most of all-encompassing attempt to define the environmental scarcity-conflict link. Although it raises interesting points, it is too vague to offer any analytic or prescriptive value. The NATO model also has some methodological issues that inhibit its utility [...]"
} 
medidas cooperativas, embora, em alguns casos, tensões e conflitos possam vir à tona. Assim sendo, autores como Indra de Soysa e Peter Nils Gleditsch procuraram incorporar em seus enfoques as funções desempenhadas pela democracia e agricultura.

Ao assumir essa posição, Gleditsch (1999) criticou os aspectos teóricos assumidos pelos enfoques anteriores. O cientista político norueguês indicou que a maioria das teorizações anteriores deixou de acrescentar maior ênfase à democracia e seus efeitos sobre as tensões e conflitos existentes em diferentes sociedades. Também apostou no pressuposto kantiano de que democracias não lutam umas contra as outras e que guerras civis são improváveis em regimes democráticos bem estabelecidos. Dessa forma, concluiu que a cooperação é o resultado mais provável entre democracias estabilizadas quando estas enfrentam penúrias ambientais. $O$ autor chegou, até mesmo, a alertar que os regimes democráticos possuem mecanismos que impedem penúrias ambientais mais sérias, os quais são "[...] liberdade de informação e de expressão, pluralismo, políticas pragmáticas por tentativa e erro, cooperação internacional, economia de mercado e mais respeito pela vida humana" (GLEDITSCH, 1999, p. 95, tradução nossa). ${ }^{37}$ Fica claro no enfoque do PRIO que a democracia possui duplo efeito: inicialmente, porque inibe a probabilidade de conflitos tanto entre países como em nível nacional e, posteriormente, porque propicia melhores condições para controlar e monitorar as condições ambientais (Esquema 7).

Após esta preocupação com os regimes democráticos, Gleditsch (1999) analisou as pseudodemocracias ou semidemocracias. Para ele, esse tipo de regime é o mais suscetível a violências internas e guerras civis, ao contrário dos regimes democráticos e autoritários. Diante disso, preconizou que, embora os problemas ambientais ocorram em escala local e nacional, estão enraizados em outras causas além da escassez de recursos, as quais serão superadas a partir de meios sociais e políticos. Ademais, o autor reiterou que não há razões plausíveis para se considerar que a escassez de recursos ambientais tenha maior potencial de gerar violência no futuro que no passado.

37 "[...] freedom of information and expression, pluralism, pragmatic trial-and-error policies, international cooperation, market-economy, and greater respect for human life". 


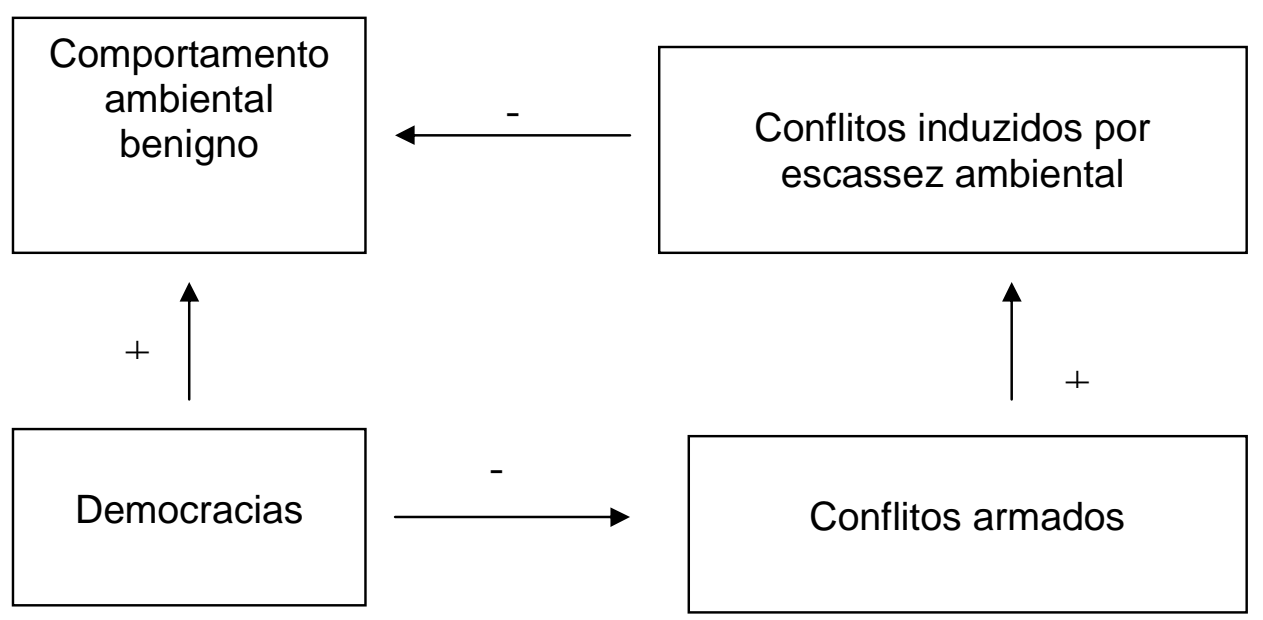

Esquema 7. O efeito duplo da democracia sobre os conflitos.

Fonte: Baseada em Gleditsch (1997).

Em um colóquio realizado pela OTAN na capital búlgara, em janeiro de 1999, o cientista político norueguês argumentou contra o conceito de conflitos ambientais. Criticando os estudos anteriores do grupo de Toronto e do grupo suíço, Gleditsch (1999, p. 56, tradução nossa) explicou que eles quase sempre consideram a degradação ambiental como:

[...] uma causa independente de conflitos. Porém, a degradação ambiental pode ser interpretada como um sintoma das formas de falência da sociedade, as quais também geram outras formas de conflito. As regras autoritárias, a falta de cooperação internacional, a pobreza, o consumo excessivo em países ricos, a globalização da economia - esses estão entre aqueles mesmos fatores que são frequentemente acusados de causar problemas ambientais. Os mesmos fenômenos estão ligados às formas de conflitos armados, os quais são dominantes hoje. ${ }^{38}$

Apresentando as diferentes dimensões que se relacionam com o conflito, como a dimensão econômica, por meio dos preços dos recursos minerais no mercado internacional, a dimensão política, por intermédio da cooperação

\footnotetext{
38 "[...] an independent cause of conflict. But environmental degradation may be interpreted as a symptom of the forms of societal failure, which generate other forms of conflict as well. Authoritarian rule, lack of international cooperation, poverty, excessive consumption in rich countries, globalization of the economy - these are among the very same factors which are frequently blamed for the environmental problems. The very same phenomena are linked to the forms of armed conflicts, which are dominant today."
} 
internacional, assim como a dimensão cultural, pela diversidade étnica, Gleditsch (1999, p. 61, tradução nossa) concluiu que:

\begin{abstract}
Alguns conflitos, para não dizer nenhum, justificam rótulos unicausais como "conflito ambiental" ou "conflito étnico". Pode-se sempre relacionar conflito a várias dimensões e a influência de um problema geralmente é modificada pela influência de outro. As questões sobre recursos e ambiente certamente desempenham um papel no conflito, mas a relação entre essas questões e o conflito armado é modificada por fatores políticos, econômicos e culturais gerais, que usualmente agem em um conflito armado. Eu colocaria isso com mais intensidade ainda: nós devemos considerar seriamente que o conceito de degradação ambiental possa, mais apropriadamente, ser visto como uma variável interveniente entre a pobreza e a má governança, por um lado, e os conflitos armados por outro. ${ }^{39}$
\end{abstract}

Contudo, as principais críticas ao enfoque do PRIO giram em torno de seu aspecto fortemente tecnocrático (FRASER, 2002). Por outro lado, ao adotar o postulado kantiano de que as democracias não travam conflitos entre si, Gleditsch (1999) se esqueceu que as democracias travam conflitos com outros regimes e que, portanto, várias vezes são responsáveis por degradações ocorridas em outros países. À vista disso, e como asseverou Renner (1996), tanto a democracia liberal como as mudanças estruturais implementadas pelo neoliberalismo mudaram a escala dos conflitos. Apesar das democracias não lutarem entre si, o que se nota é o aumento dos conflitos na escala intranacional (O'LOUGHLIN, 2005; RENNER, 1996). Destarte, fica claro em relação a essa corrente que abarca o primeiro enfoque que não há relação direta de causalidade entre recursos naturais e conflitos, havendo, para a maioria dos estudos que adotam esta perspectiva, dimensões mais gerais de conflitos, às quais a dimensão ambiental se alia de forma a dar origem a eles. Depreende-se, como bem argumentou Gleditsch (1999), que não existe conflito ambiental para a maioria desses estudos.

Como consequência das várias críticas recebidas pelos esforços aqui descritos em relacionar escassez de recursos naturais e conflitos, a partir do início dos anos 2000 surgiu uma segunda subcorrente que procura relacionar recursos

\footnotetext{
39 "Few, if any conflict, justify single-issue labels like 'environmental conflict' or 'ethnic conflict'. We can always relate conflict to several issue dimensions and the influence of one issue is usually modified by the influence of another. Resource and environmental issues do play a role in conflict, but the relationship between these issues and armed conflict is modified by the general political, economic, cultural factors at work in armed conflict generally. I would put this even more strongly: we should seriously consider the notion that environmental degradation may more appropriately be seen as an intervening variable between poverty and poor governance on the one hand and armed conflict on the other."
} 
naturais e conflitos armados. Não obstante, esse novo esforço se baseia em um postulado que procura avaliar os efeitos de conflitos armados prolongados sobre os recursos naturais. Para os autores ligados a essa posição, não há relação unicausal de mão única entre escassez de recursos e conflitos, mas pensam eles que os próprios conflitos podem ocasionar a escassez de recursos (COLLIER; HOEFLER, 2003; LE BILLON, 2001a; 2001b; 2005; SOYSA, 2002; SOYSA; WAGNER, 2003). Embora essa subcorrente seja ampla e parta de diversos enfoques da economia política dos conflitos, apresentaremos suas contribuições a partir principalmente do trabalho do geógrafo canadense Philippe Le Billon, uma vez que suas pesquisas estão entre as poucas que mostram preocupação com a dimensão espacial e a construção territorial a partir dos recursos naturais.

A primeira medida dos autores dessa subcorrente foi anular a crença de que apenas a escassez pode engendrar conflitos. Assim, Le Billon (2001b, p. 565, tradução nossa) advertiu que:

Outros exames quantitativos da relação entre recursos e conflitos através de modelos multivariados confirmam parcialmente $o$ argumento das guerras por recursos escassos e completamente o argumento das guerras por recursos abundantes. Baixos níveis de violência (25-1.000 mortes em batalhas por ano) têm uma relação positiva com a degradação ambiental [...], e ademais, baixos níveis de dotação de recursos renováveis não estão associados com o risco de conflito armado; ao passo que recursos renováveis em abundância, em países que de outra forma são pobres, e recursos não-renováveis, em todos os países, aumentam a probabilidade de conflito armado $[\ldots]^{40}$

Tendo como base os dados desses estudos empíricos, Le Billon (2001b, p. 565, tradução nossa) concluiu que:

As perspectivas tanto de abundância de recursos como de escassez de recursos não levam em conta a natureza socialmente construída dos recursos e, ao fazê-lo, falham em explicar porque a abundância ou a escassez de recursos valiosos não é um fator necessário ou suficiente de conflito. Pedras preciosas ou petróleo também podem ser mobilizados em desenvolvimento pacífico, como ocorre respectivamente em Botsuana ou Noruega, por exemplo. De modo semelhante, a escassez de recursos não impediu o desenvolvimento pacífico em muitos países, como o Japão,

\footnotetext{
40 "Other quantitative examinations of resources and conflicts links through multivariate models confirm part of the scarce resource war argument and the overall argument of abundant resource war. Low levels of violences (25-1000 battle-related deaths per year) have a positive relation with environmental degradation [...], yet low levels of renewable resources endowment are not associated with the risk of armed conflict; while abundant renewable resource in otherwise poor countries and non-renewable resources in all countries increases the likelihood of armed conflict [...]."
} 
frequentemente citado como exemplo de país altamente desenvolvido e pobre em recursos. ${ }^{41}$

O autor partiu do princípio que todo recurso natural implica territorialização e, portanto, para compreendermos a relação entre conflito e recursos naturais, é necessário fazer uma classificação destes a partir de certos aspectos geográficos. Por conseguinte, Le Billon (2001b) passou a dividir os recursos naturais, em um primeiro momento, a partir de sua distribuição geográfica, classificando-os em recursos ponto (point resources) e recursos difusos (diffuse resources). Os primeiros são aqueles que se concentram em determinada área, caracterizando-se por serem passíveis de exploração pela indústria extrativa (por exemplo, a mineração). Já os recursos difusos são aqueles que se distribuem amplamente pelo espaço mundial e são explorados pela indústria produtiva. Em uma segunda classificação, o autor procurou ressaltar a facilidade ou a dificuldade que o poder estatal pode ter em manter o controle sobre determinados recursos. Assim, nessa segunda divisão, Le Billon (2001b, p. 570, tradução nossa) considerou os recursos como próximos ou distantes em relação à área core do Estado:

Em poucas palavras, quanto maior a distância ou a dificuldade de acesso a partir do centro de controle, maior será o custo de controle e maior será o risco de perder o recurso para o adversário. Em outras palavras, um recurso próximo à capital tem menos probabilidade de ser capturado por rebeldes que um recurso próximo a uma fronteira. ${ }^{42}$

Partindo da análise locacional dos recursos e da sua distribuição no território, o geógrafo canadense fez uma análise fatorial traçando uma tipologia dos conflitos (Quadro 3). Para Le Billon (2001b), conflitos armados se referem à implantação de violência física organizada, incluindo golpe de estado, terrorismo e conflitos armados intra ou interestatais, além do que, a desestruturação contemporânea de muitos conflitos armados também resulta em um continuum entre banditismo, crime organizado e conflitos armados.

\footnotetext{
41 "Both the resource abundance and resource scarcity perspective fail to take into account the socially constructed nature of resources, and in so doing, fail to explain why an abundance or scarcity of valuable resources is not a necessary or sufficient factor of conflict. Gems or oil can also be mobilised in peaceful development, as is the respective case in Botswana or Norway, for example. Similarly a scarcity of resources did not prevent peaceful development in many countries, Japan being frequently cited as an example of a highly developed resource-poor country."

42 "In short, the greater the distance or difficulty of access from the centre of control, the greater the cost of control and the higher the risk of losing the resource to the adversary. In other words, a resource close to the capital is less likely to be captured by rebels than a resource close to a border."
} 
Quadro 3. Relação entre a distribuição geográfica do recurso e a natureza do conflito, de acordo com Le Billon.

\begin{tabular}{|c|c|c|}
\hline \multirow{2}{*}{$\begin{array}{c}\text { Distância da } \\
\text { capital do país }\end{array}$} & Recurso ponto & Recurso difuso \\
\hline & $\begin{array}{c}\text { Controle do Estado/golpe de } \\
\text { Estado }\end{array}$ & Rebelião/tumulto \\
\hline \multirow[t]{2}{*}{ Perto } & $\begin{array}{c}\text { Argélia (gás) } \\
\text { Angola (petróleo) } \\
\text { Chade (petróleo) } \\
\text { Congo, Brazzaville (petróleo) } \\
\text { Irã-Iraque (petróleo) } \\
\text { Iraque-Kuwait (petróleo) } \\
\text { Libéria (borracha, minério de } \\
\text { ferro) } \\
\text { Ruanda (café) } \\
\text { Nicarágua (café) }\end{array}$ & $\begin{array}{c}\text { El Salvador (café) } \\
\text { Guatemala (terra) } \\
\text { Israel-Palestina (água } \\
\text { potável) } \\
\text { México (terra) } \\
\text { Senegal-Mauritânia (terra) }\end{array}$ \\
\hline & Secessão & Guerrilha \\
\hline Longe & $\begin{array}{c}\text { Angola-Cabinda (petróleo) } \\
\text { Cáucaso (petróleo) } \\
\text { República Democrática do } \\
\text { Congo (cobre, cobalto e ouro) } \\
\text { Indonésia (petróleo, cobre e } \\
\text { ouro) } \\
\text { Marrocos-Saara Ocidental } \\
\text { (óleo) } \\
\text { Nigéria-Biafra (petróleo) } \\
\text { Papua Nova Guiné- } \\
\text { Bougainville (cobre) } \\
\text { Sudão (petróleo) }\end{array}$ & $\begin{array}{c}\text { Afeganistão (ópio) } \\
\text { Angola (diamantes) } \\
\text { Burma (ópio e madeira) } \\
\text { Cáucaso (drogas) } \\
\text { Colômbia (cocaína) } \\
\text { Kurdistão (heroína) } \\
\text { Peru (cocaína) } \\
\text { Libéria (madeira, diamantes e } \\
\text { drogas) } \\
\text { Serra Leoa (diamantes) }\end{array}$ \\
\hline
\end{tabular}

Fonte: Baseado em Le Billon (2001a, p.39; 2001b, p. 39).

Naturalmente, a aplicação de conceitos geográficos trouxe grande aporte ao entendimento da escala espacial dos conflitos. No entanto, a classificação dos recursos empreendida por Le Billon vem sendo criticada, sobretudo porque alguns 
recursos podem ser tanto difusos como ponto. Em adição a isso, determinados recursos não são nem ponto e nem difusos, uma vez que se situam exatamente entre as duas categorias. Outro motivo de crítica é que ainda não resta claro se ambas as categorias causam os mesmos impactos nos conflitos (LUJALA, 2003). Ross (2004) propôs outra classificação dos recursos naturais, dividindo-os em recursos mais ou menos passíveis de serem saqueados (lootable natural resources).

O cientista político da Universidade da Califórnia, Michael Ross, estuda a relação entre recursos naturais e conflitos políticos a partir de uma classificação dos recursos envolvendo três parâmetros: saqueabilidade (lootability), legalidade (legality) e capacidade de obstrução (obstructibility). Ross (2004, p. 350, tradução nossa) preconizou que:

Os recursos são saqueáveis se puderem ser facilmente apropriados por indivíduos ou pequenos grupos de trabalhadores não-especializados. [...] Quando um recurso é facilmente obstruído - isto é, seu transporte pode ser facilmente bloqueado por um pequeno número de indivíduos com armas relativamente baratas - isto tenderá a aumentar a duração e a intensidade dos conflitos, novamente oferecendo à parte mais fraca uma vantagem. ${ }^{43}$

Recursos saqueáveis, legais e fáceis de serem transportados têm grande probabilidade de se relacionar a conflitos armados, principalmente no que concerne a seu financiamento (ROSS, 2003).

Lujala (2003) também destacou a importância dessas características para a compreensão da relação entre recursos naturais e conflitos armados, porém procurou incorporar a classificação de Le Billon (2001a) a esse debate levantado principalmente por economistas. A partir da consideração dos recursos minerais, Lujala (2003, p. 11-12, tradução nossa) afirmou que:

Para classificar os recursos naturais de acordo com as suas características e para avaliar o grau de saqueabilidade de diferentes recursos, vários aspectos da "cadeia de mineração" devem ser considerados. Esses incluem não somente a facilidade de extração e transporte, mas também de exploração, refino e armazenamento antes do transporte. Aspectos como disponibilidade de recursos substitutos e raridade também podem afetar a lucratividade dos recursos. Nesse capítulo, os aspectos da exploração dos recursos minerais são considerados a partir de dois ângulos: a saqueabilidade do recurso a partir do ponto de vista dos rebeldes e o controle do fluxo de renda pelo governo/elite. O primeiro aspecto trata do

\footnotetext{
43 "Resources are lootable if they can be easily appropriated by individuals or small groups of unskilled workers. [...] when a resource is easily 'obstructable' - that is, its transportation can be easily blocked by a small number of individuals with relatively inexpensive weapons - it will tend to increase the duration and intensity of conflicts, again by offering the weaker party an advantage."
} 
financiamento rebelde durante um conflito, e o segundo, da extensão na qual o fluxo de renda pode ser controlado pelo governo. ${ }^{44}$

Fazendo uma revisão da literatura, abarcando 20 pesquisas relativas à análise das relações entre recursos naturais e guerras civis (Quadro 4), Ross (2004, p. 352, tradução nossa) assinalou quatro regularidades existentes entre esses estudos:

(1) A dependência em petróleo parece estar ligada ao desencadeamento do conflito, mas não à duração do conflito. Há alguns indícios de que a dependência do petróleo (e possivelmente a dependência em minerais) está mais fortemente associada com conflitos separatistas que outros tipos de conflitos. (2) Pedras preciosas, ópio, coca e cannabis não parecem estar relacionados com o início do conflito, mas parecem prolongar guerras preexistentes. O papel desempenhado pela madeira permanece sem verificação. (3) Não há dados estatísticos - e pouquíssimas evidências a partir de estudos de caso - que conectem commodities agrícolas a início ou duração de guerra civil. (4) A alegação de que as commodities primárias estejam associadas com o início da guerra civil parece não ser robusta. ${ }^{45}$

Essa segunda subcorrente do primeiro enfoque apresentou grandes contribuições à compreensão de outras formas de relação entre os recursos naturais e conflitos armados. Aquela ênfase exagerada na escassez de recursos, dada pela primeira subcorrente, acabou sendo contraposta por uma nova maneira de estudar os conflitos.

Por outro lado, embora essa corrente utilize o termo "guerra por recursos" (resource wars), aproxima-se da primeira subcorrente ao afirmar a inexistência de conflitos exclusivamente ambientais ou, pelo menos neste caso, exclusivamente relacionados aos recursos naturais.

\footnotetext{
44 "To classify natural resources according to their characteristics and to assess the degree of lootability of different resources, several aspects of "mining chain" have to be considered. These include not only the ease of extraction and transportation but also exploration, and refining and storage before transportation. Things like availability of substitutes and rareness may also affect the profitability of resources. In this chapter, the aspects of mineral resource exploitation are considered from two angles: lootability of the resource from the rebels' point of view and controllability of revenue flows by the government/elite. The first aspect accounts for rebel financing during a conflict, the second the extent to which the revenue flows can be controlled by government."

45 "(1) Oil dependence appears to be linked to the initiation of conflict, but not conflict duration. There is some evidence that oil dependence (and possibly mineral dependence) is more strongly associated with separatist conflicts than other types of conflicts. (2) Gemstones, opium, coca, and cannabis do not seem to be linked to the initiation of conflict, but they do seem to lengthen pre-existing wars. Timber's role remains untested. (3) There is no statistical evidence - and very little case study evidence - that links agricultural commodities to either the initiation or the duration of civil war. (4) The claim that primary commodities are associated with the onset of civil war does not appear to be robust."
} 
Quadro 4. Pesquisas quantitativas sobre recursos naturais e guerras civis.

\begin{tabular}{|c|c|c|c|c|}
\hline Estudo & Cobertura & Medida do recurso & $\begin{array}{c}\text { Variável } \\
\text { dependente }\end{array}$ & Conclusão \\
\hline $\begin{array}{l}\text { Collier e } \\
\text { Hoefler } \\
(1998)\end{array}$ & $\begin{array}{c}27 \text { guerras } \\
(1960-1992)\end{array}$ & $\begin{array}{c}\text { Exportações } \\
\text { primárias-produto } \\
\text { interno bruto (PIB) }\end{array}$ & $\begin{array}{l}\text { Desencadeamento } \\
\text { de guerra civil }\end{array}$ & $\begin{array}{l}\text { Aumenta a } \\
\text { probabilidade } \\
\text { de guerras }\end{array}$ \\
\hline $\begin{array}{l}\text { Collier e } \\
\text { Hoefler } \\
\text { (2002a) }\end{array}$ & $\begin{array}{c}52 \text { guerras } \\
(1960-1999)\end{array}$ & $\begin{array}{l}\text { Exportações } \\
\text { primárias-PIB }\end{array}$ & $\begin{array}{l}\text { Desencadeamento } \\
\text { de guerra civil }\end{array}$ & $\begin{array}{l}\text { Aumenta a } \\
\text { probabilidade } \\
\text { de guerras }\end{array}$ \\
\hline $\begin{array}{l}\text { Collier e } \\
\text { Hoefler } \\
(2002 b)\end{array}$ & $\begin{array}{c}48 \text { guerras } \\
(1960-1999)\end{array}$ & $\begin{array}{l}\text { Exportações } \\
\text { primárias-PIB }\end{array}$ & $\begin{array}{l}\text { Desencadeamento } \\
\text { de guerra civil }\end{array}$ & $\begin{array}{l}\text { Aumenta a } \\
\text { probabilidade } \\
\text { de guerras }\end{array}$ \\
\hline $\begin{array}{c}\text { Elbadawi e } \\
\text { Sambanis } \\
(2002)\end{array}$ & $\begin{array}{l}108 \text { guerras } \\
(1960-1999)\end{array}$ & $\begin{array}{l}\text { Exportações } \\
\text { primárias-PIB }\end{array}$ & $\begin{array}{l}\text { Desencadeamento } \\
\text { de guerra civil }\end{array}$ & $\begin{array}{c}\text { Fraco ou } \\
\text { nenhum efeito }\end{array}$ \\
\hline $\begin{array}{c}\text { Fearon } \\
\text { eLatin (2003) }\end{array}$ & $\begin{array}{c}97 \text { guerras } \\
(1960-1999)\end{array}$ & $\begin{array}{l}\text { Exportações } \\
\text { primárias-PIB }\end{array}$ & $\begin{array}{l}\text { Desencadeamento } \\
\text { de guerra civil }\end{array}$ & $\begin{array}{l}\text { Nenhum efeito } \\
\text { significativo }\end{array}$ \\
\hline $\begin{array}{c}\text { Fearon } \\
\text { eLatin (2003) }\end{array}$ & $\begin{array}{l}122 \text { guerras } \\
(1945-1999)\end{array}$ & $\begin{array}{c}\text { Exportações de } \\
\text { petróleo (dummy) }\end{array}$ & $\begin{array}{l}\text { Desencadeamento } \\
\text { de guerra civil }\end{array}$ & $\begin{array}{l}\text { Aumenta a } \\
\text { probabilidade } \\
\text { de guerras }\end{array}$ \\
\hline Hegre (2002) & $\begin{array}{c}50 \text { guerras, } \\
(1960- \\
1997)\end{array}$ & $\begin{array}{c}\text { Exportações } \\
\text { minerais/exportações } \\
\text { totais }\end{array}$ & $\begin{array}{l}\text { Desencadeamento } \\
\text { de guerra civil }\end{array}$ & $\begin{array}{l}\text { Nenhum efeito } \\
\text { significativo }\end{array}$ \\
\hline Hegre (2002) & $\begin{array}{c}50 \text { guerras, } \\
(1960- \\
1997)\end{array}$ & $\begin{array}{l}\text { Exportações } \\
\text { primárias-PIB }\end{array}$ & $\begin{array}{l}\text { Desencadeamento } \\
\text { de guerra civil }\end{array}$ & $\begin{array}{l}\text { Aumenta a } \\
\text { probabilidade } \\
\text { de guerras }\end{array}$ \\
\hline $\begin{array}{c}\text { Humphreys } \\
\text { (2003) }\end{array}$ & $\begin{array}{l}122 \text { guerras } \\
(1945-1999)\end{array}$ & Produção de petróleo & $\begin{array}{l}\text { Desencadeamento } \\
\text { de guerra civil }\end{array}$ & $\begin{array}{l}\text { Aumenta a } \\
\text { probabilidade } \\
\text { de querras }\end{array}$ \\
\hline $\begin{array}{c}\text { Humphreys } \\
\text { (2003) }\end{array}$ & $\begin{array}{l}122 \text { guerras } \\
(1945-1999)\end{array}$ & Reservas de petróleo & $\begin{array}{l}\text { Desencadeamento } \\
\text { de Guerra Civil }\end{array}$ & $\begin{array}{l}\text { Nenhum efeito } \\
\text { significativo }\end{array}$ \\
\hline $\begin{array}{c}\text { Humphreys } \\
\text { (2003) }\end{array}$ & $\begin{array}{l}122 \text { guerras } \\
(1945-1999)\end{array}$ & $\begin{array}{l}\text { Produção de } \\
\text { diamantes }\end{array}$ & $\begin{array}{l}\text { Desencadeamento } \\
\text { de querra civil }\end{array}$ & $\begin{array}{l}\text { Nenhum efeito } \\
\text { significativo }\end{array}$ \\
\hline $\begin{array}{c}\text { Humphreys } \\
\text { (2003) }\end{array}$ & $\begin{array}{l}122 \text { guerras } \\
(1945-1999)\end{array}$ & $\begin{array}{l}\text { Produção de } \\
\text { diamantes }\end{array}$ & $\begin{array}{c}\text { Duração da guerra } \\
\text { civil }\end{array}$ & $\begin{array}{c}\text { Reduz a } \\
\text { duração da } \\
\text { querra }\end{array}$ \\
\hline $\begin{array}{l}\text { Reynal- } \\
\text { Querol } \\
(2002)\end{array}$ & $\begin{array}{c}91 \text { guerras, } \\
(1960- \\
1995)\end{array}$ & $\begin{array}{l}\text { Exportações } \\
\text { primárias-PIB }\end{array}$ & $\begin{array}{c}\text { Desencadeamento } \\
\text { e prevalência de } \\
\text { guerra civil }\end{array}$ & $\begin{array}{c}\text { Apenas } \\
\text { aumenta a } \\
\text { probabilidade } \\
\text { de guerras não- } \\
\text { étnicas }\end{array}$ \\
\hline $\begin{array}{l}\text { Elbadawi e } \\
\text { Sambanis } \\
(2002)\end{array}$ & $\begin{array}{l}108 \text { guerras } \\
(1960-1999)\end{array}$ & $\begin{array}{l}\text { Exportações } \\
\text { primárias-PIB }\end{array}$ & $\begin{array}{l}\text { Prevalência de } \\
\text { guerra }\end{array}$ & $\begin{array}{c}\text { Fraco ou } \\
\text { nenhum efeito }\end{array}$ \\
\hline $\begin{array}{l}\text { Collier, } \\
\text { Hoeffler e } \\
\text { Söderbom } \\
(2004)\end{array}$ & $\begin{array}{c}52 \text { guerras } \\
(1960-1995)\end{array}$ & $\begin{array}{l}\text { Exportações } \\
\text { primárias-PIB }\end{array}$ & $\begin{array}{c}\text { Duração da guerra } \\
\text { civil }\end{array}$ & Nenhum efeito \\
\hline
\end{tabular}




\section{Conclusão}

Quadro 4. Pesquisas quantitativas sobre recursos naturais e guerras civis.

\begin{tabular}{|c|c|c|c|c|}
\hline Estudo & Cobertura & Medida do recurso & $\begin{array}{c}\text { Variável } \\
\text { dependente }\end{array}$ & Conclusão \\
\hline $\begin{array}{c}\text { Fearon } \\
(2004)\end{array}$ & $\begin{array}{c}122 \text { guerras } \\
(1945-1999)\end{array}$ & $\begin{array}{c}\text { Contrabando (drogas } \\
\text { e pedras preciosas) }\end{array}$ & $\begin{array}{c}\text { Duração da } \\
\text { Guerra Civil }\end{array}$ & $\begin{array}{c}\text { Aumenta a } \\
\text { duração da } \\
\text { guerra civil }\end{array}$ \\
\hline $\begin{array}{c}\text { Doyle e } \\
\text { Sambanis } \\
(2000)\end{array}$ & $\begin{array}{c}124 \text { guerras } \\
(1945-1997)\end{array}$ & $\begin{array}{c}\text { Exportações } \\
\text { primárias-PIB }\end{array}$ & $\begin{array}{c}\text { Sucesso na } \\
\text { construção da Paz }\end{array}$ & $\begin{array}{c}\text { Dificulta a } \\
\text { construção da } \\
\text { paz }\end{array}$ \\
\hline $\begin{array}{c}\text { de Soysa } \\
(2002 b)\end{array}$ & $\begin{array}{c}77 \text { estados } \\
(1989-1999)\end{array}$ & $\begin{array}{c}\text { Estoque de recursos } \\
\text { naturais per capita }\end{array}$ & $\begin{array}{c}\text { Desencadeamento } \\
\text { de Guerra Civil } \\
\text { (>25 mortes) }\end{array}$ & $\begin{array}{c}\text { Nenhum efeito } \\
\text { significativo }\end{array}$ \\
\hline $\begin{array}{c}\text { de Soysa } \\
(2002 b)\end{array}$ & $\begin{array}{c}77 \text { estados } \\
(1989-1999)\end{array}$ & $\begin{array}{c}\text { Estoque de minerais } \\
\text { per capita }\end{array}$ & $\begin{array}{c}\text { Desencadeamento } \\
\text { de Guerra Civil } \\
\text { (>25 mortes) }\end{array}$ & $\begin{array}{c}\text { Diminui a } \\
\text { probabilidade } \\
\text { de conflitos }\end{array}$ \\
\hline $\begin{array}{c}\text { de Soysa } \\
(2002 b)\end{array}$ & $\begin{array}{c}138 \text { estados } \\
(1989-1999)\end{array}$ & $\begin{array}{c}\text { Exportador de } \\
\text { petróleo (dummy) }\end{array}$ & $\begin{array}{c}\text { Desencadeamento } \\
\text { de Guerra Civil } \\
\text { (>25 mortes) }\end{array}$ & $\begin{array}{c}\text { Aumenta a } \\
\text { probabilidade } \\
\text { de conflitos }\end{array}$ \\
\hline $\begin{array}{c}\text { Buhaug e } \\
\text { Gates }(2002)\end{array}$ & $\begin{array}{c}262 \\
\text { conflitos } \\
(1946-2000)\end{array}$ & $\begin{array}{c}\text { Recursos minerais em } \\
\text { zonas de conflito } \\
\text { (dummy) }\end{array}$ & $\begin{array}{c}\text { Extensão da zona } \\
\text { de conflito }\end{array}$ & $\begin{array}{c}\text { Aumenta a } \\
\text { extensão da } \\
\text { zona de conflito }\end{array}$ \\
\hline
\end{tabular}

Fonte: Ross (2004, p. 339, tradução nossa).

\section{Exemplo dessa aproximação com o pensamento da primeira subcorrente é a} conclusão de Le Billon (2001b, p. 580, grifo nosso, tradução nossa):

Conflitos armados e recursos naturais podem estar diretamente relacionados de dois modos principais: conflitos armados motivados pelo controle dos recursos e recursos integrados no financiamento de conflitos armados. Embora poucas guerras sejam inicialmente motivadas por conflito pelo controle de recursos, muitas integram os recursos naturais à sua economia política. Seria um erro reduzir os conflitos armados a guerras induzidas pela cobiça por recursos, pois os fatores políticos e de identidade permanecem chave, e o controle dos recursos locais influencia as agendas e as estratégias dos beligerantes. Esta influência acontece por intermédio de esquemas locais de exploração dos recursos, envolvendo a produção de territórios com base em localização dos recursos, controle e acesso a trabalho e capital, estruturas institucionais e práticas de gestão dos recursos, bem como incorporações nas redes de comércio global. ${ }^{46}$

\footnotetext{
46 "Armed conflicts and natural resources can be directly related in two main ways: armed conflicts motivated by the control of resources, and resources integrated into the financing of armed conflicts. Although few wars are initially motivated by conflict over the control of resources, many integrate resources into their political economy. While it would be an error to reduce armed conflicts to greeddriven resource wars, as political and identity factors remain key, the control of local resources influence the agendas and strategies of belligerents. This influence is played out through local resource exploitation schemes, involving the production of territories based on resource location, control and access to labour and capital, institutional structures and practices of resource management, as well as incorporations into global trading networks."
} 
Outro ponto que merece destaque em relação a essa subcorrente é sua dedicação exclusiva a conflitos armados, com base sobretudo no número de mortos em combate. Dessa forma, parece estar vinculada às preocupações do conceito de segurança nacional mais estrito, ligado, por excelência, aos assuntos militares. Esse enfoque não leva em conta uma série de tensões menores, que muitas vezes desencadeiam ou se relacionam a conflitos de maior extensão. Por outro lado, a má gestão dos recursos e a violência estrutural podem ser mais letais que os conflitos propriamente ditos e a carência de serviços básicos pode provocar número de mortes maior que vários conflitos armados. A ênfase na violência armada comprova que este tipo de agressão é mais facilmente notado que a violência estrutural. Uma última contribuição oferecida pelos autores dessa subcorrente é a preocupação com a dimensão espacial. Embora muitos deles procurem utilizar esse parâmetro a partir da análise estatística, acabam se esquecendo que o conceito de próximo e distante não se limita à distância objetiva. A atuação das diferentes redes técnicas e informacionais sobre o território acaba por tornar locais considerados objetivamente distantes mais próximos do que se possa imaginar.

3.1.2 O segundo enfoque: revisando conflitos por meio da história das sociedades e do meio ambiente

O segundo enfoque foi desenvolvido por estudiosos da história natural, da paleoantropologia e da arqueologia. Essas pesquisas possuem como alvo principal a história de grandes civilizações e suas estratégias de sobrevivência. Diamond (1999) procurou, por meio do recorte da geografia histórica e biológica, responder à pergunta colocada por um morador de Papua Nova Guiné durante uma de suas viagens: Por que algumas sociedades possuem um estilo de vida mais desenvolvido que outras? Investigando o sucesso e o fracasso de diversas sociedades ao longo do tempo, o autor concluiu que a resposta para esta pergunta se encontra na geografia.

Em sua concepção, os povos europeus foram mais bem-sucedidos que os demais em decorrência de melhores condições geográficas. Inicialmente, sua proximidade com a região constituída pelo Crescente Fértil da Idade Antiga Ihes 
possibilitou maior facilidade de se alimentar, além do que o clima, a fauna e a flora também se constituíram em diferenciais, segundo o autor norte-americano. Entre muitos casos históricos, alguns até mesmo duvidosos, Diamond (1999) comentou que, como os cavalos não são nativos das Américas, quando os europeus os utilizaram para as batalhas militares de colonização do novo continente, lograram grande vantagem, uma vez que os nativos norte-americanos não possuíam exemplares iguais para fins bélicos. Para o autor, as condições ambientais são fator importante no desenvolvimento futuro das sociedades.

Em um trabalho subsequente, Diamond (2005) analisou de forma mais profunda os mecanismos utilizados pelas sociedades de forma a explicar porque algumas entram em colapso e outras não. Fazendo um estudo de diferentes casos, tanto de sucesso quanto de falência das sociedades, procurou adotar uma postura menos determinista em relação ao ambiente, especialmente no que concerne aos modos de tomada de decisão por parte das sociedades e, principalmente, de seus líderes (DIAMOND, 2005, p. 447-448).

Embora continuasse afirmando que a questão ambiental é uma das causas precípuas para o colapso das sociedades, Diamond (2005) defendeu que os sistemas de decisão dentro das sociedades possuem a sua importância e que, em determinados casos, podem gerar o colapso delas, expresso de maneira mais explícita por meio de conflitos generalizados.

O grande problema da análise de Diamond (2005) é a falta de conceitos precisos e de provas completamente confiáveis, pois, baseando-se em casos já utilizados em estudos anteriores e que foram amplamente criticados, parece não trazer nenhuma conclusão nova. Prova disso é sua constante referência ao caso da ilha de Páscoa. O antropólogo inglês da Universidade de Liverpool, Peiser (2005, p. 515, tradução nossa), fez duras críticas ao trabalho de Diamond:

Enquanto a teoria do ecocídio tornou-se quase paradigmática nos círculos ambientais, um escuro e sangrento segredo paira sobre a premissa da autodestruição da llha de Páscoa: um verdadeiro genocídio dizimou a população indígena Rapa Nui e sua cultura. Diamond ignora, ou negligencia, a abordagem das verdadeiras razões por trás do colapso Rapa Nui. Outros pesquisadores não têm dúvidas de que seu povo, sua cultura e seu ambiente foram destruídos, para todos os efeitos, por europeus comerciantes de escravos, baleeiros e colonos - e não por si mesmos! Afinal, a crueldade e o rapto sistemático pelos europeus comerciantes de escravos, a situação de quase extermínio da população indígena da ilha e a destruição deliberada do meio ambiente da ilha tem sido consideradas 
como "uma das mais hediondas atrocidades cometidas pelos homens brancos nos mares do Sul" [...], "talvez a mais terrível peça de genocídio na história da Polinésia" $[. . .]^{47}$

Peiser (2005) ainda argumentou que houve uma série de equívocos cometidos pelo biólogo norte-americano, principalmente no que concerne a evidências pouco confiáveis, a algumas pesquisas não citadas por Diamond (2005) que comprovam o contrário de suas ideias e, particularmente, a distorções promovidas pelo autor. Le Billon (2001b, p. 564, tradução nossa) também o criticou abertamente:

\begin{abstract}
Segundo os defensores da hipótese das guerras por recursos escassos, as pessoas ou nações lutarão entre si para garantir o acesso aos recursos necessários para a sua sobrevivência: quanto mais escassos os recursos, mais duro o combate [...] Um exemplo é a progressiva degradação dos recursos naturais na ilha de Páscoa pelos seus habitantes polinésios, que deu origem a uma mortífera luta e canibalismo até que o número de habitantes foi reduzido de 20.000 , em seu "apogeu", para 2.000, quando os primeiros europeus chegaram em 1722 [...]. Enquanto alguns dos mais enviesados exames oferecem evidências grotescamente convincentes, existem diversos contra-argumentos à generalização da perspectiva da guerra por recursos escassos. ${ }^{48}$
\end{abstract}

Outro trabalho na mesma linha metodológica foi desenvolvido pelo antropólogo norte-americano Tainter (1988), que procurou analisar de que forma as sociedades no passado entraram em colapso e quais fatores estiveram envolvidos mais fortemente neste processo. Sua primeira preocupação referiu-se a determinar o conceito de colapso, que para ele é um processo essencialmente político, como se pode deduzir a partir da seguinte explicação:

\footnotetext{
47 "While the theory of ecocide has become almost paradigmatic in environmental circles, a dark and gory secret hangs over the premise of Easter Island's self-destruction: an actual genocide terminated Rapa Nui's indigenous populace and its culture. Diamond ignores, or neglects to address the true reasons behind Rapa Nui's collapse. Other researchers have no doubt that its people, their culture and its environment were destroyed to all intents and purposes by European slave-traders, whalers and colonists - and not by themselves! After all, the cruelty and systematic kidnapping by European slave-merchants, the near-extermination of the Island's indigenous population and the deliberate destruction of the island's environment has been regarded as 'one of the most hideous atrocities committed by white men in the South Seas" [...], "perhaps the most dreadful piece of genocide in Polynesian history' [...]."

48 "According to advocates of the scarce resource wars hypothesis, people or nations will fight each other to secure access to the resources necessary for their survival: the more scarce the resource, the more bitter the fight [...] An example is the progressive degradation of Easter Islands' natural resources by its Polynesian inhabitants, which ended through internecine struggle and cannibalism until the number of inhabitants was reduced from 20,000 at its 'apogee' to 2,000 when Europeans first arrived in 1722 [...]. While some of the most nuanced examinations offer convincing anecdotal evidence, there are several counter-arguments to the generalization of the scarce resource war perspective."
} 
Há, em primeiro lugar e acima de tudo, uma ruptura de autoridade e controle central. Antes do colapso, revoltas provinciais separatistas sinalizam o enfraquecimento do centro. As receitas do governo geralmente declinam. Inimigos estrangeiros têm cada vez mais sucesso. Com menores receitas, as forças armadas podem se tornar ineficazes. A população fica cada vez mais insatisfeita, enquanto a hierarquia busca mobilizar recursos para enfrentar o desafio. Com a desintegração, a direção central não é mais possível. $O$ antigo centro político sofre uma significativa perda de proeminência e poder. É frequentemente saqueado e pode vir a ser abandonado. Pequenos e instáveis Estados emergem no antigo território unificado, entre os quais, a antiga capital pode ser um. Muito frequentemente, estes lutam pela dominação, de modo que um período de conflito se segue. A tutela do direito e da proteção erguida sobre a população é eliminada (TAINTER, 1988, p. 19, tradução nossa). ${ }^{49}$

No entanto, como bem ressalta o autor, diferenças entre as sociedades antigas e as sociedades modernas existem. Para o antropólogo norte-americano, essas diferenças se situam particularmente em relação à complexidade das sociedades mais modernas, que são cada vez mais complexas, porquanto:

Complexidade é geralmente entendida como se referindo a coisas como o tamanho de uma sociedade, o número e a especificidade de suas partes, a variedade de papéis sociais especializados que incorpora, o número de distintas personalidades sociais presentes e a variedade de mecanismos para organizar estes em um todo coerente e funcional. $\mathrm{O}$ aumento de qualquer destas dimensões leva ao aumento da complexidade de uma sociedade (TAINTER, 1996, p. 62, tradução nossa). ${ }^{50}$

Procurando respostas para os fatores que podem levar as sociedades mais complexas ao colapso, Tainter (1988) passou a analisar diferentes teorias para a ocorrência deste fenômeno e suas respostas: a) diminuição ou esgotamento de um recurso vital do qual a sociedade depende; b) utilização de um novo recurso básico; c) ocorrência de grandes catástrofes; d) respostas insuficientes e falta de adaptação a determinadas circunstâncias; e) imperialismo de outras sociedades complexas; f)

\footnotetext{
49 "There is, first and foremost, a breakdown of authority and central control. Prior to collapse, revolts and provincial breakaway signal the weakening of the center. Revenues to the government often decline. Foreign challengers become increasingly successful. With lower revenues the military may become ineffective. The populace becomes more and more disaffected as the hierarchy seeks to mobilize resources to meet the challenge. With disintegration, central direction is no longer possible. The former political center undergoes a significant loss of prominence and power. It is often ransacked and may ultimately be abandoned. Small, petty states emerge in the formerly unified territory, of which the previous capital may be one. Quite often these contend for domination, so that a period of conflict ensues. The umbrella of law and protection erected over the populace is eliminated."

50 "Complexity is generally understood to refer to such things as the size of a society, the number and distinctiveness of its parts, the variety of specialized social roles that it incorporates, the number of distinct social personalities present, and the variety of mechanisms for organizing these into a coherent, functioning whole. Augmenting any of these dimensions increases the complexity of a society."
} 
invasões; g) conflitos de classes e contradições sociais; h) disfunções sociais; i) cadeia concatenada de eventos; j) fatores econômicos.

Chama-nos a atenção a avaliação que Tainter (1988) fez acerca da hipótese de diminuição ou esgotamento dos recursos, reiterando que é uma das mais atrativas no meio acadêmico. Autores atraídos por essa hipótese afirmam que muitas sociedades se tornam menos complexas por conta da diminuição ou do esgotamento de um determinado recurso básico essencial e, assim, entram em colapso. Tainter (1988) esclareceu que, para tanto, alguns autores chegaram a pressupor que as sociedades veem as perturbações ocorrendo sem tomar nenhuma medida preventiva. Para o autor, as sociedades complexas são caracterizadas por constantes fluxos de informação e de institucionalização de agências reguladoras, grande coordenação entre as suas partes e reunião de recursos. Significativa parte dessa estrutura possui a capacidade de encontrar as deficiências em seu modo de agir. Dessa forma, argumentou Tainter (1988, p. 50, tradução nossa) que:

[...] com essa estrutura administrativa e capacidade de alocar tanto trabalho quanto recursos, lidar com condições ambientais adversas pode ser uma das coisas que as sociedades complexas fazem melhor [...] É curioso que elas entrassem em colapso quando encontrassem precisamente aquelas condições que estão preparadas para contornar. ${ }^{51}$

Levando em consideração essas características, o antropólogo norteamericano concluiu que o processo de colapso se origina essencialmente a partir das próprias formas de estruturação das sociedades. Isso ficou implícito quando Tainter (1988, p. 51, tradução nossa) comentou que:

É inteiramente possível, claro, que possam ocorrer flutuações ou deteriorações ambientais de tal forma que os atuais sistemas de produção e arranjos sociais não consigam superar. Os teóricos do esgotamento dos recursos, de fato, teriam apenas este argumento. Vários tipos de informação são necessários, no entanto, para realmente demonstrar que tais condições podem causar colapso. Os dados em questão incluiriam clima, população, produtividades agrícolas ou de outros recursos, exigências anuais da população e do sistema sociopolítico e capacidades adaptativas da sociedade em questão. Esses dados não têm sido sistematicamente procurados nos estudos sobre colapso.

Se uma sociedade não pode lidar com o esgotamento dos recursos (o que todas as sociedades são, em certa medida, destinadas a fazer), então a questão verdadeiramente interessante gira em torno da sociedade e não do recurso. Quais fatores estruturais, políticos, ideológicos ou econômicos em

51 "With their administrative structure and capacity to allocate both labor and resources, dealing with adverse environmental conditions may be one of the things that complex societies do best [...] It is curious that they would collapse when faced with precisely those conditions they are equipped to circumvent." 
uma sociedade impediram uma resposta apropriada? Isto não é uma pergunta à toa, embora pareça simples, uma vez que a literatura sobre esgotamento de recursos contém algumas ambiguidades perturbadoras. ${ }^{52}$

\begin{abstract}
Rejeitando várias das explicações analisadas para o colapso, o autor se concentrou nas explicações econômicas, as quais, em sua concepção, parecem
\end{abstract} sugerir melhores condições de reflexão. Partindo da análise dos custos empregados para resolver uma série de problemas pelos quais a sociedade passa e seus níveis de complexidade, Tainter (1996, p. 64-65, tradução nossa) apresentou o Gráfico 1, chegando à conclusão de que:

À medida que uma sociedade aumenta em complexidade, expande investimentos em coisas como produção de recursos, processamento de informações, administração e defesa. A curva de custo/benefício para estas despesas pode aumentar favoravelmente no início, à medida que as soluções mais simples, gerais e baratas são adotadas (uma fase não mostrada neste gráfico). No entanto, à medida que uma sociedade encontra novas pressões e as soluções mais baratas já não são suficientes, sua evolução prossegue em uma direção mais dispendiosa. Por fim, uma sociedade em crescimento atinge um ponto em que investimentos contínuos em complexidade produzem retornos mais elevados, mas a uma taxa marginal decrescente. Em um ponto, como B1, C1 neste gráfico, uma sociedade entrou na fase em que começa a tornar-se vulnerável ao colapso. $^{53}$

Por outro lado, Tainter (1996) reiterou que colapso não quer dizer falência total da sociedade, mas a estruturação da antiga sociedade em uma nova forma de organização menos complexa e mais simples. De acordo com esse pensamento, o

\footnotetext{
52 "It is entirely possible, of course, that environmental fluctuations or deterioration may occur that existing production systems and social arrangements cannot overcome. Resource depletion theorists, indeed, would have to make just such an argument. Several kinds of information are needed, though, to truly demonstrate that such conditions can cause collapse. The data in question would include climate, population, crop or other resource yields, yearly requirements of the population and of the sociopolitical system, and the adaptive capabilities of the society in question. Such data have not been systematically sought in the study of collapse.

If a society can not deal with resource depletion (which all societies are to some degree designed to do) then the truly interesting question revolves around the society, not the resource. What structural, political, ideological or economic factors in a society prevented an appropriated response? This is no idle question, however simple it may seem, for the literature on resource depletion contains some disturbing ambiguities."

53 "As a society increases in complexity, it expands investment in such things as resource production, information processing, administration, and defense. The benefit/cost curve for these expenditures may at first increase favorably, as the most simple, general, and inexpensive solutions are adopted (a phase not shown on this chart). Yet as a society encounters new stresses, and inexpensive solutions no longer suffice, its evolution proceeds in a more costly direction. Ultimately a growing society reaches a point where continued investment in complexity yields higher returns, but at a declining marginal rate. At a point such as B1, C1 on this chart a society has entered the phase where it starts to become vulnerable to collapse."
} 
colapso é somente uma fase caótica de estruturação antes que uma sociedade menos complexa torne-se, finalmente, mais bem estruturada.

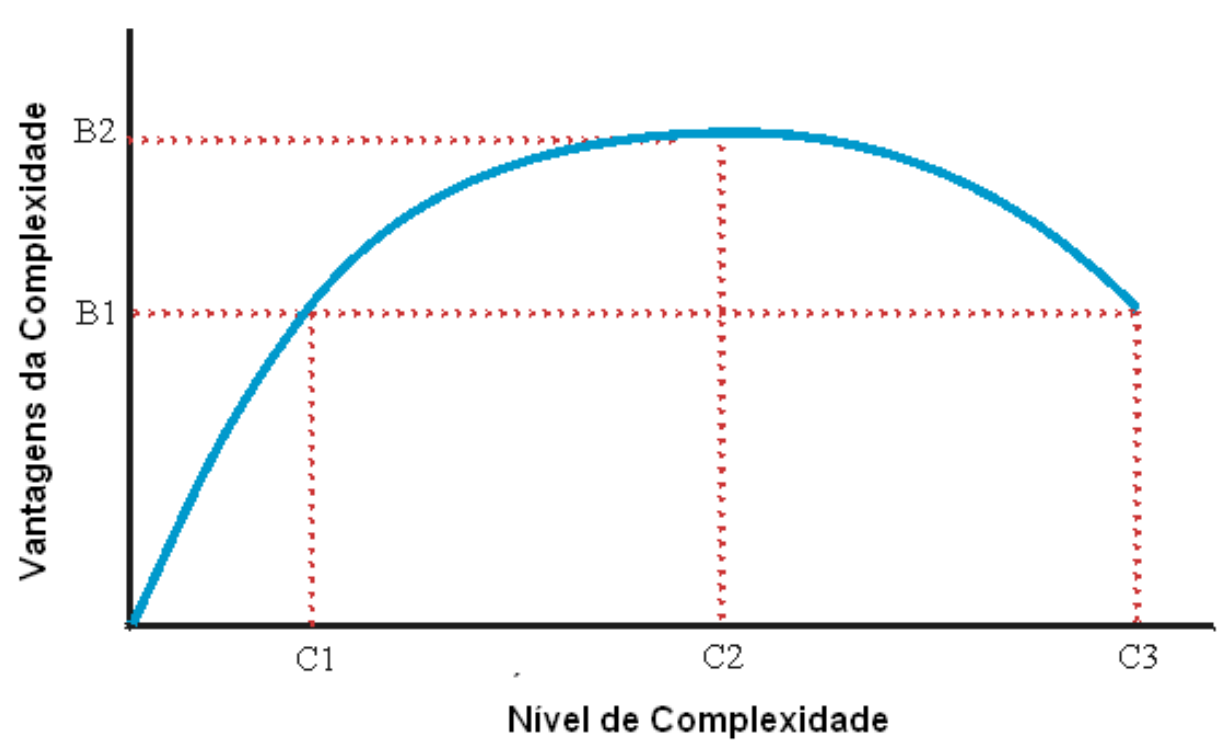

Gráfico 1. Síntese das sociedades propensas a entrar em colapso: benefícios reduzidos para alto nível de complexidade.

Fonte: Tainter (1996, p. 64).

Fica bastante claro, a partir da proposta de Tainter (1996), que os conflitos giram significativamente em torno das questões políticas em seu modo de analisar o colapso social. O autor descarta categoricamente conflitos relacionados tanto à escassez quanto à abundância de recursos. De certa forma, segue a escola econômica baseada nas crenças do Marquês de Condorcet de que o progresso humano está habilitado a superar qualquer grande pressão, a não ser que a sociedade, por si mesma, não seja tão bem estruturada a ponto de entrar em declínio.

Além disso, a proposta do antropólogo norte-americano parece radicalizar quanto à influência das questões naturais. Ao partir da premissa de que se a sociedade não é capaz de superar pressões naturais há algo equivocado com ela mesma, Tainter (1996) parece não levar em consideração a lei da diferenciação espacial. Cada porção do espaço geográfico apresenta características físico-sociais diferentes e, portanto, revela possibilidades diversificadas às sociedades. Assim sendo, não apenas a organização social é importante, mas as condições do meio 
geográfico também participam, ainda que de forma indireta, da própria organização social.

Neste segundo enfoque, enquanto a postura de Diamond (2005) mostra, em certo grau, um determinismo ambiental, a posição de Tainter (1988) denota justamente o contrário, porquanto este desconsiderou completamente a influência dos fatores físicos sobre as sociedades, uma vez que, segundo ele, estas são organizadas para se sobrepor a diversas pressões, inclusive físico-naturais. Uma postura que procura analisar a interação entre meio natural e meio social na perspectiva do segundo enfoque foi representada pelo filósofo britânico Blackburn (1992). Diferentemente dos autores anteriores, este empregou o método dedutivo, primeiramente criando um arcabouço teórico para, posteriormente, ir analisando casos específicos ao longo da história.

Blackburn (1992) partiu do pressuposto que tanto o marxismo quanto a geopolítica analisam a realidade de forma incompleta. Por um lado, o marxismo falha por levar em conta tão-somente a luta de classes e olvidar o confronto das grandes potências no plano internacional, ainda mais quando não se possui uma gendarme (polícia, autoridade superior) no plano global. Por outro, o autor nos lembra que o marxismo também falhou porque se preocupou essencialmente com a produção e menos com o consumo. Assim, ao salientar a importância do método dialético e, portanto, ao destacar de forma mais intensa a produção em detrimento do consumo, o marxismo deixou de considerar que os significados de seus conceitos devem estar vinculados aos seus opostos

A geopolítica, por seu turno, também falhou, porque sua premissa básica, de acordo com Blackburn (1992, p. 32), "é a prevenção da destruição provocada socialmente pelos homens, seja internamente ao Estado, seja externamente entre Estados. Na pior das hipóteses, isso pode levar ao estatismo e belicismo". Ademais, uma parte das teorias geopolíticas "subestima a criatividade e o poder das sociedades humanas fora da esfera do Estado" (BLACKBURN, 1992, p. 32). Entretanto, um dos pontos fortes da geopolítica reside em chamar a atenção para as forças naturais, ainda que com cunho determinista.

Tendo em mente o princípio da relação dialética entre a criação promovida pela produção (derivada da economia) e a destruição levada adiante pela geopolítica, Blackburn (1992) passou a refletir melhor sobre esses dois conceitos. 
Para ele, a criação e a destruição são duas forças presentes não apenas no meio social. Baseando-se na teoria sartreana do prático inerte e da necessidade (SARTRE, 1976), Blackburn (1992) asseverou que as forças físicas da natureza exercem tanto forças criativas quanto destruidoras sobre as sociedades. Destarte, o conceito de prático inerte de Sartre pareceu não estar completamente correto para Blackburn (1992) quando este destacou que as forças criativas, bem como as destrutivas, também são exercidas e produzidas pelas sociedades, sendo exemplo disso os processos produtivos e as guerras, respectivamente.

De acordo com o filósofo britânico, os Estados estão continuamente lidando tanto com forças criativas quanto destrutivas, sejam elas proveniente do meio natural ou social. O modo como as sociedades lidam com essas duas forças faz com que estabeleçam diferentes modos de vida, os quais podem se situar tanto no domínio da necessidade quanto no da liberdade em duas dimensões: material e cultural. Salientando a importância desse processo, Blackburn (1992) argumentou a necessidade da institucionalização de um modo de segurança de forma a proteger o Estado igualmente contra forças destrutivas da natureza e de outros Estados. Outrossim, esse modo de segurança também deve impulsionar os processos criativos naturais e sociais.

O trabalho de Blackburn (1992) apresentou uma série de contribuições à discussão acerca da segurança e do papel fundamental da geopolítica ao abordar a atuação das forças físicas. Outro aspecto primordial de sua obra reside na discussão do campo da segurança não restrita à área militar, mas também envolvendo diferentes aspectos que se relacionam com os processos destrutivos sociais e naturais. No entanto, o autor levou em conta principalmente a relação entre Estados, se esquecendo da atuação e da relação entre outros atores sociais de diversas escalas. Dessa forma, o filósofo britânico se referiu exclusivamente ao clássico conceito de geopolítica. Mesmo levando em conta as relações geopolíticas entre Estados, afirmou que tanto as forças sociais como as naturais estão em interação. Isso signifca afirmar que as guerras e os conflitos entre Estados não ocorrem exclusivamente por atuação das forças naturais e, portanto, conflitos exclusivamente motivados por forças naturais não existem a partir da filosofia histórica traçada por Blackburn (1992). 
3.1.3 O terceiro enfoque: sociologia ambiental - sobrepondo os conflitos sociais aos problemas ambientais?

O terceiro enfoque é oriundo, em grande parte, da sociologia ambiental, que procura construir um novo tipo de conflito em torno das questões ambientais. Diferentemente das duas abordagens anteriores, esta procede de uma concepção de conflito não necessariamente vinculada à ideia de confronto armado e violento, embora não ofereça uma teorização bem estabelecida e completa do que seja conflito ambiental ou socioambiental. Dependendo do ponto de vista de que se parte, os conflitos ambientais podem possuir conceituações diferentes, contraditórias e até paradoxais. Para os autores vinculados ao realismo, o conflito ambiental existe baseando-se em uma dimensão exclusivamente ambiental em detrimento de outras dimensões sociais. Já o construcionismo tem como pressuposto que os conflitos ambientais e socioambientais são, na verdade, uma forma de percepção de antigos conflitos sociais enquanto problemas ambientais, por meio do avanço da consciência ambiental sobre a sociedade.

Já o realismo social preconiza que as relações sociais devem ser analisadas em conjunção com outros fenômenos de outras dimensões, entre eles os físicos, biológicos e ecossistêmicos. Os representantes dessa corrente levam adiante o argumento de que os fatores biológicos e físicos ajudam a explicar os fatos sociais e, portanto, o mainstream (principal corrente) da sociologia falha por não levar em conta os pressupostos das outras disciplinas (LIDSKOG, 2001). Os grandes adeptos desse pensamento abarcam desde a economia política, como Schnaiberg (1987) e sua teoria ambiental de cunho marxista, até a teoria ecológica explícita de Dunlap e Catton (1992/93), denominada the new ecological paradigm (o novo paradigma ecológico).

Tendo como base essas premissas, surgiram diversas concepções do que seria um conflito ambiental ou socioambiental, cujo conceito teve sua gênese no pressuposto de que a questão em disputa se reduz ao meio natural. Para seus proponentes, havia questões exclusivamente relacionadas ao meio natural que seriam a causa exclusiva do conflito. Porém, como alguns autores posteriormente reconheceram, a matéria é bem mais complexa que simplesmente resoluta ao meio natural. Consequentemente, passou-se a falar em conflito socioambiental. 
Enfatizando a importância da ecologia política, Little (2001, p. 107) afirmou que:

Podemos definir os conflitos socioambientais como disputas entre grupos sociais derivadas dos distintos tipos de relação que eles mantêm com seu meio natural. $O$ conceito socioambiental engloba três dimensões básicas: 0 mundo biofísico e seus múltiplos ciclos naturais, o mundo humano e suas estruturas sociais, e o relacionamento dinâmico e interdependente entre esses dois mundos.

Levando adiante esse conceito de conflito ambiental, o antropólogo criou uma tipologia de conflitos socioambientais. O primeiro tipo é aquele em torno do "controle sobre os recursos naturais"; o segundo se origina dos "impactos sociais e ambientais gerados pela ação humana e natural"; e, finalmente, o terceiro ocorre a partir de disputas pelo "uso dos conhecimentos ambientais". Ademais, Little (2001, p. 108) advertiu que não "se trata de uma tipologia rígida, mas sim de um mecanismo heurístico que deve ser utilizado com flexibilidade".

Por essa conceituação, fica explícito que o autor reflete a respeito do conceito de conflitos socioambientais a partir do processo analítico, fazendo recortes muitas vezes problemáticos da realidade. Ao separar analiticamente o mundo natural e o mundo humano, acaba-se por criar alguns problemas posteriores, mormente se não se lançar mão do procedimento de síntese, aspecto com o qual, em nenhum momento, Little (2001) pareceu se preocupar. Nossa pergunta é a mesma que Santos (1999, p. 34-35) fez ao se pronunciar sobre a separação entre um meio técnico e um meio geográfico: "porque uni-los, através de uma separação, em vez de considerá-los como fundidos ao produzir o meio geográfico?”. Ora, não se está aqui falando de meio geográfico? Segundo Silva (1978, p. 10), "o meio natural e o meio cultural formam o meio geográfico. Este modifica-se no decorrer do tempo à medida que se desenvolvem a história natural e a história humana." Não obstante, ao realizar um recorte tão radical, Little (2001) parece ter perdido de foco que os próprios homens, enquanto seres biológicos, possuem um pé no mundo biofísico e o outro no mundo social.

Ainda outro aspecto problemático se resume em torno da amplitude dada por ele ao conceito do termo socioambiental, quando afirmou que este engloba os "mundos biofísico e humano" além de suas interações. Isso confere certa imprecisão ao conceito de conflito socioambiental, pois estaríamos englobando todos os conflitos possíveis e, portanto, não se está caracterizando algo novo, mas somente 
trocando o nome dado a algo já conceituado. Embora os conceitos de outras disciplinas devam ser remodelados quando são incluídos em uma disciplina específica, isso não significa algo novo ontologicamente, como querem determinar alguns desses autores. Esse tipo de delimitação ocorre justamente pela imprecisão do conceito de meio ambiente, já explicitada por nós no segundo item deste trabalho (A Hidra de Lerna: quando cortes e recortes epistemológicos não resolvem a questão).

Outra concepção de conflito ambiental foi dada pelo geógrafo Acselrad (2004, p. 24) quando procurou acrescentar uma dimensão geográfica ao seu conceito de conflito socioambiental:

[...] aqueles envolvendo grupos sociais com modos diferenciados de apropriação, uso e significação do território, tendo origem quando pelo menos um dos grupos tem a continuidade das formas sociais de apropriação do meio que desenvolvem ameaças por impactos indesejáveis - transmitidos pelo solo, água, ar ou sistemas vivos - decorrentes do exercício das práticas de outros grupos. O conflito pode derivar da disputa por apropriação de uma mesma base de recursos, ou de bases distintas, mas interconectadas por interações ecossistêmicas mediadas pela atmosfera, pelo solo, pelas águas etc. Este conflito tem por arenas unidades territoriais compartilhadas por um conjunto de atividades cujo "acordo simbólico" é rompido em função da denúncia dos efeitos indesejáveis da atividade de um dos agentes sobre as condições materiais do exercício das práticas de outros agentes.

Um fator importante citado pelo autor é a apropriação territorial. Naturalmente, todo conflito implica efeitos territoriais e, assim, essa não seria uma característica exclusiva daqueles do tipo socioambiental, mas sim de todo conflito social, embora uma boa parte dos estudos sociológicos e da ciência política tenha começado a atentar para esta dimensão há pouco tempo. Na geografia, Claval (1979) e Raffestin (1993) já sinalizavam para este aspecto ao discorrer sobre o poder.

Embora esse conceito seja bem mais delimitado, existem ainda alguns problemas ontológicos. Em primeiro lugar, ao delimitar espacialmente o conflito em "unidades territoriais compartilhadas por um conjunto de atividades", esse conceito não leva em conta conflitos entre atores que não ocupam uma mesma unidade territorial, lugares conectados por redes técnicas e não apenas por aquelas naturais ou ecossistêmicas, como advertiu Acselrad (2004). Dessa forma, pela atuação das redes técnicas, não há como simplesmente discorrer sobre interações ecossistêmicas. 
Em segundo lugar, as relações conflituosas são bem mais complexas, podendo englobar muitas outras dimensões além do "acordo simbólico" e os efeitos ecossistêmicos. O acordo simbólico pode ser rompido por uma série de outras tensões sociais e, portanto, o conflito não seria exclusivamente ambiental. Os recursos naturais podem ser utilizados como arma geopolítica e, consequentemente, a temática ambiental seria apenas um pretexto para outras questões.

A corrente do construcionismo, por outro lado, não nega que haja fenômenos de outras dimensões, mas Acselrad (2004, p. 24) argumentou que "a análise sociológica das questões ambientais deve se preocupar essencialmente com a dimensão social”. Refletindo a respeito da visão construcionista, Lidskog (2001, p. 121, tradução nossa) concluiu que "consequentemente, a tarefa sociológica é explicar quais processos sociais causam alguma coisa para aparecer como um problema ambiental". 54

No Brasil, uma parte dessa teoria se baseia na ideia do paradigma multissetorial, partindo da premissa que a consciência ambiental vai sendo apropriada de maneira diversa pelos vários setores da sociedade, o que pode ocasionar conflitos quanto à concepção de meio ambiente. Referindo-se ao paradigma multissetorial, Alonso e Costa (2002, p. 119) relataram que:

\begin{abstract}
Essa interpretação se ampara em uma perspectiva cognitiva: apresenta o ambientalismo como espécie de "idéia-força", cuja difusão dependeria do empenho de um grupo especial de atores em favor da conscientização dos demais. O ambientalismo ganha status de movimento social especial [...], surgindo da sociedade civil organizada para esclarecer e corrigir tanto a política estatal como a economia. A interpretação divide a sociedade em elites que, tão logo esclarecidas, passariam a adotar uma postura ambientalmente correta.
\end{abstract}

Ao adotar essa postura valorativa em relação à questão ambiental, fica claro que, se há conflitos entre diversos protagonistas, esses embates se dariam somente na esfera dos valores e, portanto, na esfera social e, desse modo, não estaríamos tratando de conflitos socioambientais de maneira ontológica. Alonso e Costa (2002, p. 120) chegaram à mesma conclusão e argumentaram que, do ponto de vista do paradigma multissetorial, "não existiriam conflitos ambientais senão em um sentido: como conflitos de valor, transitórios por definição, já que uma vez esclarecidos, os

\footnotetext{
54 "Consequently, the sociological task is to explain which social processes cause something to appear as an environmental problem."
} 
atores tenderiam a aderir a práticas sustentabilistas". Seguindo os preceitos desse paradigma, o conflito não se situaria na dimensão ambiental, mas tão-somente na dimensão social. À vista disso, seria paradoxal utilizar o termo conflito socioambiental para essa teoria, uma vez que ela parte dos valores sociais. Estaríamos, então, falando de conflitos sociais e meio ambiente e não de conflitos socioambientais. "A ênfase na dimensão valorativa do ambientalismo põe de lado a lógica dos interesses, ignorando a dimensão prática do fenômeno" (ALONSO; COSTA, 2002, p.120).

Vários autores brasileiros, preocupados com o assunto, vêm trabalhando sob a perspectiva construcionista por meio das contribuições de autores como Hannigan (1995). Essa postura tem dado grande importância à construção argumentativa nas arenas públicas, especialmente no que concerne às disputas técnicas e políticas. Esses autores destacam a importância da "construção pública" de temas como "impacto ambiental" e "risco ambiental".

Na concepção de Fuks (2001), o que qualifica um conceito como ambiental é a percepção dos atores envolvidos nele. Avaliando conflitos considerados ambientais por essa abordagem, o autor chegou à seguinte conclusão:

\begin{abstract}
Os casos apresentados ilustram como o enquadramento ambiental dos conflitos corresponde a uma fase tardia de suas carreiras. A inserção da questão ambiental no desdobramento dos conflitos revela um quadro de continuidade fundado na compatibilidade entre o conceito abrangente de meio ambiente usado como suporte para argumentação do Ministério Público e a visão urbanística dos problemas ambientais. Esta compreensão serve de referência para a maior parte das compreensões de meio ambiente como problema social elaboradas pelos atores evolvidos nos conflitos ambientais no Rio de Janeiro, constituindo um dos aspectos centrais do esquema argumentativo (FUKS, 2001, p. 110).
\end{abstract}

Então, para o autor, o conflito ambiental se caracteriza como uma segunda fase de conflitos originados a partir de dimensões sociais que, algumas vezes, nem sequer se relacionam com uma "questão ambiental" diretamente. Em contraste, definir se o conflito se torna ambiental ou não fica a cargo do Ministério Público, o qual deve decidir acerca de seu procedimento de levar adiante ou não alguma ação enquanto tal.

Em sua conclusão sobre os conflitos que analisou no Rio de Janeiro, ao compará-los com o coneito clássico de conflito ambiental, Fuks (2001, p. 216, grifo nosso) declarou que: 
Primeiramente, nesses conflitos, há de um lado, o predomínio de atores que não são, prioritariamente, identificados como defensores do meio ambiente e, de outro, a presença discreta de ambientalistas [...] Um outro aspecto importante é que, embora os conflitos ambientais, no Rio de Janeiro, possam expressar o embate entre visões de mundo movidas por visões antagônicas e irreconciliáveis, essa visão não tem como fundamento, de um lado, a defesa intransigente do mundo natural e, de outro, a ideologia do progresso. Trata-se, antes de mais nada, de uma luta em torno do uso do solo urbano, na qual estão em disputa valores e princípios de diversas ordens, como qualidade de vida e direito à moradia.

Adicionalmente, o trabalho produzido por Fuks (2001) trouxe contribuições a esse debate quando este enfatizou a compreensão dada pelos atores à questão envolvida no conflito. A partir de seu trabalho, ficou evidente que os conflitos que analisou, ainda que considerados como ambientais pelo arcabouço jurídico, se referem muito mais a questões sociais, tratando-se, portanto, de conflitos sociais. Evidentemente, pela abrangência dada ao conceito de meio ambiente - incluindo praticamente a realidade inteira -, vários postularão que são conflitos socioambientais. Entretanto, muitos geógrafos, entusiasmados com a sua disciplina, optarão por afirmar que se tratam de conflitos socioespaciais ou mesmo urbanos. Como já asseveramos anteriormente, e ainda reiteraremos quando da abordagem deste tema mais à frente, todo conflito social possui uma dimensão espacial, assim como toda sociedade ocupa um espaço e, consequentemente, todos os conflitos sociais repercutem, quer de maneira direta ou indireta, sobre este espaço.

Todavia, quando Fuks (2001) deixou a caracterização do conflito a cargo das definições legais apropriadas pelo Ministério Público, acabou se esquecendo que o processo de produção das provas fica sob a responsabilidade das partes e, por conseguinte, o juiz decide a partir das provas produzidas pelas partes no processo. Sendo assim, nem sempre uma análise do processo jurídico consegue elucidar satisfatoriamente o que ocorreu, uma vez que o que não pode ser provado pelo artifício das provas não existe para o mundo do direito, como já havia apontado anteriormente a corrente jurídica da tópica de Viehweg (1979). Por outro lado, a argumentação dada no processo pode se tratar de uma estratégia jurídica, principalmente quando se propala que um determinado fato ocorrido se refere a uma questão ambiental, de forma a conseguir certos benefícios concedidos pela lei, como comprovou a teoria jurídica da nova retórica de Perelman e Olbrechts-Tyteca (2005).

Além disso, vários autores que adotaram os enfoques da ecologia política e da análise locacional dos conflitos urbanos chegaram a conclusões semelhantes. 
Desde o surgimento da Escola de Chicago, de Park e Burgess, ainda no início do século XX, estudos de sociologia urbana vêm apontando para o fato de que os conflitos urbanos giram, na maioria das vezes, em torno da questão do uso do solo urbano, particularmente no que concerne à degradação do antigo centro urbano. Ainda durante a década de 1970, vários geógrafos políticos anglo-saxões, como Cox (1970), Wolpert (1970), e Janelle (1977 apud FLINT; TAYLOR, 2000), fizeram reflexões sobre os conflitos urbanos e chegaram a conclusões semelhantes às do autor. Janelle (1977 apud FLINT; TAYLOR, 2000) fez uma análise dos atores envolvidos em conflitos urbanos, revelando que tanto os propositores de mudança do uso do solo urbano quanto aqueles contrários a ela foram identificados, de tal forma que a natureza do conflito pôde ser compreendida. A maioria dos propositores de mudança de uso do solo urbano é composta por grandes corporações do ramo imobiliário e instituições do setor público, enquanto dois terços dos opositores são comunidades de moradores. No final do estudo, Janelle (1977 apud FLINT; TAYLOR, 2000, p. 333-334) enfatizou "a complexidade das interdependências entre os participantes no conflito e mudança do uso do solo [urbano]. A simples interpretação ecológica é substituída por um modelo pluralista de geografia do conflito". 55

A problematização levada adiante pela sociologia ambiental vem sendo criticada principalmente porque procura criar um novo tipo de conflito quando o que há, em realidade, é um conjunto complexo de variáveis. Outros autores, como Alonso e Costa (2002, p. 119), atestaram que:

O foco "socioambiental" não distingue, antes sobrepõe, itens mais facilmente identificáveis como "ambientais" - poluição do ar e das águas, preservação de regiões ecológicas "virgens" - de questões às quais a Sociologia nomeava, até [os] anos 70, "problemas sociais": especialmente saneamento e pauperização, nas cidades, e impactos sobre o estilo de vida de comunidades indígenas e/ou tradicionais, no interior do país.

Não obstante, apenas sobrepor o fator ambiental sobre as demais dimensões sociais não contribui muito, uma vez que é necessário saber de que forma as relações que estas dimensões mantêm entre si se estruturam sobre as relações que estes aspectos mantêm entre si. Por outro lado, o que atualmente se está chamando de dimensão ambiental era, anteriormente, chamado de problema social. Como

\footnotetext{
55 "[...] the complexity of the interdependencies of conflict participants in land-use change. Simple ecological interpretation is replaced by a pluralist model of the geography of conflict."
} 
apontou Barbanti Júnior (2002, p. 5) ao falar sobre o conceito de conflito socioambiental:

Uma das tendências do momento pode ser chamada de instrumentalização do tema. Nesta tendência, o uso da palavra "conflito" aparece dissociado de teorias de conflito. O texto que se referia a um "problema ambiental" hoje descreve um "conflito ambiental".

Contudo, ao criar mais uma nova categoria de conflito, esses autores acabaram recortando ainda mais a realidade, o que dificulta sobremaneira aquele movimento de interdisciplinaridade ou transdisciplinaridade que até mesmo alguns deles tanto buscavam. Adicionalmente, como apontaram alguns teóricos anteriormente visitados neste trabalho, desde que conflitos armados causam "problemas ambientais" (degradação ambiental, poluição dos mananciais, desmatamento, etc.), então, seriam eles também conflitos socioambientais? Ou, ainda, quando conflitos são financiados por recursos naturais, também teríamos conflitos socioambientais? Não estamos, então, sobrepondo "itens identificáveis como ambientais" aos temas sociais? No entanto, nenhum dos autores ligados à sociologia ambiental, ou mesmo os propositores do conceito de conflito socioambiental, apontaram esses exemplos citados como casos de conflitos socioambientais. Logo, trata-se de uma sobreposição enviesada da dimensão ambiental. $O$ que se pode inferir é que, ao lidar com o tão discutível conceito de meio ambiente, todos os conflitos, afinal, acabam sendo socioambientais, principalmente quando se quer colocar os problemas ambientais em maior evidência que outros, como afirmam alguns autores da ecologia política. Nesse sentido, Alonso e Costa (2002, p. 117) ponderaram que:

Grande parte do que se convencionou chamar de abordagem socioambiental está profundamente marcada por um viés engajado, que confunde a trajetória do movimento ambientalista com a trajetória política e social da questão ambiental, transformando suas concepções ideológicas em pressupostos analíticos para compreender a dinâmica ambiental. Para construir, em bases sólidas, uma ciência social dos problemas ambientais no Brasil, precisamos superar essa contaminação entre juízos políticos e adotar uma postura de suspensão de valores, ao menos durante a análise.

Os três enfoques aqui apresentados possuem uma concepção diferenciada de conflito, principalmente no que concerne à sua escala. $O$ primeiro enfoque se ocupa essencialmente dos conflitos intranacionais e os chamados failed states (estados falidos). Por seu turno, o segundo enfoque procura argumentar no sentido do fracasso do Estado e, talvez, até muito mais do que isso, apresentar de que 
forma certas civilizações foram completamente dizimadas. Portanto, aqui estamos mencionando precipuamente guerras e conflitos de maior extensão. Por último, o terceiro enfoque, da sociologia ambiental, em alguns casos articula mais problemas que conflitos, bem como conflitos menos intensos e violentos. Isso não quer dizer que algum deles tenha mais ou menos importância que os outros.

Outro faceta que procuramos salientar em relação aos enfoques é que não há razões para se argumentar a existência de um novo tipo de conflito denominado ambiental. A maioria dos estudos demonstra que existem inúmeras variáveis que se coadunam com a variável ambiental para resultar em conflitos. Outrossim, querer sobrepor questões ditas ambientais aos temas sociais implica criar uma nova categoria de conflito (o socioambiental) para nominar aquelas situações que anteriormente eram chamadas de conflito social, embora ontologicamente estejamos tratando do mesmo tipo de fato. 


\section{MARTE OU MINERVA: QUANDO A GUERRA DA ÁGUA É MENOS LETAL QUE AS RELAÇÕES DE PODER}

$\mathrm{Na}$ mitologia grega, a deidade da guerra é representada por duas figuras: de uma lado, Marte, o deus todo poderoso, capaz de lutar as batalhas mais sangrentas; de outro, Minerva, a deusa da guerra branda e da diplomacia, porém capaz de ser mortal. Tendo em mente essas duas figuras míticas, devemos refletir acerca do tipo de conflito a que os recursos hídricos estão relacionados. Seriam eles conflitos de grande letalidade ou de menor intnsidade? Não seriam as relações de poder mais letais que os próprios conflitos?

\subsection{Da guerra da água aos conflitos sociais relacionados a recursos hídricos}

Após a análise aqui empreendida acerca das diversas formas pelas quais os recursos naturais se relacionam com conflitos, é imprescindível verificar de que modo os recursos hídricos especificamente se relacionam com os conflitos. Tanto a escassez como a abundância estão relacionadas a conflitos? Ou apenas a escassez pode desencadear conflitos? Há outros mecanismos pelos quais os recursos hídricos podem se relacionar a conflitos?

Quando se menciona a temática de recursos naturais e conflitos, talvez o primeiro recurso que venha à mente seja a água, insumo aventado como a principal fonte de conflitos do século XXI por muitas personalidades políticas. Em 1979, alguns dias após a assinatura do histórico tratado de paz com Israel, o presidente egípcio Anwar Sadat afirmou que a única coisa que poderia levar o Egito à guerra novamente seria a água (STARR, 1991). Ainda em 1990, o rei Hussein da Jordânia teria afirmado que as disputas por água poderiam levar à guerra como chantagem para tentar abrir os canais do socorro necessário dos árabes. (STARR, 1991). Todavia, a afirmação mais conhecida foi aquela feita pelo Secretário Geral da Organização das Nações Unidas (ONU), Boutros Boutros Ghali, de que as guerras do século XXI seriam travadas por água. 
No que concerne à academia, vários estudos, desde a década de 1980, já alertavam quanto à possibilidade dos recursos hídricos ocasionarem guerras. Em seu artigo para uma das revistas norte-americanas mais conceituadas em política externa, Cooley (1984) apontou de que forma as tensões políticas se relacionam com o acesso aos recursos hídricos. O autor considerou que os recursos hídricos per se não têm o condão de ocasionar conflitos, mas se unem a tensões de outras dimensões, principalmente de origem política, para ocasionar conflitos:

Toda vez, a questão da água tem contribuído para impedir um acordo. Embora a necessidade de um plano acerca da partilha racional e global do regime de água seja cada vez mais clara, isso parece menos tangível à medida que as questões relacionadas com a água são agravadas por tensões políticas (COOLEY, 1984, p. 3, tradução nossa). ${ }^{56}$

Ao contrário das afirmações de personalidades políticas, para Cooley (1984), as tensões políticas anteriores tornam à partilha da água no Oriente Médio, sobretudo quando se quer retomar vantagem ou benefício perdido em ocasiões anteriores sob a forma de maior consumo de água.

Starr (1991) também mencionou a eminência de conflitos relacionados à água em 10 locais, a maior parte deles no Oriente Médio, mas também em outras partes do planeta, como Chipre, Malta, Argélia, Egito e Marrocos. O autor ressaltou a importância de uma intervenção norte-americana nesses países. Naturalmente, seu artigo e o tom de sua argumentação acabaram servindo mais como propaganda política internacional em favor da intervenção norte-americana, como se pode notar pela seguinte passagem:

Os Estados Unidos poderiam desempenhar um papel de liderança no sentido de reunir as partes para os problemas de água do Oriente Médio, terminando um período de lento progresso em direção a um reconhecimento conjunto de uma ameaça comum. Os Estados Unidos também têm conhecimentos técnicos excepcionais sobre a água para auxiliar o Oriente Médio com a crise emergente. O governo americano, através de seus muitos departamentos e agências, levou a cabo extensos programas de assistência técnica em água no mundo inteiro. O consórcio tranquilo ${ }^{57}$ de talentos dedicados à água, escondido nos recessos do governo americano, poderia balizar os Estados Unidos como um líder no

\footnotetext{
56 "Each time, the water question has helped to block agreement. While the need for a rational, overall water-sharing scheme steadily grows more apparent, it seems less attainable, as water issues are aggravated by political tensions."

${ }^{57}$ N.T. O autor faz um trocadilho para se referir à falta de empenho do governo americano em colocar em prática os seus conhecimentos e técnicas relacionados à água, pois "quiet pool" pode significar tanto piscina tranquila como consórcio tranquilo.
} 
esforço mundial para responder à emergência hídrica (STARR, 1991, p. 33, tradução nossa). ${ }^{58}$

Evidentemente, verifica-se que há duas posturas em relação a guerras por recursos hídricos: alguns acreditam ser factível a sua ocorrência, enquanto outros não levam adiante esta crença. Harvey (1996) postulou que o debate ambiental está estruturado em dois polos: o primeiro, baseado na escassez e no legado de Thomas Malthus; o segundo, fundamentado na teoria da modernização e nas contribuições deixadas pelo Marquês de Condorcet. Por outro lado, os autores que estudam a economia política de conflitos armados, como Le Billon e Ross, indicaram que os recursos hídricos pouco participam da economia da guerra.

Existem vários estudos que se posicionam a favor da primeira corrente, prevendo que a chamada escassez ecológica já está acontecendo e poderá levar a conflitos. Gleick (1993, p. 79, tradução nossa) esclareceu que "onde a água é escassa, a competição por provisões limitadas pode levar as nações a ver o acesso à água como uma questão de segurança nacional, como um elemento cada vez mais importante da política interestatal, incluindo conflitos violentos". ${ }^{59}$ Falkenmark (1990) apontou na mesma direção ao sinalizar a possibilidadde de risco de conflitos entre países a jusante e a montante das fontes de água, principalmente no Oriente Médio e na África.

Outros que compartilham essa visão são os geopolitólogos Klare (2002) e Galland (2008). Ao analisar as tensões relacionadas a bacias transfronteiriças do Tigre-Eufrates, do Indo e do Jordão, Klare (2002, p. 189, tradução nossa) argumentou que:

É evidente que cada um dos três sistemas fluviais descrito acima abriga um risco significativo de conflito violento. O risco decorre do fato de que a demanda por água está aumentando, enquanto a oferta não, e também do fracasso dos países ribeirinhos nestes sistemas para estabelecer um regime

\footnotetext{
58 "The United States could play a leading role in bringing together the parties to Middle East water problems, ending a period of sluggish progress toward a common appreciation of a common threat. The United States also has unique expertise on water to assist the Middle East with the emerging crisis. The U. S. government, through its many departments and agencies, has undertaken extensive technical water assistance programs throughout the world. The quiet pool of dedicated water-related talent, hidden in the recesses of the U. S. government, could mark the United States as a leader in the global effort to respond to the water emergency."

59 "Where water is scarce, competition for limited supplies can lead nations to see access to water as a matter of national security, as an increasingly salient element of interstate politics, including violent conflict".
} 
integral da bacia hidrográfica na distribuição equitativa dos recursos partilhados. $^{60}$

Autores mais cautelosos, como Homer-Dixon (1995, p. 1, tradução nossa), atestaram que o risco de uma guerra entre países por água é possível, embora possa ocorrer somente sob algumas condições restritas:

[...] o país a jusante deve ser altamente dependente de recursos hídricos para o seu bem-estar nacional, o país a montante deve ser capaz de restringir o fluxo do rio; deve haver uma história de antagonismo entre os dois países; e, o mais importante, o país a jusante deve ser militarmente muito mais forte que o país a montante. ${ }^{6}$

No entanto, Homer-Dixon (1995) fez uma ressalva, afirmando que atualmente essa situação é pouco provável e que anúncios alarmistas a respeito da Guerra da Água acabam por fazer com que a população se esqueça de que a escassez hídrica pode trazer uma série de efeitos mais diretos à sua vida, como doenças, aumento da pobreza, redução da quantidade de alimentos produzida e migrações.

Com a mesma cautela, Wallensteen e Swain (1997) ponderaram que em rios em que existem problemas quanto à qualidade da água, como no caso do Reno e do Colorado, há grande incentivo para a cooperação entre os Estados. Todavia, quando a querela gira em torno da quantidade do recurso, há menos incentivos para a cooperação e a gestão conjunta dos cursos d'água. Exemplo disso são os rios Nilo e Ganges, tornando-se pivôs de ameaças militares e boicotes, os quais, frequentemente, passam a fazer parte da rotina diplomática dos países que atravessam.

A segunda posição é representada pelos adeptos da teoria da modernização, também chamados de cornucopianos. Para os autores dessa corrente, a modernização e o progresso humano são capazes de se sobrepor a quaisquer problemas apresentados pela natureza. Assim sendo, tanto a escassez quanto a abundância de recursos se referem a como geri-los.

\footnotetext{
60 "Clearly each of the three river systems described above harbors a significant risk of violent conflict. The risk stems from the fact that the demand for water is growing while the supply is not, and from the failure of the riparians in these systems to establish an integrated basinwide regime for equitable distribution of the shared resources."

61 "[...] the downstream country must be highly dependent on the water for its national wellbeing; the upstream country must be able to restrict the river's flow; there must be a history of antagonism between the two countries; and, most importantly, the downstream country must be militarily much stronger than the upstream country".
} 
Os seguidores desse pensamento vêm alertando sobre a necessidade de abandonar a posição malthusiana, uma vez que os conflitos relacionados à escassez de recursos hídricos se localizam em determinadas regiões, não estando disseminados de forma geral em todo o espaço mundial. Argumentam, dessa forma, que conflitos localizados são mais suscetíveis de acontecer, porém com baixa intensidade de violência armada. Em contraste, rechaçam a ideia de Guerra da Água, sugerindo que não passaria de uma lenda promovida por estudos enviesados, os quais deixam de levar em consideração vários outros fatores que atuam diretamente sobre o desencadeamento de conflitos internacionais.

O professor de relações internacionais, Barnett (2001, p. 55, tradução nossa), encontra-se entre os muitos que se posicionam contra a possibilidade de a escassez dos recursos hídricos ocasionar guerras, porquanto:

Um problema crítico com a tese da guerra da água (e de fato com toda a literatura acerca do conflito ambiental) é a impossibilidade de distinguir claramente entre os vários fatores que contribuem para o combate. Quando se muda a hipérbole, fica evidente que poucas guerras foram induzidas pela escassez de água por si só. Como Lipschutz observou, os exemplos apresentados como evidência das guerras por água tendem a ser sobre algo além disso. ${ }^{62}$

Lowi (1996, apud BARNETT, 2001, p. 55, tradução nossa) observou que: "parece que o amplo contexto político é mais relevante que a instância específica 1xda escassez de água”. ${ }^{63}$ Em outra publicação, Lowi (1999, p. 240, tradução nossa) manteve sua posição quanto ao conflito entre palestinos e israelenses declarando que: "A história demonstra que uma solução política do conflito israelo-árabe, incluindo um resultado mutuamente aceitável do estatuto final das negociações, é o primeiro passo essencial". ${ }^{64}$ Dessa forma, a questão política é primordial em relação à da gestão dos recursos hídricos na região.

Vários outros autores vêm afirmando, categoricamente, que as tensões entre Estados não estão diretamente relacionadas aos recursos hídricos. Segundo Wolf

\footnotetext{
62 "A critical problem with the water war thesis (and indeed all the environment-conflict literature) is the impossibility of clearly distinguishing among the many factors which contribute to warfare. When one shifts through the hyperbole, it seems that few wars have been induced by water shortages alone. As Lipschutz has observed, examples offered as evidence of wars over water tend to be about something else."

${ }_{63}$ "It seems that the broader political context is more relevant than the specific instance of water scarcity."

64 "History shows that a political settlement of the Arab-Israeli conflict, including a mutually acceptable outcome of the final status negotiations, is the essential first step."
} 
(1998, p. 252-253), "Nunca houve guerra da água em 4.500 anos; há, portanto poucas chances de que haja uma recentemente [...]". Em outro artigo, Wolf et al. (2005) reiteraram essa mesma posição; no entanto, acrescentaram outras contribuições, asseverando que o número de acordos internacionais relacionados à gestão é muito maior que o número de ocorrências de tensões ou de conflitos entre países. Ademais, destacaram que, apesar da retórica dos governantes políticos, a maioria das ações tomadas em relação à água é branda. Por último, comentaram que os registros históricos provam que disputas internacionais por água foram resolvidas mesmo entre inimigos e até quando os conflitos surgem por outras causas que não a água.

Allan (1999), Turton (2000), Baechler (1999), De Villiers (2001) e Ayeb (1998) também levaram a sério a crença de Wolf (1998), enquanto Ravnborg (2004, p. 18, tradução nossa, itálico da autora) afirmou que:

$\mathrm{Na}$ literatura, tem havido uma tendência de meramente selecionar estudos de caso das bacias mais "tensas", tais como do Jordão, Tigre, Eufrates, Indo e Nilo, assim fazendo com que as tentativas para tirar conclusões gerais a partir desses estudos de caso para aplicar a bacias internacionais como um todo sejam questionáveis. Além disso, tem havido uma tendência em excluir a cooperação dos estudos sobre a relação entre a escassez da água e as relaccões internacionais, o que torna os testes de causalidade incompletos $[\ldots]^{65}$

Entrementes, mesmo a partir desses casos mais extremos, há estudos que refutam a tese de que a relação conflitiva esteja diretamente relacionada à água. Ao analisar o conflito israelo-palestino, Feitelson (2002) argumentou que o discurso do governo israelense em relação aos recursos hídricos tem mudado com o passar do tempo. Basicamente, os discursos apresentadas pelos governos anteriores de que a água era escassa para ser dividida entre árabes e israelenses já não faz mais parte do repertório de argumentação. Portanto, os recursos hídricos já não estão mais em pauta quando se abordam as questões que dificultam acordos entre as suas partes.

Em relação à bacia do Indo, por exemplo, Allan (2003) fez uma reflexão sobre as tensões existentes entre Índia e Paquistão, após o que chegou à conclusão de que a probabilidade de ocorrência de um conflito internacional por água naquela

\footnotetext{
65 'In the literature, there has been a tendency merely to select case studies from the 'hottest' basins such as the Jordan, Tigris, Euphrates, Indus and Nile, thus making attempts to draw general conclusions from these case studies to international basins as a whole questionable. Moreover, there has been a tendency to exclude cooperation from studies on the relationship between water scarcity and international relations, which makes tests of causality incomplete [...]"
} 
região é mínima, citando o acordo de 1960, relativo àquelas águas, assinado pelos dois países.

Soysa e Gleditsch (1999, p. 80, tradução nossa) são da opinião que "há disputas por outros rios também, notavelmente o Ganges e o Nilo, mas nenhuma possui conexão direta com os conflitos armados enumerados pelo projeto ${ }^{66}$ [da universidade de] Upsala [...]". 67 Adicionalmente, os autores afirmaram que a água está mais relacionada a conflitos e tensões na escala do lugar e que a quantidade de água necessária para a satisfação das necessidades humanas é mínima quando comparada à daquela utilizada para fins industriais e agropastoris. Dessa forma, concluíram que "é duvidoso se até o momento qualquer guerra foi disputada principalmente pela água, mas existem numerosos acordos internacionais que regulam a utilização dos rios. Em suma, não há qualquer razão racional para haver uma guerra da água" (SOYSA; GLEDITSCH, 1999, p. 71, tradução nossa). ${ }^{68}$

Estudos empíricos, analisando os casos apresentados como conflitos entre Estados que compartilham rios ou bacias transfronteiriças, confirmam que as tensões e mesmos alguns poucos conflitos existentes estão muito mais relacionados às tensões antigas relacionadas à própria linha de fronteira que pela escassez dos recursos hídricos. Em adição a isso, comprovam que a escassez de água está mais relacionada a conflitos localizados e de intensidade diminuta no que concerne à violência armada.

Toset, Gledistch e Hegre (2000) buscaram analisar a relação entre conflitos internacionais, escassez de água e rios transfronteiriços. Para tanto, utilizaram informações coletadas durante o período 1816-1992 de um banco de dados contendo 1.274 díades com rios transfronteiriços, com base nos registros das Nações Unidas, os quais incluem todos os rios do mundo com mais de $10 \mathrm{~km}$ de extensão, com exceção da Ásia. Ainda acrescentaram dados sobre tipos de regimes dos países fronteiriços (número de democracias) e desenvolvimento econômico (consumo de energia elétrica per capita e PIB per capita). Seguindo essas diretrizes

\footnotetext{
66 Trata-se do projeto levado a cabo pelos autores visando refletir a relação entre mudanças ambientais e conflitos armados.

67 "There are disputes over other rivers as well, notably over the Ganges and the Nile, but none have a direct connection to the armed conflicts listed by the Upsala project."

68 "It is questionable whether so far any war has been fought mainly over water, but there are numerous international agreements regulating the use of rivers. To sum up, there is no rational reason for having a water war."
} 
estatísticas, os autores chegaram à conclusão de que o efeito da variável existência de rio transfronteiriço é muito menor que o da variável contiguidade entre países. Embora a variável escassez de água tenha apresentado resultado significativo para conflito, os resultados daquela pesquisa mostraram que há outros fatores que atuam junto com ela e que não puderam ser determinados robustamente a partir dos dados disponíveis no banco de dados utilizado.

Ao analisar o banco de dados do International Crisis Behavior Project (Projeto sobre o Comportamento das Crises Internacionais) (BRECHER; WILKENFELD, 1997), Wolf (1999a; 1999b) encontrou 412 crises no período de 1918 a 1984, entre as quais, apenas quatro estavam parcialmente relacionadas à água. Posteriormente, no banco de dados do seu projeto denominado Transboundary Freshwater Dispute Database (Banco de Dados sobre Disputa Transfronteiriça por Água Doce), Wolf (1999b) encontrou mais três casos de crises ligadas aos recursos hídricos.

Procurando corrigir as falhas do trabalho de Toset, Gledistch e Hegre (2000), Gleditsch et al. (2006) empregaram um novo banco de dados, contendo informações coletadas durante o período compreendido entre 1880 e 2001, acerca de díades da América do Norte e do Sul, ilha de Hispaniola (Haiti e República Dominicana), Eurásia, Grã-Bretanha, África, Bornéu e Nova Guiné. Além de dados sobre a quantidade de rios e bacias transfronteiriças, os pesquisadores também utilizaram dados sobre tipos de regimes políticos, histórico de paz e desenvolvimento econômico.

Procedendo a uma análise multivariada, Gleditsch et al. (2006) concluíram que a variável escassez de água não apresentou resultados significativos no que concerne a conflitos. Por outro lado, a variável existência de bacias transfronteiriças, principalmente quando a quantidade absoluta de recursos hídricos era grande, se relacionou significativamente à existência de conflitos. No entanto, os autores declararam a necessidade de conduzir mais estudos para corroborar a conclusão apontada pela análise estatística, de acordo com a qual, países poderiam lutar não pelo recurso hídrico em si, mas sim pelas oportunidades oferecidas pela bacia hidrográfica, tais como energia hidroelétrica, facilidade de comunicações e amplas oportunidades para a irrigação. Outro aspecto importante é que a variável ocorrência de guerras (mais de 1.000 mortes) não foi significativa, sugerindo que os conflitos 
entre Estados podem ser sérios, mas é pouco provável que tenham grande extensão, como uma guerra.

Dessa forma, os estudos aqui apresentados apontaram categoricamente para uma diminuta probabilidade de que guerras relacionadas à escassez de recursos hídricos ocorram. Em outra perspectiva, o estudo de Gleditsch et al. (2006) parece invocar o caso de conflitos pelas oportunidades oferecidas pelas bacias hidrográficas, embora não traga resultados conclusivos, uma vez que se necessita da agregação de outros dados não computados na ocasião. Fundamentalmente, sua análise estatística apontou que esses conflitos não significam guerras, mas conflitos localizados e de menor extensão.

Como os estudos empíricos e teóricos apontam para a improvável existência de Guerras da Água, poderiam os recursos hídricos se relacionar a conflitos sociais de grande extensão? Em relação à abundância de recursos hídricos, autores que estudaram a economia política dos conflitos intraestatais destacaram que a água não é o tipo de recurso natural que se apresenta como saqueável (lootable) para fins de financiamento de lutas armadas (LUJALA; GLEDITSCH; GILMORE, 2005). No que toca à escassez de recursos hídricos, muitos pesquisadores que condenaram a teoria da Guerra da Água relataram que esta condição pode se relacionar a conflitos localizados e de menor extensão que guerras propriamente ditas. Wolf (1998, p. 261, tradução nossa) afirmou que "embora as guerras da água possam ser um mito, a relação entre recursos hídricos e estabilidade política não é”. ${ }^{69}$ Ravnborg (2004, p. 26, tradução nossa) também levou adiante a temática de conflitos intestinos e recursos hídricos:

No entanto, está longe de ser verdade que todas as situações de conflito relacionadas a água e cooperação sejam internacionais em sua origem ou mais bem tratadas em nível internacional. Primeiro, alguns conflitos que são considerados como conflitos fronteiriços são essencialmente conflitos locais que apenas acabaram por acontecer em uma bacia transfronteiriça. [...] $]^{70}$

\footnotetext{
69 "While water wars may be a myth, the connection between water and political stability certainly is not."

70 "However, it is far from being the case that all situations of water-related conflict and cooperation are international in origin or are best dealt with at the international level. First, some conflicts which are regarded as transboundary conflicts are essentially local conflicts which just happen to take place in a transboundary basin. [...]"
} 
Vários outros pesquisadores compartilham essa posição, como Homer-Dixon (1995), Bethemont (1999), Lasserre e Descroix (2005) e Wolf et al. (2005). Todavia, não passariam essas argumentações de conjecturas sem base empírica, assim como aquelas relativas à Guerra da Água?

No tópico 3.1.1 deste trabalho (O primeiro enfoque: conflitos violentos escassez ou abundância de recursos naturais?) apresentamos as considerações que o modelo SFTF faz a respeito da relação entre recursos naturais e conflitos armados. Nele, Esty et al. (1999) concluem que apenas indiretamente os recursos hídricos participam de conflitos armados, principalmente quando interferem na variável bem-estar material, embora neguem uma relação direta significativa entre recursos hídricos e conflitos internos ocasionando a falência de Estados.

O estudo de caso na região de Gaza, elaborado por Kelly e Homer-Dixon (1998), indica que os recursos hídricos apresentam alguma relação com as tensões correntes na região. Várias evidências são apresentadas pelos autores para corroborar isso, como dados acerca da redução da quantidade relativa de água e sua relação com a redução da produtividade agropastoril e o empobrecimento da população daquele local. Não obstante, embora os recursos hídricos estejam relacionados com o conflito, isso não quer dizer que eles sejam a causa direta dele. Nesse sentido, Kelly e Homer-Dixon (1998, p. 99, itálico nosso, tradução nossa) assinalaram que:

A interação entre escassez severa de suprimentos, demanda e estrutura tem impedido o desenvolvimento e tem contribuído para o empobrecimento da população de Gaza. As condições econômicas e sociais deterioradas produziram queixas coletivas e violência contra Israel e, mais recentemente, contra a Autoridade Palestina. As soluções para a crise da água em Gaza não irão, por si só, solucionar o conflito. No entanto, ações em direção à conservação e reabilitação do aquífero e a repartição mais equitativa da água que está disponível serão elementos essenciais para uma paz estável. ${ }^{71}$

Esta passagem não deixa margem a dúvidas, porquanto, para esses autores, os recursos não são a causa direta do conflito. Em outros estudos empíricos, esse fato também parece se confirmar. Assim sendo, Hauge e Ellingsen (1998, p. 300,

\footnotetext{
71 "The interaction of severe supply, demand and structural scarcities has constrained development and has contributed to the impoverishment of Gaza's population. Deteriorating economic and social conditions have produced collective grievance and violence against Israel and, more recently, against the PA. Solutions to the water crisis in Gaza will not in themselves solve the conflict. Nonetheless, steps toward the conservation and rehabilitation of the aquifer and the more equitable apportionment of water that is available will be essential elements of a stable peace."
} 
tradução nossa) iniciaram seu estudo ponderando que "a maioria das pesquisas sobre degradação ambiental e conflitos armados internos não leva em consideração outros fatores geradores de conflitos". ${ }^{72}$ Outra crítica feita pelos autores, principalmente aos estudos de Homer-Dixon (HOMER-DIXON, 1990; HOMERDIXON, 1999; HOMER-DIXON; BLITT, 1998) é que este somente leva em conta os efeitos da escassez ambiental nos resultados da política e economia nacionais, se esquecendo que a maior parte da escassez é causada por escolhas políticas e econômicas. Outros centistas, tais como Gleditsch (1998) e Levy (1995), também concordam com essa assertiva, uma vez que pouca atenção tem sido dada à relativa importância dos recursos naturais como causa de conflitos.

Visando entender melhor a relação entre degradação ambiental e conflitos armados, Hauge e Ellingsen (1998) levaram a cabo um modelo logarítmico baseado em dados de todos os países do mundo no período entre 1980 e 1992. As variáveis independentes analisadas foram disponibilidade de água doce per capita, degradação do solo, área desmatada, densidade populacional (que apresentou altos índices), renda salarial (que apresentou desigualdades), nível de desenvolvimento econômico (PIB per capita), regime político, estabilidade política (mesmo regime político por 10 anos) e passado recente de conflitos (presença de conflitos no ano anterior). As variáveis dependentes foram a incidência de conflitos armados internos (menos de 1.000 mortes ou 25 batalhas com morte em um ano) e a incidência de guerras civis (mais de 1.000 mortes ou 25 batalhas com morte em um ano). Os autores afirmaram que "o raciocínio para o uso de duas diferentes variáveis dependentes é verificar se existem muitas diferenças no modo como nossas variáveis independentes afetam a guerra civil em comparação com os conflitos armados internos" (HAUGE; ELLINGSEN, 1998, p. 306, tradução nossa). ${ }^{73}$

A partir dessa análise estatística, Hauge e Ellingsen (1998) concluíram que as três variáveis ambientais (disponibilidade de água doce per capita, degradação do solo e área desmatada) apresentaram resultados muito significativos para conflitos armados, mas não para guerras civis, corroborando a afirmação de Homer-Dixon (1995) que os fatores ambientais contribuem mais para a ocorrência de conflitos

\footnotetext{
72 "[...] most research on environmental degradation and domestic armed conflict fail to take into consideration other conflict-generating factors."

73 "The reasoning behind using two different dependent variables is to see whether there are many differences in how our independent variables affect civil war compared with domestic armed conflicts."
} 
menores que de guerras. Portanto, Hauge e Ellingsen (1998 p. 314, tradução nossa) preceituaram que:

[...] países que sofrem degradação ambiental - e particularmente, degradação do solo - são mais suscetíveis a conflitos civis. No entanto, fatores econômicos são muito mais importantes para a previsão de conflitos domésticos armados que os fatores ambientais. Em geral, isso também é verdadeiro para os fatores políticos. $^{74}$

Essa afirmação pode ser comprovada pelos dados apresentados nas Tabelas

1 e 2

Tabela 1. Probabilidade de ocorrência de guerras civis quando fatores de risco são acrescentados (período entre 1980 e 1992).

\section{Probabilidade de guerra civil (\%)}

\begin{tabular}{cccc}
\hline $\begin{array}{c}\text { Variável } \\
\text { independente }\end{array}$ & Desmatamento & $\begin{array}{c}\text { Altos níveis de } \\
\text { degradação do } \\
\text { solo }\end{array}$ & $\begin{array}{c}\text { Baixa } \\
\text { disponibilidade } \\
\text { de água doce }\end{array}$ \\
\hline- & 0,47 & 1,35 & 0,66 \\
$\begin{array}{c}\text { Alta densidade } \\
\text { populacional }\end{array}$ & 0,66 & 1,91 & 0,93 \\
$\begin{array}{c}\text { Alta desigualdade } \\
\text { na renda }\end{array}$ & 1,21 & 3,46 & 1,70 \\
$\begin{array}{c}\text { Pobreza } \\
\text { Semi-democracia }\end{array}$ & 15,45 & 20,26 & 10,91 \\
$\begin{array}{c}\text { Instabilidade } \\
\text { política }\end{array}$ & 19,31 & 34,76 & 20,43 \\
$\begin{array}{c}\text { Histórico de } \\
\text { conflitos }\end{array}$ & 98,73 & 41,10 & 25,16 \\
\hline
\end{tabular}

Fonte: Hauge e Ellingsen (1998, p. 311, tradução nossa).

Nota-se que o histórico de conflitos se relaciona fortemente com a probabilidade de que exista conflito no ano seguinte. Isso pode se dar porque o

74 "[...] countries suffering from environmental degradation - and in particular from land degradation are more prone to civil conflict. However, economic factors are far more important in predicting domestic armed conflict than environmental factors. In general, this also holds true of political factors." 
conflito continua de um ano para outro, ou pela ação do processo de escalada de conflito, no qual um conflito leva a outro pouco tempo depois, especialmente como forma de sublimação de tensões e conflitos anteriores não resolvidos. Esse fator também foi salientado pela pesquisa do grupo suíço liderado por Baechler (1999) a partir do conceito de estrutura histórica de conflitos.

Tabela 2. Probabilidade de ocorrência de conflitos armados quando fatores de risco são acrescentados (período entre 1980 e 1992).

Probabilidade de conflito armado (\%)

\begin{tabular}{cccc}
\hline $\begin{array}{c}\text { Variável } \\
\text { independente }\end{array}$ & Desmatamento & $\begin{array}{c}\text { Altos níveis de } \\
\text { degradação do } \\
\text { solo }\end{array}$ & $\begin{array}{c}\text { Baixa } \\
\text { disponibilidade } \\
\text { de água doce }\end{array}$ \\
\hline- & 4,36 & 8,32 & 3,84 \\
$\begin{array}{c}\text { Alta densidade } \\
\text { populacional }\end{array}$ & 6,60 & 12,34 & 5,84 \\
$\begin{array}{c}\text { Alta desigualdade } \\
\text { na renda }\end{array}$ & 11,51 & 20,59 & 10,25 \\
$\begin{array}{c}\text { Pobreza } \\
\text { Semi-democracia }\end{array}$ & 29,32 & 45,27 & 26,70 \\
$\begin{array}{c}\text { Instabilidade } \\
\text { política }\end{array}$ & 50,74 & 67,26 & 47,50 \\
Histórico de & 61,78 & 76,33 & 58,66 \\
conflitos & 98,03 & & 97,77 \\
\hline
\end{tabular}

Fonte: Hauge e Ellingsen (1998, p. 311, tradução nossa).

Os dados apresentados por Hauge e Ellingsen (1998) nos fazem refletir até que ponto os fatores ambientais estão realmente envolvidos nos conflitos. A escassez de recursos hídricos apresentou resultado significativo, assim como os outros fatores ambientais, apenas para conflitos de baixa intensidade de violência. Em contraste, fatores políticos, econômicos e históricos parecem ser bem mais relevantes que os ambientais para explicar empiricamente as causas de conflito de 
baixa intensidade de violência. E, de acordo com esses resultados, os fatores ambientais não são relevantes para a ocorrência de guerras civis.

Raleigh e Urdal (2007) também realizaram um estudo aplicando os cenários mais drásticos do aquecimento global apresentados no Relatório do IPCC de 2007. Como sua contribuição, também fizeram uso de Sistema de Informações Geográficas (SIG) e criaram variáveis independentes a partir de um conjunto de dados georeferenciados do banco de dados da Universidade de Uppsala/PRIO. Os dados georeferenciados foram colhidos a partir de unidades espaciais de análises que equivalem a polígonos medindo $100 \mathrm{~km}$ x $100 \mathrm{~km}$ e cobrem todos os países com mais de 100.000 habitantes.

Como variáveis independentes, Raleigh e Urdal (2007) elegeram escassez de água doce, alto crescimento populacional, degradação do solo, densidade populacional e desenvolvimento econômico, enquanto a variável dependente foi a incidência de guerra civil (mais de 25 batalhas com mortes por ano). A partir dessas considerações, realizaram uma regressão ordinal logística, que apontou para um resultado significativo quando se considera a relação entre escassez de água doce e conflito. Conforme Raleigh e Urdal (2007, p. 686, tradução nossa), "no nível mais elevado de escassez de água doce, o risco adicional de conflito é de aproximadamente $6 \%$ quando o crescimento populacional é zero". ${ }^{75}$ Ademais, alertaram que esse percentual pode ser maior em casos extremados:

Somente em áreas de extensiva pressão hídrica e de maiores níveis de crescimento populacional é que o risco adicional de conflitos tem um forte aumento para $37 \%$. Embora o risco adicional de conflito em decorrrência da interação entre níveis muito altos de escassez de água e crescimento populacional muito alto seja bastante elevado, é importante notar que a probabilidade de uma área experienciar ambos os extremos é muito baixa e que os riscos de conflitos em baixos níveis de ambas as variáveis são insignificantes (RALEIGH; URDAL, 2007, p. 686, tradução nossa). ${ }^{76}$

Por outro lado, os autores reforçaram a tese de que os fatores econômicos e políticos explicam os conflitos mais significativamente que os fatores ambientais. Para eles, "PIB com baixos níveis são o mais importante preditor de conflitos

\footnotetext{
75 "[...] at the highest level of water scarcity the added risk of conflict is approximately $6 \%$ when population growth is zero."

76 "Only in areas of extensive water pressure and the highest levels of population growth does the additional risk of conflict strongly increase to $37 \%$. Although the additional conflict risk due to the interaction between very high levels of water scarcity and very high population growth is quite large, it is important to note that the likelihood of an area experiencing both extremes is very low, and that conflict risks at lower levels of both variables are negligible."
} 
armados, com exceção dos Estados mais ricos, em que ele exibe um efeito insignificante" (RALEIGH; URDAL, 2007, p. 691, tradução nossa). ${ }^{77}$ Outro fator essencial na previsão de conflitos é a instabilidade política, Raleigh e Urdal (2007, p. 691, tradução nossa) argumentam que:

[...] enquanto a instabilidade política é um forte catalisador de conflitos internos em Estados pobres, não parece interagir com os fatores demográficos e ambientais de forma a aumentar os riscos de conflitos. Tais resultados e pressupostos sugerem que os fatores ambientais $e$ demográficos possam estar em segundo plano em relação a outros desencadeadores de conflitos armados. ${ }^{78}$

O trabalho de Raleigh e Urdal (2007) trouxe melhores explicações a conflitos internos e, especialmente, conferiu maior precisão a este tipo de pesquisa, porquanto ao aplicar dados georeferenciados, pode-se compreender melhor a relação entre as variáveis em uma escala menor, uma vez que os conflitos de menor intensidade não ocorrem em todo o território nacional. A partir das pesquisas empíricas aqui apresentadas, nota-se que a escassez de recursos hídricos se relaciona com conflitos de menor extensão e intensidade. Parece-nos que as relações de poder construídas por meio dos recursos hídricos e suas implicações nas práticas cotidianas podem ser mais letais que os próprios conflitos nos quais este tipo de recurso participa de forma secundária. A esse respeito, Wolf et al. (2005, p. 89, tradução nossa) se pronunciaram garantindo que "o acesso insuficiente à água é a principal causa de perda de subsistências e, portanto, alimenta conflitos relacionados à subsistência". ${ }^{79}$

Assim sendo, devemos dar mais atenção à interação entre relações de poder e conflitos, que muitas vezes acabam sendo negligenciadas nas pesquisas, sobretudo quando se trata de estudos na área de segurança, vez que vem sendo dado mais foco aos conflitos armados de várias escalas. Ademais, em vez de nos preocupar em criar novas tipologias de conflitos, seria mais produtivo estudar as diferentes interações entre recursos naturais e conflitos, independentemente de elas se basearem em causalidades diretas ou indiretas, até porque se trata de uma

\footnotetext{
77 "Lower levels of GDP [gross domestic product] are the most important predictor of armed conflicts, with the exception of wealthier states where it exhibits an insignificant effect."

78 "[...] while political instability is a strong driver of internal conflict in poor states, it does not seem to interact with demographic and environmental factors to increase the risk of conflict. Such results and assumptions suggest that environmental and demographic factors may be second to other drivers of armed conflict."

79 "Insufficient access to water is a major cause of lost livelihoods and thus fuels livelihood-related conflicts."
} 
relação multicausal complexa e, portanto, torna-se irrelevante apontar um polo dessa relação como mais importante.

Outro aspecto que nos parece relevante, que foi destacado por Deudney (1999), é o contexto geográfico, de grande importância para compreender de que forma os aspectos estruturais do conflito se relacionam com os aspectos conjunturais. Ao mencionar "survival studies" (estudos de sobrevivência), Brown (2008, p. 23) também enfatizou a importância do contexto regional em conflitos, mesmo em um mundo globalizado. Consequentemente, deveríamos avançar em direção à aplicação de uma geografia regional, desde que os conflitos sociais relacionados ao meio ambiente são mais localizados e menos extensos, como apontaram estudos anteriores. Reiteramos a importância do contexto regional e de sua relação com contextos de escalas maiores. Dessa forma, conflitos ocasionados pela água nada mais são que uma forma de estruturação de conflitos maiores em um contexto regional, revelando a interação entre fatores do contexto regional com outros de escalas maiores.

Agnew (2001) comentou acerca da importância da identidade e do contexto regional para compreender revoltas e conflitos que não se referem diretamente à identidade étnica, mas sim à regional. Paasi (2003, p. 477, tradução nossa) também chamou a atenção para a relevância do contexto em que as identidades regionais se baseiam, pois "a questão da identificação regional implica dois contextos entrelaçados: cultural-histórico e político-econômico". ${ }^{80}$ Logo, torna-se imprescindível estudar as tensões regionais sobrepostas por tensões de outras escalas na esfera regional se quisermos apreender as diferentes relações que os recursos hídricos mantêm com as demais dimensões sociais. Para lograr tal intento, a aplicação da geopolítica a partir do método regional é fundamental.

\subsection{Geopolítica da água: ampliando as concepções do hidrokratos}

Levando em conta as contribuições da geopolítica crítica moderna ${ }^{81}$, pode-se avançar em uma concepção mais abrangente do poder relacionado aos recursos

\footnotetext{
80 "The question of regional identification implies two intertwined contexts: cultural-historical and political-economic."

${ }^{81}$ Aqui diferenciamos a geopolítica crítica moderna, representada por Lacoste (1988), Claval (1979) e Raffestin (1993), daquela de cunho americano iniciada por O'Tuathail (1996) com base nas correntes pós-modernas.
} 
hídricos. Sob a ótica dessa corrente, o poder não deve significar apenas poder do Estado, mas também as relações de poder que permeiam as ações e os vínculos entre atores das pequenas escalas.

Nessa perspectiva, o conceito de segurança ambiental pautado na preocupação com as probabilidades de escassez e as políticas do Estado acaba não abrangendo uma série de rivalidades concernentes aos recursos hídricos, das quais vários atores das escalas menores participam. Então, o conceito de geopolítica da água visa abandonar o enfoque exclusivamente estatal, que se preocupava em excesso com as "guerras da água", para se ocupar das tensões nas mais diversas escalas, apresentando-se como um avanço. Não obstante, trata-se muito mais de geopolítica aplicada à reflexão dos recursos hídricos que propriamente de geopolítica exclusiva da água ou dos recursos hídricos.

Buscando contribuir com esse debate, Lacoste (2003, p. 84-85, tradução nossa) apresentou a geopolítica da água da seguinte forma:

Por geopolítica se entende a análise das lutas de poder em um território, quer se trate de enfretamento entre Estados que disputam a soberania ou influência sobre os outros territórios, quer seja em outro nível, de rivalidades dentro de um mesmo Estado. A expressão "geopolítica da água", cada vez mais utilizada, faz referência, em primeiro lugar, às rivalidades políticas em torno das bacias hidrográficas ou à distribuição do caudal dos rios, incluindo a exploração dos recursos hidrológicos subterrâneos. Esses tipos de rivalidades, que podem se traduzir em obras ou projetos hidráulicos, não se produzem unicamente entre Estados cujos territórios são atravessados ou divididos por um mesmo rio, mas no interior de um mesmo Estado e entre regiões distintas ou grandes cidades, cada uma das quais persegue o aproveitamento dos recursos hídricos procedentes de bacias hidrográficas mais ou menos próximas. ${ }^{82}$

Fica claro que, para o geógrafo francês, a geopolítica da água não diz respeito apenas à água em si, mas que também outros fatores, especialmente os políticos, se entrelaçam com as disputas pelos recursos hídricos. Ainda a esse respeito, Lacoste (2003) acrescentou o caso do conflito árabe-israelense, sinalizando que este não se restringe apenas aos recursos hídricos. De outra parte,

\footnotetext{
82 "Por geopolítica se entiende el análisis de las luchas de poder en un territorio, ya se trate de enfrentamiento entre estados que se disputan la soberanía o influencia sobre otros territorios o bien a otro nivel, de rivalidades dentro de un mismo estado. La expresión 'geopolítica del agua' cada vez más utilizada, hace referencia, en primer lugar, a la rivalidades políticas en torno a cuencas hidrográficas o la distribución del caudal de los ríos, o incluso a la explotación de los recursos hidrológicos subterráneos. Este tipo de rivalidades, que pueden traducirse en obras o proyectos hidráulicos, no se producen únicamente entre estados cuyos territorios son atravesados o divididos por un mismo río, sino en el interior de un mismo estado y entre distintas regiones o grandes ciudades, cada una de las cuales persigue el aprovechamiento de los recursos hídricos procedentes de cuencas hidrográficas más o menos próximas."
} 
o autor também salientou a questão das escalas, vez que os conflitos não estão circunscritos apenas às esferas interestatais, mas ligam-se a outros tipos de conflitos intraestatais, como guerras civis, rebeliões e conflitos étnicos.

Em outro artigo, Lacoste (2001, p. 4-5, tradução nossa) procurou estender esse conceito acrescentando outros aspectos relacionados à tensão gerada pelos recursos hídricos:

Sabe-se que na análise dos problemas geopolíticos, quer dizer, a rivalidade de poderes sobre os territórios, nós damos uma grande importância às representações mais ou menos subjetivas e contraditórias, as quais se referem a cada um dos protagonistas desses conflitos. Também é preciso enfocar sob um sentido mais extenso as questões de geopolítica da água. Nós entendemos, assim, não somente o exame das rivalidades políticas na repartição dos caudais fluviais, mas ainda a análise crítica das representações que difundem as mídias, quando se trata de recursos hídricos, de sua valorização ou das concorrências que eles suscitam sobre os territórios de menor ou maior extensão. ${ }^{83}$

Evidentemente, a representação social que diferentes grupos fazem dos recursos hídricos pode realmente gerar tensões; no entanto, restringir-se às representações culturais pode significar um reducionismo perigoso, porquanto apenas as representações sociais não são suficientes para a compreensão dos conflitos e tensões em sua profundidade, como afirmamos em relação à geopolítica pós-moderna.

Giblin (2003, p. 9, tradução nossa) também concordou com a definição de geopolítica da água aplicada por Lacoste e, ao se perguntar se a água é um problema de geopolítica na França, advertiu:

Que a água é uma questão de geopolítica é uma evidência quando se trata das rivalidades entre Estados pelo controle dos territórios onde se encontram as fontes de aprovisionamento consideradas indispensáveis à existência propriamente dita da população. Mas, na França, em que os problemas de água podem ser considerados em termos geopolíticos, uma vez que a penúria não ameaça o país de forma alguma?

Uma vez mais lembremos que nossa concepção geopolítica não se limita ao estudo de conflitos interestados, mas que toda rivalidade de poderes que se exerce sobre um ou mais territórios remete à geopolítica, quer se trate de rivalidades entre forças políticas rivais, entre poderes locais - comunidade

\footnotetext{
83 "On sait que dans l'analyse des problèmes géopolitique, c'est-à-dire les rivalités des pouvoir sur des territoires, nous accordons une grande importance aux représentations plus ou moins subjectives et contradictoires auxquelles se réfèrent chacun des protagonistes de ces conflits. Aussi nous faut-il envisager sous un sens plus large les questions de géopolitique de l'eau. Nous entendons ainsi non seulement l'examen des rivalités politiques dans la répartition des débits fluviaux, mais encore l' analyse critique des représentations que diffusent les médias, dès lors qu' il est questions de ressources en eau, de leur mise en valeur ou des concurrences qu' elles suscitent sur des territoires de plus ou grandes dimensions."
} 
contra departamento, departamentos entre si, ou departamento e região mas também rivalidades entre forças econômicas e sociais que se enfrentam pelos diferentes usos do território. ${ }^{84}$

A autora declarou claramente que as tensões relacionadas aos recursos hídricos envolvem forças de diferentes tipos sobre o território, as quais podem ser econômicas, sociais e políticas. Portanto, isso faz com que os conflitos e as tensões nunca sejam tão-somente pelos recursos, mas envolvam os mais diversos fatores. Dessa forma, fica evidente que o conceito de geopolítica da água não procura propalar este recurso natural como única fonte de tensões, mas antes refletir de que forma as diversas tensões se relacionam aos recursos hídricos e vice-versa, sem preponderância de um sobre o outro. Giblin (2003) também observou a temática das escalas enfocada por Lacoste (1974) e comentada neste trabalho anteriormente.

No Brasil, alguns geógrafos vêm igualmente trabalhando nessa perspectiva. Dessa forma, ao expor seu conceito acerca de geopolítica da água, Pires do Rio (2006, p. 7) ponderou que:

A partir de um raciocínio cuja base pressupõe a interseção de conjuntos espaciais de diferentes ordens de grandeza, a abordagem geopolítica se direciona para as disputas e os meios empregados pelas diferentes forças, formais e informais, em território concreto. [...] Nesse sentido, os conflitos, as disputas e os embates ocorrem entre regiões, unidades administrativas, cidades e áreas irrigadas que integram uma mesma bacia. Ao mesmo tempo, as companhias de água e esgoto, as empresas de engenharia responsáveis pelas obras hidráulicas, as agências de bacia e de regulação, as empresas grandes consumidoras de água, as companhias geradoras de eletricidade e os produtores emergem como atores importantes dos conflitos de uso e no processo de gestão dos recursos hídricos.

Nesse caso, a autora enfatizou principalmente a gestão das bacias hidrográficas como o território por excelência para analisar as disputas geopolíticas. Além disso, ela também citou a questão anteriormente aventada das escalas de conflito.

\footnotetext{
84 "Que l'eau soit une question de géopolitique c'est une évidence quand il s'agit des rivalités d'Etats pour le contrôle de territoires où se trouvent des sources d'approvisionnement jugées indispensables à l'existence même de la population. Mais en France en quoi les problèmes de l'eau peuvent-ils être posés en termes géopolitiques puisque la pénurie ne menace nullement le pays?

Une fois encore rappelons que notre conception de géopolitique ne se limite pas à l'étude des conflits interètatiques, mais que toutes rivalités de pouvoirs s' exerçant sur un ou des territoires relèvent de la géopolitique, qu'il s'agisse de rivalités entre forces politiques rivales opposées, entre pouvoirs locaux - commune contre département, départements entre eux, ou département et région - mais aussi rivalités entre forces économiques et sociales qui s'affrontent sur des usages différents du territoire".
} 
Discorrendo sobre a geopolítica da água, Becker (2004, p. 144, tradução nossa) asseverou que a abordagem deste conceito gera algumas considerações:

Por um lado, há uma real e contínua preocupação com a sobrevivência humana. Por outro lado, a atual tendência dominante é a comercialização de elementos naturais: um mercado para o ar, vida e água é forjado [...] sob a retórica de grandes riscos e ameaças para a humanidade.

A última preocupação é a falta de água. Esta situação tem sido notada e anunciada como uma real catástrofe global. Tem sido dado à água um valor similar àquele do petróleo no século XX e ela tem sido chamada de ouro azul. A hidropolítica está se desenvolvendo no mundo. ${ }^{85}$

Com seu conceito de geopolítica da água, Becker (2004) procurou mostrar que a apropriação do recurso água implica uma série de discursos sobre o poder, quer para se referir à perda da soberania nacional dos países sobre certos recursos a partir de retórica de uma catástrofe global, quer para aludir à formação de um mercado e de uma gestão mais seguros dos recursos. Dentro desse contexto, a autora concluiu que a política externa aplicada à água como objeto de poder - a hidropolítica - vem sendo continuamente empregada pelos Estados.

Embora Becker (2004) tenha argumentado pela consideração dos recursos hídricos enquanto poder, não somente os recursos hídricos fluviais ou os aquíferos são instrumentos para o poder. Atualmente, existe uma tendência em considerar como recursos hídricos somente aqueles mananciais superficiais, oriundos de rios, lagos e lagoas, e os subterrâneos, originários dos aquíferos e lençóis freáticos. Inevitavelmente, há diversas outras situações além dessas, em que os recursos hídricos podem se tornar instrumento tanto para exercer o poder como para praticar a sobrevivência. Diante disso, o conceito de segurança ambiental referente às condições mínimas necessárias para a manutenção da vida humana encontra-se diretamente vinculado ao controle dos recursos hídricos, seja no âmbito da necessidade, seja na esfera da liberdade, como apresentado anteriormente por Blackburn (1992). O controle sobre os recursos hídricos permite, em grande parte, o controle sobre a vida, não apenas animal, mas também humana, porquanto $63 \%$ do

\footnotetext{
85 "On the one hand, there is an actual and continuous concern about human survival. On the other hand, the current dominant trend is the commercialization of natural elements: a market for air, life and water is forged (Becker, 2001) under the rhetoric of great risks and threats to humanity.

The latest concern is the lack of water. This situation has been noted and announced as an actual global catastrophe. Water has been given a strategic value similar to that of petroleum in the 20th century and has been called blue gold. Hydropolitics is developing in the world."
} 
nosso peso corpóreo corresponde ao seu conteúdo em água. Destarte, os recursos hídricos são um dos mais eficientes instrumentos para se exercer o "biopoder", expresso da seguinte maneira por Foucault (2005, p. 292, itálico nosso):

Enfim, último domínio (enumero os principais, em todo caso os que apareceram no final do século XVIII e no início do XIX; haveria muitos outros depois): a preocupação com as relações entre a espécie humana, os seres humanos enquanto espécie, enquanto seres vivos, e seu meio, seu meio de existência - sejam os efeitos brutos do meio geográfico, climático, hidrográfico: os problemas, por exemplo, dos pântanos, das epidemias ligadas à existência dos pântanos durante toda a primeira metade do século XIX. E, igualmente, o problema desse meio, na medida em que não é um meio natural e em que repercute na população; um meio que foi criado por ela. Será, essencialmente, o problema da cidade. Eu Ihes assinalo aqui, simplesmente, alguns dos pontos a partir dos quais se constituiu essa biopolítica, algumas de suas práticas e as primeiras das suas áreas de intervenção, de saber e de poder ao mesmo tempo: é da natalidade, da morbidade, das incapacidades biológicas diversas, dos efeitos do meio, é disso tudo que a biopolítica vai extrair seu saber e definir o campo de intervenção de seu poder.

Desde a Antiguidade, o controle sobre os recursos hídricos tem sido de fundamental importância tanto para a manutenção das vidas humanas quanto para o funcionamento das sociedades dentro de certa normalidade. Daí decorre a relevância da construção de canais de irrigação para o plantio, bem como de diques para deter o avanço das inundações provocadas pelas cheias dos rios. Em sua monumental obra intitulada Despotismo Oriental, Wittfogel (1966) fez uma análise das sociedades hidráulicas no modo asiático de produção, destacando a importância do controle sobre os recursos hídricos para a segurança e a manutenção desse tipo de comunidade ao longo do tempo. Wittfogel (1966, p. 33-34, tradução nossa) apontou que as características da água em relação a outros elementos fazem com que ela seja mais facilmente manipulada:

A temperatura e a superfície, por causa de suas respectivas dimensões cósmicas e geológicas, interromperam completamente ou limitaram muito a ação humana nas épocas pré-industrial e posterior. Pelo contrário, a água não é demasiadamente remota nem demasiadamente massiva para não sofrer a manipulação do homem. Nesse aspecto, se parece com as outras variáveis, vegetação e solo. Mas, difere de ambas em sua suscetibilidade ao movimento e às técnicas exigidas para manipulá-la [...] e isso não é tudo. Correndo automaticamente, a água aparece desigualmente na paisagem, reunindo-se seja abaixo da superfície como água subterrânea, ou em cima dela, nas cavidades isoladas (poças, poços, lagos) ou leitos contínuos (correntes, rios). Essas formações têm significado menor na zona agrícola 
que goza de precipitações amplas, mas se faz imensamente importante na paisagem deficitária de água. ${ }^{86}$

O cientista natural Schauberger (1998, p. 10, letras maiúsculas do autor, tradução nossa) apresentou a água como um elemento essencial na natureza, funcionando analogamente aos vasos sanguíneos no corpo humano, pois "indubitavelmente, a mais poderosa das pontes para a evolução da vida humana é representada pela entidade ÁGUA". ${ }^{87}$

Em decorrência dessas características, ao longo do tempo, a água se tornou um recurso por excelência, utilizado pelos homens não apenas para o seu desenvolvimento natural, mas também para se sobrepor a outros grupos humanos. Ao relatar como a passagem para formas mais avançadas de regadio atuou sobre certas sociedades, Wittfogel (1966, p. 37, tradução nossa) explicou que:

A maioria de todos os caçadores, pescadores e cultivadores por meio da chuva [e não por meio de irrigação], que mantiveram seu modo tradicional de vida, foram reduzidos à insignificância, quando não completamente aniquilados [...] Os representantes da agricultura de chuva criaram história em algumas áreas do ocidente que se adequaram de modo único a este tipo de economia. Mas, os agricultores hidráulicos surgiram e eliminaram a maioria dos povos vizinhos, onde quer que as condições locais e as circunstâncias unilaterais favorecessem uma economia e um estatismo agroadministrativo. $^{88}$

Isso se deu a partir de técnicas mais avançadas de agricultura de regadio que originaram formas mais desenvolvidas de organização social e política em um ambiente neohistórico (WITTFOGEL, 1966).

\footnotetext{
86 "La temperatura y la superficie, a causa de sus respectivas dimensiones cósmicas y geológicas, han cortado completamente o limitado mucho la acción humana en las épocas preindustrial y posterior. Por el contrario, el agua no es demasiado remota ni demasiado masiva para no sufrir la manipulación del hombre. En este aspecto, se parece a las otras variables, vegetación y suelo. Pero difiere de ambas en su susceptibilidad al movimiento y a las técnicas exigidas para manipularla [...] y eso no es todo. Corriendo automáticamente el agua aparece desigualmente en el paisaje, reuniéndose ya bajo la superficie como agua subterránea, o encima de ella en la cavidades aisladas (charcas, pozos, lagos) o lechos continuos (corrientes, ríos). Estas formaciones son de significado menor en la zona agrícola que goza de precipitaciones amplias, pero se hace inmensamente importante en el paisaje deficitario de agua."

87 "Indisputably the mightiest bridge of all for the evolution of life is represented by the entity WATER."

88 "La mayoría de todos cazadores, pescadores y cultivadores por medio de la lluvia, que mantuvieron su modo tradicional de vida, fueron reducidos a la insignificancia, cuando no completamente aniquilados [...] Los representantes de la agricultura de lluvia crearon historia en algunas áreas de Occidente, que se adecuaban de modo único a este tipo de economía. Pero los agricultores hidráulicos surgieron y eliminaron a la mayoría de los pueblos vecinos donde quiera que las condiciones locales y las circunstancias internacionales unilaterales favorecían una economía y un estatismo agroadministrativo."
} 
Todavia, ao mesmo tempo em que novas técnicas são criadas pelos homens, também as formas de utilização dos recursos são ampliadas. Nesse sentido, os recursos são, inicialmente, matérias naturais; todavia, à medida que os homens vão criando funções e utilidades para elas, estas vão se tornando cada vez mais recursos (RAFFESTIN, 1993). Portanto, os recursos hídricos já possuem as mais diversas utilidades além daquelas normalmente tratadas pela hidráulica e pelos conceitos de geopolítica da água apresentados anteriormente. Pode-se, então, estender a abrangência dos recursos hídricos para além das fontes superficiais subterrâneas e, destarte, abarcar os recursos hídricos não apenas no estado líquido, mas no gasoso e no sólido, assim como também em suas mais diversas funções e não somente com as finalidades precípuas de abastecimento ou geração de energia.

Por conseguinte, a geopolítica da água lida igualmente com outras situações em que o controle tanto qualitativo quanto quantitativo dos recursos hídricos implica controle sobre as condições de vida das pessoas, tratando-se, portanto, de relações de poder em que determinados grupos podem decidir sobre o destino dos demais grupos. Um exemplo disso é o fato de que o controle sobre a chuva vem, cada vez mais, se tornando objeto sujeito à geopolítica, embora não apenas como fenômeno sujeito à previsão do homem e, portanto suscetível a uma "certa ludibriação" da natureza pelos homens, para usar uma expressão de Santos (2008, p. 100). Durante as Olimpíadas de Pequim, o governo chinês colocou de prontidão cinco aviões e uma bateria antiaérea para bombardear as nuvens com hidrogênio, fazendo com que a chuva ocorresse antes de chegar a Pequim (LORES, 2008), apesar de não ter sido divulgado se essas precipitações prejudicaram ou favoreceram as regiões para as quais foram desviadas. Mesmo no Brasil, já há uma empresa responsável por fazer com que a precipitação das chuvas se desencadeie, auxiliando tanto empreendedores privados como empresas públicas ${ }^{89}$. Nota-se que a questão se refere a uma dimensão política, porquanto onde e quando se deve fazer chover?

Além do mais, com a introdução das tecnologias de captação de água da chuva na construção civil e o gradativo aumento da consciência ecológica dos estratos sociais médios e baixos, acredita-se que, em curto período de tempo, essa modalidade de técnica começará a causar "prejuízos" financeiros às empresas de abastecimento de água e, portanto, não tardará que se crie uma taxa pela utilização

\footnotetext{
${ }^{89}$ Trata-se da empresa Modclima, com sede em Bragança Paulista: <http://www.modclima.com.br>.
} 
desse tipo de serviço ou, em um cenário radical, que se pague pela quantidade de água captada das chuvas. Esse tipo de ação, muito provavelmente, levará a tensões.

No que tange ao aproveitamento dos recursos hídricos em estado gasoso, a título de ilustração, já se fala na captação de água das neblinas e das nuvens mais baixas a partir de tiras de polipropileno. As pesquisas de Cosandey e Robinson (2000), Leconte (1998) e Schemenauer e Cereceda (1994) mostram que isso é tecnicamente possível, embora essa metodologia somente seja passível de uso em áreas restritas do Sudão, Quênia, Namíbia, Ilhas Canárias, Etiópia, Califórnia e países andinos na costa do Pacífico. De acordo com Lasserre e Descroix (2005), no Quênia, para cada metro cúbico de tira de polipropileno se conseguiu recuperar 30 L/dia de água (Tabela 3). Em contraste, quando se capta água das nuvens, dependendo da frequência e da quantidade, pode-se prejudicar as chuvas que provavelmente precipitariam em outro lugar.

Tabela 3. Produção média de água a partir de neblina em quatro países diferentes.

\begin{tabular}{cccc}
\hline País & $\begin{array}{c}\text { Produção média } \\
\text { de água }\left(\mathrm{I} / \mathrm{dia} / \mathbf{m}^{3}\right)\end{array}$ & $\begin{array}{c}\text { Duração da } \\
\text { temporada de } \\
\text { neblina (dias) }\end{array}$ & $\begin{array}{c}\text { Produção } \\
\text { média anual de } \\
\text { água (L/ano/m } \\
\text { de tira de } \\
\text { propileno) }\end{array}$ \\
\hline $\begin{array}{c}\text { Cabo Verde } \\
\text { Chile }\end{array}$ & 10 a 20 & n.d. & --- \\
Peru & 3 & 365 & 1.095 \\
Quênia & 9 & 210 & 1.890 \\
\hline
\end{tabular}

Fonte: Lasserre e Descroix (2005, p. 108).

Os recursos hídricos também são indispensáveis para a formação de um espaço habitável para o homem, podendo ser utilizados para umidificar ambientes secos. A construção do lago Paranoá serviu para amenizar a baixa umidade relativa do ar durante o período de estiagem em Brasília, DF e, logicamente, também serviu a funções paisagísticas (VESENTINI, 1996) e para emissão de dejetos e efluentes já 
tratados. Enquanto a capital do país possui esse recurso, a maior parte das cidades satélites em seu entorno encontra-se relegada à sequidão do Planalto Central.

O monitoramento das condições e da qualidade dos recursos hídricos também permite o controle sanitário. A construção de barragens está associada ao aumento dos casos de inúmeras moléstias, como a dengue e doenças causadas por parasitas. A construção da barragem da usina hidrelétrica de Serra da Mesa, localizada no norte goiano, nos municípios de Colinas do Sul e Minaçu, às margens do rio Tocantins, está associada ao aumento do número de focos de transmissão da esquistossomose (THIENGO; SANTOS; FERNANDEZ, 2005). O mesmo se pode afirmar em relação às áreas industriais próximas aos mananciais, pois uma boa parte dessas atividades acaba contaminando os cursos d'água quando não há uma fiscalização mais rígida por parte dos entes públicos.

Outra situação em que os recursos hídricos provocam relações de poder ocorre a partir da noção de água virtual, conceito criado pelo economista britânico Allan (1996) para designar a água incorporada na produção de alimentos. Allan (1998, p. 545) apontou que:

Alguma noção da relação entre água e comida - o nexo entre recursos hídricos e alimentos - pode ser compreendida a partir da seguinte relação: para produzir uma tonelada de grãos, necessita-se de mil toneladas (metros cúbicos) de água. Se um indivíduo ficar sem água, será muito mais fácil ter acesso a uma tonelada de grãos que a mil toneladas de água, necessárias para produzir essa quantidade de grãos. Sistemas eficazes e eficientes de comércio internacional para grãos têm funcionado por mais de dois mil anos. $^{90}$

Com o passar do tempo, esse conceito de água virtual foi estendido por Allan (2003), indo além do seu escopo inicial, passando a ser compreendido como a água utilizada para a produção de commodities agrícolas e não-agrícolas, ambas não contabilizadas nos custos de produção. Atualmente, a definição mais aceita é a de água utilizada para a produção de commodities (HOEKSTRA; HUNG, 2005; MERRET, 2003; OKI; KANAE, 2004; YANG; ZEHNDER, 2007; ZIMMER; RENAULT, 2003).

\footnotetext{
90 "Some notion of the relationship between water and food - the water-food nexus - can be grasped from the following relationship: to produce one tonne of grain, you need 1000 tonnes (cubic meters) of water. Should an individual run out of water, it would be much easier to access one tonne of grain than the 1000 tonnes of water required to produce it. Effective and efficient international trading systems for grain have operated for more than 2000 years".
} 
Então, a partir do conceito de água virtual, pode-se compreender uma série de relações de poder. Por meio da contabilização do comércio internacional de água virtual, verificam-se duas situações que demonstram os meandros do poder. $\mathrm{Na}$ primeira delas, os países pagam menos pela importação de grãos do que se tivessem de produzi-los no mercado interno. A esse respeito, Allan (1998, p. 546) adverte que:

[...] a água virtual embutida no grão está sendo negociada a preços menores que os de seu custo de produção. O preço (constante) dos cereais tem caído no mercado mundial por cerca de um século. O preço subiu em 1996 para 240 dólares por tonelada, mas caiu novamente para 140 dólares em maio de 1997. O preço de produção de uma tonelada de trigo está em torno de 200 dólares. Aquelas economias que importam grãos estão obtendo uma barganha subsidiada. As economias pouco eficientes no manejo da água recebem um duplo benefício por meio do acesso à água virtual a um preço incalculavelmente vantajoso.

Evidentemente, a situação pode ajudar a que países que possuem acesso a escassos recursos hídricos não passem por situações de penúria. Mas, a partir do momento em que os preços das commodities no mercado internacional não sejam tão rentáveis, muitos países que concentram a maior parte de sua produção no setor de tecnologia e de bens duráveis, principalmente os países mais desenvolvidos, terminarão por se aproveitar dessa situação em detrimento dos países subdesenvolvidos agroexportadores. Nesse contexto, os países desenvolvidos deixariam de causar uma boa parte da degradação que ocorreria em seus territórios caso produzissem ali as commodities que ora importam.

A segunda situação pode se dar a partir do exemplo dado por Holerman e Neubert (2006, p. 33):

[...] mesmo em termos globais, o comércio de água virtual pode levar à perda de recursos hídricos quando o país importador produz com grande eficiência hídrica. Em 1995, por exemplo, a Indonésia importou 2,3 toneladas de grãos da Índia. Enquanto a Índia precisou de $17,4 \mathrm{~km}^{3}$ de água para produzir essa quantidade de grãos, a Indonésia teria usado apenas $16,7 \mathrm{~km}^{3}$. A perda total de água pode, portanto, ser considerada em 0,7 $\mathrm{km}^{3}$. Outro exemplo revela perdas devido a técnicas de cultivo diferentes: no mesmo ano, o Sudão importou grãos da África do Sul e da Rússia, entre

91 "[...] the virtual water embedded in grain is being traded at less than its production cost. The (constant) price of cereals has fallen on the world market for about a century. The price spiked in 1996 to $\$ 240$ per tonne but fell back to $\$ 140$ per tonne by May 1997 . The cost of producing a tonne of wheat is about $\$ 200$. Those economies that import grain are getting a subsidized bargain. Waterdeficient economies receive a double benefit through accessing embedded virtual water at an incalculably advantageous price." 
outros países, causando uma perda total de $0,2 \mathrm{~km}^{3}$ em água para irrigação. ${ }^{92}$

Nessa situação, fica claro que os países podem traçar estratégias de segurança buscando preservar os seus recursos naturais a partir do consumo de commodities provenientes do mercado internacional. As economias dos países em desenvolvimento e subdesenvolvidos são, na maior parte, dependentes da exportação de commodities para os países mais desenvolvidos. Esse, aliás, é um dos meios de se economizar o consumo de água nacional a partir do consumo de água virtual de outros países. De modo a explicitar essa relação, na Tabela 4 fazemos uma comparação do volume de água virtual necessário para produzir algumas commodities em países desenvolvidos (Estados Unidos e Japão) e nos países do BRIC (Brasil, Rússia, Índia e China, formando um grupo de países em desenvolvimento).

Tabela 4. Comparação do consumo médio de água virtual para produzir algumas commodities em países desenvolvidos e nos países do BRIC.

Commodity Consumo médio de água virtual para produzir commodities $\left(\mathrm{m}^{3} / \mathrm{t}\right)$

\begin{tabular}{cc}
\hline Países & Países em desenvolvimento \\
desenvolvidos &
\end{tabular}

$\begin{array}{cccccc}\begin{array}{c}\text { Etados } \\ \text { Unidos }\end{array} & \text { Japão } & \text { Brasil } & \text { Rússia } & \text { Índia } & \text { China } \\ 1.656 & 1.585 & 4.003 & 3.118 & 3.702 & 1.716\end{array}$

\begin{tabular}{ccccccc}
\hline $\begin{array}{c}\text { Arroz } \\
\text { (sem palha) }\end{array}$ & 1.656 & 1.585 & 4.003 & 3.118 & 3.702 & 1.716 \\
Milho & 489 & 1.493 & 1.180 & 1.397 & 1.937 & 801 \\
Soja & 1.869 & 2.326 & 1.076 & 3.933 & 4.124 & 2.617 \\
Trigo & 849 & 734 & 1.616 & 2.375 & 1.654 & 690 \\
Carne & 13.193 & 11.019 & 16.961 & 21.028 & 16.482 & 12.560 \\
Leite & 695 & 812 & 1.001 & 1.345 & 1.369 & 1.000
\end{tabular}

Fonte: Hoekstra e Chapagain (2007).

92 "[...] even in global terms, trade in virtual water may lead to the 'loss' of water resources where the importer produces with greater water efficiency. In 1995, for example, Indonesia imported $2.3 \mathrm{~m}$ tons of grain from India. While India needed $17.4 \mathrm{~km}^{3}$ of water to produce that grain, Indonesia would have used only $16.7 \mathrm{~km}^{3}$. The global loss can therefore be put at $0.7 \mathrm{~km}^{3}$. Another example reveals the losses due to different growing methods: in the same year Sudan imported grain from South Africa and Russia among other countries and so caused a global loss of irrigation water of $0.2 \mathrm{~km}^{3}[\ldots]$ " 
Nota-se que, para a produção da maioria das commodities apresentadas, os países do BRIC consomem maior quantidade de água virtual. Essa relação desigual não ocorre somente entre países, podendo ocorrer até entre diferentes regiões de um mesmo país.

A criopolítica também é outra forma de se exercer poder a partir dos recursos hídricos, a começar pelo fato de que dois terços de toda a água doce potável do planeta encontram-se nas geleiras e nos polos. Apenas um terço encontra-se na atmosfera, rios, lagos e lençóis subterrâneos. Sabe-se que o gelo polar exerce importante influência no comportamento climático do globo, enquanto o gelo das montanhas regula a vazão e o ciclo fluviais. Nesse contexto, tanto o Ártico como a Antártida são locais estratégicos.

Embora o interesse pela Antártida tenha se dado porque o controle militar daquele espaço significava ter o controle dos acessos estratégicos (VILA, 2004) e também por conta de seus recursos minerais (CHILD, 1988; CLARK, 1988), não se pode esquecer do caráter estratégico daquele continente como laboratório de pesquisa, tanto da vida marinha e polar quanto do próprio planeta. Não foi por acaso que diversos países ali fixaram suas bases de pesquisa. Assim, a criopolítica existe como um projeto voltado para a busca do saber e do controle de técnicas e conhecimentos sobre a vida. Exemplo disso são as medições e as comparações dos níveis de dióxido de carbono na atmosfera ao longo do tempo, que somente foram possíveis a partir da coleta de ar congelado durante a última glaciação e que ainda permanece em grandes profundidades no gelo antártico e ártico.

Enfim, são inúmeras as situações em que os recursos hídricos acabam expressando relações de poder. Citamos aqui apenas algumas delas para dar uma noção de quão amplas podem ser. A partir desses exemplos, fica clara a existência de uma geopolítica utilizada para melhor compreender situações em que os recursos hídricos participam mais ou menos diretamente das relações de poder ou dos conflitos, juntamente com outros fatores. Se assim não fosse, teríamos inúmeras geopolíticas, tais como geopolítica do petróleo, geopolítica étnica, e até mesmo uma geopolítica fluvial, que, aliás, é o título da obra de Tosi (1999), como se cada dimensão da vida social fosse compartimentada e isenta da influência das demais. Portanto, a adoção de um neokantismo radical acaba por se tornar insustentável. 
Outros esforços conceituais têm sido implementados de forma a levar em consideração a dimensão política da água. Nessa perspectiva, destacam-se os conceitos de hidropolítica e segurança hídrica. Segundo Elhance (1999, p. 218, tradução nossa), a "hidropolítica é o estudo sistemático de conflito e cooperação entre Estados por recursos hídricos que transcendem as fronteiras internacionais". 93 Nota-se que essa concepção leva em conta as tensões políticas entre Estados, ou seja, a escala primordial de reflexão no âmbito da hidropolítica situa-os como os principais atores.

Essa definição de hidropolítica não é uma exceção, porquanto de acordo com Turton (2002), inúmeros proponentes a defendem. Evidentemente, considerar apenas os Estados como os protagonistas desse cenário deixa de considerar vários outros atores igualmente importantes, como empresas transnacionais, movimentos sociais, entre outros que atuam neste âmbito. Dessa forma, a reflexão sob a perspectiva da hidropolítica não considera as contribuições de um enfoque multiescalar propiciado pela geopolítica da água. Contudo, uma questão ainda mais primordial consiste em simplesmente ignorar a gestão do território. Ao se deixar de lado esse aspecto, as decisões políticas, os conflitos e as tensões perdem o seu contexto e o seu locus, logo tornando a reflexão enviesada. Os geógrafos Lasserre e Descroix (2005) afirmaram categoricamente que não há gestão eficiente de recursos hídricos sem levar em consideração o território. Alguns autores, como Meissner (1999) e Turton (2002), vêm defendendo uma abordagem mais ampla da hidropolítica, principalmente no que se refere às escalas, com a finalidade de retificar essas questões epistemológicas. Apesar de o conceito de hidropolítica defender uma reflexão que abranja os recursos hídricos em sua totalidade, na prática, a maioria dos estudos centra-se na gestão de bacias hidrográficas e aquíferos. Talvez a única exceção seja a análise do comércio de água virtual, como apresentam os trabalhos de Allan (1998; 1999), Hoekstra e Chapagain (2007) e Hoekstra e Hung (2005). Na sua prática, a concepção de hidropolítica não engloba a análise dos recursos hídricos de forma mais ampla, assim como defendemos nas páginas anteriores. Essas questões metodológicas em relação ao conceito de hidropolítica não são insignificantes, como aponta Lacoste (2001, p. 5, tradução nossa):

\footnotetext{
93 "Hydropolitics is the systematic study of conflict and cooperation between states over water
} resources that transcend international borders." 
[...] as previsões de uma pretensa "hidropolítica" anunciam "guerras da água" praticamente inevitáveis que seriam o perigo maior do terceiro milênio. Trata-se de uma representação muito discutível. De fato, na maior parte dos casos, uma análise geopolítica séria mostra que a água não é o objetivo primordial que explicaria e justificaria por si mesmo todos os conflitos que estão por acontecer. ${ }^{94}$

Outros pesquisadores têm reafirmado a importância dos recursos hídricos para o campo de reflexão dos estudos sobre segurança. No que tange a esse aspecto, vem sendo comentado o conceito de water security. A tradução para o português causa uma série de complicações, uma vez que o termo security se relaciona diretamente a conflitos, enquanto o vocábulo safety é mais amplo e, portanto, vai além do significado contido pelo primeiro (BOSNJAKOVIC, 1996 apud CUNHA, 1998). Então, o conceito de segurança hídrica se refere explicitamente a tensões e conflitos. Porém, quanto se passa ao significado dado ao conceito de segurança hídrica, nota-se que há uma divergência.

Muitos autores têm expressamente defendido uma abordagem do conceito de segurança hídrica que não considera os recursos hídricos como objeto de estudo do campo da segurança nacional, assim enfocando essencialmente as catástrofes relacionadas a esses recursos. Assim sendo, excluem-se os conflitos e as relações de poder vinculados aos recursos hídricos. Schultz e Uhlenbrook (2007, p. 2, tradução nossa) relataram que:

A segurança hídrica envolve o uso sustentável e a proteção dos sistemas hídricos, a proteção contra calamidades relacionadas à água (inundações e secas), o desenvolvimento sustentável dos recursos hídricos e a salvaguarda (do acesso) às funções e aos serviços para os seres humanos e 0 ambiente. ${ }^{95}$

A Global Water Partnership também definiu segurança hídrica nos mesmos moldes de Schultz e Uhlenbrook (2007). De acordo com essa instituição:

O termo "segurança hídrica" procura captar o complexo conceito de manejo holístico da água e o equilíbrio entre proteção do recurso e uso do recurso. A segurança hídrica precisa ser considerada nos níveis local, nacional e regional. Juntamente com melhorias na segurança da saúde, educacional, energética e alimentar, a segurança hídrica aumentada pode evitar ameaças produzidas pela poluição e favorecer o objetivo global de

\footnotetext{
94 '[...] les augures d'une prétedue 'hydropolitique' annoncent des 'guerres de l'eau' pratiquement inéluctables qui seráit le péril majeur du troisième millénaire. II s'agit d'une representation très discutable. En effet, dans la pluspart de cas, une analyse géopolitique sérieuse montre que l'eau n'est pas cet enjeu primordial qui expliquerait et justfierait à lui seul tous les conflicts à venir."

95 "Water security involves the sustainable use and protection of water systems, the protection against water related hazards (floods and droughts), the sustainable development of water resources and the safeguarding of (access to) water functions and services for humans and the environment."
} 
diminuição da pobreza, evolução do bem-estar social, produtividade e capacidade concomitantemente com a sustentabilidade ambiental (GWP, 2000 , p. 12, tradução nossa). ${ }^{96}$

Essa concepção de segurança hídrica não é uma exceção, vez que encontramos em vários outros trabalhos definições muito semelhantes às aqui citadas (BELTRÁN-MORALES et al., 2007; CALOW et al., 2002; COSGROVE, 2003; FAO, 2000; LOË, 2007; MALIK, 2008; WHITE et al., 2007). Uma pequena variação a essa visão é encontrada no trabalho de Hermann e Robiou (2004) e nas recomendações da U. S. Environmental Protection Agency (USEPA, Agência de Proteção Ambiental Norte-americana), que acrescentam a necessidade de proteção dos recursos hídricos contra atentados terroristas à concepção apresentada anteriormente (USEPA, 2006), modificação ocorrida após os atentados de 11 de setembro de 2001.

Observa-se que os conceitos tanto de segurança hídrica quanto de hidropolítica acabam olvidando uma dimensão importante dos conflitos hídricos: as relações de poder que permitem a determinados grupos exercer certo controle sobre a vida de outros. O conceito de hidropolítica enfrenta alguns problemas, não apenas pela questão das escalas, mas sobretudo por considerar apenas os recursos hídricos superficiais e, quando muito, os subterrâneos. Já o conceito de segurança hídrica não considera os recursos hídricos entremeados por relações de poder e conflitos, às quais diversos grupos e agentes estão submetidos quando lidam com sua gestão.

A partir desses exemplos, torna-se natural proceder a uma ampliação da reflexão do poder de tal sorte a englobar os recursos hídricos em sua totalidade, não tratando tão-somente dos recursos hídricos subterrâneos e superficiais, mas igualmente dos atmosféricos. Ademais, deve-se abranger, ainda, os recursos hídricos em seus três estados - líquido, gasoso e sólido -, uma vez que a criopolítica também exerce controle sobre a vida no planeta.

\footnotetext{
96 "The term 'water security' aims to capture the complex concept of holistic water management and the balance between resource protection and resource use. Water security needs to be considered at local, national and regional levels. Together with improvements in health, education, energy and food security, increased water security can avoid threats from pollution and support the overall goal of poverty alleviation, improved human well-being, productivity and capacity alongside environmental sustainability."
} 
À vista disso, propomos uma geopolítica que estude a ligação entre os recursos hídricos lato sensu e as relações de poder e conflitos sociais. Para tanto, não se pode enfocar exclusivamente os recursos hídricos, devendo-se cotejar as suas conexões com as demais dimensões sociais, conformando arranjos territoriais que expressem relações de poder. Naturalmente, essas relações de poder significam controle sobre a vida em geral, porquanto não há vida sem recursos hídricos. Portanto, essa geopolítica que propomos faz referência ao que hoje se costuma chamar segurança ambiental. Para Deudney (1999, p. 26, tradução nossa), "essa teoria inicialmente naturalista e geopolítica é também a predecessora dos estudos contemporâneos sobre segurança ambiental". ${ }^{97}$ Matthew (2002) também mostrou a importância da geopolítica para os estudos de segurança ambiental. Fazse imprescindível enfatizar, ainda, que essa geopolítica lato sensu relacionada aos recursos hídricos não deve se ocupar exclusivamente dos conflitos, mas também precisa consagrar-se às relações de poder que, na maior parte das vezes, são mais letais que os conflitos violentos propriamente ditos.

\subsection{Por uma geopolítica voltada à instabilidade}

Na geografia política, tem havido uma tendência um tanto dicotômica quando se tenta separar o poder ou as relações de poder do conflito e da guerra. Durante o seu período clássico, a geopolítica, campo por natureza do poder do Estado, se preocupou com a guerra e os conflitos entre Estados. A partir da década de 1970, a tendência contraposta a esta, a geopolítica crítica, passou a se ocupar de forma mais cuidadosa das relações de poder e da luta de classes, se descuidando da geografia dos conflitos, ou pelo menos deixando-a em segundo plano, uma vez que a geopolítica clássica servia, antes de mais nada, para que as potências hegemônicas fizessem a guerra. Falava-se em geografia do poder ou em geografia da guerra. Por outro lado, alguns geógrafos e sociólogos procuraram explorar a dimensão espacial dos conflitos por meio da análise locacional (COX, 1970; WOLPERT, 1970). Retornando a esse mesmo enfoque, atualmente, cientistas

\footnotetext{
97 "This early naturalist and geopolitical theory is also the predecessor of contemporary environmental security studies."
} 
políticos e geógrafos vêm tentando construir uma teoria geográfica do conflito (BUHAUG; GATES, 2002; LE BILLON, 2002b).

Em nossa opinião, ainda carecemos de uma teoria segundo a qual os conceitos geográficos possam explicar os conflitos. Uma análise locacional dos conflitos, embora ajude as demais ciências a adotar uma dimensão espacial do fenômeno, não contribui de forma direta para que a ciência geográfica os compreenda, uma vez que esta se utiliza de outros caminhos para entendê-los e explicá-los, principalmente a partir de um enfoque da estruturação territorial e das especificidades das regiões.

Além disso, a nosso ver, tanto o poder quanto o conflito são parte do mesmo fenômeno, porém em fases e processos distintos, como bem postularam Clausewitz (2005), quando afirmou que "a guerra era a continuação da política por outros meios", ou o filósofo Foucault (2005, tradução nossa), ao apontar que a inversão do postulado era igualmente verdadeira, pois "a política é a continuação da guerra por outros meios". O axioma foucaultiano ressalta bem o que Galtung (1982 apud ROSS, 2004, tradução nossa) chamou de "paz negativa", vez que a não existência de guerra em um dado momento não significa que estejamos passando por um período de paz. O general Couto e Silva (1967), em seus escritos, salientou o surgimento de uma guerra total enquanto confronto não apenas no campo militar, mas também nos campos psicossocial, econômico, entre outros. Weber (1949 apud COSER, 1956, p. 21, tradução nossa) também preceituou que "a paz não é nada mais do que uma mudança na forma do conflito, ou nos antagonistas, ou nos objetos do conflito, ou finalmente nas chances de seleção". 98

A relação entre o poder e o conflito se estrutura continuamente, não havendo ordem eternamente permanente. Essa posição encontra sua raiz mais profunda no legado de Heráclito, de acordo com o qual tudo no universo flui a partir da contradição, inclusive a guerra. Essa posição também é defendida pela sociologia do conflito e um de seus proponentes, o sociólogo Collins (1975, p. 13, tradução nossa), elucidou que:

"Mudança social" não é algo que aconteça ocasionalmente, mas é antes a falta de mudança, a qual é uma ilusão. A estrutura das relações de poder em uma organização varia de minuto a minuto, embora tenda a retornar a

\footnotetext{
98 "Peace is nothing more than a change in the form of conflict or in the antagonists or in the objects of the conflict, or finally in the chances of selection."
} 
um ponto semelhante. A distinção formal-informal desaparece em grande parte; ambos esses conceitos referem-se ao tipo de relações que são encetadas à medida que as pessoas entram em contato. A estrutura organizacional deve ser vista como algo que é constantemente recriado; seus determinantes devem todos fluir por meio de um conjunto de pressões sobre os indivíduos que começam a adotá-las. ${ }^{99}$

Outro autor importante da teoria do conflito, Rex (1981, p. 123, tradução nossa), ao propor um novo enfoque, procurou ressaltar a instabilidade implícita nessas condições apontando que "as situações de conflito podem conduzir, após a implantação de sanções, à manutenção do status quo, à trégua e ao acordo ou à 'revolução' [...]". ${ }^{100}$ No primeiro caso, a estrutura do poder do agente hegemônico é mantida, embora possa se tornar ainda mais forte. No segundo caso, algumas concessões podem ser feitas aos demais atores hegemonizados, implicando modificação do arranjo do poder após o conflito. No último caso, aquele denominado "revolução" pelo autor, os antigos protagonistas hegemonizados podem reverter a organização das relações de poder tornando-se os novos atores hegemônicos.

Adotando um posicionamento intermediário, entre os funcionalistas e os cientistas sociais da teoria do conflito, Lipset (1990, p. 1, tradução nossa) destacou a importância das mudanças levadas adiante pelos conflitos, porém procurou se eximir de uma teoria do conflito radical:

Todas as sociedades complexas são caracterizadas por alto grau de tensão e conflito internos, mas instituições e valores consensuais são condições necessárias para a sua persistência. Assim, qualquer esforço para lidar com sistemas políticos ou sociais deve tratar de conflito e de consenso. ${ }^{101}$

Levando adiante a relação entre conflito e consenso a partir do legado de Max Weber e Karl Manheim, Lipset (1990) explicou que a estabilidade e a instabilidade dos sistemas sociais se baseiam nos dois tipos principais de racionalidade: a substantiva (Wertrationalität) e a funcional (Zweckrationalität). A primeira envolve

\footnotetext{
99 ' 'Social change' is not something that happens occasionally, it is rather the lack of change which is an illusion. The structure of power relations in an organization fluctuates minute by minute, although tending to return to a similar point. The formal-informal distinction largely disappears; both of these concepts refer to the kind of relationships that are enacted as people happen to come into contact. Organizational structure must be seen as something that is continually recreated; its determinants must all flow through a set of pressures on individuals who go about enacting it."

100 "Conflict situations may lead after the deployment of sanctions to the maintenance of the status quo, to truce and compromise or to 'revolution' [...]"

101 "All complex societies are characterized by a high degree of internal tension and conflict, but consensual institutions and values are necessary conditions for their persistence. Hence, any effort to deal with political or social systems must treat conflict and consensus."
} 
julgamentos conscientes sobre os objetivos, ao passo que a segunda se preocupa com os meios para se alcançar os objetivos. A racionalidade funcional está diretamente vinculada à manutenção do equilíbrio de um sistema, enquanto a racionalidade substantiva está relacionada ao avanço ou à modificação do equilíbrio sistêmico.

Dessa forma, o conflito é um estágio de reestruturação e transição entre dois períodos com estruturas sociais diferentes. Mesmo com a manutenção do status quo pelos atores hegemônicos, isso não significa que se manteve a mesma estrutura, uma vez que o conflito sempre provoca novas formas de interação entre os agentes.

Poderia-se, então, afirmar que o conflito é uma fase de transição caótica? Naturalmente que não, pois o conflito parece, ao contrário, ser um fenômeno de enrijecimento da estrutura social que, por sua vez, não consegue se manter estável pela falta de flexibilidade para acomodar as tensões sociais inerentes a todas as sociedades. Logo, não se trata de um processo caótico, mas antes de organização em excesso. Consequentemente, o que ocorre não é uma "explosão" da estrutura social, porém uma "implosão", com grupos sociais compactos e rígidos se fragmentando ao entrar em choque uns contra os outros. Rex (1981, p. 104-105, tradução nossa) concordou com essa visão quando asseverou que:

[...] a teoria do conflito não implica uma redução da sociedade a uma guerra de cada indivíduo contra cada outro individuo durante todo o tempo. Conflito não significa desordem aleatória. Ele deve permitir a formação de coletividades em busca do conflito e assume a interrelação funcional entre as áreas institucionais de forma que os conflitos em uma área são sustentados pelos conflitos em outras. ${ }^{102}$

Contudo, o que existe no período entre dois conflitos? Pode-se falar em ordem? Evidentemente, o que existe é uma ordem tênue, porquanto existem tensões inerentes à própria continuidade da sociedade que precisam ser geridas com flexibilidade para que possam ser acomodadas. Por isso mesmo, quanto mais estratificada for a sociedade, mais facilmente essas tensões poderão ser geridas, uma vez que a situação descrita anteriormente por Rex (1981), em que muitas tensões em uma única dimensão social podem sustentar as tensões nas outras dimensões, acaba não ocorrendo com muita frequência. Assim sendo, a densidade

102 "[...] conflict theory does not imply a reduction of society to a war of each individual against very other individual all of the time. Conflict does not mean random disorder. It must allow for the formation of collectivities in pursuit of conflict and it assumes functional interconnectedness between institutional areas so that conflicts in one area are sustained and supported by conflicts in others." 
de dimensões sociais envolvidas não é grande e estas não intensificam ou canalizam as tensões sociais.

Por outro lado, isso não quer dizer que não exista ordem, ainda que precária, pois "as sociedades humanas devem, se querem persistir, ser capazes de se gerir com êxito e, portanto, todos os indivíduos devem ser funcionalmente adequados; se não, eles seriam extintos [...]" (HOBSBAWN 1973 apud LIPSET, 1990, p. 13). ${ }^{103}$ Com isso, o historiador britânico procurou ressaltar o caráter sistêmico aqui existente. Seguindo as diretrizes iniciais estabelecidas para o presente trabalho, esta ordem foi estruturada a partir da interação dos agentes, porém a própria estrutura anterior apresenta certas condições para a forma como essas interações se organizam entre os agentes.

Muitos autores têm caracterizado a fase entre dois conflitos como aquela marcada pela existência de um poder legítimo ou consensual. A maior expressão dessa corrente é o postulado de Weber (1999, p. 50, tradução nossa) de que o Estado possui o monopólio legítimo dos meios de violência, pois para ele:

Poder significa toda possibilidade de impor as suas próprias vontades, mesmo que sejam resistidas, em relações sociais, nas quais essa possibilidade se baseia [...] O termo "poder" é sociologicamente amorfo. Todas as qualidades concebíveis de seres humanos e de todas as constelações concebíveis podem colocar alguém na posição de impor a sua própria vontade em uma dada situação. ${ }^{104}$

Fundamentalmente, trata-se de uma posição radical em que um agente consegue impor totalmente a sua vontade a outrem e, no caso do Estado, ainda por meio do uso de violência legítima. Por outro lado, o autor salienta o fato de que o poder nunca é totalmente aceito, mas que sofre resistência (Widerstreben). Daí porque mencionar uma ordem ainda que tênue e não totalitária. Por certo que hoje, como afirmou Lebrun (1981), o poder é menos impositivo e busca o controle como forma de garantir direitos e segurança aos cidadãos. Em adição a isso, o poder busca controlar sem ser visto em ação, como provou Foucault (2005) e, portanto, evita-se a imposição por meio da violência.

\footnotetext{
103 "Human societies must, if they are to persist, be capable of managing themselves successfully, and therefore all existing ones must be functionally adequate; if not they would become extinct [...]"

104 "Macht bedeutet jede Chance innerhalb einer sozialen Beziehung den eignen Willen auch gegen Widerstreben durchzusetzen, gleichviel worauf diese Chance beruht [...] Der Begriff 'Macht' ist soziologisch amorph. Alle denkbaren Qualitäten eines Menschen und alle denkbaren Konstellationen können jemand in die Lage versetzen, seinen Willen in einer gegebenen Situation durchzusetzen."
} 
Arendt (1985), por seu turno, ponderou que o poder não necessita de justificativas, mas de legitimidade, desde que surge quando um grupo de pessoas se reúne e age de comum acordo. Para a filósofa alemã, poder e violência não são sinônimos, uma vez que a primeira se caracteriza por sua instrumentalidade, enquanto o segundo surge a partir de um acordo entre as partes. Habermas (1980) também ressaltou a necessidade de uma forma de agir comunicacional, em que as partes dissidentes tenham necessidade de se comunicar para chegar a um determinado consenso expresso pelo acordo. Porém como o próprio Habermas (1980) se preocupou em apontar, a legitimação não acabaria se dando por um desconhecimento daqueles que se encontram sob o jugo do poder? Então, com o avanço da racionalidade e o debate acerca dos fatos a partir da verdade, a legitimidade entraria em colapso, porque o questionamento da autoridade em pauta seria desafiado pela racionalidade.

Certamente, o controle não pode ser definido apenas como aquele exercido sobre os homens, porém também sobre o restante da natureza, pois, para exercê-lo, faz-se necessário organizar o espaço em que se encontra. Ao discorrer sobre o poder, Giddens (2003) enumerou dois tipos de recursos aos quais o poder pode recorrer: os alocativos e os autoritários. Os recursos alocativos se referem a formas de capacidade transformadora que geram controle sobre os objetos, bens ou fenômenos materiais, enquanto os recursos autoritários se referem a tipos de capacidade que originam controle sobre as pessoas.

Em relação a essa dupla instrumentalidade do poder, o cientista político Deutsch (1983, p. 46, itálico do autor) relatou que:

O poder consiste acima de tudo em comandar a natureza e os homens. Estas duas espécies de poder agem, por vezes, uma sobre a outra. No decurso da história, tem acontecido que quando o homem aumenta o seu poder sobre a natureza, ele é capaz de usar esse poder maior que adquiriu como um meio de aumentar o seu próprio poder sobre outros homens [...] Estas duas espécies de poder diferem em pontos importantes. O poder sobre a natureza representa algo que o homem pode compartilhar. O poder sobre os homens é algo pelo qual o homem tem que lutar [...] O poder sobre a natureza é qualquer coisa que a humanidade pode aumentar coletivamente e tem vindo a aumentar desde há meio milhão de anos. É um jogo de soma variável no qual os jogadores competem uns com os outros, mas em que todos podem ganhar conjuntamente, à custa da banca, da natureza.

O sociólogo Mann (1986, p. 6, tradução nossa), ao discutir sobre o poder social, seguiu na mesma direção de Deutsch (1983), ressaltando que: 
Em seu sentido mais geral, o poder é a habilidade de perseguir e alcançar objetivos por meio do domínio de seu próprio ambiente. O poder social carrega dois sentidos mais específicos. O primeiro restringe seu significado ao domínio exercido sobre outros povos. Um exemplo é: o poder é a probabilidade de um ator dentro de um relacionamento social estar em uma posição para realizar sua própria vontade apesar da resistência [...] Mas como Parsons notou, tais definições restringem o poder a seu aspecto distributivo, poder de A sobre B. Para que B ganhe poder, A deve perder algum - seu relacionamento é de "um jogo de soma zero", em que uma quantidade fixa de poder pode ser distribuída entre os participantes. Parsons observou corretamente um segundo aspecto coletivo do poder, por meio do qual as pessoas que estão em cooperação podem aumentar o seu poder conjunto sobre terceiros ou sobre a natureza [...] $\mathrm{Na}$ maioria das relações sociais, ambos os aspectos do poder, distributivo e coletivo, explorador e funcional, operam simultaneamente e estão entrelaçados. ${ }^{105}$

\section{Quando mencionou a vontade de viver como apenas uma das formas de} vontade de potência, Nietzsche (2001, aforismo 303) lembrou-nos que:

O que o homem quer, o que a menor parcela de organismo vivo quer, é um plus de potência. Na aspiração para um fim há tanto prazer quanto desprazer, daquela vontade o homem busca a resistência, tem necessidade de algo que se Ihe oponha... O desprazer, obstáculo da vontade de potência, é, portanto, um fato normal, o ingrediente normal de todo fenômeno orgânico; o homem não o evita, ao contrário, tem contínua necessidade dele: qualquer vitória, qualquer sentimento de prazer, qualquer acontecimento pressupõe resistência vencida [...] o organismo é totalmente uma complexidade de sistemas que lutam pelo crescimento dos sentimentos de potência.

Desse modo, fica claro que toda forma de vida possui o instinto de afirmar a sua existência sobre o mundo pela expressão do poder. Quanto a isso, o homem não é diferente, pois procura manter a sua existência, seja em relação aos outros homens, seja em relação ao restante das forças da natureza. Naturalmente, isso não significa, necessariamente, uma relação de confronto direto e violento erga omenes ou ante o resto da natureza. Até porque existem formas de poder em que ambos os polos saem ganhando. Afinal, nem todo poder pode ser considerado um jogo de soma zero.

\footnotetext{
105 "In its most general sense, power is the ability to pursue and attain goals through mastery of one's environment. Social power carries two more specific senses. The first restricts its meaning to mastery exercised over other people. An example is: Power is the probability that one actor within a social relationship will be in a position to carry out his own will despite resistance [...]. But as Parsons noted, such definitions restrict power to its distributive aspect, power by A over B. For B to gain power, A must lose some - their relationship is a 'zero-sum game' where a fixed amount of power can be distributed among participants. Parsons noted correctly a second collective aspect of power, whereby persons in cooperation can enhance their joint power over third parties or over nature [...]. In most social relations both aspects of power, distributive and collective, exploitative and functional, operate simultaneously and are intertwined."
} 
A esse respeito, Blackburn (1992) demonstrou que, além das forças destrutivas, também existem forças de cooperação, pois os seres humanos devem procurar satisfazer as necessidades de vida, seja produzindo-a eles mesmos, seja obtendo-as de outros por meio de comércio e tributos. O vampiro da razão, portanto, abrange não somente as forças destrutivas originais da natureza como também a predação da humanidade sobre outras espécies e seu meio ambiente comum, além da predação inter-humana envolvida no imperialismo e da dominação de classe. À luz do tumulto da destruição que a natureza e os seres humanos podem infligir-se mutuamente, poder-se-ia perguntar como cada um deles, ou ao menos estes últimos, conseguiram sobreviver. Na verdade, é claro que as forças destrutivas em ação na história são contrabalançadas por forças criativas mais poderosas da natureza e da vida. A nossa espécie, em particular, tem acesso a um planeta abundante e, acima de tudo, tem poderes recuperativos e inteligência racional, que pode prevenir a destruição.

Por certo, muitas vezes os resultados da cooperação não são simétricos, isto é, os atores recebem vantagens dessa relação de forma desigual. Por isso mesmo, as relações de poder não devem ser consideradas um jogo de soma zero, já que, reiteradas vezes, o domínio é consentido porque, no final das contas, se obtém alguma forma de conveniência. Além disso, ao utilizarmos o controle da natureza e transformá-la segundo as nossas conveniências, estamos empregando-a como instrumento. Com isso, portanto, realçamos sua instrumentalidade, tanto para a cooperação entre os grupos sociais como para o estabelecimento do poder, ao excluir alguns grupos da conveniência que o controle sobre a natureza pode nos proporcionar. Destarte, o poder acaba fazendo uso da violência, ainda que de maneira não explícita. Isso fica claro quando Galtung, Jacobsen e Brand-Jacobsen (2002) diferenciam a violência direta da indireta, vez que a violência direta se refere a atos físicos de agressão, enquanto a indireta ou estrutural é construída nos próprios sistemas sociais econômicos e políticos que governam as sociedades, os Estados e o mundo. A violência estrutural implica "alocação diferenciada de bens, recursos, oportunidades entre diferentes grupos classes, gêneros, nacionalidades etc." (GALTUNG; JACOBSEN; BRAND-JACOBSEN, 2000, p. 17, tradução nossa). Nesse sentido, a violência está presente tanto no poder como no conflito e, 
consequentemente, não pode ser o caráter de distinção entre esses dois últimos conceitos.

O poder é, então, essa ordem tênue, flexível e muitas vezes precária, que alguns agentes estabelecem a seu favor de forma desigual, ainda podendo ocorrer em detrimento de terceiros. Uma vez que a satisfação das conveniências ocorre de maneira desigual, isso já causa o estabelecimento de violências estruturais. Por certo, o poder é uma relação que convêm aos agentes, já que não teriam essas conveniências sem o estabelecimento das relações de poder. $E$, por isso, há uma ordem efervescente que pode tanto se manter por um determinado período como ir se modificando gradualmente a partir da reprodução da estrutura pelos agentes.

Mas, o que vem a ser, então, o conflito? Obviamente, essa ordem é constantemente desafiada por suas tensões internas. Não obstante, o conflito ocorre estruturalmente quando há uma quebra dessa ordem por meio da contestação de agentes organizados, enrijecendo as relações a partir da formação de grupos polarizados e antagônicos de agentes se confrontando por interesses irreconciliáveis.

Cooley (1930) propôs que "os conflitos, de algum modo, são a vida da sociedade, e o progresso emerge de uma luta na qual o indivíduo, classe ou instituição procura realizar a sua própria idéia do que é bom”. Park e Burgess (1924) tentaram aprofundar mais o conceito, postulando que o conflito é uma disputa em que o contato é uma condição indispensável, um ato consciente, evocando sempre as mais profundas emoções e sentimentos. Park (1941 apud COSER, 1956, p. 20, tradução nossa) reiterou que "o conflito tende a ocasionar uma integração e uma superordenação e subordinação dos grupos em conflito". 106 Simmel (1955), por sua vez, afirmou que o conflito é um processo de sociabilização pelo qual se promove a coesão dos grupos sociais e se evita o seu isolamento. Ademais, os conflitos funcionam como válvulas escape, atenuando a tensão entre os grupos sociais.

Seguindo o postulado kantiano de "reino dos fins", Rex (1981, p. 119, tradução nossa) preconizou que "o conceito de conflito como o temos empregado

\footnotetext{
106 "Conflict tends to bring about an integration and a superordination and subordination of the conflict groups."
} 
[...] se refere à ação significativa na busca de metas". ${ }^{107}$ Todavia, os atores não seguem os seus objetivos de forma tão racional. Conforme Rex (1981, p. 5), "a prática da resolução de conflito, frequentemente e com razão, coloca ênfase em cima do mal-entendido, uma vez que greves e guerras, por exemplo, podem resultar de tal mal-entendido". ${ }^{108}$ Apesar dos agentes seguirem os seus fins, à medida que as tensões aumentam, existe a tendência de que aspectos psicológicos e emocionais comecem a fazer parte do contexto, como exemplifica o conceito de ambivalência (REX, 1981). Por outro lado, quando existe o conflito, isso não significa necessariamente que haja a presença de violência física, como afirmam vários cientistas políticos ao propor o conceito de conflito político (DAVIES, 1985; ECKSTEIN, 1985; GURR, 1985). A violência não é uma condição necessária para definir o conflito, assim como nem todos os conflitos implicam violência direta, porquanto podem ser resolvidos pelo consenso, estabelecendo um novo acordo.

Seguindo as diretrizes de Simmel (1955), Coser (1956, p. 35) teceu o seguinte argumento:

Parece ser geralmente aceito pelos sociólogos que a distinção entre "nós
mesmos, o nosso grupo, ou o grupo interno, e todos os demais, ou o grupo
dos outros, os grupos de fora" é estabelecida no e através do conflito. Isso
não está confinado ao conflito entre classes, embora os conflitos de classe
apareçam como a ilustração mais conveniente para muitos observadores.
Os conflitos por nacionalidade e étnicos, ou o conflito entre vários estratos
em estruturas burocráticas oferecem exemplos igualmente relevantes.

Rex (1981, p. 105, tradução nossa) também concordou com Coser (1956), já que para ele "claramente, a teoria do conflito pode ser aplicada em vários níveis. Ela pode ser aplicada às relações entre díades de indivíduos e às relações em larga escala entre coletividades, tais como classes e nações". ${ }^{110}$

Seguindo as recomendações dos dois autores mencionados, resta claro que a teoria do conflito pode ser reconstruída a partir do conceito de território, já que

\footnotetext{
107 "The concept of conflict as we have used it [...] has reference to meaningful action in pursuit of goals."

108 "The practice of conflict resolution often and quite rightly lays emphasis upon misunderstanding, since strikes and wars, for example, may result from such misunderstanding."

109 "It seems to be generally accepted by sociologists that the distinction between 'ourselves, the wegroup, or in-group, and everybody else, or the others-group, out-groups' is established in and through conflict. This is not confined to conflict between classes, although class conflicts have appeared as the most convenient illustration to many observers. Nationality and ethnic conflicts, or conflict between various strata in bureaucratic structures afford equally relevant examples."

110 "Clearly, conflict theory can be applied at various levels. It can be applied in the individual dyadic relations and in large scale relations between collectivities such as class and nations."
} 
a ocorrência de conflitos envolve estruturação de diferentes grupos a partir de diversas relações sociais. Certamente, essas relações se materializam no território e, portanto, todo conflito acaba envolvendo uma dimensão territorial, ainda que seu fim último não seja propriamente o território. A integração grupal se traduz também em maior diferenciação, intensificando a territorialidade dos atores. A esse respeito, o geógrafo alemão Reuber (1999, p. 3, tradução nossa) apontou que:

Os conflitos de fronteira se agitam no poder dos atores políticos, porque as linhas virtuais, que também dividem completamente a república alemã, são de longe mais do que uma quadriculação administrativa da ordem. Os territórios políticos são a base espacial do poder e suas fronteiras são "poder-fronteiras".

Evidentemente, para se estabelecer uma teoria geográfica do conflito não se pode utilizar o conceito de ação assim como se faz nas ciências sociais. Os tipos de atores na geografia são diferentes daqueles das ciências sociais. Uma rede de cidades, um conjunto de empresas ou uma rede de atores sociais são protagonistas que somente são enfatizados diretamente pela teoria geográfica. Consequentemente, trata-se de uma tipologia de atores diferentes. O professor Santos (1999, p. 67) enfatizou que a "ação é própria do homem, uma vez que ele possui objetivo e finalidade" e, mais à frente, relatou que a "ação humana não se restringe apenas aos indivíduos, já que as empresas e as instituições também possuem a faculdade do agir humano". Não obstante, é necessário considerar, ainda, os objetos. Para Santos (1999), embora os objetos não ajam, podem tornarse necessários para certos tipos de ações e, sem eles, a eficácia da ação não seria completa. Por fim, o autor estabelece que ação e objetos ocorrem conjuntamente.

Buscando propiciar subsídios para uma teoria geográfica do conflito, Reuber (1999, p. 29, tradução nossa) indicou que:

Uma pesquisa geográfica do conflito deve naturalmente trazer para a discussão o papel do espaço explicitamente. Esse procedimento não pode despertar, entretanto, a impressão que a estrutura físico-material forma uma quase objetiva categoria, para não dizer auto-suficiente, "fora" do sistema social. ${ }^{112}$

111 "Grenzkonflickte rütteln an der Macht der politischen Akteure, denn die virtuellen Linien, die auch die Bundesrepublick lückenlos aufteilen, sind weit mehr als ein verwaltungstechnisches Ordnugsraster. Politische Territorien sind die räumlich Basis der Macht und ihre Grenzen sind 'MachtGrenzen'."

112 "Eine geographischen Konfliktforschung sollte natürlich die Rolle 'des Raumes' explizit thematisieren. Dieses Vorgehen Darf aber nicht den Eindruck erwecken, dass physisch-materielle Strukturen gewissermassen eine eigene, quase objektive Kategorie 'ausserhalb'des sozialen Systems bilden." 
Assim, parece-nos que o geógrafo alemão se preocupou essencialmente com os atores sociais, embora tenha querido enfatizar, nesse caso, a necessidade de se levar em conta não apenas o espaço físico, mas o social também. Acreditamos, entretanto, que para o presente estudo, essa concepção de ação não seja suficiente, sobretudo se considerarmos que para compreender a ação dos diferentes atores é necessário que se abarque conjuntamente a atuação social e os objetos geográficos. Uma cidade, enquanto protagonista, não pode ser compreendida apenas pela ação social de seus habitantes ou de seus grupos sociais, pois há, ainda, uma gama de objetos técnicos a serem examinados.

Quando se discorre acerca do poder como forma de controle sobre a natureza, deve-se ressaltar que ele ocorre não apenas pela posse da "matéria natural". Ademais, é necessário que se tenha a posse da técnica para lograr transformar a matéria natural em recurso natural. Tendo esse aspecto em mente, Raffestin (1993) traçou uma tipologia de atores, considerando que há aqueles que detêm apenas matérias naturais, outros que detêm apenas a técnica e, por fim, alguns que detêm ambos ou nenhum. Dessa forma, o poder expressa-se pela combinação entre matéria natural e objetos técnicos, assim como também o poder sobre um grupo de indivíduos pode ser consentido por meio de recursos discursivos difundidos a partir de objetos informacionais. É nesse sentido que os objetos técnicos, juntamente com as ações sociais, formam híbridos para o poder. Por isso mesmo, a definição de violência a partir de sua instrumentalidade não convém aos propósitos de um enfoque geopolítico do conflito.

Em outra perspectiva, acreditamos que o enfoque deva se centrar no território, campo das relações de poder por excelência (SOUZA, 2009). Em sua proposta acerca de um enfoque funcional para a geografia política, Hartshorne (1950) mencionou a atuação de forças centrífugas e centrípetas nos territórios estatais, apontando que o território nacional seria um campo no qual forças a favor e contra a integração agiriam entre cada uma das regiões do Estado. Gottmann (1975, p. 31, tradução nossa) também procurou destacar essa qualidade do território ao defini-lo como:

[...] uma parte do espaço geográfico, isto é, o espaço concreto acessível às atividades humanas [...] O território é fruto da divisão e da organização. Do mesmo modo que cada unidade do espaço geográfico, ele deve ser, em 
teoria, limitado, embora sua forma possa ser modificada por expansão, retração ou subdivisão. ${ }^{113}$

Além do mais, Gottmann (1975) alertou que os territórios podem ser organizados a partir de duas ideias principais - segurança e movimento - expressas pelos conceitos de iconografia e circulação.

Fica claro a partir da teoria de Gottmann (1975) que o conceito de território implica uma forma de organização do espaço geográfico, porquanto para dar um determinado uso e finalidade a ele, torna-se necessário, antes de tudo, organizá-lo. Deve-se acrescentar que essa ordem territorial ocorre não apenas por dispositivos materiais como também por meio de uma ordem simbólica expressa pelo conceito de iconografia. Esse aspecto também é mencionado por Hartshorne (1940) a partir do conceito de Estado.

Quando procurou entrelaçar as teorias geográficas de Hartshorne (1940) e de Gottmann (1952), Jones (1954) criou uma original teoria do poder a partir da ideia de campo de força e sua relação com conflitos. Um campo de força origina certa ordem estruturada como resultado da atuação de diferentes forças. Essa concepção fica explícita quando o autor procura determinar as situações em que os campos de diferentes forças, ao entrar em contato, podem gerar conflito. Para Jones (1954), o fato de os campos estarem em contato não significa necessariamente que eles entrarão em conflito. Se a relação entre eles for meramente "cinética", resultando apenas em movimento, então, não haverá relações de conflito. Contudo, quando as situações são "dinâmicas", envolvendo restrição de movimentos pela atuação de uma força contra outra, então, normalmente, há uma tendência a engendrar conflitos (JONES, 1954). Esse postulado parece ir em direção a uma teoria do conflito geografizada, principalmente aquela desenvolvida por Coser (1956).

Desde então, a ideia de território como campo de força tem estado presente na maioria das definições. Obviamente, a concepção de território enquanto propriedade exclusiva, quer seja do Estado, quer de outros atores em outras escalas, termina por ser impossibilitada. E a ideia de território como "apropriação no seu sentido mais abrangente" (MORAES, 1984, p. 91) reconhece uma

\footnotetext{
113 "[...] a portion of geographic space, that is, concrete space accessible to human activities [...] Territory is the fruit of partitioning and of organization. Like every unit of geographic space, it must be in theory limited, although its shape can be modified by expansion, shrinkage or subdivision."
} 
multidimensionalidade de atores, vez que vários indivíduos podem se apropriar de um mesmo espaço, o que resulta em diferentes tipos de relações sociais. Em seu dicionário, Johnston, Gregory e Smith (1994, p. 620, maiúsculas dos autores, tradução nossa) chamaram a atenção para o fato de o território se referir, em uma acepção mais geográfica, "a um delimitado ESPAÇO SOCIAL ocupado e usado por diferentes grupos sociais como consequência de suas práticas de TERRITORIALIDADE ou do campo de poder exercido sobre o espaço por instituições dominantes". ${ }^{114}$ A partir da perspectiva de multidimensionalidade do poder desenvolvida por Foucault, todos os atores sociais acabam participando da política lato sensu. Assim sendo, a geógrafa Becker (1983, p. 7-8, sublinhado da autora) argumentou que:

No momento em que se retorna à análise das relações de poder, e se focaliza a prática espacial, o território volta a ser importante, não mais como espaço próprio do Estado-Nação, mas sim dos diferentes atores sociais, manifestações do poder de cada um sobre uma área precisa. $\underline{O}$ território é um produto "produzido" pela prática social, e também um produto "consumido", vivido e utilizado como meio, sustentando, portanto, a prática social.

Ora, se o território é produzido pelas práticas sociais e estas, por seu turno, implicam conflitos (em alguns momentos), ainda mais quando estes servem para intensificar diferenças entre os diversos grupos sociais, como afirmou Coser (1956), então, todo conflito cria uma dimensão territorial, ainda que a questão principal do conflito não seja uma disputa por território. O geógrafo norte-americano Cox (1991, p. 6, tradução nossa) enfatizou esse aspecto ao dissertar sobre o conceito de território:

Colocar a questão dos limites territoriais dessa maneira é também colocar a pergunta acerca do que está sendo delimitado: isto não é uma mera extensão territorial, mas certo conjunto de relações sociais que são, por uma razão ou outra, localizadas. Combinando isso com a definição anterior mais abrangente do político, o território emerge como uma arena para conflitos: conflito entre negócio e trabalho, por exemplo, entre diferentes faixas etárias, ou entre os gêneros. ${ }^{115}$

\footnotetext{
114 "[...] a bounded SOCIAL SPACE occupied and used by different social groups as a consequence of their practice of TERRITORIALITY or the field of power exercised over space by dominant institutions."

115 "To pose the issue of territorial bounds in this way is also to pose the question of what is being bounded: this is not mere territorial extent but some set of social relations which are, for some reason or another, localized. Combining this with the earlier-broader-definition of the political, territory emerges as an arena for conflict: conflict between business and labour, for example, between different age groups, or between the genders."
} 
O geógrafo brasileiro Souza (2005, p. 86, itálico e aspas do autor), procurando adotar uma concepção mais fluida e menos rígida de território (diferente daquela de propriedade), observou que:

Território será um campo de forças, uma teia ou rede de relações sociais que, a par de sua complexidade interna, define, ao mesmo tempo, um limite, uma alteridade: a diferença entre "nós" (o grupo, os membros da coletividade ou "comunidade", os insiders) e "os outros" (os de fora, os estranhos, os outsiders).

Novamente, aqui fica expressa aquela concepção apresentada pela teoria dos conflitos, a partir de uma relação de diferenciação entre grupos, definindo concomitantemente tanto uma alteridade como um limite. A partir do seu conceito de sistema territorial Raffestin (1993, p. 150) assegura que um "sistema de tessituras, de nós e redes organizadas" construídos pelos diferentes atores permite manter ou impor uma ou várias ordens. Naturalmente, essa ordem é construída a partir da interação entre as diferentes representações que os demais atores produzem sobre os seus próprios territórios, e à medida que procuram implementá-las a partir de "práticas espaciais", determinados aspectos desse fenômeno podem ser "visualizados". Como relatou Becker (1983), essa ordem territorial envolve definição de limites e, portanto, de formas territoriais e malhas territoriais que se constituem em expressões espaciais das relações de poder. Resta claro que uma boa parte dessas relações de poder não pode ser visualizada diretamente na paisagem. Por outro lado, essa ordem se traduz em uma flexibilidade espaço-temporal, de forma a gerir as tensões entre os atores nas diferentes dimensões sociais.

Essa possibilidade da instalação de uma ordem também foi contemplada por Agnew e Corbridge (1995) quando enfatizaram a importância de uma organização do espaço mundial pelos vários protagonistas, assim implementando uma ordem geopolítica. Essa ordem se baseia em alguns princípios, como definição de atores, regras de operação, princípios de interação entre os atores, aceitação de princípios comuns e, no caso da escala global, comércio, força e diplomacia. Além do mais, uma ordem territorial implica regras de produção territorial nas diferentes dimensões sociais, tanto materiais como imateriais, princípios de interação entre os atores e suas territorialidades e aceitação de normas comuns. Assim, a partir da relação sistêmica entre produção simbólica dos territórios pelos atores e materialização das malhas, redes e centros construídos em suas práticas sociais, uma ordem territorial 
acaba sendo produzida. Haesbaert (2006) referiu-se a esse aspecto ao definir o território "a partir da imbricação de múltiplas relações de poder, do poder mais material das relações econômico-políticas ao poder mais simbólico das relações de ordem mais estritamente cultural".

Em contraste, os territórios não podem ser mais concebidos como zonas contínuas, uma vez que, na implantação de redes de objetos técnicos, existem diferentes zonas que se interligam por meio delas. Haesbaert (2006) construiu a possibilidade de territórios descontínuos e sobrepostos, com base na velocidade da circulação, os chamados territórios-redes. Souza (2005, p. 94) também balizou essa posição argumentando que:

A complexidade dos teritórios-rede, articulando, interiormente a um território descontínuo, vários territórios contínuos recorda a necessidade de se superar uma outra limitação embutida na concepção clássica de território [...] Não apenas o que existe, quase sempre, é uma superposição de diversos territórios, com formas variadas e limites não-coincidentes, como, ainda por cima, podem existir contradições entre as diversas territorialidades, por conta de atritos e contradições existentes entre os respectivos poderes [...]

Assim, fica explícito que as malhas territoriais se sobrepõem, formando, inclusive, combinações entre territorialidades antagônicas. Por isso mesmo, as relações de poder devem ser mais fluidas e flexíveis, se desejado que a ordem territorial seja mantida, de forma a atenuar os atritos e as contradições do movimento cinético, nos termos de Jones (1954).

Por meio da atuação das territorialidades, podem-se remanejar alguns pressupostos para uma compreensão geográfica dos conflitos. À vista disso, o conceito de territorialidade precisa ser explicitado. Sack (1986, p. 19, tradução nossa) definiu territorialidade "como tentativa por um indivíduo ou grupo, de afetar, influenciar ou controlar pessoas, fenômenos e relações, delimitando e assegurando controle sobre uma área geográfica". Soja (1971 apud RAFFESTIN, 1993) apontou que a territorialidade é composta por três elementos: senso de identidade espacial, senso de exclusividade e compartimentação da interação humana. Já Johnston, Gregory e Smith (1994, p. 620, tradução nossa) definiram territorialidade como "a organização espacial de pessoas e grupos sociais por meio da demarcação de fronteiras". 116 Além disso, acrescentaram que "[...] mais tipicamente, porém, a

\footnotetext{
116 "The spatial organization of persons and social groups through the demarcation of boundaries."
} 
territorialidade humana é vista como a estratégia por meio da qual os indivíduos e grupos exercem controle sobre uma dada porção do espaço" (JOHNSTON; GREGORY; SMITH, 1994, p. 620, tradução nossa). ${ }^{117}$ Por fim, realçaram que "a territorialidade é colocada em prática por intermédio de: (1) aceitação popular das classificações do espaço (por exemplo, 'nosso' versus 'seu'); (2) comunicação de um SENTIDO DE LUGAR (onde marcas e FRONTEIRAS têm significado); e (3) reforço do controle sobre o espaço (por meio de VIGILÂNCIA, POLICIAMENTO e legitimação)" (JOHNSTON; GREGORY; SMITH, 1994, p. 620, itálico e maiúsculas dos autores, tradução nossa). ${ }^{118}$

Raffestin (1993, p. 160) parece ter adotado um enfoque menos radical ao delimitar a territorialidade "como um conjunto de relações que se originam num sistema tridimensional sociedade-espaço-tempo em vias de atingir a maior autonomia possível com os recursos do sistema". Por outro lado, o autor suíço enfatizou que as territorialidades "são dinâmicas, uma vez que os elementos que a constituem são susceptíveis de variações no tempo" (RAFFESTIN, 1993, p. 161). Aqui deve ser ressaltado que, graças à variação espaço-temporal, essas relações se tornam mais flexíveis. Raffestin (1993, p. 162) ainda nos lembra que "a territorialidade se expressa em todas as escalas sociais e espaciais". Becker (1983, p. 8) concordou com a opinião de Raffestin (1993), porquanto para a geógrafa brasileira, "a territorialidade é, pois, um fenômeno associado à organização do espaço em territórios diversos, considerados exclusivos por seus ocupantes, é uma relação com o espaço, considerando os demais atores". Evidentemente, essa organização do espaço em territórios não significa que todos os territórios sejam exclusivos, muito embora os discursos dos atores procurem retratá-lo assim, daí a importância do discurso como forma de se alcançar certa ordem territorial, vez que a territorialidade expressa "relações de poder, da oposição do local ao universal, dos conflitos entre a malha concreta e a malha abstrata concebida e imposta pelos poderes hegemônicos" (BECKER, 1988, p. 108).

\footnotetext{
117 "[...] More typically, however human territoriality is seen as the strategy whereby individuals and groups exercise control over a given portion of space."

${ }_{118}$ Territoriality is put into practice through: (1) popular acceptance of classifications of space (e.g. 'ours' versus 'yours'); (2) communication of a SENSE OF PLACE (where markers and BOUNDARY have meaning); and (3) enforcing control over space (be means of SURVEILLANCE, POLICYNG and legitimation)."
} 
Não obstante, quando a ordem territorial não pode ser mantida sem maiores tensões entre as territorialidades dos diversos protagonistas, o que ocorre é uma coalizão entre diversos atores em polos antagônicos, pois os conflitos tendem a aumentar a alteridade e a diferenciação entre os indivíduos e, principalmente, entre os grupos, como visto anteriormente na definição de Coser (1956). No início do século passado, ao discutir sobre a guerra, Ratzel (1974, p. 26, tradução nossa) já apontava que "os conflitos entre diferentes relações com o solo são uma das forças do impulso da vida dos povos". ${ }^{119}$ Embora o geógrafo alemão se referisse a solo (Boden), território em seu sentido material, argumentava na direção de que o processo de imposição de sucessivas ordens territoriais fizesse parte da própria evolução humana.

Acrescentando as indicações de Jones (1954) de uma teoria do campo para a geografia política, podemos afirmar que a ordem territorial precisa ser reproduzida de maneira flexível, isto é, com a menor aplicação de força possível e com a maior aplicação de recursos comunicativos como meio de se produzir o consenso. Nos termos da teoria de Raffestin (1993), isso seria explicável pela menor aplicação de energia possível e maior aplicação de informação. Daí a importância dos discursos do poder como forma de atingir o nível de consenso necessário.

Dessa forma, propomos alguns pressupostos retirados a partir da teoria do conflito estabelecida por Coser (1956) e por Rex (1981), assim como do resgate de alguns conceitos geopolíticos clássicos e da teoria do conflito político, enquadrandoos para uma concepção geográfica do conflito. A intenção não é criar um arcabouço teórico geral, mas sim alguns postulados geográficos para a compreensão do conflito considerado neste estudo:

\section{1) Os conflitos funcionam como válvulas de escape para sentimentos de} hostilidade entre atores. A hostilidade pode ser expressa tanto nos atores que foram à fonte de frustração como em outros que não se relacionam com a frustração. Sem a existência de conflitos, a relação entre esses indivíduos não poderia ser mantida. Coser (1956) ainda diferenciou os conflitos em realísticos e não-realisticos. Os do primeiro tipo são aqueles nos quais os protagonistas buscam fins irreconciliáveis, enquanto os do segundo tipo são aqueles nos quais um dos

\footnotetext{
119 "Die Konflikte verschiedener Schätzungen des Bodens sind eine der Triebkräfte des Völkerslebens."
} 
atores envolvidos considera o conflito um meio de liberar tensões implícitas na relação com o seu antagonista ou em outra relação. Porém, todo conflito é uma fusão desses dois tipos mencionados. A esse respeito, Rex (1981, p. 23, tradução nossa) afirmou que "poucos seres humanos em contextos institucionais são capazes de eliminar os 'sentimentos pessoais' inteiramente". ${ }^{120}$

2) "O comportamento sempre acontece em um campo social e aquele conflito enquanto fenômeno social pode ser compreendido apenas ao acontecer dentro de padrões de interações" (COSER, 1956, p. 56, tradução nossa). ${ }^{121}$ Porém, para que esse campo social se expresse como tal, necessita da organização de um espaço, assim conformando "territórios"; portanto, as interações sociais provocam interações entre diferentes territorialidades. Em contraste, não se faz suficiente a explicação dos conflitos por meio da frustração dos indivíduos engendrando atos de agressão. O aspecto cultural também é importante, como bem preconizou Fromm (2004) ao comentar sobre sociedades que apresentam baixos níveis de violência. $O$ autor apontou que as interações culturais entre os protagonistas criam contextos específicos para a sublimação dos sentimentos de hostilidade. Quanto mais organizado o complexo de atores (isto é, sem maiores contradições sociais), e quanto mais suas territorialidades são sobrepostas, maior se torna a possibilidade de que recorram à agressão, porquanto uma grande densidade de relações sociais mantidas entre os atores representa relações mais próximas entre eles e, daí, a possibilidade da presença da ambivalência. Coser (1956, p. 68, tradução nossa) já advertia que "uma maior intensidade de conflitos pode ser esperada nessas relações em que os participantes foram induzidos a suprimir os sentimentos de hostilidade". ${ }^{122}$ Assim, o "medo de conflitos intensos pode levar à supressão dos sentimentos de hostilidade; e, em troca, o acúmulo de tais sentimentos tem probabilidade de intensificar ainda mais o conflito assim que ele é desencadeado" (COSER, 1956, p. 68, tradução nossa). ${ }^{123}$

\footnotetext{
120 "[...] few human beings in institutional contexts are able to eliminate 'personal feelings' entirely."

121 "Behavior always takes place in a social field and that conflict as social phenomenon can be understood only as occurring within patterns of interactions."

122 "a greater intensity of conflict can be expected in those relationships in which the participants have been led to suppress hostile feelings."

123 "[...] the fear of intense conflict may lead to suppression of hostile feelings; and in turn, the accumulation of such feelings is likely to further intensify the conflict once it breaks out."
} 
3) Quanto maior for a sobreposição de territorialidades de atores com fins e relações contraditórias ${ }^{124}$ nas diferentes dimensões sociais, mais equilibrada e flexível se torna a ordem territorial, uma vez que as tensões acabam sendo liberadas a partir da discussão da ordem em apenas uma das dimensões sociais, já que não há uma polarização de atores, o que desemboca em conflitos menos intensos e com padrão realístico. Porém, quanto mais polarizado o conjunto de territorialidades, formando zonas homogêneas com territorialidades de atores buscando cada vez mais os mesmos interesses nas diferentes dimensões sociais, mais intensos podem ser os conflitos entre essas diferentes zonas. Isso porque quanto mais próximas as relações entre as territorialidades, maior a possibilidade de conflitos não-realísticos. A partir da ocorrência da ambivalência interna, ou seja, quando uma das partes busca tanto apoio quanto desejo de agredir a outra (REX, 1981), para o conjunto de indivíduos em uma zona homogênea de territorialidades não-contraditórias pode ser mais fácil atenuar as tensões internas em atores situados em outras zonas. Para Coser (1956, p. 79, tradução nossa):

[...] as múltiplas afiliações de indivíduos a grupos tornam possível uma multiplicidade de conflitos que trespassam a sociedade. Tal participação segmental, então, pode resultar em um tipo de mecanismo de equilíbrio, impedindo clivagens profundas ao longo de um eixo. A interdependência de grupos em conflito e a multiplicidade de conflitos não-acumulativos fornecem um, embora obviamente não o único, controle contra uma falência consensual básica em uma sociedade aberta. ${ }^{125}$

Rex (1981, p. 10, tradução nossa) afirmou que conflitos permeados pela ambivalência tendem a se tornar mais intensos, porquanto "este comportamento 'compulsivo' pode ser generalizado a partir de uma interação particular para todas as interações na relação com as outras". ${ }^{126}$

4) Nas áreas em que os atores com territorialidades conflitantes não chegam a um consenso facilmente, uma ameaça externa pode aumentar a coesão zonal dessas territorialidades. Empregando os termos de Coser (1956, p. 94, tradução nossa), "enquanto a ameaça externa é percebida como uma

\footnotetext{
${ }^{124}$ Por relações contraditórias queremos manifestar, sustentados por Rex (1981), um choque de objetivos que são perseguidos em diferentes instituições.

125 "[...] multiple group affiliations of individuals make for a multiplicity of conflicts criss-crossing society. Such segmental participation, then can result in a kind of balancing mechanism, preventing deep cleavages along one axis. The interdependence of conflicting groups and the multiplicity of noncumulative conflicts provide one, though not, of course, the only check against basic consensual breakdown in an open society."

126 "Such 'compulsive' behavior may be generalized from the particular interaction to all interactions in the relationship to others."
} 
preocupação para o grupo inteiro (ou a sociedade), os conflitos internos não dificultam ações em concerto contra o inimigo externo". ${ }^{127}$ Para tanto, deve haver um mínimo consenso entre os atores, ou seja, deve haver uma ordem territorial mínima que valha a pena ser mantida por eles. Adicionalmente, deve haver um reconhecimento de todos os envolvidos de que realmente há uma ameaça para o grupo como um todo. Porém, se as territorialidades não mantêm entre si um consenso básico, a ameaça não leva à maior coesão social, mas pode significar uma apatia ou desintegração social (COSER, 1956).

5) Quanto menos concentrados espacialmente forem os territórios contínuos de coalizões de atores em rede, mais flexível se torna o arranjo territorial. Isso pode ser explicado a partir do resgate do conceito geopolítico de checkerboard, vez que quanto mais os territórios descontínuos dos atores em rede estiverem difundidos espacialmente, formando um tabuleiro de xadrez, mais facilmente o equilíbrio de poder será mantido (KELLY, 1986).

6) O conflito dá início a um novo tipo de interação entre os atores e, portanto, implica rearranjo de suas territorialidades ou grupos delas, já que a ordem territorial foi desafiada e uma nova reconstrução dela emerge após o conflito. De acordo com Coser (1956), os conflitos podem iniciar um outro tipo de interação entre as partes que eram anteriormente antagônicas, desde que agem como estímulo para estabelecer novas regras, normas e instituições, portanto servindo como agente de socialização para ambas as partes em conflito.

7) Os conflitos são formas de testar as relações de poder entre os atores, o que pode implicar rearranjo da ordem territorial. Coser (1956, p. 137, tradução nossa) asseverou que "os conflitos consistem em um teste de poder entre partes antagônicas. A acomodação entre eles é possível somente se cada uma delas tiver noção da força relativa de ambas as partes". ${ }^{128}$. Os conflitos são rearranjos do poder que se materializam no território por meio da reestruturação das tessituras, das redes e dos polos. Quando os atores não mais aceitam uma determinada ordem territorial, podem desafiá-la não apenas por meios da produção simbólica, mas também material.

\footnotetext{
127 "As long as the outside threat is perceived to concern the entire group (or society), internal conflicts do not hinder concerted action against the outside enemy."

128 "Conflict consists in a test of power between antagonistic parties. Accomodation between them is possible only if each is aware of the relative strength of both parties".
} 


\title{
8) Quando atores hostis das escalas maiores interpelam coalizões de
} atores contrários em uma determinada região, tornam a intensidade do conflito regional ainda maior. Nesse caso, tensões de escalas maiores acabam se sobrepondo às tensões menores já existentes entre os atores regionais. Trata-se do resgate do conceito geopolítico de shatterbelt, isto é, de sobreposição (estratégica/local) de rivalidades de diferentes escalas. Como Kelly (1986, p. 176, tradução nossa) preceituou que:

\begin{abstract}
Um shatterbelt é uma região geográfica por cujo controle as Grandes Potências competem seriamente. As Grandes Potências competem porque percebem fortes interesses em agir assim e porque estão presentes oportunidades para estabelecer alianças de base com os Estados da região. [...] Um shatterbelt surge quando as bases de uma Grande Potência rival estão presentes em uma área. ${ }^{129}$
\end{abstract}

Trazendo esse conceito para escalas menores, ele passa a significar sobreposição de rivalidades de diferentes escalas. Em contraste, a rivalidade da escala maior se territorializa na região a partir do contexto regional e, dessa forma, o conflito acaba sendo resultante da interação entre as duas formas de rivalidades e o contexto regional. Levando-se em conta que as tensões relacionadas aos recursos naturais ocorrem especialmente na escala regional, outras tensões ocasionadas por outros fatores das escalas maiores acabam se juntando a ela, tornando a escalada do conflito ainda mais intensa. Além do mais, pode ocorrer o que Rex (1981) chamou de conflito interinstitucional, ou seja, conflitos existentes entre duas instituições podem se amalgamar. Ao discutir acerca da agressão coletiva, Smelser (1963 apud BARKAN; SNOWDEN, 2001, p. 21 tradução nossa) afirmou, por meio do seu conceito de precipitating factors (fatores precipitantes), que "esses são eventos que desencadeiam episódios específicos de ação coletiva". ${ }^{130}$ Dessa forma, muitas tensões locais podem desencadear conflitos não apenas locais, como também em outras escalas em um shatterbelt.

9) Conflitos na escala nacional localizados em regiões mais próximas da capital tendem a desencadear golpes de Estado, enquanto conflitos mais afastados da capital tendem a desencadear separatismo. Os estudos de Buhaug

\footnotetext{
129 "A shatterbelt is a geographic region over whose control Great Powers seriously compete. Great Powers compete because they perceive strong interests for doing so and because opportunities are present for establishing alliance footholds with states of the region. [...] A shatterbelt originates when rival Great Power footholds are present in an area."

130 "These are events that trigger particular episodes of collective action [...]"
} 
e Gates (2002) e Le Billon (2002) confirmam esse postulado. Buhaug e Gates (2002), por seu turno, reiteraram que a natureza da rebelião e a do grupo rebelde influenciam o local em que o conflito se localiza. Regiões de fronteira tendem a ser controladas com maior dificuldade pelos Estados, por conta da influência territorial de outros atores e, principalmente, pela atuação dos demais Estados fronteiriços, daí advindo a possibilidade de separatismos. Por seu turno, as regiões mais bem controladas pelo poder central são mais sujeitas a golpes de Estado.

10) A interação entre os atores durante o conflito baseia-se na disposição dos recursos disponíveis. A localização espacial relacional dos recursos no território e dos atores resulta em diferentes formas de rivalidade. Para compreender a estratégia dos atores, faz-se necessário entender os tipos de recursos com os quais eles podem contar, bem como seu sítio e sua localização. Diferentes tipos de objetos técnicos permitem variadas formas de ação e estratégia, daí a importância de se verificar a densidade de objetos técnicos à disposição dos protagonistas. Quando se procura estudar a relação dos recursos hídricos com conflitos, é imprescindível compreender os objetos técnicos, os recursos normativos e discursivos, assim como a matéria natural (água) que estão à disposição dos atores (RAFFESTIN, 1993).

11) Uma vez que os conflitos relacionados aos recursos naturais são localizados, o estudo deve enfocar a escala da região levando em conta as principais transformações na morfologia territorial. Ao refletir sobre os enfoques para estudo de conflitos pela geografia política, Reuber (1999) propôs que a percepção das diferenças regionais baseadas na cultura e na política fossem refletidas. A concepção de Gottmann (1975) do confronto entre iconografias e circulação expressa bem essa ideia. As transformações regionais promovidas pelo avanço do livre mercado e a implantação de diferentes tipos de redes têm acentuado o sentimento de alteridade. Em acordo com o que Agnew (2001) expressou, esse sentimento não é somente provocado por fatores étnicos, mas também por fatores econômicos salientados pela nova dinâmica territorial implementada após o surgimento do neoliberalismo. Hagmann (2005, p. 20, tradução nossa) indicou que "diferentes tipos e intensidades de conflitos violentos estão misturados e agregados com desprezo pelas especificidades regionais ou diferenças qualitativas em sua 
manifestação". ${ }^{131}$ A modificação do contexto econômico e político pode ocasionar uma série de conflitos, como bem apontam os cientistas políticos em seu conceito de agressão coletiva. "A violência coletiva, em contraste, tem o expresso objetivo de apoiar ou impedir mudanças nas arenas sociais, políticas e econômicas da sociedade" (BARKAN; SNOWDEN, 2001, p. 5, tradução nossa). ${ }^{132}$

12) As bacias hidrográficas nem sempre são suficientes para compreender completamente de que forma os recursos hídricos se relacionam a conflitos sociais. Vários autores da hidropolítica e da geopolítica da água têm afirmado que a bacia hidrográfica é a principal escala de análise para se compreender conflitos relacionados com os recursos hídricos (LASSERRE; DESCROIX, 2005; UITTO; WOLF, 2002). Embora em algumas oportunidades eles tenham razão, há situações em que os fluxos hídricos são completamente desviados, transformados e obstaculizados pelos objetos técnicos. Existem situações em que duas bacias são completamente integradas pelas redes técnicas, excluindo totalmente a "fronteira natural entre elas". Contudo, quando nos debruçamos sobre uma geopolítica lato sensu para estudar os recursos hídricos, notamos que existem outras escalas além das bacias hidrográficas que se tornam igualmente importantes. Em sua crítica à ecologia política praticada pelo Worldwatch Institute, Luke (2000) declarou que atualmente já não se pode falar de regiões ecológicas puras, porquanto a difusão de diferentes objetos técnicos acabou por constituir diferentes regiões híbridas tecnoecológicas. Destarte, considerar apenas a escala das bacias hidrográficas parece não ser razoável para a compreensão das diferentes questões envolvendo as relações de poder e conflitos.

13) A escala temporal parece impor determinadas dinâmicas ao estudo do conflito, vez que as próprias regiões são construtos sociais condicionados por práticas historicamente contingentes (PAASI, 2003). Dessa forma, contextos históricos violentos podem gerar ainda mais conflitos. Os estudos de Baechler (1999), Hauge e Ellingsen (1998) e Raleigh e Urdal (2007) ressaltaram que os contextos históricos marcados por conflitos podem desencadear um número ainda maior deles. Fuks (2001) apontou na mesma direção ao conceituar a carreira

\footnotetext{
131 "Different types and intensities of violent conflict are intermingled and aggregated with disregard for regional specificities or qualitative differences in their manifestation."

132 "Collective violence by contrast has the express goal of aiding or impeding change in the social, political and economic arenas of society."
} 
de conflito, isto é, uma série de conflitos que vão sendo desencadeados uns após os outros. Homer-Dixon (1999) se referiu ao mesmo fenômeno ao propor a possibilidade de uma escalada de conflitos. Evidentemente, contextos históricos violentos podem desencadear ainda mais conflitos; porém, isso não é obrigatoriamente correlato, vez que os agentes podem decidir se querem ou não recorrer à violência. É claro que nesse tipo de contexto existem mais incentivos para se recorrer à violência do que a mecanismos concertados por meio da negociação e do consenso.

Acreditamos que estes postulados podem nos ajudar a explicar a dinâmica territorial do conflito, assim como os objetivos buscados pelos diferentes atores. Incontestavelmente, o contexto histórico é importante para compreendermos as práticas regionais. Ademais, nos propomos a aplicar a geopolítica para a compreensão da instabilidade, do contínuo e do descontínuo, bem como do diacrônico e do sincrônico, porquanto conflitos são fatores estruturados e estruturantes em diferentes escalas temporais, as quais se ordenam e reordenam de acordo com a organização de diferentes eventos. 


\section{PACHAMAMA OU CHINA SUPAY: A GUERRA DA ÁGUA COMO VITÓRIA E DERROTA QUE COEXISTEM}

$\mathrm{Na}$ cosmovisão andina, uma das entidades mitológicas mais conhecidas é materializada pela figura da Pachamama. Não se caracterizada tão-somente por representar a mãe-terra, mas antes por sua natureza complexa e multiforme. No âmbito urbano, a Pachamama tem sido representada simplistamente apenas como a personificação do ventre materno que dá à luz e oferece cuidados especiais às suas crias. Entrementes, a natureza de Pachamama é dual, e assim como ela pode apresentar esse lado suave e benévolo, também pode se fazer ver pelo polo do mal. Assim, ela igualmente tem a prerrogativa de se transformar na natureza cruel e violenta que não permite deslize aos homens, podendo se transmutar em "China Supay", ou seja, a mulher do demônio, o diabólico, traduzido para aymara por Supay.

Essa dupla configuração da personalidade de Pachamama exemplifica o reducionismo que muitas vezes impomos aos acontecimentos da vida. A Guerra da Água em Cochabamba é vista por muitos como a vitória da sociedade civil sobre a multinacional Aguas del Tunari, esquecendo-se da natureza dual desse conflito. Como pensar apenas em vitória quando passado quase um decênio do conflito toda a zona sul daquela cidade continua sem aprovisionamento de água e esgoto? $\mathrm{E} 0$ que dizer do Projeto Múltiplo Misicuni, que ainda não provê a tão sonhada e prometida água aos habitantes da zona sul da cidade? Na verdade, o que ocorreu ali se traduz em coexistência de vitória e derrota, de afirmação e negação, dualmente construindo o presente.

\subsection{Da segurança cultural e natural ao território do risco}

Desde os tempos imemoriais do império incaico, o Vale Central de Cochabamba era ocupado por uma colcha de retalhos constituída por diferentes tribos conquistadas pelos guerreiros incaicos. A região sempre foi valorizada por suas melhores condições fisiográficas para os cultivos agrícolas, principalmente para 
o abastecimento dos principais agrupamentos humanos no altiplano, tanto no período pré-colonial quanto posteriormente. Tanto o antropólogo romeno-norteamericano Murra (1956) como o geógrafo alemão Troll (1968) já haviam chamado a atenção para a "integração vertical" econômica incaica como forma de complementação entre os diferentes nichos ecológicos, sobretudo no que concerne ao cultivo agrícola. A própria nominação quchapampa, em quéchua, quer dizer pântano, enfatizando a aptidão das terras da região como mais propícias à agricultura.

Por outro lado, o Vale Central de Cochabamba tinha e ainda mantém a vocação estratégica, pois, por um lado, situa-se em uma área de transição entre o planalto boliviano (Ilanos) e a meseta andina (altiplano) e, por outro, está encravado entre os agrupamentos humanos mais consolidados e a Amazônia boliviana. Dessa forma, essa área sempre teve como uma de suas principais funções o papel de integração, como região de fronteira, mesmo anteriormente, entre os povos incaicos e os nativos chiriguanos. Em um período mais recente, demarca-se como região fronteiriça entre as porções oriental e ocidental bolivianas e como um dos principais polos da frente pioneira em El Chapare, em direção à Amazônia boliviana.

Com a colonização espanhola e a implantação das funções agro-pastoris, o Vale Central de Cochabamba tornou-se o principal núcleo fornecedor de produtos agrícolas para os grandes centros mineradores (Potosí e Sucre) e sua elite no altiplano, Ihe rendendo a alcunha de el granero del Alto Peru (o celeiro do Alto Peru). Desde então, essa região vem figurando como rica e fértil no imaginário dos vallunos $^{133}$. Não obstante, em decorrência da má organização da produção local e da falta de ordenamento territorial e ambiental adequado, desde o século XIX, o Vale Central de Cochabamba vem se transmutando de região fértil em área marcado pelo risco e a degradação ambiental.

Nos últimos 200 anos, a região vem passando por penúrias acentuadas, assinaladas por longos períodos de estiagem, salinização dos solos e intensificação de processos erosivos, a ponto de prejudicar a produção agrícola regional e a subsistência da população. A título de exemplo, Jackson (1994, p. 16, tradução nossa) relatou que:

${ }^{133}$ Oriundos do Vale Central de Cochabamba. 
Uma amostragem dos nascimentos e mortes nos anos 1800-1809 mostra que em anos sem crises a população de Tarata teve moderado crescimento e pode ser caracterizada como tendo uma população com alta fertilidade e alta mortalidade. No entanto, em 1804 e 1805, no pico de uma crise de subsistência, a paróquia sofreu uma perda populacional líquida de 445 , em decorrência de aumento de mortalidade e queda no número de nascimentos em $1805 .^{134}$

Atualmente, a situação tem se agravado, mormente no que se refere ao aprovisionamento de água. Conforme o Ministério do Desenvolvimento Sustentável e Meio Ambiente (MDSMA, 1996 apud SAAVEDRA, 2005, p. 49, tradução nossa) se referiu ao Vale Central de Cochabamba, "esta ecorregião se caracteriza por erosões geológicas naturais e fenômeno de sedimentação de alta intensidade, assim como processos antrópicos acelerados de degradação do solo e desertificação". ${ }^{135}$.

Essa transformação do Vale Central de Cochabamba tem se de dado sobretudo pelo processo de modernização radical da região que visou promovê-la a principal polo de integração nacional. Devido à sua posição estratégica, no centro do país, as políticas territoriais têm privilegiado Cochabamba desde os anos $50 \mathrm{com}$ vários investimentos e fixação de objetos. Essas alterações radicais, e muitas vezes descontroladas, têm cristalizado uma série de tensões e conflitos na região.

Dessa forma, o Vale Central de Cochabamba se caracteriza como uma região de fronteira interna. Geiger (1994, p. 54) argumentou que as regiões de fronteira se apresentam "como regiões avançadas de um país, cuja dinâmica econômica e social pode ser relacionada seja a progressos tecnológicos, seja a novas formas de organização social, ou, a ligações com outras formações socioeconômicas." Laserna et al. (2000a, p. 73) apontou que Cochabamba possui uma função estratégica como região de integração dos principais centros do país e, por conta disso, tem se constituído como uma área de contrastes. Em primeiro lugar, por ter forte tradição e identidade agrícola e indígena (em sua maioria quéchua), mas, por outro lado, também ser atualmente o principal centro de integração nacional. Em segundo lugar, desde o período colonial o Vale Central tem sido o terceiro maior centro populacional

134 "A sample of births and deaths for the years 1800-1809 shows that in non-crisis year, the population of Tarata experienced moderate growth, and can be characterized as having been a high fertility and a high mortality population. However, in 1804 and 1805, at the height of the subsistence crisis, the parish suffered a net loss in population of 445 , due to increased mortality and a drop in the number of births in 1805."

135 "This ecoregion is characterized by natural geological erosion and sedimentation phenomena of high intensity, as well as man-induced accelerated land degradation processes and desertification." 
do país, porém, apenas recentemente, tem se destacado por seu produto interno. Por fim, a região natural tem recebido uma série de redes de objetos técnicos, que têm transformado sua antiga paisagem bucólica em uma natureza "maquínica", também modificada pelos grandes fluxos de diferentes naturezas. Destarte, o Vale Central de Cochabamba se caracteriza pelo embate entre forças centrípetas e centrífugas, ou pela presença de uma forte identidade regional que vem sendo contraposta pelas forças dos movimentos de diferentes escalas que se apropriam das vantagens da região, significando para alguns atores da região uma série de riscos e desvantagens.

Visando melhor situar a questão, faz-se necessário adentrar a seara da localização geográfica e a descrição dos aspectos físicos, de forma a propiciar a compreensão da territorialização dos riscos. Para tanto, nos baseamos em estudos já efetuados, valendo destacar, mais uma vez, que não é nosso propósito realizar uma descrição exaustiva e altamente centrada nos processos físicos, uma vez que no Vale Central de Cochabamba há uma natureza híbrida, mesclando objetos técnicos a objetos naturais.

Para entender os aspectos fisiográficos do Vale Central de Cochabamba torna-se imperioso, ainda, localizar a região natural, de modo a compreender a penúria social, situando-a em um contexto maior: o do Departamento de Cochabamba. A província de Cochabamba se encontra na parte central do país, entre as latitudes $16^{\circ} 30^{\prime}$ e $18^{\circ} 00^{\prime} \mathrm{S}$ e longitudes $64^{\circ} 30^{\prime}$ e $67^{\circ} 30^{\prime} \mathrm{W}$, assim reproduzindo uma síntese dos aspectos físicos bolivianos, uma vez que se caracteriza por uma variedade de climas, relevos e vegetação (Mapa 1).

Embora se situe em latitudes com características tropicais, o clima é bastante diverso, indo do tropical ao polar, sendo este último encontrado no pico das altas cadeias montanhosas. Consequentemente, as temperaturas também dependem, em grande parte, do relevo encontrado no Departamento de Cochabamba. Ademais, a pluviosidade tende a ser maior na região norte, diminuindo em direção ao sul do departamento (SALAZAR; MONTENEGRO, 1997ano apud SAAVEDRA, 2005, p. 51). As chuvas se concentram no período de dezembro a março. Em contraste, no Gráfico 2 pode-se observar que o volume pluviométrico varia fortemente entre a região do trópico cochabambino e as demais regiões que compõem o Departamento de Cochabamba. Segundo a classificação de Köppen, podem-se encontrar três 
regimes climáticos no Departamento de Cochabamba: árido, temperado úmido e tropical chuvoso (SAAVEDRA, 2005, p. 51).

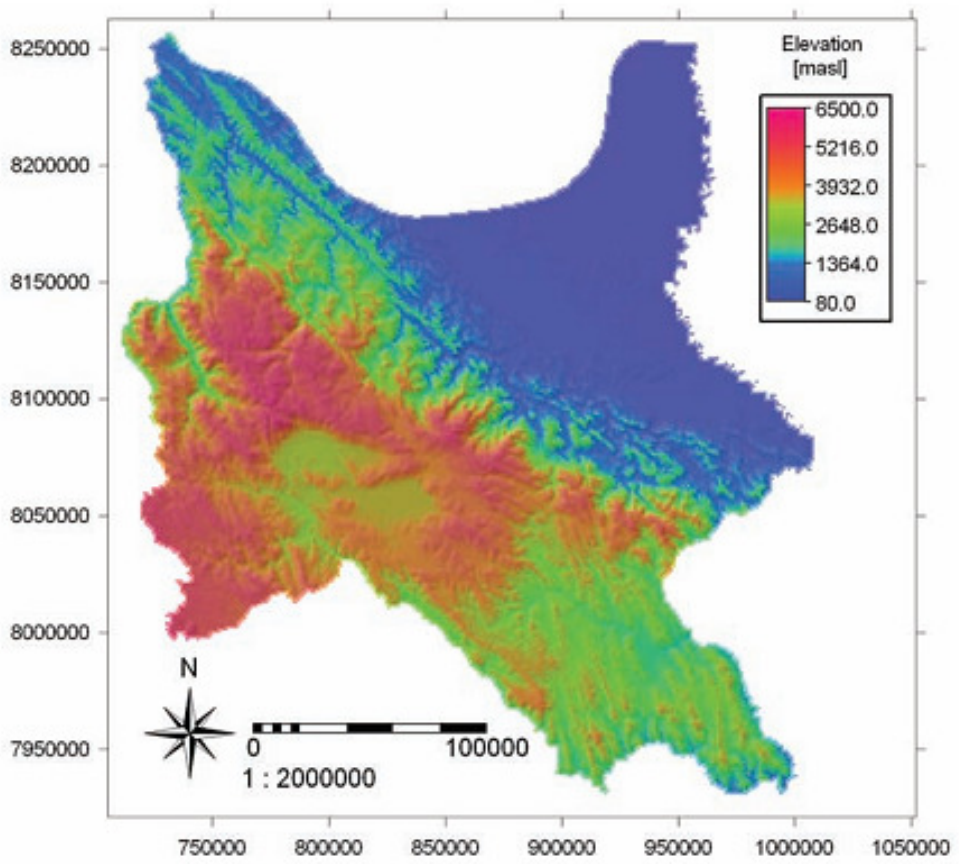

Mapa 1. Relevo do Departamento de Cochabamba.

Fonte: Saavedra (2005, p. 52).

A temperatura e o volume pluviométrico variam consideravelmente na Cordilheira dos Andes. Os vales cochabambinos apresentam temperatura amena, variando entre $17^{\circ} \mathrm{C}$ e $25^{\circ} \mathrm{C}$, assim como baixo a moderado volume pluviométrico (média de $400 \mathrm{~mm}$ a $760 \mathrm{~mm}$ ao ano). Acima da altitude de $3.500 \mathrm{~m}$ pode nevar, havendo deposição permanente de neve acima de $4.600 \mathrm{~m}$. As áreas acima dessa atitude apresentam clima polar (Mapa 2).

As planícies do norte e leste apresentam clima tropical com alta temperatura e umidade. Outra característica importante é a presença de chuvas durante todo o ano (JETTÉ; ROJAS, 1998). Em algumas localidades, pode-se deparar com temperaturas médias diárias acima de $30^{\circ} \mathrm{C}$, enquanto nas altas montanhas da região a temperatura anual média é de $8^{\circ} \mathrm{C}$ e a média pluviométrica anual varia de $600 \mathrm{~mm}$ a $1.000 \mathrm{~mm}$. Já nos vales, a temperatura média anual fica em torno de $17^{\circ} \mathrm{C}$ e a média pluviométrica varia de $400 \mathrm{~mm}$ a $650 \mathrm{~mm}$. Por fim, nos trópicos, as temperaturas médias são de $25^{\circ} \mathrm{C}$ e o volume pluviométrico varia de $1.000 \mathrm{~mm}$ a $3.000 \mathrm{~mm}$ (MDSMA, 1996 apud SAAVEDRA, 2005). 


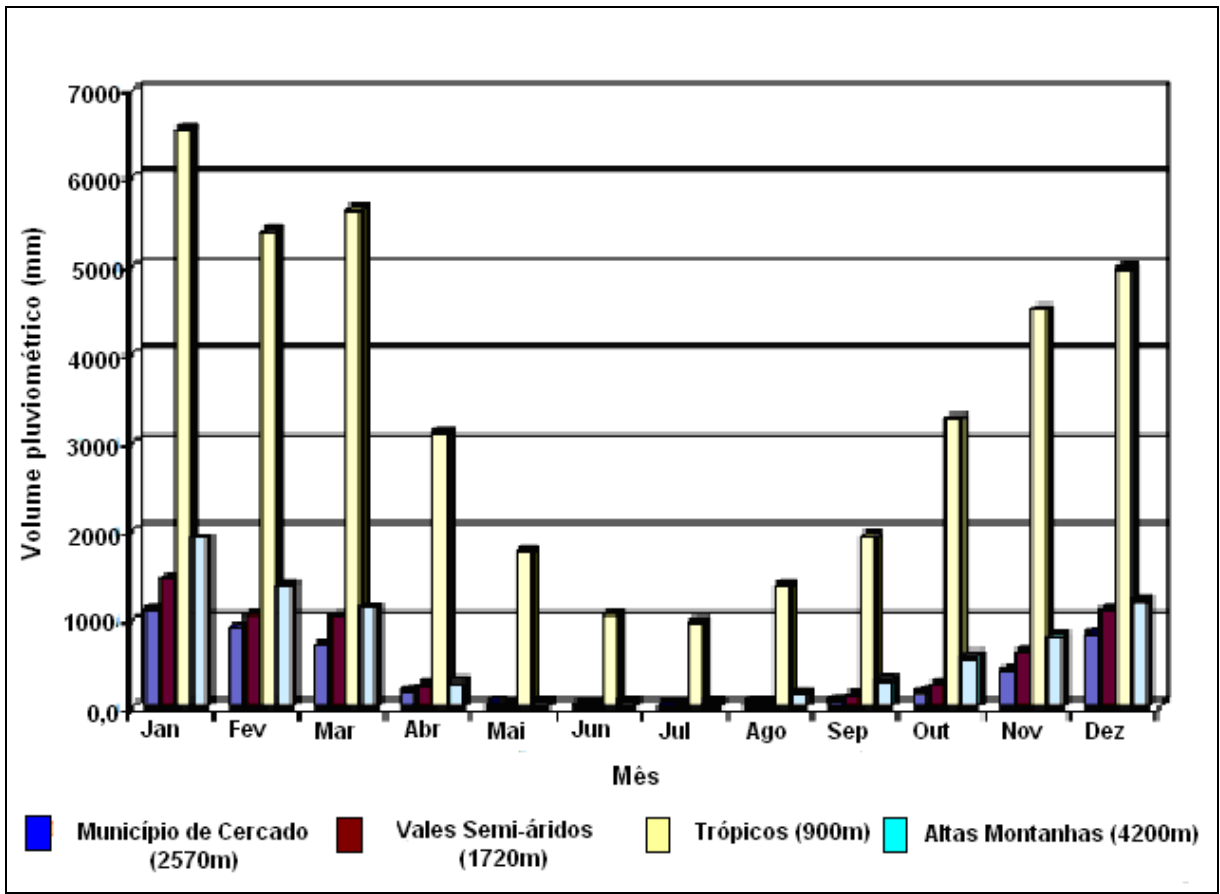

Gráfico 2. Distribuição pluviométrica mensal nas quatro regiões fisiográficas do Departamento de Cochabamba de 1961 a 2003.

Fonte: Saavedra (2005, p. 52).

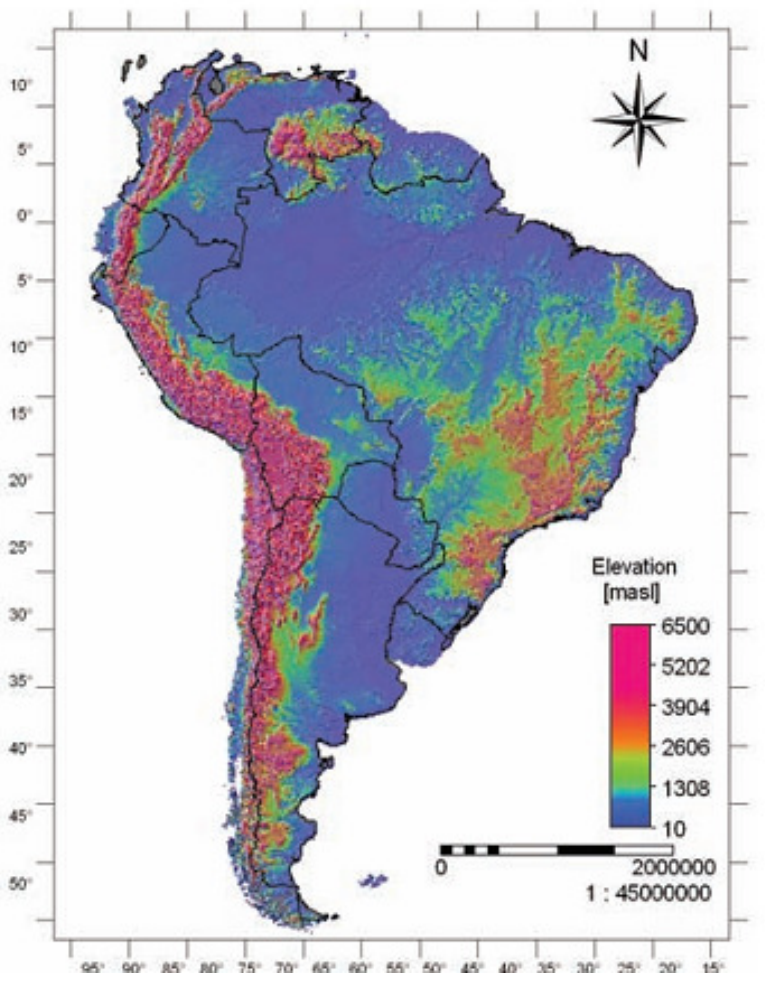

Mapa 2. Bolívia no contexto fisiográfico sul-americano.

Fonte: Saavedra (2005, p. 50). 
O Departamento de Cochabamba é dominado por rochas sedimentárias e ígneas, variando de arenito e quartzito a xistos e siltitos. As rochas nas encostas da Cordilheira incluem quartzitos, conglomerados, arenitos, siltitos e xistos da idade Cambriana (GEOBOL, 1992; 1998). Durante o quaternário, grande volume de sedimentos foi acumulado nos vales de Cochabamba, especialmente Vale Alto, Vale de Sacaba, Vale Baixo e Vale Central. O fundo dos vales é composto com uma sequência espessa de depósitos quaternários, a começar pelos depósitos lacustres do Pleistoceno consistindo de argila, e areia e areias sílicas nas áreas mais baixas, que se desenvolvem em sedimentos fluviais e fluvio-lacustres até o topo. Assim, a região da planície (llanos) é geologicamente jovem. O processo de sedimentação amazônica continua ativo, enquanto os rios carregam sedimentos por meio de suas águas, percorrendo seus cursos para a parte mais baixa da Cordilheira, mudando continuamente seus canais, depositando e redepositando seus sedimentos ao longo deste caminho. Os sedimentos dessa região são, em sua maior parte, de origem aluvial do Pleistoceno atrasado e quaternário (SAAVEDRA, 2005).

No que concerne à vegetação, as regiões das altas montanhas andinas e o altiplano apresentam extensas áreas de pastagens. A puna úmida é coberta de pastagens e matagais. Acima de $4.000 \mathrm{~m}$, a vegetação em áreas úmidas (ou bofedales), inclui plantas submersas. Nos vales andinos secundários, há uma predominância "das florestas semi-áridas. Os matagais semi-áridos são compostos de espécies frequentemente espinhosas. As florestas decíduas subúmidas são distribuídas na seção oriental de Cochabamba em uma cota menor que $900 \mathrm{~m}$ de altitude. A floresta cobre os sedimentos não consolidados, que dão forma a montes baixos a leste dos piemontes das montanhas. A floresta amazônica sazonalmente úmida, situada na região do nordeste de Cochabamba, começa em áreas abaixo da cota de $1.100 \mathrm{~m}$. A floresta sazonalmente inundada ao longo dos rios principais na zona de floresta tropical é chamada de várzea. Esta área tem sido extremamente perturbada pela prática da agricultura com utilização de queimadas, principalmente por colonos e cocaleros, bem como pela indústria madeireira, que se implantaram no nordeste do Departamento de Cochabamba em busca de melhores oportunidades após a crise dos anos 80 (Mapa 3).

Ao centro do Departamento de Cochabamba, se encontra um conjunto de vales, do qual faz parte o Vale Central, que são geomorfologicamente caracterizados 
como bacias intramontanha, circundadas de relevos montanhosos, que alcançam a cota de $5.000 \mathrm{~m}$ acima do nível do mar. A bacia de Cochabamba se estende por uma área de aproximadamente $1.150 \mathrm{~km}^{2}$ e sua base se encontra na cota de 2.500 $\mathrm{m}$ de altitude (Mapa 2).

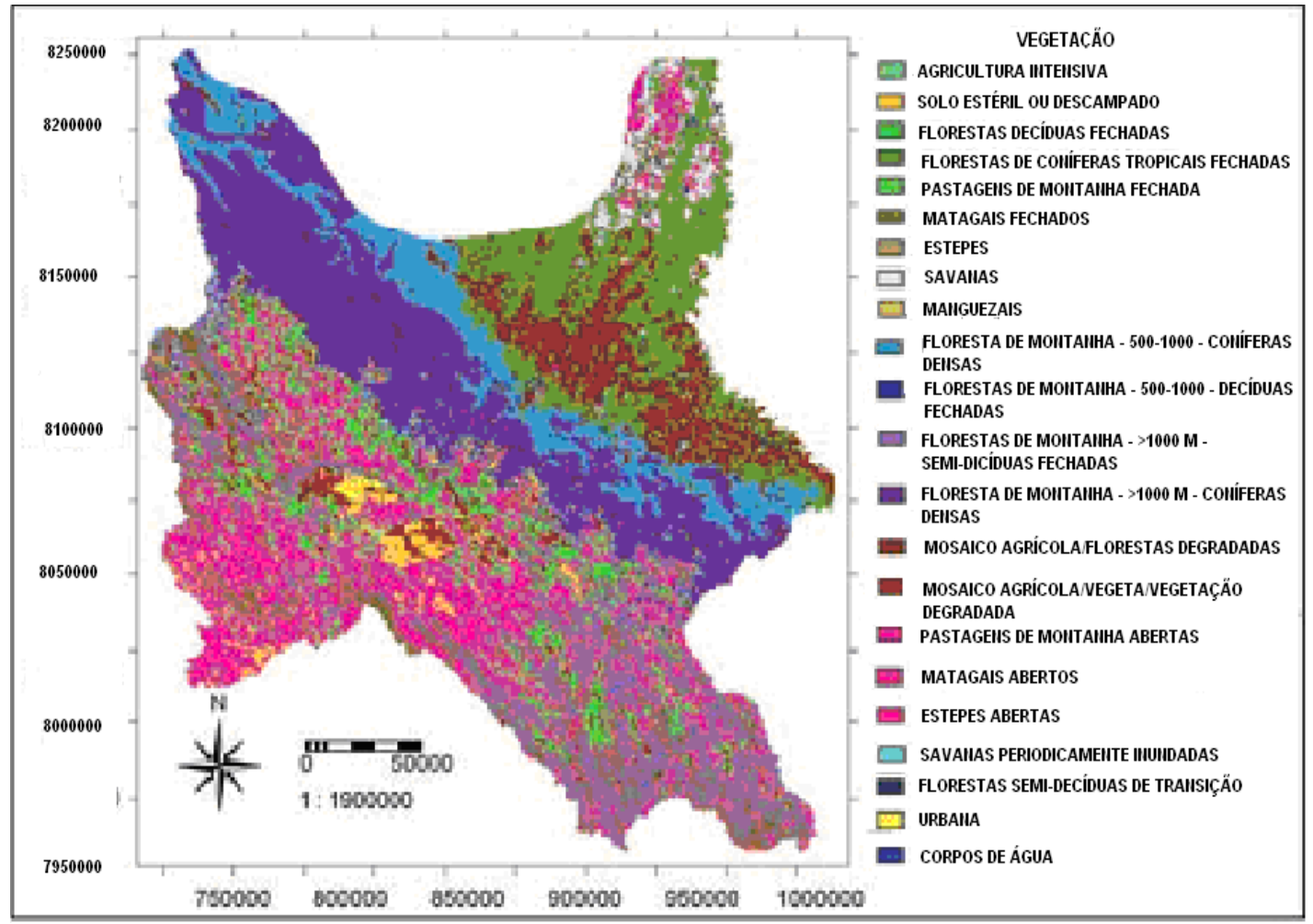

Mapa 3. Cobertura vegetal do Departamento de Cochabamba.

Fonte: Saavedra (2005, p. 55).

O clima do vale é temperado, com temperatura média anual de $17,5^{\circ} \mathrm{C} \mathrm{e}$ chuvas ocorrendo no período de outubro a abril, com média pluviométrica variando entre $400 \mathrm{~mm}$ e $500 \mathrm{~mm}$ ao ano (Gráfico 2).

A vegetação já foi, em grande parte, extirpada para a implantação do cultivo agrícola, uma vez que os solos eram originalmente férteis; porém, nos últimos anos, o vale vem apresentando graves problemas de degradação ambiental, incluindo salinização dos solos, períodos de seca prolongados, perda da cobertura vegetal e erosão hídrica e eólica (LASERNA, 1995).

O Vale Central, assim como todo o sistema de vales em Cochabamba, se integra diretamente com as demais regiões fisiográficas do Departamento de 
Cochabamba denominadas Cordilheira e Trópico, não havendo separação rígida entre elas. Aliás uma parte dos processos que vem afetando o Vale Central se expressa por processos antrópicos existentes em outra áreas. Dessa forma antes de separar, a Cordilheira é justamente o espaço que une o sistema de vales ao Trópico. Enquanto os sistemas de vales se caracterizam pelo clima árido, na vertente norte da Cordilheira ocorre justamente o contrário, pois os índices de pluviosidade e de evapotranspiração são os mais altos do país (LASERNA, 1995, p. 22). Essa região também é chamada de El Chapare ou Trópico de Cochabamba e abriga uma série de bacias hidrográficas que confluem em direção ao rio Mamoré, assim caracterizando nas terras mais baixas do Trópico uma rede de canais de comunicação fluvial.

A região do Trópico se caracteriza por sua fragilidade ecológica. Laserna (1995, p. 23) nos lembra que o impacto ambiental ocasionado por assentamentos populacionais tende a ser crescente e severo. A fronteira agrícola tem aberto novas frentes em El Chapare, decepando bosques para a implantação da atividade agrícola, que se revela danosa à região. "A taxa de desmatamento para a área de colonização (somente) dentro do trópico de Cochabamba se eleva a $3,6 \%$ de sua superfície a cada ano e é uma das mais altas do mundo" (LASERNA, 1995, p. 23, tradução nossa). ${ }^{136}$ Os efeitos dessa prática não se restringem ao Trópico, mas vêm afetando todo o clima do Departamento de Cochabamba e, de maneira mais direta, o regime de chuvas.

Os bosques da vertente norte da Cordilheira (Trópico) produzem umidade pelo processo de evapotraspiração, a qual se converte em massas de ar quente. Estas, por sua vez, conformam nuvens que podem ascender na atmosfera até encontrar ventos capazes de movimentá-las para pontos em que a pressão e a temperatura consigam promover a condensação de suas partículas de água, assim provocando chuvas (LASERNA, 1995).

Esse fenômeno ocorre com maior frequência nos meses de outubro a março, quando essas nuvens conseguem atingir altitudes a ponto de sobrepor os picos mais altos da Cordilheira, precipitam-se em forma de chuvas por sobre os maciços e até mesmo na região dos vales. Esse processo é particularmente responsável pela

\footnotetext{
136 "La tasa de deforestación para el área de colonización (solamente), dentro del trópico de Cochabamba asciende al 3,6\% de su superfície cada año, y es una de las más altas del mundo."
} 
manutenção do conjunto de lagoas existente nos maciços. Além do mais, graças a esse fenômeno as águas das chuvas penetram nos solos das principais cumeadas andinas em Cochabamba, que reabastecem vários aquíferos no Vale Central de Cochabamba (Esquema 8) (LASERNA, 1995; NEUMANN; RENNER; TORREZ, 2000).

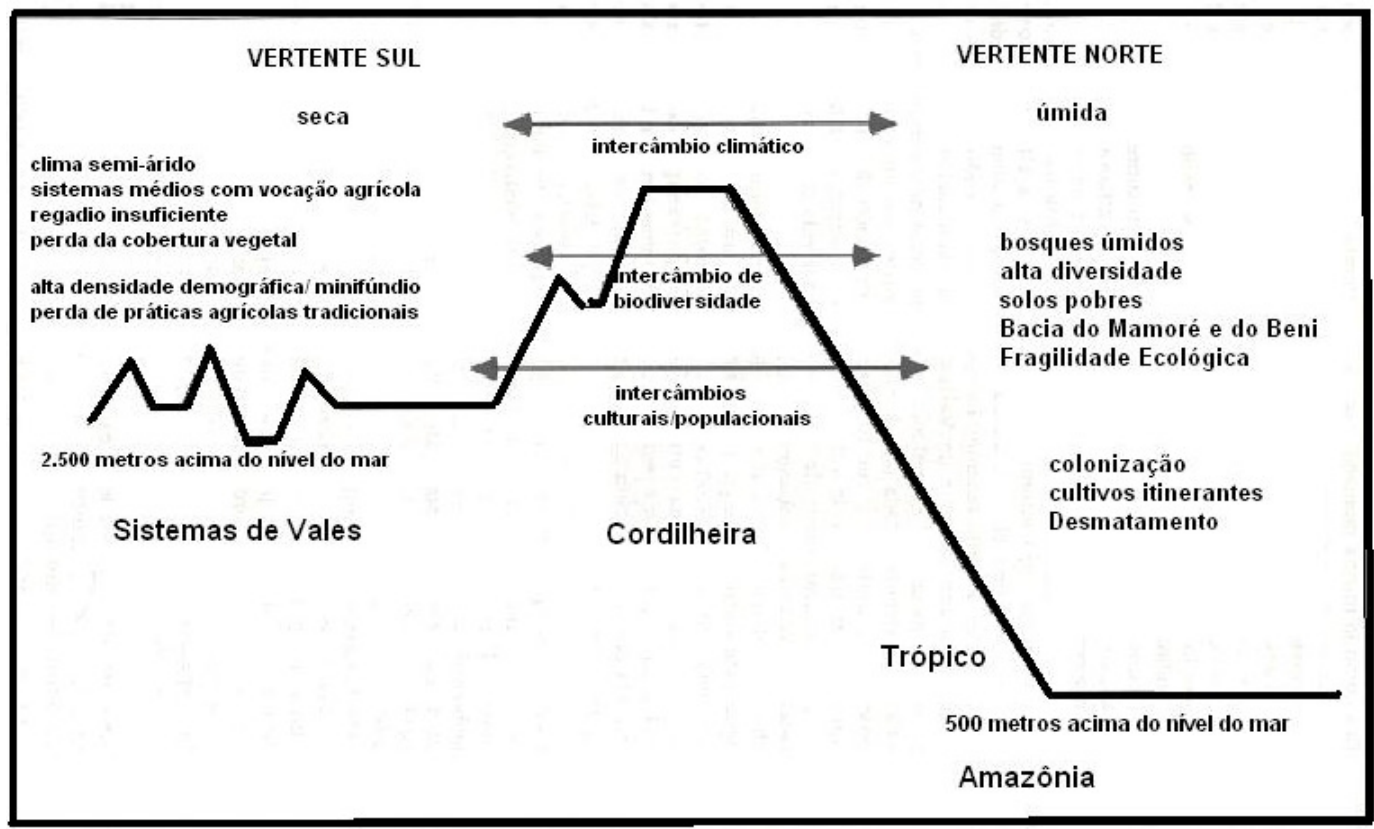

Esquema 8. Perfil básico do relevo do Departamento de Cochabamba.

Fonte: Laserna (1995, p. 21).

Como destaca Laserna (1995), outro aspecto climático importante ocorre quando os ventos alísios, provenientes do Oceano Atlântico, trazem umidade e se tornam ainda mais carregados de vapor de água oriundo do processo de evapotranspiração. Boa parte desses ventos se choca contra a Cordilheira, auxiliando na manutenção das condições climáticas e de umidade ali existentes. Alguns deles conseguem sobrepor os maciços da Cordilheira, adentrando o Vale Central por meio de passos, entre os quais, os mais conhecidos são o Passo de San Miguel e o Passo de Corani. Dentro dos sistemas de vales, esses ventos fazem com que o ar circule, recolhendo vapor de água gerado nesse espaço, elevando-o em forma de nuvens até que, sob certas condições de pressão e temperatura, as massas se convertam em chuva. Por fim, ao circular o vale, esses ventos ainda 
podem se chocar com as massas de ar quente provenientes do Trópico, novamente ajudando a proporcionar condições de precipitação (Esquema 9).

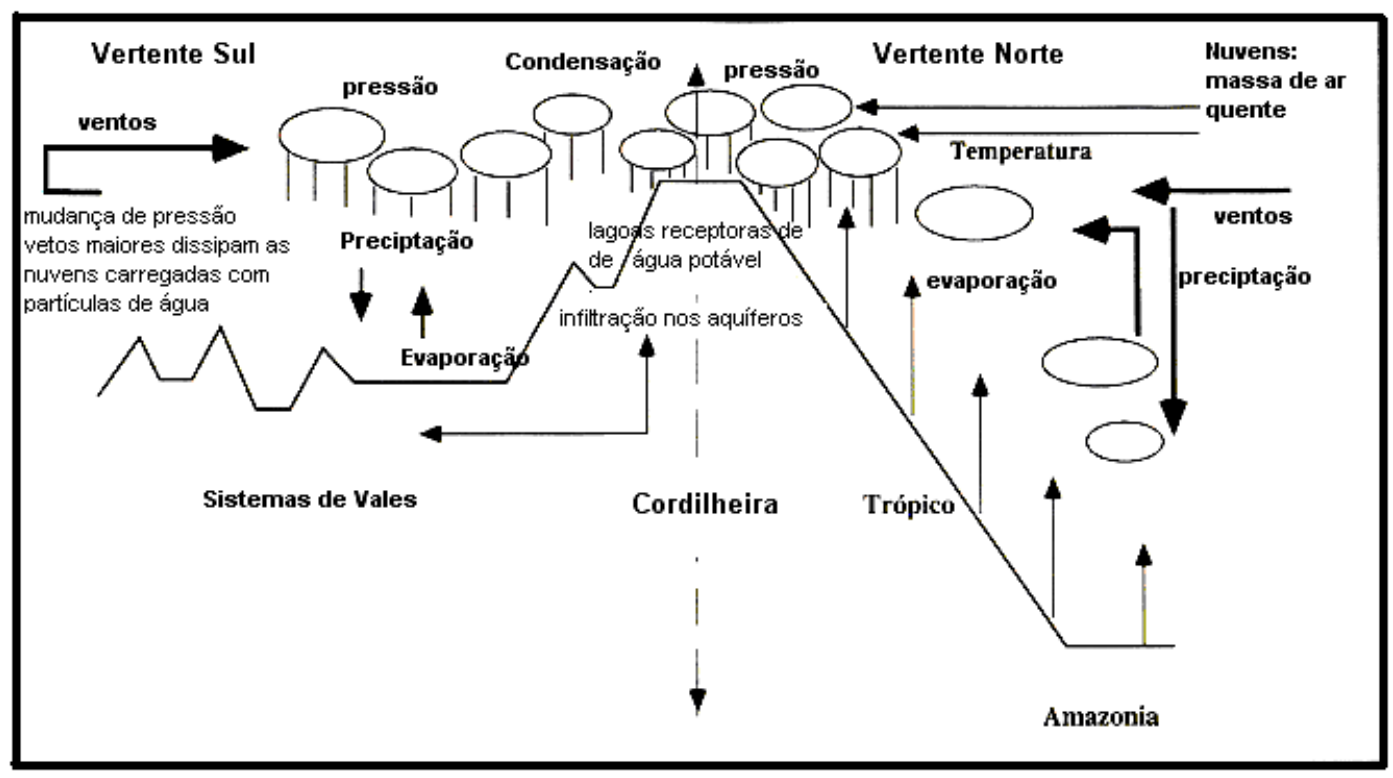

Esquema 9. Complementaridade climática no Departamento de Cochabamba.

Fonte: Laserna (1995, p. 25).

Naturalmente, com a degradação natural que vem sendo promovida em El Chapare a partir da implantação tanto da agricultura itinerante como da intensiva, o que se observa é a rápida deterioração das condições de equilíbrio desse sistema climático. Laserna (1995) afirmou que não há como assinalar quanto dessa degradação é responsável pelo aumento da aridez e o prolongamento do período de seca nos vales e também denunciou que 16.000 caminhões de madeira são retirados ao ano de El Chapare, a uma taxa de desmatamento de 3,6\% ao ano apenas nas áreas de colonização. lo autor também destacou o projeto de colonização da ladeira norte da Cordilheira (em Tablas Monte) por 600 famílias, o que já fornece indícios suficientes de que um processo está ligado ao outro.

É natural que a diminuição da cobertura vegetal para a agricultura faça com que o fenômeno de evapotranspiração ocorra com menor intensidade, oferecendo menor quantidade de vapor à atmosfera. Não obstante, em sua avaliação sobre os efeitos da perda da cobertura vegetal, Conti (2002, p. 25-26) explicou que: 
Como consequência, e isso interessa aos climatólogos, o volume de micropartículas de origem vegetal em suspensão na atmosfera, por exemplo os polens, é drasticamente reduzido e o processo de formação da chuva torna-se mais difícil. Isso porque as gotículas de água condensada necessitam dessas partículas (chamadas de "núcleos biogênicos") para iniciar a coalescência e a formação das nuvens [...] Por outro lado, a capacidade refletora da superfície, ou seja, o albedo, aumenta cerca de três vezes no solo nu, ocasionando perda de energia incidente e reduzindo a temperatura da superfície. Como resultado, enfraquecem-se as correntes convectivas ascendentes, desestimulando a formação da chuva. Essa redução das precipitações já foi demonstrada em várias partes do mundo [...] O ciclo hidrológico e a reciclagem do vapor d’água são, também, perturbados. Em nosso país, é conhecida a pesquisa realizada na Amazônia por Enéas Salati, segundo a qual, 50\% do vapor d'água presente da baixa atmosfera é proveniente da própria floresta, permitindo concluir que a eliminação da mata acarretaria a diminuição das chuvas à metade $[\ldots]$.

Dessa forma, as nuvens que ascendem até a vertente norte vão se tornando cada vez mais diminutas e menos intensas, engendrando menor volume de precipitações tanto em cima dos maciços como nos vales.

Outrossim, a diminuição da pluviosidade nos vales causa diminuição da umidade do ar, o que ocasiona ventos mais rápidos, uma vez que não encontram a menor resistência no ar. Com este processo, as pequenas quantidades de vapor de água ali existentes são dispersas, podendo esse fenômeno, que tem se manifestado de forma direta na taxa pluviométrica (Esquema 10), se estender inclusive em relação à concentração de nuvens em cima dos maciços (LASERNA, 1995). Quando apresentou dados acerca da distribuição espacial do volume pluviométrico para os períodos entre 1961 e 1990 e entre 1998 e 2003 (Mapa 4), Saavedra (2005) sinalizou nessa direção. Nota-se que o volume pluviométrico nos vales e no altiplano diminuiu consideravelmente, tendo havido avanço do clima semi-árido no sentido norte do Departamento de Cochabamba, embora este fenômeno possa ser apenas expressão de uma variação climática temporária.

No entanto, o processo de degradação natural não vem ocorrendo apenas em El Chapare, mas também no próprio Vale Central. O avanço das áreas urbanas sobre as encostas das montanhas, assim como a utilização das áreas da Cordilheira para atividades econômicas e agropastoris acima de $2.700 \mathrm{~m}$ de altitude são as maiores marcas da falta de ordenamento territorial. Essas ações têm, inclusive, implicado invasão de áreas de proteção, como do Parque del Tunari e da área de descarga dos aquíferos (CONDORETTY, 2003). 


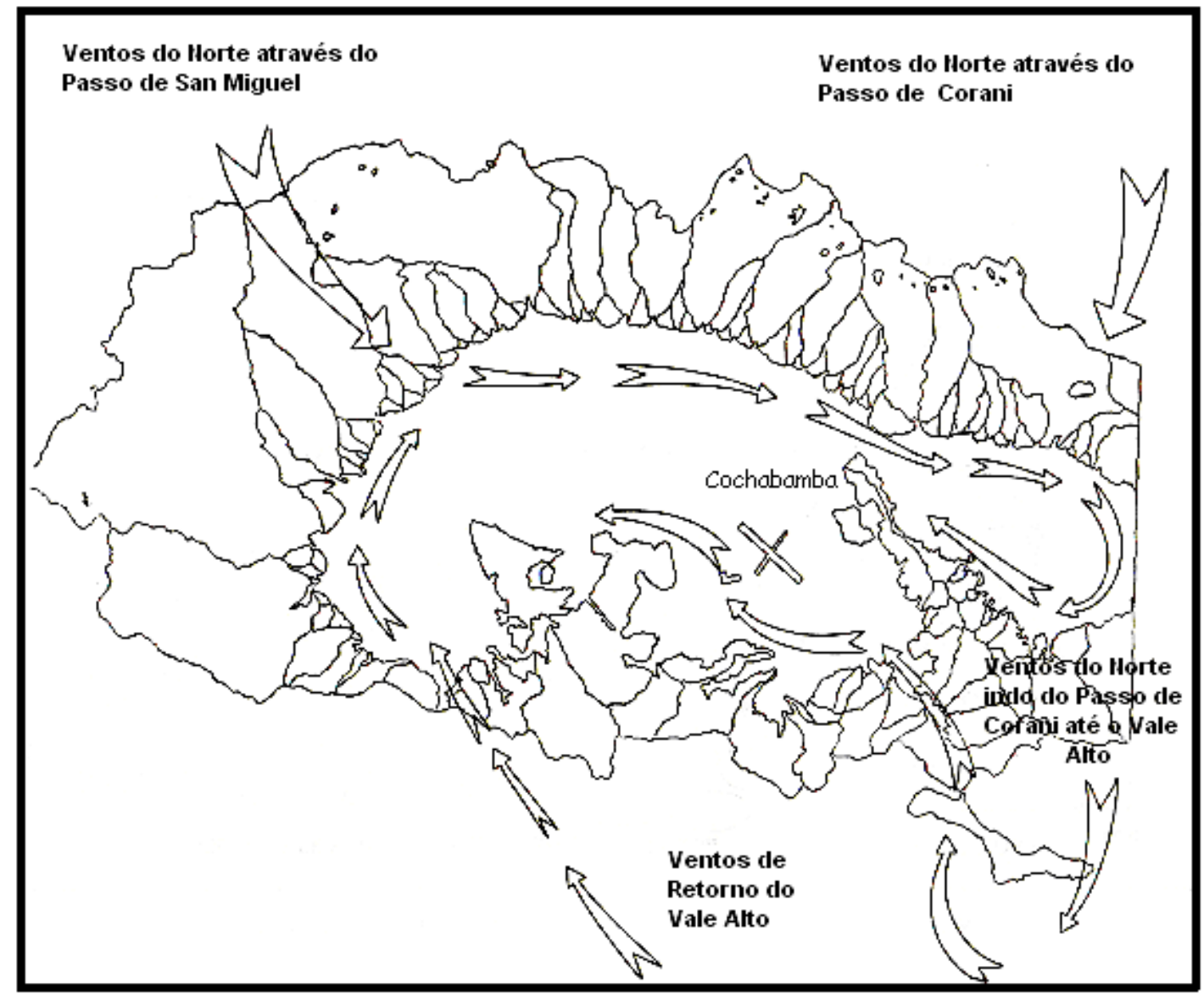

Esquema 10. Circulação aproximada dos ventos provenientes da vertente norte no Vale Central de Cochabamba.

Fonte: Laserna (1995, p. 26).
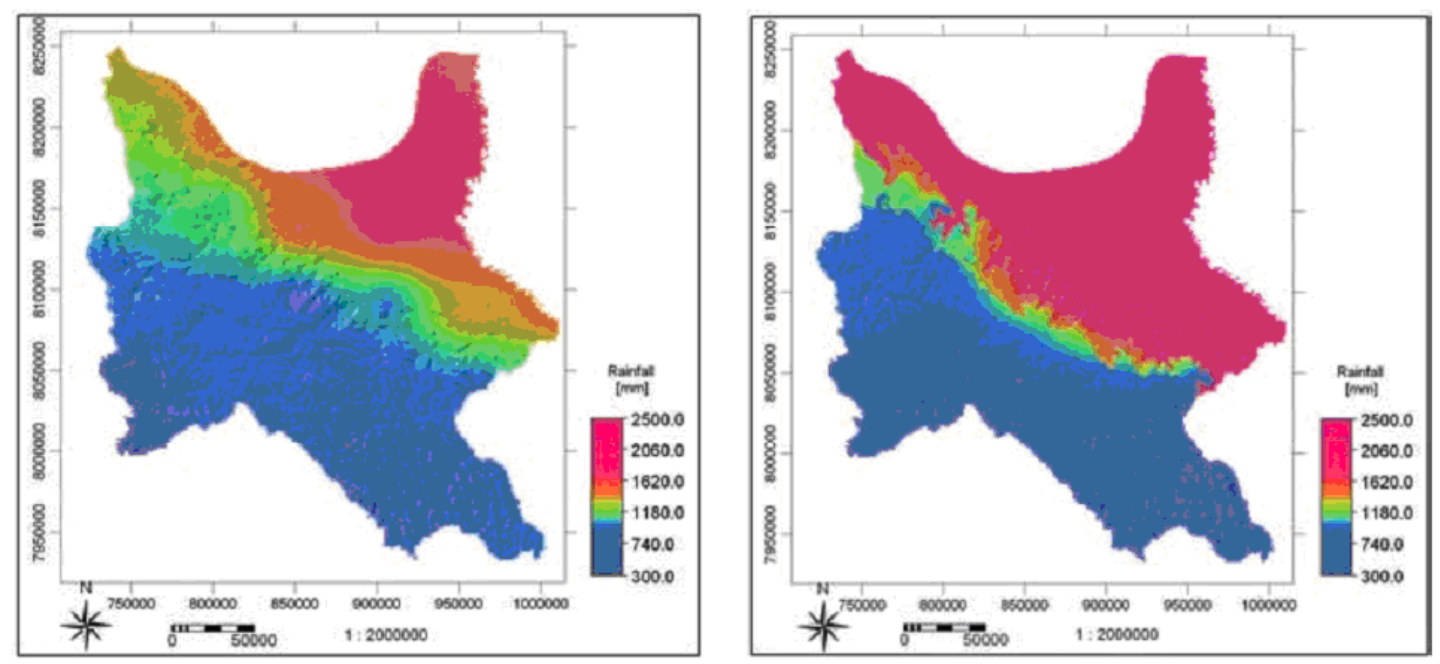

Mapa 4. Distribuição espacial da taxa pluviométrica para os períodos entre 1961 e 1990 (à esquerda) e entre 1998 e 2003 (à direita) no Departamento de Cochabamba.

Fonte: Saavedra (2005, p. 77). 
O Mapa 5 e a Fotografia 1 apresentam o uso do solo na bacia hidrográfica do rio Rocha, localizada no Vale Central de Cochabamba, apontando para o avanço das atividades econômicas sobre os mananciais. Nesse contexto, o aumento populacional e a falta de saneamento básico vêm contaminando os aquíferos presentes no Vale Central.

Além disso, o complexo hidrográfico da região apresenta-se frágil, vez que é composto de apenas um rio perene, o rio Rocha, surgido a partir do rio Maylanco, que nasce na Cordilheira do Vale de Sacaba, a partir da água de degelo, de lagoas oligotróficas glaciares e dos bofedales. Os demais rios dessa bacia são intermitentes (com exceção do rio Tamborada) e durante o período de chuva nascem ao norte, na Cordilheira do Tunari, e deságuam no rio Rocha, cujas águas têm sido constantemente usadas para a deposição de resíduos sólidos. Este rio, por seu turno, percorre todo o Vale Central de nordeste a sudoeste, indo, após o estreito de Parotani, desaguar no rio Caine, um dos principais da bacia do rio Grande (Mapa 6).

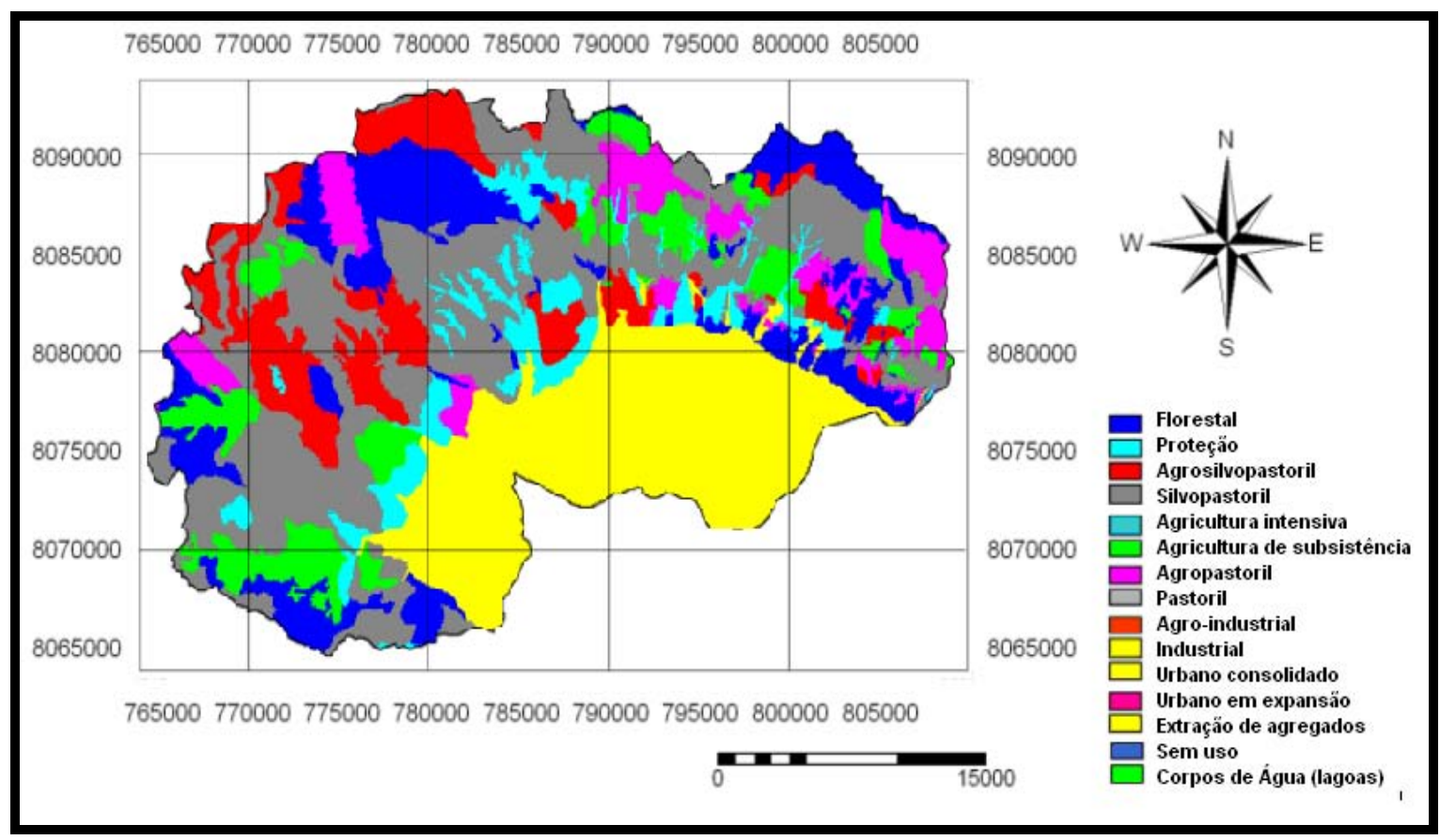

Mapa 5. Uso do solo na bacia hidrográfica do rio Rocha no Vale Central de Cochabamba.

Fonte: Sossa e Ontiveros (2006?, p. 4). 


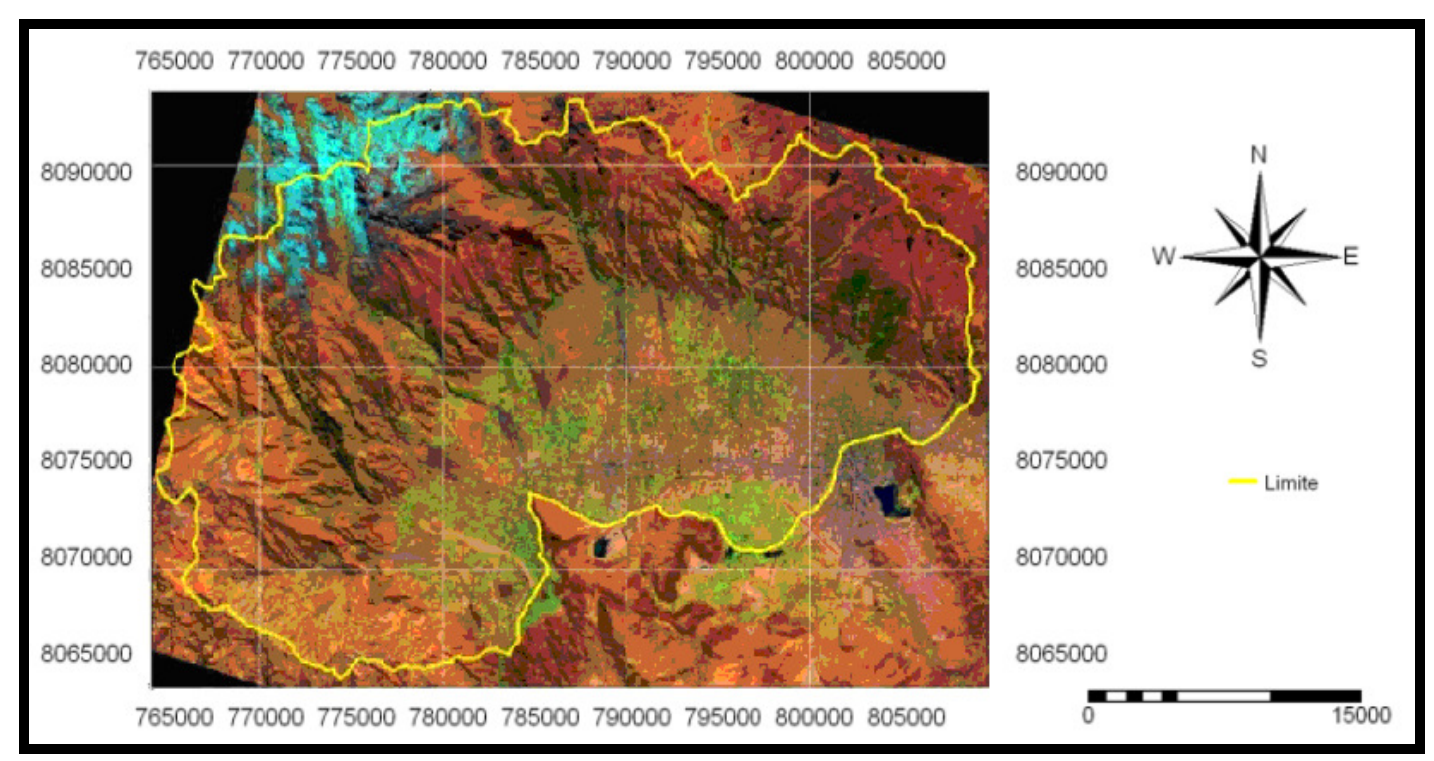

Fotografia 1. Imagem de satélite do Vale Central de Cochabamba com sobreposição da área da bacia hidrográfica do rio Rocha.

Fonte: Sossa e Ontiveros (2006?, p. 4).

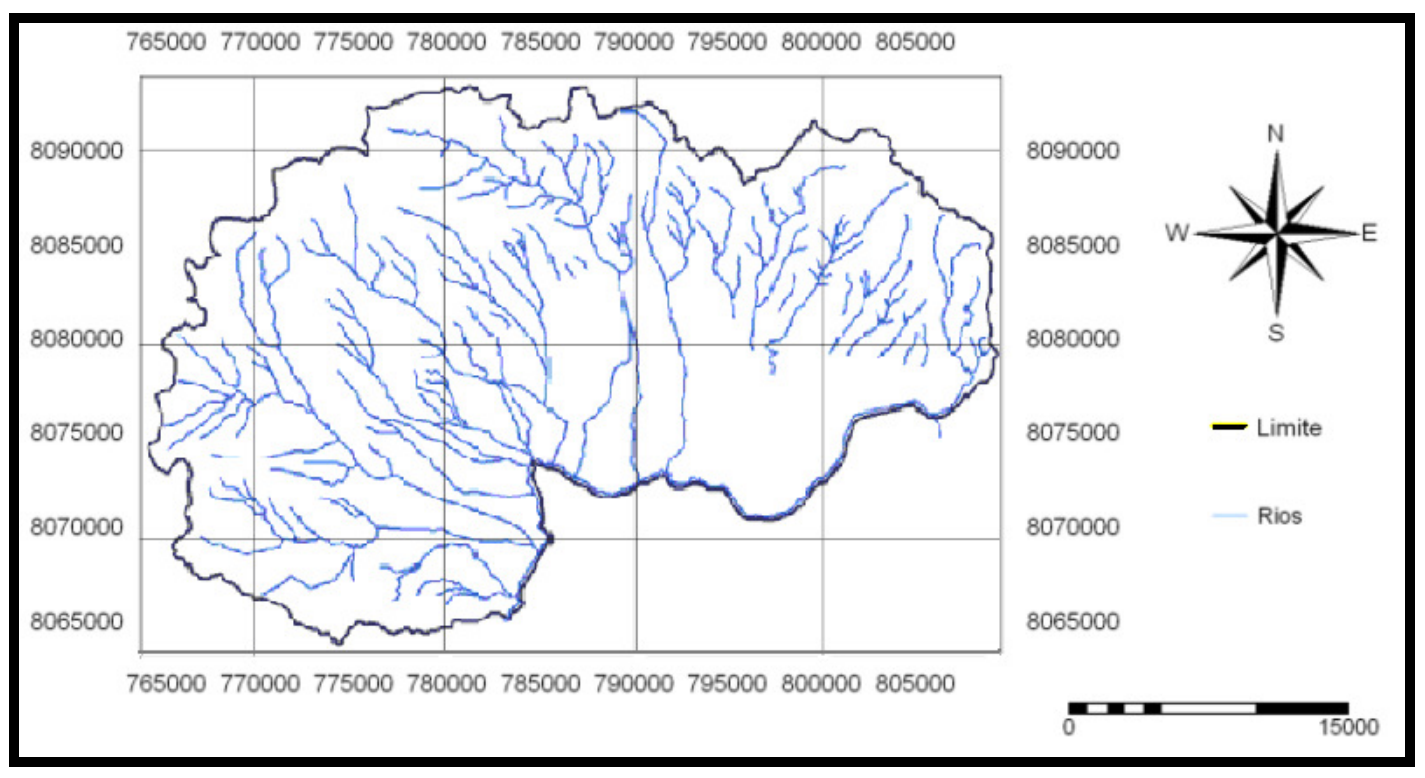

Mapa 6. Bacia hidrográfica do rio Rocha no Vale Central de Cochabamba.

Fonte: Sossa e Ontiveros (2006?, p. 5).

Como consequência dos fracos volumes de água superficiais, sobretudo dos arroios, as principais fontes de água para a área metropolitana de Cochabamba têm sido os aquíferos que se encontram no subsolo do vale. Neumann, Renner e Torrez (2000, p. 4, tradução nossa) relataram que: 
O fluxo geral das águas subterrâneas está orientado para o centro da bacia, perpendicularmente aos limites do vale. A recarga ocorre majoritariamente em uma franja situada na borda norte do vale por infiltração das águas superficiais que provêm da cordilheira. Especialmente nos cones aluviais, a permeabilidade é alta, o que permite que $20 \%-25 \%$ da precipitação pluvial de infiltre $[\ldots]^{137}$ (Esquema 11).

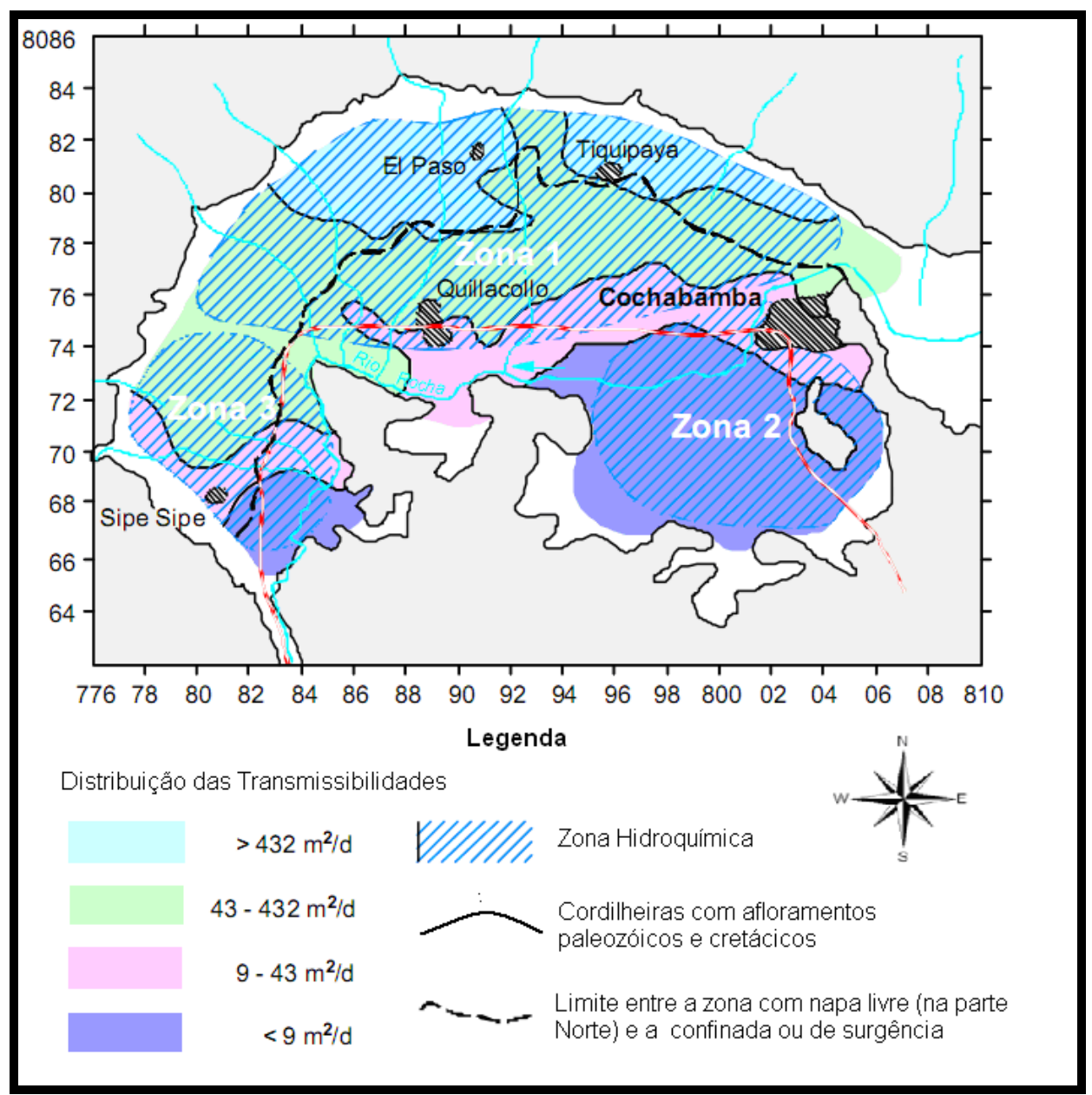

Esquema 11. Situação hidrogeológica do Vale Central de Cochabamba.

Fonte: Neumann, Renner e Torrez (2000, p. 3).

De acordo com o trabalho de Neumann, Renner e Torrez (2000), essas regiões, os lençóis de água subterrâneos são freáticos, mas mais ao sul, a superfície piezométrica muda para condições confinadas, em decorrência da presença de camadas superficiais argilosas com $10 \mathrm{~m}$ a $30 \mathrm{~m}$ de espessura. Ao longo do ano

137 "El flujo general de las aguas subterráneas está orientado hacia al centro de la cuenca, perpendicularmente a los límites del valle. La recarga sucede mayormente en una franja ubicada en el borde norte del valle por infiltración de las aguas superficiales que provienen de la cordillera. Especialmente en los abanicos aluviales, la permeabilidade es alta, lo que permite que el $20 \%-25 \%$ de la precipitación pluvial se infiltre [...]" 
hidrogeológico, os níveis hidrostáticos variam entre aproximadamente $20 \mathrm{~m}$ nas zonas de recarga a $1 \mathrm{~m}$ na zona sul ou na região de descarga e:

Apesar das grandes quantidades de água subterrâneas que são extraídas do vale, nos últimos anos o nível piezométrico da bacia em geral não tem baixado. Somente em alguns lugares com uma exploração intensa através dos poços, a produtividade se sobrepõe à recarga, o que se manifesta em uma diminuição local do nível estático (NEUMANN; RENNER; TORREZ, 2000 , p. 5 , tradução nossa). ${ }^{138}$

A produtividade de água subterrânea do terreno é de $30 \mathrm{~L} / \mathrm{s}$ para poços com $125 \mathrm{~m}$ de profundidade e o rendimento dos poços mais profundos, como o perfurado em El Paso I, com $550 \mathrm{~m}$ de profundidade, não sobrepõe o dos poços menos profundos, que exploram os aquíferos mais superficiais. Isso se deve ao fato de que as estruturas geológicas mais profundas do Vale Central de Cochabamba são compostas de camadas argilosas intercaladas com areia e cascalho. Outro aspecto importante é que, quanto mais ao sul da bacia do Vale Central, menor se torna a produtividade hídrica, uma vez que na parte mais setentrional do vale, os depósitos geológicos são compostos de materiais volumosos, como blocos e cascalhos de origem arenosa ou areno-argilosa. Porém, mais ao centro da bacia, os depósitos se constituem de grãos mais finos e com qualificação melhor, como areais intercaladas com horizontes argilosos. Por fim, na área mais a sudeste do vale, a camada sedimentária é composta de limos a cascalhos de origem arenosa e argilosa (NEUMANN; RENNER; TORREZ, 2000).

Tendo estudado a riqueza do aquífero do Vale Central de Cochabamba, Neumann, Renner e Torrez (2000) chegaram à conclusão de que as águas subterrâneas daquela região constituem a fonte mais importante para consumo humano e irrigação, além do que, até o momento, não sofreram deterioração em grande escala. Quantitativamente, o balanço hídrico do Vale Central parece apoiar a conclusão dos autores, porquanto uma pesquisa encomendada pelo governo boliviano revelou que o caudal de ingresso gira em torno de 66 milhões $\mathrm{m}^{3} / \mathrm{ano}$, sendo 41 milhões $\mathrm{m}^{3}$ /ano oriundos de água superficial, 17 milhões $\mathrm{m}^{3} /$ ano das precipitações e 8 milhões $\mathrm{m}^{3} / a n o$ de reabsorção da água de irrigação. Da mesma forma, o fluxo de saída de água subterrânea fica em torno de 66 milhões $\mathrm{m}^{3}$ /ano,

\footnotetext{
138 "A pesar de las grandes cantidades de agua subterránea que son extraídas del valle, en los últimos años el nivel piezométrico en la cuenca en general no ha bajado. Solamente en algunos lugares con una explotación intensa a través de los pozos, la productividad sobrepasa la recarga lo que se manifiesta en una depresión local del nivel estático."
} 
sendo 49 milhões $\mathrm{m}^{3}$ /ano por extração dos poços, 11 milhões $\mathrm{m}^{3}$ /ano por evapotranspiração dos pântanos e 6 milhões $\mathrm{m}^{3}$ /ano por saída de águas superficiais para os rios (MERCADO CONSULTANTS, 1996 apud NEUMANN; RENNER; TORREZ, 2000).

Portanto, caso se confirme a hipótese apresentada por Laserna (1995) de que o volume pluviométrico do Vale Central de Cochabamba está sendo afetado, provavelmente o balanço hídrico desses aquíferos será modificado, podendo haver desequilíbrio hídrico como o que já ocorre nas zonas mais exploradas. Evidentemente, os recursos hídricos subterrâneos podem ser afetados, assim como já o foi o rio Rocha, pela falta de saneamento básico na região metropolitana de Cochabamba, bem como em decorrência das atividades industriais e agrícolas que se desenvolvem na parte mais setentrional do vale, onde se localizam os lençóis freáticos e, portanto, há mais suscetibilidade à degradação. Cabe perguntar se o aumento populacional per se não constituiria outro fator a ser acrescentado, considerando-se as dinâmicas de ocupação e povoamento da região, principalmente após a revolução de 1952 na Bolívia.

\subsection{Vale Central de Cochabamba: o ditado de Tupac Katari se faz presente}

Um dos grandes líderes indígenas aymaras, Tupac Katari, antes de ser executado por liderar uma rebelião indígena contra as violências promovidas pela colonização espanhola, afirmou que morreria temporariamente, mas que voltaria em milhares de milhares. No Vale Central de Cochabamba, o ditado de Katari parece realmente ter se materializado, tendo em vista que os atos de violência promovidos tanto pela colonização espanhola como pelas elites bolivianas contra os povos originários, de maneira geral, e contra os aymaras, em especial, fez com que boa parte deles deixasse para trás a vida no altiplano e seguisse para Cochabamba ou Santa Cruz de la Sierra. Todavia, o caso de Cochabamba é emblemático, vez que desde o período colonial vem constantemente recebendo a migração do altiplano.

Para compreender a dinâmica de ocupação e povoamento do Vale Central de Cochabamba, faz-se importante que voltemos no horizonte temporal antes ainda da revolução de 1952, porquanto durante o período incaico a região já se encontrava 
ocupada por diferentes grupos étnicos. Ao longo do tempo, a constituição desses diferentes assentamentos humanos implicou a estruturação de uma identidade regional e, por conseqüência, a formatação de territorialidades de cunho étnico, que ainda se mantêm fortemente arraigadas na região.

A estratégia do controle de diferentes pisos ecológicos por parte dos povos incaicos nada mais foi do que uma forma de se adaptar às condições ecológicas andinas, principalmente após o fracasso da civilização Tiwanaku. Inicialmente, o Vale Central servia como espaço agrícola, colonizado pelas etnias Chuyes, Sipesipe e Cota para o cultivo de milho e o abastecimento dos assentamentos no altiplano. Em adição a isso, mais ao leste, a região também servia como ponto de defesa contra a etnia Chiriguana. Posteriormente, mais colonos temporários (mitimaq) e permanentes (mitimaes), assim como guerreiros aymaras foram deslocados para a região. Wachtel (1982 apud JACKSON, 1994) asseverou que 14.000 colonos e guerreiros se estabeleceram na região. Dessa forma, o Vale Central se constituiu em uma região evidentemente agrícola pela vocação de seu solo, bem como de fronteira entre o império Inca e os povos Chiriguanos.

Após a chegada dos colonizadores espanhóis, o espaço do Vale Central foi reestruturado a partir da implantação das reducciones, isto é, do restabelecimento espacial da dispersa população indígena em espaços específicos, dessa forma aumentando o espaço a ser ocupado pelas haciendas espanholas. As reducciones se situavam, em sua maior parte, nos atuais municípios de Sipesipe e Quillacollo. Ademais, implementou-se o sistema de encomiendas, título que garantia aos colonizadores espanhóis direito de jurisdição, recolhimento de tributos e mão-deobra (mita). Dessa forma, a organização do espaço do Valle de Cochabamba, durante o período colonial, traduziu-se no fornecimento de mita para as minas de prata, para o abastecimento agrícola das elites coloniais no altiplano, bem como para a região de contato entre os colonizadores e os povos indígenas. Consequentemente, a estrutura colonial permitiu o estabelecimento de uma oligarquia rural materializada pelas haciendas, construindo territórios segregados: reducciones para os povos nativos, haciendas e chácaras para os conquistadores. Essa forma de configuração territorial naquele período está representada no Esquema 12, podendo-se observar que enquanto a maior parte das comunidades de povos originários se encontrava na parte oeste do vale (Valle Bajo), grande parcela 
da oligarquia rural (elite crioula) e dos estratos médios (pequenos comerciantes, constituídos de mestizos) se localizava na parte mais central do vale.

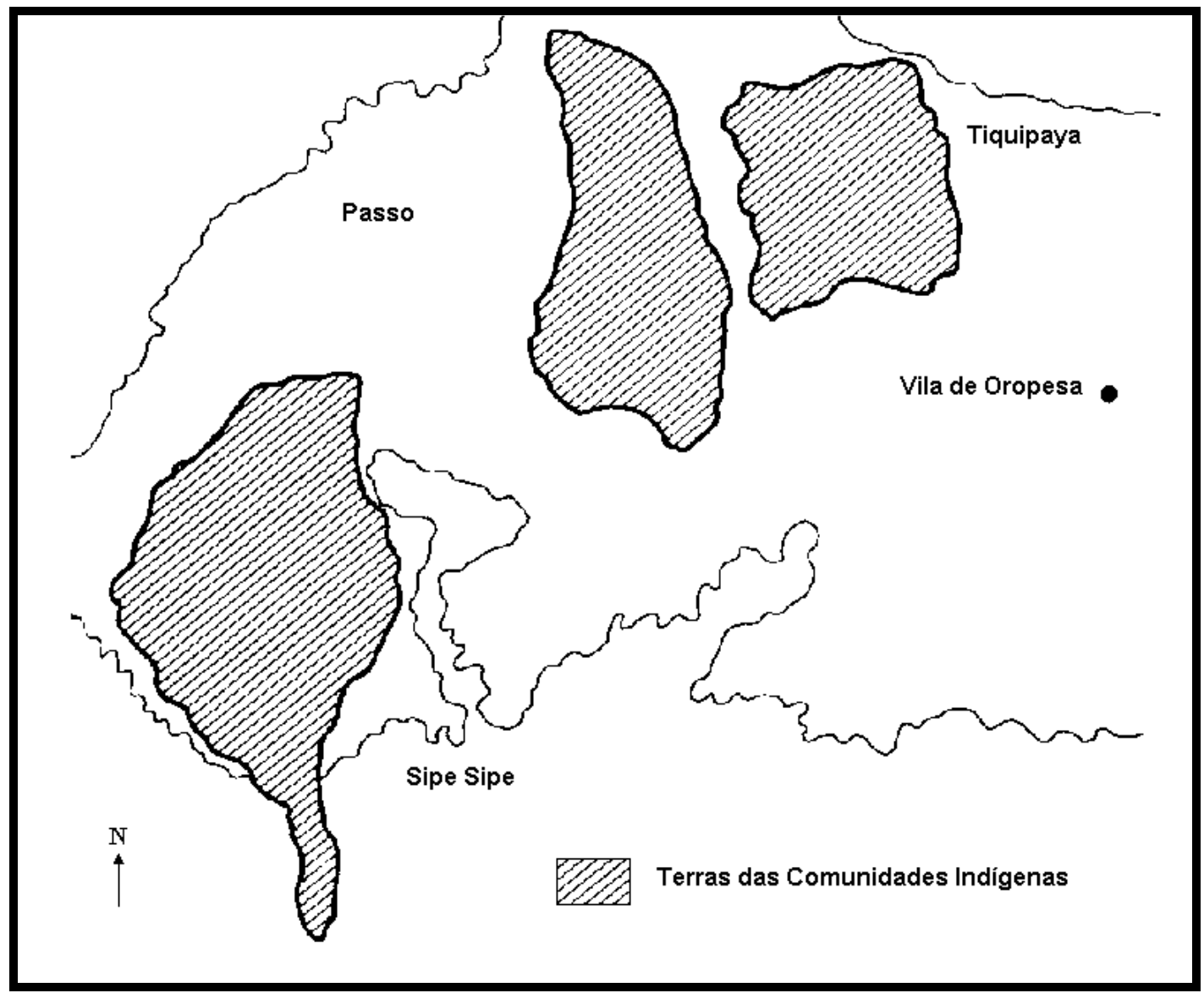

Esquema 12. Terras comunitárias de origem no Vale Central de Cochabamba antes de 1825.

Fonte: Jackson (1994, p. 71).

A população total do Partido de Cercado em 1788 perfazia 23.305 pessoas, sendo $25 \%$ delas de origem espanhola, $50 \%$ mestiços e $25 \%$ originários e mulatos. Outro aspecto importante é que, dos 125.245 habitantes da Província de Cochabamba, aproximadamente 18\% eram do Partido de Cercado, o que aponta para a polarização da área rural em relação à vila de Oropesa (LARSON, 1998).

A independência boliviana, em 1825, de certa forma modificou a organização territorial do Vale Central. A subida ao poder da elite política ligada à mineração e impulsionada pela filosofia liberal fundou as bases de uma economia nacional baseada na monoexportação da prata e, posteriormente, de estanho. Evidentemente, as ideias liberais iam contra os princípios da elite agrária e 
conservadora de Cochabamba, principalmente porque a partir de então, a abertura do mercado nacional para os produtos agrícolas internacionais significou maior concorrência para a oligarquia cochabambina. Acrescente-se a isso a construção da ferrovia ligando o porto de Antofagasta (ainda sob território boliviano) aos centros mineradores no altiplano. Nesse contexto, a política da nova elite boliviana terminou por extinguir a posição estratégica do Vale Central de Cochabamba em relação aos principais centros mineradores. A partir da abertura das principais ferrovias bolivianas, entre 1880 e 1925, os centros do altiplano passaram a comprar produtos agrícolas de melhor qualidade e a preços mais baixos que os praticados em Cochabamba, especialmente trigo e milho provenientes do Chile e dos Estados Unidos (LARSON, 1998).

Com o declínio da renda produzida pela agricultura nos Vales de Cochabamba, ocorreu o parcelamento das antigas haciendas em terrenos menores, comprados ou arrendados por pequenos proprietários (piqueros), dando origem a minifúndios (Tabela 5). A agricultura ainda teve uma sobrevida com a ascensão da produção de álcool a partir do milho subsidiada pelo governo; porém, após os anos 40, os problemas voltariam definitivamente, uma vez que a crise do estanho no mercado internacional não permitia mais ao governo oferecer regalias aos produtores de Cochabamba.

Tabela 5. Propriedades privadas no Vale Central de Cochabamba e de Sacaba em quatro décadas.

\begin{tabular}{ccccc} 
Jurisdição & \multicolumn{4}{c}{ Propriedades privadas (no) } \\
\cline { 2 - 5 } & $\mathbf{1 9 0 0}$ & $\mathbf{1 9 1 2}$ & $\mathbf{1 9 2 4}$ & $\mathbf{1 9 4 5}$ \\
\hline Passo & 347 & 1.775 & 2.506 & 2.665 \\
Colcapirhua & 1.518 & 2.042 & 2.565 & 2.154 \\
Sipesipe & 401 & 1.754 & 3.363 & 3.610 \\
Tiquipaya & 1.054 & 1.310 & 1.924 & 1.688 \\
Quillacollo & 2.006 & 3.461 & 4.733 & 3.997 \\
Cercado & 2.373 & - & 3.293 & 1.452 \\
Sacaba & - & 4.597 & - & 6.320 \\
\hline
\end{tabular}

Fonte: Jackson (1994, p. 168 e 179). 
Jackson (1994, p. 139) ressaltou que:

Cochabamba era uma das duas regiões na Bolívia que possuía uma maior classe de pequenos proprietários antes da reforma agrária de 1953, e a hacienda de Cochabamba tendia a ser menor que o grande latifúndio que dominava a maior parte do restante do país. ${ }^{139}$

Em contraste, a reforma produzida pelo governo de Mariano Melgarejo (18641871) procurava acabar com o monopólio indígena sobre as terras comunitárias e de origem, permitindo que fossem comercializadas com o intuito de acabar com a segregação territorial e a integração dos povos indígenas à vida oficial boliviana. No entanto, a medida se revelou ineficaz em Cochabamba, onde permaneceu essa polaridade espacial: a região do Vale Baixo para povos originários e a parte mais central e as vilas para a elite crioula (JACKSON, 1994).

No século XX, a cidade de Cochabamba tornou-se o segundo maior centro urbano boliviano, porém sua importância econômica no cenário nacional era muito reduzida ${ }^{140}$, particularmente após a falência da produção agrícola cochabambina diante da modernização do território e da economia nacional. Entre 1920 e1930, a agricultura no vale ainda experienciou certo crescimento a partir da produção de milho para a produção de álcool e da chicha (bebida alcoólica produzida a partir do milho). Desta feita, o centro urbano ainda atraiu migrantes movidos pela agricultura, bem como no final dos anos 40 , pelo baixo preço da terra e a possibilidade de ascensão social. O parcelamento da terra acabou constituindo no Vale Central os chamados minifúndios, isto é, pequenas propriedades rurais voltadas mais para o mercado regional que para a exportação. Cerca de $70 \%$ a $80 \%$ das propriedades no Vale Central e de Sacaba possuem extensão menor que 1 ha (LARSON, 1998). Portanto, a divisão fundiária no Vale Central de Cochabamba ocorreu mais por força da economia que como consequência da Reforma Agrária, que viria a ser colocada em prática após 1953. Não obstante, enquanto a situação fundiária do Vale Central se alterou substancialmente, em outras regiões do Departamento de Cochabamba, o latifúndio permaneceu intacto até a reforma agrária de 1953.

\footnotetext{
139 "Cochabamba was on of the two regions in Bolivia that had a larger class of small holders prior to the 1953 agrarian reform, and the Cochabamba hacienda tended to be smaller than the great latifundio that dominated much of the rest of the country."

${ }_{140}$ Pelo recenseamento de 1900 , a província de Cochabamba contribuia com apenas $0,95 \%$ das exportações nacionais (JACKSON, 1994).
} 
Após a revolução de 1952, o governo boliviano passou a implementar um plano de integração nacional, procurando articular as três regiões fisiográficas da nação: altiplano, vales e planície (Ilanos). Nesse contexto, Cochabamba desempenhou função essencial, funcionando como polo de conexão entre o oriente e o ocidente. Para tanto, passou a receber uma série de investimentos federais, como a construção da estrada ligando-a a Santa Cruz de la Sierra, em 1954 e, ulteriormente, a construção da refinaria Gualberto Villaroel, assim como de gasodutos e polidutos para exploração de petróleo e gás em El Chapare. Por um lado, o governo buscava impulsionar o desenvolvimento do oriente boliviano ${ }^{141}$, estimulando uma "marcha para o oriente", e de outro, procurava diversificar a decadente economia boliviana de forma a dar uma solução para o fracasso da agricultura cochabambina.

A fixação de diversos objetos e redes técnicas no Vale Central trouxe nova dinâmica à região, mormente no que concerne ao fluxo populacional e às dinâmicas de imigração. Embora desde 1900 Cochabamba já estivesse recebendo fluxo migratório constante, produzido por antigos trabalhadores da mineração em decadência, em sua maioria oriundos de Oruro, a implantação de rodovias e ferrovias vivificou ainda mais a função da localidade como polo de integração nacional. O fluxo migratório trazido ao Vale Central foi pujante. Adicionalmente, a construção viária fez com que os centros populacionais do Vale Central interagissem de forma ainda mais direta, assim engendrando a metropolização do Vale Central de Cochabamba. A ocupação do espaço do Vale Central se deu, sobretudo, em torno dos principais eixos viários: para oeste, por meio da Rodovia Blanco Galindo, em direção a Quillacollo, Vinto e Sipesipe; para leste, pela Avenida Circonvalación, em direção a Sacaba; e para sudeste, pela Rodovia do Valle Hermoso (Fotografia 2).

Por outro lado, a ocupação exaustiva do Vale de Sacaba, principalmente do município de Mercado, tem levado a expansão urbana a se orientar para as zonas rurais da província de Quillacollo e Tiquipaya, dando origem a tensões, especialmente por se tratar de área com forte identidade, porquanto é remanescente das antigas regiões em que comunidades indígenas campesinas se instalaram durante o período colonial. Resta claro que o avanço urbano sobre essas áreas

\footnotetext{
${ }^{141}$ Situados nos llanos (planície), constituídos pelos Departamentos de Pando, Beni e Santa Cruz de La Sierra.
} 
também tem significado não apenas para as transformações sociais, mas essencialmente para as ambientais, já que se caracterizam também pela presença de aquíferos.

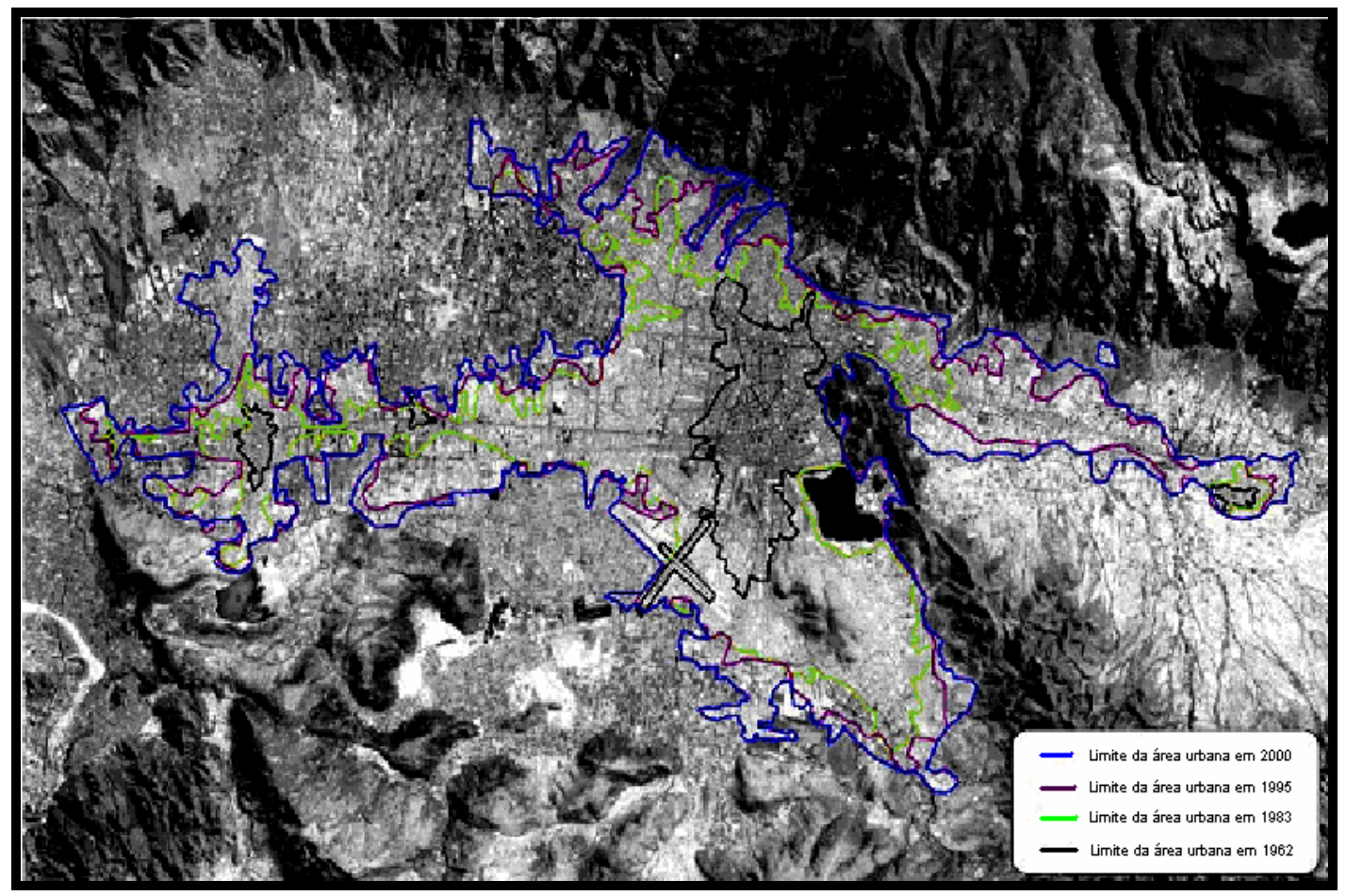

Fotografia 2. Expansão da área urbana no Vale Central de Cochabamba, no período entre 1962 e 2000.

Fonte: PROGEO (2003).

Deve-se ressaltar que os fluxos migratórios possuem importância não somente para compreender o processo de urbanização de Cochabamba, como também para desvendar a constituição das territorialidades e a tensão existente entre modernização e conservação, tanto na dimensão ambiental como na cultural. Nesse sentido, o fenômeno migratório tem sido responsável por uma série de modificações dos lugares.

Vários autores têm destacado a importância do fluxo migratório nas dinâmicas territoriais existentes no Vale Central de Cochabamba. Ao refletir sobre este caso Blanes (2006, p. 28, tradução nossa) afirmou que:

Dois fatores impulsionaram este processo de adensamento: as migrações para a zona tropical do Chapare, que aumentaram as populações da periferia ao usá-las como estações intermediárias na migração a partir de outros lugares de fora do departamento; e o crescimento econômico, a raiz 
do incremento dos fluxos no eixo central do país que impulsionaram tanto o adensamento do núcleo como dos centros periféricos ${ }^{142}$

A socióloga Ledo García (2000) também relatou que os fluxos imigratórios para Cochabamba vêm ocorrendo desde 1900; porém, com a implantação das políticas territoriais, bem como do modelo econômico proposto pelo governo do MNR, de Paz Estenssoro, o processo se intensificou pelo desenvolvimento econômico de Cochabamba e Santa Cruz de la Sierra, ao passo que os centros mineiros do altiplano entraram em decadência. Com a falência das minas de estanho e, em seguida, em meados da década de 1980, com o fenômeno da "relocalização mineira"143, uma boa parte da população migrou para Cochabamba, tanto para o Vale Central quanto para a região de El Chapare. Ledo García (2000) salientou que $70 \%$ dos migrantes que se dirigiram a Cochabamba durante os anos 90 eram oriundos do altiplano e, dessa forma, a população do município de Cercado se "altiplanizou".

Boa parte da população migrante do altiplano se estabeleceu nas áreas periurbanas de Cochabamba, sobretudo nos distritos da zona sul, que possuem forte identidade com o trabalho minerador, como é o caso dos bairros Siglo XX e San Sebastian Pagador, entre outros. Em consequência, a construção da territorialidade dos imigrantes do altiplano se deu principalmente na zona sul da cidade, marcada por estilo de vida e aspectos culturais peculiares, como a festa de San Miguel e artesanatos típicos do Departamento de Oruro (GOLDSTEIN, 2004). Do total de imigrantes que se dirigiram a Cochabamba em 2001, chegou a $48 \%$ a parcela daqueles oriundos do altiplano, sendo $22 \%$ (66.721 pessoas) provenientes do Departamento de Oruro (INE, 2002b, p. 14). A reterritorialização dos migrantes do altiplano no município de Cercado pode ser notada principalmente pelos habitantes que se autoidentificam com a etnia aymara. Ademais, a partir de meados dos anos 90, por pressão norte-americana, o governo boliviano implementou o combate às plantações de coca em El Chapara, fazendo com que houvesse um vertiginoso fluxo migratório da área rural do Trópico para a região metropolitana de Cochabamba.

142 "Dos factores impulsaron este proceso de densificación: las migraciones a la zona tropical del Chapare, que agrandaron las poblaciones de la periferia al usarlas como estaciones intermedias en la migración desde otros lugares fuera del departamento; y el crecimiento económico, a raíz del incremento de los flujos en el eje central del país que impulsaron tanto la densificación del núcleo central como de los centros periféricos."

${ }^{143}$ Episódio no qual 23.000 funcionários das instalações da Corporación Minera de Bolívia (Comibol) foram despedidos em decorrência da queda do preço do estanho no mercado internacional. 
Estima-se que a redução do plantio de coca entre 1997 e 2000 tenha diminuído o PIB nacional em 655 milhões de dólares, além de significar a perda de 59.000 postos de trabalhos diretos e indiretos (FUNDACIÓN MILENIO, 2001).

Fundamentalmente, a expansão da zona sul da cidade se deu por força do grande mercado ao ar livre, chamado La Cancha, que desde o início do século XIX funcionava como ponto de articulação entre as áreas urbanas e rurais, uma vez que grande parte da produção agrícola regional era e continua sendo ali comercializada. Atualmente, a feira serve também para o comércio de aparelhos eletrônicos contrabandeados. Essa força de polarização de La Cancha pode ser notada pela alta densidade populacional na área ao lado da Lagoa Alalay (Mapa 7). Assim, o núcleo urbano do município de Cercado se expressa com maior força que os demais da região metropolitana de Cochabamba. Apenas a região urbanizada do município de Quillacollo possui densidade populacional no mesmo patamar de Cercado, o que se deve a um forte comércio local de produtos agrícolas.

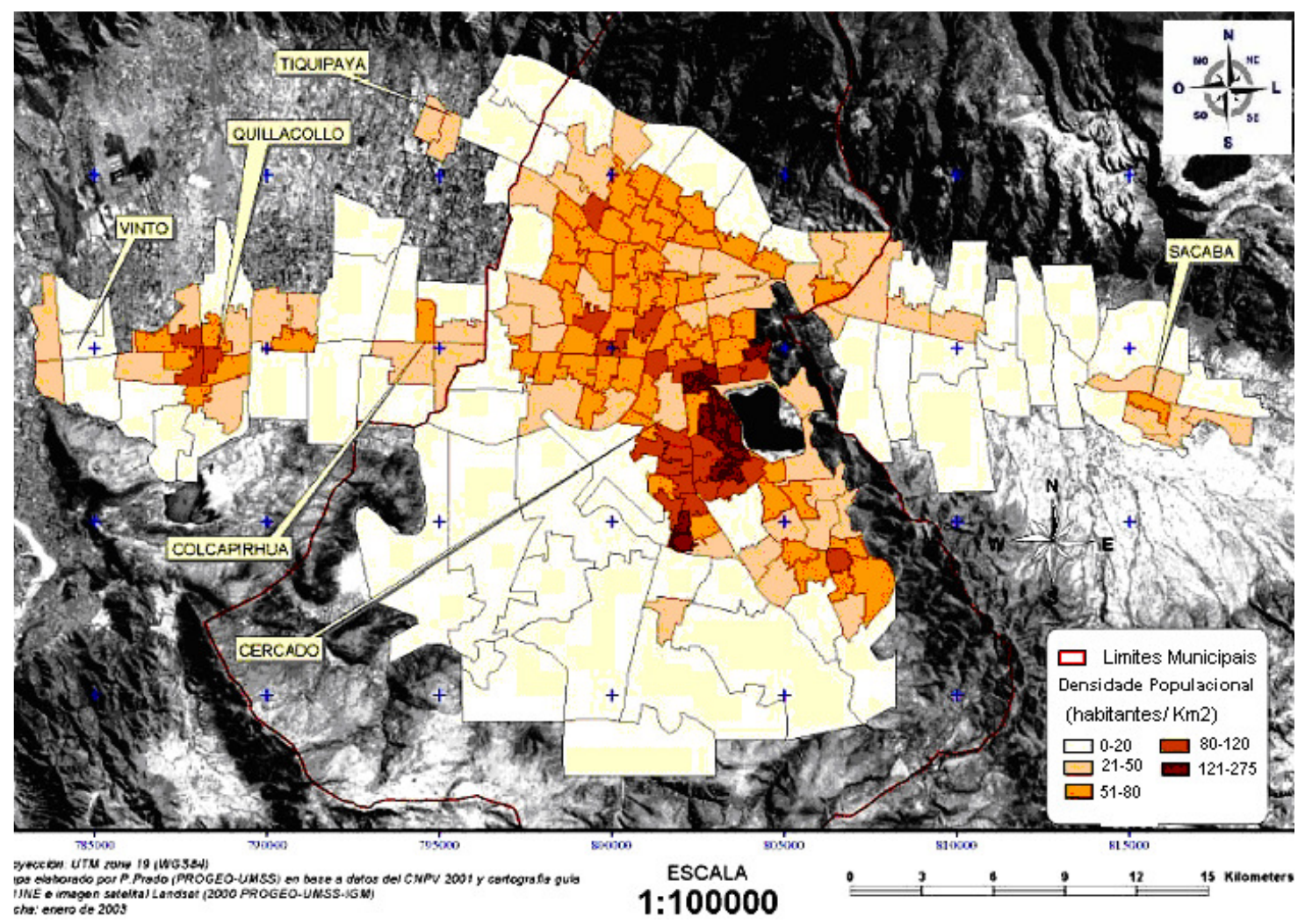

Mapa 7. Densidade demográfica da região metropolitana de Cochabamba em 2001.

Fonte: PROGEO (2003). 
O adensamento urbano da região metropolitana de Cochabamba tem se constituído, ao longo do tempo, mais por força da migração $(2,9 \%)$ que pelo crescimento vegetativo (1,6\%) (LEDO GARCÍA, 2000). Em contraste, a migração de outros municípios do Departamento de Cochabamba para o município de Cercado contabilizou 17\% em 1992 e 14,3\% em 1996, e vem diminuindo a cada recenseamento. Concomitantemente à expansão da área urbana de Cochabamba e ao aumento da densidade populacional apresentado por Cercado, os demais municípios daquela região metropolitana também passaram a apresentar altos índices de crescimento populacional (Gráfico 3) e, a partir de 1992, observa-se que esta região já possuía metade da população do Departamento e no censo seguinte, mais da metade.

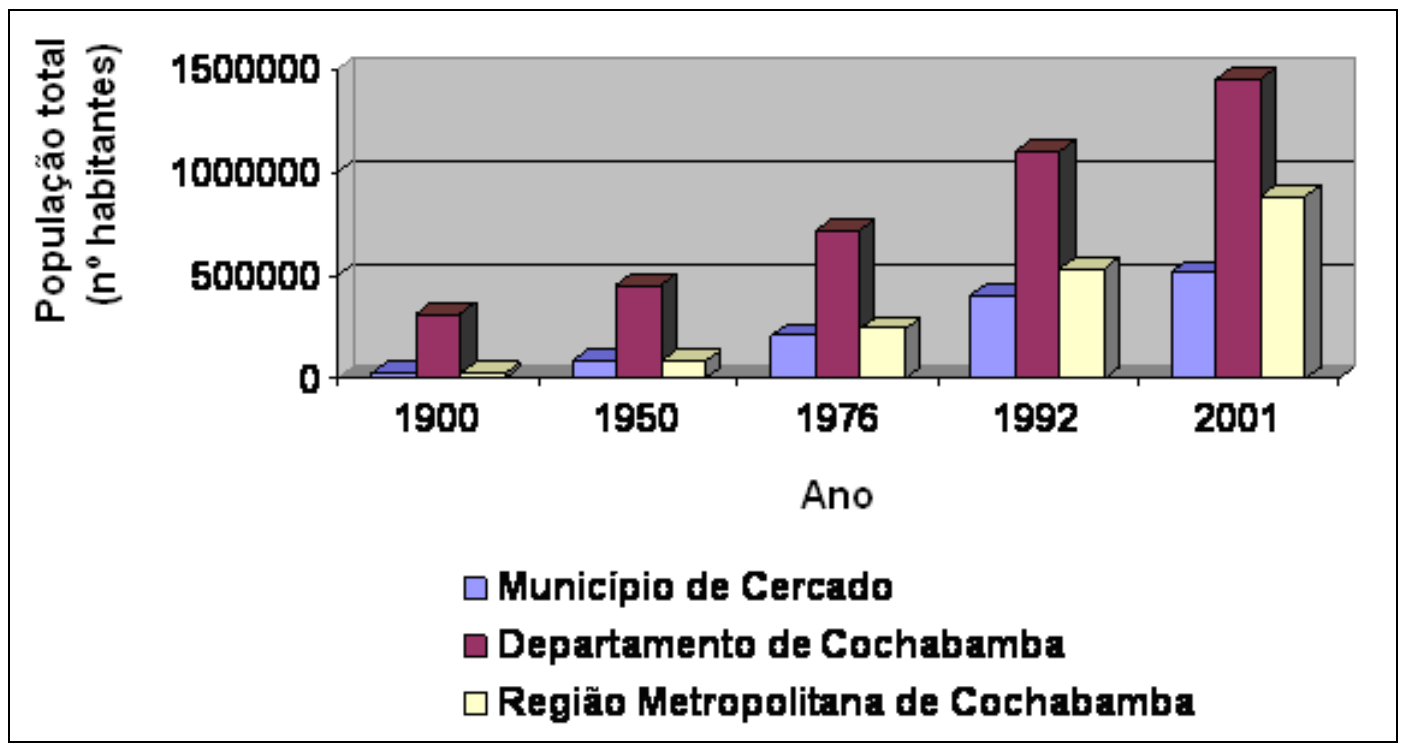

Gráfico 3. Comparação da população total do município de Cercado, na região metropolitana de Cochabamba, e do Departamento de Cochabamba durante o período entre 1900 e 2001.

Fonte: Organizado pelo autor com base em INE (2002a, p. 4). Para os anos de 1900 e 1950, apenas repetimos a população do município de Cercado para a região metropolitana, uma vez que o processo de metropolização ainda não havia se dado.

A urbanização dos municípios menores que constituem a região metropolitana bem como a expansão da área metropolitana ocorreram por conta da alta densidade do município de Cercado, com mais de $1.500 \mathrm{hab} / \mathrm{km}^{2}$, embora venha apresentando crescimento populacional menor a cada recenseamento. Entre 1950 e 1976, Cochabamba atingiu crescimento de 3,91\%, impulsionado principalmente pela 
migração interna no Departamento de Cochabamba (36\% dos imigrantes) e, em menor parte, pela migração de outros departamentos. Para o período entre 1976 e 1992, exibiu crescimento de 4,32\%, impulsionado pelos fluxos migratórios de outros departamentos. Contudo, para último período de recenseamento (1992-2001), o crescimento se reduziu a 2,56\% (INE, 2002a, p. 5).

Esse pujante crescimento populacional tem causado uma série de dificuldades para a população de Cochabamba. A expansão da área urbanizada sem a aplicação das diretrizes de ordenamento territorial em determinadas regiões tem permitido a formação de áreas de risco, particularmente pelo avanço das villas misérias pelas encostas da Cordilheira. Por certo, a falta de estrutura habitacional e de serviços básicos tem se tornado ainda mais crítica pelo constante acréscimo populacional. Outra consequência da expansão da área urbana se traduz no avanço sobre espaços marcados por forte identidade indígena (quéchua) e agrícola, especialmente entre os municípios de Quillacollo e Tiquipaya, gerando conflitos acerca do uso do solo.

Na Tabela 6, observa-se nos municípios adjacentes ao município de Cercado que tanto a população urbana quanto a rural têm apresentado crescimento, embora haja alguns casos, como em Vinto e Sipesipe, em que a população rural ainda seja maioria. Existem situações como a de Tiquipaya, em que as profundas transformações produzidas pelo avanço da modernização se manifestaram pelo crescimento estrondoso da população urbana, de quase $300 \%$, ainda que a população rural apresentasse também algum crescimento. A manutenção de boa parte da população rural (em torno de 14\%) na região metropolitana se deu principalmente pelas oportunidades oferecidas pela agricultura, tornando-se solução para um contingente de desempregados e migrantes no final dos anos 90, não apenas como fonte de renda, mas sobretudo como forma de subsistência.

Outra manifestação das transformações por que passava essa região metropolitana se cristalizaram a partir da configuração de uma área eminentemente de migrantes do altiplano na zona sul de Cercado. Esse espaço se constituiu no território dos "inimigos" da população originalmente oriunda de Cochabamba, pela invasão das áreas consideradas inicialmente como virgens e destinadas a lazer e contato com a natureza. 
Tabela 6. População urbana e rural em vários municípios da região metropolitana de Cochabamba em 1992 e 2001.

\begin{tabular}{|c|c|c|c|c|c|c|}
\hline \multirow[t]{3}{*}{ Município } & \multicolumn{6}{|c|}{ População ( $n^{\circ}$ de habitantes) } \\
\hline & \multicolumn{3}{|c|}{1992} & \multicolumn{3}{|c|}{2001} \\
\hline & Urbana & Rural & Total & Urbana & Rural & Total \\
\hline Cercado & 397.171 & 17.136 & 414.307 & 516.683 & 341 & 517.024 \\
\hline Quillacollo & 51.418 & 17.609 & 69.027 & 78.324 & 25.882 & 104.206 \\
\hline Sipesipe & 2.033 & 17.974 & 20.007 & 3.134 & 28.203 & 31.337 \\
\hline Tiquipaya & 3.037 & 10.334 & 13.371 & 26.732 & 11.059 & 37.791 \\
\hline Vinto & 9.493 & 11.080 & 20.573 & 14.180 & 17.309 & 31.489 \\
\hline Colcapirhua & 19.547 & 2.672 & 22.219 & 41.637 & 343 & 41.980 \\
\hline Sacaba & 47.559 & 22.051 & 69.610 & 92.581 & 24.519 & 117.100 \\
\hline
\end{tabular}

Fonte: INE (2002a, p. 6-7).

Como se pode notar, as políticas territoriais implementadas pelo governo nacional a partir de 1953 surtiram forte efeito sobre a região de Cochabamba. Naturalmente, a forte migração não teve como origem apenas as políticas territoriais, mas a falência da economia de enclave mineiro, assim como os prolongados períodos de secas que têm afetado o altiplano e arruinado a agricultura de cunho familiar também contribuíram para esse efeito. Ainda uniram-se a esses fatores as oportunidades apresentadas pela colonização no Trópico de Cochabamba e a economia da coca, incluindo-se aquela mais dinâmica do narcotráfico que ali se implantou. Dessa forma, as dinâmicas migratórias no Vale de Cochabamba se manifestaram a partir de fatores a longo prazo, provocados particularmente pelo intento de modernização do país como um todo e de seus principais centros urbanos em particular. Portanto, as políticas migratórias foram um dos fatores que influenciaram estruturalmente a criação de um complexo de risco em Cochabamba, moemente por se tratar de uma zona frágil no que concerne ao seu espaço natural e suscetível às penúrias ambientais, que se acentuaram ainda mais com o adensamento populacional. 


\subsection{Estrutura e função do Vale de Cochabamba: planificando territórios de risco}

Como apresentamos no tópico anterior, o Vale de Cochabamba se articulou durante o período colonial, e mesmo posteriormente, como espaço agrícola destinado ao abastecimento das elites no altiplano, assim como para o fornecimento de mão-de-obra para o setor minerador. A partir do final do século XIX, o mercado agrícola de Cochabamba entrou em colapso em decorrência da modernização do território nacional e do aumento da concorrência internacional em torno de produtos que se tornaram mais baratos pela construção de uma rede ferroviária ligando o altiplano aos portos do Pacífico.

A modernização que se buscou implementar a partir de então no território nacional também influenciou a elite política de Cochabamba, cada vez mais formada por estratos urbanos vinculados ao comércio. Para a nova elite cochabambina, faziase necessário modernizar a cidade, transformando-a de uma vila colonial agrária em uma cidade moderna para o futuro. Caricaturalmente, os ex-combatentes da Guerra do Chaco voltavam para Cochabamba, porém o número de habitações existentes na cidade não era suficiente para abrigá-los. Este fato levou as autoridades locais a repensar a situação e a elaborar novos planos para a gestão territorial urbana. Ainda em 1937, veio à tona a questão de como incorporar as áreas das antigas haciendas na parte setentrional de Cercado. O conselho municipal de Cochabamba convidou o arquiteto argentino Miguel Rodriguez para realizar um plano regulatório (plan regulador) para a gestão urbana daquele município.

Como esclarece Solares Serrano (1990), a proposta de Rodriguez se centrou principalmente em integrar as áreas residenciais ao norte do rio Rocha ao centro da cidade. Para tanto, o arquiteto indicou a extensão em direção ao norte das ruas já existentes no centro. Adicionalmente, duas ruas diagonais seriam construídas para conectar o centro às áreas suburbanas a oeste, Cala Cala e La Recoleta. De acordo com este plano, o velho centro da cidade funcionaria como elemento de polarização da área urbana, por meio do que os subúrbios de Cochabamba (norte, nordeste e oeste) se articulariam. Enquanto isso, a zona sul da cidade, lar dos residentes mais pobres da cidade, era vista por Rodriguez como um campo de ciganos, com os miseráveis dando mostras de degeneração e vícios. 
A partir dos anos 40, com o aumento da migração interna no Departamento de Cochabamba pela chegada de mais combatentes da Guerra do Chaco, o plano sugerido por Rodriguez estava entrando em colapso. Camponeses indígenas se dirigiam à cidade para construir ruas e casas de forma não planejada, constituindo prolongamentos das ruas até então construídas. Por outro lado, muitos especuladores (loteadores) tiraram proveito da situação, vendendo loteamentos apresentados como "modernos" a preços muito elevados. Não obstante, como havia falta de habitações, logo se conseguia vendê-los. A ação dos loteadores rapidamente transformou a paisagem do Vale Central. O aparecimento de ilhas de loteamentos no meio de pastagens e plantações no Vale de Cochabamba, principalmente na parte sul de Cercado, se tornou comum. Em seguida, os loteadores foram considerados inimigos da cidade de Cochabamba, uma vez que criavam péssimas condições sanitárias e "ameaçavam" os cidadãos daquele município (SOLARES SERRANO, 1990).

Após o fracasso do plano de Rodriguez, a prefeitura (alcaldia) de Cochabamba estabeleceu diferentes diretrizes para a urbanização. O objetivo foi estabelecer leis que priorizassem a organização sanitária da cidade e sua higiene. Buscando implementar os princípios estabelecidos naquele diploma legal, a prefeitura organizou um grupo de arquitetos, que posteriormente veio a ser o Departamento de Arquitetura da Prefeitura. Esse grupo trabalhou na criação do plano regulador, visando criar soluções para o crescimento populacional e a expansão desordenada (SOLARES SERRANO, 1990).

A partir da década de 1950, a prefeitura (alcaldia) passou a colocar em prática as diretrizes previstas no plano regulador. O encarregado de aplicá-las foi um arquiteto da região, Jorge Urquidi Zambrana. Infuenciado pelas ideias modernistas, Urquidi procurou transformar a estrutura colonial da cidade, modernizando-a de forma a torná-la "eficiente", a partir dos princípios de ordem, equilíbrio e produtividade econômica (ANAYA, 1947 apud GOLDSTEIN, 2005).

Esses princípios significavam, de forma pragmática, a constituição de diferentes zonas urbanas. Urquidi Zambrana também havia sido fortemente influenciado pela concepção de cidade-jardim e procurava conciliar as características preconizadas para este estilo de urbanismo com o projeto de uma cidade moderna. $\mathrm{O}$ conceito de cidade-jardim seguia justamente princípios opostos 
ao do plano anterior, uma vez que, com sua aplicação, visava-se descentralizar a cidade a partir da constituição de outros centros que abrangessem as várias dimensões da vida. Dessa forma, a cidade-jardim seria conformada por uma rede de diferentes unidades urbanas interconectadas por um sistema de transporte, assim criando uma conurbação. Ademais, a cidade-jardim deveria ser circundada por um cinturão verde agrícola, de forma a propiciar o abastecimento da cidade com produtos hortifrutigranjeiros frescos e baratos. Para tanto, era necessário constituir uma autoridade central, com o objetivo precípuo de evitar os efeitos da especulação acerca do preço da terra.

Além de designar um plano regulador, Urquidi Zambrana também estabeleceu um plano regional para a gestão urbana de todo o Vale Central de Cochabamba, procurando integrar as áreas urbanas com as rurais, porém simultaneamente mantendo certa diferenciação entre elas. Adicionalmente, se procurou equilibrar a distribuição da população pelo Vale Central, com o intuito de evitar que o cinturão verde fosse rompido pela expansão urbana. No entanto, para lograr êxito em tal empreitada, seria essencial impulsionar outros núcleos urbanos, como Quillacollo a oeste, Sabaca a leste e a comunidade agrária de Valle Hermoso no sudeste. Aproveitando o princípio do plano de Rodriguez de centro articulador da vida urbana, Urquidi Zambrana sugeriu que todo agrupamento urbano deveria possuir um núcleo em torno do qual "células" ou unidades vicinais (unidades vecinales) se constituiriam. Para 0 arquiteto, as unidades vicinais seriam comunidades autossustentáveis de 15.000 a 20.000 habitantes, constituídas a partir de círculos concêntricos ao entorno do centro urbano e articulados por um sistema de transporte (URQUIDI ZAMBRANA, 1967 apud GOLDSTEIN, 2005, p. 67).

Naturalmente, o sistema de transporte idealizado por ele foi facilitado pelos planos do governo nacional de transformar Cochabamba em um polo de expansão na porção oriental boliviana, assim como de articulação entre as diferentes regiões do país. Por conseqüência, a construção de estradas de rodagem pelo governo nacional facilitou a interligação entre os núcleos urbanos do Vale Central. Resta saber até que ponto a construção das estradas, em adição ao cinturão verde programado pelo Departamento de Arquitetura da prefeitura, não foram responsáveis por si só pela expansão urbana. 
Essa preocupação com a integração entre homem e natureza foi expressa, ainda, pelo planejamento de ruas largas, com jardins e amplos espaços verdes para lazer. Em adição a isso, o cinturão verde deveria ser mantido como demarcador da fronteira entre a zona urbana e a rural. Urquidi Zambrana foi um dos fundadores do Parque del Tunari, que abrange uma boa parte da área da Cordilheira ao norte do município de Cercado. Em relação à zona sul daquela cidade, o arquiteto programava a construção de grandes parques que transformariam a vida precária dos migrantes. Além disso, as áreas rurais circundando a cidade deviam ser mantidas pelo controle centralizado, assim limitando o avanço da urbanização (GOLDSTEIN, 2005).

Boa parte das medidas previstas no plano de Urquidi Zambrana acabou fracassando, principalmente pelas políticas territoriais adotadas pelo governo nacional. A construção de estradas, como afirmamos anteriormente, impulsionou ainda mais a imigração para Cochabamba, ali engendrando uma urbanização vigorosa. Entre 1976 e 1992, a taxa de urbanização daquele município foi de 3,64\% e para o período entre 1992 e 2001, aumentou para 4,19\% (INE, 2002a). Por outro lado, as medidas econômicas do Plano Bohan ${ }^{144}$ de investir toda a arrecadação da Corporación Minera de Bolivia (COMIBOL, Corporação Mineira da Bolívia) no desenvolvimento de Santa Cruz de la Sierra fortaleceram ainda mais os fluxos migratórios rumo aos vales e aos llanos. Desafortunadamente, o plano de Urquidi Zambrana não levava em conta a fragilidade do Vale de Cochabamba, desde que para molhar todos os jardins programados seria necessário utilizar recursos hídricos já não tão abundantes como outrora. Naturalmente, a ideia de constituir núcleos urbanos secundários de forma a promover a metropolização do Vale de Cochabamba seguiu adiante, porém, de maneira bem menos equilibrada como previa o plano original.

Ainda no final dos anos 50, havia falta de moradias na região e, por conta da especulação, grande parte dos migrantes era incapaz de pagar os altos preços de uma moradia no centro da cidade. Por conseguinte, os migrantes começaram a se

\footnotetext{
${ }^{144}$ Plano criado pelo economista norte-americano Marvin Bohan, em 1942, que traçava as diretrizes para a diversificação econômica boliviana a partir da marcha para o Oriente e do fomento das atividades agropecuárias na região. Grande parte dessas diretrizes coincidia com as conclusões do Memorandum de 1907, plano de ajuda americano, segundo o qual o avanço ao Oriente se daria pelo asfaltamento da estrada ligando Cochabamba a Santa Cruz de la Sierra. De forma a implantar toda a infraestrutura necessária, seria preciso, ainda, criar instituições de fomento, como posteriormente ocorreu com a Corporación Boliviana de Comércio (MESA; GISBERT; MESA, 2003).
} 
organizar em sindicatos de inquilinos como meio de garantir habitação permanente para seus membros, ainda que isso significasse a invasão das áreas nãourbanizáveis pela alcaldia. Nesse período, ocorreram as primeiras invasões no Cerro San Miguel e Cerro Verde. Essas áreas eram consideradas pelo Plano Regulador como essenciais para o desenvolvimento equilibrado da cidade, uma vez que faziam parte do cinturão verde e também estavam destinadas ao lazer em contato com a natureza. Sob essa perspectiva, significativa parcela dos migrantes aymaras acabava sendo vista pelos cochabambinos como indigente e ameaça ao bom funcionamento da cidade. Inclusive, Goldstein (2005, p. 73, tradução nossa) comentou que:

Não é surpreendente, assim, que os padrões irregulares de ocupação e colonização das áreas verdes pelos sindicatos dos migrantes fossem vistos pela população nativa de Cochabamba como uma ameaça contaminante à própria vida da cidade. As caracterizações dos colonos pela imprensa dessa época apresentavam os migrantes como uma influência suja e poluidora e os seus assentamentos não-regulados como um ataque ao corpo físico da cidade, deixando doença e destruição em sua esteira. ${ }^{145}$

Ledo García (2000, p. 107, tradução nossa) também concordou com Goldstein (2005), porquanto:

[...] as pessoas que residem na parte sul da cidade se integraram à vida urbana em condições desvantajosas, pois eles têm uma evidente falta dos serviços mais básicos e em decorrência disso, o clima social é de tensão com o resto da cidade. ${ }^{146}$

A construção dessa territorialidade migrante se baseou principalmente no aspecto cultural, por meio da língua falada, dos costumes e das vestimentas diferentes. Enquanto os originários de Cochabamba estão acostumados a utilizar o quéchua, a língua nativa mais empregada pelos migrantes que chegavam à cidade era o aymara. Dessa forma, tanto para a elite como para os demais cidadãos de Cochabamba, a identidade cultural da cidade estava sob iminente perigo, podendo ser perdida ou mesmo "contaminada". Essa diferença cultural era visível, por

\footnotetext{
${ }^{145}$ "It is not surprising, then, that the irregular settlement patterns and colonization of the green areas by the migrants unions were viewed by the native Cochabamba population as a contaminating threat to the very life of the city itself. Press characterizations of the land colonizations at this time characterized migrants as a dirty and polluting influence and their unregulated settlement as an attack on the physical body of the city, leaving disease and destruction in their wake."

146 " [...] the people who are resident in the southern part of the city have integrated into the City life in disadvantageous conditions, where they have a very evident lack of the most basic services and due to this the social climate is one of tension with the rest if the City."
} 
exemplo, nas saias (pollera) mais longas e enfeitadas das migrantes aymaras em contraste com as polleras mais curtas das nativas de Cochabamba. Para muitos, a chegada dos migrantes aymaras representou muito mais que uma ameaça à saúde e ao bem-estar daqueles que vivam na cidade, sendo um perigo para a hierarquia racial estabelecida (GOLDSTEIN, 2005).

O número de invasões atingiu o seu pico entre os anos 60 e 70 e, em adição a isso, havia o fato de que grande parte dos proprietários de terra no cinturão verde do Vale de Cochabamba notou que se podia ganhar mais dinheiro vendendo a terra, como consequência da especulação imobiliária, do que mantendo seu minifúndio voltado para a produção agrícola. Por outro lado, ainda havia os incentivos do governo nacional para a implementação de indústrias manufatureiras no município. A implantação de infraestrutura de transporte, por si só, já atraía empresas para Cochabamba por sua localização estratégica no centro do país. A partir da década de 1970, com o incentivo dado pelo governo para a exploração de gás e petróleo nos llanos e a descoberta de um campo de petróleo e gás em El Chapare, foi implantada a refinaria Gualberto Villaroel na zona sul da cidade. Como mostraremos mais adiante, a implantação desta refinaria também teve influência do governo militar brasileiro.

Diante do fracasso do plano de Urquidi Zambrana, a alcaldia de Cochabamba procurou segregar a população de migrantes, não aceitando a regularização das invasões e até mesmo negligenciando esta parte da cidade. Conforme a alcaldia, tratava-se de uma "zona congelada". A partir dos anos 80, com a chegada de mais 13.000 migrantes, em média, a cada ano, entre 1987 e 1992, em decorrência da relocalização mineira, este problema se acentuou (LEDO GARCÍA, 2000, p. 108). Nesse cenário, não é surpreendente constatar que mais de $80 \%$ dos loteamentos na zona periurbana de Cochabamba eram ilegais, abrigando $40 \%$ da população do município de Cercado (GOLDSTEIN, 2005). Quase metade da população de Cercado não tinha acesso aos recursos mais básicos e, concentrando-se na zona sul da cidade, justamente a área de menor produção de água subterrânea, tampouco podiam-se criar soluções mais fáceis de acesso aos recursos hídricos, como a perfuração de poços ou a utilização das águas superficiais.

Assim, no início dos anos 1990, Cochabamba constituía uma verdadeira colcha de retalhos, com seu entorno pauperizado, enquanto o centro da cidade se 
mantinha como o núcleo da vida urbana, o espaço dos mais ricos, daqueles que falam o castelhano como língua principal. Evidentemente, negligenciar o problema somente o tornava maior e cada vez mais incontrolável. A partir da implantação da Lei no 1.551 (Ley de Participación Popular - LPP, Lei de Participação Popular) (BOLIVIA, 1994c), o prefeito (alcalde) de Cochabamba, Manfred Reyes Villa, buscou reintegrar as áreas ilegais esquecidas durante muito tempo. Para tanto, descentralizou a alcaldia com a criação dos talleres zonales (subprefeituras). A função desse novo órgão era trabalhar em conjunto com as comunidades para tentar superar suas deficiências, por intermédio da maior participação cidadã de seus moradores. Já o governo nacional buscava a descentralização do poder estatal por meio da participação local, a partir da criação da OTB, instituição com certa autonomia criada para gerir problemas locais. Concomitantemente, o governo passou a ter maior conhecimento acerca das áreas de ocupação, muitas vezes clandestinas e ilegais, sobre as quais nem mesmo a alcaldia tinha informações, desse modo ampliando as lentes do governo federal sobre o seu próprio território.

O novo programa da alcaldia trouxe vários avanços para a população local, particularmente no que concerne à cidadania. Outrossim, acentuou ainda mais as tensões existentes entre as diferentes áreas da cidade, porquanto os moradores desses locais estavam se tornando cada vez mais conscientes das tensões e diferenças sociais em relação aos demais habitantes da área urbana e, portanto, suas reivindicações se tornaram mais intensas e numerosas. Nesse contexto, pouco tempo depois, o governo passou a acentuar seu legalismo e formalismo, retirando o componente social do programa (GOLDSTEIN, 2005). Este assunto será retomado no item 4.3 deste trabalho.

Nota-se que ao longo do tempo houve uma profunda transformação em Cochabamba ocasionada pelo confronto entre o planejamento urbano regional e municipal e o planejamento territorial do Estado boliviano. Enquanto o primeiro buscava a criação de uma estrutura urbana equilibrada, estável e bem distribuída, o segundo buscava a ocupação dos vales, gerando certa instabilidade para a estrutura urbana. Naquele momento, Cochabamba passava a ter a função de polo de integração entre as diferentes regiões da Bolívia e, para tal, deveria mudar sua estrutura urbana vinculada à agricultura. A implantação de uma rede de estradas $e$ da ferrovia até Oruro foi transformando o Vale de Cochabamba. Territorialmente, o 
confronto dessas duas formas diferenciadas de planejamento se materializou de duas maneiras. Primeiramente, no conflito entre as territorialidades dos campesinos quéchuas de Vinto, Tiquipaya e Sipesipe e as territorialidades urbanas, especialmente aquelas das indústrias e empresas que se apropriam dos novos espaços urbanizados. Em segundo lugar, no confronto entre as territorialidades dos migrantes aymaras da zona sul, as do governo municipal e as dos cochabambinos de origem.

O choque inicial de territorialidades aconteceu pela expansão urbana desordenada e o rápido processo de modernização do Vale Central de Cochabamba. O incentivo proporcionado pelo governo nacional ao investir na região como polo de integração nacional trouxe não apenas um fluxo migratório constante, mas também a implantação de um polo de pequenas indústrias manufatureiras, principalmente ao longo dos principais eixos viários, ligando o município de Cercado aos demais municípios do Vale Central. Juntamente com a implantação dessas indústrias, vêm ali se estabelecendo vários núcleos populacionais (Mapa 8).

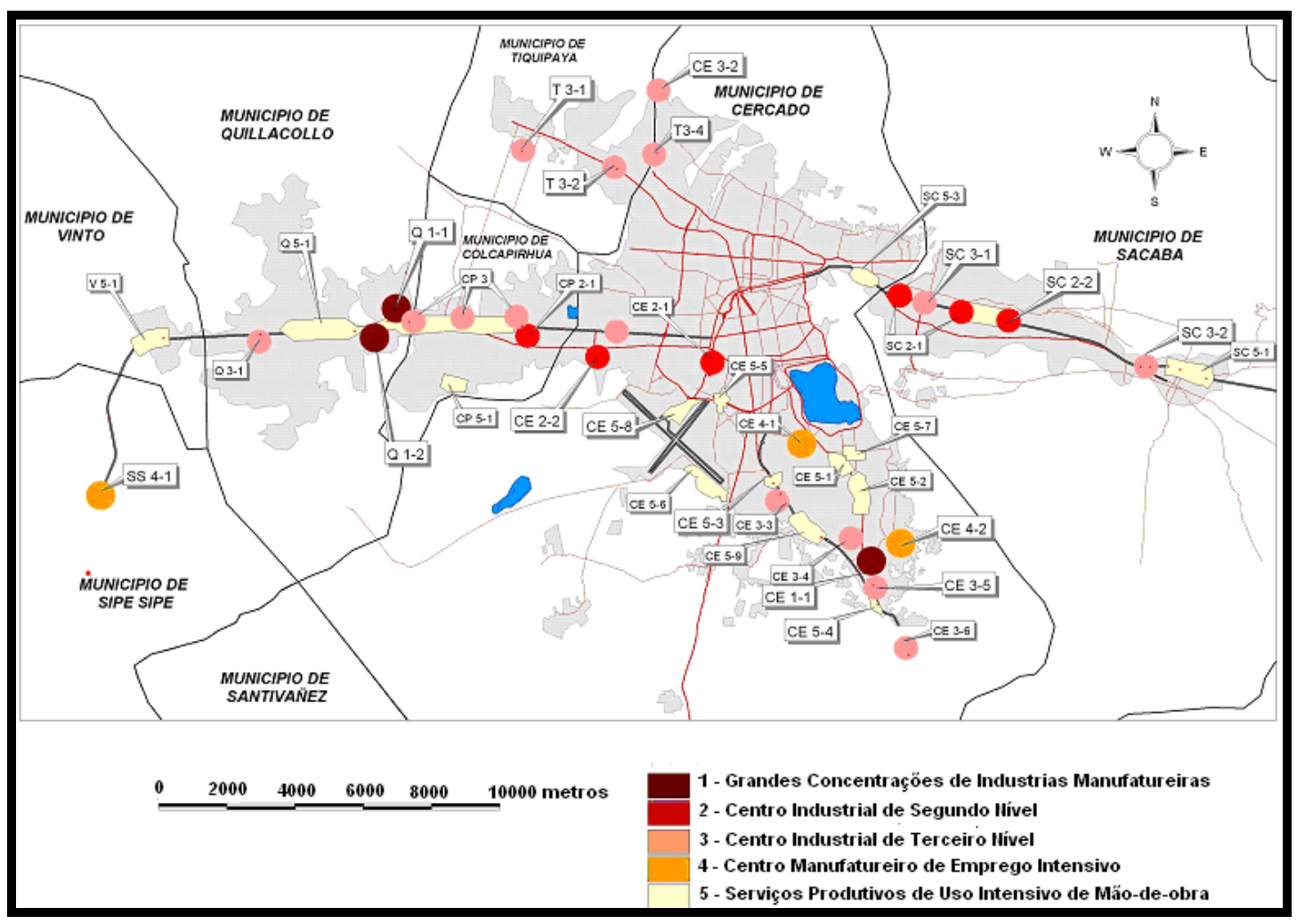

Mapa 8. Região metropolitana de Cochabamba: complexos industriais e localização das indústrias. Fonte: PROGEO (2003). 
A rápida e radical modernização das áreas rurais dos municípios a oeste de Cercado promoveu uma transformação latente na paisagem rural, o que pode ser observado sobretudo na transformação da própria estrutura produtiva da região. Os antigos assentamentos e os pequenos camponeses com forte identidade quéchua vêm sendo comprimidos pela expansão das áreas urbanas, principalmente as vinculadas aos novos polos industriais que se configuram ao longo da rodovia que conecta Cochabamba a Oruro e a La Paz (Tabela 7).

Verifica-se que a agricultura contribuía em mais de $30 \%$ do PIB em 1965, ao passo que a partir do final dos anos 90 se estabilizou em 10\%. Enquanto isso, a implantação dos setores mais modernos, como transporte e comunicações, comércio e finanças e manufatura, passou de $41 \%$ na década de 1970 para 57,8\%, em 2007, estabilizando-se neste patamar.

Ademais, a população economicamente ativa (PEA) também tem passado por transformações drásticas (Tabela 8). Entre 1992 e 2001, nota-se que houve uma "descamponização" da PEA na região metropolitana de Cochabamba, pois a agricultura emprega uma parte dessas pessoas apenas naqueles municípios de forte tradição camponesa e indígena, como é o caso de Sipesipe, Vinto e Tiquipaya.

Percebe-se, por outro lado, que o avanço das atividades mais modernas em direção ao campo tem provocado uma série de tensões como consequência das mudanças em termos de uso do solo, assim como pela transformação da "paisagem cultural" e dos modos de vida. O segundo local em que o conflito de planejamentos ocorre é a zona sul de Cercado. A ocupação pelos migrantes aymaras dos espaços destinados ao contato com a natureza (Cerro Verde e Cerro San Miguel) gerou, e continua gerando, dissensões. Verifica-se que a zona sul da cidade se caracteriza pela forte identidade indígena em geral, enquanto a área mais a sudeste é evidenciada pela territorialidade aymara, embora haja a presença desta etnia em toda a zona periurbana do município de Cercado, ainda que de forma incipiente.

A construção dessa territorialidade não se deu apenas com base na etnia, mas principalmente pelas precárias condições de vida e pelo menosprezo dos demais cidadãos que ali habitavam. Nesse caso, a criação de um verdadeiro território de risco ocorreu por causa da precariedade dos serviços básicos a que estão submetidos os migrantes aymaras. No entanto, essa construção territorial ocorreu também no sentido simbólico. 
Tabela 7. Composição do PIB de acordo com a atividade econômica, no Departamento de Cochabamba, Bolívia, entre 1965 e 2007.

\begin{tabular}{lcccccccccc}
\hline \multirow{2}{*}{ Atividade econômica } & \multicolumn{10}{c}{ Contribuição para a composição do PIB (\%) } \\
\cline { 2 - 10 } & $\mathbf{1 9 6 5}$ & $\mathbf{1 9 7 0}$ & $\mathbf{1 9 7 7}$ & $\mathbf{1 9 8 2}$ & $\mathbf{1 9 8 8}$ & $\mathbf{1 9 9 2}$ & $\mathbf{1 9 9 9}$ & $\mathbf{2 0 0 1}$ & $\mathbf{2 0 0 4}$ & $\mathbf{2 0 0 7}$ \\
\hline Agricultura & 31,9 & 23,0 & 20,1 & 26,4 & 19,6 & 18,1 & 11,2 & 10,7 & 11,2 & 10,9 \\
Mineração & 2,4 & 2,4 & 1,5 & 1,0 & 2,3 & 2,1 & 6,5 & 7,7 & 7,3 & 6,2 \\
Manufatura & 14,6 & 17,3 & 17,8 & 16,1 & 23,9 & 22,8 & 21,2 & 20,6 & 21,0 & 22,4 \\
Eletricidade & - & 2,2 & 2,2 & 3,1 & 2,8 & 2,8 & 1,8 & 1,9 & 2,0 & 2,0 \\
Construção & 4,9 & 4,8 & 4,6 & 2,0 & 5,9 & 4,5 & 3,4 & 3,0 & 2,8 & 2,8 \\
Comércio e finanças & - & 15,1 & 18,8 & 13,3 & 19,5 & 19,4 & 22,7 & 22,2 & 19,3 & 19,9 \\
Transporte e comunicações & - & 8,6 & 10,4 & 14,2 & 10,5 & 12,9 & 13,9 & 14,3 & 15,4 & 15,5 \\
Serviços de pessoal & - & 7,9 & 7,7 & 6,4 & 4,4 & 4,4 & 4,9 & 5,1 & 5,2 & 5,1 \\
Restaurantes e hotéis & - & - & - & - & 2,7 & 4,0 & 3,1 & 3,2 & 3,0 & 2,8 \\
Administração pública & - & 6,8 & 7,9 & 8,5 & 7,8 & 8,6 & 8,1 & 8,0 & 8,3 & 8,5 \\
Outros & 46,2 & 11,9 & 9,0 & 9,0 & 0,6 & 0,4 & 3,2 & 3,3 & 4,5 & 3,9 \\
\hline
\end{tabular}

Fonte: Laserna (1995, p. 94) e INE (2007). 
Tabela 8. PEA por setor de atividade nos municípios da região metropolitana de Cochabamba em 1992 e 2001.

\begin{tabular}{lcccccc}
\hline Município & \multicolumn{7}{c}{ PEA (\%) } \\
\cline { 2 - 7 } & \multicolumn{2}{c}{ Agricultura } & \multicolumn{2}{c}{ Indústria } & \multicolumn{2}{c}{ Comércio } \\
\cline { 2 - 7 } & $\mathbf{1 9 9 2}$ & $\mathbf{2 0 0 1}$ & $\mathbf{1 9 9 2}$ & $\mathbf{2 0 0 1}$ & $\mathbf{1 9 9 2}$ & $\mathbf{2 0 0 1}$ \\
\hline Cochabamba & 3 & 4 & 16 & 15 & 13 & 26 \\
Quillacollo & 22 & 14 & 17 & 17 & 16 & 22 \\
Sipesipe & 59 & 56 & 7 & 11 & 4 & 9 \\
Tiquipaya & 40 & 22 & 10 & 14 & 10 & 18 \\
Vinto & 41 & 34 & 12 & 13 & 8 & 16 \\
Colcapirhua & 8 & 9 & 23 & 20 & 17 & 22 \\
Sacaba & 31 & 19 & 12 & 15 & 6 & 19 \\
\hline
\end{tabular}

Fonte: INE (2005, p. 51-54).

A territorialidade formada pelos migrantes do altiplano era considerada de risco para os demais cochabambinos, dessa forma engendrando fortes tensões que se materializaram no território do Município de Cercado. Por outro lado, existe uma verdadeira hierarquia social materializando os espaços da discriminação (Mapas 9, 10,11 e 12).

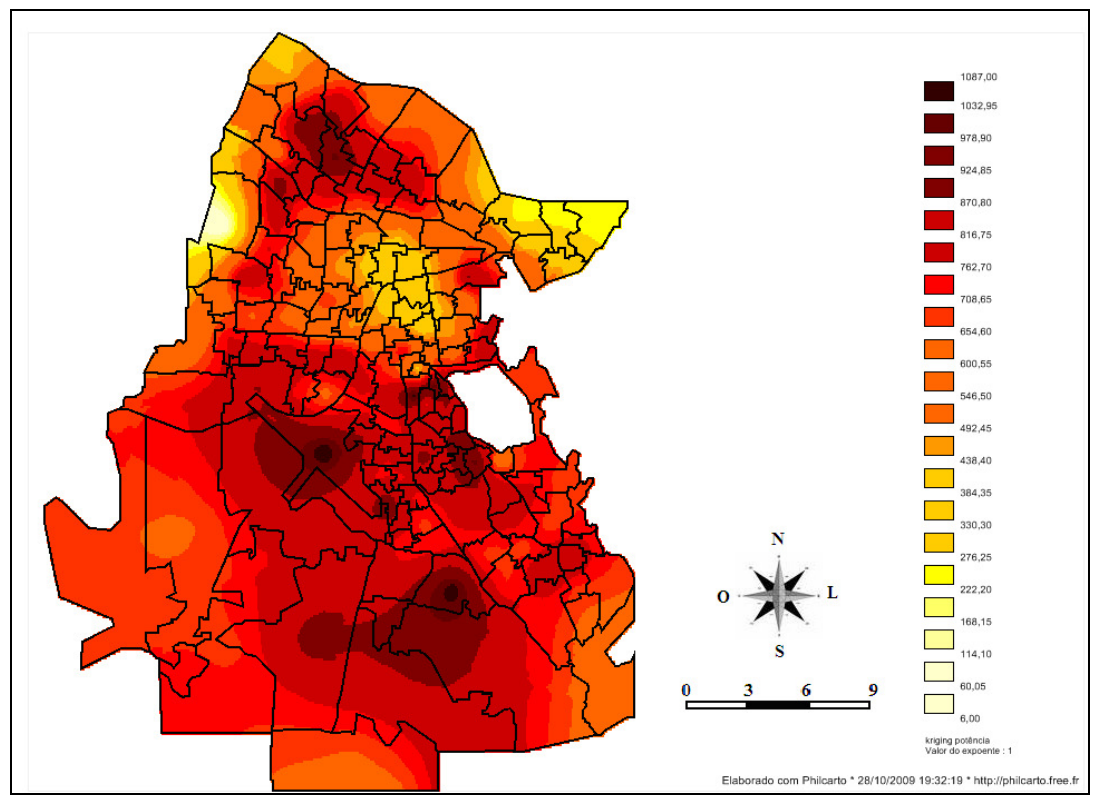

Mapa 9. Indivíduos do município de Cercado, região metropolitana de Cochabamba, que se autoidentificam com alguma etnia indígena, de acordo com as zonas de recenseamento em 2001.

Fonte: Organizado pelo autor com base em dados de INE (2001b). 


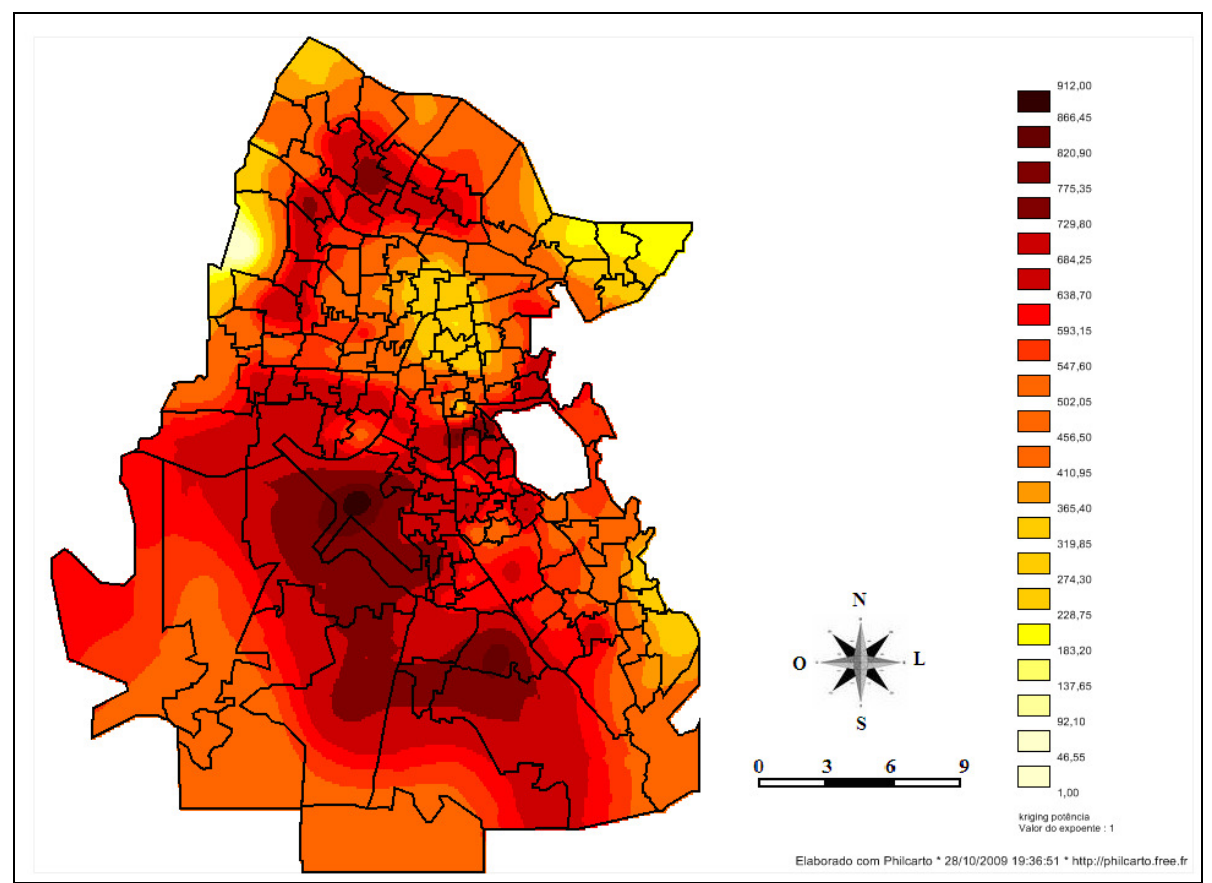

Mapa 10. Indivíduos do município de Cercado, região metropolitana de Cochabamba, que se autoidentificam com a etnia quéchua, de acordo com as zonas de recenseamento em 2001.

Fonte: Organizado pelo autor com base em dados de INE (2001b).

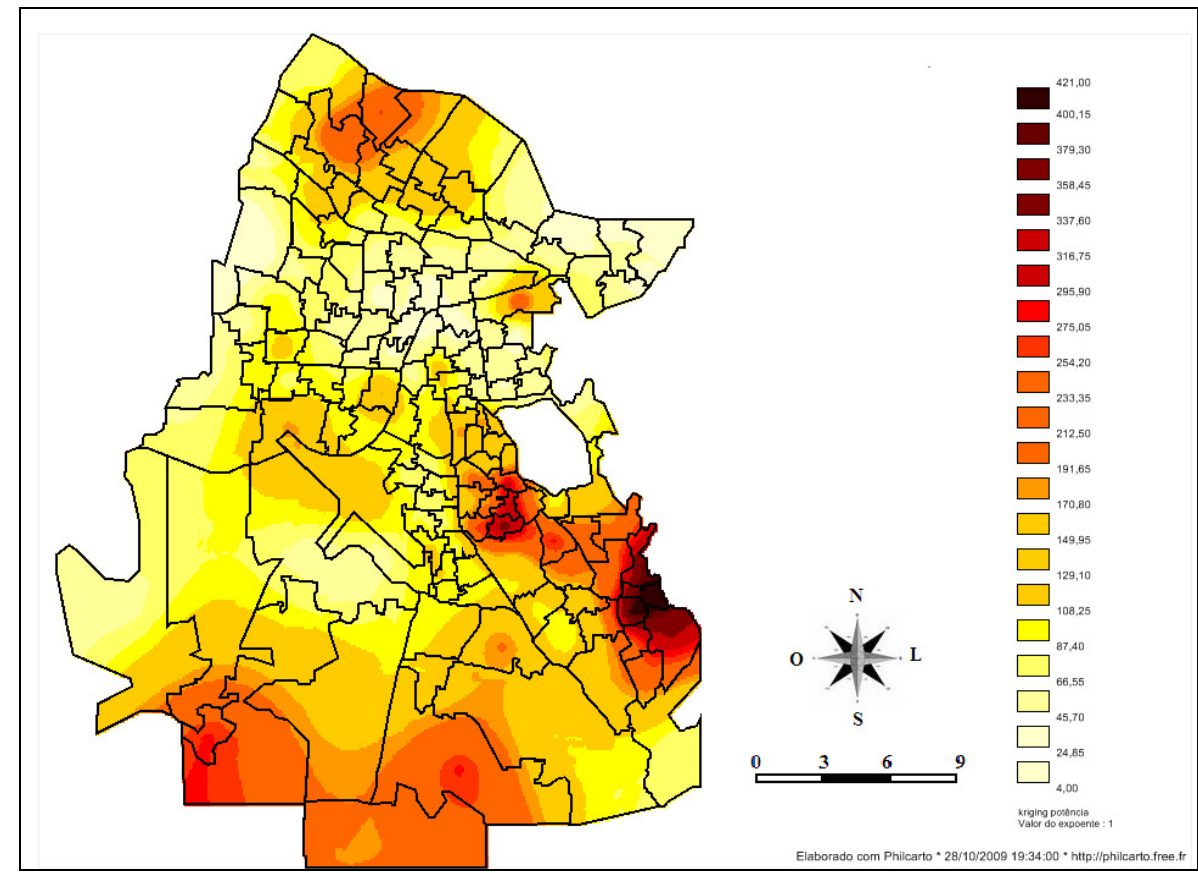

Mapa 11. Indivíduos do município de Cercado, região metropolitana de Cochabamba, que se autoidentificam com a etnia aymara, de acordo com as zonas de recenseamento em 2001.

Fonte: Organizado pelo autor com base em dados de INE (2001b). 


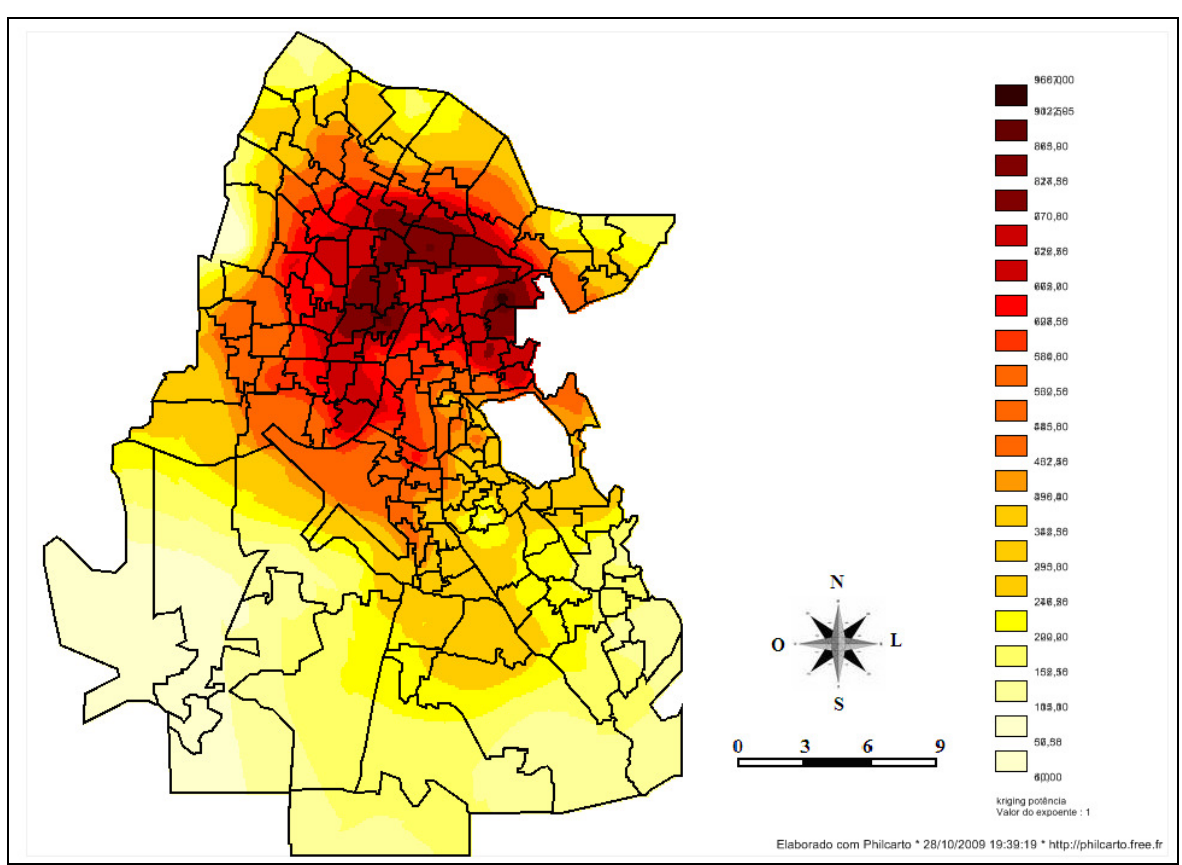

Mapa 12. Indivíduos do município de Cercado, região metropolitana de Cochabamba, que não se autoidentificam com qualquer etnia indígena, de acordo com as zonas de recenseamento em 2001.

Fonte: Organizado pelo autor com base em dados de INE (2001b).

Nota-se a forte ocupação do centro da cidade por aqueles que não se identificam com qualquer etnia, pertencentes principalmente aos estratos sociais urbanos mais altos. No entorno do núcleo urbano encontra-se uma zona de transição entre o centro e a área periurbana, constituída por um espaço ocupado pelos estratos médios urbanos compostos, em sua maior parte, por habitantes da etnia quéchua e indivíduos que não se identificam com qualquer etnia e, em menor proporção, por migrantes aymaras que conseguiram ascender na escala social. Os indivíduos que ocupam esta área intermediária trabalham majoritariamente no setor de transporte e nas indústrias que se situam às margens da Avenida Circunvalación, a qual une as estradas que ligam Cochabamba a Santa Cruz de la Sierra e a La Paz. Já a área mais meridional do município de Cercado destina-se aos que ocupam a escala mais baixa da hierarquia social, constituída, em sua grande maioria, por grupos étnicos. Aqueles que se autoidentificam como quéchua se ocupam em menor parte da agricultura no distrito agrícola de La Maica, uma das poucas áreas conservadas do cinturão verde. Outros ainda trabalham como obreiros no polo industrial que ali se situa e também em La Cancha. Mais a sudeste, se encontra a 
territorialidade aymara, ocupando-se prioritariamente do comércio informal em La Cancha, com uma menor parcela dedicada à agricultura em La Maica.

Outra marca do confronto dos planejamentos nacional e regional deixada na zona sul foi a fixação de uma série de objetos técnicos que não se encontravam no plano original de Urquidi Zambrana, como a construção do aeroporto internacional Jorge Wilsterman, da base aérea e de um polo industrial a partir da construção da refinaria Gualberto Villaroel. A fixação desses objetos se deu especialmente a partir da construção da rodovia ligando Cochabamba a Santa Cruz de la Sierra ainda nos anos 50 .

Como apontamos neste tópico, o planejamento nacional buscou a transformação da região do Vale Central, tornando-o um ponto de articulação entre as diferentes regiões do país. Para tanto, a implantação de diversos objetos conectados em rede procurava acelerar e aumentar os fluxos e a interação entre os complexos regionais bolivianos. Por outro lado, o planejamento regional buscava reordenar a cidade, porém de maneira equilibrada e controlada. Ademais, visava manter a identidade regional, circundando a cidade com um cinturão verde, com a finalidade de promover o abastecimento de produtos agrícolas e a manutenção da coesão urbana. Esse embate de visões diferentes não por acaso ocorreu a partir da década de 1950, quando Gottmann (1975) analisava o território por meio da tensão entre uma ideologia e a identidade regional (as iconografias), sendo constantemente desafiadas pelas forças dos objetos técnicos que aceleravam e transformavam as regiões (a circulação).

Mas por que tanto citamos território, quando nosso assunto principal é a relação entre conflito e água? Não estaríamos fugindo de nosso foco principal? Não devemos nos esquecer que o território influencia a relação dos atores com os recursos hídricos e, dessa forma, as tensões territoriais apresentadas neste tópico explicam uma boa parcela dos problemas relacionados ao conflito. Assim, devemos ressaltar que esse choque de planejamentos criou verdadeiros territórios de risco, também sendo responsável pela origem das diferentes territorialidades que se fizeram presentes durante o conflito de abril de 2000. 


\subsection{A LPP e os talleres zonales: segmentando ainda mais territórios já fragmentados}

A LPP (BOLIVIA, 1994c) trouxe uma série de mudanças para a organização territorial da Bolívia, enquanto em nível nacional se buscava maior autonomia econômica, sobretudo pela liberalização do comércio por meio da Lei № 1.544 (Ley de capitalización, Lei de capitalização) (BOLIVIA, 1994b), as comunidades locais também passaram a receber outras incumbências que antes estavam sob responsabilidade do Estado. Ao mesmo tempo, procurou-se descentralizar a estrutura do poder político por meio da criação das OTBs e, posteriormente, pela Lei no 1.654 (Ley de descentralización administrativa, Lei de descentralização administrativa) (BOLIVIA, 1995). Apresentamos aqui os resultados da aplicação da LPP na região do Vale Central de Cochabamba e sua relação com a Guerra da Água, principalmente ao acentuar conflitos políticos comunitários e discriminação social.

A LPP foi proposta com o intento de oferecer maior autonomia às comunidades, tanto nas áreas rurais quanto nas urbanas. $\mathrm{O}$ ordenamento territorial de 1972, vigente antes da aplicação da LPP, considerava como município apenas as áreas urbanas, enquanto as áreas rurais eram diretamente administradas pelo governo nacional. A implantação do novo ordenamento objetivava alcançar essencialmente quatro princípios: 1) expandir a jurisdição dos conselhos municipais para abranger as áreas rurais; 2) transferir a responsabilidade da administração da saúde, educação e infraestrutura aos conselhos municipais; 3) alocar recursos nacionais e fundos diretamente para os conselhos municipais, de acordo com o número de habitantes; 4) criar o Comitê de Vigilância a partir do qual as associações de bairros, assim como organizações camponesas e indígenas, poderiam ter acesso às decisões políticas em escala municipal (MAYORGA, 1997 apud SOLDAL, 2008).

A descentralização ocorria não apenas em termos políticos, por intermédio de mecanismos de fiscalização e poder de impedimento do Comitê de Vigilância em relação ao prefeito (alcade), mas também em termos fiscais. Empregando o mecanismo de co-participação tributária, o governo central redistribuiu $20 \%$ do que fora arrecado nacionalmente aos municípios a partir de uma contabilidade populacional (KOHL, 2002). Para isso, a reforma institucional foi colocada em prática 
com a criação das OTBs. Conforme o Decreto Supremo no 23.858 (BOLIVIA, 1994a), podem se tornar OTBs todas as juntas vecinales (associações de bairros), comunidades campesinas (comunidades camponesas), assim como pueblos indígenas (organizações indígenas).

Uma vez cadastradas as OTBs, seus líderes podem tanto eleger quanto ser eleitos representantes no Comitê de Vigilância. Além de poder controlar e mesmo propor o impeachment do alcalde, o Comitê de Vigilância ainda atua como órgão consultivo da administração pública para a aplicação dos fundos provenientes do mecanismo de co-participação tributária (Esquema 13). Dessa forma, o Comitê de Vigilância se tornou uma instituição popular de fiscalização com poderes nunca antes disponíveis aos cidadãos bolivianos.

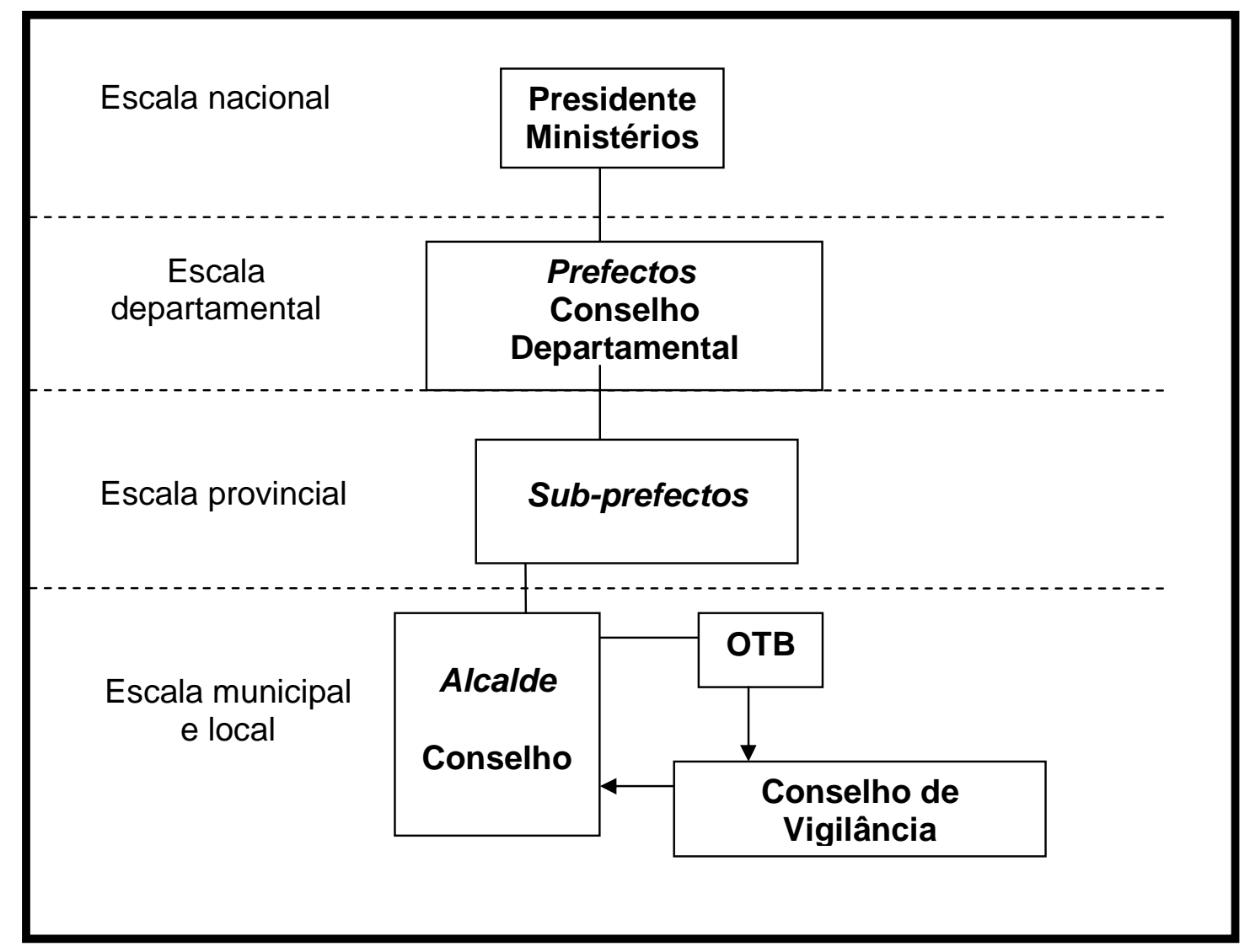

Esquema 13. Estrutura institucional do Estado boliviano após as reformas estruturais de 1994.

Fonte: Original do autor. 
Embora a LPP tenha apresentado uma série de avanços, como a maior participação política, várias críticas vêm sendo feitas aos resultados por ela promovidos e as discussões a respeito de seus efeitos na Bolívia têm sido controversas. A maior parte da literatura aponta que, em teoria, a LPP parecia ser um mecanismo que estimularia a descentralização do país. No entanto, na prática, notou-se que houve a cooptação dos líderes das OTBs por parte dos partidos e mesmo dos alcaldes.

Analisando a descentralização promovida pelo Estado boliviano a partir de 1994, Suvelza (2002) declarou que houve justamente uma antítese do ordenamento territorial anterior. Enquanto o ordenamento territorial de 1972 procurou descentralizar a partir do fortalecimento das funções do departamento, o de 1994 radicalizou e fortaleceu os municípios, enquanto os departamentos continuaram com pouca autonomia. Para o autor, houve principalmente uma quebra de hierarquia das escalas, muitas vezes implicando conflitos de competência ou atuação demasiada de uma escala sobre a outra.

Blanes (1999) também avaliou os resultados da LPP em algumas comunidades indígenas do Departamento de La Paz, após o que asseverou que mesmo os efeitos positivos comumente apresentados como vantagens trazidas pela LPP não podem ser atribuídos somente a ela. Isso é decorrência de um processo de modernização acentuada nas comunidades tradicionais, que já estava em marcha antes mesmo da aplicação deste diploma legal. Na opinião do autor, a maioria desses estudos se baseia mais em hipóteses gerais que em constatações.

Por outro lado, Blanes (1999) apontou alguns resultados promovidos pela LPP em La Paz: a) a relação entre as OTBs e seus dirigentes se dinamiza e se redefine, mas sua autoridade é debilitada; b) a solidariedade entre as comunidades é debilitada; c) o município se torna o eixo ordenador ante as territorialidades tradicionais; d) a cidadania municipal avança a partir das relações entre o governo municipal e as OTBs.

Estudando o caso de La Paz durante a Guerra do Gás, Ticona (2005) demonstrou que os mecanismos da LPP estabeleceram certas relações de poder baseadas no clientelismo. Afinal, o que parece ter ocorrido não foi a aceitação e a penetração das práticas sociais das comunidades indígenas e camponesas dentro 
do jogo político, mas antes o contrário. A esse respeito, Ticona (2005, p. 187-188, tradução nossa) revelou que:

[...] muitos dirigentes vicinais continuaram desempenhando esse papel de mediador dos partidos políticos, em funções do governo nacional e/ou municipal. A finalidade nem sempre foi buscar o desenvolvimento dos bairros, mas sim se beneficiar pessoalmente com os recursos econômicos vicinais, por intermédio de manejos dolosos. ${ }^{147}$

O geógrafo norte-americano Kohl (2002, p. 465, tradução nossa) também concordou com a afirmação de Ticona (2005) e ainda acrescentou que a LPP mudou a escala de oposição de forças:

Enquanto a Capitalização abre as fronteiras do país ao capital global, a LPP redireciona o foco de atenção dos movimentos populares da arena nacional para a local. Realmente, a LPP teve sucesso em mudar a direção de grande parte da resistência popular aos programas neoliberais recentes por meio da alocação de recursos suficientes para as municipalidades de forma a atrair a atenção das populações locais, o que também serviu para redefinir os espaços de oposição. ${ }^{148}$

Ao realizar esse movimento de escalas, a resistência se torna fragmentada e, simultaneamente, as relações sociais envolvendo diferentes atores são desmanchadas por tensões internas aos lugares ou mesmo entre lugares. Diminuindo a métrica das relações de poder para o lugar, muitas delas que se instituem a partir das escalas maiores acabam sendo esquecidas ou diluídas por outras mais próximas e, reiteradas vezes, mais intensas. Para o ex-líder mineiro, atualmente consultor da união dos produtores de coca, Kruse (1997 apud KOHL, 2002, p. 466, tradução nossa), "Com a participação popular, nós estamos lutando por centavos enquanto a Capitalização retirou todos os demais dólares da mesa". ${ }^{149}$

O aumento das tensões comunitárias, principalmente pela sobreposição das territorialidades "legais" e políticas, por meio das OTBs, sobre as territorialidades

\footnotetext{
147 " [...] muchos dirigentes vecinales han continuado desarollando ese rol de mediador de los partidos políticos, en funciones del gobierno nacional y/o municipal. La finalidad no siempre fue de buscar el desarrollo de los barrios, sino de beneficiar-se personalmente con los recursos economicos vecinales, a traves de manejos dolosos."

148 "While Capitalization opens the country's borders to global capital, LPP refocuses the attention of popular movements from national to local arenas. Indeed, the LPP successfully changed the direction of much of the popular resistance to recent neoliberal programs by allocating enough resources to municipalities to attract the attention of local populations, which has also served to redefine the spaces of opposition."

149 "With popular participation, we're fighting for pennies while Capitalization has taken all the dollars off the table."
} 
culturais construídas pelas relações culturais e sociais, também foi notada por Pierola (2006, p. 183, itálico do autor) no Departamento de Oruro:

[...] sustentamos que a LPP aprofunda e acelera processos de diferenciação social, dissolve formas de solidariedade territorial, debilita as relações entre as comunidades e suas autoridades, e coloca em primeiro lugar o valor do político diante do social. É um acontecimento que propicia que o estatal penetre e domine o social nos espaços públicos locais em todos os cantos do território nacional, e o município ocupa papel central no novo ordenamento territorial.

Blanes (1999, p. 29, tradução nossa) igualmente observou essa forma de sobreposição de territorialidades, implicando contradições e tensões em nível de lugar:

A percepção e o processamento da desigualdade geram processos de compensação mediante o uso crescente de "nós", com o qual os dirigentes se queixam de terem sido considerados como qualquer um. É a observação desde o interior da comunidade até o exterior, em direção ao município, onde já não são considerados como antes, como os de tal comunidade. Esse "nós" é diferente quando se fala dentro da comunidade, busca a imposição de hierarquias, falando de dentro para fora se busca a coesão interna frente à desagregação que provoca a relação no cenário do município. Nem sempre, o "nós", olhando para fora, reforça o "nós interno"; temos observado processos de fragmentação comunitária interna. [...] Essa relação entre o coletivo comunitário e o municipal, entre o comunitário e o individual é a base da grande ambiguidade que reveste as relações sociais neste âmbito das comunidades. ${ }^{150}$

Essas dissensões não se restringem apenas a conflitos de interesse, mas também a atos de violência coletiva, como acontece nos eventos de linchamentos de autoridades ou de pessoas relacionadas ao governo, como o episódio que ocorreu no município de Ayo Ayo. Refletindo a respeito dos motivos e das causas para o linchamento do alcalde de Ayo Ayo, Vilas (2008, p. 114, tradução nossa) afirmou que:

Da noite para o dia, a Bolívia saiu da centralização para a descentralização fiscal - o número de municípios com autonomia fiscal subiu de 24 para 314 - mas esses municípios não receberam treinamento ou estruturas para lidar com suas novas responsabilidades. As disputas pelos "fundos de

\footnotetext{
150 "La percepción y procesamiento de la desigualdad, genera procesos de compensación mediante el uso creciente del "nosotros", con el que los dirigentes se quejan de haber sido considerados como a cualquiera. Es la mirada desde el interior de la comunidad hacia fuera, hacia el municipio, donde ya no son considerados como antes, como los de tal comunidad. Este "nosotros" es diferente cuando se habla dentro de la comunidad busca la imposición de jerarquías, hablando desde adentro hacia fuera se busca la cohesión interna frente a la disgregación que provoca la relación en el escenario del municipio. No siempre el "nosotros", mirando hacia fuera, refuerza el "nosotros interno"; hemos observado procesos de fragmentación comunitaria interna [...] Esta relación entre lo colectivo comunitario y lo municipal, entre lo comunitario y lo individual es la base de la gran ambigüedad que revisten las relaciones sociales en este ámbito de las comunidades."
} 
coparticipação" fizeram com que as autoridades locais mergulhassem de cabeça na política nacional, alimentando e criando novos conflitos locais. ${ }^{151}$

Em Cochabamba, os resultados apresentados pela LPP não diferem muito do que vem acontecendo no restante do território nacional. Medeiros (2001), em um trabalho de campo no município de Arque, apontou que os mecanismos de participação popular não têm funcionado como deveriam, servindo, na verdade, tãosomente como mecanismos de controle da atuação de comunidades sobre as quais o Estado, anteriormente, sequer tinha ao certo conhecimento de sua existência. Por outro lado, a autora demonstrou que diferentes tensões também vêm surgindo na área:

[...] muito significativo é o fato de que o processo de implementação da lei, por si só, se tornou uma arena para o confronto entre moradores da vila e os camponeses da comunidade. Um local de contestação onde cada passo do processo, cada artigo da lei, instância ou função é suscetível a interpretações diferentes e contraditórias (MEDEIROS, 2001, p. 418, tradução nossa). ${ }^{152}$

Ademais, a autora ainda procurou demonstrar que mesmo com a aplicação dos mecanismos democráticos, existem "fronteiras" muito fortes e permanentes na sociedade boliviana, as quais não permitem um debate totalmente livre e democrático, assim como a própria forma de organizar a participação democrática implica, de certa forma, novas fronteiras:

É muito importante, contudo, considerar a ação sutil dessas estratégias hegemônicas, as linhas de fronteira já estabelecidas, os limites predefinidos para o que se pode conseguir no espaço aberto para os cidadãos participantes. Algumas limitações são inerentes à natureza do local e coexistem com as fronteiras reais do município. Assim, por exemplo, o pequeno município de Arque não pode sequer começar a contemplar as soluções para os níveis alarmantes de degradação ecológica que tão dramaticamente afetam toda a região dos vales inter-andinos (MEDEIROS, 2001, p. 419, tradução nossa). ${ }^{153}$

\footnotetext{
151 "Overnight Bolivia went from fiscal centralization to decentralization - the number of municipalities with fiscal autonomy went from 24 to 314 - but these municipalities were not given training or structures for coping with their new responsibilities. Fights over 'coparticipation funds' plunged local authorities headlong into national politics, feeding and creating new local conflicts."

152 "[...] very significant is the fact that the process of implementation of the law itself has become an arena for the confrontation between town dwellers and community peasants. A site of contestation where every step of the process, every article of the law, instance or function is susceptible to different and contradictory interpretations."

153 "It is really important, however to reckon with the subtle works of these hegemonic strategies, the boundary lines already set, the predefined limits to what can be achieved in the space opened for participatory citizens. Some limitations are inherent to the nature of the local and coextensive with the actual boundaries of the municipality. Thus, for example, the small municipality of Arque cannot even begin to envisage the solutions for the alarming levels of ecological degradation that so dramatically affect the whole region of inter-Andean valleys."
} 
No município de Cercado, esse processo também ocorre com muita frequência, particularmente no que concerne aos bairros situados nas zonas periurbanas. Goldstein (2005) assegurou que a implantação dos talleres zonales (posteriormente, das casas comunales) implicou ruptura do status quo estabelecido pelos líderes locais, sobretudo porque os valores comunitários acabavam sendo rompidos por valores tecnocráticos. Se, por um lado, boa parte da comunidade se sentia mais livre da atuação do poder dos líderes comunitários, por outro, a comunidade como um todo se tornava mais suscetível às manobras políticas por parte de diferentes atores políticos como consequência da falta de coesão social.

Essas tensões podem ter se manifestado por meio de ações coletivas violentas, reiteradas vezes contra atores não relacionados diretamente com a origem da tensão. A esse respeito, ao analisar os casos de linchamento no bairro de San Sebastian Pagador, na zona sul do município, Goldstein (2005, p. 393-394, tradução nossa) argumentou que:

O repentino surgimento de linchamentos a partir de 2000 não é, argumento eu, coincidência. A fúria popular contra o Estado neoliberal, fomentada desde a implementação da Nova Política Econômica (decreto lei 21.060) em 1985 , começou a se cristalizar e a encontrar expressão por volta da virada do milênio. Significativamente, 2000 foi o ano em que a "Guerra da Água" irrompeu em Cochabamba [...] Em 2000, as pessoas em Cochabamba tinham se tornado mais pobres e cada vez mais frustradas com o Estado privatizador, cujas promessas de grande prosperidade para todos claramente fracassaram em se materializar. ${ }^{154}$

As desigualdades e segregações promovidas pelo ajuste estrutural foram, ao longo do tempo, gestando tensões muito fortes em todo o território nacional. Naturalmente, dependendo do contexto espaço-temporal, diferentes motivações desencadeavam as tensões acumuladas durante esse tempo. No município de Cercado, mesmo antes da implementação da LPP, as iniciativas de descentralização e participação popular, por meio dos talleres zonales e do conselho municipal, ficaram marcadas negativamente, especialmente porque já vinham apresentando, de certa forma, os resultados mostrados atualmente pela LPP. Em 1992, por conta do impeachment do alcalde proposto pelo conselho municipal e em decorrência de lutas políticas, o município de Cercado ficou sem este tipo de autoridade por quase

\footnotetext{
154 "The sudden upsurge in lynchings since 2000 is not, I would argue, coincidental. Popular rage against the neoliberal state, brewing since the implementation of the New Economic Policy (state decree 21060) in 1985, began to crystallize and find expression around the turn of the millennium. Significantly, 2000 was the year the 'Water War' erupted in Cochabamba [...] By 2000, people in Cochabamba had become poorer and increasingly frustrated with a privatizing state whose promises of greater prosperity for all had clearly failed to materialize."
} 
um ano, fato semelhante também tendo ocorrido no município de Puerto Villaroel em 1999 (CÓRDOVA, 2001; HERBAS; LIZÁRRAGA, 2001).

Outro aspecto importante da LPP foi a distribuição da coparticipação tributária, principalmente no que se refere às áreas rurais e urbanas. Até 1994, havia duas Bolívias: uma rural e outra urbana. Com vista a corrigir essas desigualdades, o novo ordenamento territorial procurou conceder maior autonomia às áreas rurais por meio da distribuição de recursos fiscais, de forma a incentivar o desenvolvimento dos pequenos municípios baseados principalmente em áreas predominantemente rurais (ARIAS, 1999 apud KOHL, 2002). Porém, esse feito causou sérios problemas nas áreas urbanas. Como reiterou o diretor de pesquisas da Secretaria Nacional de Participacion Popular (SNPP), Rojas (1997 apud KOHL, 2002, p. 464, tradução nossa):

Nos maiores municípios - La Paz, Cochabamba, e Santa Cruz - o município tem pouca liberdade com relação ao que fazem com o dinheiro por causa das demandas das grandes cidades. Lá, o processo é o mesmo de sempre: vizinhanças brigando por recursos, ou em alguns casos partidos [membros da oposição política] tentando assegurar que o partido da situação não roube muito. Nos municípios menores e rurais, os padrões são diferentes. Primeiro, todo mundo edifica a praça central, reconstroi o prédio da escola, edifica um posto de saúde - tenham eles medicamentos ou não - e talvez eles comprem um jipe para o prefeito. ${ }^{155}$

Essa disputa por recursos dentro dos próprios municípios pode ser notada em Cercado. Enquanto os bairros mais humildes, principalmente os distritos 7, 14 e 9 da zona sul da cidade, recebem as menores quantias oriundas da coparticipação tributária, os distritos mais ricos recebem a maior parte (Mapas 13, 14, 15 e 16). Os projetos que são contemplados por verbas procedentes da coparticipação tributária e os distritos que devem recebê-las são escolhidos conjuntamente pelo alcalde, o conselho municipal e o comitê de vigilância quando da implementação de um Plano de Desenvolvimento Municipal. Porém, como salientou Blanes (1999, p. 16, tradução nossa):

Ao não contar com estruturas institucionais acabadas e modernas, a redistribuição dos recursos escassos entre populações muito pobres, para as quais sempre chegavam de forma paternalista e clientelista, se constituiu inevitavelmente em uma disputa pelos recursos, que neste como em outros

\footnotetext{
155 "In the large municipalities - La Paz, Cochabamba, and Santa Cruz - the municipality has little freedom in what they do with the money given the demands of the big cities. There the process is the same as always: neighborhoods fighting for resources, or in some cases [members of opposition political] parties trying to ensure that the ruling party doesn't steal too much. In the smaller, rural municipalities the patterns are different. First everyone does the plaza, redoes the school house, builds a health clinic - whether they have medicines or not - and maybe they by a jeep for the Mayor."
} 
casos se trata de obras. O lento reconhecimento legal das OTBs por parte da Alcaldia e da Prefectura impediu a realização de obras em vários cantões, isso se devendo ao desconhecimento dos procedimentos na aplicação da lei, assim como de seus direitos e obrigações neste novo marco do município. ${ }^{156}$

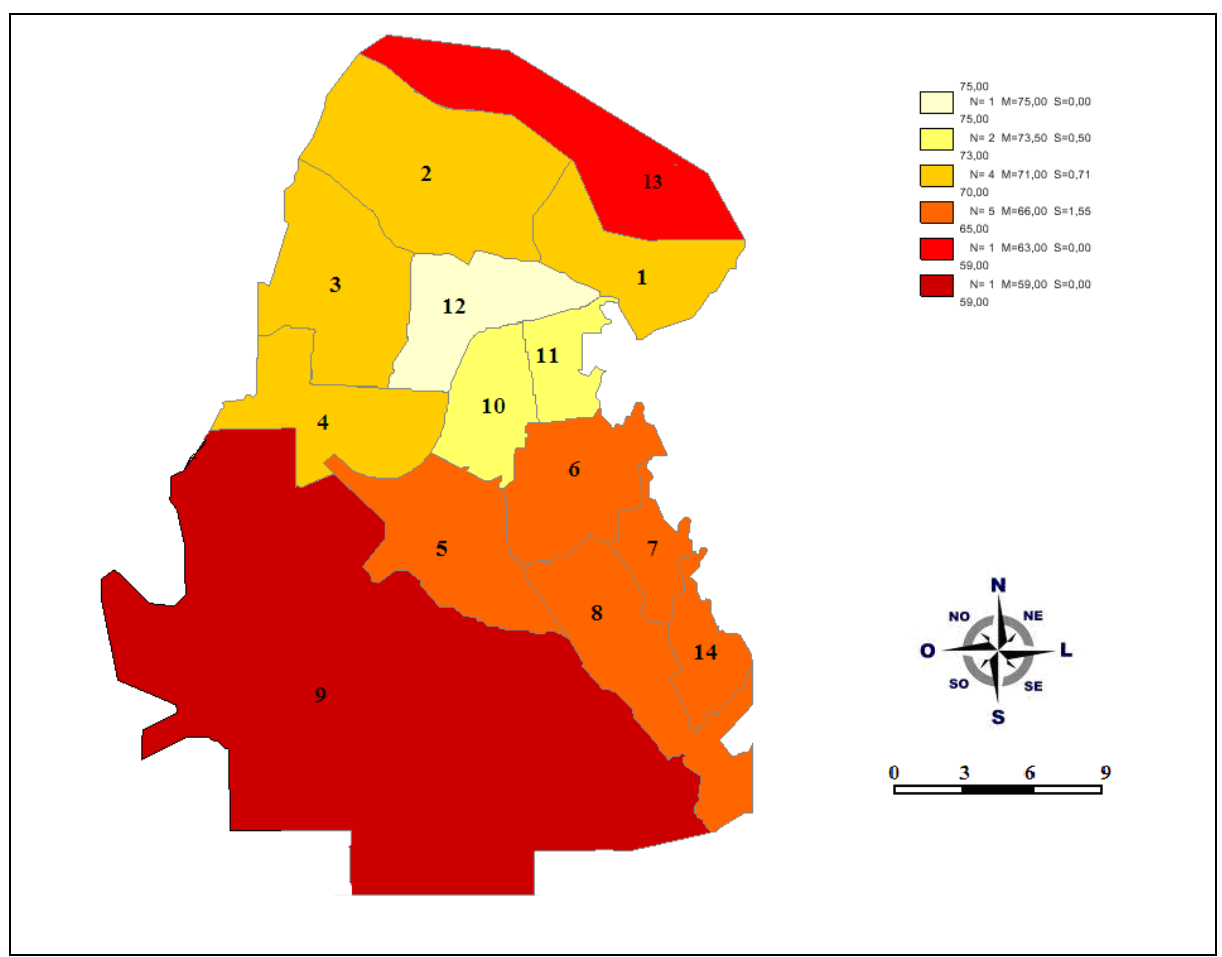

Mapa 13. Expectativa de vida ao nascer (anos) nos diferentes distritos municipais do município de Cercado, região metropolitana de Cochabamba, em 2000.

Fonte: Organizado pelo autor com base em dados de INE (2001b).

Por outro lado, quando comparamos os recursos recebidos pelos vários municípios da área metropolitana de Cochabamba, observamos que o município de Cercado é o que menos recebe recursos per capita (Tabela 9). Deve-se acrescentar que, de maneira geral, os municípios mais urbanizados necessitam de investimentos em infraestrutura mais elevados. Assim, tentar remediar os equívocos do antigo ordenamento territorial tem feito com que os principais centros do corredor econômico boliviano estejam sempre sob forte dificuldades financeiras para atender a todos os setores urbanos.

\footnotetext{
156 "Al no contar con estructuras institucionales acabadas y modernas la redistribución de los recursos escasos y entre poblaciones muy pobres y a las cuales se llegaba siempre de forma paternalista y clientelar, se constituyó inevitablemente en una disputa por los recursos, que en éste como en otros casos se trata de obras. El lento reconocimiento legal de las OTBs por parte de la Alcaldía y la Prefectura, impidió la realización de obras en varios cantones, debido ello al desconocimiento de los procedimientos en la aplicación de Ley, así como sus derechos y obligaciones en este nuevo marco de lo municipal."
} 


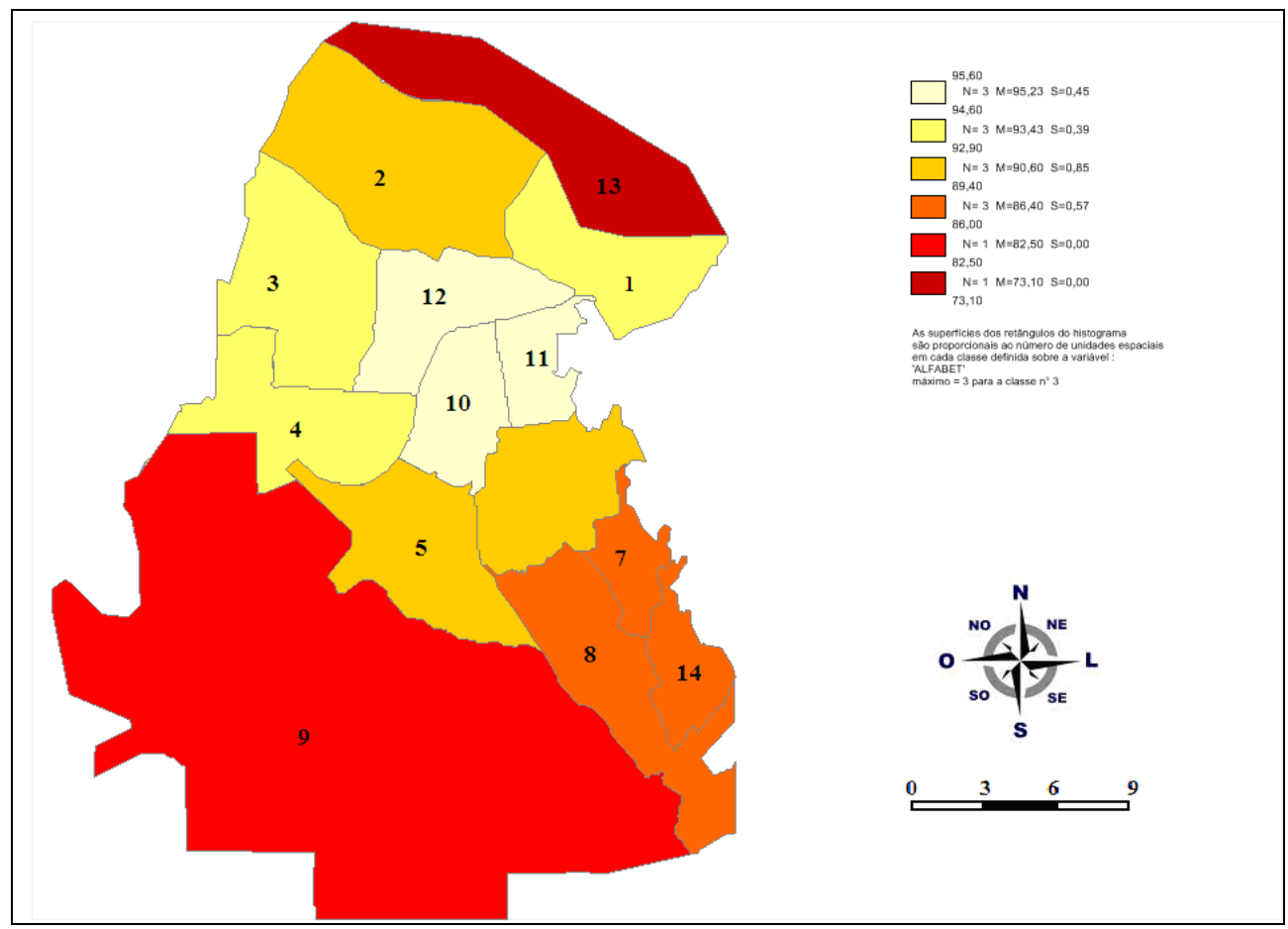

Mapa 14. Taxa de alfabetização (\%) nos diferentes distritos municipais do município de Cercado, região metropolitana de Cochabamba, em 2000.

Fonte: Organizado pelo autor com base em dados de INE (2001b).

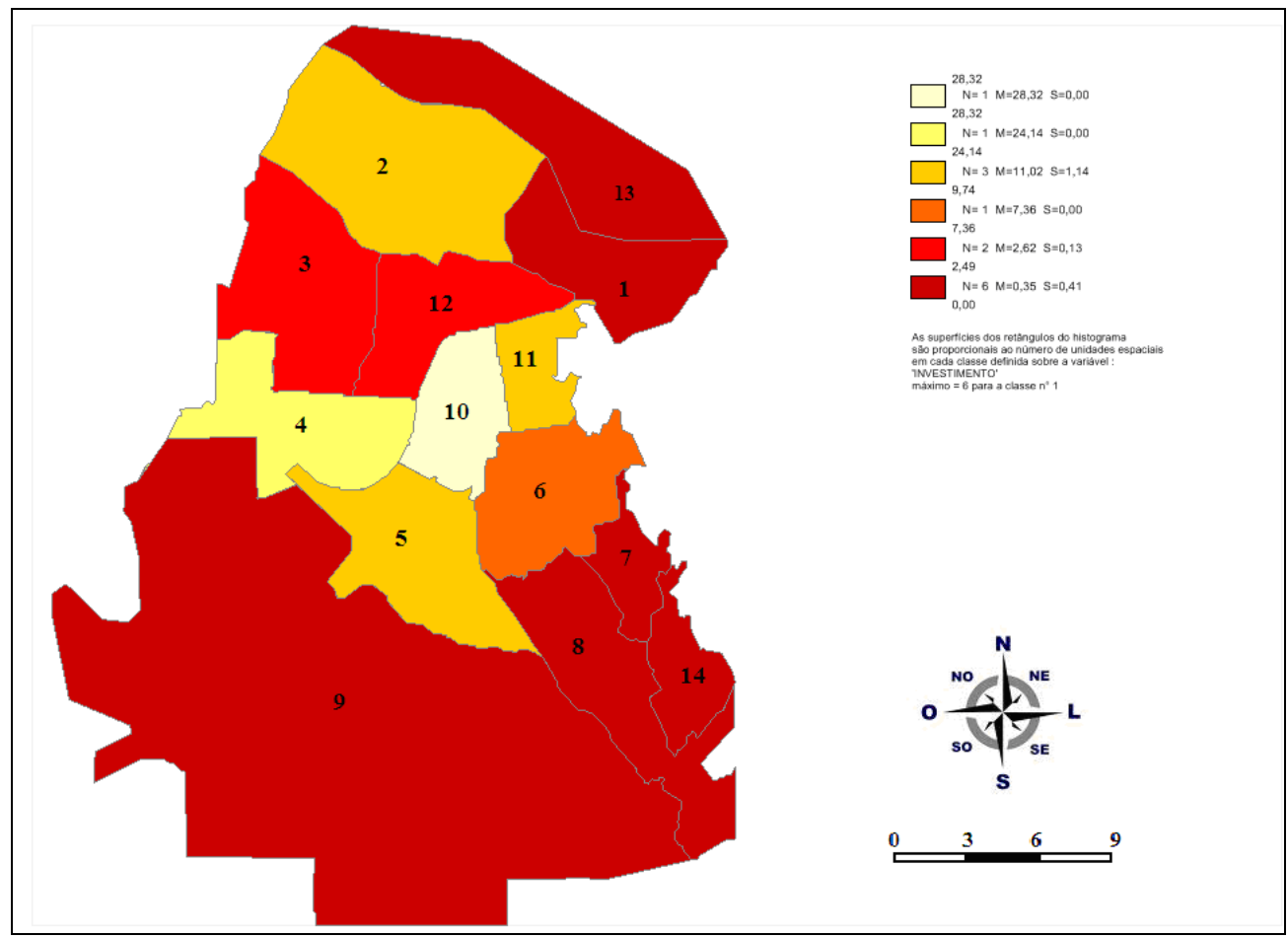

Mapa 15. Distribuição dos recursos provenientes dos mecanismos de coparticipação popular (\%) nos diferentes distritos municipais do município de Cercado, região metropolitana de Cochabamba, em 2000.

Fonte: Organizado pelo autor com base em dados de INE (2001b). 


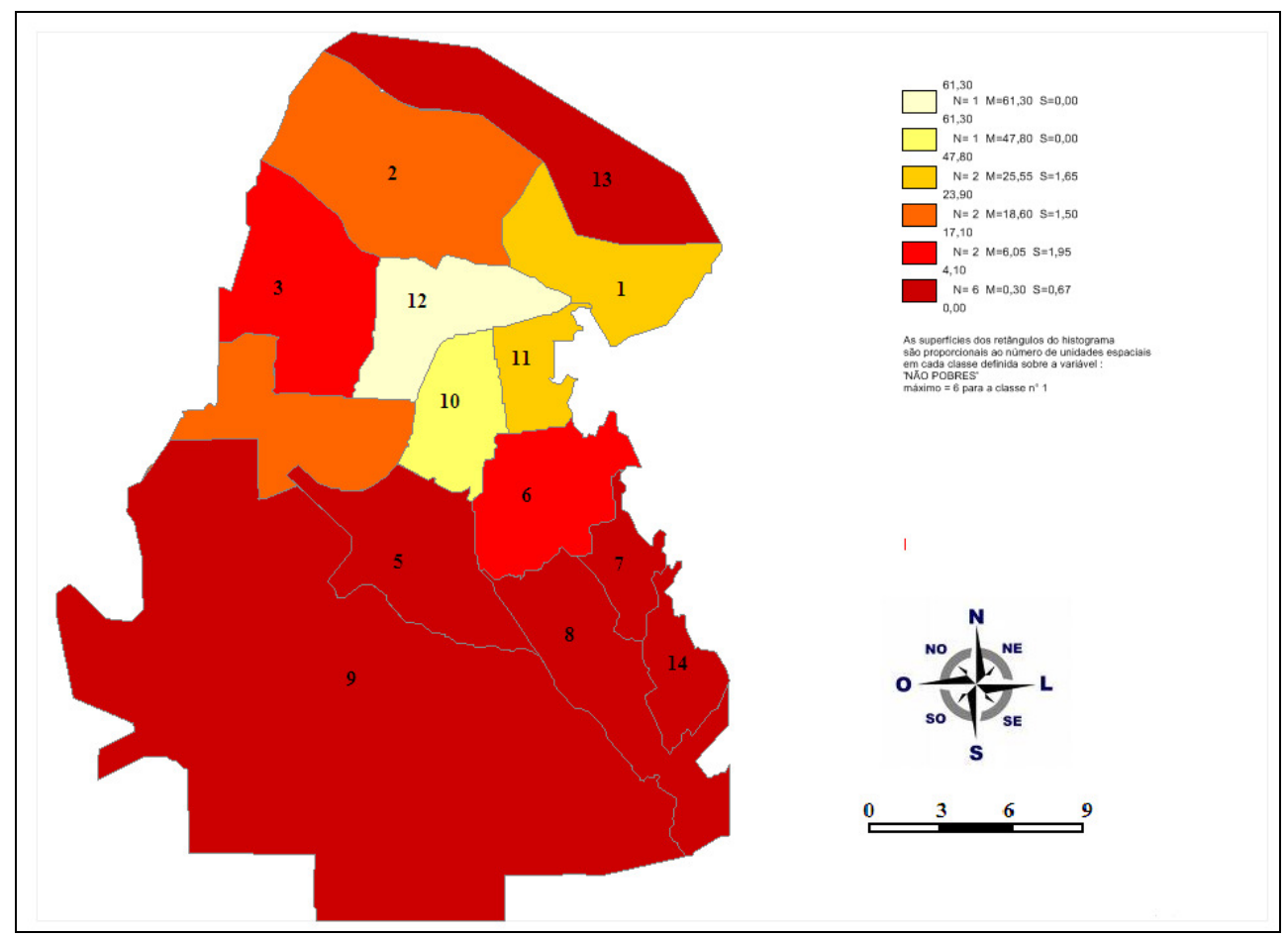

Mapa 16. População não-pobre (\%) nos diferentes distritos municipais do município de Cercado, região metropolitana de Cochabamba, em 2000.

Fonte: Organizado pelo autor com base em dados de INE (2001b).

Tabela 9. Investimentos públicos da Lei no 2.235 (BOLIVIA, 2001) e da Lei no 1.551 (BOLIVIA, 1994c) na região metropolitana de Cochabamba em 2002.

\begin{tabular}{lccccc}
\hline Município & $\begin{array}{c}\text { População } \\
\text { cadastrada } \\
\text { pelas OTBs } \\
\text { (no de } \\
\text { habitantes) }\end{array}$ & $\begin{array}{c}\text { Lei no 2.235 } \\
\text { (bolivianos) }\end{array}$ & $\begin{array}{c}\text { Lei no 1.551 } \\
\text { (bolivianos) }\end{array}$ & $\begin{array}{c}\text { Total } \\
\text { (bolivianos) }\end{array}$ & $\begin{array}{c}\text { Investimento } \\
\text { per capita } \\
\text { (bolivianos) }\end{array}$ \\
\hline Cercado & 425.081 & 18.650 .918 & 81.551 .679 & 100.202 .597 & 235,7 \\
Colcapirhua & 22.219 & 1.070 .383 & 4.262 .709 & 5.333 .092 & 240,0 \\
Quillacollo & 69.027 & 4.720 .983 & 13.242 .812 & 17.963 .795 & 260,2 \\
Sipesipe & 19.132 & 2.715 .251 & 3.670 .469 & 6.385 .720 & 333,7 \\
Tiquipaya & 13.371 & 1.973 .306 & 2.565 .223 & 4.538 .529 & 339,4 \\
Vinto & 21.448 & 2.238 .783 & 4.114 .793 & 6.353 .576 & 296,2 \\
Sacaba & 57.353 & 5.975 .225 & 11.003 .158 & 16.978 .383 & 296,0 \\
\hline
\end{tabular}

Fonte: Cálculos e organização do autor a partir de Instituto Nacional de Estadísticas (INE, 2005).

Adicionalmente, ao analisar a distribuição dos recursos provenientes da coparticipação tributária na escala municipal, verificamos que os distritos mais 
nobres têm recebido a maior parte deles, enquanto aqueles que mais necessitam de investimentos, principalmente aqueles da zona sul, têm recebido uma mínima parte. Dessa forma, quando se trata de municípios altamente urbanizados, a distribuição dos recursos entre distritos é decidida a partir do Plano de Desenvolvimento Municipal. Não obstante, como já abordamos anteriormente, a participação dos líderes de OTBs tem sido cooptada por partidos e mesmo pelo alcalde. Por isso, uma boa parte dos recursos é destinada aos distritos mais nobres sem que haja questionamento por parte dos líderes das OTBs e mesmo do comitê de vigilância. Além disso, percebe-se que o volume de investimentos em serviços de infraestrutura básica e saúde foi mínimo no período entre 1996 e 2000, o que demonstra que os recursos recebidos acabavam sendo manipulados apenas em prol do setor econômico e, primordialmente, em favor das classes mais abastados (Tabela 10).

Tabela 10. Distribuição de recursos dos investimentos municipais (em \%) por setor entre 1996 e 2000.

\begin{tabular}{lccccc}
\hline \multirow{2}{*}{ Setor } & \multicolumn{5}{c}{ Distribuição de recursos (\%) } \\
\cline { 2 - 6 } & $\mathbf{1 9 9 6}$ & $\mathbf{1 9 9 7}$ & $\mathbf{1 9 9 8}$ & $\mathbf{1 9 9 9}$ & $\mathbf{2 0 0 0}$ \\
\hline Infraestrutura urbana & 62 & 60 & 67 & 70 & 54 \\
Serviço de infraestrutura básica & 2 & 3 & 3 & 0 & 1 \\
lluminação & 7 & 5 & 3 & 2 & 2 \\
Sinalização nas ruas & 5 & 4 & 1 & 0 & 0 \\
Infraestrutura educacional & 6 & 11 & 0 & 15 & 25 \\
Infraestrutura de saúde & 0 & 0 & 0 & 0 & 0 \\
Ecologia e meio ambiente & 10 & 6 & 2 & 0 & 1 \\
Desenvolvimento social & 6 & 10 & 21 & 11 & 15 \\
Desenvolvimento esportivo & 0 & 1 & 1 & 1 & 1 \\
cultural & & & & & \\
Total em dólares norte- & 23.978 & 31.468 & 22.288 & 34.887 & 24.541 \\
americanos & & & & & \\
\hline
\end{tabular}

Fonte: Ledo García (2002, p. 219).

Destarte, a distribuição dos recursos tributários no município de Cercado e o planejamento urbano levaram adiante a lógica da segregação. $O$ drástico contraste entre os distritos da zona sul da cidade e o restante do município foi responsável 
pela constituição de uma "cidade dual". Antes mesmo dos acontecimentos da Guerra da Água, Ledo García (2000, p. 184, tradução nossa) parecia anunciar que as tensões urbanas se encontravam no seu auge e que poderiam, a qualquer momento, ser expressas em conflitos violentos:

Cochabamba é uma cidade dual: uma cidade onde as estruturas sociais e econômicas estão (competem?) uma contra a outra e ainda assim estão conectadas em uma malha dificilmente separável. Contudo, este vale tranquilo está se tornando um lugar de violência, fruto da discriminação e das tensões que afetam as pessoas todos os dias. A ostentação da luxúria deve produzir frustração e raiva, assim como desespero, em uma sociedade que não faz nada para superar as diferenças sociais. Há o começo de uma nova economia da segurança privada, de uma nova "estética do medo". O medo da delinquência contribui para criar distâncias e separações entre grupos. Há bairros fechados por todos os lados, especialmente na rica zona norte. Encontros em lugares públicos são cada vez mais tensos e até mesmo violentos: o medo e os estereótipos estão dominando as pessoas. ${ }^{157}$

Portanto, o arranjo territorial do Vale Central materializava uma estrutura rígida, principalmente levando-se em conta a forte diferenciação espacial na região metropolitana de Cochabamba. Além da segregação vinculada à dimensão econômica e social, ainda havia aquela relacionada aos recursos hídricos, como veremos mais à frente. Como bem analisou Goldstein (2005), existiam tensões muito fortes provocadas não apenas pelos efeitos da LPP, mas igualmente pela modernização promovida pelo planejamento do governo nacional no Vale Central de Cochabamba, especialmente em relação às áreas rurais com forte identidade indígena.

Essa estrutura rígida se expressa pela existência de territórios quase "exclusivos" em que há mínima sobreposição de territorialidades, representada pela constituição de três territorialidades inflexíveis e uma flexível, que garante certa estabilidade ao arranjo territorial urbano. A primeira é aquela dos migrantes da zona sul da cidade, caracterizados pela autoidentificação com a etnia aymara e ocupados no comércio informal do mercado La Cancha. A segunda é aquela dos camponeses indígenas das áreas rurais do Vale Central, construída principalmente pela forte

\footnotetext{
157 "Cochabamba is a dual City: a City where the social and the economic structures are (compete?) one against each other and yet are linked in a hard-to-unravel mesh. However this tranquil valley is turning into a place of violence, the fruit of discrimination and the stresses that affect people day in and day out. The ostentation of luxury must produce frustration and anger as well despair in a society that does not do anything to overcome that widening gap. There is the beginning of a new economy of private security, of a new 'aesthetic of fear'. Fear of delinquency contributes to creating distances and separation among groups. There are enclosed neighborhoods all around, especially in the well-to-do north. Meetings in public places are increasingly tense and even violent: fear and stereotypes are ruling people."
} 
ligação histórica com essas zonas, pela cultura quéchua da região e pelo trato com os recursos naturais. A terceira é aquela construída pelas classes mais altas de Cochabamba, representada por altos comerciantes e empresários bem-sucedidos, os quais souberam tirar vantagem dos investimentos feitos pelas políticas territoriais na região. Já a territorialidade flexível é híbrida, marcada não por uma identidade específica, mas por uma não-identificação com quaisquer dessas territorialidades anteriores. Além disso, a construção dessas territorialidades também se baseava no princípio de raça, simbolizada pelos descendentes de espanhóis que se faziam representar institucionalmente pela Corporação de Desenvolvimento de Cochabamba. Os demais habitantes da cidade os caracterizavam pelo termo "los q'aras", que simbolicamente se refere àqueles que exploram as pessoas com o fim de se tornar mais ricos (Quadro 5).

Quadro 5. Natureza das territorialidades na região metropolitana de Cochabamba.

\begin{tabular}{|c|c|c|c|c|}
\hline \multirow{4}{*}{ Dimensão social } & \multicolumn{4}{|c|}{ Territorialidade } \\
\hline & $\begin{array}{l}\text { Migrantes do } \\
\text { altiplano }\end{array}$ & $\begin{array}{l}\text { Camponesa } \\
\text { indígena }\end{array}$ & Elite dirigente & Híbrida \\
\hline & \multicolumn{4}{|c|}{ Etnia } \\
\hline & Aymaras & Quéchuas & Espanhola & Multiétnica \\
\hline Acesso à água & Caminhão pipa & $\begin{array}{l}\text { Poços e fontes } \\
\text { superficiais }\end{array}$ & $\begin{array}{l}\text { SEMAPA e poços } \\
\text { individuais }\end{array}$ & $\begin{array}{l}\text { SEMAPA e } \\
\text { poços } \\
\text { comunitários }\end{array}$ \\
\hline Lugar & $\begin{array}{l}\text { Zona sul do } \\
\text { Município de } \\
\text { Cercado }\end{array}$ & $\begin{array}{c}\text { Área rural dos } \\
\text { Municípios da } \\
\text { Região } \\
\text { Metropolitana }\end{array}$ & $\begin{array}{l}\text { Centro do Município } \\
\text { de Cercado }\end{array}$ & $\begin{array}{c}\text { Áreas } \\
\text { periurbanas } \\
\text { mais próximas } \\
\text { ao centro }\end{array}$ \\
\hline $\begin{array}{c}\text { Atividade } \\
\text { Profissional }\end{array}$ & Comércio informal & $\begin{array}{l}\text { Agricultura } \\
\text { familiar }\end{array}$ & Empresariado & $\begin{array}{l}\text { Trabalhador } \\
\text { fabril, } \\
\text { pequenos } \\
\text { comerciantes }\end{array}$ \\
\hline $\begin{array}{l}\text { Principal forma de } \\
\text { organização }\end{array}$ & $\begin{array}{l}\text { Associação de } \\
\text { bairros } \\
\text { (Junta Vecinal) }\end{array}$ & $\begin{array}{l}\text { Comunidades } \\
\text { camponesas }\end{array}$ & $\begin{array}{c}\text { Corporação de } \\
\text { Desenvolvimento } \\
\text { Regional; comitê } \\
\text { cívico }\end{array}$ & $\begin{array}{c}\text { Associação de } \\
\text { bairros (Junta } \\
\text { Vecinal) }\end{array}$ \\
\hline Natureza & $\begin{array}{l}\text { Rígida (inimigos } \\
\text { de Cochabamba) }\end{array}$ & $\begin{array}{l}\text { Rígida (povos } \\
\text { originários) }\end{array}$ & $\begin{array}{c}\text { Rígida (elite criolla, } \\
\text { los q'aras) }\end{array}$ & $\begin{array}{c}\text { Flexível } \\
\text { (por exclusão) }\end{array}$ \\
\hline Territorialidades & $\begin{array}{c}\text { Tradicional } \\
\text { (nativa } \\
\text { reterritorializada) }\end{array}$ & $\begin{array}{l}\text { Tradicional } \\
\text { (nativa } \\
\text { camponesa) }\end{array}$ & $\begin{array}{c}\text { Moderna } \\
\text { (econômica) }\end{array}$ & $\begin{array}{c}\text { Híbrida } \\
\text { (moderno- } \\
\text { tradicional) }\end{array}$ \\
\hline
\end{tabular}

Fonte: Original do autor. 
A rigidez dessas territorialidades se fundamentou a partir da existência de diversas relações sociais que foram se construindo a partir da diferenciação cultural, política, econômica e espacial. Assim, essas territorialidades foram se estruturando a partir da polarização social, tornando ainda mais tensas as relações sociais, uma vez que a diferenciação ia, cada vez mais, incluindo novas dimensões sociais. Uma exceção a essas territorialidades rígidas eram as áreas em que esses distintos territórios se sobrepunham, conformando áreas de contato mas não de articulação social e territorial completa entre seus polos, pelo contrário apresentando uma articulação incompleta, pois esta sobreposição acabava moldando uma nova identidade social por exclusão. Nessas áreas, se constituíram identidades sociais híbridas e móveis, porquanto a maior parte da população era constituída por estratos médios marcados culturalmente pela multietnicidade. Dessa forma, não havia uma diferenciação social tão contrastante como a existente entre o centro e a zona sul da cidade, embora houvesse a conformação de uma territorialidade flexível e híbrida permitindo mínima articulação entre as territorialidades rígidas.

Um dos exemplos mais emblemáticos dessas áreas é o de La Cancha, no qual, a partir das relações econômicas, essas três territorialidades rígidas acabam se articulando parcialmente por meio do comércio. No espaço desse mercado, boa parte do comércio informal dos moradores da zona sul e a produção dos pequenos agricultores do Vale Central abastecem clientes dos estratos médios e pobres urbanos, bem como os revendedores do comércio formal do centro da cidade. Assim, a articulação promovida por La Cancha permite que, de certa forma, haja um contato social, ainda que indireto, entre indivíduos que se consideram tão diferentes. Esse exemplo deixa claro que, apesar do arranjo territorial rígido, ainda há uma certa articulação, mesmo que incompleta, não permitindo a total segregação.

No período que antecedeu a Guerra da Água, o acesso aos recursos hídricos estava entremeado por uma série de outras relações de diferenciação, as quais configuraram um arranjo territorial rígido expresso pela coexistência mal articulada desses três tipos de territorialidades inflexíveis no Vale Central. Essa estrutura territorial que se estabeleceu em Cochabamba nada mais foi do que o resultado do confronto entre o planejamento nacional e regional desde meados dos anos 50 . Esse efeito foi intensificado pela aplicação da LPP, sobretudo porque, a partir desse momento, a lógica política se infiltrou nas comunidades e, dessa forma, a divisão da 
receita tributária endereçada pelo governo federal acabou sendo implementada, em sua maior parte, nos distritos mais nobres, já que esses tinham maior força política. Portanto, o desequilíbrio social urbano se agravou ainda mais, aumentando as tensões já fermentadas pelo ajuste estrutural nacional, assim como pelo programa Coca Zero, a partir do qual, muitos camponeses plantadores de coca se viram obrigados a migrar para o município de Cercado. Consequentemente, antes mesmo que o estresse hídrico se fizesse presente mais fortemente, já havia outras tensões marcantes na sociedade cochabambina.

\subsection{Histórico das políticas hídricas no Vale Central de Cochabamba}

As primeiras formas de gestão dos recursos hídricos no Vale Central de Cochabamba datam da implantação dos povos incaicos, a partir dos mitimaes e mitimaques. Cada etnia tinha a sua própria terra e seus próprios recursos hídricos, os quais eram considerados como unidades comunitárias ou, em língua nativa, como suyus. Como explica Zimmerer (2000, p. 156, tradução nossa):

Suyu se aplicava tanto a uma imagem de irrigação como à sua área de operação. Ecológica e culturalmente, o suyu em Cochabamba era a organização da irrigação de acordo com agrupamentos de campos alimentados por um canal principal e geridos de acordo com esta unidade baseada em canais [...] Além da irrigação, o termo suyu também se referia à divisão socioespacial de direitos e responsabilidades que estavam ligadas à gestão de outros recursos. ${ }^{158}$

Portanto, a gestão estava fortemente marcada por traços culturais ligados às práticas religiosas, que marcavam formas e direitos de uso, manutenção e desenvolvimento dos recursos hídricos, os chamados usos y costumbres. Essa forte tradição cultural sempre esteve profundamente enraizada nas tradições culturais do Vale Central de Cochabamba. Mesmo após a chegada dos espanhóis, boa parte desses direitos acabou sendo herdada, uma vez que encomenderos e hacendados espanhóis disputavam entre si a propriedade tanto da terra quanto dos recursos hídricos e uma forma de resolver as contendas foi o reconhecimento da herança dos

\footnotetext{
158 "Suyu applied both to an image of irrigation and to its actual area of operation. Ecologically and socially, the suyu in Cochabamba was the organization of irrigation according to the clusters of fields fed by a primary canal and managed according to this canal-based unit [...] In addition to irrigation, the term suyu also referred to the sociospatial division of rights and responsibilities that attached to the management of other resources."
} 
direitos de cada etnia colonizada para cada conquistador (SALAZAR ORTUÑO, 2000; ZIMMERER, 2000).

Em relação aos recursos hídricos, esses direitos eram representados pelos turnos de água, isto é, determinado período de tempo em que se possuía o direito de usar as águas de um rio ou lago durante o dia. Embora tenha havido essa herança por parte dos colonizadores espanhóis, isso não significava que o uso y costumbres e os sistemas de suyus fossem seguidos completamente (SALAZAR ORTUÑO, 2000). Como Zimmerer (2000, p. 164, tradução nossa) advertiu, "o uso da irrigação baseada nos suyus pelas fazendas coloniais nos vales de Cochabamba cresceu a partir de uma combinação do emprego seletivo e alteração das práticas já existentes" ${ }^{159}$ Então, em um primeiro momento, foi se constituindo uma apropriação das práticas incaicas por parte dos espanhóis como forma de adaptação às condições da região. Evidentemente, essa apropriação "seletiva" dos direitos indígenas e, principalmente, a remoção dos nativos para as reducciones confinadas nas encostas da cordilheira no Valle Bajo, trouxeram uma série de conflitos entre colonizadores e indígenas, especialmente no que se refere aos direitos pela água (ZIMMERER, 2000).

Após a fundação da Vila de Oropeza, em 1571, iniciou-se uma série de trabalhos hidráulicos objetivando o aprovisionamento de água para a população da vila. Naturalmente, tratava-se de uma minoria em comparação com as reducciones. Os primeiros objetos hidráulicos constituíram-se de caixas de água construídas com cal e pedra para captação das águas que fluíam das vertentes do rio Condorillo (SALAZAR ORTUÑO, 2000). A partir disso, os hacendados utilizaram-se de uma boa parte desses objetos hidráulicos como forma de manter seu poder em relação às autoridades da vila, os encomenderos, e principalmente em relação aos povos indígenas. Podemos mencionar como exemplo os trabalhos para o desvio do rio Condorillo em direção a La Chimba e La Maica (setor sudoeste do município de Cercado), pelo hacendado Martin de la Rocha, como forma de facilitar a irrigação de suas terras em detrimento das demais áreas, sendo atualmente, por este motivo, denominado rio Rocha (URQUIDI, 1971 apud SALAZAR ORTUÑO, 2000). Embora nesse período não houvesse escassez de água, o controle sobre os recursos era uma forma de demonstração de poder e controle sobre os demais atores. Por

\footnotetext{
159 "Use of suyu-based irrigation by colonial haciendas in the Cochabamba valleys grew from a mix of the selective borrowing and alteration of existing practices".
} 
conseguinte, as relações de poder sobre os recursos hídricos eram marcadas territorialmente pelo confronto entre haciendas e reducciones indígenas e entre haciendas e a vila de Oropeza, devendo-se ressaltar que os hacendados levavam clara vantagem nesta disputa.

Após a independência, o problema de aprovisionamento ruim de água para a cidade de Cochabamba se acentuou, mormente porque a maioria das fontes de água se situava em propriedades privadas com direitos outorgados a haciendas, povos indígenas, chacareros e outros centros urbanos. Entre 1825 e 1950, a responsabilidade pela gestão hídrica ficou a cargo do governo departamental (prefectura), que apesar de inúmeras tentativas não conseguiu solucionar o problema de escassez de água potável para a cidade de Cochabamba, em decorrência da falta de incentivos e investimentos do Estado. Apenas a captação de empréstimos foi facilitada pelo governo central. Por sua vez, a grande oligarquia rural de Cochabamba não exercia pressão sobre o governo central, pois o problema de falta de abastecimento público era remediado na zona rural pela existência de sistemas de irrigação e captação de água das vertentes e nascentes.

No intervalo entre 1808 e 1879, Cochabamba passou por prolongados períodos de seca em três oportunidades (entre 1808 e 1809, em 1857 e entre 1878 e 1879), os quais foram ainda mais intensificados pela contaminação das águas e a disseminação de epidemias, provocando milhares de mortes (SALAZAR ORTUÑO, 2000). A mais grave delas foi a do último período, nos anos de 1878 e 1879, em que morreram 2.871 e 2.673 pessoas na cidade de Cochabamba, respectivamente, configurando quase o dobro da taxa de mortalidade registrada para o período entre 1875 e 1878 (JACKSON, 1994). Os efeitos dessa crise de abastecimento de água, complicada pela disseminação de epidemias, pode ser comprovado, inclusive, pela redução da população do departamento entre 1854 e 1882 a quase metade (INE, $2001 b) .{ }^{160}$ No entanto, apesar da grave crise, nenhum conflito violento foi relatado para este período.

Em 1896, foi inaugurado o serviço de abastecimento de água potável de Cochabamba, em cuja construção foi empregado o primeiro sistema de conexões feitas de ferro e asfalto. Porém, devido à rigidez do material utilizado em uma zona

\footnotetext{
${ }^{160}$ A população total do Departamento de Cochabamba, que totalizava 322.900 pessoas em 1854 , passou a 176.600 pessoas em 1882.
} 
sísmica, o tempo de duração do encanamento não passou de 15 anos. Já em 1911, todo o encanamento estava completamente em ruínas e água consumida acabava sendo contaminada (SALAZAR ORTUÑO, 2000). Além da criação do serviço de abastecimento de água potável, outras obras também foram implementadas em consequência do crescimento populacional e, especialmente, da percepção, após as crises do século XIX, de que a cidade carecia de melhor infraestrutura de abastecimento deste insumo para superar as estações de seca mais drásticas. Somente em 1923, o abastecimento de água domiciliar foi implantado na cidade, contabilizando 639 domicílios aprovisionados com água e 407 com esgoto (SALAZAR ORTUÑO, 2000). Resta claro que essa infraestrutura estava longe de ser razoável, haja vista que em 1950, o sistema de aprovisionamento de água alcançava apenas 51\% dos domicílios de Cochabamba (SALAZAR ORTUÑO, 2000).

Durante esse período, a Ley de Dominio y Aprovechamiento de Aguas (Lei de Domínio e Aproveitamento de Águas) (BOLIVIA, 1906) considerava os recursos hídricos como propriedade privada e, em todos os momentos, a gestão da prefeitura respeitou essa propriedade particular das fontes de água utilizadas na irrigação e em nenhuma ocasião procurou restabelecer a posse pública ou mesmo redistribuir os direitos de água das fontes do Vale Central. Além disso, as principais autoridades da prefectura pertenciam à oligarquia rural, o que, por si só, já explicava o motivo de a cidade ser relegada a segundo plano quando a questão era abastecimento público. Esse período ficou marcado pelo confronto territorial entre a área urbana e a rural. Devemos salientar, ainda, que a própria lei reconhecia o uso y costumbres das comunidades indígenas camponesas. Assim, a territorialidade indígena que, anteriormente, se via em desvantagem, nesse período passou a ter melhores condições de abastecimento de água que a área urbana do município de Cercado.

A cidade de Cochabamba chegou à metade do século $X X$ produzindo apenas 30 litros de água por dia para cada habitante, volume considerado insuficiente, principalmente levando em conta as temporadas de forte seca que ali ocorrem. Outro aspecto importante que se pode perceber é que, desde 1825, o sistema de abastecimento público pouco avançou em relação à quantidade per capita aprovisionada (Tabela 11). Em adição a isso, deve-se ressaltar a péssima qualidade da água consumida, consequente ao péssimo estado do sistema de encanamento, constantemente afetando a população urbana que se via afligida por enfermidades. 
Tabela 11. Oferta líquida de água potável de diferentes fontes para o município de Cercado entre 1825 e 1950.

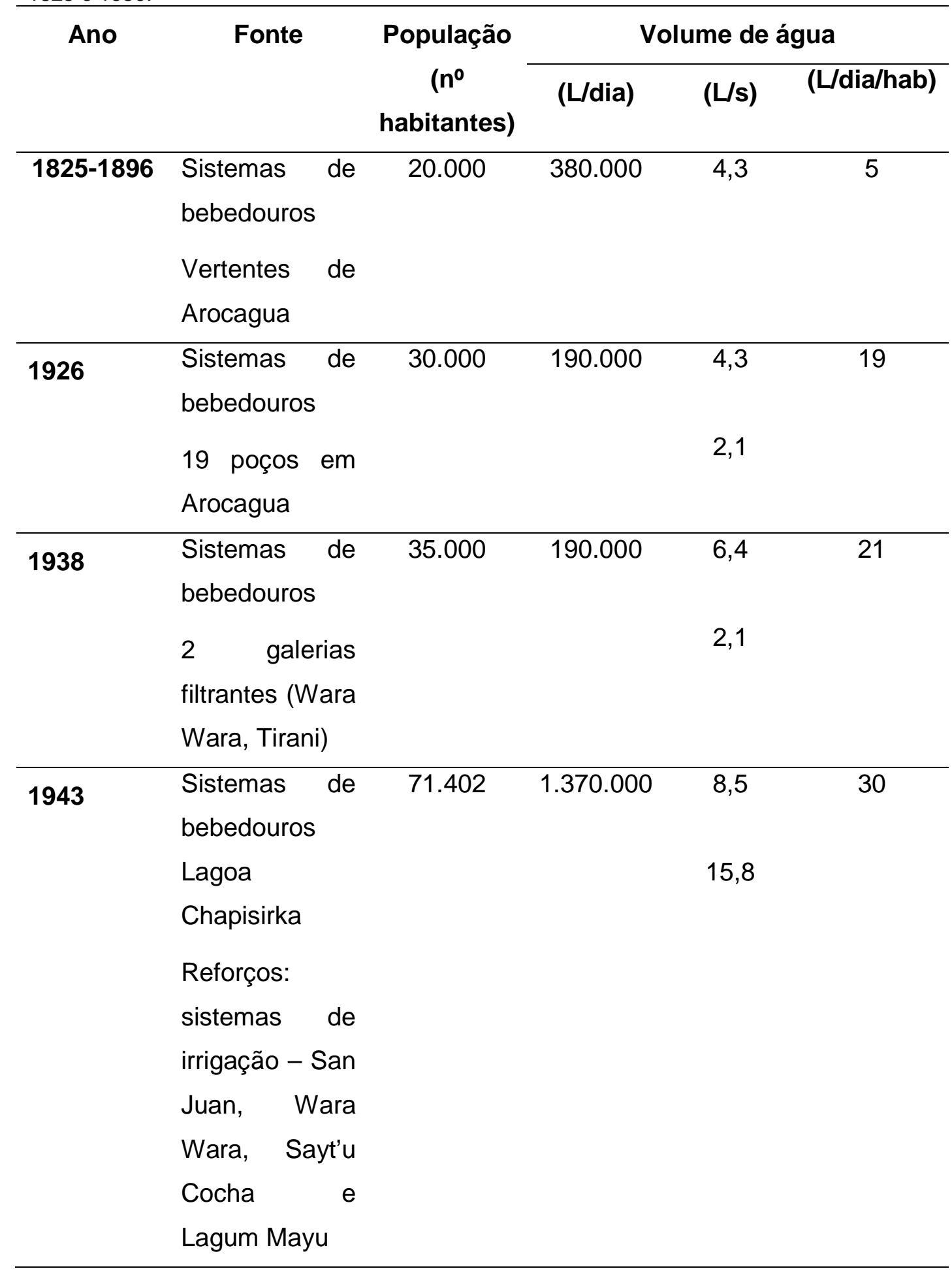

Fonte: Salazar Ortuño (2000, p. 10, tradução nossa).

Após a revolução de 1952, as reformas estatais procuraram descentralizar as responsabilidades do Estado, uma vez que a concentração excessiva de tarefas 
acabava por engessá-lo, efeito bem expresso pela falência das políticas hídricas em Cochabamba. Nessa perspectiva, a partir da criação do Departamento de Águas, a gestão dos recursos hídricos deixou de ser ofício do governo departamental e passou a ser responsabilidade do município. Durante os 17 anos de gestão municipal, dois projetos foram colocados em prática. O primeiro foi a perfuração de poços artesianos na cidade financiada pela cobrança de tarifas e o segundo foi a expropriação das Lagoas San Juan e San Pablito.

Nesses 17 anos, o Estado não procurou financiar ou investir fundos nacionais na resolução dos problemas hídricos do Vale Central. Por conseguinte, o governo municipal se viu obrigado a procurar outras soluções a partir de financiamentos do Banco Interamericano de Desenvolvimento (BID). Porém, esta instituição condicionava a outorga dos financiamentos à criação de um órgão independente do município: o SEMAPA. Em conformidade com isso, Salazar Ortuño (2000, p. 13, tradução nossa) relatou que:

O novo enfoque de administração que era incentivado pela alcaldia de Cercado não levava em conta a situação vigente, no uso e na demanda de novas fontes de água para os municípios e comunidades do Vale Central, os quais devido ao crescimento demográfico demandam maior quantidade de água para o consumo humano, para os novos produtos agropecuários, para intensificar a produção, impulsionar o crescimento industrial [...] $]^{161}$

Esse planejamento micro, apenas em nível municipal, foi responsável pelo surgimento de tensões, sobretudo no que diz respeito à população dos demais municípios. Essa relação conflituosa entre o município de Cercado e a população dos demais municípios pelas fontes subterrâneas no Vale Central de Cochabamba ocorreu precipuamente por falta de um plano regional que levasse em conta a gestão dos recursos hídricos de forma conjunta e não segmentada. Assim sendo, a partir dos anos 60, as relações de poder atinentes aos recursos hídricos incluíram de forma mais intensa no confronto o SEMAPA e o município de Cercado contra a população dos demais municípios do Vale Central, principalmente das áreas rurais. Logo, aquele intento de modernização radical da região do Vale Central pelas políticas territoriais foi, aos poucos, estruturando uma série de tensões, as quais

\footnotetext{
161 "El nuevo enfoque de administración que se impulsaba desde la alcaldia de Cercado, no tomaba en cuenta la situación vigente en el uso y demanda de nuevas fuentes de agua para los municipios y comunidades del Valle Central, las cuales debido al crecimiento demográfico, demanda mayor cantidad de agua para consumo humano, para los nuevos productos agropecuarios, para intensificar de la producción, impulsar el crecimiento industrial [...]"
} 
giravam em torno da modernização regional confrontada especialmente pela existência de uma população com forte identidade estabelecida nas áreas rurais.

Pode-se verificar na Tabela 12 que quase todos os municípios da região metropolitana de Cochabamba tiveram poços perfurados em seu território para satisfazer as necessidades hídricas daquele município. Porém esse enfoque a curto prazo, voltado apenas para a perfuração de poços, se mostrou ineficiente, fundamentalmente porque o volume caudal desse projeto, em todos os casos, se revelou menor que o esperado. Evidentemente, o planejamento regional para o Vale Central, criado ainda nos 50, não procurava criar um órgão regional de gestão dos recursos hídricos. Consequentemente, cada município possuía um órgão de gestão para os recursos hídricos e, na maioria das vezes, os órgãos das diferentes localidades não dialogavam entre si. Posteriormente, com a descentralização da gestão hídrica pela criação do SEMAPA, esse relacionamento entre órgãos gestores se tornou ainda mais difícil.

Tabela 12. Poços perfurados pelo SEMAPA no Vale Central de Cochabamba entre 1979 e 1992.

\begin{tabular}{lcccc} 
Localidade & $\begin{array}{c}\text { Poços } \\
\text { perfurados } \\
\left(\mathbf{n}^{\circ}\right)\end{array}$ & Custo (\$US) & $\begin{array}{c}\text { Produção } \\
\text { esperada } \\
(\mathbf{L} / \mathbf{s})\end{array}$ & $\begin{array}{c}\text { Produção } \\
\text { real em 1998 } \\
(\mathbf{L} / \mathbf{s})\end{array}$ \\
\hline Cercado & 12 & \pm 1 milhão & 105 & 32 \\
Colcapirhua & 6 & 458.500 & 105 & 0 \\
Sacaba & 6 & - & - & - \\
Vinto & 10 & - & 126 & 67 \\
Quillacollo & 5 & - & 150 & 0 \\
Coña Coña & 9 & - & - & 0 \\
Tiquipaya & 3 & $>1.5$ milhões & 150 & 0 \\
El Paso & 22 & $>3$ milhões & $>500$ & 348
\end{tabular}

Fonte: Documentos e Informes da Gerencia de Operação SEMAPA (1995, 1996, 1997, 1998 apud SALAZAR ORTUÑO, 2000, p. 16, tradução nossa).

Isso denota a falta de um planejamento regional que levasse em conta não apenas o ordenamento territorial, mas também a gestão dos recursos hídricos, o que, na maior parte das vezes, foi responsável pelo surgimento de conflitos de 
interesses entre as comunidades camponesas da região metropolitana e o SEMAPA, essencialmente porque os usos y costumbres das comunidades indígenas camponesas não estavam sendo respeitados.

Por outro lado, desse período em diante, começou a ser notada a penetração dos atores de escalas maiores na região, principalmente como resultado do financiamento de projetos, dando início à estruturação do shatterbelt e à sobreposição das territorialidades dos protagonistas da escala sul-americana e global, implicando diferentes projetos e interesses na região. Claramente, essa abertura foi se dando gradualmente, a partir da ascensão dos governos militares na Bolívia, que teve seu início em 1964. Entre 1970 e 1992, o SEMAPA recebeu mais de 51 bilhões de dólares de diferentes financiadores internacionais (Tabela 13). A consecução desses financiamentos não sem dava sem que certos requisitos fossem cumpridos, tal como a descentralização do órgão gestor dos recursos hídricos quando da criação do SEMAPA. Assim, vários outros interesses na gestão hídrica da região foram se sobrepondo aos interesses locais e regionais.

A despeito dos pesados investimentos na perfuração de poços, a desigualdade no acesso aos recursos hídricos continuou fortemente marcada pela segregação da zona sul, que continuava sem acesso ao aprovisionamento público de água e esgoto. Em adição a isso, deve-se destacar que as más condições de vida dos habitantes da área não se vinculavam apenas ao abastecimento de água, mas basicamente à falta de atendimento médico, segurança e serviços básicos, expressos pela própria ausência do Estado.

Deve-se acrescentar, ainda, que o serviço de abastecimento de água em Cochabamba era prestado de forma discriminatória, uma vez que os bairros mais nobres tinham acesso a maior volume de água, mesmo durante períodos de racionamento. Corroborando essa afirmação, Ledo (2006) apontou que o consumo de água nos domicílios de melhor qualidade de Cochabamba era seis vezes maior que o daqueles considerados de má qualidade. Mélançon (2005, p. 92), em seu trabalho de campo em Cochabamba, mostrou que o acesso à água dos domicílios localizados nos bairros menos abastados de Cochabamba (categoria 1), ainda que conectados à rede de distribuição, é restrito, uma vez que recebem o serviço apenas durante 5 horas por dia, enquanto nos bairros mais nobres (categoria 4), os domicílios recebem o serviço, na maior parte das vezes, durante as 24 horas do dia. 
Também vimos anteriormente que a situação se torna ainda mais calamitosa pela falta de repasse dos investimentos provenientes da LPP. Os distritos mais necessitados recebem apenas $2 \%$ desses recursos financeiros, ou seja, a segregação e a discriminação espacial em relação aos bairros da zona sul vêm sendo perpetuadas desde antes do conflito.

Tabela 13. Síntese dos principais investimentos internacionais no SEMAPA entre 1970 e 1992.

\begin{tabular}{|c|c|c|c|}
\hline Ano & $\begin{array}{c}\text { Fonte de } \\
\text { financiamento }\end{array}$ & Uso do crédito & Investimento (\$US) \\
\hline 1970 & $\mathrm{BID}, 159 / \mathrm{SF}-\mathrm{BO}$ & $\begin{array}{l}\text { Infraestrutura; } \\
\text { melhorias em } \\
\text { Escalerani; } \\
\text { perfuração de } 4 \\
\text { poços }\end{array}$ & 3.800 .000 \\
\hline $1975-1983$ & $\mathrm{BID}, 414 / \mathrm{SF}-\mathrm{BO}$ & $\begin{array}{c}\text { Infraestrutura; } \\
\text { melhorias em } \\
\text { Escalerani, San } \\
\text { Juan, San Pablito, } \\
\text { Wara Wara, } \\
\text { Chungara e } \\
\text { Arocagua; } \\
\text { perfuração de } 38 \\
\text { poços }\end{array}$ & 25.729 .827 \\
\hline 1987 & $\begin{array}{l}\text { Banco Central } \\
\text { Argentino }\end{array}$ & Perfuração de poços & 980.593 \\
\hline 1991 & $\begin{array}{l}\text { Banco Mundial - } \\
\text { JICA }\end{array}$ & $\begin{array}{l}\text { Reparo de poços; } \\
\text { reinstalação de } 16 \\
\text { bombas; } \\
\text { perfuração de } 15 \\
\text { poços }\end{array}$ & 1.200 .000 \\
\hline 1992 & Governo francês & $\begin{array}{l}\text { Perfuração de } 2 \\
\text { poços profundos } \\
(500 \mathrm{~m}) \text { e } 6 \\
\text { semiprofundos } \\
(240 \mathrm{~m})\end{array}$ & 5.833 .333 \\
\hline Total & & & 51.477 .753 \\
\hline
\end{tabular}

Fonte: Documentos e Informes da Gerencia de Operação SEMAPA (1995, 1996, 1997, 1998 apud SALAZAR ORTUÑO, 2000, p. 15, tradução nossa).

Às vésperas da Guerra da Água, o SEMAPA se via às voltas com vários problemas operacionais. Em primeiro lugar, não conseguia abastecer de água toda a população do município de Cercado. Em segundo lugar, a infraestrutura para abastecimento de água era completamente ineficiente, pois $54 \%$ de toda a água distribuída era perdida (NICKSON; VARGAS, 2002; SEMAPA, 2002) e o SEMAPA empregava 4,7 funcionários para cada 1.000 conexões, o dobro das demais empresas de abastecimento de água na Bolívia. Em 1997, o sistema de captação de 
água do SEMAPA produzia apenas $500 \mathrm{~L} / \mathrm{s}$, quando tinha capacidade para produzir $645 \mathrm{~L} / \mathrm{s}$ (BARRAGÁN et al., 1998). Graças a esse pífio desempenho e também à negligência do Estado boliviano em relação à região, o SEMAPA acumulava uma dívida de 30 milhões de dólares (NICKSON; VARGAS, 2002). Devido a todas essas circunstâncias, o SEMAPA não pode cumprir todos os requisitos para receber um financiamento de 75 milhões de dólares do Banco Mundial (SOLDAL, 2008).

Até então, o abastecimento de água promovido pelo SEMAPA se baseava precipuamente na captação de água subterrânea dos poços perfurados em Vinto e no distrito de Paso, os quais contabilizavam mais da metade de toda a água captada. Ademais, em sua maior parte, as águas superficiais captadas eram provenientes das canalizações implantadas ainda nos anos 70 , aproveitando as águas de lagoas no alto da cordilheira, pois a água do rio Rocha é imprópria para o consumo (Fotografia 3 e Tabela 14).

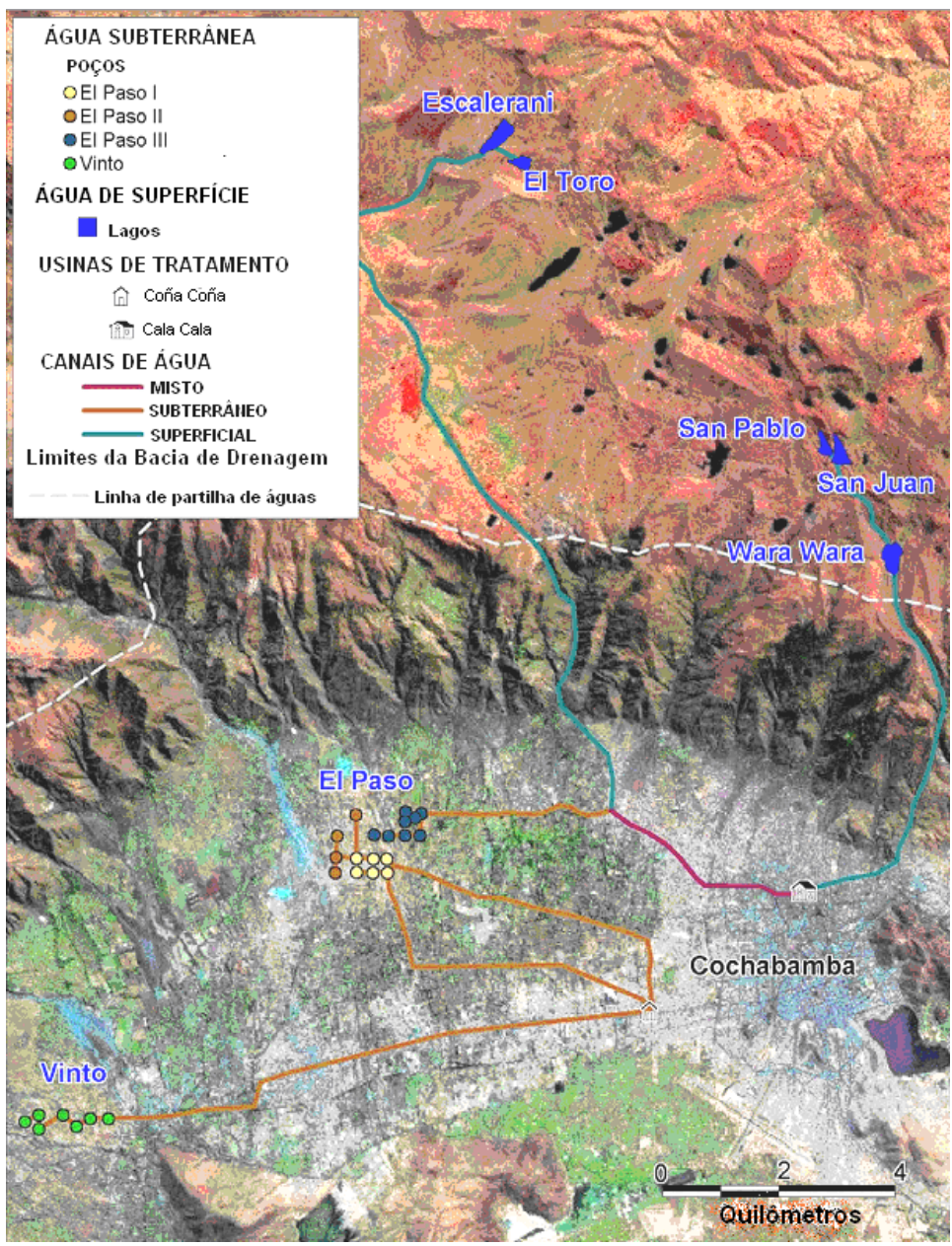

Fotografia 3. Principais fontes e objetos técnicos utilizados na captação de água pelo SEMAPA. Fonte: Mélançon (2005, p. 47). 
Tabela 14. Produção das principais fontes de água utilizadas pelo SEMAPA em 2001.

\begin{tabular}{ccc}
\hline Localidade & \multicolumn{2}{c}{ Volume de produção de água } \\
\cline { 2 - 3 } & Fonts) & $(\%)$ \\
\hline & 70,17 & 8,23 \\
Vinto & 116,11 & 13,61 \\
Paso I & 181,03 & 21,22 \\
Paso II & 170,52 & 19,99 \\
Pasolll & 20,21 & 2,37 \\
Outras & 558,04 & 65,42 \\
\hline Subtotal & Fontes superficiais & 29,10 \\
\hline & 248,27 & 4,42 \\
\hline Escalerani & 37,67 & 1,06 \\
\hline Wara Wara & 9,09 & 34,58 \\
Outras & 295,03 & 100,00 \\
\hline Subtotal & 853,07 &
\end{tabular}

Fonte: SEMAPA (2002, p. 24).

Acrescente-se que apenas $41,2 \%$ de toda água captada era faturada, contabilizando um volume de 409,47 L/s para uma população na época de 517.024 pessoas na época (SEMAPA, 2002). Com esse desempenho, o SEMAPA ofertava $68 \mathrm{~L} /$ dia de água para cada habitante, quantidade considerada completamente insuficiente. Nesse contexto, nota-se que toda a zona sul da cidade não era atendida pela rede de abastecimento público com serviço de água potável e esgoto em 2001. Em contraste, todo o centro da cidade era beneficiado por esses serviços básicos. Por causa da falta de aprovisionamento desses serviços, boa parte das áreas periféricas do município de Cercado procurou satisfazer as suas carências a partir da perfuração de poços. O caso dos bairros da zona sul era ainda mais grave, vez que sua localização geográfica não favorece a perfuração de poços, cujos rendimentos estão entre os mais baixos do Vale. Assim, até o presente momento, o abastecimento tem sido feito por meio de caminhões pipa, e a água fica armazenada em galões de ferro (turril) em péssimas condições, o que deteriora sua qualidade. No que se refere à falta de serviço de esgoto, era comum que as pessoas construíssem latrinas, ou mesmo que fizessem as suas necessidades ao ar livre. Naturalmente, essa carência tem feito com que boa parte das águas subterrâneas seja contaminada, em particular nas áreas em que os aquíferos são livres e, portanto, há maior facilidade de penetração dos resíduos. Ademais, nota-se que as carências da zonal sul da cidade vão ainda mais além, porquanto mesmo o acesso a energia elétrica é restrito (Mapas 17, 18, 19, 20, 21, 22, 23 e 24). 


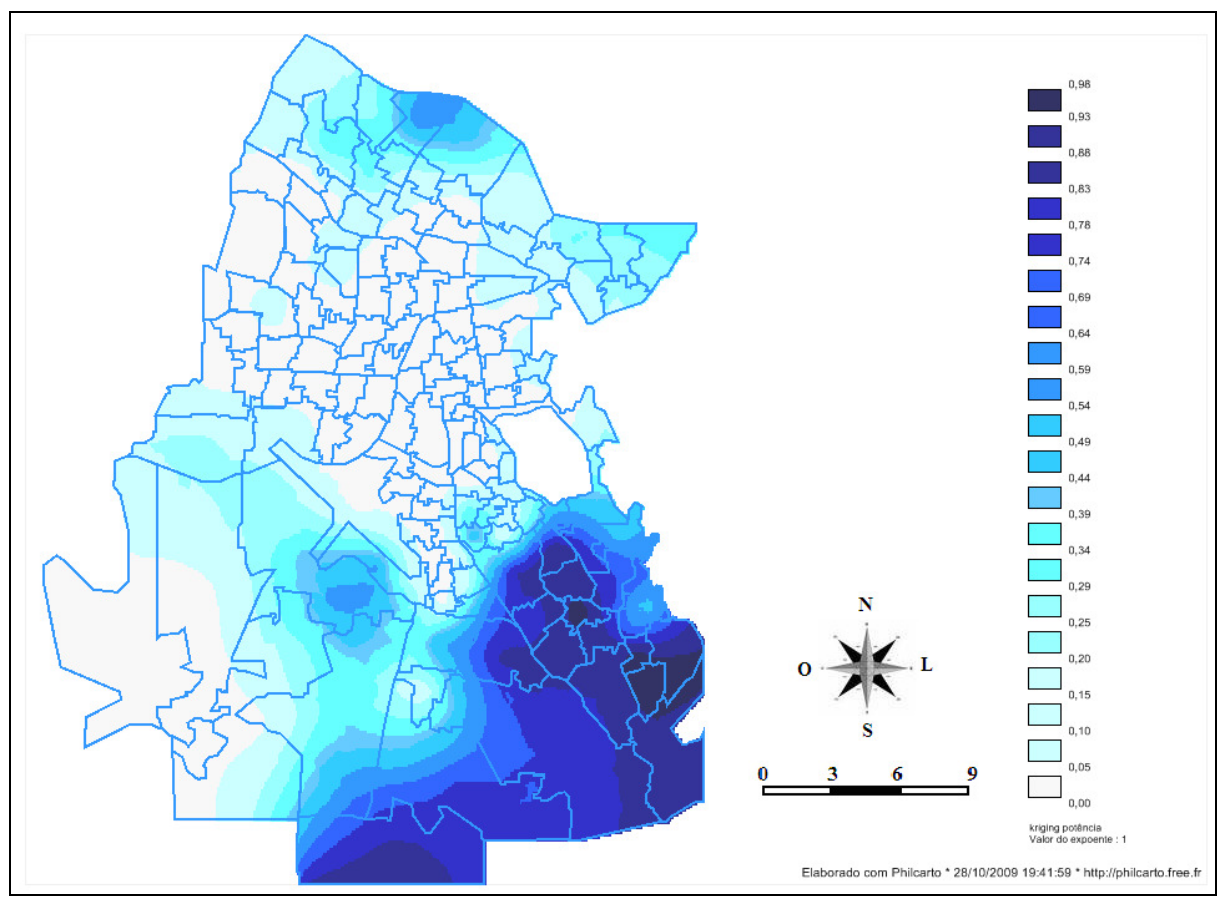

Mapa 17. Habitações abastecidas com água proveniente de caminhões-pipa (\%), de acordo com as zonas de recenseamento, nos diferentes distritos municipais do município de Cercado, região metropolitana de Cochabamba, em 2000.

Fonte: Organizado pelo autor com base em dados de INE (2001b).

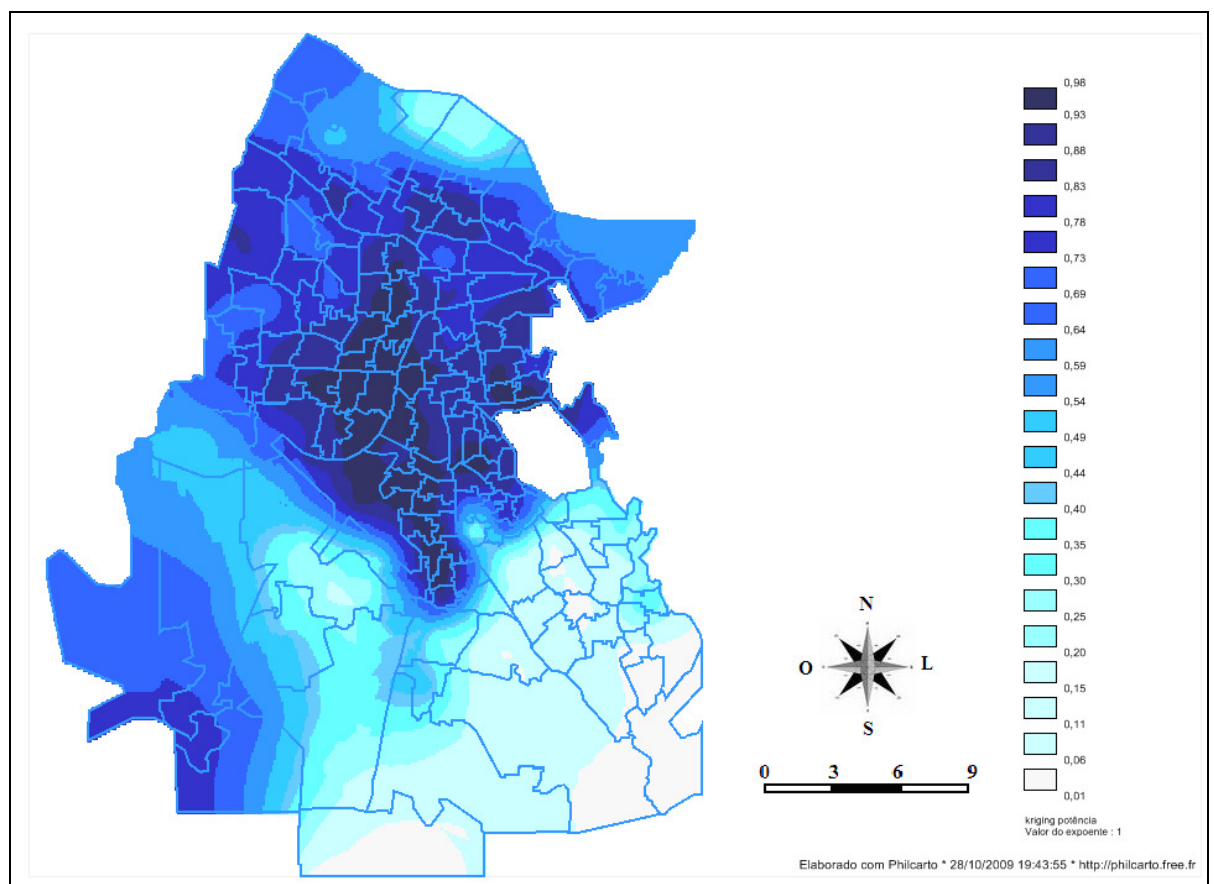

Mapa 18. Habitações abastecidas com água pela rede do SEMAPA (\%), de acordo com as zonas de recenseamento, nos diferentes distritos municipais do município de Cercado, região metropolitana de Cochabamba, em 2000.

Fonte: Organizado pelo autor com base em dados de INE (2001b). 


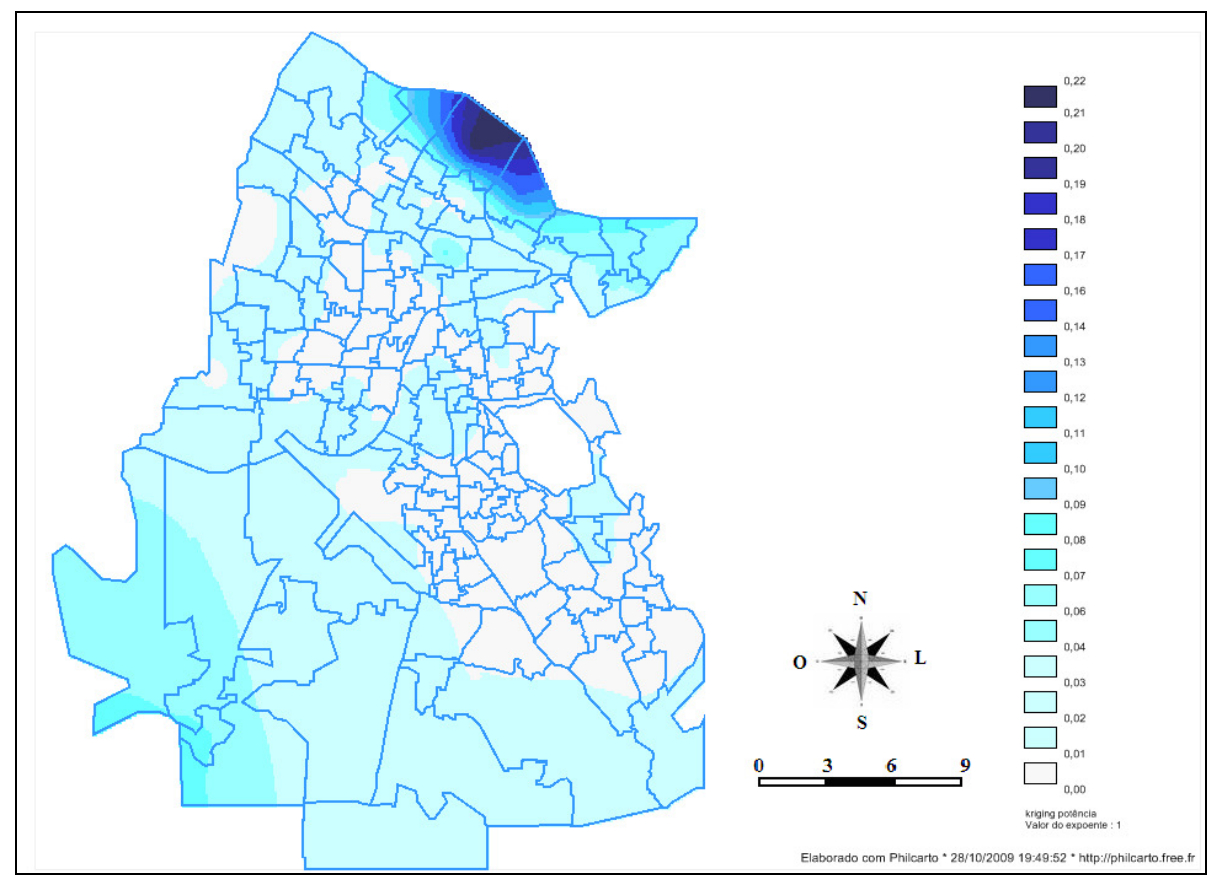

Mapa 19. Habitações abastecidas com água proveniente de rio, lago ou vertente (\%), de acordo com as zonas de recenseamento, nos diferentes distritos municipais do município de Cercado, região metropolitana de Cochabamba, em 2000.

Fonte: Organizado pelo autor com base em dados de INE (2001b).

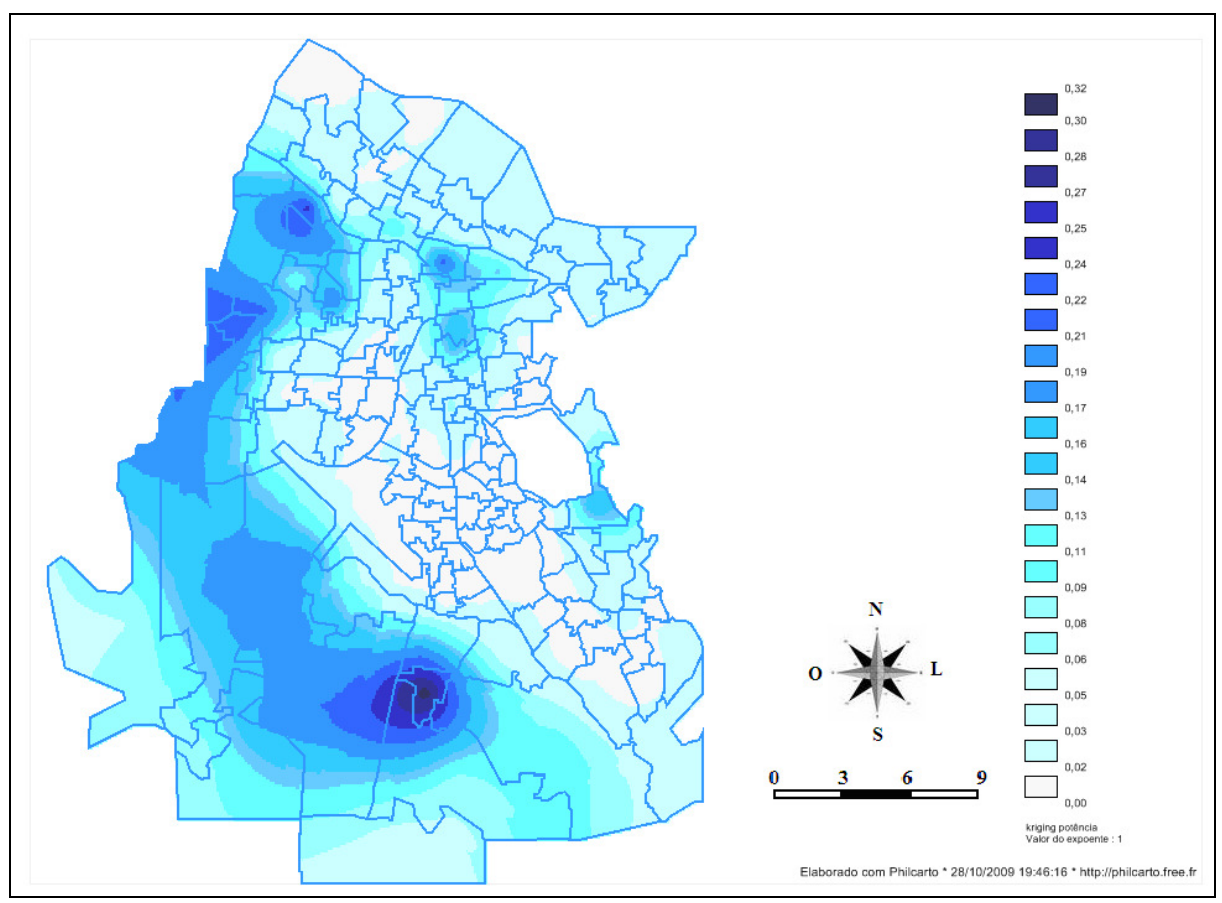

Mapa 20. Habitações abastecidas com água proveniente de poço (\%), de acordo com as zonas de recenseamento, nos diferentes distritos municipais do município de Cercado, região metropolitana de Cochabamba, em 2000.

Fonte: Organizado pelo autor com base em dados de INE (2001b). 


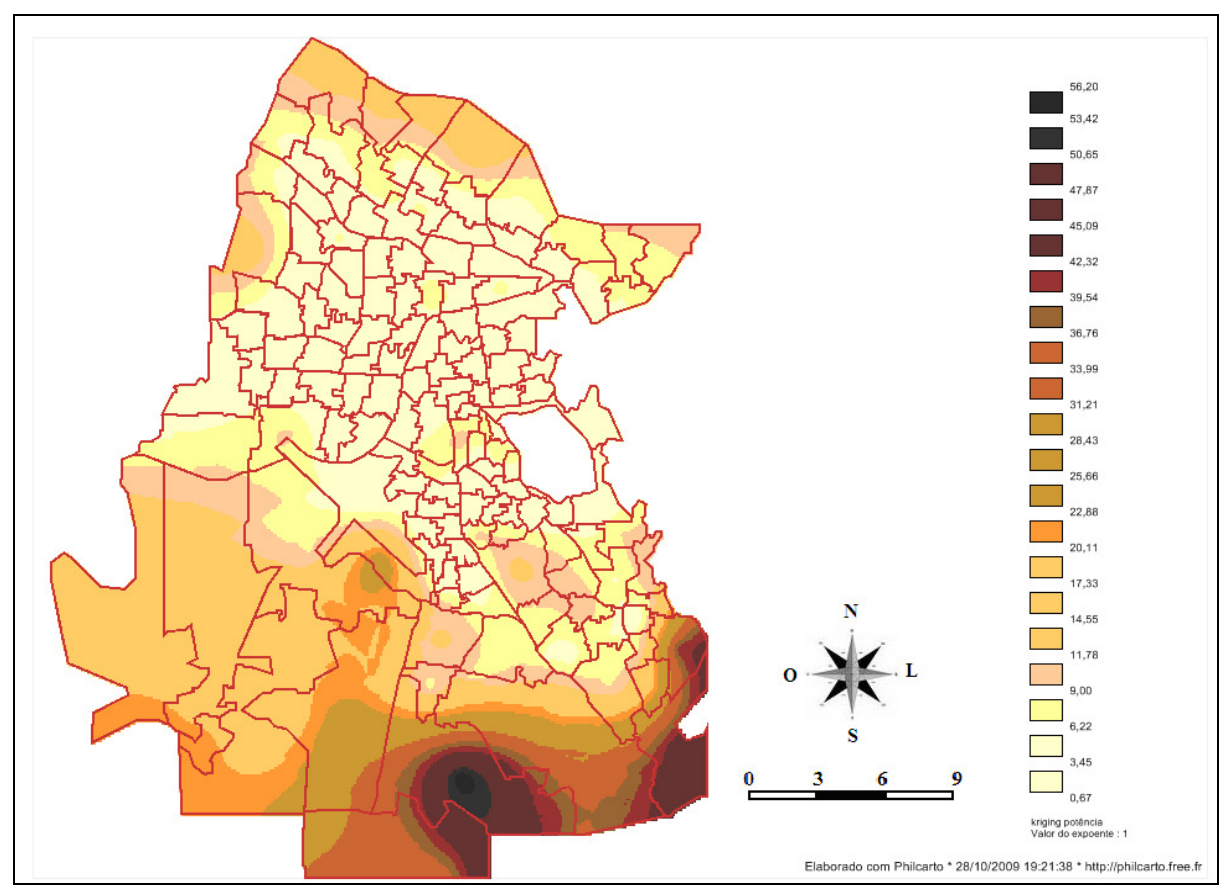

Mapa 21. Habitações não servidas pela rede de energia elétrica (\%), de acordo com as zonas de recenseamento, nos diferentes distritos municipais do município de Cercado, região metropolitana de Cochabamba, em 2000.

Fonte: Organizado pelo autor com base em dados de INE (2001b).

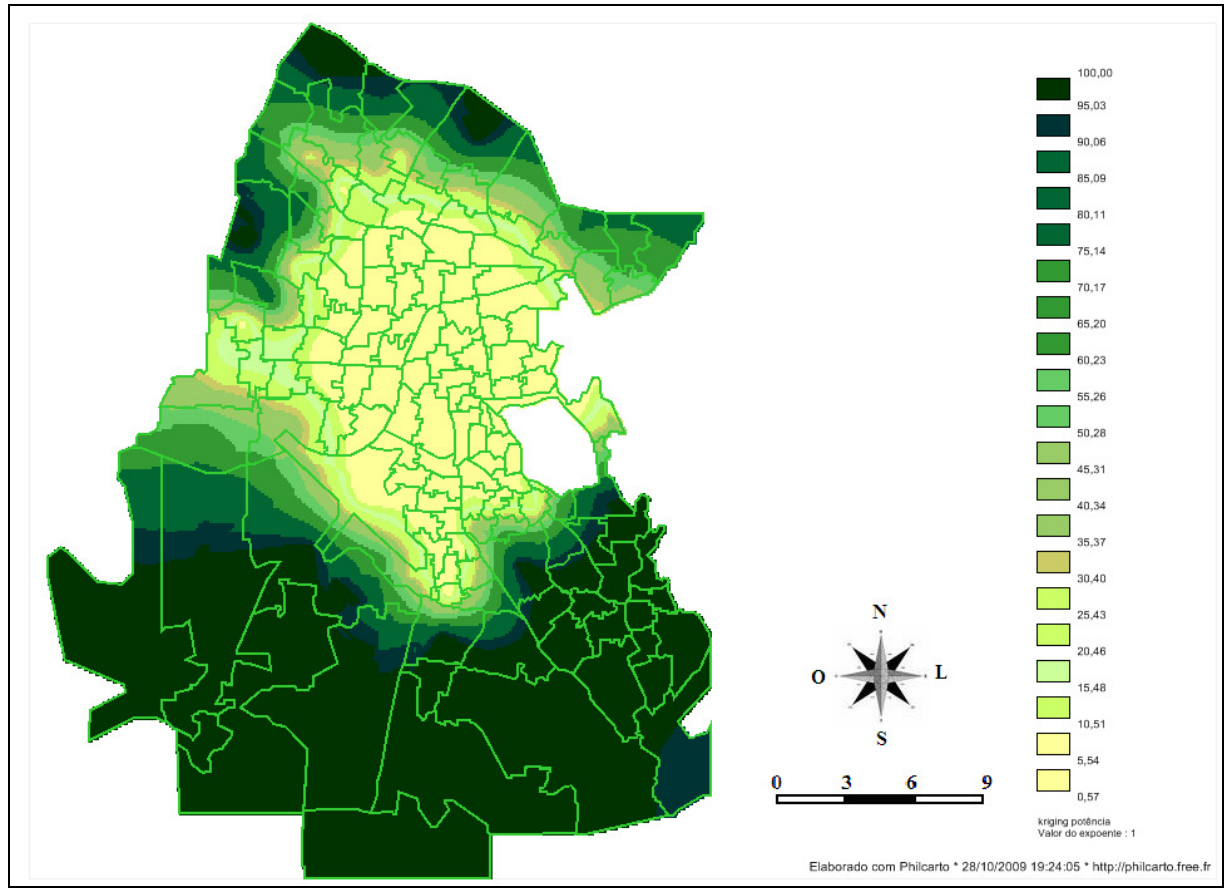

Mapa 22. Habitações não servidas pela rede de esgoto (\%), de acordo com as zonas de recenseamento, nos diferentes distritos municipais do município de Cercado, região metropolitana de Cochabamba, em 2000.

Fonte: Organizado pelo autor com base em dados de INE (2001b). 


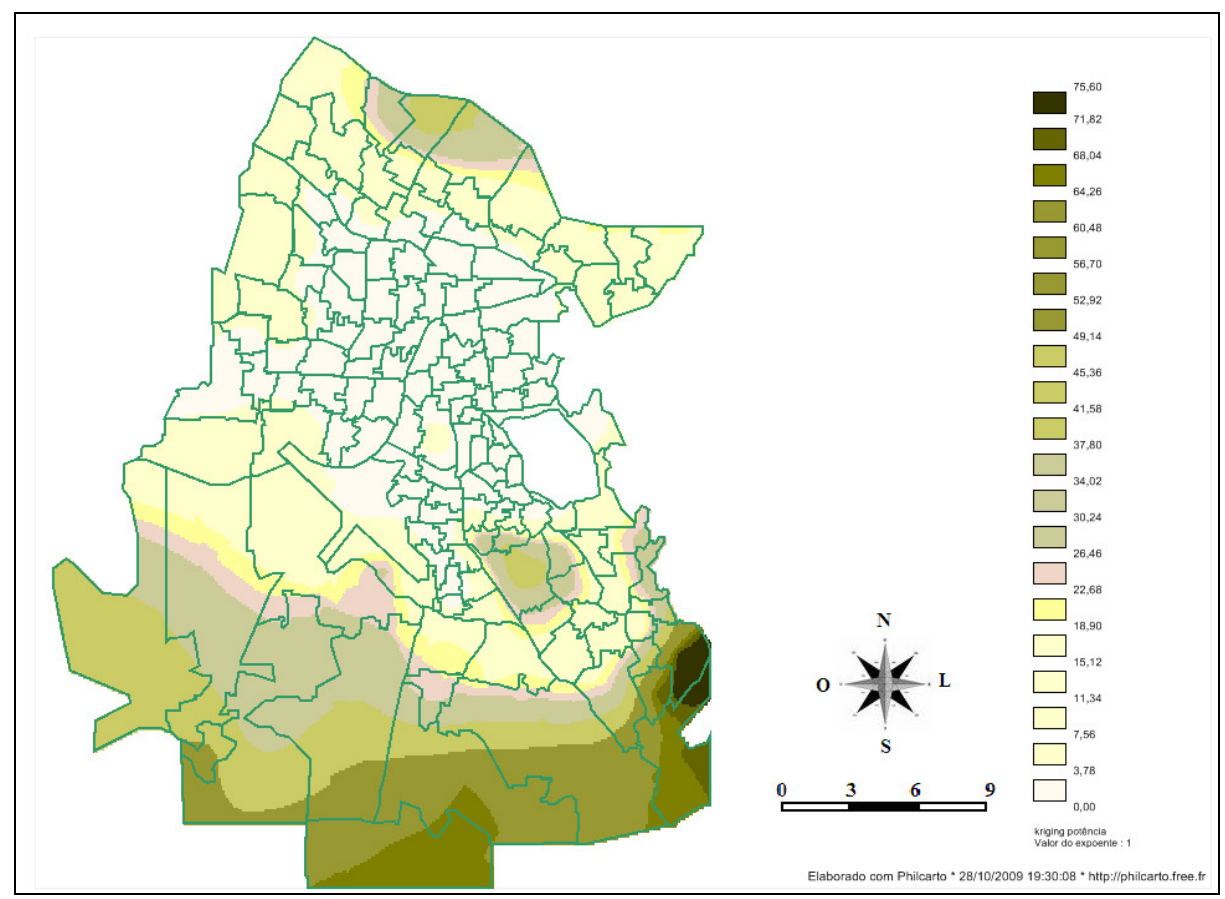

Mapa 23. Habitações sem banheiro ou latrina (\%), de acordo com as zonas de recenseamento, nos diferentes distritos municipais do município de Cercado, região metropolitana de Cochabamba, em 2000.

Fonte: Organizado pelo autor com base em dados de INE (2001b).

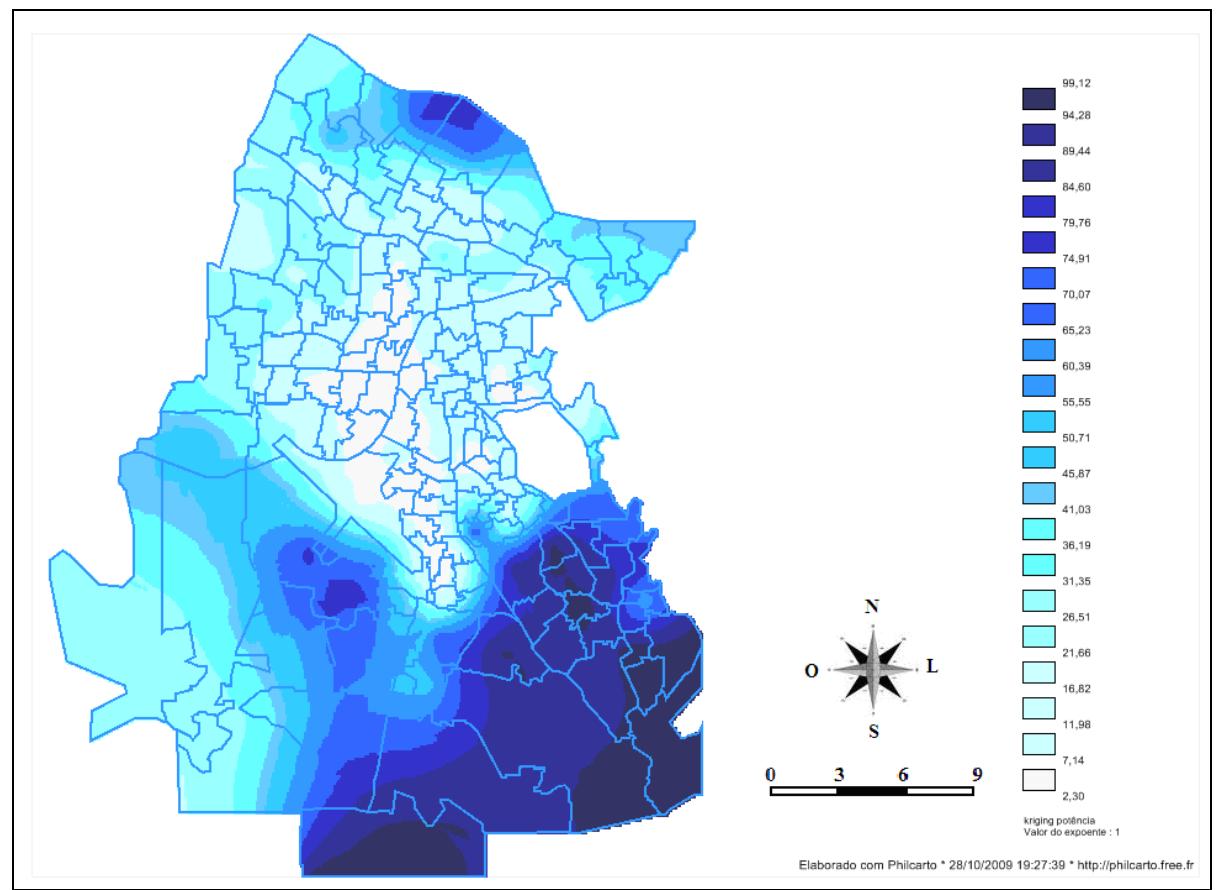

Mapa 24. Habitações não servidas pela rede de água do SEMAPA (\%), de acordo com as zonas de recenseamento, nos diferentes distritos municipais do município de Cercado, região metropolitana de Cochabamba, em 2000.

Fonte: Organizado pelo autor com base em dados de INE (2001b). 
A construção desse arranjo territorial segregador implicou não apenas possibilidades de desenvolvimento humano restritas, mas também no controle sobre a vida dos cidadãos do município de Cercado, bem como do Vale Central. Pode-se perceber que a geopolítica lato sensu relacionada aos recursos hídricos (sobre a qual discorremos anteriormente) se fazia - e ainda se faz - fortemente presente no Vale Central. As diferentes relações de poder implícitas pelo acesso e controle dos recursos hídricos (em sua acepção lata) resultavam em diferentes possibilidades de vida, especialmente no que tange a acesso ao serviço de abastecimento de água e esgoto. Até mesmo a fisiografia dos bairros mais nobres apresenta vantagens consideráveis em relação à captação de água dos aquíferos. Evidentemente, não se trata apenas de uma forma de domínio sobre os recursos hídricos superficiais e subterrâneos, mas igualmente das múltiplas finalidades dos recursos, também implicando controle sobre as técnicas de exploração, o que chamaríamos de hidrokratos, para não mencionar o hidropoder tradicional, ligado apenas às relações de poder que se vinculam à exploração dos recursos hídricos subterrâneos. Esse hidrokratos se refere a várias outras relações de poder apresentadas anteriormente, nas quais os recursos hídricos facilitam o controle sobre o espaço e, também, sobre a vida.

A maior expressão do hidrokratos pode ser visualizada na Tabela 15, em que são apresentadas diferentes situações dos diversos polos sociais envolvidos nas relações de poder. Nota-se que as desigualdades sociais, particularmente no que concerne ao serviço de abastecimento de água e esgoto, resultavam em drásticas diferenças relacionadas às condições de vida. Observa-se que as habitações mais pobres consumiam menores quantidades de água, provocando diferença de longevidade de um terço em relação às habitações mais nobres. Outro índice marcante, que materializa esse hidrokratos, é a taxa de mortalidade infantil, porquanto nos lares mais humildes, a cada 1.000 partos há 100 mortes de crianças a mais que nos lares mais abastados. Pode-se assegurar que essa diferença representava um verdadeiro infanticídio legitimado. Levando em conta que, na pior das hipóteses, esses indicadores se referiam a habitações conectadas à rede do SEMAPA, pode-se afirmar que as condições das habitações não atendidas pelos serviços de abastecimento de água eram ainda piores do que as daquelas habitações classificadas como ruins na Tabela 15. Um exemplo disso é o caso da 
OTB Barrios Unidos, situado no distrito 14. Antes do ano 2000, a média de consumo de água girava em torno de $11 \mathrm{~L}$ /dia para cada pessoa (CODAPO, 2006). Portanto, a situação dos bairros mais humildes de Cochabamba era lastimável, uma vez que o consumo de água por dia recomendado pela Organização Mundial da Saúde (OMS) deve ser de pelo menos $50 \mathrm{~L} / d i a$, incluindo o volume de água consumido para higiene (HOWARD; BARTRAM, 2003).

Tabela 15. Comparação dos indicadores econômicos, sociais e técnicos do serviço de abastecimento de água em diferentes categorias de habitações no município de Cercado em 1996.

\begin{tabular}{|c|c|c|c|c|}
\hline \multirow[t]{2}{*}{ Indicador } & \multicolumn{4}{|c|}{ Qualidade da habitação } \\
\hline & Boa & Regular & Ruim & Total \\
\hline \multicolumn{5}{|c|}{ Número de conexões } \\
\hline Total & 18.685 & 19.884 & 7.688 & 46.267 \\
\hline Doméstico & 16.249 & 18.663 & 7.552 & 42.464 \\
\hline Não doméstico ${ }^{1}$ & 2.446 & 1.221 & 136 & 3.803 \\
\hline \multicolumn{5}{|c|}{ Consumo (\%) } \\
\hline Doméstico (\%) & 45 & 38 & 17 & 100 \\
\hline Não doméstico (\%) & 59 & 36 & 5 & 100 \\
\hline Total (\%) & 48 & 38 & 14 & 100 \\
\hline \multicolumn{5}{|c|}{ Consumo doméstico e custos } \\
\hline Por lar (L/dia) & 731 & 430 & 125 & 429 \\
\hline Por pessoa (L/dia) & 165 & 99 & 22 & 95 \\
\hline $\begin{array}{l}\text { Tamanho médio do lar } \\
\text { ( } \mathrm{n} \text { o pessoas) }\end{array}$ & 4,4 & 4,4 & 5,7 & 4,8 \\
\hline Renda mensal familiar (Bs./mês) ${ }^{2}$ & 2.500 & 814 & 576 & 1.130 \\
\hline $\begin{array}{l}\text { Gasto com água por mês } \\
\text { (Bs./mês) }\end{array}$ & 26,09 & 26,01 & 39,23 & 30,4 \\
\hline $\begin{array}{l}\text { Proporção da renda familiar gasta } \\
\text { com água (\%) }\end{array}$ & 1 & 3 & 7 & 3 \\
\hline \multicolumn{5}{|c|}{ Indicador de qualidade de vida } \\
\hline Expectativa de vida (anos) & 67 & 57 & 47 & 58 \\
\hline $\begin{array}{l}\text { Mortalidade infantil (mortos por } \\
1.000 \text { nascidos) }\end{array}$ & 45 & 105 & 146 & 97 \\
\hline
\end{tabular}

${ }^{1}$ Uso comercial, industrial e público. ${ }^{2}$ Bolivianos por mês.

Fonte: Ledo (2006, p. 70). 
A situação da zona sul do município de Cercado era a mais drástica em comparação com os demais municípios da região metropolitana de Cochabamba. Isso porque mesmo nas áreas rurais do Vale Central, a boa disponibilidade tanto de água subterrânea como de água superficial, bem como as características fisiográficas da região possibilitavam a captação de água a partir da perfuração de poços e a utilização de antigos sistemas de irrigação. Não obstante, "esses municípios administram seus empreendimentos de água municipais extremamente ineficientes e rejeitam ofertas de fusão com o incentivo de conexão gratuita com a rede do SEMAPA" (MARVIN; LAURIE, 1999, p. 348, tradução nossa). ${ }^{162}$ Em relação à proporção da população atendida, o serviço se revelava ineficiente, já que nos municípios de Tiquipaya, Vinto e Sipesipe apenas 64\%, 47\% e 55\% da população, respectivamente, era servida pela rede de abastecimento pública de água (INE, 2001b). Dessa forma, a caracterização que se pode visualizar no Mapa 25 expressa a situação apenas em parte. Porém, como já advertimos, a situação da zona sul era realmente a pior do Vale Central de Cochabamba.

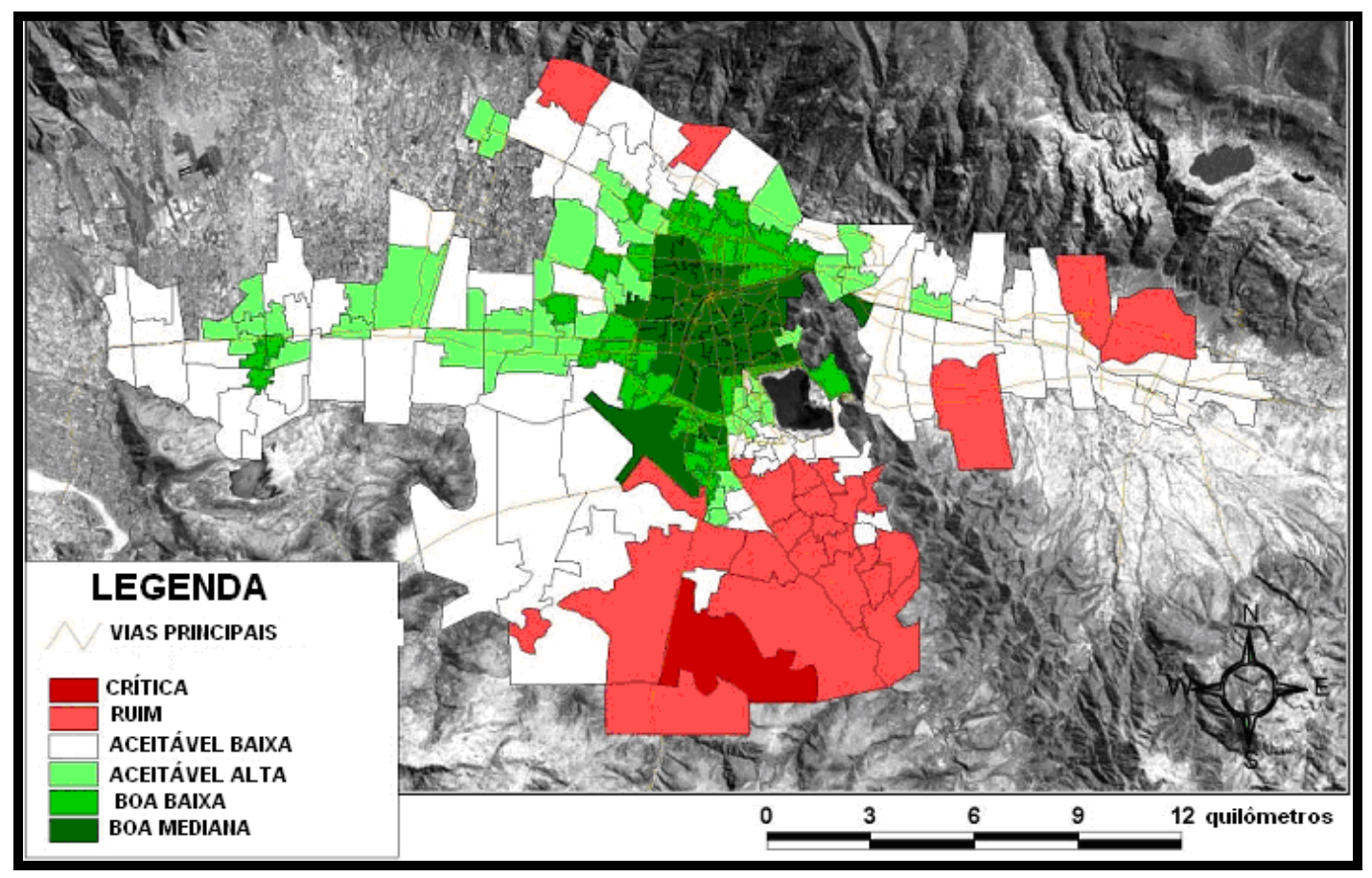

Mapa 25. Qualidade dos serviços básicos, de acordo com as zonas de recenseamento, na região metropolitana de Cochabamba, em 2003.

Fonte: PROGEO (2003).

\footnotetext{
162 "These municipalities run their own extremely inefficient municipal water undertakings and rejected merger offers with the incentive of free connection to the SEMAPA network."
} 
Devemos salientar, porém, que a falta de esgoto era o que mais preocupava, vez que aproximadamente $25 \%$ das casas dos municípios da região metropolitana de Cochabamba (com exceção de Cercado) não eram atendidas por esse serviço público básico (INE, 2001b). Dessa forma, uma boa parte dos recursos hídricos acabava sendo contaminada. No Departamento de Cochabamba, entre as enfermidades transmissíveis registradas, $50 \%$ dos casos eram de diarréias ocasionadas por consumo de água contaminada (BARRAGÁN et al., 1998).

Diante dessa grave situação, dois grandes projetos foram apresentados em 1996 como solução para o problema de escassez de água em Cochabamba. Desde os anos 50, um plano de regional de desenvolvimento havia previsto um projeto múltiplo que não apenas proporcionaria água potável para consumo humano, mas também para irrigação e produção de energia hidroelétrica, o Projeto Múltiplo Misicuni, o qual, mais que a solução para o problema da água em Cochabamba, representava simbolicamente a identidade regional caminhando para o progresso e o desenvolvimento (MARVIN; LAURIE, 1999) (Fotografia 4).

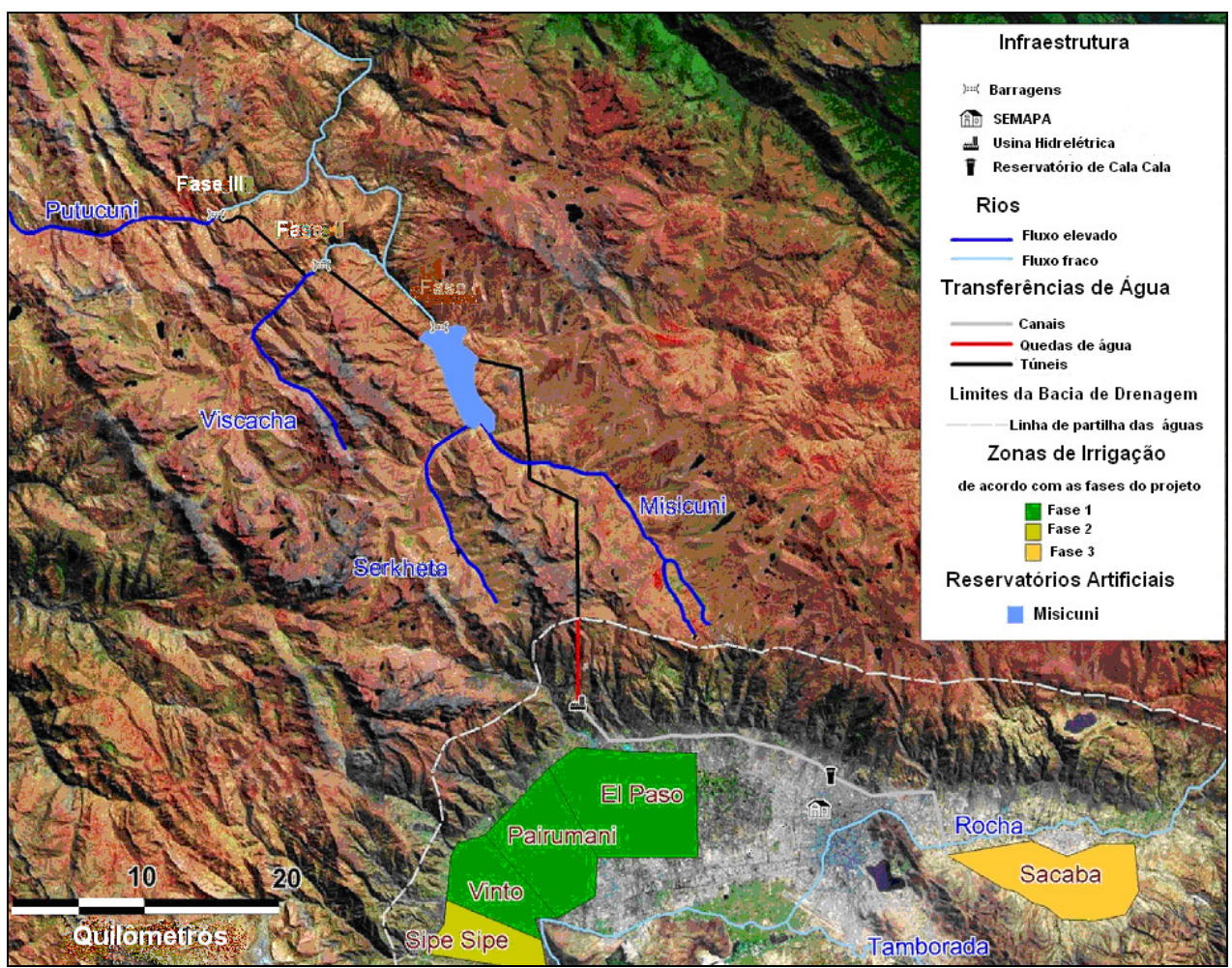

Fotografia 4. Infraestrutura do Projeto Múltiplo Misicuni para o Vale Central de Cochabamba e suas três fases.

Fonte: Mélançon (2005, p. 47). 
Laserna (2000a; 2000b) reputou Misicuni como um sonho plasmado no imaginário regional desde os anos 60 , porém um sonho muito caro, porquanto apenas para a execução da fase inicial, necessitava-se de 70 milhões de dólares, sem levar em conta as demais fases para as quais eram necessários ainda mais 200 milhões de dólares. Nesse projeto ainda era prevista a construção de uma barragem represando o rio Misicuni, de forma a constituir um lago de $120 \mathrm{~m}$ de profundidade no alto da cordilheira. Além disso, Misicuni era um projeto arriscado, pois incluía a perfuração de um túnel de quase $20 \mathrm{~km}$ de comprimento desde o cume da cordilheira até o Vale Central. Some-se a isso, o fato de que o seu tempo de consecução era longo, já que para entrar em completa operação demoraria 20 anos. Em sua primeira fase, seria voltado prioritariamente a projetos de irrigação no Vale Baixo de Cochabamba, enquanto apenas secundariamente suas águas poderiam ser aproveitadas para distribuição na zona sul da cidade. No campo político, deve-se ressaltar que Misicuni sempre foi apoiado pelas elites regionais como forma de propaganda eleitoral e pelo seu apelo popular. Em 1996, Cochabamba passou por um período de seca prolongada e logo a possibilidade de implantação do projeto voltou à tona.

O segundo grande projeto previsto para Cochabamba foi proposto inicialmente pela companhia estatal de energia elétrica ainda nos anos 60 . Pelas dificuldades e grandes desafios enfrentados pelo Projeto Misicuni, o governo nacional, ainda em 1996, buscou financiamento internacional e apoio da empresa Corani S.A. (antiga ENDE) como forma de melhorar a infraestrutura e os atributos do projeto (Fotografia 5). O projeto Corani recebeu apoio não apenas do governo nacional, como também dos organismos nacionais, principalmente do BID e Banco Mundial. Como requisito para o financiamento de projetos hídricos, essas instituições exigiam que o SEMAPA fosse privatizado como parte da implementação de um mercado de águas. Ainda estava prevista a aprovação de uma lei que visava acabar com o mercado negro de água em Cochabamba, principalmente daquela vendida pelos caminhões-pipa (aguateros).

O Projeto Corani contava com várias vantagens sobre o Projeto Múltiplo Misicuni (Tabela 16). Em primeiro lugar, o tempo de entrada em operação era curto, o que já podia proporcionar água além do necessário tanto para consumo humano quanto para irrigação no Vale Central de Sacaba (MARVIN; LAURIE, 1999). Em 
segundo lugar, o Projeto Corani necessitava da metade dos investimentos necessários para a consecução do Projeto Múltiplo Misicuni. Além disso, não seria necessário financiamento público, diferentemente do primeiro projeto. Assim sendo, a viabilidade de execução do Projeto Corani era muito mais certa e segura (LASERNA, 2000a). Outra vantagem do Corani se referia ao aspecto técnico, porquanto sua implantação era tecnicamente menos complexa (MARVIN; LAURIE, 1999) e sua situação geográfica favorecia o abastecimento da zona sul da cidade. Além disso, pode-se ponderar que, nos demais atributos, o Projeto Corani praticamente se compatibilizava com a proposta do Projeto Múltiplo Misicuni.

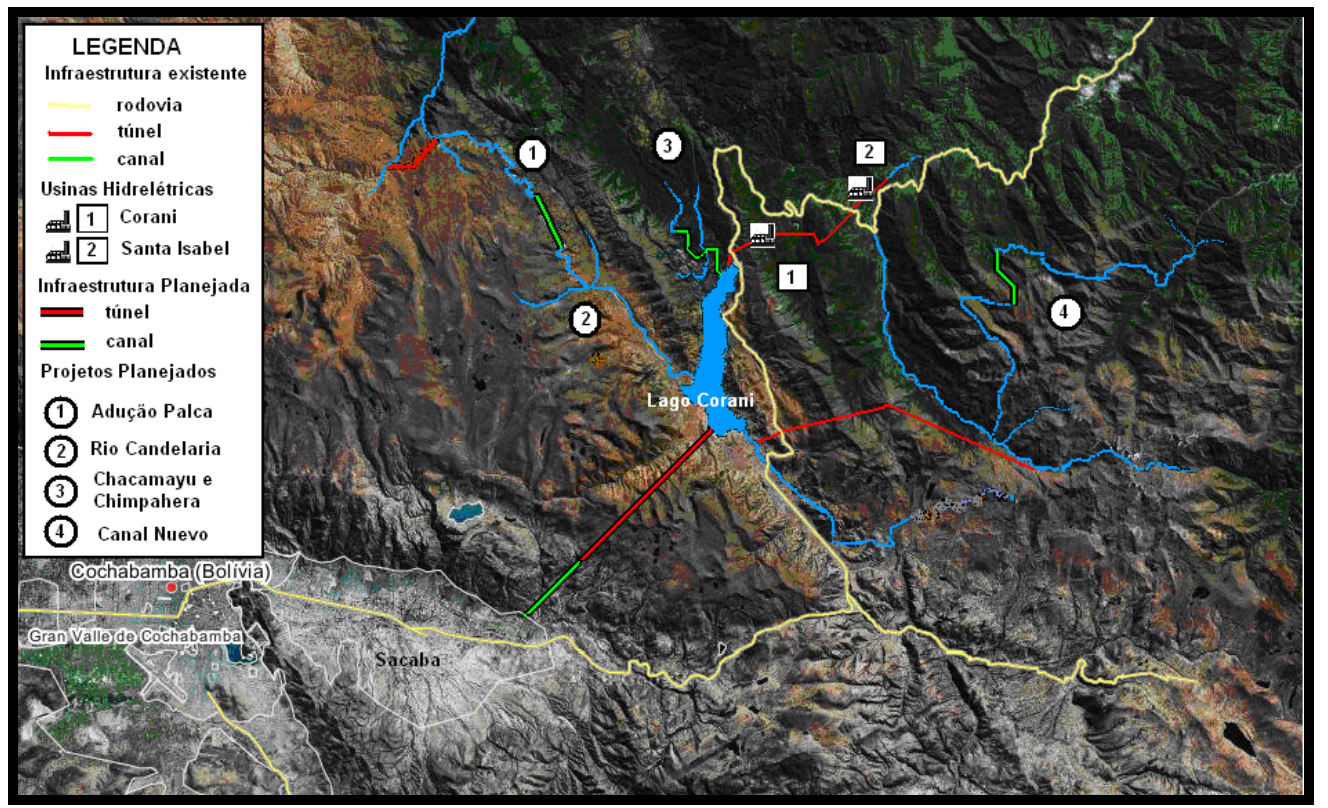

Fotografia 5. Infraestrutura existente e planejada para a implantação do Projeto Corani.

Fonte: Organizado pelo autor a partir de Marvin e Laurie (1999 apud MELANÇON, 2005, p. 57).

Pouco tempo antes das eleições de 1997, a alcaldia e o comitê cívico conseguiram desarticular a proposta do governo federal em relação ao Projeto Corani. Isso também se deveu à participação da população local, que cobrava, a qualquer custo, a implementação do tão sonhado Projeto Múltiplo Misicuni. Em consequência do jogo político, mais uma vez, a gestão hídrica foi levada adiante levando em conta tão-somente os interesses vinculados ao processo e às demandas eleitoreiras. Em Cochabamba, a gestão dos recursos hídricos sempre foi uma forma de se conseguir notoriedade política, seja reduzindo o preço das tarifas de água antes das eleições, seja prometendo o grande sonho de água farta para 
Cochabamba, em detrimento de projetos mais factíveis, como o Corani. A partir da escolha do Projeto Múltiplo Misicuni, a gestão hídrica em Cochabamba entrou em grande debacle, que veio a culminar com a Guerra da Água.

Tabela 16. Comparação entre o Projeto Múltiplo Misicuni e o Projeto Corani.

\begin{tabular}{|c|c|c|}
\hline Característica & Misicuni & Corani \\
\hline $\begin{array}{l}\text { Quantidade de água total } \\
\left(\mathrm{m}^{3} / \mathrm{s}\right)\end{array}$ & 6,6 & 4 \\
\hline $\begin{array}{l}\text { Quantidade de água } \\
\text { urbana }\left(\mathrm{m}^{3} / \mathrm{s}\right)\end{array}$ & 4,27 & 2 \\
\hline $\begin{array}{l}\text { Custo da água urbana } \\
\left(\mathrm{US} \$ / \mathrm{m}^{3}\right)\end{array}$ & 0,20 & 0,21 \\
\hline $\begin{array}{l}\text { Quantidade de água para } \\
\text { irrigação }\left(\mathrm{m}^{3} / \mathrm{s}\right)\end{array}$ & 2,33 & 2 (indireto) \\
\hline $\begin{array}{l}\text { Custo da água para } \\
\text { irrigação }\left(U S \$ / \mathrm{m}^{3}\right)\end{array}$ & 0,08 & 0,08 \\
\hline $\begin{array}{l}\text { Superfície de terras } \\
\text { irrigadas }\end{array}$ & 10.800 (Vale Central) & $\begin{array}{c}\text { ? (Vale. de Sacaba, zona } \\
\text { sul) }\end{array}$ \\
\hline $\begin{array}{l}\text { Volume do reservatório } \\
\text { (milhões de } \mathrm{m}^{3} \text { ) }\end{array}$ & 185 & 141 \\
\hline Altura da barragem $(\mathrm{m})$ & 120 (barragem principal) & ? (construída desde 1966) \\
\hline $\begin{array}{l}\text { Comprimento dos túneis } \\
(\mathrm{km})\end{array}$ & $2 \times 19,5$ & 16. \\
\hline $\begin{array}{l}\text { Comprimento dos canais } \\
\text { de derivação }(\mathrm{km})\end{array}$ & 71 (para irrigação) & 14 (sem irrigação) \\
\hline $\begin{array}{l}\text { Produção } \quad \text { hidrelétrica } \\
(\mathrm{MWh})\end{array}$ & 120 (suplementar) & 126 (em construção) \\
\hline $\begin{array}{l}\text { Tempo de realização } \\
\text { (anos) }\end{array}$ & $\begin{array}{c}4-5\left(1^{\underline{a}} \text { fase }\right) \\
20 \text { total }\end{array}$ & 3 a 4 total \\
\hline $\begin{array}{l}\text { Custo total (milhões de } \\
\text { US\$) }\end{array}$ & $\begin{array}{l}147\left(1^{\underline{a}} \text { fase }\right) \\
311,78 \text { total }\end{array}$ & 162,9 total \\
\hline $\begin{array}{ll}\text { Financiamento } & \text { público } \\
\text { (milhões de US\$) } & \end{array}$ & 42,3 & 0 \\
\hline $\begin{array}{ll}\text { Investimento } & \text { privado } \\
\text { (milhões de US\$) } & \end{array}$ & 213 & 88 \\
\hline $\begin{array}{l}\text { Autofinanciamento } \\
\text { (reinvestimento) (milhões } \\
\text { de US\$) }\end{array}$ & 57 & 74,9 \\
\hline
\end{tabular}

Fonte: Mélançon (2005, p. 47). 
Nota-se, assim, que a maior parte da crise da água por que tem passado Cochabamba não foi ocasionada diretamente pelos fatores físicos. Após tamanha transformação produzida no Vale Central de Cochabamba, a poluição dos aquíferos, a migração em massa, a ocupação desordenada dos espaços, é surpreendente que ainda se possa viver ali com certa segurança. A maior parte dos problemas relacionados aos recursos hídricos na região está vinculada à gestão dos recursos hídricos e, principalmente, ao ordenamento urbano territorial. O descompasso entre as políticas hídricas e as mudanças drásticas pelas quais passava Cochabamba foi tamanho, a ponto de ter ocorrido uma situação em que um projeto de abastecimento de água previsto para beneficiar um bairro de 500 casas, após um ano tivesse de suportar 1000 casas (MARVIN; LAURIE, 1999), ou seja, a própria planificação dos projetos era realizada de forma incompleta e reducionista. Deve-se acrescentar a isso que a questão tampouco se restringe à falta de tecnologia, já que existiam diferentes projetos para dotar de água o Vale Central. O engenheiro Prudencio V. (1998), pesquisador da Consorcio para el Desarrollo Sostenible de la Ecorregión Andina (CONDESAN, Consórcio para o Desenvolvimento Sustentável da Ecoregião Andina), apresentou em 1998 um relatório com inúmeros projetos para o Vale Central por Ocasião do Fórum da Água em Cochabamba, muitos dos quais eram bem menos complexos que o Projeto Múltiplo Misicuni e necessitavam de financiamentos reduzidos.

Isso posto, parece-nos que a questão tem sido, em grande parte, política, uma vez que a água em Cochabamba tem sido reiteradamente um tema conveniente para as pretensões políticas e bastante utilizado para a manipulação das massas. A opção pela execução do Projeto Múltiplo Miscuni em detrimento de outro bem mais factível, como o Projeto Corani, corrrobora esse fenômeno. Acrescente-se a isso o fato de que as tarifas praticadas pelo SEMAPA estavam congeladas há alguns anos, desde quando a empresa entrou em processo de falência (LASERNA, 2000a). Portanto, a politização da questão da água em Cochabamba vem produzindo efeitos perversos, mormente para as áreas mais humildes da cidade. Logo, não se pode afirmar que a crise da água pela qual Cochabamba passa se deve à escassez absoluta do recurso natural, mas antes a uma escassez relativa, criada por sua distribuição desigual e orientada por fatores políticos. Para os atores políticos, a continuidade da crise da água na região tem 
sido conveniente, porque, ao longo de anos, este assunto vem se transformando facilmente em instrumento de manobra política na região.

\subsection{Processo e dinâmica dos conflitos: água e polarização territorial}

5.6.1 Antecedentes do conflito à luz da instrumentalização dos recursos hídricos para a política

No Vale Central de Cochabamba, a questão da ineficiência do abastecimento de água potável para toda a população sempre se fez presente, como vimos no tópico anterior. A despeito dos limites impostos pela fisiografia da região e da ineficiência das políticas nacionais, a população daquela área, de uma forma ou de outra, tem conseguido criar meios para se abastecer de água, seja a partir da construção de poços e canais de irrigação, seja empregando mecanismos econômicos, seja por meio da venda de recursos hídricos (aguateros). Evidentemente, esses mecanismos improvisados, utilizados como forma de adaptação às limitações geográficas, jamais foram completamente satisfatórios.

Como já mencionado, o Vale Central de Cochabamba passou por várias penúrias ambientais graves, a exemplo das crises de 1808 e 1887. Todavia, a escassez de água nunca havia sido usada como pretexto para desencadear conflitos na região metropolitana de Cochabamba até 1995. Aliás, ao contrário disso, os recursos hídricos têm se apresentado como instrumento de solidariedade nas comunidades mais humildes de Cochabamba (WUTICH, 2006). Apesar das desigualdades drásticas materializadas na região, isso não impediu a implantação de uma mínima ordem territorial, expressa pela estruturação das três formas de territorialidade no Vale Central, anteriormente apontada, isto é, a dos migrantes da zona sul, a dos camponeses indígenas e a da elite dirigente.

Em relação aos recursos hídricos, esta ordem estava plasmada na ideia de que a rede de abastecimento do SEMAPA estava destinada aos setores mais nobres do município de Cercado e a parte dos setores médios. As áreas rurais da região metropolitana de Cochabamba eram regidas pelos usos y costumbres e, 
portanto, sua população se autoabastecia com água proveniente dos poços comunitários e das nascentes da região. Por fim, restava à zona sul abastecer-se com água de fornecedores privados (aguateros). No entanto, a partir dos anos 70, o crescimento populacional pujante do município de Cercado fez com que todas as fontes hídricas em seu território não fossem mais suficientes para o abastecimento da população mais abastada. Por conseguinte, essa ordem territorial foi sendo, aos poucos, desafiada e contestada pelo município de Cercado e o SEMAPA, que visavam garantir os recursos hídricos necessários ao abastecimento dos bairros mais nobres do Vale Central de Cochabamba.

Em várias ocasiões, essa ousadia foi expressa por inúmeras tentativas de perfuração de poços profundos e semiprofundos no território dos outros municípios. Essa quebra da ordem territorial foi responsável por iniciar a polarização dos atores, além de aumentar a desconfiança da população dos municípios vizinhos em relação ao SEMAPA. Com essa contestação da ordem territorial vigente, as autoridades de Cercado e o SEMAPA objetivavam, especificamente, conseguir maior volume de água para o consumo dos bairros mais nobres de Cochabamba, embora, de certa forma, uma pequena parte da população mais humilde ainda pudesse se beneficiar desse serviço.

Esse episódio expressou não apenas uma contestação da ordem territorial pela discussão da gestão dos recursos hídricos, mas também da própria racionalidade camponesa. Ao analisar esse conflito, Crespo e Halkyer Orellana (1999, p. 71, tradução nossa) afirmaram que:

O modelo do desenvolvimento regional busca se articular ao processo modernizador, sob lógicas privatizadoras, ênfase no mercado como regulador por excelência da vida econômica, e tende a fortalecer as atividades urbanas, marginalizando os setores econômico-produtivos tradicionais, como são os pequenos produtores (agrícolas e pecuários) do vale cochabambino. $^{163}$

Portanto, a questão envolvida se vinculava não apenas aos recursos hídricos, mas igualmente ao modo de vida e à própria racionalidade camponesa que estava sendo contestada pela expansão do modo de vida urbano. A partir da implantação da nova política econômica na Bolívia, por Sanchez de Lozada, começou a ser

163 "El modelo de desarrollo regional busca articularse al proceso modernizador, bajo lógicas privatizadoras, énfasis en el mercado como regulador por excelencia de la vida económica, y tiende a fortalecer a las actividades urbanas, marginando a sectores económico productivos tradicionales como son los pequeños productores parcelarios (agrícolas y pecuarios) del valle cochabambino." 
priorizado o moderno como forma de se alcançar o progresso e, nessa perspectiva, o modo de vida camponesa era visto como atrasado.

O desafio da ordem territorial vigente produziu alguns efeitos que desencadearam a Guerra da Água. Primeiramente, os camponeses regantes de Vinto e Sipesipe conformaram a FEDECOR. Em segundo lugar, o confronto entre essas duas territorialidades colocou em evidência o fato de que o Projeto Múltiplo Misicuni ainda estava apenas no papel, fazendo apelo à identidade regional e ao tão sonhado projeto. Por fim, vários atores políticos perceberam que a água poderia representar um papel importante nas eleições nacionais de 1996. Ainda durante os conflitos relacionados à perfuração de poços na zona rural pelo SEMAPA, os líderes do comitê cívico e as autoridades políticas regionais fizeram uma campanha para que as obras do Projeto Múltiplo Misicuni se iniciassem. Dando apoio a essa proposta, a Federación de Juntas Vecinales (FEJUVE, Federação de Associação de Bairros) organizou a marcha pela cochabambinidade (CRESPO; HALKYER ORELLANA, 1999). Nas eleições presidenciais de 1996, os partidos que apoiavam o Misicuni formaram uma coalizão elegendo Hugo Banzer para presidente.

Como parte do programa de ajuste estrutural, o governo central visava privatizar o SEMAPA e, em troca disso, receberia um financiamento do Banco Mundial para a realização dos projetos hídricos (ULTIMA HORA, 1997 apud MÉLANÇON, 2005). Embora o Banco Mundial apoiasse o Projeto Corani, após tanta insistência popular e política, essa instituição concordou que o Projeto Múltiplo Misicuni fosse executado. Assim que Banzer tomou posse, as autoridades locais não podiam esperar a hora em que o SEMAPA fosse privatizado e o Misicuni se tornasse realidade. A privatização também era apoiada pela maior parte da população (MÉLANÇON, 2005).

Com o intento de implementar o Misicuni a qualquer custo, a licitação para a concessão do SEMAPA foi feita levando em conta a possibilidade dos participantes em concretizar o projeto. Dessa forma, o critério de melhores preços, maior cobertura e qualidade do serviço foi relegado a segundo plano. Após várias tentativas fracassadas de licitar a concessão do SEMAPA, por conta da desistência de várias empresas diante de um empreendimento tão arriscado, os demais 
licitantes resolveram se unir formando o Consorcio Internacional Aguas del Tunari ${ }^{164}$. Diante dessa situação, em vez de declarar deserta a licitação, o governo resolveu negociar diretamente com o único licitante que restava (LASERNA, 2000a). Naturalmente, esse tipo de ação era ilegal, porque a legislação previa que a licitação somente poderia ocorrer com ao menos três participantes. Outro aspecto que chamou a atenção foi o fato de que toda a negociação foi levada a cabo sem consulta à população e sem transparência. $A$ assinatura do contrato teve apenas um ato solene no dia 3 de setembro de 1999, do qual participaram o presidente Hugo Banzer, o prefeito Hugo Galindo, o alcalde Manfred Reyes Villa, os diretores de Aguas del Tunari e do SEMAPA.

O que estava no contrato foi sendo revelado à sociedade civil aos poucos, por meio da ação de diferentes movimentos sociais. Todo um arcabouço jurídico estava construído de forma a garantir o prosseguimento da concessão, oferecendo várias vantagens à concessionária como forma de manter a continuidade do Projeto Múltiplo Misicuni em detrimento da qualidade do serviço prestado e daquilo que havia sido prometido à sociedade civil em pleno pleito eleitoral. Entre as principais mudanças negociadas se encontrava a flexibilização do projeto, reduzindo os seus atributos, bem como o aumento das tarifas de água logo após o início da concessão.

A redução dos atributos do projeto foi tamanha que, posteriormente, foi apelidado de "Misicunito". A quantidade de água total captada era pelo menos cinco vezes menor que o previsto no projeto original, a produção de energia elétrica se reduzia a um quarto do planejado anteriormente, e a superfície irrigada era bem menor que a calculada antes. Apesar de todas essas reduções das potencialidades do projeto, seu custo de execução não foi substancialmente reduzido, porquanto diminuiu em apenas aproximadamente $30 \%$ (Tabela 17).

Em relação às tarifas de água, sabe-se que, indubitavelmente, houve aumento, mas não há consenso na literatura. Há autores, como Stoehr (2006), que citam aumentos de $200 \%$ a $400 \%$ das tarifas. Outros, mais engajados na Guerra da Água, como um dos líderes da Coordinadora del Agua, Franz Taquichiri Yapura, mencionam aumentos de $600 \%$ a $800 \%$ (CECEÑA, 2005). E ainda há aqueles que

${ }^{164}$ A divisão acionária desse consórcio foi conformada da seguinte maneira: $55 \%$ das ações pertenciam à International Water Holding (fusão entre a americana Bechtel e a italiana Edison), $25 \%$ pertenciam à Abengoa Servícios Urbanos, 5\% à ICE Água e Energia, 5\% à Companhia Boliviana de Engenharia, $5 \%$ à Sociedad Boliviana de Cemento (SOBOCE) e $5 \%$ à Construtora Petricevic S. A. 
asseguram que houve aumento para os que consumem água excessivamente, enquanto para os consumidores mais humildes, houve até redução de preço em alguns casos (NICKSON; VARGAS, 2002).

Tabela 17. Comparação entre o Projeto Múltiplo Misicuni original e o Projeto "Misicunito".

\begin{tabular}{|c|c|c|}
\hline Característica & Misicuni & Misicunito \\
\hline $\begin{array}{l}\text { Quantidade de água total } \\
\left(\mathrm{m}^{3} / \mathrm{s}\right)\end{array}$ & 6,6 & 1 a 1,5 \\
\hline $\begin{array}{l}\text { Quantidade de água } \\
\text { urbana }\left(\mathrm{m}^{3} / \mathrm{s}\right)\end{array}$ & 4,27 & 0,5 a 1 \\
\hline $\begin{array}{l}\text { Custo da água urbana } \\
\left(\mathrm{US} \$ / \mathrm{m}^{3}\right)\end{array}$ & 0,20 vendida ao SEMAPA & Aumento de $35 \%$ e $20 \%$ \\
\hline $\begin{array}{l}\text { Quantidade de água para } \\
\text { irrigação }\left(\mathrm{m}^{3} / \mathrm{s}\right)\end{array}$ & 2,33 & 0,5 \\
\hline $\begin{array}{l}\text { Custo da água para } \\
\text { irrigação }\left(\mathrm{US} \$ / \mathrm{m}^{3}\right)\end{array}$ & 0,08 & 0,08 \\
\hline $\begin{array}{l}\text { Superfície de terras } \\
\text { irrigadas }\end{array}$ & 10.800 (Vale Central) & 500 (Vale Central) \\
\hline $\begin{array}{l}\text { Volume do reservatório } \\
\text { (milhões de } \mathrm{m}^{3} \text { ) }\end{array}$ & 185 & 100 \\
\hline Altura da barragem (m) & 120 (barragem principal) & 95 \\
\hline $\begin{array}{l}\text { Comprimento dos túneis } \\
(\mathrm{km})\end{array}$ & $37 \mathrm{~km}$. & 19 \\
\hline $\begin{array}{l}\text { Comprimento dos canais } \\
\text { de irrigação }(\mathrm{km})\end{array}$ & 71 (para irrigação) & Não menciona \\
\hline $\begin{array}{l}\text { Produção hidrelétrica } \\
\text { (MWh) }\end{array}$ & 120 (suplementar) & 40 \\
\hline $\begin{array}{l}\text { Tempo de realização } \\
\text { (anos) }\end{array}$ & $\begin{array}{c}4-5\left(1^{a} \text { fase }\right) \\
20 \text { total }\end{array}$ & $\begin{array}{l}2 \text { (água urbana) } \\
7 \text { total }\end{array}$ \\
\hline $\begin{array}{l}\text { Custo total (milhões de } \\
\text { US\$) }\end{array}$ & $\begin{array}{l}147\left(1^{\mathrm{a}} \text { fase }\right) \\
311,78 \text { total }\end{array}$ & 217 (uma única fase) \\
\hline $\begin{array}{l}\text { Financiamento público } \\
\text { (milhões de US\$) }\end{array}$ & 42,3 & 42,3 \\
\hline $\begin{array}{ll}\text { Investimento } & \text { privado } \\
\text { (milhões de US\$) }\end{array}$ & 213 & 97 \\
\hline $\begin{array}{l}\text { Autofinanciamento } \\
\text { (reinvestimento) (milhões } \\
\text { de US\$) }\end{array}$ & 57 & 78 \\
\hline
\end{tabular}

Fonte: Organizada pelo autor com base em Maldonado Rojas (2004, p. 35-36), Oporto Castro (1999 apud MÉLANÇON, 2005, p. 80) e Crespo (2000 apud MÉLANÇON, 2005, p. 80).

Soldal (2008) também concordou que a literatura apresenta resultados diversos quando o assunto se refere ao aumento das tarifas de água em 
Cochabamba no início do ano de 2000. Porém, o autor advertiu que se faz necessário examinar o tipo de aumento de preço da água que se realizou, bem como as consequências disto para a população. O tipo de tarifa implementado é denominado Increasing Block Tariff (IBT, tarifa que aumenta por bloco de consumidores) Esse tipo de tarifação define os consumidores residenciais em quatro categorias. A categoria 1 se refere a lotes vazios, moradores de casas abandonadas, casas em litígio de propriedade e casas em demolição. Pertencem à categoria 2 as casas precárias e as casas não-funcionais abastecidas por meio de bebedouros públicos. São classificados na categoria 3 os moradores de classe média que possuem "casas econômicas", alojamentos sociais e apartamentos funcionais. A categoria 4 se refere a moradores das classes mais nobres que têm a propriedade de casas luxuosas, construídas com materiais de primeira qualidade, com todas as comodidades e dois pisos (CALISAYA HINOJOSA, 2004 apud MÉLANÇON, 2005).

A tarifação progressiva entre categorias já havia sido implementada pelo SEMAPA em 1992; entretanto, era digressiva intracategorias, ou seja, quanto maior o volume de água consumido, menor o preço do metro cúbico de água. No novo modelo IBT, foi estabelecida uma tarifação progressiva entre categorias, porém, o modelo buscava fazer com que os consumidores chegassem a um patamar médio de consumo (Mapa 26). Pelos dados da Tabela 18 pode-se ter uma ideia da variação dos preços, devendo-se observar que o aumento das tarifas oscila entre $10 \%$ e mais de $100 \%$. Outro aspecto que deve ser desatacado é que o aumento das tarifas das categorias 1 e 2 , para os menores volumes de consumo, é superior ao aumento das categorias 3 e 4 . Assim, não correspondia à realidade o argumento de Nickson e Vargas (2002, p. 108, tradução nossa) de que:

A nova estrutura de tarifas era socialmente progressiva, pois incorporava taxas diferenciadas dentro do preço fixado, com moradores de alta renda (categoria 4) pagando quase três vezes mais que os moradores de baixa renda (categoria 2) para os primeiros $12 \mathrm{~m}^{3} .^{165}$

Portanto, pode-se confirmar que, proporcionalmente, o aumento para os mais pobres era maior que aquele praticado para os mais ricos. Não obstante, deve-se ressaltar que, diante de um projeto hídrico milionário, vinculado à concessão pelo

165 "The new tariff structure was socially progressive. In incorporated differential rates within the fixed charge, with high-income householders (residential 4) paying nearly three times as much as lowincome householders (residential 2) for the first $12 \mathrm{~m}^{3}$." 
governo, somado à situação deficitária do SEMAPA quando adquirido, seria esperado um aumento de tarifas como consequência natural. Porém, evidentemente, não da forma como foi realizado.

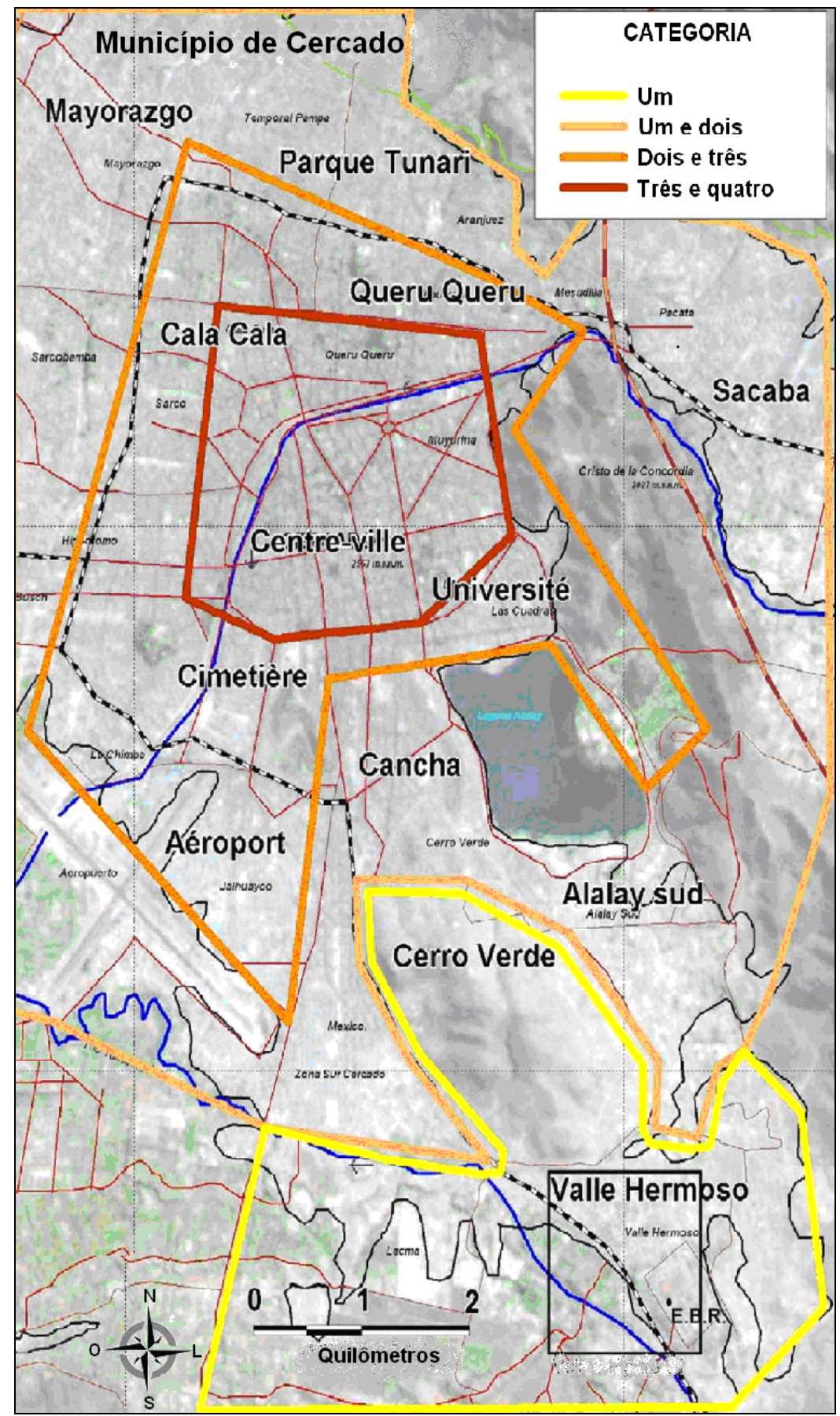

Mapa 26. Distribuição espacial da clientela de Aguas del Tunari no município de Cercado, de acordo com categorias de tarifação.

Fonte: Mélançon (2005, p. 85). 
Tabela 18. Tarifação pelo serviço de abastecimento de água e esgoto no município de Cercado, de acordo com categorias de tarifação.

\begin{tabular}{|c|c|c|c|c|}
\hline \multirow[t]{2}{*}{ Consumo $\left(\mathrm{m}^{3}\right)$} & \multicolumn{2}{|c|}{ Tarifa (bolivianos) } & \multirow{2}{*}{$\begin{array}{c}\text { Aumento da } \\
\text { tarifa (\%) }\end{array}$} & \multirow{2}{*}{$\begin{array}{c}\text { Tarifa Aguas } \\
\text { del Tunari } \\
\text { (bolivianos/ } \\
\left.\mathrm{m}^{3}\right)^{1} \\
\end{array}$} \\
\hline & $\begin{array}{c}\text { SEMAPA } \\
(1999)\end{array}$ & $\begin{array}{c}\text { Aguas del } \\
\text { Tunari (2000) }\end{array}$ & & \\
\hline \multicolumn{5}{|c|}{ Categoria 1} \\
\hline 10 & 14,00 & 18,40 & 31,43 & 1,84 \\
\hline 11 & 14,00 & 18,40 & 31,43 & 1,67 \\
\hline 12 & 14,00 & 18,40 & 31,43 & 1,53 \\
\hline 13 & 15,00 & 20,10 & 34,00 & 1,56 \\
\hline 14 & 15,00 & 21,60 & 39,35 & 1,54 \\
\hline 15 & 16,00 & 23,20 & 45,00 & 1,55 \\
\hline \multicolumn{5}{|c|}{ Categoria 2} \\
\hline 10 & 25,50 & 31,00 & 21,57 & 3,10 \\
\hline 11 & 25,50 & 31,00 & 21,57 & 2,82 \\
\hline 12 & 25,50 & 31,00 & 21,57 & 2,58 \\
\hline 13 & 26,50 & 33,90 & 27,92 & 2,61 \\
\hline 14 & 27,50 & 36,80 & 33,82 & 2,63 \\
\hline 15 & 29,00 & 39,80 & 37,24 & 2,65 \\
\hline 20 & 35,00 & 54,40 & 55,43 & 2,72 \\
\hline 30 & 49,00 & 84,90 & 73,27 & 2,83 \\
\hline 40 & 63,00 & 116,20 & 84,44 & 2,91 \\
\hline 50 & 76,50 & 147,40 & 92,68 & 2,95 \\
\hline \multicolumn{5}{|c|}{ Categoria 3} \\
\hline 10 & 45,00 & 49,50 & 10,00 & 4,95 \\
\hline 11 & 45,00 & 49,50 & 10,00 & 4,50 \\
\hline 12 & 45,00 & 49,50 & 10,00 & 4,13 \\
\hline 13 & 46,50 & 53,60 & 15,27 & 4,12 \\
\hline 14 & 47,50 & 57,70 & 21,47 & 4,12 \\
\hline 15 & 49,00 & 61,60 & 26,71 & 4,11 \\
\hline 20 & 57,00 & 81,80 & 43,16 & 4,08 \\
\hline 30 & 74,50 & 123,30 & 65,50 & 4,11 \\
\hline 40 & 90,50 & 166,30 & 83,76 & 4,16 \\
\hline 50 & 106,50 & 209,30 & 96,53 & 4,19 \\
\hline \multicolumn{5}{|c|}{ Categoria 4} \\
\hline 10 & 73,00 & 88,30 & 20,96 & 8,83 \\
\hline 11 & 73,00 & 88,30 & 20,96 & 8,03 \\
\hline 12 & 73,00 & 88,30 & 20,96 & 7,36 \\
\hline 13 & 75,00 & 93,50 & 24,67 & 7,19 \\
\hline 14 & 76,50 & 98,80 & 29,15 & 7,06 \\
\hline 15 & 78,50 & 104,10 & 32,61 & 6,94 \\
\hline 20 & 87,50 & 130,60 & 49,26 & 8,53 \\
\hline 30 & 107,00 & 165,30 & 73,18 & 6,18 \\
\hline 40 & 126,00 & 242,10 & 92,14 & 6,05 \\
\hline 50 & 145,00 & 298,90 & 106,14 & 5,98 \\
\hline
\end{tabular}

Tarifas praticadas em janeiro de 2000.

Fonte: Águas del Tunari S. A. (2000 apud MÉLANÇON, 2005, p. 86, tradução nossa). 
Em 2000, a clientela da companhia Aguas del Tunari era composta de 5\% de usuários da categoria $1,35 \%$ da categoria $2,32 \%$ da categoria $3,18 \%$ da categoria 4 e $10 \%$ da categoria comercial. Levando em conta a quantidade de clientes por categoria, parece que esse modelo de tarifação visava oferecer menor aumento para as categorias que possuíam maior quantidade de clientes, principalmente a 3. Ainda assim, os maiores aumentos para a categoria 1 não se justificavam, porque a população mais humilde passaria, a partir de então, a pagar os maiores encargos para consumo cada vez mais diminutos.

O contrato de concessão ainda descrevia pontos conflitantes com os usos y costumbres dos trabalhadores camponeses no Vale Central de Cochabamba. Primeiro, porque o preço de US $\$ 0,08$ por $\mathrm{m}^{3}$ oferecido para a irrigação tornava inviável a agricultura dos pequenos produtores da região. Segundo, porque a concessionária podia ampliar sua área de atuação sem ter a obrigação de fornecer água para irrigação (CRESPO; FERNÁNDEZ; PEREDO, 2004). Dessa forma, os direitos garantidos pelos usos y costumbres se tornavam ameaçados. Um exemplo disso pode ser visto no item 16 do contrato que dizia:

O concessionário deverá tomar as medidas necessárias e realizar os
esforços razoavelmente necessários para identificar novos corpos de água
naturais ou artificiais, vertentes, poços nascentes ou aquíferos
subterrâneos, ou qualquer outro recurso de água natural de acordo com a
necessidade para cobrir a ampliação do serviço e atender às necessidades
que se espera que surjam no futuro, e deverá solicitar à Superintendência
de Águas o direito de usar as ditas fontes de água [...] (Contrato de
Concesión del Agua Potable, ano??? apud CRESPO; FERNÁNDEZ;
PEREDO, 2004, p. 112, tradução nossa). ${ }^{166}$

Por conseguinte, o contrato concede poder à concessionária de explorar novos poços ou fontes de recursos hídricos, dando novamente fôlego ao tipo de gestão de recursos hídricos que foi colocado em prática pelo SEMAPA ainda nos anos 90. Por outro lado, deveria ser reconhecido que a região já estava apresentando dificuldades para a prática da agricultura, principalmente a de pequena extensão. Ademais, a perfuração de poços, a existência de mercado negro de água e a falta de regulação colocava a situação natural da região sob um perigo ainda maior.

166 "El concesionario deberá tomar las medidas necesarias y realizar los esfuerzos razonablemente necesarios para identificar nuevos cuerpos de aguas naturales o artificiales, vertientes, pozos surgentes o napas subterráneas o cualquier otro recurso de agua cruda según sean necesarios para cubrir la ampliación del servicio y atender las necesidades que se esperan surjan en el futuro, y deberá solicitar a la Superintendencia de Aguas el derecho de usar dichas fuentes de agua [...]" 
Um terceiro fator que se apresentou, ainda, como antecedente importante da Guerra da Água foi a situação criada pela Lei no 2.029 (Ley de servicios de agua potable y alcantarillado sanitário, Lei de serviços de água potável e esgoto sanitário) (BOLIVIA, 1999b). Até então, a gestão e os direitos sobre os recursos hídricos eram regidos pela antiga Ley de Dominio y Aprovechamiento de Aguas (BOLIVIA, 1906), que aplicava e reconhecia os usos y costumbres e, portanto, admitia o direito de propriedade sobre os recursos hídricos. Segundo esse diploma legal, são proprietários dos direitos de água os donos das terras onde esses recursos sejam encontrados ou passem. Deve-se acrescentar que se tratava de um direito consuetudinário, não sendo necessário um título de posse de direitos sobre os recursos hídricos. Porém, isso não queria dizer que se podia usar todo o recurso em detrimento de terceiros a jusante, já que esses direitos eram regulados, assim como no período incaico, por turnos. Normalmente, se reconhecia que os proprietários a montante possuíam mais direitos a turnos que aqueles situados a jusante. Isso, portanto, significava que o direito sobre a utilização dos recursos hídricos era reconhecido, mas que não havia propriedade privada (exclusiva) sobre eles, mesmo porque, conforme advertem Barragán et al. (1998, p. 56, tradução nossa), o artigo 136 da Constituição Boliviana de 1994 reconhecia os recursos hídricos como domínio originário da nação, o que significava afirmar que "o poder originário desses bens implica o 'poder absoluto desde a origem' que tem o Estado sobre os mesmos". ${ }^{167}$

Pois bem, a nova lei procurava regular não a propriedade do recurso hídrico, mas a distribuição dos recursos hídricos para fins de abastecimento público de água potável e esgoto. Portanto, não fazia menção às fontes de recursos hídricos, não afetando diretamente o direito daqueles camponeses que utilizavam as suas fontes de água para irrigação de campos ou para o próprio consumo. Não obstante, esse diploma legal afetava principalmente os camponeses que utilizavam os seus recursos hídricos para fins de abastecimento da comunidade, conformando sistemas de água potável (CRESPO, FERNÁNDEZ, 2004). Adicionalmente, a nova lei afetava os sistemas de água urbanos, porquanto vários moradores da área perfuraram poços como forma de abastecimento de água alternativo, já que o serviço público não atendia a toda a população. Naturalmente, a construção desse arcabouço

\footnotetext{
167“El dominio originario de estos bienes implica el 'poder absoluto desde el origen' que tiene el Estado sobre los mismos."
} 
jurídico deixava espaço para muitas dúvidas, sobretudo porque o diploma legal era confuso e trazia modificações para o que há muito vinha sendo praticado pelas comunidades do Vale Central de Cochabamba.

Portanto, essa lei afetava boa parte dos usos y costumbres dos camponeses indígenas em vários de seus artigos, entre os quais, abordaremos apenas os principais. Assim, em seu Artigo 8º, alínea k, essa lei define:

Entidade Prestadora de Serviços de Água Potável e Esgoto Sanitário (EPSA): Pessoa jurídica, pública ou privada, que presta um ou mais dos Serviços de Água Potável e Esgoto Sanitário, e que tem alguma das seguintes formas de constituição:

i. empresa pública municipal, dependente de um ou mais Governos Municipais;

ii. sociedade anônima mista;

iii. empresa privada;

iv. cooperativa de serviços públicos;

v. associação civil;

vi. as comunidades indígenas e camponesas, em virtude do artigo 171 da Constituição Política do Estado;

vii. qualquer outra organização que conte com uma estrutura jurídica reconhecida pela lei, exceto os Governos Municipais (BOLIVIA, 1999b, tradução nossa). ${ }^{168}$

Verifica-se que a lei considera organizações com fins e propósitos tão desiguais como pertinentes a uma mesma categoria. À vista disso, a livre concorrência que se procurava estabelecer para o mercado de águas, acabou criando condições para a formação de um monopólio de empresas privadas que estavam preparadas para esse fim.

Esse diploma legal ainda distinguia zonas para concessão e para licenças. Foram classificadas como zonas sujeitas a concessão aquelas em que se havia mais de 10.000 habitantes e que, portanto, eram consideradas rentáveis. A concessão, prevista para um período de 40 anos e com garantia de exclusividade de

168 "Persona jurídica, pública o privada, que presta uno o más de los Servicios de Agua Potable y Alcantarillado Sanitario y que tiene alguna de las siguientes formas de constitución:

i. empresa pública municipal, dependiente de uno o más Gobiernos Municipales;

ii. sociedad anónima mixta;

iii. empresa privada;

iv. cooperativa de servicios públicos;

v. asociación civil;

vi. las comunidades indígenas y campesinas, en virtud del artículo 171 de la Constitución Política del Estado;

vii. cualquier otra organización que cuente con una estructura jurídica reconocida por Ley, excepto los Gobiernos Municipales." 
prestação do serviço pela entidade concessionária, era destinada a empresas privadas, grandes cooperativas e empresas públicas. Por sua vez, a licença, outorgada para a entidade prestadora por 5 anos sem exclusividade de prestação do serviço, era reconhecida para áreas com menos de 10.000 habitantes ou áreas com população superior a esse limite porém muito dispersa, destinando-se a pequenas cooperativas, comitês de água, camponeses e governos municipais.

Esse tipo de dispositivo legal é um exemplo que corrobora nossa afirmação de que a regulação acabava criando um monopólio de empresas privadas. Para buscar o fornecimento de melhores serviços, seria imprescindível promover maior concorrência nas áreas sujeitas à concessão (entre empresas privadas) e menor naquelas sujeitas à licença (pequenas cooperativas). Essa lei produziu justamente o efeito contrário, garantindo uma série de direitos para as áreas sujeitas à concessão, assim privilegiando o monopólio sobre os serviços em uma determinada área (CRESPO, FERNÁNDEZ, 2004).

O artigo 29ㅜㄹ por seu turno, acabou conformando esse processo, pois proibe qualquer outra forma de abastecimento de água e serviço de esgoto nas áreas sujeitas à concessão que não a prestada pela entidade concessionária (CRESPO, FERNÁNDEZ, 2004). Sob outro ponto de vista, o artigo procurava também controlar a perfuração de mais poços e o avanço do mercado negro de água existente na região metropolitana de Cochabamba, fenômeno que estava contribuindo para a ocorrência de degradação dos recursos hídricos. Outro artigo que ia nessa mesma direção, o 76², proibe a perfuração de novos poços após a promulgação da lei.

Ainda outros artigos expressavam a contradição entre a racionalidade e o modo de vida tradicional dos camponeses e indígenas e a racionalidade moderna ocidental. Assim é que pelo artigo $72^{\circ}$ os usuários são obrigados a se conectar com a rede de serviço de água potável e de esgoto sanitário. Para a racionalidade urbana, essas são medidas normais, pois desde que haja a prestação do serviço de abastecimento de água, os usuários devem usufruir dele, mesmo porque nas áreas urbanizadas muito dificilmente se poderá dispor de serviço alternativo. Todavia, na perspectiva do modo de vida camponês, ainda havia a possibilidade de usufruir das diferentes fontes de água que já vinham sendo utilizadas desde tempos remotos por inúmeras gerações anteriores. Daí o repúdio de grande parte dos camponeses a esse dispositivo legal. 
Antes de declarar a Lei no 2.029 (BOLIVIA, 1999b) completamente injusta, devemos levar em conta que ela procurava introduzir uma racionalidade moderna, de cunho econômico, em uma região habitada basicamente por uma população regida por uma racionalidade social e comunitária. Isso redundou em uma série de contradições. Em determinados aspectos, pode-se asseverar que a lei, além de ser injusta, era irracional, especialmente no que concerne à definição das áreas sujeitas à concessão e à licença e seus respectivos direitos. Porém, em outros artigos, percebe-se que o legislador procurou implementar uma gestão mais racional e controlada dos recursos naturais, para tentar evitar a continuidade da perfuração descontrolada de poços e canais de irrigação, que vinha ocorrendo há pelo menos 30 anos no Vale Central de Cochabamba.

A aplicação da Lei no 2.029 (BOLIVIA, 1999b), o aumento das tarifas de água e a execução do Projeto Múltiplo Misicuni esboçavam o contexto conjuntural e regional que desencadearia o conflito sobre a água, implicando a liberação de uma série de tensões que vinham se acumulando na sociedade cochabambina. Além disso, faz-se necessário esclarecer que junto com as demandas relacionadas a esses três aspectos, foram se adicionando outros pleitos. Portanto, é importante que se visualize de que forma a interação entre todos esses fatores também teve sua parcela de contribuição na estruturação desse contexto.

5.6.2 Atores e conflitos: da velha ordem territorial a uma nova ordem territorial

A Guerra da Água marcou a passagem de uma ordem territorial antiga a uma nova ordem territorial no Vale Central. Após 30 anos em que as territorialidades camponesas foram desafiadas pelas territorialidades urbanas, em um período de extrema instabilidade, o fim deste conflito marcou o estabelecimento de um novo pacto territorial. Além disso, a Guerra da Água em Cochabamba se caracterizou pelo confronto entre demandas da sociedade civil cochabambina ao governo e à multinacional e por haver uma disputa interna na própria sociedade civil a respeito de qual instituição a representaria perante o governo central.

Dessa forma, tornou-se necessária a reflexão sobre os atores envolvidos no conflito representando anseios e interesses das diferentes territorialidades. Não 
houve, como alguns atores procuraram caracterizar a Guerra da Água, apenas um confronto entre o consórcio multinacional Aguas del Tunari e a sociedade cochabambina (CECEÑA, 2005; CUBA, 2000; SHULTZ, 2000). Muito pelo contrário, houve 0 confronto ainda de interesses entre as diferentes territorialidades polarizadas na disputa entre o representante da sociedade cochabambina: Coordinadora del Agua ou comitê cívico?

O comitê cívico foi legalmente constituído em 1972 como o representante da sociedade civil na Bolívia, cada província possuindo um. Apesar de ter essa importante incumbência, o presidente dessa instituição não é eleito diretamente pelos cidadãos. Cada sindicato profissional, câmaras empresariais e instituições financeiras possuem direito a um voto e, assim, acabam escolhendo quem os representará. Boa parte dos comitês cívicos acabou sendo tomada pelos partidos. Assim, a maior parte da população acabava não escolhendo quem realmente os representaria.

A postura do comitê cívico pode ser dividida em duas fases. Na primeira, foi presidido por Edgar Montaño, que em dezembro de 1999 renunciou ao cargo e se candidatou ao conselho municipal pelo partido do alcalde (prefeito) Manfred Reyes Villa. Durante o período de sua presidência, o comitê procurou dar certo impulso à concessão do SEMAPA, ainda que discretamente por meio de algumas críticas ainda tímidas ao modelo de concessão. Outro aspecto importante de sua postura foi uma atitude agressiva em relação ao Comité de Defensa del Agua y la Economía (CODAEP, Comitê de Defesa da Água e da Economia) e a FEDECOR. Essas duas instituições conformariam posteriormente a Coordinadora del Agua (GARCÍA; GARCÍA; QUITÓN, 2003).

Em um segundo momento, a partir de 2000, sob a liderança de Mauricio Barrientos, o comitê cívico passou a ter uma postura mais propositiva e negociadora, ainda que continuasse com as duras críticas em relação à Coordinadora del Agua. García, García e Quitón (2003, p. 86, tradução nossa) apontaram que ambas a gestões tinham um propósito comum: "[...] fazer prevalecer o poder cívico de representação dos interesses regionais dentro da legalidade institucional”169. Essa

\footnotetext{
169 “[...] hacer prevalecer el poder cívico de representación de los intereses regionales dentro de la legalidad institucional."
} 
postura legalista pode ser notada principalmente nos seguintes posicionamentos do comitê cívico de Cochabamba durante a Guerra da Água, em que ambos os presidentes procuraram rechaçar as ações da Coordinadora del Agua.

O antigo presidente do comitê cívico, Edgar Montaño, deu os seguintes depoimentos:

O verdadeiro rosto desse Comitê [CODAEP], que é apócrifo, não conta com nenhuma representatividade, mas é ainda um Comitê que nasce exclusivamente da orientação política de um partido (MNR) que defendeu o projeto Corani (EL DEBER, 1999). ${ }^{170}$

Quero pedir ao governo que acelere a resposta ás demandas efetuadas pelo Comitê Cívico, destinado a diminuir a taxa de retorno, buscar recursos para que o tema do incremento tarifário não impacte a economia familiar e ao contrário o privilegie (OPINIÓN, 1999). ${ }^{171}$

Já o presidente que assumiu a partir de 2000, Mauricio Barrientos, teceu os seguintes comentários:

Demandamos ao governo imediata suspensão da aplicação das tarifas de água e a construção de Misicuni, sem cortes e nem demora. Determinamos a defesa da nossa institucionalidade que pretende ser avassalada por outras organizações (ULTIMA HORA, 2000). ${ }^{172}$

Não podemos arriscar que a empresa se retire. Com essa situação estamos correndo o risco de não receber maiores investimentos durante muitos anos e isto seria um pecado tremendo. O que se deve fazer é ter cuidado e profissionalismo com o que se faz (OPINIÓN, 2000). ${ }^{173}$

As ações da Coordinadora não me preocupam muito, porque é uma entidade ilegítima na qual os seus representantes se "auto-manobram" (LOS TIEMPOS, 2000). ${ }^{174}$

170 "El verdadero rostro de esse Comitê [CODAEP], que es apócrifo, no cuenta com ninguna representatividad, mas aún es um Comitê que nace exclusivamente de la orientación política de um partido (MNR) que defendio el proyecto Corani."

171 "Quiero pedir al gobierno que acelere la respuesta a los planteamientos efectuados por el Comité Civico destinado a disminuir la tasa de retorno, buscar recursos para el tema del incremento tarifario no impacte la economia familiar y al contrario los privilegie."

172 "Demandamos al gobierno la inmediata suspensión de la aplicación de la tarifas y la construcción de Misicuni, sin cortes ni demoras. Determinamos la defensa de nuestra institucionalidad que pretende ser avasallada por otras organizaciones."

173 "No podemos arriesgarnos que la empresa se retire. Con esa situación estamos arriesgándonos a no recibir mayores inversiones durante muchos años y esto seria un pecado tremendo. Lo que se debe hacer es tener cuidado y profesionalismo en lo que se hace."

174 "Las acciones de la Coordinadora no me preocupan mucho, porque es una entidad ilegítima en la que sus representantes se 'automanobram'." 
No que concerne às principias demandas do Comitê, durante a presidência de Montaño, os seus pleitos eram garantir a assinatura do contrato com Aguas del Tunari, uma vez que o próprio comitê havia anteriormente defendido o grande sonho de Cochabamba. Naturalmente, essa posição visava também legitimar a política do governo municipal (GARCÍA; GARCÍA; QUITÓN, 2003). Já na presidência de Barrientos, o comitê protestava contra a elevação dos preços da tarifas de água, assim como requeria a revisão do contrato com Aguas del Tunari (GARCíA; GARCÍA; QUITÓN, 2003). Em relação à Lei no 2.029 (BOLIVIA, 1999b), o comitê apenas requereu timidamente uma discussão sobre os seus dispositivos legais. Como bem salientaram García, García e Quitón (2003, p. 87, tradução nossa):

Mas não apenas defender a revisão do contrato e reduzir o incremento tarifário, ainda que se incline a favor de um revisão do contrato antes de sua anulação são as tarefas pendentes que se espera desta autoridade. Falta ainda conduzir as protestas contra a Lei 2029 cada vez mais fortes das organizações camponesas. Em suma articular as demandas urbanas com as rurais. ${ }^{175}$

Portanto, no que tange as disputas entre as territorialidades, as propostas do comitê cívico representavam essencialmente os interesses das territorialidades urbanas, isto é, das classes mais nobres e médias urbanas. Aqui se deve acrescentar que os bairros da zona sul da cidade não foram diretamente afetados pela questão da água, já que não estavam conectados a rede de serviço de Aguas del tunari e tampouco aos sistemas alternativos de água. Assim, nem a Lei no 2.029 (BOLIVIA, 1999b), nem o aumento das tarifas de água ia contra os seus interesses. Por outro lado, o projeto "Misicunito" contemplava em seus planos a extensão do abastecimento de água à zona sul da cidade.

Ao mesmo tempo em que vai havendo essa divisão pela representação da sociedade civil entre Coordinadora del Agua e comitê cívico, o conflito vai se intensificando e adquirindo uma roupagem nova. Segundo Dominguez e Jiménez (2000, p. 6):

É interessante observar como em fevereiro ambas instituições, representantes dos interesses cochabambinos, perseguem um mesmo objetivo: que não se incrementem as tarifas; sem embargo diferenças surgidas em face da estratégia de solução (pre-acordos e medidas de

\footnotetext{
175“Pero no sólo defender la revisión del contrato y reducir el incremento tarifario aunque se inclina a favor de una revisión del contrato antes de su anulación son las tareas pendientes que esperan a esta autoridad. Falta conducir las protestas contra la Ley 2029 cada vez más recias de las organizaciones campesinas. En suma articular las demandas urbanas con las rurales."
} 
pressão) fazem que eventualmente elas se convertam em atores hostis, em franca pugna pelo poder local. ${ }^{176}$

Naquele período, o governo já havia prometido revisar a Lei ํo 2.029 (BOLIVIA, 1999b), porém restavam ainda a questão da concessão do SEMAPA e aumento das tarifas de água. Assim, à medida que a luta política se acentua, os dois principais atores procuram se distanciar e se fazer distinguir um do outro, por meio da radicalização de suas demandas:

Da noite para o dia, a sociedade civil aparece dividida e, a medida que o conflito se acentua, se constitui, a exceção de alguns setores como os empresários privados, em um bloco enfrentado ao governo, com uma capacidade desconhecida até então. Os representantes institucionalizados cambaleiam e perdem espaços de poder frente a Coordinadora, que aglutina a um conjunto de setores sumamente diverso (ORTEGO, 2000, p. 16)..$^{177}$

A Coordinadora del Agua surge da união de diversos setores envolvidos no começo do ano 2000. Até então o movimento de questionamento do modelo de concessão e execução do projeto Misicuni e da Lei o 2.029 (BOLIVIA, 1999b) fora levado adiante pelo CODAEP, pelo Fórum Cochabambino del Médio Ambiente y Desarrollo (FOCOMADE, Fórum Cochabambino do Meio Ambiente e Desenvolvimento), bem como pela FEDECOR. Esse movimento se restringia essencialmente ao campo, uma vez que as tarifas somente receberiam um incremento a partir de primeiro de Janeiro de 2000. Porém, a partir de janeiro de 2000 passa a incorporar em seu núcleo a Federação de Trabalhadores Fabris, incluindo assim as demandas urbanas de forma mais intensa.

Dois momentos marcam a postura do movimento. O primeiro momento é o da formação do CODAEP em que se criticam as principais falhas do contrato de concessão e a flexibilização do Projeto Misicuni, o modelo de aumento das tarifas, e a aprovação da Lei no 2.029 (BOLIVIA, 1999b). Essa postura foi ainda mais

176 "Es interesante observar como en febrero ambas instituciones, representantes las dos de los intereses cochabambinos, persiguen un mismo objetivo: que no se incrementen las tarifas; sin embargo diferencias surgidas ante las estrategias de solución (pre-acuerdos y medidas de presión) hacen que eventualmente se conviertan en actores enfrentados, en franca pugna por el poder local."

177 "De la noche la mañana, la sociedad civil aparece dividida y, a medida que el conflicto se agudiza, se constituye, a excepción de algunos sectores como los empresarios privados, en un bloque enfrentando al Gobierno, con una capacidad de presión desconocida hasta la fecha. Los representantes institucionalizados se tambalean y pierden espacios de poder frente a la Coordinadora, que aglutina a un conjunto de sectores sumamente diversos" (ORTEGO, 2000, p. 16) 
acentuada quando da promulgação do diploma legal, dando início aos primeiro bloqueios. Dessa forma, o que deu início ao conflito de forma concreta foi a promulgação da Lei no 2.029 (BOLIVIA, 1999b) (LASERNA, 2000a) com Convocatória da FEDECOR. Em um segundo momento, com a conformação da Coordinadora del Agua, o movimento social buscou anular o contrato com Aguas del Tunari e garantir a revogação da referida lei, acordada com o governo. De um lado, a anulação do contrato permitiria acabar com o aumento das tarifas de água e as irregularidades do contrato de concessão, de outro lado, ela é o resultado da ampliação das medidas de radicalização do movimento como forma de se fazer diferenciar do comitê cívico. O líder do movimento, Oscar Oliveira, desde o começo do ano de 2000 fazia referência ao neoliberalismo, às transnacionais e ao governo como os principais responsáveis pela má gestão dos recursos hídricos no país e principalmente pela má qualidade de vida dos bolivianos. Dessa forma, a empresa era completamente responsabilizada pela situação crítica existente naquele momento.

Por outro lado, o movimento parece não se preocupar com o fato de que a anulação do contrato implicava no cancelamento do projeto Misicuni que de certa forma era solução para a situação mais precária da cidade: aquela dos bairros da zona sul (GARCÍA; GARCÍA; QUITÓN, 2003, p. 98). Segundo Laserna (2000a, p. 44):

A elevação das tarifas, acordadas no contrato para atrair os enormes investimentos requeridos para ampliar a rede e realizar Misicuni foi associada de imediato ao caráter privado da empresa e, por tanto, a sua racionalidade capitalista baseada no lucro e nos ganhos. Racionalidade que ainda hoje tem limitada legitimidade em Cochabamba, onde milhares de pequenos produtores, comerciantes e transportadores atuam no mercado mas o rechaçam, não se consideram como empresários e duvidam de sua própria ação mercantil. ${ }^{178}$

A ampliação dos discursos do movimento chama atenção principalmente porque antes da conformação da Coordinadora del Agua as propostas estavam exclusivamente centradas na questão da gestão da água em Cochabamba. Porém, a partir da entrada de outros atores e a conformação desse movimento, as

\footnotetext{
178 "La elevación de tarifas, acordada en el contrato par atraer las enormes inversiones requeridas para ampliar la red y hacer Misicuni, fue asociada de inmediato al carácter privado de la empresa y, por tanto, a su racionalidad capitalista basada en lucro y la ganancia. Racionalidad que aún hoy tiene limitada legitimidad en Cochabamba, donde miles de pequeños productores, comerciantes y transportistas actúan en el mercado pero lo rechazan, no se perciben a si mismos como empresarios y dudan de su propia acción mercantil."
} 
demandas começam a se diversificar incluindo outros pontos relacionados ao neoliberalismo e a situação econômica como forma de se diferenciar do comitê cívico e com o fim de atrair ainda mais outros atores (GARCÍA; GARCÍA; QUITÓN, 2003; LASERNA, 2000a). De acordo com Ortego (2000, p. 22):

Lidamos com a hipótese de que a Coordinadora não tinha vontade necessária para entrar em um real processo de negociação (entendendo a negociação como um processo em que as partes cedam algo para conseguir algo), já que pensamos que desde o princípio seus objetivos estavam orientados à rescisão do contrato, ou - utilizando em outras palavras - a impor a sua posição; quer dizer que sua posição não se moveu a um ápice em todo o processo. Isto não significa que todos os membros da Coordinandora iniciaram as negociações com esse espírito, senão que, no processo, as tendências mais radicais impuseram a sua lei. ${ }^{179}$

Um dos mediadores da Igreja Católica no conflito, o padre Gregório Iriarte ressalta a postura da Coordinadora del Agua durante as negociações foi radical em querer que o contrato fosse anulado:

[...] primeiro momento se pretendia que se mudasse o contrato...até que no ultimo [momento] aceitaram mudar o contrato, mas [Oscar] Oliveira e esses [os membros da Coordinadora] lá [nas negociações] já não estão [...] estavam todos nas paralisações [...] se decidiu então pela má solução: banir a empresas, expulsar então [...] não tiveram diálogo [...] Por outro lado, não se resolveu o problema da água ainda, há muita corrupção (IRIARTI, 2006). ${ }^{180}$

A partir dessa estratégia, o movimento passou a chamar mais atenção para os interesses urbanos e conseguiu atrair aqueles setores que se vinculava não apenas a questão da água, mas principalmente em relação a caótica situação econômica do país. Outro aspecto que atraiu a população foi o importante espaço público aberto pela Coordinadora del Agua. A livre participação social e discussão das demandas envolvidas no conflito foram um chamativo e importante passo na conscientização popular. Essa forma de negociação entre os líderes dos vários

\footnotetext{
179 "Manejamos la hipótesis de que la coordinadora no tenia voluntad necesaria para entrar en un proceso real de negociación (entendiendo la negociación como un proceso en el que las partes ceden algo para conseguir algo), puesto que pensamos que desde un principio sus objetivos han estado orientados a la rescisión del contrato, o - utilizando otras palabras - a imponer su posición; es decir que su posición no se movió un ápice en todo el proceso. Esto no significar que todos los miembros de la coordinadora iniciaran la negociación con ese espíritu, sino que, en el proceso, las tendencias más radicales impusieron su ley."

180 " "....] en el primer momento se pretendía de que se cambiara el contracto,... hasta de que lo ultimo accederán a cambiar el contracto, pero [Oscar] Oliveira y esos [los miembros de la Coordinadora] allá [en las negociaciones] ya no están y estaban todos ya paralizados [...] se ha decidido entonces por la mala solución: echar la empresa, entonces expulsar [...] no han tenido dialogo [...] Por otro lado, no se ha arreglado el problema del agua no se ha arreglado todavía, hay mucha corrupción" (IRIARTI, Gregório. Comunicação pessoal em entrevista concedida ao autor. El Alto, 17 de janeiro de 2006).
} 
movimentos sociais que conformavam a Coordinadora del Agua foi um importante marco de legitimação desse movimento social, ao contrário do comitê cívico e dos partidos políticos, que se vinculavam a um formalismo e legalismo que a acabava afastando a participação dos cidadãos.

O acirramento e a polarização dos atores entre a Coordinadora del Agua e o comitê cívico fizeram com que o conflito se tornasse mais tenso e "emocional", fazendo com que outras questões se adicionassem à questão da água, como a questão da erradicação da coca no Trópico Cochabambino, e inclusive envolvendo antigos "concorrentes políticos" em pólos opostos, é o caso de Evo Morales e Alejandro Veliz (ORTEGO, 2000) (Quadro 6). De um lado, o comitê cívico defendendo principalmente a redução das tarifas de água e a revisão do contrato de concessão, ou seja, os interesses das territorialidades urbanas, de outro, a Coordinadora del Agua procurando levar adiante a anulação do contrato de concessão e a revogação da Lei no 2.029 (BOLIVIA, 1999b), isto é, interesses da territorialidade camponesa indígena e daquela territorialidade híbrida dos setores médios urbanos.

Quadro 6. Polarização política em torno dos dois representantes da Sociedade Civil durante a Guerra da Água.

Coordinadora del Agua Comitê Cívico

\footnotetext{
Federación de Trabajadores Fabriles

Federação de Cocaleros (Evo

Morales) e FEDECOR (Omar

Federación de Campesinos (Alejo

Veliz)

Fernandez)

Federación del autotransporte pesado

Federación Departamental del autotransporte

FEJUVE (Pueblo)

FEJUVE (NFR)

Federación Universitaria Local (FUL) Cúpula da Universidad Mayor de San Simon (UMSS)

Asociación de Empresarios

Federación de Empresarios Privados

Perforadores de Pozos

de Cochabamba

Comitês Cívicos provinciais

Brigada Parlamentar de Cochabamba

Central Obrera Departamental (COD)

Fonte: Organizado pelo autor com base em Dominguez e Jimenez (2000, p. 9).
} 
Do lado inverso do conflito, os atores estatais (governo central, departamental e municipal) procuravam explorar ao máximo a oposição entre os dois representantes da sociedade civil, principalmente ao não reconhecer a Coordinadora del Agua como um ator "legal" e com personalidade jurídica para debater o assunto. Além disso, esses atores procuraram levar adiante o contrato como forma de realizar Misicuni. Naturalmente, o fracasso de Misicuni representaria a falência política do presidente Hugo Banzer, bem como da gran alianza (CRESPO, 2000b).

Outra diretriz seguida foi não contradizer as recomendações o Banco Mundial sobre a política de serviços básicos, ou seja, não subvencionar os serviços de água e esgoto e de outra parte priorizar as concessões ao setor privado. Claramente, isso significava proteger os interesses de Aguas del Tunari, postura fortemente seguida pelos atores estatais. Um fato explicito a este respeito é o fato do consórcio Aguas del Tunari não haver participado de nenhuma negociação relativa ao contrato de concessão com os representantes da sociedade civil (CRESPO, 2000b)

No final de 1999, houve eleições para a alcaldia, e Manfred Reyes Villa foi reeleito. Durante a campanha eleitoral, Villa que anteriormente apoiou e assinou o contrato com o consórcio transnacional, passou a partir de então a uma postura opositora, principalmente porque naquele momento a população cochabambina começava a manifestar-se contra o projeto. Esta mudança de postura levou a quebra da grande coalizão de partidos que havia eleito Hugo Banzer a presidente do país em 1996. Assim, além da disputa entre o comitê cívico e a Coordinadora del Agua, estabelece uma disputa político entre o governo nacional e o governo municipal, implicando inclusive num conflito mediático entre os dois protagonistas dessa disputa: Hugo Banzer e Manfred Villa (GARCÍA; GARCÍA; QUITÓN, 2003).

A falência das instituições políticas pode ser notada principalmente pela incapacidade do governo em tornar públicos as decisões políticas. Junte-se a isso a pouca habilidade de Hugo Banzer em manejar os meios de comunicação de forma a explicar os propósitos do contrato de concessão bem como o aumento das tarifas de água. Essas debilidades vão se materializar na estreita abertura à negociação, expressos de forma concreta em um autoritarismo e repressão como forma de enfrentar o conflito de interesses (CRESPO, 2000b). 
Talvez uma das falhas principais dos atores estatais e principalmente do governo tenha sido a incapacidade em aproveitar os erros da Coordinadora del Agua. Segundo Crespo (2000b, p. 11), "a Coordinadora cometeu vários erros táticos que, em termos de guerra de posições, não foram aproveitados pelo governo."181 Ademais, a postura radical de desconhecer a Coordinadora como representante legitimo da sociedade civil trouxe ainda mais revolta à população cochabambina, contribuindo para que a Coordinadora del Agua fosse considerada o fiel representante do "povo cochabambino". Um instrumento discursivo utilizado pelo presidente Banzer para justificar a sua posição foi caracterizar a Coordinadora del Agua enquanto um movimento social vinculado a narcotraficantes, uma vez que o líder cocalero apoiou as marchas e protestos organizados pela Coordinadora del Agua. Aqui fica evidente que a questão da erradicação da coca se fez fortemente presente no conflito.

Em relação ao governo departamental, este possuía um papel indireto em relação às políticas de abastecimento de água e esgoto, dessa forma, a sua atuação durante o conflito foi de seguir as ordens do governo central, visando a manutenção da legalidade e o cumprimento do contrato de concessão. Porém, à medida que a situação ia se tornando caótica, o prefecto foi adotando uma postura intermediária entre a postura do governo central e aquela representada pelos movimentos sociais, para em um último momento finalmente decidir-se pela posição dos movimentos sociais. Dessa forma, assim como o alcalde sua postura apresenta traços contraditórios. Em relação ao embate entre o governo central e o municipal, o prefecto procurou esquivar-se dessa polêmica disputa.

No que concerne à conformação territorial e a estruturação do shatterbelt, percebe-se que na escala nacional o confronto entre territorialidades estava representado pela Coordinadora del Agua defendendo os interesses da territorialidade camponesa indígena e principalmente aquela dos estratos urbanos médios no que concerne à discussão sobre a questão hídrica. Ao radicalizar o seu discurso, esse movimento social passa a representar o grande anseio da população mais humilde do Vale Central no que concerne aos efeitos nocivos do Ajuste Estrutural. Segundo Assies (2003, p. 32), algo "mais estava em jogo do que

\footnotetext{
181 "La Coordinadora cometió varios errores tácticos que, en términos de guerra de posiciones, no fueron aprovechados por el Gobierno."
} 
simplesmente a questão da água. A Coordinadora del Agua constituiu um importante desafio ao sistema representativo legalmente instituído, que falhou em canalizar as preocupações e interesses de diversos setores da população [...]". ${ }^{182}$ Um exemplo disso é o caso da territorialidade dos migrantes aymaras. Analisando a situação levando em conta apenas a situação hídrica, pode-se inferir que não havia motivo para que esta zona participasse da Guerra da Água, uma vez que nem a privatização do SEMAPA e nem a Lei no 2.029 (BOLIVIA, 1999b) afetavam a situação do acesso à água nesta zona. Sob o ponto de vista de uma racionalidade econômica, essa zona teria motivos para apoiar as propostas do comitê cívico e rechaçar a proposta da Coordinadora del Agua, uma vez que a construção do Projeto Misicuni era a única solução à situação caótica desta área (SOLDAL, 2008). Porém aqui se revela, a junção dos fatores da escala regional com as escalas maiores, a zona sul da cidade apoiou a Coordinadora del Agua, devido ao seu discurso anti liberalismo e assim o conflito na verdade foi uma forma de atenuar as tensões sociais acumuladas pelos efeitos da LPP, do Ajuste Estrutural boliviano, bem como das tensões acumuladas pela segregação. Ao analisar a Guerra da Água, Ortego aponta que o conflito foi vivido com uma alta carga de emotividade pela população de Cochabamba:

Estes [fatores psicossociais] se relacionam com a alta emotividade com que as pessoas viveram o processo, os problemas de percepção que midiatizaram as condutas da população e o fenômeno do deslocamento das frustrações sociais sob um ator do conflito. Todos estes elementos contribuíram que em determinados momentos se produza uma 'desracionalização coletiva' no conflito da água (ORTEGO, 2000, p. 16). ${ }^{183}$

Esta "desracionalização coletiva", porém deve ser analisada mais atentamente no que concerne à zona sul. Em relação ao bairro Alto Cochabamba, o dirigente da OTB dessa área, Rogelio Cruz afirmou que:

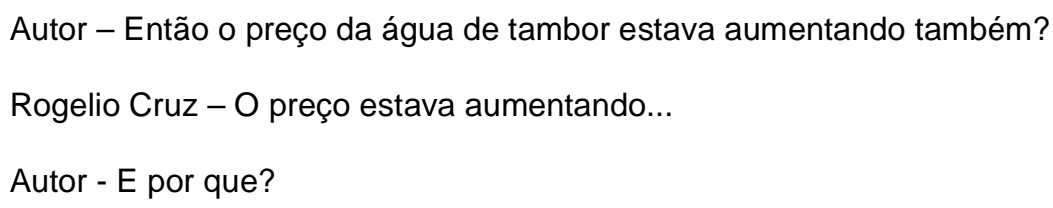

\footnotetext{
182 "But more was at stake than just the water issue. The Coordinadora came to constitute an impotant challenge to the instituted system of legally accredited representation, which failed to channel the concerns and interests of large sectors of the population [...]"

${ }^{183}$ Estos tiene que ver con la alta emotividad con la que la gente ha vivido el proceso, los problemas de percepción que mediatizaron las conductas de población y el fenómeno del desplazamiento de las frustraciones sociales hacia un actor del conflicto. Todos estos elementos contribuyeron a que en determinados momentos se produzca una 'desnacionalización colectiva' en el conflicto del agua
} 
Rogelio Cruz - Era decisão dos transportistas...dos caminhões cisternas, pegavam água na cidade e vendiam nos bairros marginais a quatro bolivianos, quatro e cinqüenta, até 5 bolivianos (...) e claro a água não era potável, a água do caminhão cisterna não era potável, não tinha cloro [...] (CRUZ, 2006). ${ }^{184}$

Nesse sentido cabe se indagar até que ponto a postura dos dirigentes da Coordinadora del Agua também não se utilizaram de posturas "paternalista e clientelista" concedendo alguns escassos benefícios a certos setores (como a reparação de um tanque para armazenar água) em troca de apoio nos protestos. Evidentemente, essa instigação ao protesto pela postura mais radical da Coordinadora del Agua ia justamente contra os interesses desse setor no que concerne ao abastecimento público.

Esta postura, por parte da Coordinadora del Agua em alguns casos é ressaltada também pelo líder dos sistemas de água de Marquina (área rural do município de Quillacollo):

Marquina tem duas lagoas, a lagoa Toro e a Lagoa Marquina,[Marquina] tem papeis, tem títulos do Supremo Governo, então...tem escrituras em outras palavras. Difícil era que [o governo] pudesse nos proibir [de usa-las], então nos utilizaram... prova disso são os lideres da Coordinadora que saíram [como] candidatos, deputados... há senadores, há conselheiros da Coordinadora (PEREDO, 2000) ${ }^{185}$

A afirmação do líder de Marquina aponta para a confusão inicialmente feita pela FEDECOR em relação à Lei no 2.029 (BOLIVIA, 1999b). O caso de Marquina reflete bem aquela situação em que a lei não afetou os camponeses que utilizavam água para irrigação do plantio e não para abastecimento de água potável da população.

Em relação ainda à zona sul, o líder da Associação dos Sistemas Comunitários de Água da Zona Sul (ASICASUR), Abraham Gandidier, por outro lado, acrescenta que:

\footnotetext{
${ }^{184}$ Autor - Entonces el precio del agua de turril estaba aumentando también? Rogelio Cruz - El precio estaba aumentando... Autor - Y por que? Rogelio Cruz - Era decisión de los transportistas ...de los carros cisterneros tomavan el água en la ciudad y vendían en los barrios marginales a cuatro bolivianos, cuatro cincuenta , hasta cinco bolivianos (...) y claro el agua no era potable... el agua del carro cisterna no era potable , no tenia cloro [...]" (CRUZ, Rogelio. Comunicação pessoal em entrevista concedida ao autor. Cochabamba, 29 de janeiro de 2006).

185 "Marquina tiene dos lagunas, la laguna Toro y la laguna Marquina, tiene papeles, tiene títulos del Supremo Gobierno, entonces...tiene escrituras en otras palabras. Difícil era que pudiera quitar a nosotros, entonces nos han utilizado... prueba de eso son los miembros de la Coordinadora que han salido candidatos, diputados, hay senadores, hay consejales de la Coordinadora" (PEREDO, Amadeos. Comunicação pessoal em entrevista concedida ao autor. Qullicollo, 29 de janeiro de 2006).
} 
Autor - se não houvesse a privatização... a situação ficaria na mesma, seria uma desvantagem? A população ia se mobilizar se não tivesse nenhuma mudança?

Abraham Grandidier - Eu estou completamente seguro que a população ia se mobilizar, mas por outros motivos que fosse exigir a dotação de água à empresa SEMAPA ou às autoridades, sim... o povo ia se mobilizar e ademais na zona sul da cidade as pessoas estavam empobrecendo e contando com a água mais cara da cidade, isso era questão de tempo, já havia exigências [...](GRANDIDIER, 2006). ${ }^{186}$

Assim, o conflito serviu em grande parte como uma válvula de escapa para várias tensões, muitas das quais não se relacionavam diretamente à questão da água é o caso da sul, bem como o caso do Sindicato dos Cocaleros que participaram em massa do conflito. Ademais, a territorialidade migrante aymara tinha dimensões sociais que se agregavam mais facilmente em relação à territorialidade híbrida dos estratos médios urbanos e à territorialidade camponesa quéchua do que em relação a territorialidade dos estratos mais altos da cidade.

O shatterbelt se estruturou a partir da união dessas três territorialidades associadas com os movimentos sociais de escalas maiores como, por exemplo, o Sindicato dos cocaleros e movimento camponês na escala nacional. Por outro lado, a territorialidade da elite dirigente foi aos poucos se posicionando conjuntamente aos interesses do governo central, do consórcio transnacional e das Instituições Internacionais como o Banco Mundial. À medida que as posições no conflito foram se radicalizando, o comitê cívico e o governo departamental foram perdendo legitimidade, uma vez que apresentavam propostas intermediárias entre os dois extremos.

Além disso, deve-se ressaltar que presença de um ator considerado estrangeiro, a multinacional, trouxe à tona todo o sentimento de nacionalismo e soberania nacional. Segundo Laserna (2000a, p. 45), a presença de transnacionais no consórcio internacional "serviu para recordar que a aspiração nacional da soberania 'ameaçada". ${ }^{187}$ Aqui se nota que a presença de um "inimigo" maior (neste

\footnotetext{
186 “Autor - si no hubiera la privatización... la situación quedaría la misma, seria una desventaja? La población iba a movilizarse, si no hubiera ningún cambio? Grandidier - Yo estoy completamente seguro que la gente se iba movilizar pero por otros motivos que sea de exigir la dotación de agua a la empresa SEMAPA o a las autoridades, si la gente se iba movilizarse y además la gente en la zona sur se esta empobreciendo y contando con agua mas cara de la ciudad eso era cuestión de tiempo, ya había exigencias 10 minutos." (GRANDIDIER, Abraham. Comunicação pessoal em entrevista concedida ao autor. Cochabamba, 22 de janeiro de 2006).

187 "[...] servio para recordar que la aspiración nacional de la soberanía nacional, amenazada esta vez por la privatización [...]"
} 
caso da nação) proporcionou a união de territorialidades que até então estavam em lados opostos, no que concerne às políticas hídricas da região (manifestadas pelo embate entre o urbano e o rural). Assim, a conformação de um shatterbelt foi aos poucos modificando o arranjo territorial, principalmente no que concerne à polarização dos atores em dois núcleos e o "esvaziamento" da posição intermediária.

\subsubsection{Fases do conflito: a lógica do amigo e inimigo}

A Guerra da Água em Cochabamba normalmente é dividida em três "batalhas" ou momento de crises mais acirradas. Acrescentaríamos, porém a esta divisão uma primeira batalha ainda em outubro de 1999 em que a FEDECOR promoveu bloqueios em todo o Vale Central de Cochabamba. A razão desse acréscimo se deve ao fato de que esta classificação faz com se olvide que o conflito teve início não pelo aumento das tarifas como alguns estudos apontam, mas sim a aplicação do projeto Misicuni e a promulgação da Lei no 2.029 (BOLIVIA, 1999b) (LASERNA, 2000a; SOLDAL, 2008).

Dessa forma, os quatro períodos de maior intensidade do conflito foram: a primeira, entre os dias 4 e 5 de novembro de 1999, quando do bloqueios das estradas ligando o Vale Alto ao Vale baixo organizada pela FEDECOR; a segunda correu em janeiro durante os bloqueios das estradas organizados pelo comitê cívico e a Coordinadora del Agua; a terceira, marcada pela "toma pacífica de Cochabamba, no mês de fevereiro; a quarta, durante a paralisação da cidade durante o mês de abril.

A primeira batalha marca a conscientização dos camponeses regantes da aprovação da Lei no 2.029 (BOLIVIA, 1999b) e principalmente dos efeitos da lei sobre os usos y costumbres. Dessa forma, os camponeses bloqueiam estradas como forma de pressão sobre o governo a fim de negociar a modificação do diploma legal. Como no primeiro dia de bloqueios nenhuma autoridade se posicionou ou iniciou alguma negociação com a FEDECOR, os camponeses decidiram manter os bloqueios. No dia seguinte, logo pela manhã, um pelotão do exercito interviu nos principais pontos de bloqueio com gás lacrimogêneo e balas de borracha. Após o 
incidente o prefecto, o superintendente de Águas e um ministro nacional iniciam uma negociação com a FEDECOR. Durnte o período de negociação se logrou um acordo entre as partes, em que se fez o compromisso que o consórcio Aguas del Tunari não iria perfurar nenhum poço em Tiquipaya, Sipe Sipe, Quillacollo, Vinto e Sacaba. Ademais se garantia que as fontes de água continuariam manejadas pelos camponeses a partir dos usos y costumbres. Porém, para que aquilo que foi acordado tivesse validade era necessário ainda modificar o contrato de concessão e a Lei no 2.029 (BOLIVIA, 1999b) (CRESPO; FERNÁNDEZ, 2004).

A segunda batalha acontece no dia 11 de janeiro de 2000, ocasião na qual tanto a Coordinadora del Agua como o comitê cívico promovem paralisações e bloqueios das estradas. O comitê demanda a revisão do contrato e a redução da elevação das tarifas. Já a Coordinadora del Agua pleiteia a anulação do contrato de concessão com Aguas del Tunari e revogação da Lei no 2.029 (BOLIVIA, 1999b). Os bloqueios das estradas lograram cercar a cidade de Cochabamba e paralisar todo o país. A Coordinadora del Agua marcou um cabildo, ${ }^{188}$ no qual se declara que o alcalde Manfred Reyes Villa, o superintendente de Águas Luis Uzin, Edgar Montaño, Guido Camacho e Oscar Coca são inimigos de Cochabamba. Além disso, a Coordinadora del Agua declarou que desconhece o comitê cívico como representante do povo cochabambino. Após forte repressão dos bloqueios e enfretamento entre forças policiais e os manifestantes, as partes envolvidas no conflito resolvem negociar. No dia 14 de janeiro, firmou-se um acordo para a dotação de água a Cochabamba, assinado pelos membros do governo, o comitê cívico e a Federação de Transportistas. Contudo, a Coordinadora del Agua não o assinou alegando que era necessário consultar as bases, e que os membros da Coordinadora del Agua eram apenas representantes da população (CRESPO; FERNÁNDEZ, 2004).

Os principais pontos do acordo eram: 1) constituir uma comissão formada por membros da Coordinadora del Agua, do comitê cívico, Federação Departamental de Autotransporte, FEJUVE, e governos departamental e central com o intuito de promover uma nova estrutura tarifária e realizar o Projeto Misicuni; 2) conformar uma comissão para concertação do projeto de Lei de aguas, mediante audiência pública;

\footnotetext{
${ }^{188}$ Encontro público em que se decide as ações a serem tomadas a partir da participação publica direta.
} 
3) a Brigada Parlamentar, o comitê cívico e a Coordinadora del Agua comprometiam a apresentar ao Congresso um projeto de lei modificando e complementando a Lei no 2.029 (BOLIVIA, 1999b) em um prazo de 45 dias; 4) os sistemas de água já existentes à concessão não seriam afetados pelo contrato de concessão a Aguas del Tunari; 5) as partes concordam em levantar todas medidas de pressão a partir da subscrição do convênio (ASSIES, 2003; GARCÍA; GARCÍA; QUITÓN, 2003).

Devido ao fracasso nas negociações, principalmente no que concerne a estrutura tarifaria, tem lugar a terceira batalha no início do mês de fevereiro. $O$ comitê cívico organiza em 2 de fevereiro uma passeata com o respaldo das autoridades municipais, conselheiros, trabalhadores do setor de transportes, associação de bairros (juntas vecinales), membros da universidade, camponeses e a população em geral. A Coordinadora del Agua por sua parte, rechaça o movimento, qualificando-o como um show para tentar salvar a imagem do último presidente do comitê cívico Edgar Montaño e do alcalde Manfred Villa. Além disso, anuncia a tomada pacífica da cidade no dia 4 de fevereiro. O governo continua com a sua posição autoritária e repressiva e envia 700 policiais de La Paz e tropas do exército. Além disso, anuncia que não permitirá nenhuma manifestação publica. No dia 4 de fevereiro, os manifestantes cercam o centro da cidade, que a partir de então se transforma numa batalha campal durante 14 horas. No dia 5 de fevereiro, a Igreja Católia e o Defensor del Pueblo ${ }^{189}$ conseguem reunir as partes visando um acordo e o fim da violência. Um acordo é firmado entre ministros de estado, o presidente do comitê cívico, o deputado e membro da Coordinadora del Agua, Gonzalo Maldonado (GARCÍA; GARCÍA; QUITÓN, 2003).

Os principais pontos acordados no convênio foram: 1) desenvolver esforços em prol do projeto Misicuni; 2) continuar com as negociações para modificar a estrutura tarifária; 3) continuar com a cobrança de tarifas vigentes em outubro de 1999 até eu se termine a negociação; 4) a brigada parlamentar junta às organizações sociais e membros dos ministérios revisariam a Lei oㅜ 2.029 (BOLIVIA, 1999b); 5) revisar o contrato de Aguas del Tunari, conforme a Constituição Nacional e a lei SIRESE, visando garantir a execução do projeto Misicuni; 6) desmobilização imediata das forças militares e dos movimentos sociais que bloqueavam a cidade; 7) liberação imediata de pessoas detidas e tratamento médico das pessoas feridas no

${ }^{189}$ Instituição independente que busca mediar os conflitos em todo o território boliviano. 
confronto; 8) não realizar medidas de pressão durante a vigência do convênio e 9) se constituem como mediadores do conflito o Monsenhor Tito Solari (Igreja Católica) e Jose Luis Baptista (Defensor del Pueblo) (LA RAZON, 06/02/2000).

Este acordo não logrou apaziguar as disputas políticas entre o comitê cívico e a Coordinadora del Agua. As posições dos dois entes se radicalizam ainda mais, cada um buscando desconhecer a legitimidade do outro. No dia 14 de março de 2000, o comitê cívico consegue um pré-acordo com o Governo congelando as tarifas de água por seis meses e posteriormente um incremento escalonado. A Coordinadora del Agua não aceita o acordo e anuncia mobilizações. No dia 26 de Março, a Coordinadora del Agua realiza uma consulta popular em que aproximadamente 50 mil pessoas de todo o Vale Central de Cochabamba participaram. A maioria absoluta dos participantes foi contra o aumento de tarifas e promulgação da Lei no 2.029 (BOLIVIA, 1999b) e a favor da anulação do contrato de concessão a Aguas del Tunari ${ }^{190}$ (LA RAZON, 06/02/2000).

A quarta e ultima "batalha" começou a se configurar quando a Coordinadora del Agua radicalizou ainda mais sua posição afirmando que haveria uma paralização de tempo indefinido enquanto o contrato com Aguas del Tunari não fosse revogado. No dia 4 de abril a Coordinadora del Agua convocou uma paralisação pacífica da cidade por meio de bloqueios. Nesse dia não houve confronto. Nos dias seguintes, as mobilizações continuam e as negociações entre a Coordinadora del Agua, o comitê cívico, o alcalde e o governo cenral se iniciam no dia 6 de março. No dia 7 de março, as mobilizações se intensificaram demandando que os pedidos da Coordinadora del Agua fossem logo colocados em prática. Na noite desse dia o prefecto anuncia a rescisão do contrato com Aguas del Tunari. Horas mais tarde, enquanto a população comemorava nas ruas, o governo central desmente a posição da autoridade departamental e decreta Estado de sítio, assim como a prisão dos membros da Coordinadora del Agua. No dia seguinte, os confrontos são os mais violentos de todo o período. A forças militares fecham rádios e emissoras, alguns membros da Coordinadora del Agua e de outros movimentos no restante do país

\footnotetext{
${ }^{190}$ As perguntas da consulta popular foram: 1. ¿Usted está de acuerdo con el incremento de tarifas? 2. ¿Usted está de acuerdo con la anulación del contrato de concesión con Aguas del Tunari? 3. ¿Usted está de acuerdo con la mercantilización del agua en la Ley 2029?. Os resultados finais da consulta popular foram $97 \%$ dos participantes reprovavam o incremento nas tarifas de água, enquanto $1 \%$ aprovava. Em relação à pergunta 2,94\% da população era a favor da anulação do contrato com Aguas del Tunari, enquanto que 4\% reprovava. Por fim, 95,6\% da população era contra a mercantilização da água promovida pela Lei oㅡ 2.029 (BOLIVIA, 1999b).
} 
são detidos enquanto outros partem para a clandestinidade. No dia 9 devido à forte manifestação popular Aguas del Tunari decide se retirar de Cochabamba. O viceministro Oras chega a um acordo com a Coordinadora del Agua. Porém, as manifestações continuaram até o dia 11, uma vez que faltava ainda a revogação da Lei no 2.029 (BOLIVIA, 1999b). Nesse dia, o presidente Banzer promulga a lei $n$. 2066 que substitui a Lei no 2.029 (BOLIVIA, 1999b) (MÉLANÇON, 2005). Esse episódio põe fim ao conflito na escala regional, porém ele atuou como a "última gota" para o desencadeamento de uma crise na escala nacional. Nesse sentido, o conflito continuou em âmbito maior, não mais relacionado à água, mas principalmente ao neoliberalismo e a política econômica nacional.

5.6.4 Consequências pós-guerra da água: ganhou-se a guerra, mas perdeu-se a água

Após a saída do consórcio transnacional Aguas del Tunari, os movimentos sociais vinculados à Coordinadora del Água e o movimento altermundialista comemoraram a vitória. Para o movimento social, um novo período iria ter início com a "vitória do povo cochabambino". Ganhou-se a guerra, mas o que fazer a partir de então para resolver a questão da água? A Coordinadora del Agua acreditava que a constituição de uma cooperativa manejada pela gestão pública e popular ao mesmo tempo conseguiria dar um novo destino ao SEMAPA residual. Porém, o que fazer para a execução do projeto Misicuni que ainda estava completamente paralisado? E a dívida do SEMAPA residual?

O SEMAPA residual procurou após estabelecer uma nova estrutura organizacional, a partir da constituição de um conselho de administração com membros eleitos pela própria sociedade civil. O diretório do SEMAPA é então constituído pelo alcalde, um representante técnico da alcaldia nomeado pelo alcalde, 3 representantes da comunidade da capital do departamento eleitos por voto direto, um representante da Federação de Profissionais do Departamento de Cochabamba, um representante dos trabalhadores do SEMAPA, eleito mediante voto secreto.

Este novo modelo trouxe uma série de avanços, porém as eleições vêm sendo marcadas por uma serie de irregularidades (CRESPO; FERNÁNDEZ, 2004; 
MÉLANÇON, 2005). Junte-se a isso a reduzida participação popular nas eleições para os três representantes populares no diretório do SEMAPA. A zona sul da cidade que até o momento é servida precariamente pela rede do SEMAPA, teve maior número de eleitores do que em todas as outras zonas juntas. Melançon aponta que apena $1 \%$ da população total do Município de Cercado participou vêm participando das eleições, o que corresponde a uma participação bem inferior aquela da consulta popular durante a Guerra da Água (MÉLANÇON, 2005). Ademais, outro aspecto negativo é fato de os partidos se embrenharem no que era para ser uma decisão comunitária.

O representante da zona sul no diretório do SEMAPA apontou que:

A situação da zona sul quanto aos serviços básico é bastante delicada, em sua maioria são pessoas de escassos recursos econômicos y frente a indiferença das autoridades do governo para solucionar estes problemas eles resolveram parcialmente os seus problemas, mas também hão decidido pressionar o SEMAPA para que dê a solução definitiva [...] (SANCHEZ apud CRESPO; FERNÁNDEZ, 2004, p. 49). ${ }^{19}$

Quando se fala em vitória é necessário saber para quem houve realmente vitória. Antes do conflito, os camponeses indígenas seriam os maiores prejudicados com a aprovação da lei. Além de perderem o controle sobre os recursos hídricos, a utilização das suas técnicas de manejo desses recursos seria restringida. Os estratos médios urbanos seriam afetados não apenas no controle sobre os recursos hídricos a partir da perfuração de poços, mas inclusive seriam obrigados a utilizar a rede pública, ou seja, deixariam de utilizar as suas próprias técnicas para se vincular a uma gestão de Aguas del Tunari. Ademais, em alguns casos teriam que pagar tarifas mais caras. Para os estratos mais altos, o contrato com Aguas del Tunari significava pagar tarifas substancialmente mais dispendiosas. Mas e o que dizer da zona sul da cidade?

A execução do projeto Misicuni e a concessão seriam a grande oportunidade dos habitantes dessa área ter acesso ao abastecimento de água. Levando em conta o resultado do conflito, acreditamos que os maiores prejudicados foram os moradores da zona sul, que ainda continuam sem água e sem nenhuma outra forma

\footnotetext{
191 "La situación en la zona sur en cuanto a los servicios básicos es delicada, en su mayoría es gente de escasos recursos económicos y ante la indiferencia de las autoridades de gobierno para solucionar estos problemas ellos han resuelto parcialmente sus problemas, pero también han decidido presionar a SEMAPA para que le de solución definitiva [..]"
} 
de abastecimento de água a exceção dos aguateros (SOLDAL, 2008). Dessa forma, o novo arranjo territorial estabelecido após a Guerra da Água favoreceu principalmente a territorialidade dos estratos mais elevados e aquela dos camponeses indígenas. Como bem apontou Mélançon (2005) em seu trabalho de campo, as comunidades da zona sul da cidade continuam consumindo a pior qualidade de água do município, além de pagar os preços mais elevados por esse recurso. Ou seja, a situação não mudou muito para essa zona (Tabela 19). O preço pago por esses moradores é bem mais elevado que o preço da água comercializado pelo SEMAPA e pelos sistemas de água.

Tabela 19. Comparação entre a Rede do SEMAPA, poços comunitários e distribuidores de água (aguateros) em 2004.

\begin{tabular}{cccccc}
\hline Associação & Preço & Número & Produção & Qualidade & Inauguração \\
& $\left(\mathrm{Bs} / \mathbf{m}^{3)}\right.$ & de & $(\mathrm{I} / \mathbf{s})$ &
\end{tabular}

Famílias

\begin{tabular}{|c|c|c|c|c|c|}
\hline A.V.H.A.P.A. & 7 & 423 & 1,5 & salgada & 1994 \\
\hline El Molino & 3 & 364 & 1,73 & ruim & 1998 \\
\hline Mula Mayu & 2,5 & 325 & 5 & boa & 2001 \\
\hline São Miguel & 3 & 240 & 1,5 & variável & 1994 \\
\hline Água Cruz & 5 & 107 & 0,32 & Ruim & 1998 \\
\hline Santa Vera & 5 & - & 0,9 & Boa & 1999 \\
\hline \multicolumn{6}{|l|}{ Cruz } \\
\hline \multirow[t]{2}{*}{ Média/total } & 4,25 & 291,8 & 1825 & variável & Entre $1994 \mathrm{e}$ \\
\hline & & & & & 2001 \\
\hline \multirow[t]{2}{*}{ SEMAPA } & & & & & № Horas de \\
\hline & & & & & Atendimento \\
\hline Categoria 1 & 1,20 & - & - & Boa & 1 a 5 \\
\hline Categoria 2 & 2,20 & - & - & Boa & 6 a 10 \\
\hline Categoria 3 & 4 & - & - & Boa & 11 a 15 \\
\hline Categoria 4 & 6,5 & - & - & Boa & $16-20$ \\
\hline Distribuidor & & & & & Sob \\
\hline (aguateros) & 20 & - & 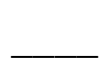 & Ruim & encomenda \\
\hline
\end{tabular}

Fonte: Mélançon (2005, p. 92). 
Deve-se ressaltar que o avanço da rede de abastecimento de água potável e esgoto à zona sul tem sido lento principalmente em relação à forte migração que continua a de forma vigorosa para o vale central de Cochabamba. As principais medidas do SEMAPA em relação ao abastecimento da zona sul tem sido subsidiar o preço da água para os mais novos lares abastecidos pelo serviço. Além disso, o SEMAPA manteve congelados os preços das tarifas de água aos valores de outubro de 1999. Naturalmente, essa postura tem gerado uma série de dificuldades financeiras e por outro lado, o consumo de água tem aumentado sem que a captação de água tenha tido uma forte elevação. Além disso, a expansão da rede do SEMAPA com o objetivo de atender a população mais necessitada tem se dado de forma lenta, nota-se pelo Mapa 27, que os avanços da rede do SEMAPA em relação a zona sul da cidade não foram tão substanciais de 2001 para 2003.

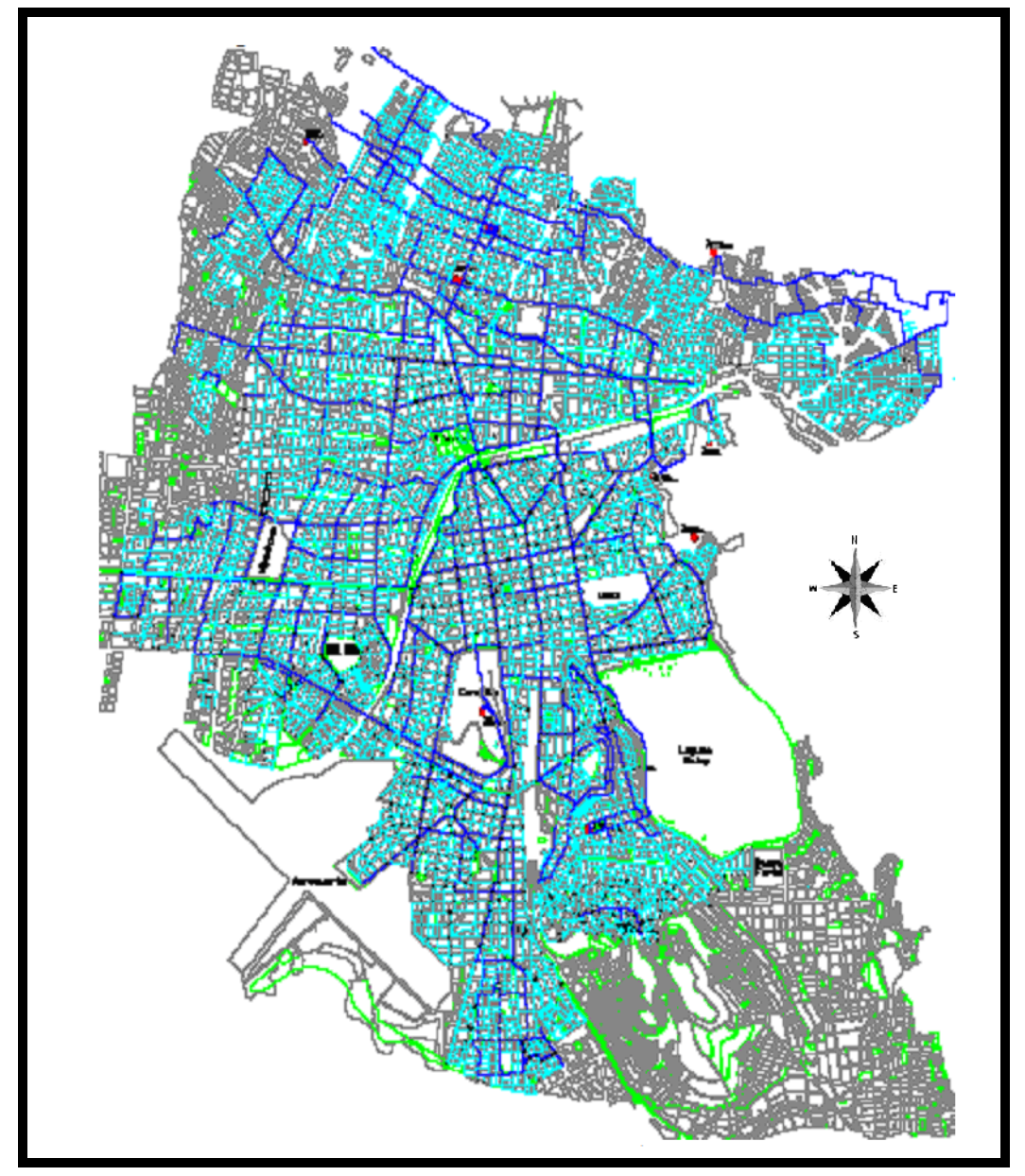

Mapa 27. Município de Cercado, região metropolitana de Cochabamba, rede de abastecimento de água potável do SEMAPA em 2003.

Fonte: Original do autor. 
Outro aspecto importante é que o SEMAPA tem apresentado importantes perdas no volume de água captada. Por exemplo, o informe "Líneas Maestras" afirma que $60 \%$ do volume de água captada desde a fonte é perdida até o consumo (SEMAPA, 2002, p. 33). Embora o SEMAPA não assuma publicamente existe alto número de conexões clandestinas. Pode-se afirmar isso com base nos dados de relógios de água da cidade de 2003 e 2004 (Mapas 28, 29 e 30). Nota-se que no centro da cidade onde e deveria ter a maior quantidade de relógios (zona pontilhada em vermelho), uma vez que a ali se encontra o maior número de casas conectadas à rede do SEMAPA, o número de relógios é bem menor quando comparado com o Mapa 31. Deve-se aqui, no entanto, fazer uma ressalva, trata-se de unidades cartográficas diferentes, enquanto que nas figuras a configuração espacial está organizada por "ciclos de água", o mapa está organizado em zonas de recenseamento. Embora não se possa se fazer uma comparação rigorosa, pode-se afirmar, no entanto que há uma grande diferença entre os resultados apresentados pelas figuras e o mapa. Outro aspecto que expressa a gestão ineficiente do SEMAPA é o fato de que atualmente não há água a ser distribuída durante as $24 \mathrm{~h}$ do dia para todos os usuários. Dessa forma, a empresa realiza um racionamento que novamente leva adiante os princípios da desigualdade. Os moradores do centro da cidade possuem acesso $24 \mathrm{~h}$ por dia ao abastecimento da rede do SEMAPA, enquanto que os bairros nas áreas periurbanas chegam a receber o serviço três vezes por semana (Mapa 31).

Essa má gestão se reflete nos 7,7 milhões de bolivianos e 6 milhões de dólares que o SEMAPA tem paralisado devido a 31 juízos de conciliação e arbitragem. $O$ atual gerente do SEMAPA, Leonardo Anaya, afirma que "se manejou a empresa pública empresa para os próprios benefícios de executivos e empregados, que acabaram gastando os recursos da empresa para o próprio benefício"192 (LOS TIEMPOS, 05/04/2009). Um exemplo disso pôde ser notado durante nosso trabalho de campo, uma parte dos membros da Coordinadora del Agua, em 2006, eram funcionários do SEMAPA, poderíamos citar nomes inclusive,

\footnotetext{
192 "Se ha manejado como se han manejado las empresas del Estado. Como si fueran empresas para beneficio propio de ejecutivos y de empleados. No solamente no se han formado cuadros de profesionales y de técnicos que manejen la empresa de forma eficiente, sino que han malgastado y mal utilizado los recursos".
} 
porém por questão de ética nos omitimos a tanto. Porém, a própria literatura tem afirmado isso (ALVAREZ, 2000).

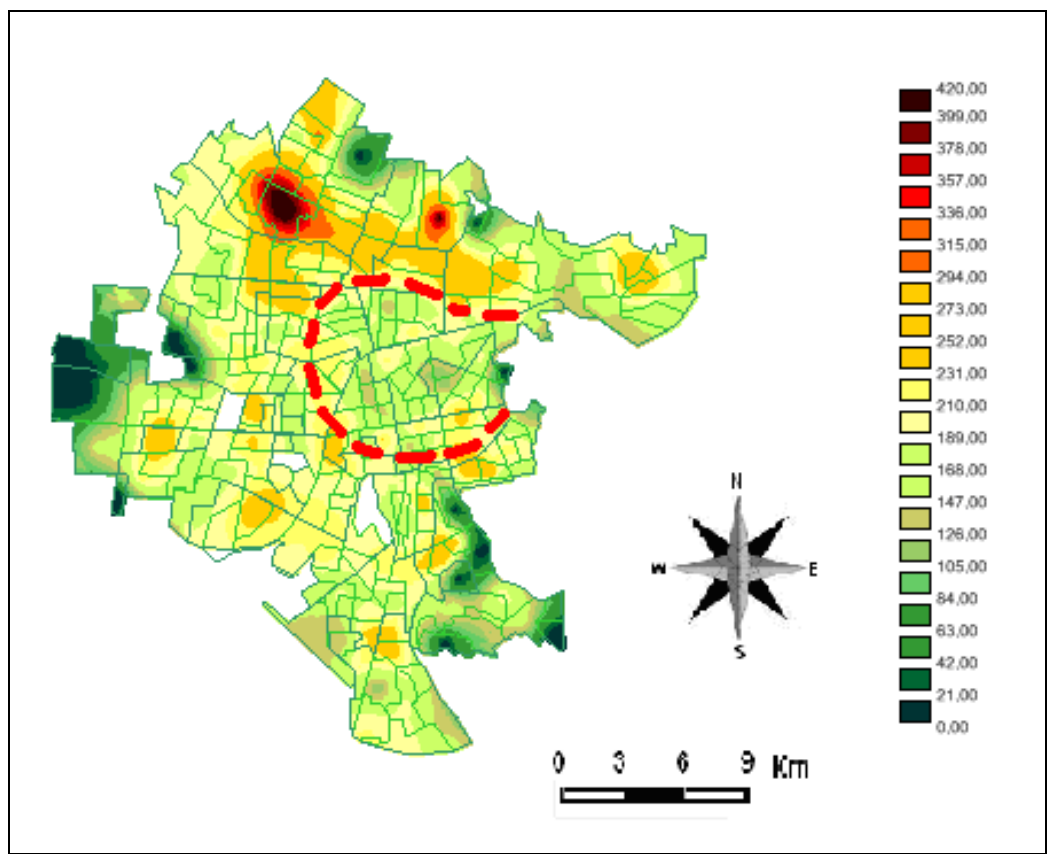

Mapa 28. Município de Cercado, região metropolitana de Cochabamba, número de medidores de água segundo ciclos em 2003.

Fonte: SEMAPA. Zonas de Racionamiento del sistema de Red de distribución en 2003.

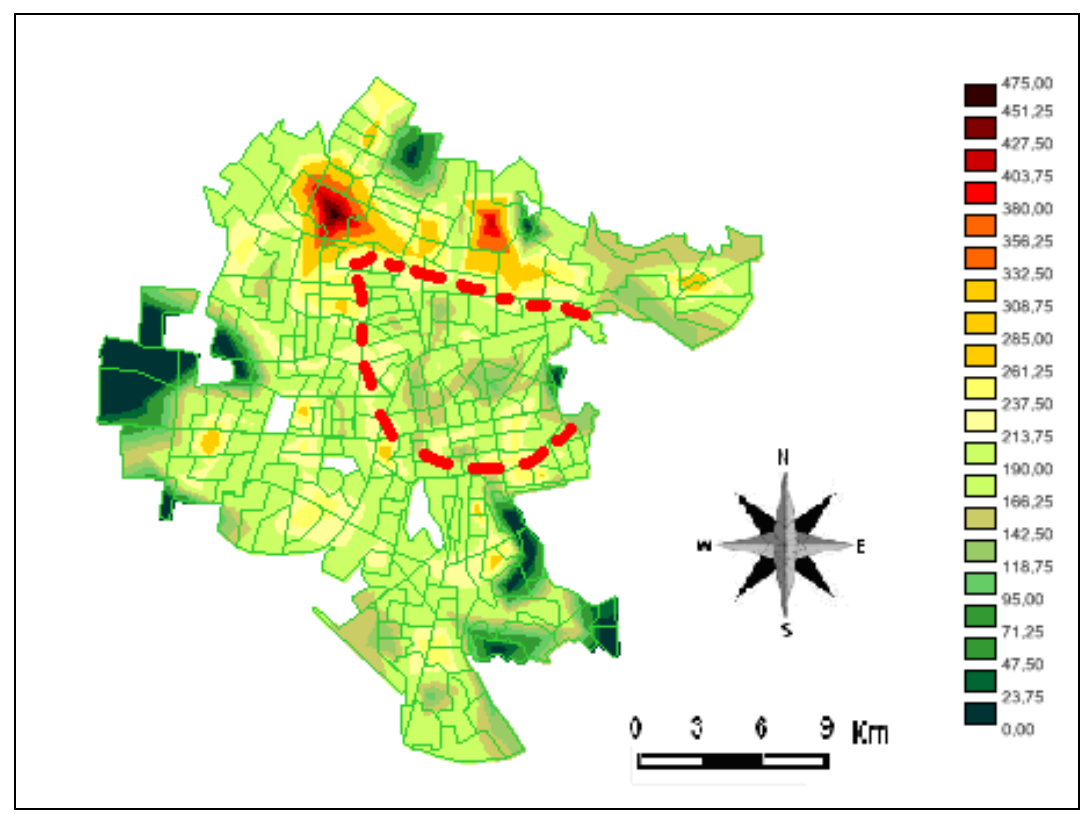

Mapa 29. Município de Cercado, região metropolitana de Cochabamba, número de medidores de água segundo ciclos em 2004.

Fonte: SEMAPA. Zonas de Racionamiento del sistema de Red de distribución en 2004. 


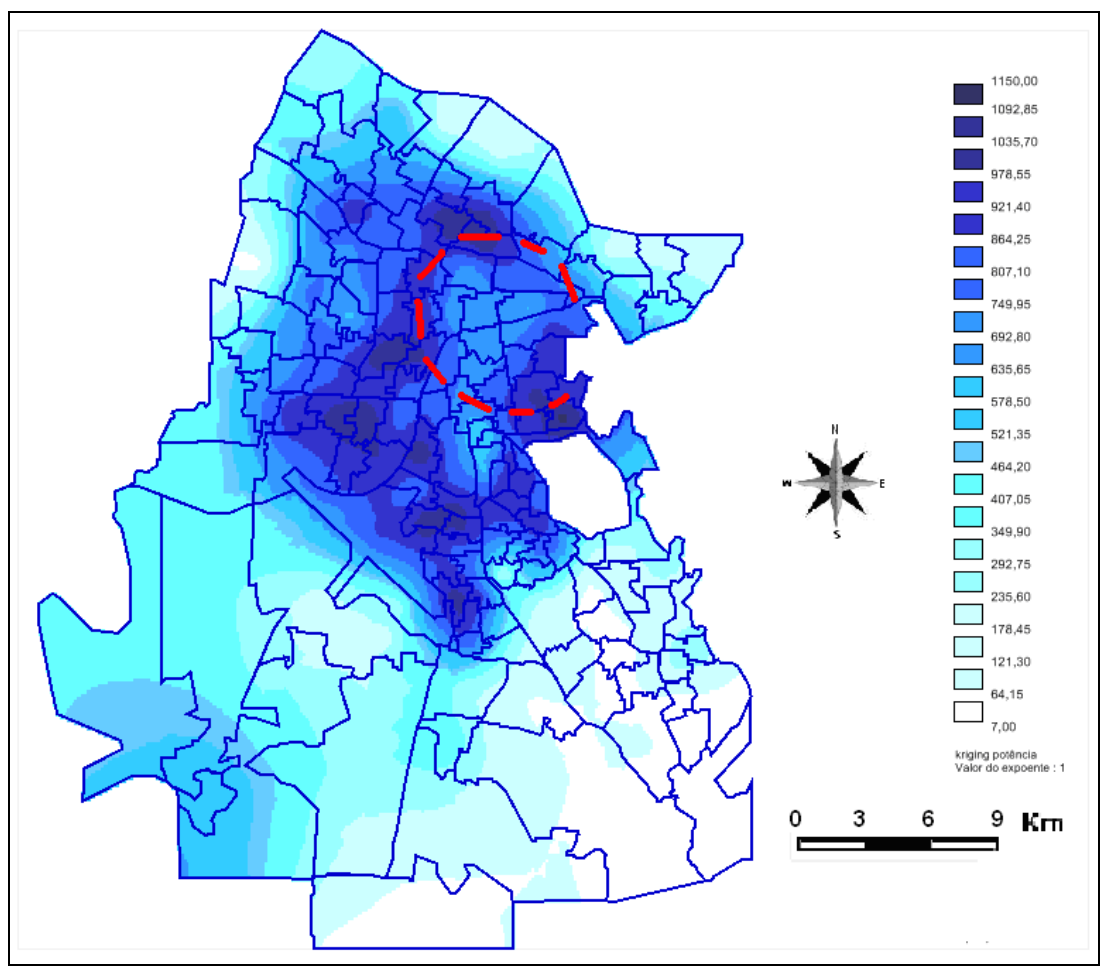

Mapa 30. Município de Cercado, região metropolitana de Cochabamba, número de habitações servida pela rede Semapa de abastecimento de água potável em 2001.

Fonte: INE. CENSO SOCIO DEMOGRÁFICO POR CIUDADES CAPITALES

Devido a essa má gestão uma boa parte daquela legitimidade que a Coordinadora del Agua teve durante o conflito, foi aos poucos se perdendo. Outro aspecto que contribuiu a esse fenômeno foi a falta de coerência de seus líderes que atacaram o comitê cívico de estar vinculado aos partido políticos (principalmente ao NFR), porém após o fim do conflito uma boa parte desses membros se lançou na vida política é caso de Evo Morales, Álvaro Garcia Linera, Omar Fernandez, Gabriel Herbas e Gonzalo Maldonado.

A falta de soluções viáveis apresentadas pela Coordinadora del Agua para o abastecimento da zona sul da cidade se apresenta como um dos principais fatores para esse fenômeno. Nos questionários aplicados por nós durante o trabalho de campo, percebe-se que raros são os membros da Coordinadora del Agua que são abastecidos pelos aguateros, apenas 3\%. Esse dado expressa uma certa desconfiança da população mais necessitada em relação à Coordinadora del Agua. Enquanto isso, os participantes da atividades da Coordinadora del Agua são em sua maioria aqueles abastecidos pela rede do SEMAPA $(45,9 \%)$ e poços comunitários (46\%). Por outro lado, 68,7\% afirma que participou na Guerra da Água reivindicando 
a expulsão de água del Tunari, 9,8\% participou demandando novas políticas de água, e apenas $1,6 \%$ pleiteando a redução do incremento das tarifas de água. $A$ anulação do contrato com Aguas del Tunari, atendeu principalmente aos interesses da territorialidade camponesa indígena e principalmente urbana, com exceção da zona sul, que na verdade acabou sendo prejudicada, uma vez que sem os aportes de Misicuni não há volume de água suficiente para ser destinado a esta área.

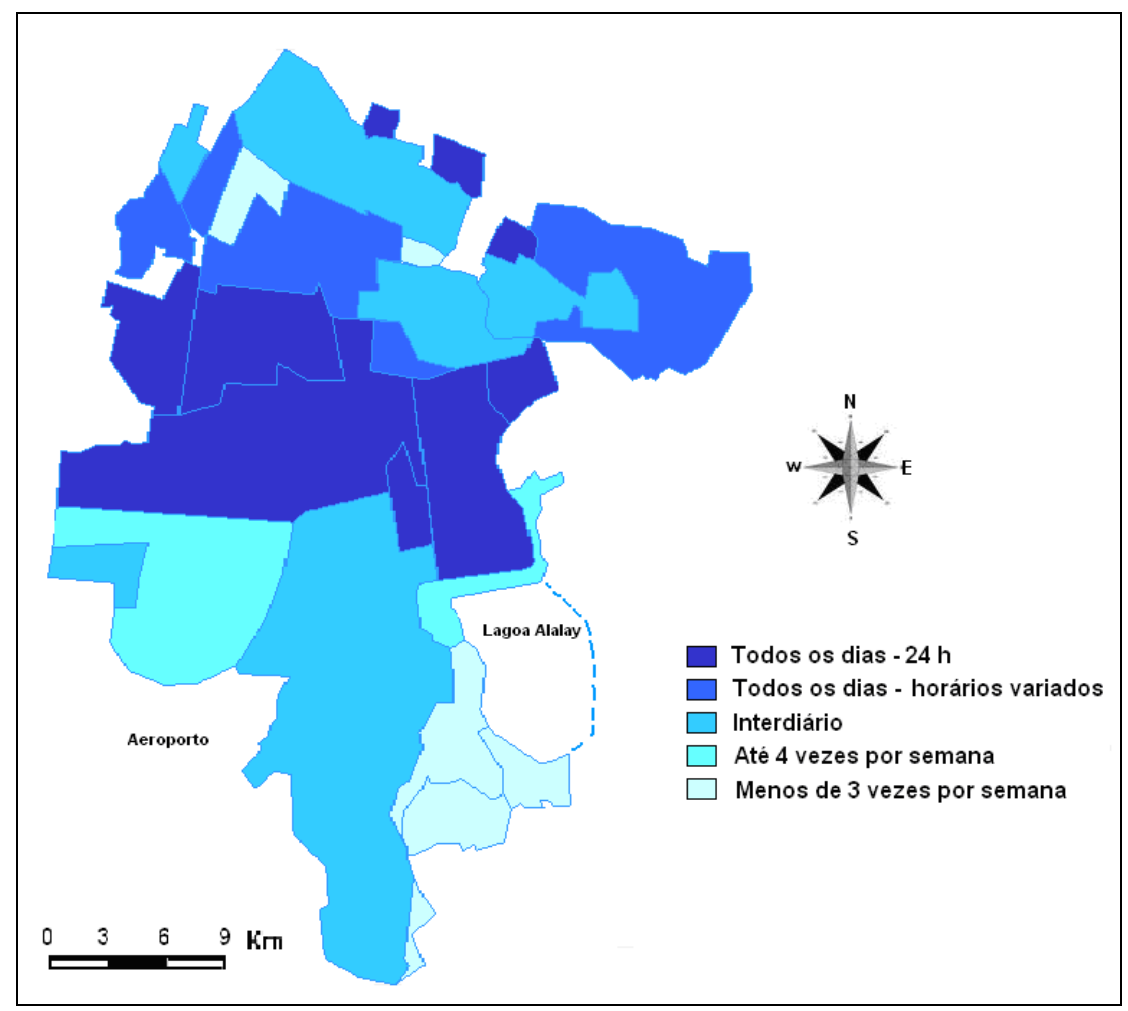

Mapa 31. Município de Cercado, região metropolitana de Cochabamba, frequência da distribuição de água pela rede de abastecimento do SEMAPA segundo zonas de recenseamento em 2006.

Fonte: SEMAPA. Zonas de Racionamiento del sistema de Red de distribución en 2004.

O sociólogo Roberto Laserna ressalta que os movimentos sociais como a Coordinadora del Agua são responsáveis pela atual crise de água em Cochabamba:

Pela primeira vez desde a Guerra da água, o líder da Coordinadora confessou publicamente que na realidade não estavam preparados para desenvolver alternativas. Em uma reportagem escrita pelo New York Times, pergutaram e eles o que aconteceu... e ele disse pela primeira vez em cinco anos que eles não tinham alternativas aos problemas que thes apresentavam e apesar disso durante o conflito ele e outros líderes como Jorge Alvarado, atual presidente de Yacimientos [Petrolíferos Fiscales Bolivianos], como Samuel Soria, que é professor da Universidade Mayor 
San Simon, anunciaram a população que eles tinham um plano para fazer Misicuni e fazê-lo mais barato. Se meteram nisso consultoras internacionais como Davis and Moore e empresas cooperativas de Cochabamba como a Cooperativa de Cimento [Cooperativa Boliviana de Cemento - COBOCE] todos eles disseram: podemos faze-lo, e se nos dá [a oportunidade] podemos fazer melhor, as [empresas] transnacionais são uns frouxos, uns vampiros [...](LASERNA, 2006). ${ }^{193}$

O antropólogo Xavier Albó também concorda com Laserna, que a Guerra da Água significou na verdade o fracasso do abastecimento de água de Cochabamba, ao invez de se priorizar a água se ressaltou outros objetivos: "Até agora a zona sul da cidade segue sem água, e Laserna tem razão quando diz que o conflito não resolveu o problema de escassez de agua na cidade"194 (ALBÓ, 2006)

O mais contraditório de todo esse processo é que Misicuni até o momento somente possui um túnel falta ainda a construção de uma represa de 120 metros bem como da Usina Hidrelétrica. Segundo o engenheiro de Misicuni Juan Carlos Cabrerizo, "as três fases do projeto somente ficarão prontas em 2035" (CABRERIZO, 20/01/06). Outro paradoxo desse processo é que a Coordinadora del Agua bem como os seus membros diante do diretório do SEMAPA pouco lograram resolver o problema do abastecimento de água em Cochabamba e a realização do Projeto Misicuni. Enquanto isso, aqueles atores considerados "inimigos de Cochabamba" conseguiram ao menos financiamentos para a construção do Túnel bem como da represa de $120 \mathrm{~m}$, é o caso do ex-alcalde e prefecto de Cochabamba Manfred Reyes Villa (LA RAZON, ).

A situação atual do SEMAPA chega ser atualmente tão crítica que o gasto da empresa chega 108.793.440 bolivianos enquanto que os ingressos não passam de 85.779.875 bolivianos, dessa forma, o pagamento das tarifas e serviços não conseguem sequer proporcionar o correto funcionamento da empresa. Ademais, a

${ }^{193}$ Por la primera vez desde la Guerra del Agua, el líder de la coordinadora Oscar Oliveira ha confesado públicamente que en la realidad no estaban preparados para desarrollar alternativas. En el reportaje que ha escribido el New York Times, preguntaron a ello que ha pasado.. y el dijo por la primera vez en cinco años que ellos no tenían alternativas a los problemas que se les presentaran y sin embargo durante el conflicto él y otros lideres como Jorge Alvarado, actual presidente de Yacimientos [petrolíferos fiscales bolivianos], como Samuel Soria que es un profesor en la Universidad Mayor San Simon han anunciado a la población que tenían alternativas, que ellos tenían un plan para hacer Misicuni y hacer-lo mas barato. Se meterán en eso consultoras internacionales como Davis and Moore y empresas cooperativas de Cochabamba como la Cooperativa de Cemento [Cooperativa Boliviana de Cemento - COBOCE] todos ellos han dicho: hay otras alternativas, podemos hacerlo, y se da a nosotros vamos a hacerlo mejor, las transnacionales son unos turros, unos vampiros [...]"

${ }^{194}$ hasta ahora la zona sur de la ciudad sigue sin água, y Laserna tiene razon, cuando dice que el conflicto no ha resuelto el problema de escasez de agua en la ciudad [...]" 
reparação da velha rede de encanamento que é um dos fatores responsáveis pelos altos índices de perdas de água da empresa, custará 100 milhões de dólares. Devido à falência completa do que se havia planejado para região já se fala em retomar o rechaçado Projeto Corani (LOS TIEMPOS, 05/04/2009).

Portanto, o conflito na escala local significou o fracasso das políticas de água e a continuidade da crise de água por que vem passando a região. Isso pode ser comprovado pelos números apresentados anteriormente. Inclusive o espaço criado pela Coordinadora del Agua acabou sendo perdido, devido à perda de legitimidade do movimento provocada principalmente pelo desgastes de seus líderes bem como o fracasso de suas soluções para o SEMAPA. Por outro lado, significou avanços momentâneos como maior participação popular, e conscientização por parte da população a respeito da gestão dos recursos hídricos. Resta saber quais foram os resultados do conflito para as escalas maiores. 


\section{PACHACUTI E COCHABAMBA: A GUERRA DA ÁGUA E A TRANSMUTAÇÃO DA NAÇÃO BOLIVIANA}

Pachacuti é um dos conceitos centrais da cosmogonia inca e aymara, o qual representa a noção de episódios regulares de destruição cataclísmica e reconstrução do mundo. Nesse sentido, a visão da história que os povos andinos têm constitui-se de inúmeros pachacutis que funcionam como períodos de revolução e rotação, não apenas temporal como espacial.

A Guerra da Água sinaliza, além de uma transformação do arranjo territorial do Vale Central de Cochabamba, a materialização de um período de modificações e transformações da nação boliviana. Em primeira instância, a Guerra da Água marcou a retomada do nacionalismo boliviano, o que desencadeou protestos em abril de 2000, passando pela Guerra da Coca e a Guerra do Gás, até desencadear a eleição do presidente Evo Morales. Em um segundo momento, a Guerra da Água representou o início do fortalecimento da territorialidade do Estado boliviano que, a partir de então, procurou controlar, de forma mais direta, seu território nacional. Assim, esse conflito simbolizou o fim tanto da modernização conservadora iniciada pelos governos militares bolivianos como das políticas econômicas neoliberais.

A Guerra da Água cristalizou, então, o mais recente pachacuti, propiciando a transformação do que havia sido construído até então e um retorno às políticas mais nacionalistas e populistas. Um novo ciclo se iniciou, marcado igualmente pela criação e pela destruição de forças plasmadas no seu território. Resta saber até onde esse novo período pode conduzir a nação boliviana.

\subsection{Transformações territoriais na Bolívia: um equilíbrio às avessas}

A revolução de 1952 marcou um período de modernização do Estado boliviano implementado pelo governo do partido político Movimiento Nacionalista Revolucionario (MNR). A derrocada da oligarquia rural e mineradora ofereceu uma oportunidade para se repensar a construção do Estado boliviano. Diante desse cenário, notava-se claramente um descompasso no desenvolvimento das diversas 
regiões bolivianas. Enquanto a porção ocidental encontrava-se intensamente ocupada e sua morfologia territorial era caracterizada pela forte densidade de redes de objetos técnicos, a porção oriental era justamente a sua antítese. Até então, essa região do país havia sido relegada a segundo plano.

Com o intuito de reequilibrar a ocupação nacional em direção ao oriente boliviano (Departamentos de Santa Cruz de la Sierra, Beni e Pando), o novo governo promoveu uma série de medidas que pretendiam implantar projetos de desenvolvimento na região, assim incentivando os fluxos migratórios. Durante a implantação desse plano, algumas reformas estruturais, a partir de 1955, objetivavam dar grande impulso à economia do oriente, a partir de Santa Cruz de la Sierra, e promover prioritariamente os setores de gás e petróleo a partir de acordos energéticos com o Brasil e a Argentina. Além disso, incentivos ao avanço da fronteira agrícola foram concedidos, beneficiando o desenvolvimento da pecuária e da agricultura. Entre 1955 e 1975, 73\% dos créditos agrícolas concedidos pelo Banco Agrícola e pela Corporación Regional del Desarrollo (Corporação Regional de Desenvolvimento) foram destinados ao oriente, sendo $71 \%$ para Santa Cruz de la Sierra (DUNKERLEY, 1984). Além de Santa Cruz de la Sierra, outras áreas, como Chapare (Departamento de Cochabamba) e Yungas (Departamento de La Paz) receberam incentivos visando o avanço da frente pioneira, embora, de certa forma, essa colonização já viesse ocorrendo de forma espontânea. Zondag (1966) relatou que nessas áreas se implantaram importantes projetos de colonização. Em abril de 1962, já havia 3.100 famílias estabelecidas no Chapare com o intuito de desenvolver o cultivo de produtos agrícolas.

Nessa estratégia, Cochabamba desempenhou papel importante, particularmente porque a principal via de acesso até o oriente se dava por meio da estrada (de terra) que liga as cidades de Cochabamba e Santa Cruz de la Sierra. Além disso, a posição central de Cochabamba no Estado boliviano Ihe concedia o status de centro irradiador de fluxos em direção ao oriente boliviano. Portanto, o papel estratégico desempenhado por essa região durante a expansão migratória para o oriente e a implantação das reformas estruturais foi substancial.

As primeiras medidas colocadas em prática foram a construção de ferrovias ligando Corumbá, no Brasil, a Santa Cruz de la Sierra, na Bolívia, se estendendo a Yacuiba (Tarija), além da rodovia asfaltada entre Cochabamba e Santa Cruz de la 
Sierra via Pojo, que foi a grande obra dos anos 50. Posteriormente, a partir dos anos 70, implementou-se maior número de eixos viários buscando a conexão dos vales aos llanos. Todavia, isso implicava a expansão da fronteira agrícola, principalmente em direção à Amazônia boliviana, a partir dos Departamentos de Cochabamba e Santa Cruz via Departamento de Beni. Para tanto, foram colocados em prática diversos projetos viários saindo de Cochabamba, um dos quais promoveu a abertura de uma segunda via ligando Cochabamba a Santa Cruz de la Sierra, desta vez passando por Puerto Villaroel, com o fim de aproveitar as potencialidades do trópico cochabambino e do rio Mamoré, indo até as proximidades da cidade de Santa Cruz de la Sierra. A partir desse eixo viário, outros dois trechos ligaram os Departamentos de Cochabamba e Santa Cruz de la Sierra a Trinidad, capital do Departamento de Beni: o primeiro saindo de Villa Tunari, no trópico cochabambino, indo pelo norte até Beni e seguindo até Trinidad; o segundo, saindo das proximidades de Santa Cruz de la Sierra, indo na direção norte e, depois, na direção oeste do Departamento de Beni até chegar a Trinidad.

A partir das iniciativas promovidas pelo governo da Bolívia buscando equilibrar a ocupação do território nacional e uma maior diversificação econômica (a partir das diretrizes do Plano Bohan), em escala nacional ocorreu uma mudança na articulação territorial boliviana, que até 1952 se baseava sobretudo nas ligações entre La Paz (centro administrativo), Oruro (centro mineiro) e Cochabamba (centro agrícola), para uma nova conexão, desta feita em direção ao oriente. Assim, aproveitando a articulação entre La Paz e Cochabamba e a estrada ligando esta última a Santa Cruz de la Sierra, formou-se um corredor econômico ${ }^{195}$. Ademais, nota-se que essa articulação atenuou os efeitos fisiográficos na integração nacional, especialmente pela existência de três grandes centros urbanos no corredor econômico, cada um deles em um piso ecológico diferente: La Paz, no altiplano, Cochabamba nos vales e Santa Cruz de la Sierra nos Ilanos ${ }^{196}$.

A esse respeito Ledo García (2000, p. 14, tradução nossa) salientou que:

\footnotetext{
${ }^{195}$ A partir dos anos 1980, verifica-se que esse planejamento territorial estava vinculado aos novos conceitos de corredor de desenvolvimento, a partir das ideias de Perroux (1991) ligadas à teoria de polos de desenvolvimento.

${ }^{196}$ Por altiplano nos referimos ao território dos Departamentos de La Paz, Oruro e Potosí; por vales, ao território dos Departamentos de Cochabamba, Chuquisaca e Tarija; e por Ilanos, aos territórios dos Departamentos de Santa Cruz, Beni e Pando. Evidentemente, trata-se de uma divisão regional aleatória, vez que existe uma pequena parte do território de Cochabamba que faz parte dos llanos, por exemplo. Entretanto, é uma divisão amplamente utilizada no caso boliviano.
} 
As cidades do Corredor Econômico Boliviano representam um novo modelo de primazia urbana, a única diferença do modelo anterior é que envolve três grandes regiões estratégicas onde se concentram os esforços de desenvolvimento: Santa Cruz, cidade moderna e preparada para se constituir em uma cidade do futuro, com uma pujante agroindústria e fluidas relações comerciais com os portos do Atlântico e do Pacífico, La Paz mantém sua condição de primeiro centro industrial do país e desenvolve ações para explorar seu rico território com grande diversidade ecológica, enquanto Cochabamba é um espaço intermediário, de integração, de articulação e encontro do conjunto nacional, e é também um espaço médio no qual os contrastes do país também se manifestam. Em muitos sentidos, Cochabamba é uma síntese da Bolívia. ${ }^{197}$

Então, observa-se a centralidade exercida por Cochabamba em relação aos vales bolivianos e sua função de articular os principais centros do Vale de Cochabamba com as outras regiões do país. Em relação ao corredor econômico, esta cidade constitui o centro articulador de duas grandes metrópoles exportadoras do país: La Paz, sob influência do Pacífico e Santa Cruz de la Sierra sob influência do Atlântico e da Bacia do Prata ${ }^{198}$. Nessa perspectiva, Calderon e Laserna (1983) argumentam que Cochabamba não constituía um núcleo exportador, embora a região mantivesse relação de proximidade com todos os grandes centros exportadores da economia boliviana, por meio do abastecimento de alimentos e de mão-de-obra. Em decorrência de sua posição no centro do país, tinha a possibilidade de reorientar seus fluxos econômicos de um mercado consumidor para outro (Potosí, Oruro, La Paz, Beni, Santa Cruz de la Sierra). Dessa forma, Cochabamba deixou de ser o principal centro agrícola do país para adotar a função de integração nacional, conectando o oriente ao ocidente boliviano.

Os efeitos produzidos pela criação dos novos eixos viários e da concessão de incentivos ao oriente se fizeram cada vez mais presentes na ocupação territorial, fundamentalmente pela concentração de mais de $60 \%$ da população nacional nos

\footnotetext{
197 "Las ciudades del Corredor Económico Boliviano representan al nuevo modelo de primacía urbana, la única diferencia del modelo anterior es que involucra tres grandes regiones estratégicas donde se concentran los esfuerzos del desarrollo: Santa Cruz ciudad moderna y preparada para constituirse en una ciudad del futuro, con una pujante agroindustria y fluidas relaciones comerciales con los puertos del Atlántico y el Pacífico, La Paz mantiene su condición de primer centro industrial del país y desarrolla acciones para explotar su rico territorio con gran diversidad ecológica, en tanto Cochabamba vendría a ser un espacio intermedio, de integración, de articulación y encuentro del conjunto nacional, y es también un espacio promedio en el que los contrastes del país también se ponen de manifiesto. En muchos sentidos, Cochabamba es una síntesis de Bolivia."

${ }_{198}$ Tanto por meio da ferrovia entre Santa Cruz de la Sierra e Puerto Suarez, indo até o Porto de Santos, como por meio da mesma ferrovia, indo até Puerto Busch e de lá para o Atlântico, no porto de Buenos Aires, por meio da Hidrovia Paraguai-Paraná-Prata.
} 
três grandes centros do corredor econômico, assim como um forte e constante fluxo migratório (Tabela 20).

Tabela 20. Distribuição populacional na Bolívia de acordo com regiões ecológicas, áreas e regiões metropolitanas de residência no período entre 1900 e 2001.

\begin{tabular}{|c|c|c|c|c|c|}
\hline \multirow[t]{2}{*}{ Região } & \multicolumn{5}{|c|}{ População (\%) } \\
\hline & 1900 & 1950 & 1976 & 1992 & 2001 \\
\hline Altiplano $^{1}$ & 51,3 & 57,5 & 52,7 & 45,0 & 41,7 \\
\hline Altiplano-urbano ${ }^{2}$ & 57,0 & 63,3 & 54,2 & 44,2 & 39,2 \\
\hline Região metropolitana de La Paz ${ }^{2}$ & 34,8 & 38,6 & 32,9 & 30,3 & 29,4 \\
\hline Vales $^{1}$ & 36,2 & 30,2 & 27,5 & 28,9 & 28,7 \\
\hline Vales-urbano $^{2}$ & 30,5 & 25,1 & 21,9 & 24,0 & 25,5 \\
\hline Região metropolitana de Cochabamba ${ }^{2}$ & 13,9 & 10,8 & 10,6 & 11,0 & 14,3 \\
\hline Llanos $^{1}$ & 12,5 & 12,3 & 19,8 & 26,1 & 29,5 \\
\hline Llanos-Urbano $^{2}$ & 12,5 & 11,6 & 23,9 & 31,8 & 35,1 \\
\hline $\begin{array}{l}\text { Região metropolitana de Santa Cruz de } \\
\text { la Sierra }^{2}\end{array}$ & 7,0 & 6,1 & 13,2 & 18,9 & 24,6 \\
\hline Corredor econômico & 43,6 & 55,5 & 56,8 & 60,2 & 68,3 \\
\hline População urbana total & 14,5 & 25,6 & 41,8 & 57,5 & 62,4 \\
\hline População rural total & 85,5 & 74,4 & 58,2 & 42,5 & 37,6 \\
\hline Total & 100 & 100 & 100 & 100 & 100 \\
\hline
\end{tabular}

Fonte: Organizada pelo autor a partir de Ledo García (2000, p. 4).

Em adição a isso, a concentração de mais da metade da população nacional no altiplano, que ocorria em 1950, foi se dissipando mormente pela força de atração de Santa Cruz de la Sierra que, na atualidade, tem alcançado crescimento populacional vertiginoso. Esse efeito também pôde ser sentido pelo decréscimo em termos relativos da população dos vales até 1976. Analisando a população da cidade de Cochabamba em relação à população urbana da região dos vales, percebe-se que esse centro detém a primazia urbana na região, com mais de $45 \%$ da população, desde o final do século XIX. Em 1900, a população do Vale Central 
de Cochabamba representava $45,4 \%$ da população urbana dos vales, mas esse índice vem tendo forte elevação nos últimos anos, passando de 45,9\% em 1992 para 56,2\% em 2001(BLANES, 2006).

Ao observar a rede de cidades, nota-se que a antiga rede urbana baseada na economia de enclave mineiro ainda persiste no altiplano. Mesmo assim, deve-se destacar que os antigos centros mineiros (Oruro e Potosí) da velha rede urbana vêm perdendo grande contingente de habitantes, à exceção de Sucre, que ainda se mantêm por meio de seu status de capital constitucional nacional.

Verifica-se, ainda, que a partir de 1992, o avanço da urbanização atingiu índices pujantes, pois mais da metade da população nacional boliviana passou a viver nos centros urbanos. Não obstante, boa parte da cidades não estava preparada para atender todo esse contingente populacional. Exemplos desse despreparo puderam ser observados pela expansão descontrolada da área urbanizada do município de Cercado, bem como pela formação de um bolsão de miséria no entorno de La Paz, constituindo o município de El Alto.

Esse fenômeno se deve, em parte, ao empobrecimento das áreas rurais do altiplano. Além disso, outros fatores também contribuíram, como é o caso da crise do estanho no mercado internacional e do planejamento territorial implantado após 1952. Esse efeito ainda foi intensificado nos anos 80, durante uma grave crise econômica e política, na qual a economia nacional foi paulatinamente abalada por crises de desaceleração produtiva, hiperinflação, recessão internacional e queda dos preços das matérias-primas no mercado internacional, inclusive o estanho, cujo principal fornecedor mundial é a Bolívia. A estagnação econômica produziu índices alarmantes de empobrecimento no altiplano, mantendo forte fluxo migratório recente dentro da própria região, principalmente em direção a El Alto. Grande parte da população imigrante de Oruro foi responsável pelo contínuo fluxo em direção ao Departamento de Cochabamba após a política de demissão de trabalhadores mineiros, episódio que foi chamado pelo governo de relocalización minera (MESA; GISBERT; MESA, 2003). ${ }^{199}$ Isso explica parcialmente o fato de que $42 \%$ dos imigrantes dos vales eram oriundos do altiplano em 1992 (LEDO GARCÍA, 2000).

\footnotetext{
${ }^{199} \mathrm{Em} 1986$, face à queda dos preços de estanho no mercado internacional e à perda de mais de 750 milhões de dólares nos últimos 10 anos pela COMIBOL, o governo decidiu pela demissão de 23.000 trabalhadores dos 30.000 que trabalhavam na usina da COMIBOL (MESA; GISBERT; MESA, 2003).
} 
Percebe-se que os efeitos das políticas territoriais tiveram efeito inesperado e talvez nefasto, pois em vez de promover o equilíbrio populacional, materializaram um desequilíbrio (Tabela 21).

Tabela 21. População migrante interdepartamental e taxa de migração líquida, de acordo com o departamento de residência habitual, no período entre 1997 e 2001.

\begin{tabular}{|c|c|c|c|c|}
\hline $\begin{array}{l}\text { Departamento de } \\
\text { residência habitual }\end{array}$ & $\begin{array}{l}\text { População } \\
\text { (no pessoas) }\end{array}$ & $\begin{array}{l}\text { Imigrantes } \\
\text { (no pessoas) }\end{array}$ & $\begin{array}{l}\text { Emigrantes } \\
\text { (no pessoas) }\end{array}$ & $\begin{array}{c}\text { Taxa de } \\
\text { migração } \\
\text { líquida (\%) }\end{array}$ \\
\hline Cochabamba & 1.243 .854 & 91.317 & 76.612 & 1,18 \\
\hline Chuquisaca & 452.188 & 30.292 & 44.704 & $-3,19$ \\
\hline Tarija & 331.213 & 30.628 & 18.896 & 3,54 \\
\hline Total nos vales & 2.027.255 & 152.237 & 140.212 & 1,53 \\
\hline La Paz & 2.055 .401 & 50.919 & 83.082 & $-1,56$ \\
\hline Oruro & 345.161 & 24.021 & 39.700 & $-4,54$ \\
\hline Potosí & 609.144 & 20.720 & 67.413 & $-7,67$ \\
\hline Total no altiplano & 3.009 .706 & 95.660 & 190.195 & $-13,77$ \\
\hline $\begin{array}{l}\text { Santa Cruz de la } \\
\text { Sierra }\end{array}$ & 1.719 .778 & 146.527 & 55.256 & 5,31 \\
\hline Beni & 306.656 & 22.132 & 35.329 & $-4,30$ \\
\hline Pando & 42.196 & 8.115 & 3.679 & 10,51 \\
\hline Total nos Ilanos & 2.068 .630 & 176.774 & 94.264 & 11,51 \\
\hline Total no país & 7.105 .591 & 424.671 & 424.671 & 100,00 \\
\hline
\end{tabular}

Fonte: Organizada pelo autor com base em dados de Ledo García (2000) e INE (2001a).

Enquanto o oriente vem atraindo constantes fluxos migratórios, o altiplano se caracteriza cada vez mais pela expulsão de migrantes. No caso do altiplano, existe um forte fluxo migratório interno das áreas rurais em direção a La Paz. Entretanto, esse centro urbano não apenas recebe migrantes como também é o principal ponto 
de origem das migrações em direção a outros centros do corredor econômico. Nesse cenário, os vales constituem uma área que apresenta moderada taxa de migração líquida, embora em termos absolutos, o Departamento de Cochabamba seja o segundo centro do país que mais recebe imigrantes. Além disso, Cochabamba é ponto de junção no que concerne às tendências atuais dos fluxos migratórios. Mazurek (2007, p. 7, tradução nossa) esclareceu que:

Cochabamba sempre foi uma cidade de transição [...] A cidade atrai a população dos municípios vizinhos (periferias das cidades, ao sul da região, a oeste de Oruro e ao norte de Potosí), principalmente do altiplano e da zona dos Vales e perde população para as planícies [...] Ela apresenta um comportamento duplo, como mediadora entre El Alto e Santa Cruz, onde existe a conformação de uma bacia de migração de proximidade associada com a emigração de cidade para cidade. ${ }^{200}$

Dessa forma, Cochabamba articula e integra parcialmente essas duas "Bolívias diversas". De um lado, a porção ocidental boliviana, constituída de uma população majoritariamente autoidentificada como colla e que, ultimamente, vem se tornando a área mais pobre do país. De outro lado, a Bolívia moderna e próspera caracterizada pela fraca autoidentificação étnica, embora uma boa parte dos discursos regionalistas se aproprie de uma pretensa ideia de nação camba (povos originários do oriente boliviano).

Além dessa função, a Região Metropolitana de Cochabamba articula área core de ocupação já consolidada no território nacional e Amazônia boliviana (Trópico cochabambino) ainda fracamente ocupada. Tanto esse processo de ocupação dos llanos setentrionais como a bipolaridade oriente-ocidente boliviano estão marcados por intenso contraste, não apenas fisiográfico e econômico, mas principalmente cultural. Ao mesmo tempo em que a região metropolitana de Cochabamba procura entrelaçar, de certa forma, os contrastes entre porção oriental e ocidental, termina por acentuar ainda mais os contrastes entre o trópico e o vale cochabambino. A implementação de redes de objetos técnicos vai marcando o compasso dessa diferenciação entre a região metropolitana e a região do trópico de Cochabamba.

Desse modo, a função de centro integrador nacional tem materializado uma série de contrastes no Vale Central de Cochabamba. Inicialmente, a criação desse

200 "Cochabamba has always been a city of transition [...] The city attracts the population from neighboring municipalities (peripheries of the cities, south of the region, west of Oruro and north Potosí), mainly from the highlands and the Valley zone and loses population towards the lowlands [...] It has a double behavior, as mediator between El Alto and Santa Cruz, where there exists the conformity of a basin of migration of proximity associated with a city to city emigration." 
forte fluxo migratório por meio do corredor econômico tornou a região metropolitana de Cochabamba ainda mais suscetível às penúrias ambientais, uma vez que sua população cresce em ritmo mais elevado do que os projetos de planejamento regional e oferecimento de serviços básicos podem acompanhar. Outro aspecto importante é que a região metropolitana de Cochabamba constitui uma área de transição entre a área core nacional e a periferia do país, o que caracteriza um contexto sujeito a conflitos (GEIGER, 1994). Ao comentar sobre a situação boliviana, Lavaud (2000, p. 179, tradução nossa) explicou que:

Dito de outra forma, temos ainda o sentimento, apesar da existência de movimentos migratórios internos crescentes do ocidente para o oriente que fazem as populações se emaranhar, que o diagnóstico formulado por L.J. Jerome em 1910 é ainda hoje verdadeiro: "A principal fraqueza da Bolívia é a sua falta de unidade; a animosidade entre os habitantes das diferentes províncias é ainda muito marcante". 201

Evidentemente, a modernização de uma região com forte identidade regional não ocorre de forma passiva, ainda mais recordando que ali surgiram as primeiras ligas camponesas na Bolívia nos anos 30. Portanto, as políticas territoriais estão entre os fatores de longo prazo que se manifestam na Guerra da Água, pelo crescimento populacional e, precipuamente, pelo contraste entre o rural e o urbano, não somente em relação às áreas urbanas rurais do vale, mas também em relação ao plantio de coca no Chapare.

A Guerra da Água marcou o início da debacle das políticas territoriais de cunho liberal. Esse período se caracterizou pela fraca presença dos atores estatais no território nacional, que passou a ser, predominantemente, organizado a partir da atuação das empresas transnacionais, dos movimentos sociais e das OTBs. Finalmente, no período entre 2003 e 2005, os movimentos sociais lograram a primazia da organização territorial em detrimento das empresas transnacionais, culminando com chegada ao poder de Evo Morales. As políticas territoriais do presidente Morales têm privilegiado a atuação do Estado em detrimento da iniciativa privada. Logo após sua chegada ao poder, Morales estatizou tanto o setor de exploração como o de refinamento de gás e petróleo, além de conceder grande

\footnotetext{
${ }^{201}$ Autrement dit, on a toujours le sentiment, malgré l'existence de mouvements migratoires internes croissants de l'Occident vers l'Orient qui font se mêler les populations, que le diagnostic formulé par L.J. Jérôme en 1910 est encore vrai aujourd'hui: 'La principale faiblesse de la Bolivie est son manque d'unité; l'animosité entre les habitants des differentes provinces est très marqués'."
} 
autonomia aos territórios comunitários indígenas. Assim, o contexto estruturado após a Guerra da Água tem se caracterizado pela retomada das políticas territoriais do governo nacional com o intuito de frear esse desequilíbrio territorial às avessas que ainda está em marcha.

\subsection{Das novas políticas econômicas à crise: quando o Estado sai de cena}

Outro fator importante na escala nacional que atuou de forma direta e a curto prazo na Guerra da Água foi a crise do ajuste estrutural implantado a partir 1994. Resta claro que apenas esse fenômeno não é suficiente para explicar completamente o conflito, porém pode-se afirmar que a Guerra da Água cristalizou fatores do contexto regional com fatores da escala nacional, tendo sido a falência do ajuste estrutural um dos fatores estruturantes da escala nacional que mais diretamente se vinculou ao conflito. Se, por um lado, as políticas territoriais criaram forte fluxo migratório para Cochabamba, por outro, as novas políticas econômicas não lograram êxito em oferecer melhores condições econômicas e de trabalho para esses migrantes, que passaram a viver na informalidade.

Após a redemocratização em 1985, a Bolívia se encontrava em uma grave crise econômica, o PIB havia decrescido em 17\% entre 1980 e 1985, as exportações se reduziram em $25 \%$ em dois anos, o desemprego havia dobrado de proporção e a inflação atingiu a casa dos 24.000\% em 1985 (ANDREAS, 1995 apud SOLDAL, 2008). A queda do preço do estanho no mercado internacional em $54 \%$ tornou a situação econômica boliviana ainda mais difícil, porquanto sua principal fonte de receita em relação à balança comercial era a exportação deste metal.

A partir desse mesmo ano, o plano de estabilização do Fundo Monetário Internacional (FMI) para a Bolívia deu início a medidas que previam a privatização das empresas estatais. Assim se iniciou a implantação do Novo Plano Econômico, com o Decreto Supremo o 21.060 (BOLIVIA, 1985) seguido pelo governo de Ángel Víctor Paz Estenssoro. Essa nova estratégia se baseava em rígida ortodoxia econômica, que logrou controlar os galopantes índices de inflação no país. Para tanto, o governo Estenssoro empreendeu um austero corte de gastos do Estado, embora não seguisse a medida tão aconselhada pelo Banco Mundial e o FMI de 
privatizar as empresas estatais. Um dos efeitos marcantes do corte de gastos foi a dispensa de 23.000 trabalhadores mineiros da COMIBOL. Diante dessas dificuldades sociais, o mercado informal e da produção de coca se tornou uma rápida e importante solução para os bolivianos desempregados (SOLDAL, 2008).

Em 1992, durante o governo de Jaime Paz Zamora, decidiu-se privatizar 30 pequenas empresas aprovadas pela promulgação da Lei № 1.544 (BOLIVIA, 1994b). Não obstante, os partidos de direita, juntamente com organismos internacionais, ainda pressionavam pela privatização das mais importantes empresas estatais bolivianas. Esse fato, porém, somente foi consumado no governo seguinte, quando o presidente Gonzalo Sánchez de Lozada y Sánchez Bustamante, "el Goni”, propôs a venda de $49 \%$ dos ativos das seis principais empresas estatais ao setor público. Inicialmente, a proposta recebeu uma série de críticas na Bolívia, porém Goni argumentou que o país ficaria com $51 \%$ dos ativos e, portanto, teria as empresas ainda sob controle. Além disso, prometeu que o capital pago pelas empresas ia ser distribuído entre os bolivianos maiores de 21 anos. Para tanto, Lozada criou o Bono Solidaridad (BONOSOL, Bônus da Solidariedade), um seguro social para os bolivianos acima de 65 anos, com a esperança de que esse tipo de medida aliviaria as críticas à privatização e geraria maior confiança dos bolivianos na força do mercado (KOHL, 2004).

Um dos aspectos mais contraditórios do processo foi que, diante da pressão das empresas privadas, em vez de $49 \%$, o governo resolveu privatizar $51 \%$ das empresas estatais, concedendo a elas maior autonomia. Em março de 1994, a Lei no 1.544 (BOLIVIA, 1994b) foi finalmente aprovada e o governo levou adiante o processo de privatização. Naquele momento, as empresas estatais contabilizavam $12,5 \%$ do PIB e $60 \%$ da receita do governo. No total, a privatização rendeu ao governo 1.67 bilhões de dólares combinados entre pagamentos e promessas de investimentos futuros. Normalmente, as empresas compradoras pagavam somente um valor mínimo à vista pela empresa capitalizada (Tabela 22). Um exemplo disso é o caso da privatização do Lloyd Aéreo Boliviano (LAB). A empresa brasileira Viação Aérea São Paulo (VASP), com o pagamento de apenas 5 milhões de dólares, adquiriu a empresa sob a condição de investir 42,5 milhões de dólares nos cinco anos seguintes (KOHL, 2004). 
Tabela 22. Preço do lance de compra das maiores empresas bolivianas capitalizadas por setor de atividade.

$\begin{array}{ccccc}\text { Setor/firma } & \begin{array}{c}\text { Mês/ano de } \\ \text { transferência }\end{array} & \begin{array}{c}\text { Principal } \\ \text { acionário }\end{array} & \begin{array}{c}\text { País de } \\ \text { origem }\end{array} & \begin{array}{c}\text { Lance por } \\ 50 \% \text { da } \\ \text { empresa }\end{array}\end{array}$

\begin{tabular}{lcccc}
\hline \multicolumn{5}{c}{ Hidrocarbonetos } \\
\hline Petrolera Chaco & $4 / 97$ & Amoco & Estados Unidos & 306.7 \\
Transredes & $4 / 97$ & Enron & Estados Unidos & 263.5 \\
Empresa Petrolera & $4 / 97$ & YPF & Argentina & 264.8 \\
Andina & & & & \\
\hline
\end{tabular}

\section{Telecomunicações}

\begin{tabular}{lccccc}
\hline ENTEL & \multicolumn{1}{l}{$11 / 95$} & \multicolumn{2}{c}{ STET } & Itália & 610.0 \\
\hline \multicolumn{5}{l}{} & \multicolumn{3}{c}{ Transporte } \\
\hline LAB (áereo) & $10 / 95$ & VASP & Brasil & 47.5 \\
ENFE (ferrovias) & $3 / 96$ & Cruz Blanca & Chile & 13.2 \\
$\begin{array}{l}\text { Andina } \\
\text { ENFE (ferrovias) }\end{array}$ & $3 / 96$ & Cruz Blanca & Chile & 25.9 \\
Oriental & & & & & \\
\hline
\end{tabular}

\begin{tabular}{|c|c|c|c|c|}
\hline \multicolumn{5}{|c|}{ Eletricidade (ENDE) } \\
\hline Corani & $7 / 95$ & $\begin{array}{c}\text { Dominion } \\
\text { Energy }\end{array}$ & Estados Unidos & 33.0 \\
\hline Guaracachi & 7/95 & $\begin{array}{c}\text { Energy } \\
\text { Initiatives }\end{array}$ & Estados Unidos & 35.0 \\
\hline Hermoso & 7/95 & $\begin{array}{c}\text { Constellation } \\
\text { Energy }\end{array}$ & Estados Unidos & 30.0 \\
\hline
\end{tabular}

Fonte: Villegas (1997 apud KOHL, 2004, p. 898).

A partir da capitalização, os investimentos privados na Bolívia aumentaram substancialmente. Podemos citar como exemplo que, antes da capitalização, o investimento direto estrangeiro girava em torno de 169 milhões de dólares. Em 1996, a empresa STET investiu mais que isso na capitalizada ENTEL. Até junho de 2000, as empresas capitalizadas tinham investido aproximadamente 2 bilhões de dólares no setor de hidrocarbonetos (BARJA; URQUIOLA, 2001). 
A questão é que a maioria dos investimentos se deu no setor de bens de capital intensivo de manufatura estrangeira e, portanto, não houve forte efeito multiplicador na economia nacional. No caso da LAB, o maior investimento da companhia foi a compra de uma aeronave Boeing. Kohl (2004) comentou que o investimento criou mais empregos em Seattle que na Bolívia e que situação semelhante ocorreu com o gasoduto Brasil-Bolívia, pois os dutos de aço para a construção da rede vieram da Argentina, do Brasil e da Coréia e os 435 milhões de dólares investidos no lado boliviano criaram menos que 600 empregos permanentes. Em 1996, quatro das empresas capitalizadas estavam entre os maiores importadores do país.

Os efeitos do ajuste estrutural sobre os empregos foram drásticos. Durante os 5 primeiros anos da implantação da nova política econômica, houve perda de 35.000 postos de trabalho do setor manufatureiro (KOHL, 2006). Entre 1989 e 1999, o número de empregos formais nos grandes centros urbanos bolivianos caiu de 50,7\% para $44,7 \%$, enquanto o de empregos informais subiu de $46,7 \%$ para $50 \%$ (THIELE, 2003). Outra importante consequência desse efeito pôde ser verificada no número de empregos da companhia Yacimientos Petrolíferos Fiscales Bolivianos (YPFB, Jazidas Petrolíferas Públicas Bolivianas) antes e depois a capitalização, pois em 1992, a empresa possuía 5.440 empregados, ao passo que em 1999, tinha apenas 954 funcionários (BARJA, URQUIOLA, 2001).

Um outro mecanismo criado pelo ajuste estrutural foi a aplicação da Lei $n^{\circ}$ 1.600 (Ley del Sistema de Regulación Sectorial - SIRESE, Lei do Sistema de Regulação Setorial) (BOLIVIA, 1994d), que autorizava a criação de superintendências para cada setor da capitalização: hidrocarbonetos, telecomunicações, eletricidade, transporte e serviços básicos. As superintendências eram órgãos administrativos altamente centralizados, que teriam como função regular cada setor a partir da capitalização. O presidente do país apenas indicava o superintendente, o qual, a partir de então, tinha autonomia e não mais se submetia ao poder político do Estado. Dessa forma, o superintendente não estava subordinado diretamente a nenhuma autoridade do poder público, nem mesmo ao presidente do país, e tampouco ao Congresso Nacional. Ainda estavam previstos mecanismos para a participação popular na regulação setorial, embora não fossem 
compulsórios, sendo raramente utilizados. Com referência a esse propósito, Perreault (2006, p. 156, tradução nossa) concluiu que:

A tomada de decisão a respeito dos recursos naturais (e de setores econômicos chave) é, nesse sentido, removida do domínio público, tornando os reguladores mais responsáveis quanto às industrias e aos atores privados, cujos investimentos eles atraem e regulam, do que ao público a quem esses recursos e empresas pertenciam anteriormente $[\ldots]^{202}$

Aos poucos, o Estado boliviano ia se desobrigando de tarefas-chave antes desempenhadas por ele. Inicialmente, repassou as principais empresas estatais para o setor privado. Além disso, até mesmo a regulação dos setores foi descentralizada em relação ao Estado, passando a ser executada por órgãos altamente centralizados (as Superintendências) dentro de seu setor específico, nos quais o controle público acabava sendo distanciado dos mecanismos de regulação. Outra medida "descentralizadora" foi a LPP e a aplicação dos mecanismos de coparticipação (comentada anteriormente neste trabalho). Apesar de se retirar da arena econômica, o Estado ainda manteve algum controle sobre a sociedade civil, especialmente por meio do aparato jurídico do Estado, que procurou legitimar as demandas econômicas empregando o princípio da legalidade (KOHL, 2006). Então, - Estado passou a se vincular apenas à função de garantidor da lei, sobretudo daquela imposta pelos atores econômicos.

Os efeitos dessa retirada do Estado dos setores estratégicos não tardaram a apresentar resultados negativos. Em 1999, o desemprego atingiu níveis insustentáveis (Gráfico 4). Em cinco anos, a taxa de desemprego quase triplicou. Para Iriarti (2005), o número de desempregados apresentava inconsistências, já que não se conseguia captar a situação real de desocupação, em especial aquela dos subempregos e da informalidade. Em Cochabamba, o número de empregados despedidos chegou a mais de 1.000 desde o começo de 2000 até o final do mês de fevereiro do mesmo ano (CEDIB, 2000). De acordo com a Federación de Trabajadores Fabriles de Cochabamba (Federação de Trabalhadores Fabris de Cochabamba) e a Dirección Departamental de Trabajo (Direção Departamental do Trabalho), 30\% da PEA do Departamento de Cochabamba estava desocupada neste período (CEDIB, 2000).

202 "Decision-making about natural resources (and key economic sectors) is in this way removed from the public domain, making regulators more accountable to the industries and private actors whose investments they attract and regulate than to the public to which these resources and enterprises formerly belonged [...]" 
Esse processo tornou-se mais dramático ainda com a grave recessão econômica a partir 1999. O crescimento econômico do país caiu de uma média de 4,5\% entre 1993 e 1998 para praticamente zero em 1999. No Departamento de Cochabamba, o crescimento do PIB caiu de uma média de 5,5\% entre 1993 e 1998 para 1,7\% em 1999 (INE, 2003; IRIARTI, 2005). Nos anos seguintes, o crescimento econômico do Departamento de Cochabamba apresentou forte estagnação. Portanto, às vésperas da Guerra da Água, a situação econômica boliviana, em geral, e cochabambina, em particular, eram problemáticas. Não foi o mero acaso que fez com que as demandas da Coordinadora del Agua não se restringissem à questão da água, mas também englobassem o custo de vida, o desemprego e a própria política econômica.

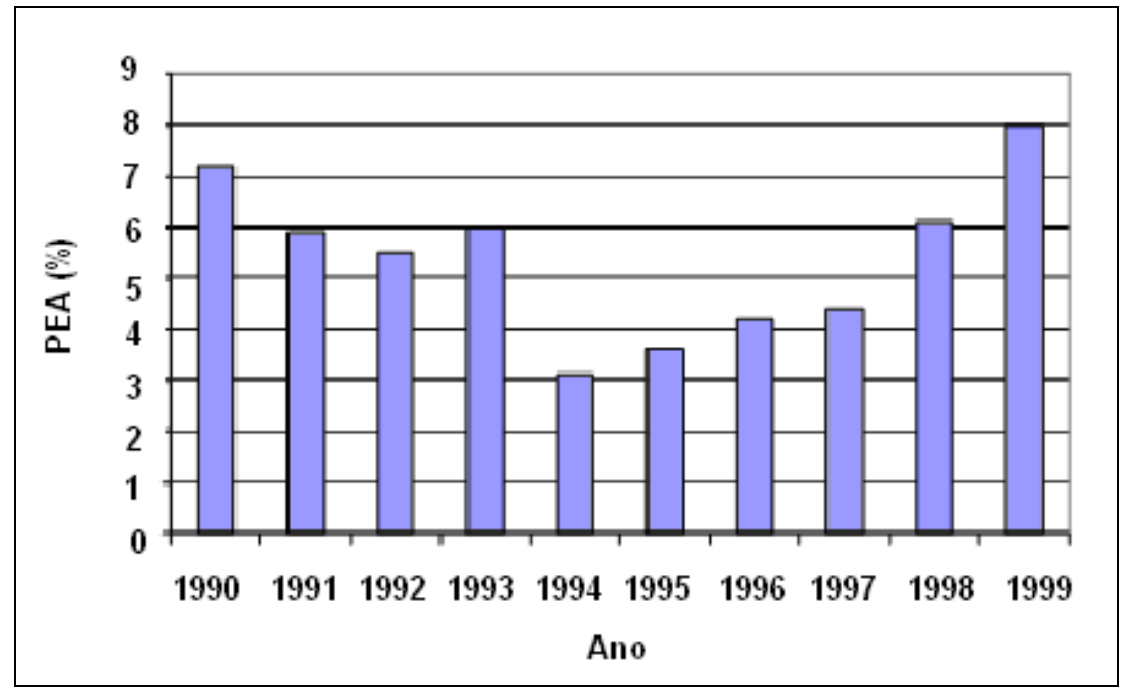

Gráfico 4. Taxa de desemprego da PEA na Bolívia no período entre 1990 e 1999.

Fonte: Barja e Urquiola (2003, p. 15).

Diante dessa conjuntura, além do mercado informal, havia ainda o mercado da produção de coca. Farthing e Kohl (2005) indicaram que a renda média produzida pelo cultivo de coca girava em torno de 1.000 a 2.000 dólares por ano para cada família, o que garantia seu sustento durante o restante do ano. A partir de 1997, em decorrência de pressão norte-americana, o governo boliviano aprovou um novo plano para a erradicação de coca, no qual se extinguia o programa de compensação da substituição dos cultivos de coca, impondo a erradicação total por meio da militarização das regiões produtores de folha de coca, o que ficou conhecido como 
Programa "Coca Zero". Antes desse programa, o número de famílias produtoras de folha de coca no Chapare era de 70.000. Na época, esse número correspondia a $85 \%$ das famílias bolivianas empregadas pelo mercado cocalero (da coca), o qual correspondia a 5\% do PIB nacional em meados dos anos 90.

A folha da planta de coca, cujo nome científico é Erythroxylon coca, ao contrário da cocaína, sempre fez parte da cultura andina, tanto em rituais como em sua medicina e na adaptação humana à puna andina. Assim, mascar folhas de coca é uma prática milenar andina largamente difundida. Adicionalmente, diversos estudos apontam que a folha de coca possui nutrientes importantes para a saúde humana (IRIARTI, 2005, p. 449). Apesar disso, deve-se ressaltar que muitos grupos de narcotraficantes se aproveitam desse aspecto para refinar cocaína na Bolívia. Inclusive, vários políticos bolivianos estiveram envolvidos com a máfia, principalmente durante a ditadura militar entre os anos 70 e 80 , tendo o CEDIB (1993, p. 37, tradução nossa) destacado a participação de setores oficiais do governo ao comentar sobre a máfia boliviana:

O "pai oficial" ou padrinho da máfia foi Roberto Suarez. Mas sempre [...] o artífice e pai camuflado foi o presidente Hugo Banzer Suárez. Sua atuação nos anos setenta ensejou que a imprensa internacional aplicasse à Bolívia o qualificativo de "país de narcotraficantes". 203

No início dos anos 90, o governo boliviano passou a utilizar o programa de compensação agrícola em que subsidiava plantações de outros produtos agrícolas em detrimento da coca. Como já mencionado, sob forte pressão norte-americana, deu-se o início da militarização da erradicação da coca no país. Entretanto, em 1997, com a volta ao poder do antigo "pai camuflado" da máfia boliviana, o presidente Banzer, o governo norte-americano passou a exigir uma posição drástica: a opção zero, ou seja, a erradicação total das plantações de coca no Chapare. Nesse contexto, iniciou-se um forte conflito entre os camponeses e a repressão militar boliviana. O número de famílias produtoras de coca após a erradicação forçada decresceu de 70.000 para 40.000 no início dos anos 2000 (SALAZAR ORTUÑO, 2003; URQUIDI, 2001).

\footnotetext{
203 "El 'padre oficial' o padrino de la mafia fue Roberto Suarez. Pero siempre [...] el artífice y padre camuflado fue el general y presidente Hugo Banzer Suárez. Su actuación en los años setenta dio pie para que la prensa internacional aplicara a Bolivia el calificativo de 'país de narcotraficantes'."
} 
Outro processo que parece ter acentuado ainda mais o descontentamento dos setores rurais foi a falta de incentivo à agricultura familiar boliviana, ao passo que os setores urbanos mais modernos e a agricultura extensiva de Santa Cruz de la Sierra receberam fortes incentivos fiscais. Os índices de pobreza no campo se mantiveram altos durante todo o período do ajuste estrutural. No Departamento de Cochabamba, 44,3\% da população rural se encontrava na condição de indigência ou total marginalidade quanto aos serviços básicos, em contraste com 6,3\% da população urbana na mesma situação (INE, 2001c). A esse respeito, Thiele (2003, p. 316, tradução nossa) argumentou que:

[...] há indícios de que a pobreza rural estagnou em um índice muito alto e que a agricultura tradicional, com a qual a maioria dos pobres do campo ganha o seu sustento, fica para trás em relação ao restante da economia. A migração pode e vai ajudar a solucionar esse problema, mas ela não pode carregar todo o fardo. Portanto, a principal prioridade deve ser aumentar a produtividade da agricultura tradicional. ${ }^{204}$

Em sua análise sobre o programa de erradicação da produção de coca no Chapare, Urquidi (2001, p. 143) apontou que:

[...] independentemente das políticas de compensação e erradicação, a substituição dos cultivos de coca não se realizou, como tampouco conseguiu levantar significativamente os índices de qualidade de vida do cocalero. Não houve investimento nas zonas de expulsão da população agrícola e não foram propostos, nos últimos quinze anos, projetos viáveis para o desenvolvimento rural.

Ao comentar sobre os efeitos da Lei no 1.544 no campo (BOLIVIA, 1994b), Soldal (2008, p. 33-34, tradução nossa) opinou que:

O que é importante é que nós podemos ver que as comunidades rurais parecem ter sido deixadas de fora. Há uma pequena tendência negativa, mas de forma alguma igual àquela nas áreas urbanas, esta grande margem oferece a possibilidade de fazer duas tentativas de julgamento: primeiro, a desigualdade entre a população urbana e a população rural parece estar aumentando, e segundo, a Lei de Capitalização parece ser ou mais ineficaz nas áreas rurais ou ter maiores efeitos negativos nas áreas rurais que nas áreas urbanas. ${ }^{205}$

\footnotetext{
204 "[...] there are indications that rural poverty stagnates at a very high level and that traditional agriculture, where most of the rural poor earn their living, lags behind the rest of the economy. Migration can, and will, help solving this problem, but it cannot bear the whole burden. Therefore, a top priority should be to enhance the productivity of traditional agriculture [...]"

205 "What is important is that we can see that the rural communities seem to be left out. There is a small negative trend, but not at all distinct as the one in the urban areas this large gap gives the possibility to make two tentative judgments: firstly, the gap between the urban population and the rural population seems to be increasing and secondly, the Law of Capitalization seems either to be rather ineffective in the rural areas or that it has larger negative effects in the rural areas than in the urban areas."
} 
Dessa forma, em âmbito nacional, os efeitos da nova política econômica se materializam na Guerra da Água, não somente sob a forma de protestos camponeses, mas também junto com a questão mais regional do programa de erradicação dos cultivos de coca. As tensões nacionais foram se alinhando pari passu com fatores do contexto regional.

Quando o governo deixou a incumbência do setor econômico exclusivamente para os atores privados e uma parte das políticas sociais a cargo da sociedade civil, o país foi, aos poucos, tornando-se refém de atores de diferentes escalas. Por outro lado, o Estado se restringia a garantir a legalidade dos mecanismos econômicos impostos pelos organismos internacionais, sem levar em consideração seus efeitos sobre a sociedade boliviana. Dessa forma, o confronto entre os atores da escala internacional e aqueles das escalas menores (representados pelos movimentos sociais), acabou por conduzir a nação boliviana a uma situação de grande tensão. Os mecanismos de segurança que o Estado deve garantir à sociedade foram negligenciados em favor de pretensas autonomia e liberdade. O sociólogo Beck (2005, p. 13, tradução nossa) reiterou que "sem segurança, a liberdade é vazia e sem sentido - faltam os fundamentos para organizar e moldar a vida em liberdade e ativamente. O contrário também é certamente válido: sem liberdade, a segurança perde o seu sentido"206 Certamente, no caso boliviano, liberdade e segurança não foram devidamente combinadas.

Após a Guerra da Água, as políticas estabelecidas pelo regime neoliberal entraram em colapso e a iniciativa privada se tornou cada vez mais incapaz de oferecer equilíbrio econômico para o país. Em consequência aos intensos protestos a partir de 2003, o Estado passou a intervir de forma mais direta na economia, com aumento dos royalties cobrados ao setor de hidrocarbonetos e intensificação da estatização das empresas de abastecimento de água e esgoto.

\footnotetext{
206 "Ohne Sicherheit ist Freiheit leer und bedeutunglos - es fehlen die Grundlagen, um das Leben in Freiheit zu plannen und Aktiv zu gestalten. Es gilt allerdings auch umgekehrt: Ohne Freiheit verliert Sicherheit ihren Sinn."
} 


\subsection{Guerra da água e política nacional: quando a questão nacional se volta para a regional}

A crise da política econômica também coincidiu com o fracasso do regime político construído durante a redemocratização. Destarte, a crescente insatisfação popular encontrava cada vez menos representantes políticos legítimos e reconhecidos pelos cidadãos bolivianos como tal e capazes de oferecer solução para o problema. Ao mesmo tempo em que os partidos políticos encontravam-se em crise, surgiram novos movimentos sociais que passaram a canalizar essa insatisfação. Diante disso, a democracia de pactos entre partidos se transformou em uma democracia de acordos entre o governo central e os movimentos sociais.

Após o fim do regime militar e a volta à democracia, iniciou-se um período na política boliviana chamado de "democracia pactuada". Nessa fase, o Congresso tornou-se o ente-chave na decisão das eleições para presidente da nação com a formação de maiorias parlamentarias. O sistema eleitoral boliviano previa que se nenhum candidato tivesse mais da metade dos votos no primeiro turno, o presidente deveria ser escolhido pelo Congresso Nacional a partir dos três candidatos mais votados.

Essa forma de sistema eleitoral recebe críticas porque permite que um candidato que recebeu menor votação que outros seja eleito pelo Congresso Nacional. Por outro lado, pequenos partidos tornam-se chave para a formação das coalizões. Esse foi o caso de Conciencia de Patria (CONDEPA) e Unión Cívica Solidaridad (UCS), partidos que durante dez anos (1989-1999) definiram as eleições por conta da dificuldade que os partidos tradicionais bolivianos tinham em lograr maioria nas eleições. Nesse período, era comum a eleição de candidatos com apenas $18 \%$ a $20 \%$ dos votos.

A gestão da água em Cochabamba e, posteriormente, a Guerra da Água revelaram a fragilidade desse sistema político e, especialmente, das coalizões formadas. Por causa da incoerência dessas alianças, muito vezes unindo correntes ideológicas completamente diversas, esses acordos políticos foram se desgastando. Durante o governo Banzer, a "democracia pactuada" começou a entrar em colapso, 
devido à perda da capacidade de administrar os conflitos internos dentro da própria aliança e mesmo da sociedade (ALENDA, 2004).

Em 1997, deu-se início à campanha eleitoral para presidente, em um momento em que a política econômica do presidente Lozada se encontrava em seu auge. O desemprego não era tão elevado ainda e os indicadores econômicos estavam finalmente equilibrados. Ainda nesse mesmo ano, Lozada negociou com o governo da Itália o financiamento da perfuração do túnel do Projeto Múltiplo Misicuni. Em decorrência das grandes dificuldades técnicas e financeiras desse projeto, 0 presidente passou a defender a opção oferecida pelo Projeto Corani. A proposta foi imediatamente rechaçada pelas autoridades políticas regionais, particularmente pelo partido regional Nueva Fuerza Revolucionaria (NFR) do alcalde Manfred Reyes Villa.

Aproveitando-se dessa oportunidade, o maior concorrente político do presidente em vigor, o general Hugo Banzer (candidato do partido Acción Democrática Nacionalista - ADN), se uniu às autoridades políticas e cívicas regionais de Cochabamba e juntos assinaram o compromisso de levar adiante o Projeto Múltiplo Misicuni caso fossem eleitos. De acordo com uma pesquisa, $76 \%$ da população cochabambina apoiava o Projeto Misicuni, 12\% apoiava o Projeto Corani e 11\% defendia a execução de ambos (GARCÍA; GARCÍA; QUITÓN, 2003).

Após a manifestação regional em favor do Projeto Múltiplo Misicuni, acolhido com fervor pela população, o presidente ficou sem apoio político. Lozada chegou a perguntar se Cochabamba queria água ou Misicuni (LASERNA, 2000a). Concluída a gestão de Lozada, foram realizadas as eleições gerais em junho de 1997. Nenhum candidato alcançou $50 \%$ dos votos, tendo a ADN do general Banzer conseguido $22,3 \%$ dos votos, enquanto o isolado partido do presidente (MNR) alcançou $18,2 \%$. Após inúmeras negociações, formou-se uma aliança, que foi chamada de Compromiso por Bolivia (Compromisso por Bolívia), também conhecida como gran alianza (grande aliança), encabeçada pela ADN, reunindo mais três partidos grandes, UCS, Movimiento de Izquierda Revolucionaria (MIR) e CONDEPA e outros quatro pequenos partidos. Essa aliança representava mais de $70 \%$ dos votos e alcançava quase cinco quartos do Congresso Nacional. Uma vez que as eleições em Cochabamba respaldavam a sua decisão, já no início do novo mandato, a coalizão impulsionou a realização do Projeto Múltiplo Misicuni. 
Em 1999, as primeiras críticas ao contrato de concessão e à Lei o 2.029 (BOLIVIA, 1999b) ameaçavam arruinar a continuidade do sucesso da coalizão durante as eleições municipais daquele mesmo ano. Entrementes, após o acordo realizado pelo governo com a FEDECOR e o Comité de Defensa del Agua y la Economıa Familiar (CODAEP, Comitê de Defesa da Água e da Economıa Familiar), a campanha para o pleito foi realizada com muita propaganda política vinculada ao Projeto Misicuni e à solução para a crise da água em Cochabamba (CRESPO; FERNÁNDEZ; PEREDO, 2004). Os resultados eleitorais respaldaram novamente a gran alianza. Das 11 cadeiras para o conselho municipal de Cercado, o MNR fez apenas um conselheiro municipal, enquanto as demais cadeiras ficaram para os partidos da mega coalizão. Além do mais, nos outros municípios da região metropolitana de Cochabamba e em escala nacional o resultado não foi diferente, consequentemente, levando a gran alianza ao seu apogeu.

Não obstante, logo após a bonança, sobreveio a tempestade. A vitória da gran alianza nas eleições municipais de Cochabamba marcou também a derrocada do governo Banzer e, em seguida, da própria coalizão, embora isso possa, à primeira vista, parecer paradoxal. Em face dos primeiros protestos contra o contrato de privatização do SEMAPA, o alcalde de Cochabamba e chefe do NFR, um dos partidos da gran alianza, passou a criticar a elevação das tarifas de água e o próprio contrato de concessão. Esse fato marcou a expulsão de seu partido da mega coalizão, que já havia excluído o CONDEPA em 1998. Ao final desse conflito, as autoridades políticas e cívicas regionais se voltaram contra o governo central.

Ademais, a Guerra da Água e outros conflitos que foram se desenrolando simultaneamente colocaram a institucionalidade do Estado em cheque. Por conseguinte, em abril de 2000, o governo declarou estado de sítio. Fazendo uma reflexão sobre a "democracia pactuada", Alenda (2004, p. 10, tradução nossa) apontou que:

Durante o governo de Banzer, tanto os pactos governamentais como o sistema de parlamentarismo presidencialista ou os mecanismos de controle social revelaram seus limites. Os resultados do Latinobarómetro de 2001 mostram que a Bolívia é o país da América Latina mais crítico para o exercício da democracia, apesar de sua valorização como regime. Junto com o Congresso, a Corte Eleitoral e o Poder Judicial, os partidos políticos 
são as instituições que menos confiança infundem. Ao final dos anos 90 , a opinião pública é inclusive a favor de seu desaparecimento. ${ }^{207}$

A perda de confiança nos partidos políticos foi um dos aspectos mais fortemente expressados durante o conflito. Os representantes "legais" da sociedade (partidos políticos e comitê cívico) perderam completamente a legitimidade, ao contrário da Coordinadora del Agua, que passou a angariar cada vez mais apoio popular. Algumas pesquisas feitas antes mesmo do conflito já apontavam essa falência das instituições políticas. Em julho de 1995, uma pesquisa realizada pela Universidade Católica Boliviana revelou que $79 \%$ dos entrevistados acreditavam que a democracia boliviana não era tão democrática (IRIARTI, 2005). Uma pesquisa de opinião realizada pelo Instituto Latinoamericano de Investigaciones Sociales (ILDIS, Instituto Latino-americano de Investigações Sociais) em 1995 corroborou a tese de Alenda (2004), porquanto reiterou que os partidos políticos eram as instituições menos confiáveis para a maioria da população da Bolívia (IRIARTI, 2005).

Evidentemente, essa descrença na política reflete bem a própria atuação dos partidos na vida política boliviana. Em seu comentário acerca do período da "democracia pactuada" e da gran alianza, Mayorga (2001, p. 122, tradução nossa), ponderou que:

[...] os integrantes fizeram da coalizão a mais heterogênea e incoerente de todas, não apenas pelo seu número excessivo e supérfluo, mas também pela supremacia dos interesses partidários no paternalismo e divisão clientelista do poder sobre os acordos em torno das políticas públicas. A inconsistência da coalizão foi demonstrada claramente com a expulsão de CONDEPA $[\ldots]^{208}$

O desgaste da "democracia pactuada" com o passar do tempo pôde ser visto pelo número de vezes em que foi decretado estado de sítio. Entre 1985 e 2003, em seis ocasiões foi declarado estado de sítio, perfazendo 21 meses, ou seja, em 18 anos de democracia pactuada, o país foi governado sob estado de sítio por quase 2 anos. Com o aumento da quantidade e da intensidade das demandas, o governo de

207 "Durante el gobierno de Banzer, tanto los pactos gubernamentales como el sistema de parlamentarismo presidencializado o los mecanismos de control social revelaron sus límites. Los resultados del Latinobarómetro de 2001 muestran que Bolivia es el país de América Latina más crítico hacia el ejercicio de la democracia, a pesar de su valoración como régimen. Junto con el Congreso, la Corte electoral y el Poder Judicial, los partidos políticos son las instituciones que menos confianza infunden. A finales de los años noventa, la opinión pública es incluso favorable a su desaparición."

208 "[...] los integrantes hicieron de la coalición la más heterogénea e incoherente de todas, no sólo por su número excesivo y superfluo, sino también por la supremacía de los intereses partidistas en el patronazgo y reparto clientelista del poder sobre los acuerdos en torno a políticas públicas. La inconsistencia de la coalición se demostró claramente con la expulsión de CONDEPA [...]" 
Banzer se viu obrigado a ceder, haja vista que nos períodos anteriores, o uso da violência legítima pelo Estado foi bem maior. No primeiro governo Lozada, durante o estado de sítio, 350 pessoas foram confinadas, enquanto no governo de Banzer, isso ocorreu com apenas 22, mas todas foram rapidamente liberadas, ao contrário dos governos anteriores (ALENDA, 2004, p. 9). Diante desse cenário Alenda (2004, p. 9-10, tradução nossa) chamou a atenção para o fato que o governo mostrava:

Incapacidade de chegar ao consenso para a aplicação de reformas estruturais ou responder às demandas da sociedade mantendo o "equilíbrio dinâmico" [...] o governo de Banzer já não consegue absorver o conflito e cede ante a pressão dos movimentos sociais $[\ldots]^{209}$

Ademais, a Guerra da Água marcou a entrada de atores não-convencionais na política. As instituições políticas foram paulatinamente se deslegitimando. UCS e CONDEPA, que até aquele momento vinham canalizando o descontentamento popular (BARRIOS MORÓN, 1993, p. 173), mesmo juntas não alcançaram sequer $6 \%$ do eleitorado nas eleições de 2002. Por outro lado, os movimentos sociais Coordinadora del Agua, Coordinadora del Gás e Coordinadora de los Productores de Coca, passaram a expressar os anseios da população e a enfrentar o legalismo radical do governo de apenas negociar com os atores institucionalizados. Dessa forma, na prática, os partidos políticos, que deveriam constituir as instituições que representam a sociedade civil perante o governo, deixaram de exercer este papel, que foi, então, assumido pelos movimentos sociais. Essa falência estrutural produziu a renúncia de dois presidentes após o início da Guerra da Água. Em 2003, Sanchez de Lozada renunciou ao seu segundo mandato, assumindo em seu lugar o vicepresidente Carlos Mesa, que governou pouco mais de um ano e meio, até julho de 2005.

O espaço político deixado por CONDEPA e UCS foi substituído nas eleições de 2002 pelo Movimiento al Socialismo (MAS), de Evo Morales, e pelo Movimiento Indígena Pachacuti (MIP), de Felipe Quispe. Apartir de sua participação na Guerra da Água, Morales conseguiu unir o apoio dos setores urbanos e rurais, alcançando quase $20 \%$ nas eleições presidenciais. Nas eleições seguintes, em 2005, Morales foi eleito, sendo o primeiro presidente aymara da história da Bolívia. Além disso, foi a primeira vez desde a redemocratização que um presidente conseguiu ser eleito

\footnotetext{
209 "Incapacidad de lograr el consenso para la aplicación de reformas estructurales o responder a las demandas de la sociedad manteniendo el 'equilibrio dinámico' [...] el gobierno de Banzer ya no logra absorber el conflicto y cede ante la presión de los movimientos sociales [...]"
} 
ainda no primeiro turno. Portanto, a Guerra da Água marcou uma transformação na vida institucional boliviana, vinculando-se ao conflito não somente questões regionais como também aspectos da própria política nacional boliviana.

\subsection{Políticas hídricas na Bolívia: públicas ou privadas?}

A falência do regime político em tecer acordos entre as diferentes demandas do país criou uma situação instável. Ante o descontentamento em relação às várias medidas implementadas pelo governo, principalmente as de cunho econômico, torna-se difícil apontar as políticas hídricas como o ponto principal de insatisfação em nível nacional. Consequentemente, ao discutir políticas hídricas na Bolívia, é necessário situá-las no contexto nacional. Há de se esclarecer que a concessão de empresas públicas de abastecimento de água potável na Bolívia já havia sido anteriormente realizada antes da concessão ao SEMAPA. A primeira empresa do setor a ser concedida foi o Servicio Autónomo Municipal de Agua Potable y Alcantarillado (SAMAPA, Serviço Autônomo Municipal de Água Potável e Rede de Esgotos), na cidade de La Paz. Ao contrário da concessão realizada em Cochabamba, não houve maiores conflitos na época, apenas manifestações e marchas que, pouco depois, foram arrefecendo. Deve-se, então, observar as diferenças e as semelhanças entre as duas formas de concessão. Isso não quer dizer que as conclusões serão definitivas, mesmo porque o horizonte espacial e o contexto eram diferentes para cada situação.

Em 1997, após a promulgação da Lei oㅜ 1.600 (BOLIVIA, 1994d), o governo passou a se preocupar com a privatização das empresas de abastecimento de água potável. Em consequência, criou-se a Superintendencia de Agua, dando início a um projeto de fortalecimento das três principais empresas do país. A primeira empresa a ser repassada para a iniciativa privada foi o SAMAPA, para tanto recebendo crédito de 490 mil dólares do Banco Mundial com o fito de melhorar a capacidade institucional da empresa e, dessa forma, atrair investimentos privados.

Do mesmo modo que ocorreu com o SEMAPA, essa concessão foi realizada sem a participação da sociedade civil e mesmo do governo municipal. Então, o controle do SAMAPA foi transferido para o consórcio internacional Aguas del Illimani 
S.A. (AISA), do qual a empresa francesa Lyonnaise des eaux era a maior acionária. A concessão tinha duração de 30 anos e previa a expansão dos serviços de abastecimento de água e esgoto. Logo no primeiro quinquênio, os investimentos alcançavam 68 milhões de dólares, sendo 15 milhões do Banco Mundial, 10 milhões da Corporación Andina de Fomento (CAF, Corporação Andina de Fomento) e 15 milhões da International Finance Corporation (IFC, Corporação Internacional de Finança). O IFC é uma instituição privada parceira do Banco Mundial que, normalmente, se torna sócia das empresas que são concessionadas com apoio deste banco objetivando dar-Ihes boa visibilidade (CRESPO; FERNÁNDEZ, 2004). No entanto, esse fato apresentava implicações contraditórias e riscos. O primeiro aspecto paradoxal foi a participação do Banco Mundial tanto como sócio da empresa privada quanto como regulador do setor ao estabelecer regras para a concessão como requisito de acesso a créditos. Outro aspecto crítico era que caso houvesse uma contenda entre o Estado boliviano e a empresa privada, a lide seria resolvida no Tribunal de Conciliação do Banco Mundial (CRESPO; FERNÁNDEZ, 2004). Nesse caso, o Banco Mundial era tanto parte do processo como o próprio juiz dele. Assim como no caso de Cochabamba, o contrato tinha cláusulas parciais que favoreciam claramente o investidor privado em detrimento do interesse público.

Uma modificação foi efetuada posteriormente para tentar dar credibilidade à empresa e diferenciá-la de Aguas del Tunari, oferecendo a concessão de uma parte das ações da empresa aos seus funcionários. Porém, essa quota era mínima, em torno de $1 \%$ do total de ações, o que significava que eles não teriam qualquer poder de decisão em relação ao demais acionistas. Era apenas uma medida de "boa fé", em uma tentativa de conferir legitimidade ao processo, assim como havia sido realizado com o SEMAPA após sua reestatização (CRESPO; FERNÁNDEZ, 2004).

Da mesma maneira que na concessão em Cochabamba, o contrato com Aguas del Illimani previa a possibilidade de exploração não somente de fontes, mas de bacias inteiras em seu Anexo 4. Adicionalmente, o contrato previa que a empresa deveria se responsabilizar pela procura de novas fontes de água de forma a melhorar o serviço de abastecimento de água. Novamente apareceram lógicas contraditórias, uma de cunho econômico e outra de âmbito social, já que os usos y costumbres não estavam sendo respeitados, conforme informaram Crespo e Fernández (2004). 
Um dos aspectos que diferencia o caso de Cochabamba da situação de La Paz é o desempenho bem mais elevado de Aguas del Illimani. A meta traçada para 2001 era alcançar $82 \%$ e $41 \%$ de residências com abastecimento de água potável e esgoto, respectivamente. Todavia, naquele período, a empresa atingiu $100 \%$ de abastecimento de água tanto em La Paz quanto em El Alto e o serviço de esgoto sanitário alcançou uma cobertura de 88\% em La Paz e 54\% em El Alto. Além disso, depois da concessão, o desempenho da empresa melhorou de forma considerável (Tabela 23).

Tabela 23. Comparação entre o desempenho das empresas SAMAPA em 1997 e Aguas del Illimani (AISA) em 2003.

Município

SAMAPA (1997)

AISA (2003)

Diferença entre

SAMAPA e AISA

\begin{tabular}{cccc}
\hline \multicolumn{5}{c}{ Água potável (\%) } \\
\hline La Paz & 92 & 100 & 8 \\
El Alto & 82 & 100 & 18 \\
\hline & \multicolumn{3}{c}{ Conexões (n⿳⺈) } \\
\hline La Paz + El Alto & 144.475 & 223.755 & 79.280 \\
\hline La Paz & \multicolumn{3}{c}{ Esgoto (\%) } \\
El Alto & 72 & 91 & 25 \\
\hline
\end{tabular}

Conexões ( $\mathrm{n}^{\circ}$ )

$\begin{array}{llll}\text { La Paz }+ \text { El Alto } & 88.408 & 750.910 & 79.280\end{array}$

Fonte: Organizada pelo autor com base em Superintendencia General (1997-2003 apud PACHECO, 2005) e AISA (2004 apud CRESPO; FERNÁNDEZ, 2004, p. 275).

Portanto, percebe-se que o serviço oferecido por AISA era bem superior ao do SAMAPA e que a concessão trouxe avanços no que concerne à expansão do atendimento aos serviços básicos. O caso de La Paz é revelador em comparação ao restante do país, pois o desempenho de AISA atingiu patamar bem superior ao das 
duas maiores empresas públicas de abastecimento de água e esgoto da Bolívia, SEMAPA e Cooperativa de Servicios Públicos Santa Cruz Ltda. (SAGUAPAC, Cooperativa de Serviços Públicos Santa Cruz Ltda.) em Santa Cruz de la Sierra, após a privatização (McKENZIE; MOOKHERJEE, 2003), como pode ser verificado na Tabela 24.

Tabela 24. Comparação da expansão do serviço de abastecimento de água nas três maiores regiões metropolitana da Bolívia por quintilhos. ${ }^{210}$

Quintilho

Expansão do serviço de abastecimento de água (\%)

\begin{tabular}{cc}
\hline La Paz e El Alto & $\begin{array}{c}\text { Cochabamba e Santa Diferença } \\
\text { Cruz de la Sierra }\end{array}$
\end{tabular}

\begin{tabular}{lcccccccc} 
& $\mathbf{1 9 9 2}$ & $\mathbf{1 9 9 4}$ & $\mathbf{1 9 9 9}$ & $\mathbf{1 9 9 2}$ & $\mathbf{1 9 9 4}$ & $\mathbf{1 9 9 9}$ & $\begin{array}{c}\mathbf{1 9 9 2 -} \\
\mathbf{1 9 9 4}\end{array}$ & $\begin{array}{c}\mathbf{1 9 9 4 -} \\
\mathbf{1 9 9}\end{array}$ \\
\hline Primeiro & 53,3 & 66,1 & 88,8 & 57,4 & 66,4 & 82,5 & 3,8 & 6,6 \\
Segundo & 70,7 & 73,3 & 93,3 & 69,8 & 74,2 & 86,9 & $-1,8$ & 7,4 \\
Terceiro & 76,0 & 77,4 & 95,6 & 75,7 & 80,6 & 89,4 & $-3,5$ & 9,5 \\
Quarto & 87,1 & 89,8 & 100 & 84,1 & 87,5 & 97,3 & $-0,7$ & 0,4 \\
Quinto & 96,2 & 94,6 & 100 & 87,8 & 93,1 & 95,4 & $-6,9$ & 3,1 \\
Geral & 78,1 & 81,7 & 94,4 & 75,6 & 80,3 & 90,7 & $-1,0$ & 2,2 \\
\hline
\end{tabular}

Fonte: McKenzie e Mookherjee (2003, p. 174).

Uma diferença importante entre esses casos é que o contrato de Aguas del Tunari, companhia responsável pelo abastecimento da região de Cochabamba, estava vinculado à execução do Projeto Misicuni, o que gerava fortes encargos para a empresa. No caso de La Paz e El Alto, a empresa AISA tinha menores encargos financeiros e, assim, pôde concentrar seus investimentos na expansão dos serviços

\footnotetext{
${ }^{210}$ Quintilho: qualquer de quatro valores que dividem os itens de uma distribuição de frequência em cinco clases, cada uma contendo um quinto da população total; também: qualquer uma das cinco classes. ("quintile: any of the four values that divide the items of a frequency distribution into five classes with each containing one fifth of the total population; also: any one of the five classes.") (MICH, 1993, p. 960, tradução nossa).
} 
básicos. Outro ponto importante é que, em Cochabamba, o SEMAPA não aumentou o número de conexões entre 1994 e 1999 (SOLDAL, 2008).

Igualmente importante é a questão dos preços das tarifas de água. Antes da concessão do SEMAPA, houve incremento tarifário da ordem de 57,7\% para a categoria doméstica, 17,9\% para a comercial e 21\% para a industrial. Assim como no caso da concessão de Cochabamba, as tarifas se indexavam ao dólar norteamericano e, após o primeiro quinquênio, seus preços deveriam ser revisados. $O$ custo de cada conexão de água estava fixado em 155 dólares e de esgoto, em 188 dólares. Após o término do primeiro quinquênio, em 2002, o consórcio AISA demandou aumento de 25\%, porém a Superintendência autorizou somente 15\%. Além disso, os custos para desfrutar do direito de conexão de água potável e esgoto sanitário aumentaram para 196 e 249 dólares, respectivamente. Na Tabela 25 encontra-se representada a estrutura tarifária praticada até então.

Tabela 25. Síntese das categorias tarifárias e volume de água consumido em La Paz, durante a gestão de AISA, no período entre 1997 e 2001.

\begin{tabular}{|c|c|c|c|c|}
\hline \multirow{2}{*}{$\begin{array}{l}\text { Nível de } \\
\text { consumo }\end{array}$} & \multirow{2}{*}{$\begin{array}{c}\text { Valor } \\
\left(\mathrm{US} \$ \mathbf{m}^{3}\right)\end{array}$} & \multicolumn{3}{|c|}{ Volume de água consumido $\left(\mathrm{m}^{3}\right)$} \\
\hline & & Doméstico & Comercial & Industrial \\
\hline Alto & 1,1862 & 301 e mais & 21 e mais & 1 e mais \\
\hline Médio alto & 0,6642 & 151 a 300 & 1 a 20 & - \\
\hline Médio & 0,4428 & 31 a 150 & - & - \\
\hline Baixo & 0,2214 & 1 a 30 & - & - \\
\hline
\end{tabular}

Fonte: Superintendencia de Aguas (1997 apud CRESPO; FERNÁNDEZ, 2004, p. 279).

Embora tenha havido incremento das tarifas de água antes da concessão para AISA, no Gráfico 5 nota-se que os preços praticados pelo consórcio eram menos elevados que os do SEMAPA em Cochabamba e da SAGUAPAC em Santa Cruz de la Sierra. Desse modo, além de haver melhorado a cobertura do serviço, AISA ainda manteve preços abaixo dos praticados nos outros centros bolivianos.

Todavia, a empresa ainda apresentava algumas irregularidades. Por exemplo, de acordo com o contrato, AISA deveria em um prazo de um ano e meio a três, 
instalar relógios nas habitações que se conectassem ao serviço público. Até 2005 havia inúmeras casas que sem medidores de água. Outro aspecto crítico é o da existência de uma clausula de confidencialidade (número 14.3.1 do contrato) em que as principais informações de funcionamento da empresa somente poderiam ser relata à Superintendência de Água. Ou seja, o interesse público, assim como na concessão do SEMAPA em Cochabamba, acabava sendo prejudicado já que somente a Superintendência de águas, órgão independente de qualquer controle público, tinha acesso às principais informações de AISA (CRESPO; FERNÁNDEZ, 2004).

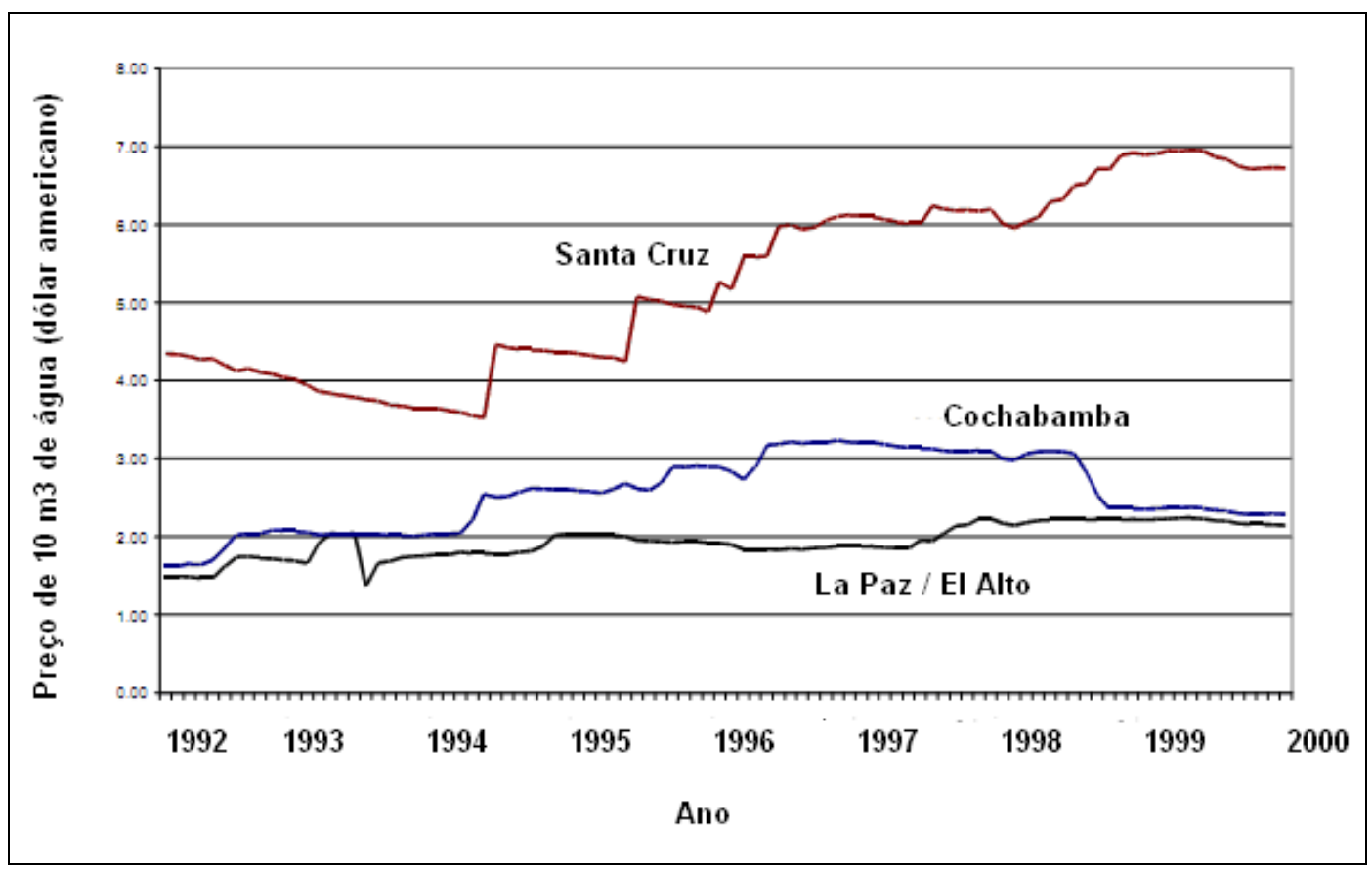

Gráfico 5. Média do preço para o consumo de $10 \mathrm{~m}^{3}$ nos três maiores centros urbanos bolivianos entre 1992 e 2000.

Fonte: Barja e Urquiola (2001, p. 23).

As maiores diferenças entre a concessão de AISA e a de Aguas del Tunari se referem precipuamente ao preço das tarifas e ao encargo de realizar o projeto Misicuni. Com a obrigatoriedade da execução do Projeto Múltiplo Misicuni, a empresa Aguas del Tunari foi obrigada a cobrar tarifas mais elevadas que aquelas praticadas por AISA. Em adição a isso, dados os elevados riscos do projeto, as 
exigências da empresa Aguas del Tunari em detrimento do interesse público foram mais duras. Também, uma vez que a pressão popular pela realização do Misicuni era grande, pois os partidos que apoiavam o projeto saíram vitoriosos nas eleições de 1997 e 1999, restava cumprir a promessa feita e colocar o projeto em execução. Para a estratégia política dos partidos da gran alianza, o Projeto Misicuni deveria ser realizado a todo custo, mesmo que passando por cima do interesse público. Isso fica claro quando se verifica que já havia planos para a campanha das eleições presidenciais de 2002: o ato principal da campanha seria a entrega do túnel Misicuni (LASERNA, 2000b). Portanto, o fracasso da realização do projeto significaria a derrota política da mega coalizão.

Resta saber por que a partir de 2003 a resistência popular exigiu a expulsão de AISA, vez que os preços praticados pela empresa estavam entre os menos elevados na Bolívia e, concomitantemente, seu desempenho era melhor. Fazendo uma análise sobre a resistência popular á AISA, Crespo e Fernández (2004) indicaram que ela foi fundamentalmente estabelecida a partir dos movimentos sociais de El Alto, enquanto em La Paz não houve maiores protestos relacionados a esta questão. Não obstante, a raiz do problema é mais profunda, não se restringindo à elevação do preço da água, que já havia sido implementada desde fevereiro de 1997. Naquele período, a crise econômica não se fazia ainda manifestar e, portanto, a percepção do incremento tarifário como uma ameaça somente ocorreu timidamente nas classes mais humildes de El Alto. A partir de 1998, o contexto econômico nacional iniciava a sua derrocada com o aumento do desemprego e a diminuição do poder de compra. Posteriormente, em 2003, o aumento de $15 \%$ das tarifas significou redução ainda maior da renda, já que a população teve de pagar mais pelo consumo de água.

Faz-se importante também diferenciar o caso de Cochabamba do de La Paz em relação ao contexto regional. A privatização do SEMAPA em Cochabamba foi imediatamente rechaçada por conta da forte tradição camponesa da região e do contraste entre a racionalidade comunitária indígena e a racionalidade econômica. Um dos líderes da Coordinadora del Agua, ao fazer uma comparação entre a resistência contra Aguas del Tunari em Cochabamba e AISA em La Paz, destacou que:

Eu diria que basicamente por duas coisas... uma das primeiras é que em El Alto não há um referente... não há um espaço único confiável [...] Por outro 
lado, há um componente importante para defender a água que são os regantes. Os regantes foram a coluna vertebral da Coordinadora. A água para eles é vida ou morte. Estava também a experiência dos cocaleros. Uma experiência de luta muito forte (OLIVEIRA, 2006). ${ }^{211}$

A população do município de El Alto se caracteriza por migrantes aymaras das áreas rurais do altiplano que se ocupam do comércio informal em La Paz. Portanto, não há ali a presença de uma forte tradição camponesa como a existente no Vale Central de Cochabamba. Então, a questão regional foi um aspecto importante no que concerne à percepção das políticas hídricas, tal como ocorreu na porção oriental boliviana, em que não houve protestos contra a privatização das empresas estatais, pelo contrário, houve reclamação por parte das elites cruceñas e tarijeñas contra os protestos durante a Guerra da Água (PERREAULT, 2006).

Já em Santa Cruz de la Sierra, nota-se que o preço da água era o mais elevado de todo o país e, durante esse período, ainda houve um incremento tarifário. Por outro lado, a baixa incidência de indivíduos da região que se autoidentificavam com alguma etnia e a presença de moderno setor econômico acabaram influenciando a percepção popular acerca das políticas hídricas. Deve-se ressaltar que, até aquele momento, as novas políticas econômicas haviam favorecido justamente a porção oriental boliviana, sobretudo em relação à evolução do Índice de Desenvolvimento Humano (IDH).

Após a Guerra da Água e a rescisão do contrato com AISA em 2005, as políticas hídricas vêm se baseando na busca de financiamentos de instituições financeiras internacionais, como a CAF e o BID. Porém o desempenho das empresas estatizadas não tem sido o mesmo das antigas empresas privadas. Em La Paz e El Alto, a atual Empresa Pública Social del Agua y Saneamiento S.A. (EPSAS, Empresa Pública Social de Água e Saneamento S.A.) possui uma dívida de 22 milhões de dólares, pratica nepotismo e seu desempenho técnico não passa de 1.000 conexões de água por ano, bem abaixo do atingido pelo consórcio AISA, que executava 20.000 conexões de água por ano (EPSAS..., 2009).

211 "Yo diría que básicamente por dos cosas... una de las primeras es que en El Alto no hay un referente... no hay un espacio único confiable [...] Por otra parte hay aquí un componente importante para defender el agua, que es los regantes. Los regantes han sido como la colona vertebral de la Coordinadora. El agua para ellos es vida o muerte. Estaba también la experiencia de los cocaleros. Una experiencia de lucha muy fuerte." (OLIVEIRA, Oscar. Comunicação pessoal em entrevista concedida ao autor. El Alto, 30 de janeiro de 2006). 
Um avanço alcançado pelas políticas hídricas foi a aprovação da Lei 꾸 2.066 logo após a Guerra da Água (BOLIVIA, 2000), a qual incorpora algumas modificações pleiteadas pela FEDECOR para a antiga Lei oㅡ 2.029 (BOLIVIA, 1999b). As principais modificações foram a criação das figuras da autorização e do registro, em adição àquelas que a lei anterior criou (concessão e licença). Enquanto a concessão e as licenças são outorgadas a prestadores de serviços, a autorização e o registro são concedidos essencialmente para o usufruto dos recursos. Mais especificamente, no artigo $8^{\circ}$ da Lei oㅜ 2.066 (BOLIVIA, 2000), o registro é oferecido também a comunidades e povos indígenas, camponeses e outras organizações sociais, que tanto podem fazer uso dos recursos hídricos como prestar serviços. Ademais, os registros são outorgados para toda a vida útil da prestação do serviço, isto é, são válidos enquanto essas entidades sociais forem capaz de continuar prestando o serviço. Em seu artigo 49, especifica que a prestação dos serviços deve ser coletiva e gratuita e no artigo 80 estabelece a proibição da captação de água mediante a perfuração de novos poços ou de outros meios sem a devida autorização (BOLIVIA, 2000).

Inegavelmente, esse diploma legal trouxe importantes avanços, embora devase ponderar acerca de sua aplicação. Depreende-se que essa lei prioriza o direito dos camponeses tanto para o usufruto dos recursos hídricos como para a prestação de serviços à comunidade em nome do Estado boliviano. Tendo em mente os milhares de poços clandestinos perfurados em Cochabamba, acreditamos que dificilmente o controle sobre novas perfurações será realizado de forma devida. Atualmente, falta ainda uma legislação que venha a substituir a arcaica Ley de Dominio y Aprovechamiento de Aguas (BOLIVIA, 1906). Existe um anteprojeto de lei, em sua versão de número 32 , tramitando no Congresso Nacional boliviano.

Em escala nacional, a Guerra da Água trouxe uma série de avanços para as políticas hídricas. Primeiramente, passou-se a discutir publicamente a gestão dos recursos hídricos e as políticas públicas. Em seguida, houve maior empenho em atualizar a legislação setorial nacional. Por fim, deve-se ainda salientar que diversos atores vêm participando do debate relativo ao projeto de lei de recursos hídricos, o que confere maior transparência e publicidade à construção das normas jurídicas.

Todavia, devem ser feitas críticas particularmente às atitudes radicais de alguns movimentos sociais, que partem do princípio que a iniciativa privada sempre 
terá como intuito a exploração dos mais pobres. Nesse caso específico, como se pode concluir a partir dos dados aqui apresentados, tanto a gestão pública como a privada se revelaram ineficientes. A gestão AISA não conseguiu administrar os serviços sem incrementar as tarifas e havia irregularidades no contrato, como a possibilidade de o Banco Mundial ser parte e, concomitantemente, julgador no processo de mediação entre as partes. Após a rescisão do contrato de AISA, a EPSAS, embora tenha como ponto positivo a prática de tarifas menos elevadas que as da gestão anterior, tem se revelado ineficiente quanto à sua capacidade de aprovisionar água. Evidentemente, o forte aumento das tarifas foi uma das falhas da gestão privada. Porém, deve-se enfatizar que o preço do metro cúbico de água cobrado em La Paz e em Cochabamba é, comparativamente, um dos mais baixos do mundo, mesmo em relação aos mais pobres países africanos e asiáticos (UNHABITAT, 2003).

Outros aspectos contraditórios das concessões foram as irregularidades jurídicas e a falta de publicidade e transparência, o que reflete a falta de regulação por parte do Estado. Dessa forma, a gestão dos recursos hídricos na Bolívia vem se apresentando, ao longo dos anos, como uma questão muito mais complexa que a simples dicotomia setor público-setor privado.

\subsection{Da Guerra da Água à Guerra do Gás: a gota d’água}

A forte migração para os centros urbanos, os efeitos engendrados pela política econômica neoliberal e as transformações institucionais do Estado deram início a um processo de instabilidade social na Bolívia. Como as áreas urbanas não possuíam estrutura suficiente de modo a oferecer as condições necessárias para ocupar economicamente todo esse contingente de migrantes, a situação econômica foi de mal a pior. Assim, além de o governo não conseguir atender as demandas da população migrante, ainda criou uma massa de trabalhadores urbanos desempregados devido à recessão econômica e ao ajuste estrutural. Diante desse caótico cenário, os partidos políticos bolivianos não conseguiram direcionar as demandas populares, principalmente da população mais humilde, gerando frustração ainda maior. Em face de um cenário tão tenso, os movimentos sociais 
passaram a ganhar legitimidade, em grande parte por suas posturas radicais, que dão à população a impressão que agem com vigor em relação ao governo, diferentemente dos partidos políticos. Diante desse cenário, os conflitos se tornaram inevitáveis. No entanto, que dimensões sociais estão relacionadas a esses conflitos? Qual a função desempenhada pela Guerra da Água nesse contexto? Seria a gestão dos recursos hídricos um aspecto predominante?

Conforme o sociólogo Laserna (2006, p. 86, tradução nossa) a Guerra da Água "marcou um ponto de inflexão a partir do qual se fez cada vez mais evidente a debilidade institucional e, portanto, do próprio governo." ${ }^{212}$ Após o desencadeamento da Guerra da Água em Cochabamba, verifica-se o aumento progressivo do número de conflitos na Bolívia (Gráfico 6). Observa-se que o número de conflitos entre o primeiro governo Sanchez de Lozada e o de Hugo Banzer duplicou em um período de menos de 4 anos e continuou crescendo até o governo de Carlos Mesa, no qual atingiu quase o dobro do número de conflitos durante todo o governo anterior. Assim sendo, em um período de 10 anos, a média mensal de números de conflito triplicou.

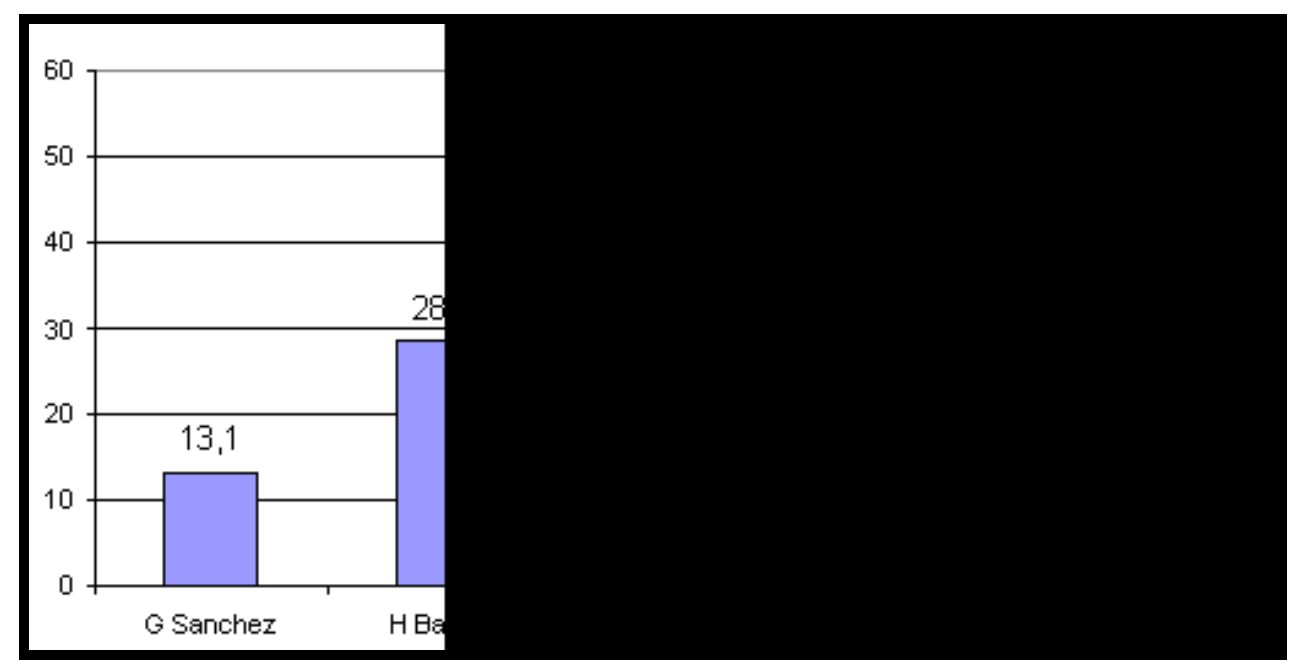

Gráfico 6. Média do número de conflitos por mês para cada governo da Bolívia no período entre 1994 e 2005.

Fonte: Laserna (2006, p. 96, tradução nossa).

\footnotetext{
212 “[...] marcó un punto de inflexión a partir del cual se hizo cada vez más evidente el debilitamiento institucional y, por tanto, del propio gobierno."
} 
A adesão ativa ao conflito também se acentuou com o passar do tempo (Gráfico 7). Entre 1994 e 2005, as marchas e manifestações totalizaram 30,3\% dos conflitos, seguido pelos bloqueios, com 15,7\%. Analisando a adesão ativa ao conflito, Laserna (2006, p. 102, tradução nossa) comentou que:

A violência foi, por isso, crescente, porque a mesma ruptura da cotidianidade implica já um grau de violência sobre os outros, seja sobre os adversários, como quando se ocupa um imóvel, ou o público em geral, como ocorre com os bloqueios. E nesse tipo de eventos também aumenta a probabilidade de enfrentamentos com as forças da ordem. ${ }^{213}$

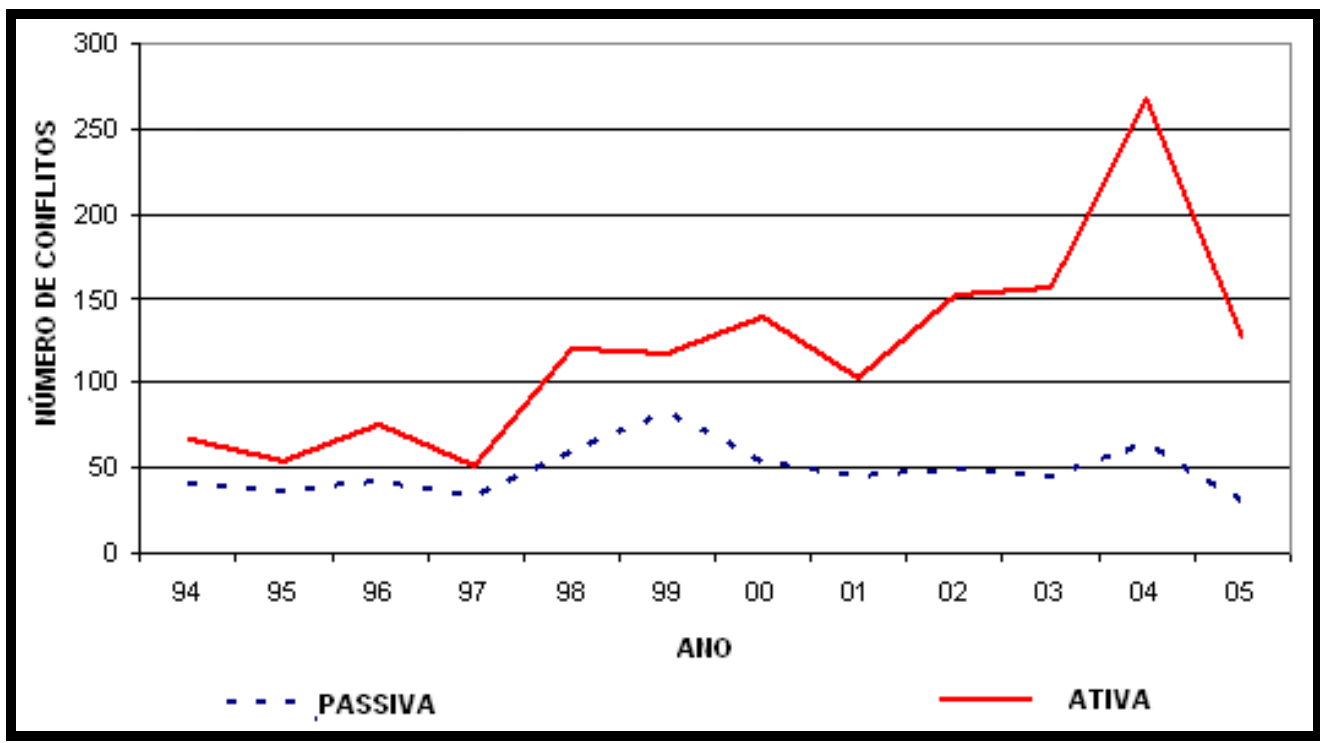

Gráfico 7. Formas de adesão a conflitos na Bolívia no período entre 1994 e 2005.

Fonte: Laserna (2006, p. 103, tradução nossa).

Dessa forma, os conflitos tinham tendência cada vez maior de chegar ao confronto físico, implicando forte presença emocional para lidar com as questões relacionadas às frustrações. Essa tendência ao confronto direto pode ter resultado não da existência de objetivos irreconciliáveis, mas da necessidade de atenuar tensões acumuladas, que era o caso da sociedade boliviana naquele momento.

Também chama a atenção o fato de que o principal "adversário" apontado pelo cidadão é o Estado, em $65,3 \%$ dos casos, seguido pela alcaldia em $10,8 \%$ das

\footnotetext{
213 "La violencia ha sido, por eso, creciente, porque la misma ruptura de la cotidianeidad implica ya un grado de violencia sobre otros, sean los adversarios, como cuando se ocupa un inmueble, o el publico en general, como ocurre con los bloqueos. Y en ese tipo de eventos también aumenta la probabilidad de enfrentamientos con las fuerzas del orden"
} 
vezes. O mais interessante é que vários movimentos sociais se utilizaram da retórica da antiglobalização contra as empresas transnacionais, embora apenas $4 \%$ dos conflitos tenham tido como adversário uma empresa privada. Esses dados deixam claro que reiteradas vezes o discurso contra as transnacionais é tão-somente um instrumento de retórica fazendo apelo dramático à soberania nacional com o objetivo precípuo de mobilizar a população (LASERNA, 2000b).

Como pode ser observado na Gráfico 8, o contexto econômico foi o principal desencadeador de conflitos entre 1997 e 2000, justamente o período em que a crise econômica estava em seu auge. Nessa categoria estão agregados motivos como melhores condições de trabalho e de consumo, bem como estabilidade trabalhista. Entre 2000 e 2003, os motivos principais apontados para os embates foram tanto as questões econômicas como as políticas conjunturais. Esse foi um período transição em que o país voltou a se recuperar economicamente, enquanto politicamente a situação se tornou instável a partir da renúncia do presidente Lozada. A partir desse episódio, as políticas conjunturais foram o aspecto predominante, provocando a queda do governo de Carlos Mesa, sucessor de Lozada.

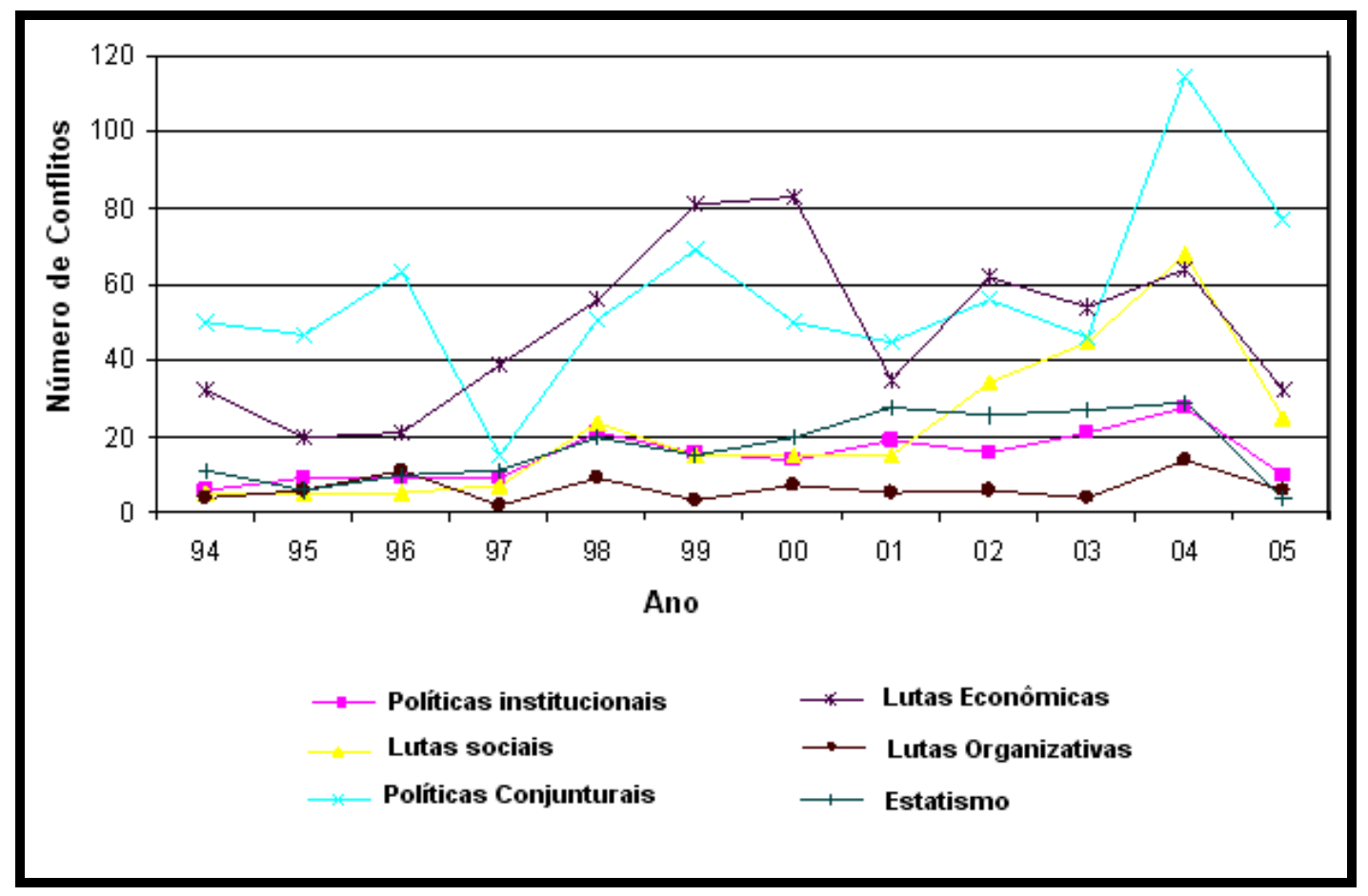

Gráfico 8. Principais motivos para o desencadeamento de conflitos na Bolívia no período entre 1994 e 2005.

Fonte: Laserna (2006, p. 105, tradução nossa). 
Com o intuito de compreender a dinâmica dos conflitos e a conjuntura em que a Guerra da Água se cristalizou, faz-se necessário observar o resultado desses embates. Essa ponderação pode elucidar especialmente a falência institucional do Estado. Refletindo sobre os dados apresentados no Gráfico 9, verifica-se que nos 3 anos anteriores a 1997 havia uma tendência a não conceder nada em relação às demandas feitas pela sociedade civil. Desde 1997 até meados de 2000, houve uma transformação desses parâmetros, percebendo-se que o governo passou a conceder algo ou tudo o que é demandado. Após a perda de sua capacidade de gerir os conflitos com a sociedade boliviana, o governo cedeu completamente às demandas populares como meio de estabilizar a conjuntura política. Podemos mencionar como exemplo claro desse fenômeno o rápido aumento do déficit fiscal, que passou de 4\% para aproximadamente $8 \%$ do PIB. Diante das pressões e da regulação financeira do Banco Mundial, o governo boliviano se viu em uma situação sem saída. Assim, a partir de 2003, passou a conceder muito pouco ou até nada às demandas sociais. De acordo com Laserna (2006, p. 107, tradução nossa) "o fato de que aumentou logo a frequência de eventos que não obtiveram nenhum resultado poderia explicar, em parte, a intensificação dos conflitos, a frustração e o aumento da violência”. 214

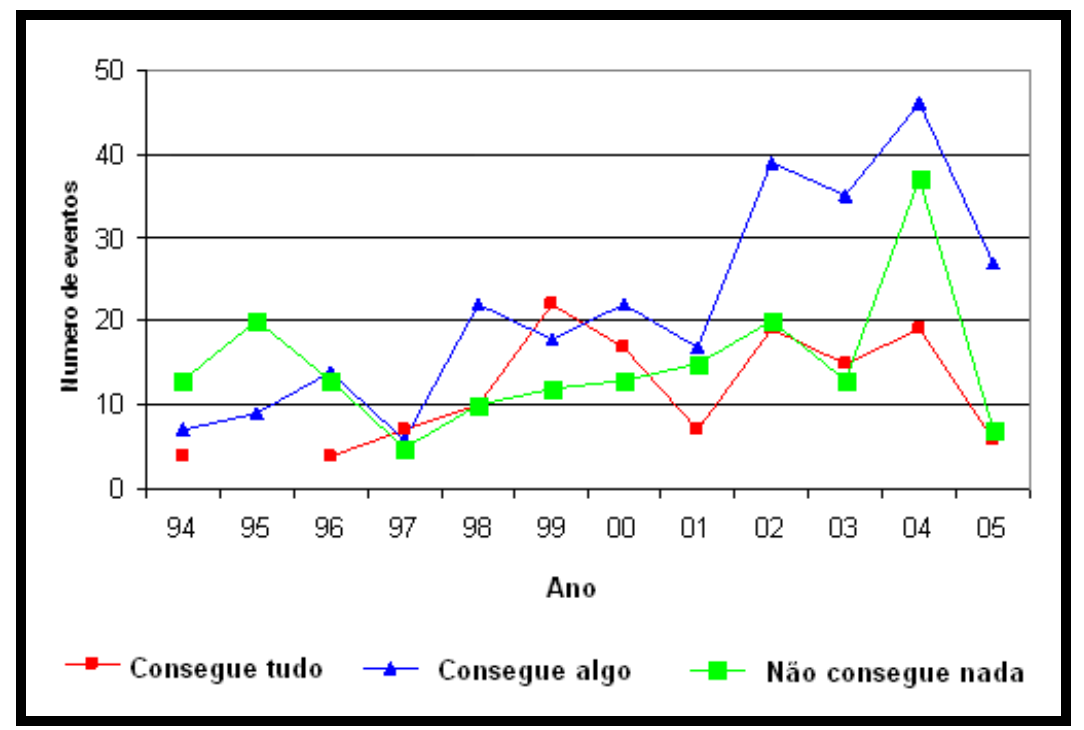

Gráfico 9. Ocorrência de conflitos sociolaborais na Bolívia no período entre 1994 e 2005.

Fonte: Laserna (2006, p. 107, tradução nossa).

\footnotetext{
214 "El hecho de que aumentara luego la frecuencia de eventos que no obtuvieron ningún resultado
} podría explicar en parte la intensificación de conflictos, la frustración y el aumento de la violencia." 
Com relação à localização do conflito, entre 1994 e 2005, estes ocorriam majoritariamente nas áreas urbanas do eixo econômico central. Para Laserna (2006), esse padrão se deve à maior probabilidade de "visibilidade" dos conflitos nessas áreas. Por certo que os conflitos em escala nacional que ocorreram no mesmo período da Guerra da Água seguiram o padrão de relacionamento com a crise econômica e, espencialmente, com as políticas conjunturais. Nâo obstante, esse padrão comum se materializou em um contexto regional diferenciado para cada caso. Portanto, as particularidades regionais podem ter a função de desencadear tensões relacionadas a escalas maiores. Em relação à Guerra da Água, a crise econômica e as políticas conjunturais se cristalizaram em uma região marcada pela falência da gestão dos recursos hídricos. A má gestão dos recursos hídricos, a politização desse tema e o fato de uma multinacional estar presente em um contrato mal formulado e executado serviram de pretexto para a liberação de toda a fúria da população local. Evidentemente, os fatores regionais também são responsáveis pelo conflito, mas não são os únicos e, muitas vezes, nem mesmo aqueles que geraram maior tensão. Discorrendo sobre a Guerra da Água, Camacho B. (2000, p. 26, negrito da autora, tradução nossa) informou que:

Os sucessos que se registraram em Cochabamba no mês de abril manifestaram a demanda regional da solução do problema da água; porém, além desse fato, foram a via de expressão de outro tipo de reivindicações (como a demanda da participação popular) para as quais a água foi somente $\mathrm{o}$ argumento desencadeador. ${ }^{215}$

Nessa passagem, a autora deixou claro que havia outras demandas e reivindicações em jogo além da água. Entretanto, quando a questão da água é posta em evidência, esse argumento passa a ser utilizado para que outros fatores sejam atenuados. Não é por acaso que outros conflitos aconteciam simultaneamente à Guerra da Água. Em relação a isso, Nickson e Vargas (2002, p. 108, tradução nossa) argumentaram que:

O conflito coincidiu com uma situação de convulsão social no país que levou o governo a declarar estado de emergência no início de abril de 2000 [...] Uma gama de fatores se combinou para produzir o conflito da água em Cochabamba. Embora a entrada em vigor do contrato de concessão tenha sido a causa imediata que detonou o protesto, a emergência desses conflitos sociais não pode ser separada de um contexto macroeconômico

215 "Los sucesos que se registraron em Cochabamba en el mês de abril pusieron de manifiesto la demanda regional de solucion del problema del agua; pero, más allá de ese hecho, fueron la via de expresión de otro tipo de reivindicaciones (como la demanda de participación popular) para las cuales el agua sólo fue el argumento desencadeante." 
mais amplo no qual eles se originam. Naquela época, havia uma crescente oposição à estratégia econômica neoliberal prevalecente. ${ }^{216}$

Outros autores, como Soldal (2008), também ressaltaram a importância do contexto regional, expressa principalmente pela privatização dos recursos hídricos e pela erradicação da coca. O sociólogo Ortego (2000, p. 16-17, tradução nossa) explicou que:

A água é um tema que marcou profundamente as pessoas e, por este motivo, e no caso concreto da região, a associação deste aspecto com o "mito" Misicuni (cumpridor dos anseios de desenvolvimento e prosperidade para a região) desencadeou toda uma série de reações emocionais regionalistas que, do nosso ponto da vista, geraram e geram uma distorção perceptiva da problemática da água em Cochabamba. Por outro lado, [...] a água transforma-se na representação de um jogo das frustrações e se produz outro mecanismo psicológico relacionado com os conflitos sociais. Estamos falando do mecanismo de deslocamento, mais conhecido coloquialmente como a busca do "bode expiatório" $[\ldots]^{217}$

No mesmo sentido raciocinou Perreault (2006, p. 151, tradução nossa) ao emitir sua opinião sobre a Guerra da Água e a Guerra do Gás, argumentando que:

Estas lutas, que em outras instâncias poderiam ter permanecido como conflitos localizados pela gestão de recursos, transcenderam o local e rapidamente ganharam importância nacional e internacional. Ao fazer esse salto escalar, os protestos relacionados à água e ao gás transformaram-se em instrumento para a expressão de frustrações múltiplas por parte do povo, com uma longa história de exploração colonial e neocolonial, marginalização e pobreza. ${ }^{218}$

\section{Essa ligação entre a escala local e a escala nacional pode ser notada por}

meio dos demais conflitos em escala nacional e que, de certa forma, mantinham um

216 "The conflict coincided with a situation of social unrest in the country at large that led the government to declare a state of emergency in early April 2000 [...] A range of factors combined to produce the water conflict in Cochabamba. Although the introduction of the concession contract was the immediate cause that detonated the protest, the emergency of such social conflicts, cannot be divorced from the wider macro-economic context in which they erupted. At the time there was a growing opposition to the prevailing neo-liberal economic strategy."

217 "El agua es un tema que ha calado profundamente en la gente, por este motivo, y en el caso concreto de la región, la asociación de este aspecto con el 'mito' Misicuni (cumplidor de los anhelos de desarrollo y prosperidad para la región) ha desencadenado toda una serie de reacciones emocionales regionalistas que, desde nuestro punto de vista, han generado y generan una distorsión perceptiva de la problemática del agua en Cochabamba. Por otro lado [...] el agua se convierte en la abanderada de un conjunto de frustraciones y se produce otro mecanismo psicológico relacionado con los conflictos sociales. Estamos hablando del mecanismo de desplazamiento, mas conocido coloquialmente como la búsqueda del 'chivo expiatorio' [...]"

218 "These struggles, which in other instances may have remained localized contests over resource management, transcended the local and quickly gained national and international importance. In making this scalar jump, protests over water and gas became venues for the expression of manifold frustrations on the part of the people with a long history of colonial and neocolonial exploitation, marginalization and poverty." 
padrão comum entre si. No caso da Guerra da Água, a partir das fontes hemerográficas, verifica-se que os bloqueios em diversas regiões tinham em comum o pleito pela revogação da Lei no 2.029 (BOLIVIA, 1999b), assim como pelo fim do programa de erradicação das folhas de coca e das principais leis implantadas pelo ajuste estrutural - Lei o 1.544 (BOLIVIA, 1994b), Lei o 1.551 (BOLIVIA, 1994c) e Lei no 2.028 (BOLIVIA, 1999a), (LOS BLOQUEOS..., 2000; MÁS..., 2000). No dia 7 de abril de 2000, havia bloqueios em Cochabamba, Yungas (La Paz), Chuquisaca, Oruro e Potosí e, apesar de haver demandas locais, a revogação da Lei ํo 2.029 (BOLIVIA, 1999b) era o pleito comum (RAZONES..., 2000). Destarte, os conflitos não ocorriam isoladamente, mas agregavam demandas locais às demandas nacionais.

A Guerra da Água marcou um período de transição na Bolívia, a partir do qual se iniciou uma retração das forças centrífugas no território boliviano, sobretudo daquelas ligadas às políticas neoliberais. A rescisão de contratos com as transnacionais, bem como a posterior estatização de boa parte de outras empresas privadas têm oferecido ao governo central maior controle do território nacional. Não obstante, em determinados casos, como na gestão dos serviços de abastecimento de água e esgoto, esse maior controle estatal não tem significado melhoria dos serviços oferecidos, muito pelo contrário. Em decorrência de atos de corrupção no governo, essas empresas estatais acabam se tornando patrimônio de apenas alguns poucos, que são privilegiados. 


\section{Inkarrí: Cochabamba e as tensões no espaço sul-americano e global}

$\mathrm{Na}$ cultura andina, o mito de Inkarrí representa a eterna esperança de que o chefe supremo Inka retorne de forma a intermediar os humanos e os deuses. $O$ termo Inkarrí mescla a palavra andina Inka ao vocábulo espanhol Rey. A crença em Inkarrí faz menção ao futuro, tempo no qual os Andes passarão por um cataclismo, marcando a destruição do domínio estrangeiro (espanhol) e a construção de um novo tempo pela volta do Inka como poder maior na Terra.

A Guerra da Água apontou, por um lado, para um retrocesso das políticas neoliberais e, por outro, para a retomada do empenho nacionalista. Inicialmente, esse empenho se deu pelo avanço das demandas populares, que culminaram na eleição do presidente Evo Morales e, posteriormente, pela própria atuação estatal. A eleição do primeiro presidente aymara em toda a história republicana boliviana trouxe de volta à memória o mito Inkarrí. Porém, a destruição do domínio estrangeiro tem se dado de forma parcial e gradativa, já que inúmeros atores das escalas maiores que a do Estado ainda agem de forma direta no território boliviano.

\subsection{Cochabamba: entre a contenção e a integração no espaço sul-americano}

A dinâmica das transformações territoriais no Vale Central de Cochabamba está diretamente vinculada à atuação de forças centrífugas e centrípetas da escala sul-americana. Em um primeiro momento, essas forças atuaram pela contenção entre Brasil e Argentina, influenciando ou rechaçando as políticas territoriais após a revolução de 1952. Em um segundo momento, quando se passou da contenção para a integração, a partir do início dos anos 80 , Cochabamba se tornou um polo de articulação não apenas nacional, mas primordialmente de integração entre os diferentes vetores sul-americanos.

Consequentemente, a atuação desses vetores influiu nas transformações pelas quais o Vale Central passou, sobretudo no que se relaciona à migração e à transformação do uso do solo pela expansão de áreas destinadas à implementação 
de objetos técnicos. Ao mesmo tempo em que houve a modernização de determinados setores produtivos, o setor de aprovisionamento de serviços básicos não foi contemplado coerentemente, gerando um descompasso entre o aumento populacional, a demanda hídrica, e a capacidade de aprovisionamento de água potável e de redes de esgoto pelo serviço público.

Em um momento inicial, a atuação das duas potências sul-americanas no período pós-Segunda Guerra Mundial se caracterizou pela disputa da supremacia no subcontinente. Vale lembrar que, naquele momento, os Estados Unidos procuravam um aliado regional para a sua política externa dos key countries (países-chave). Nesse contexto, se firmar como a grande potência regional significava tornar-se aliado dos norte-americanos, o que era, indiscutivelmente, uma grande vantagem.

Apoiando-se nas teorias geopolíticas construídas pelos militares, as duas potências procuraram expandir a sua rede de transportes, criando, assim, uma dependência dos países mediterrâneos (Bolívia e Paraguai) em utilizá-las. Essa satelitização dos países sem costa marítima passou, então, a ser o principal objetivo de Brasil e Argentina. Na visão geoestratégica desses dois países, a Bolívia se situa em uma área estratégica a ser influenciada, uma vez que ali há ricas jazidas de vários minerais. Ademais, no território boliviano se encontra o divortium aquarium sul-americano, ou seja, as nascentes das principais bacias hidrográficas da América do Sul se situam ali, e ter acesso a elas significa ter contato com diferentes partes do continente, o que é considerado símbolo de poder.

A importância dessa região é destacada na visão geopolítica tanto brasileira como argentina. Do lado brasileiro, o General Mário Travassos (1935, p. 176) já ressaltava a importância da Bolívia como ponto de encontro das influências andinas, platinas e amazônicas, dando-lhe o status estratégico de heartland sul-americano:

[...] as bacias do Prata e do Amazonas disputam o planalto boliviano, luta que certos caprichos geográficos favorecem ora a uma, ora a outra dessas bacias. Não há como negar que o equilíbrio político sul-americano se definirá num futuro bem próximo, segundo as oscilações do já famoso triângulo Cochabamba (influências andinas), Sucre (influências platinas) e Santa Cruz (influências amazônicas).

Estando as influências brasileiras cristalizadas na cidade de Santa Cruz de la Sierra e as argentinas em Sucre, o jogo geopolítico das duas potências foi decidido na atração da cidade de Cochabamba para a esfera de uma dessas outras duas 
cidades, o que significou, naquele momento, a implantação de infraestrutura de transporte.

Outros geopolitólogos brasileiros também concordaram com Travassos (1935), como o militar aviador Rodrigues (1947), que traçou uma teoria de pontos de confrontação entre Brasil e Argentina a partir do conceito de puncti dolens. ${ }^{219} \mathrm{Um}$ desses pontos de confrontação no continente sul-americano era o triângulo estratégico boliviano de Travassos (1935). Anos mais tarde, um dos membros da Sorbonne na Escola Superior de Guerra, o general Couto e Silva (1967), esquadrinhava o conceito de "área de soldadura continental". Essa região se constituía de um núcleo de junção continental entre a Bacia do Amazonas e a Bacia do Prata, formado por Bolívia, Paraguai e os estados de Mato Grosso e Mato Grosso do Sul.

Os discursos do poder do lado argentino também interpretavam o contexto geopolítico daquele momento de forma semelhante e, simultaneamente, também traçavam a estratégia da sua nação em direção aos países-tampões. Em seus escritos, o General Juan Enrique Guglialmelli (1979-1980) afirmava que seu país era ameaçado pela ambição histórica brasileira em absorver os países mediterrâneos sul-americanos de modo a assegurar uma rota até o Pacífico em detrimento da esfera de influência argentina. Boscovich (1986) defendia o mesmo discurso de Guglialmelli (1979-1980). De acordo com o seu plano nacional, a Argentina devia bloquear o acesso brasileiro aos corredores de exportação que conectam o Paraguai e a Bolívia aos superportos de Santos e Rio Grande.

A influência desses discursos na política argentina ainda pode ser comprovada pela afirmação de Alfredo Risso Romano (apud PEREIRA, 1974, p. 72), consultor do ex-chanceler argentino Nicanor Costa Méndez:

Paraguai e Bolívia são o heartland da América Meridional, e torna-se cada vez mais evidente que quem exercer predominância nesses estados dominará totalmente a Bacia do Prata e a nação que exercer a liderança nessa zona-chefe estará destinada a ser, indiscutivelmente, a primeira potência latino-americana.

Os projetos nacionais das duas potências regionais colocaram em prática, em pleno território boliviano, uma boa parte dos discursos geopolíticos aconselhados

\footnotetext{
${ }^{219}$ Termo que se refere aos pontos de confrontação entre Brasil e Argentina, sendo o triângulo estratégico boliviano é um deles.
} 
por seus analistas. Do lado brasileiro, construiu-se a ligação rodoviária conectando a Plataforma Central de Reserva brasileira a Corumbá, no Mato Grosso do Sul, assim permitindo a ligação até Santa Cruz de la Sierra. Posteriormente, o governo revolucionário boliviano construiu a autoestrada ligando Santa Cruz de la Sierra a Cochabamba, a qual dava acesso desde o Porto de Santos até os portos chilenos do Pacífico. Em relação à conexão ferroviária, em 1957, o governo brasileiro terminou a obra da Ferrovia Noroeste ligando Bauru a Corumbá, na divisa com a Bolívia. Além disso, com os recursos previstos no Tratado de Petrópolis, os governos brasileiro e boliviano decidiram investir na construção da ferrovia ligando Corumbá a Santa Cruz de la Sierra.

Ainda em relação ao país andino, a empreitada pela sua satelitização por parte do Brasil foi mais adiante. Com o intuito de impedir a implantação dos planos sociais durante o avanço da revolução de 1952, o governo brasileiro apoiou logística e militarmente o golpe militar cruceño 220 de 1970, liderado pelo General Hugo Banzer. Poucos dias após a tomada do poder pelo militar, Brasil e Bolívia assinaram o Convênio de Cochabamba, no qual o país andino se comprometia a fornecer ao país-irmão 240 milhões de pés cúbicos diários de gás natural, por um prazo de 20 anos, totalizando 1,7 trilhões de metros cúbicos. Em contrapartida, o Brasil se comprometia a construir o gasoduto Brasil-Bolívia (GASBOL), uma usina petroquímica e uma refinaria em Cochabamba, uma usina siderúrgica para a jazida de El Mutum ${ }^{221}$ e a conexão ferroviária entre Santa Cruz de la Sierra e Cochabamba. Por último, concedia quatro zonas francas $^{222}$ à Bolívia (MELLO, 1997; SCHILLING, 1981). Outro ponto importante foi a construção de um segundo ramal rodoviário ligando Cochabamba a Santa Cruz de la Sierra.

A atuação argentina no país andino não se deixou superar pela potência amazônica. Em 1925, o ramal ferroviário ligando Cochabamba à ferrovia La PazBuenos Aires já havia sido construído. Adicionalmente, o país platino ainda construiu mais um ramal ligando o norte argentino até Santa Cruz de la Sierra, de forma a diminuir a influência brasileira em um dos vértices do triângulo estratégico boliviano. Igualmente importantes foram os acordos sobre a exportação de hidrocarbonetos da

\footnotetext{
${ }^{220}$ Oriundo do Departamento de Santa Cruz de la Sierra.

${ }^{221}$ Trata-se de uma jazida de minério de ferro, estimada em 30 a 40 bilhões de toneladas do minério, que se encontra a $30 \mathrm{~km}$ da fronteira entre Brasil e Bolívia. Para os argentinos, a exploração de $\mathrm{El}$ Mutum era um projeto imprescindível, que fracassou com os tratados entre Bolívia e Brasil.

${ }^{222}$ Corumbá, Porto Velho, Belém e Santos.
} 
Bolívia para a Argentina, da monta de 1,1 trilhões de metros cúbicos, sendo 150 milhões de pés cúbicos em 20 anos, além da construção do gasoduto integrando os dois países (MELLO, 1997).

Diante desse quadro de confrontação tácita entre Brasil e Argentina, Cochabamba foi recebendo uma série de objetos técnicos. Naturalmente, uma boa parte desses projetos foi utilizada pelo governo militar da Bolívia como forma de promover, ainda que de forma desarticulada, a integração nacional já iniciada pelo Plano Bohan. No entanto, há de se ressaltar que os efeitos desse jogo geopolítico na escala sul-americana trouxeram várias consequências para Cochabamba. Entre elas se destacam o descompasso entre o planejamento regional e o planejamento nacional e a grande migração para o Vale Central a partir da abertura de várias estradas.

A partir do final dos anos 70, houve um arrefecimento dos regimes militares no continente sul-americano. A relação entre Brasil e Argentina, pautada majoritariamente pela contenção, se transmutaria gradualmente para uma ligação vinculada à integração. Destarte, desse novo período surgiram vários tratados e iniciativas de integração, a começar pelo Tratado da Bacia do Prata, o qual, posteriormente, deu origem ao Fondo Financiero para el Desarrollo de la Cuenca del Plata (FONPLATA, Fundo Financeiro para o Desenvolvimento da Bacia do Prata). Outra iniciativa foi a criação da Comunidad Andina de Naciones (CAN, Comunidade Andina de Nações), que deu origem a um fundo do qual não apenas os países andinos participam, mas também Brasil, Chile, México, Paraguai, entre outros. Os resultados da maioria dessas iniciativas de integração têm sido menores que aqueles da CAN (MESA; GISBERT; MESA, 2003).

Nesse novo contexto, a Bolívia, em geral, e Cochabamba, em particular, deixaram de ser áreas de confrontação e passaram a receber diferentes tipos de infraestrutura visando a integração regional sul-americana. Para tanto, o Vale Central passou a receber novos investimentos, como a construção de uma rede de polidutos e oleodutos ligando-o não somente a Santa Cruz de la Sierra como também a Oruro e La Paz. Também foi construída nas proximidades de Cochabamba a maior usina hidrelétrica da Bolívia, Santa Isabel, além da Usina Hidrelétrica Corani. Outrossim, a infraestrutura de transporte foi melhorada, principalmente de forma a integrar os diferentes corredores de transporte que 
passam pela Bolívia, planejados a partir da Iniciativa para la Integración de la Infraestructura Regional Suramericana (IIRSA, Iniciativa para a Integração da Infraestrutura Regional Sul-americana). Em adição a isso, foi implantada a rede de fibra ótica conectando os principais centros urbanos bolivianos.

Ao longo do tempo, tanto no período de contenção como no de integração, foi se cristalizando uma dinâmica territorial que conformava a visão geopolítica sulamericana. O triângulo estratégico foi se territorializando na Bolívia, pela implementação de diferentes redes de objetos técnicos, reiteradas vezes anexados mais por outros interesses que pelos nacionais. Deve-se, contudo, fazer a ressalva de que com o declínio da mineração e a passagem da capital para La Paz, Sucre perdeu a importância que possuía anteriormente. Cada vez mais, Tarija aparecia como um novo vértice do triângulo, sobretudo por possuir aproximadamente $85 \%$ das reservas provadas de gás e petróleo e ser responsável por 14\% do PIB boliviano (CEDIB, 2005) (Mapa 32).

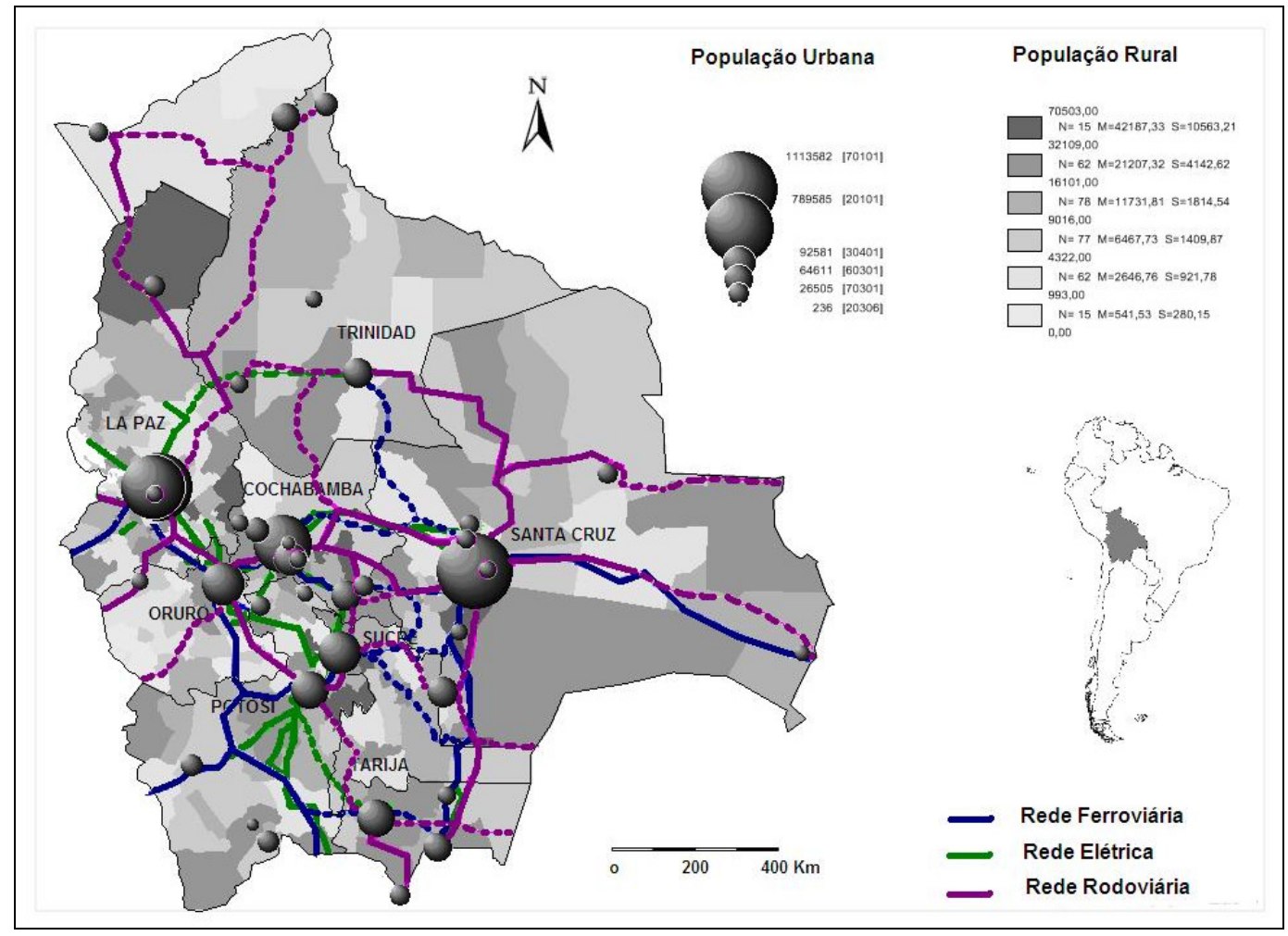

Mapa 32. Principais redes de objetos técnicos na Bolívia e a posição estratégica de Cochabamba no contexto nacional.

Fonte: Organizado pelo autor com base em dados de Pfrimer e Roseira (2009). 
Mas qual a relação disso com a Guerra da Água? Não seria o jogo geopolítico sul-americano um aspecto secundário a se correlacionar com o conflito? Existem fortes vínculos entre as forças das escalas sul-americanas e o desencadeamento do conflito. Inicialmente, uma boa parte das políticas territoriais bolivianas acabou se aproveitando das transformações territoriais impulsionadas no país não apenas pelo governo central, mas também por atores das escalas maiores; porém, mais do que o efeito esperado de equilíbrio territorial, o que atualmente vem acontecendo é um desequilíbrio territorial ao contrário. As fortes migrações para Santa Cruz de la Sierra e Cochabamba foram e têm sido intensificadas pela melhoria da infraestrutura de transporte. Por outro lado, deve-se reconhecer que elas também têm ajudado na integração do território nacional, ainda que de maneira desarticulada.

A maioria dos fundos internacionais voltados para a integração regional tem se olvidado, em alguns casos, de seus efeitos negativos para os interesses locais. No caso de Cochabamba, percebe-se que os fundos internacionais têm concedido maiores incentivos às forças econômicas sem levar em conta as consequências sociais. Ao ressaltar as oportunidades que os mecanismos de integração regional podem oferecer à Bolívia, Pareja (1978, p. 215, tradução nossa) apontou os efeitos colaterais deste projeto:

Indubitavelmente, haverá núcleos nos quais os clássicos parâmetros microeconômicos de avaliação de projetos não serão aplicáveis e terão de absorver altos custos sociais para provocar seu desenvolvimento e segurança nacional. ${ }^{223}$

No caso de Cochabamba, os efeitos desse projeto têm provocado o aumento da demanda de água, não somente pela migração como igualmente pelo aumento da atividade econômica. Não obstante, os financiamentos de projetos visando a melhoria do serviço de abastecimento de água potável e esgoto têm ficado mais a cargo do governo nacional. Talvez a única instituição que tem investido de forma mais direta nesse setor seja a CAF. Por outro lado, deve-se destacar que grande parte desses financiamentos acaba criando condições que vão contra a gestão tradicional dos recursos hídricos. Crespo e Fernández (2004) relataram que a maioria dos financiamentos internacionais no setor de abastecimento de água potável em Cochabamba tem requisitado a transformação do status de empresa

223 "Sin lugar a dudas, habrá núcleos en que los clásicos parámetros microeconómicos de evaluación de proyectos no serán aplicables y habrá que absorber altos costos sociales para provocar su desarrollo y seguridad nacional." 
pública para o de sociedade anônima mista, o que implica a mercantilizarão da água, aspecto que vai de encontro à forma tradicional de gestão da água na região.

Outra faceta desse problema concerne aos inúmeros conflitos que estão surgindo em áreas rurais, que se veem, cada vez mais, sob forte pressão da expansão urbana. Esse é o caso de Tiquipaya, que vem passando por fortes transformações do uso do solo (BARBATO; CAPRIOLO, 2005), as quais têm provocado inúmeros contrastes para a comunidade indígena tradicional, como argumentaram alguns autores (MOLINA, 2005; VARGAS, 2005).

Por fim, nota-se que a alta densidade técnica na região do Vale Central permite que os atores das escalas maiores possam atuar diretamente sobre a região. Sem a implantação desse conjunto de redes técnicas, isto é, sem rede de fibra ótica e telefonia, sem estradas, sem rede elétrica, vários atores que são oriundos das escalas maiores não teriam condições técnicas de atuar no conflito, caso de várias organizações não-governamentais (ONGs) que deram suporte à Coordinadora del Agua, como a Democracy Center (Centro de Democracia) ${ }^{224}$. Resta claro que a própria conformação do consórcio transnacional Aguas del Tunari se tornaria mais difícil sem essa alta densidade de objetos técnicos, mesmo porque a concessão se tornaria menos rentável. Não foi por acaso que a maioria das empresas privatizadas se encontrava no corredor econômico boliviano (La Paz, Cochabamba e Santa Cruz de la Sierra). Essa tensão entre protagonistas de diferentes escalas estruturando o shatterbelt somente foi possível pela presença desse grande número de objetos técnicos

Devido à localização estratégica de Cochabamba para a integração, tanto em nível nacional quanto em âmbito sul-americano, interesses de diversas escalas estavam em jogo durante a Guerra da Água. Ademais, a geopolítica de contenção e, posteriormente, a de integração acabaram influenciando os projetos das políticas territoriais bolivianas. Portanto, nota-se que a implantação dessa rede técnica foi responsável pela constituição de uma natureza híbrida no Vale Central de Cochabamba. O contexto da Guerra da Água não pode ser condicionado tãosomente a uma natureza natural, mas também a uma natureza híbrida, já que a escassez em Cochabamba se relaciona diretamente à falta de engenhosidade social e técnica.

${ }^{224}$ Endereço eletrônico da ONG Democracy Center: <http://www.democracyctr.org/index.php>. 


\subsection{Guerra da Água no espaço global: materializando tensões da maior escala na região}

Nesse tópico exploramos a atuação de diferentes atores da escala global na região de Cochabamba. A partir disso, verifica-se que houve a formação de uma rede de indivíduos de diferentes escalas em polos antagônicos estruturando o shatterbelt. Em decorrência do recuo do Estado boliviano de seu território e da escala de sua atuação sobre o território nacional, observa-se que as territorialidades construídas acima e abaixo da escala do Estado puderam atuar de forma direta no território nacional.

Autores como Fukuyama (1992) têm apontado, com base no pressuposto kantiano, que as democracias liberais não travam guerras entre si. Partindo desse princípio, se elas não batalham entre si, travam muitas guerras com outros países não democráticos. $\mathrm{E}$, além disso, há outro fenômeno que fica bem explícito na Guerra da Água: o número de países democráticos ao longo do tempo tem aumentado, ao passo que o número de guerras envolvendo países vem diminuindo; entretanto, o número de conflitos intranacionais, como guerras civis e outros de diferentes naturezas, vêm aumentando vertiginosamente (O'LOUGHLIN, 2005; RENNER, 1996).

No caso boliviano, percebe-se que, além de permitir a atuação desses protagonistas, o recuo do Estado também a incentivou. Todavia, isso não quer dizer que o Estado boliviano tenha desaparecido, porquanto esse foi apenas um recuo estratégico com o intuito de trazer o foco de sua escala de atuação para o âmbito local. Assim ocorreu com a LPP (BOLIVIA, 1994c), vez que concedeu possibilidades de planejamento por parte dos movimentos sociais reconhecidos legalmente. Por outro lado, a própria constituição das OTBs permitiu maior conhecimento do território e dos atores (antes invisíveis para o Estado) em escala nacional por meio do cadastramento desses movimentos sociais. Outro exemplo foi a Lei ํo 1.544 (BOLIVIA, 1994b), que repassou vários setores produtivos para a iniciativa privada. Nessa perspectiva, interesses locais passaram a se confrontar com interesses de outras escalas. Sem a forte presença do Estado, os conflitos deixaram de ter majoritariamente a configuração Estado versus Estado e passaram a adotar um 
novo formato, em que atores pertencentes a redes de diferentes escalas acabaram se estruturando em polos antagônicos.

De acordo com Renner (1996, p. 28, tradução nossa):

$\mathrm{Na}$ ausência de normas e regras fortes, a globalização poderia se transformar em uma situação de cada um por si, uma intensa competição entre comunidades em nível mundial por empregos, salários e bem-estar econômico. Por gerar grande apreensão e sentimentos de insegurança, a incerteza e a desigualdade causadas pelo processo de globalização estão, por si mesmas, se tornando uma fonte de conflitos. ${ }^{225}$

Concordando com a afirmação de Renner (1996), Nascimento (2001, p. 8889) elucidou que:

Neste processo, os termos nacionais vão perdendo gradativamente sua força e vigor; mas, sobretudo, sua capacidade em produzir identidades e regular conflitos, absorvidos pelo espaço mundial, sem que isto signifique, em absoluto, o desaparecimento ou perecimento do Estado [...]

É difícil dimensionar a importância do fato de que a sociedade moderna não tem exterior. De que tudo que lhe é externo, o é temporariamente. Tudo o que se encontra fora é incorporado, absorvido, transformado.

Sem exterioridade, os conflitos na sociedade moderna tendem a ser, sobretudo, internos ao inverso das sociedades pretéritas. Agora, os povos estranhos ou adversários estão em seu interior [...]

Assim sendo, com o avanço da democracia liberal, da economia de mercado e da política neoliberal, os conflitos têm adotado uma nova configuração. Porém, ao contrário do que afirmou Nascimento (2001), preconizamos que os conflitos são "glocais", isto é, não são apenas internos (locais), mas apresentam uma estruturação do contexto e dos atores das escalas maiores (globais) na escala do lugar a partir da formação de polos antagônicos. Desse modo, a distinção entre os níveis interno e externo acaba se diluindo, porquanto essas esferas interagem e se fundem.

\footnotetext{
225 "In the absence of strong rules and norms, globalization could turn into a free-for-all, an intensifying competition among communities worldwide over jobs, income, and economic well-being. By generating deep apprehension and feelings of insecurity, the very unevenness and uncertainty of the globalization process is in itself becoming a source of conflict."
} 
7.2.1 A influência norte-americana: Plan Dignidad (Plano Dignidade), recursos naturais e água

A influência norte-americana na Guerra da Água em Cochabamba pôde ser notada de forma mais direta em dois períodos distintos: um mais antigo e outro mais recente. No primeiro, o governo norte-americano demonstrou sua preocupação com o destino da revolução de 1952 e sua influência nas políticas territoriais e nos projetos de colonização do Chapare. No segundo, o governo dos Estados Unidos se expressou na conjuntura do conflito por meio da Drug Enforcement Administration (DEA, Força Administrativa de Narcóticos) e passou a atuar diretamente sobre o mercado de coca no Chapare, incluindo a construção de três bases norteamericanas na região. A participação do movimento cocalero se manifestou, em grande parte, como reação à presença norte-americana na região por meio da DEA.

Por causa de sua importância para o equilíbrio geopolítico da América do Sul, bem como da existência de importantes reservas de recursos naturais em seu território, a Bolívia sempre esteve sob a alça de mira das principais potências mundiais. Galeano (1990) corroborou essa afirmação e Zunes (2001, p. 34, tradução nossa) asseverou que a revolução de 1952 na Bolívia pôde se consolidar não por esquecimento norte-americano, mas, pelo contrário, "um dos aspectos mais interessantes e frequentemente negligenciados é o papel dos Estados Unidos em moldar o curso da revolução". ${ }^{226}$.

Nesse sentido, o primeiro aspecto que gostaríamos de salientar é a influência norte-americana nas políticas territoriais bolivianas. Naquele momento, o governo de Paz Estenssoro buscava dar prosseguimento ao plano traçado pelo economista norte-americano Marvin Bohan, impulsionando a "macha ao oriente". Para esse fim, Cochabamba e Santa Cruz de la Sierra eram os polos principais de desenvolvimento. Até meados dos anos 60, com a construção das infraestruturas de transporte procurava-se impulsionar esses dois centros urbanos. Porém, a partir do final dos anos 60, os investimentos foram majoritariamente concedidos a Santa Cruz de la Sierra, pois os Estados Unidos já haviam se posicionado a favor do Brasil

\footnotetext{
226 "[...] one of its most interesting and frequently overlooked aspects is the role of the United States in shaping the course of the revolution."
} 
como aliado regional. Logo, cabia colocar a Bolívia na órbita de influência brasileira. Consoante Andrade (2007, p. 132):

Os Estados Unidos concediam empréstimos agrícolas desde que estes fossem direcionados para a região colonizada de Santa Cruz, onde se desenvolve uma agricultura baseada em empresas agrícolas de alta rentabilidade. Para as regiões do Altiplano e dos Vales, esses recursos eram vetados.

Zondag (1966) comentou que o governo norte-americano, além de prestar assistência técnica, ainda concedeu um crédito de 50 milhões de dólares para a compra de maquinário e desenvolvimento da agricultura moderna na região de Santa Cruz de la Sierra.

Os efeitos desse fenômeno a longo prazo se materializaram na agricultura de minifúndio no Vale Central e na ausência de um plano de desenvolvimento agrário para a região. Em consequência da escassez de terras para os novos migrantes, boa parte deles se dirigiu ao Chapare e a Santa Cruz de la Sierra. O desenvolvimento desta última localidade também foi responsável pelo forte fluxo de migrantes do altiplano para a cidade de Cochabamba, pois uma parte desses migrantes encontrou maior dificuldade de adaptação na capital cruceña que em Cochabamba, em decorrência de aspectos culturais e fisiográficos (COTTLE; RUIZ, 1993).

O segundo aspecto relacionado à influência norte-americana na Bolívia se refere à sua atuação no Chapare com o fito tanto de controlar uma área estratégica rica em recursos naturais quanto de erradicar os plantios de coca. A ação norteamericana no Chapare remonta aos anos 60, quando foi criada a Estación Experimental de Chipiriri (Estação Experimental de Chipiriri), visando a diversificação de culturas e a substituição dos cultivos de folha de coca. Pela forte pressão norteamericana, em seu segundo governo, Paz Estenssoro promulgou um Decreto Supremo ratificando a Convenção Única sobre Entorpecentes, realizada em Nova York em 1961 (CEDIB, 1993). Segundo essa convenção, tanto a folha de coca como a cocaína são entorpecentes. O diploma legal boliviano tinha como meta a erradicação paulatina dos cultivos de coca e a sua substituição por outras culturas, bem como a erradicação da mastigação das folhas de coca (akullico) em um prazo de 25 anos (SALAZAR ORTUÑO, 2004). 
Em 1978, durante o governo militar do General Banzer, além da promulgação do Decreto lei $n=16.562$ (BOLIVIA, 1979), para controle de substâncias perigosas e da criação da agência interministerial Proyecto de Desarrollo Chapare-Yungas (PRODES, Projeto de Desenvolvimento Chapare-Yungas), implantou-se no Chapare - Instituto Boliviano de Tecnologia Agropecuaria (IBTA, Instituto Boliviano de Tecnologia Agropecuária), que se converteu em uma estação experimental voltada para a produção e o melhoramento de frutos cítricos. Para esse fim, se realizou a primeira importação de material genético dos Estados Unidos.

\begin{abstract}
Outro dos elementos da instrumentalização do IBTA, é que sob essa instância, os técnicos agrônomos se constituem em recenseadores e registradores dos cultivos de coca. Finalmente, [isso quer] dizer que os técnicos e assessores do IBTA não conseguem formular nos anos da ditadura uma proposta técnica sobre uma política de desenvolvimento agropecuário do Trópico, isso devido à verticalidade na tomada de decisões, própria deste regime militar totalitário, no qual as decisões são tomadas nos níveis governamentais (ministros e secretários) com supervisão de assessores da embaixada norte-americana (SALAZAR ORTUÑO, 2004, p. 5, tradução nossa). ${ }^{227}$
\end{abstract}

A partir de 1981, o governo da Bolívia passou a implantar a erradicação forçada ou voluntária da coca. Para a consecução de tal plano, com o auxílio logístico e técnico norte-americano, o governo boliviano criou um batalhão especial para patrulhar a área do Chapare, denominado Unidad Móvil de Patrullaje Rural (UMOPAR, Unidade Móvel para o Patrulhamento Rural). Além disso, a United States Agency for International Development (USAID, Agência Norte-americana para o Desenvolvimento Internacional) passou a auxiliar várias atividades relacionadas à substituição dos cultivos de coca. A partir daquele momento, houve tendência cada vez maior de militarizar a questão. Embora houvesse a iniciativa de substituir voluntariamente os cultivos em troca de uma compensação, esse processo ocorreu de maneira muito tímida no Chapare (MARCONI, 1998).

Por seu turno, Urquidi (2001) informou que o programa de compensação também ocasionava efeitos colaterais, porque a migração para as zonas de

\footnotetext{
227 "Otro de los elementos de la instrumentalización del IBTA, es que bajo esta instancia, los técnicos agrónomos se constituyen en censadores y registradores de los cultivos de coca. Finalmente decir, que los técnicos y asesores del IBTA no logran formular en los años de la dictadura una propuesta técnica sobre una política de desarrollo agropecuario del Trópico, ello debido a la verticalidad en la toma de decisiones, propia de este régimen militar totalitario, en el que las decisiones se toman en niveles gubernamentales (ministros y secretarios) con supervisión de asesores de la embajada norteamericana."
} 
produção de coca não ocorria somente por haver intensos fatores de expulsão das zonas de origem, mas principalmente pelo ciclo vicioso que a compensação gerava. O montante pago pela compensação chegava a 2 mil dólares por hectare e esse programa durou até 1998, quando a erradicação se tornou exclusivamente forçada por meio da militarização da região. Adicionalmente, devido à recessão econômica no final dos anos 90, muitos dos cocaleros que anteriormente haviam recebido a compensação, acabaram voltando a plantar coca, uma vez que nunca houve um verdadeiro plano de desenvolvimento regional (KOHL; FARTHING, 2001).

A partir de agosto de 1997, o governo norte-americano pressionou ainda mais a erradicação da coca, ocasião em que o General Hugo Banzer foi eleito presidente da república. Os quase dez anos de seu primeiro governo haviam sido marcados pelo incremento da área de plantio de coca e pela implantação do narcotráfico na Bolívia. Temendo um retorno a essa situação e as consequências de uma "colombianização" da região de Chapare e Yungas, o governo norte-americano forçou uma medida pronta e radical: a opção zero. Assim, a erradicação da coca passou a se dar apenas de forma militarizada e forçada. O governo boliviano promulgou o Decreto Supremo nำ24.963 (Plan Dignidad, Plano Dignidade) (BOLIVIA, 1998), também chamado de programa coca zero, criou um miniexército sob o jugo da DEA, formado por pessoal das forças armadas, da polícia boliviana e também por agentes norte-americanos, e adquiriu material bélico, como helicópteros de guerra e aviões. Assim, foi criada uma Fuerza de Tarea Conjunta (FTC, Força Tarefa Conjunta) e foram construídos três quartéis na região sob controle de agentes norte-americanos (CAMARGO, 2006). Salazar Ortuño (2003, p. 5, tradução nossa) observou que:

Pouco ou nada se tem escrito sobre o alcance das redes de inteligência montada pela FTC no Trópico de Cochabamba, mas é evidente que existem dois grandes centros de operação, um dirigido diretamente por fontes da NAS, DEA e CIA norte-americanas e o outro por instâncias da FTC. Em ambos os casos, o modus operandi consiste em infiltrar seus agentes em organizações de produtores de coca, incorporar informantes em algumas localidades $[\ldots]^{228}$

\footnotetext{
228 "Poco o nada se tiene escrito sobre el alcance de las redes de inteligencia montadas por la FTC en el Trópico de Cochabamba, pero es evidente que existen dos grandes centros de operación, uno dirigido directamente por fuentes de la NAS, DEA y CIA norteamericanas, y el otro por instancias de la FTC. En ambos casos el modus operandi consiste en: infiltrar a sus agentes en organizaciones de productores de coca; incorporar a informantes en algunas localidades [...]"
} 
Diante de tamanha repressão, falta de diálogo e planejamento para a resolução da questão, o movimento cocalero aderiu de forma direta à Coordinadora del Agua. Embora a aprovação da Lei no 2.029 (BOLIVIA, 1999b) tenha afetado uma parte dos cocaleros, a demanda principal estava vinculada ao Plan Dignidad. Embora houvesse a participação desse movimento na Guerra da Água, a erradicação da produção de coca somente foi resolvida após vários enfrentamentos, durante o episódio que ficou conhecido como Guerra da Coca. Dessa forma, o descontentamento dos camponeses do Chapare se expressou não somente contra o programa de erradicação da coca, mas também pela falta de incentivos à agricultura tradicional e de um projeto sério de desenvolvimento para a região.

Outro aspecto polêmico se refere à construção das três bases controladas por agentes norte-americanos, vez que no Chapare se encontram importantes reservas de gás e petróleo (em Bulo Bulo e no Parque Carrasco), assim como de diversidade biológica. Portanto, fica a dúvida até que ponto esses quartéis serviriam apenas para a erradicação dos cultivos de coca ou também teriam a função de controlar os recursos naturais ali existentes. Igualmente importante é o fato de que a agricultura regional recebeu incentivos tão parcos que a disparidade do IDH entre a população urbana e a rural era substancial.

7.2.2 Um conflito de redes: empresas transnacionais e movimentos sociais

O recuo institucional do Estado boliviano, que mencionamos anteriormente, e a penetração de rivalidades das escalas maiores foram, aos poucos, estruturando um shatterbelt. No caso da Guerra da Água, nota-se que ONGs internacionais e empresas transnacionais se tornaram reconhecidas pela LPP (BOLIVIA, 1994c) como as instituições responsáveis pelos investimentos em políticas públicas e pelo auxílio ao desenvolvimento regional. Consequentemente, atores externos ao arcabouço do Estado se tornaram cada vez mais atuantes e presentes no próprio planejamento territorial. Não queremos afirmar, com isso, que a atuação desses protagonistas tenha sido necessariamente negativa; entrementes, quando muitos deles têm tanta autonomia, como no caso boliviano, corre-se o risco de 
fragmentação territorial e, particularmente, de incoerência e confronto entre os objetivos planificados.

Em decorrência da fraqueza institucional do Estado boliviano, várias ONGs vêm implementando projetos em diferentes áreas sociais e auxiliando movimentos sociais e OTBs no desenvolvimento social e participação política. Embora uma parte dos projetos levados adiante por certas ONGs tenha apresentado resultados positivos, outra parcela de ONGs tem sido cooptada pelos organismos internacionais de financiamento (BEBBINGTON, 2004).

Da mesma forma que as ONGs e os movimentos sociais internacionais, as empresas transnacionais foram reconhecidas pelo governo boliviano como importantes atores no desenvolvimento econômico a partir da promulgação da Lei no 1.544 (BOLIVIA, 1994b). Embora não necessariamente as ONGs e as empresas transnacionais sigam lógicas que se opõem às suas ações, observa-se que como protagonistas políticos, na maior parte das vezes, essas instituições atuam em lados opostos (BEBBINGTON, 2004).

Essa incongruência e até mesmo o confronto na região entre interesses dos atores da escala global puderam ser verificados durante a Guerra da Água. Após o fim do confronto local entre Coordinadora del Agua e Aguas del Tunari, o conflito estendeu-se para as escalas nacional e internacional. $\mathrm{Na}$ escala nacional, os movimentos sociais regionais estenderam suas agendas para outros temas além da questão da água, enfatizando especialmente a privatização das empresas nacionais e as políticas neoliberais. Além disso, a disputa entre o movimento social e o consórcio transnacional ampliou-se para a escala internacional, uma vez que Aguas del Tunari iniciou uma demanda no valor de 50 milhões de dólares contra o Estado boliviano no International Center for Settlement of Investment Disputes (ICSID, Centro Internacional para Arbitragem de Disputas sobre Investimentos - CIADI) ${ }^{229}$.

A partir da saída de Aguas del Tunari da Bolívia, a Guerra da Água se tornou um caso notório e emblemático utilizado pelo movimento altermundialista na retórica contra o neoliberalismo. Desde então, a Coordinadora del Agua tem recebido o auxílio de inúmeras ONGs e de outros movimentos sociais da escala internacional.

${ }^{229}$ O CIADI é uma instituição internacional autônoma, cujo propósito primário é prover facilidades para a conciliação ou arbitragem de disputas referentes a investimentos entre investidores estrangeiros e os seus países anfitriões. 
Durante o World Social Forum (Fórum Social Mundial) de 2003, muito se discutiu sobre a problemática desse conflito e novas redes de movimentos sociais internacionais vinculados à Coordinadora del Agua foram articuladas, como a Red Vigilancia Interamericana para la Defensa y Derecho al Agua (VIDA, Rede de Vigilância Interamericana para a Defesa e Direito à Água). ${ }^{230}$

A esse respeito, Crespo e Fernández (2004) argumentaram que a Coordinadora del Agua constitui mais uma rede de movimentos sociais que propriamente um movimento social. Essa nova forma de organização social, mais flexível, permite a participação de diferentes movimentos sociais e de centros de pesquisas, assim como maior contato entre diferentes demandas. Outro aspecto que esses autores ainda ressaltaram é a participação de intelectuais e da mídia como forma de articular coerentemente uma série de demandas a partir dos diferentes pontos da rede de movimentos sociais (Esquema 14).

Em sua análise acerca da Guerra da Água, Soldal (2008) declarou que os velhos movimentos sociais conformados essencialmente pelos sindicatos, como a Central Obrera Boliviana ( $\mathrm{COB}$, Central de Trabalhadores Boliviana), foram substituídos por uma nova forma de organização social caracterizada por sua flexibilidade, o que the concede mais chances de participação social, ao contrário da velha forma, em que havia uma hierarquia rígida.

Crespo, Fernández e Peredo (2004) revelaram a importância da utilização da mídia como forma de chamar a atenção não apenas do público e da mídia, mas principalmente do governo, para as suas demandas. Trata-se de uma forma de espetacularização da questão, como a queima pública dos talões de tarifas de água. Naturalmente, essa forma de estratégia utilizando objetos comunicacionais e informacionais somente foi possível pela existência de alta densidade técnica na região. Sendo assim, embora a modernização da região tenha gerado tensões, por outro lado também propiciou várias oportunidades de ação para os protagonistas sociais. Graças a essas possibilidades, a rede de movimentos sociais foi se tornando cada vez mais ampla, possibilitando, assim, protestos no estrangeiro contra Aguas del Tunari. Como exemplo disso podemos citar as passeatas em San Francisco (Estados Unidos) diante da sede de Bechtel e a guerra travada no cyber

${ }^{230}$ Endereço eletrônico da ONG VIDA: <http://www.laredvida.org/noticias.php?tipo_noticia=Noticia>. 
espaço pela Coordinadora del Agua, com o auxílio da ONG Democracy Center, contra Bechtel e Abengoa.

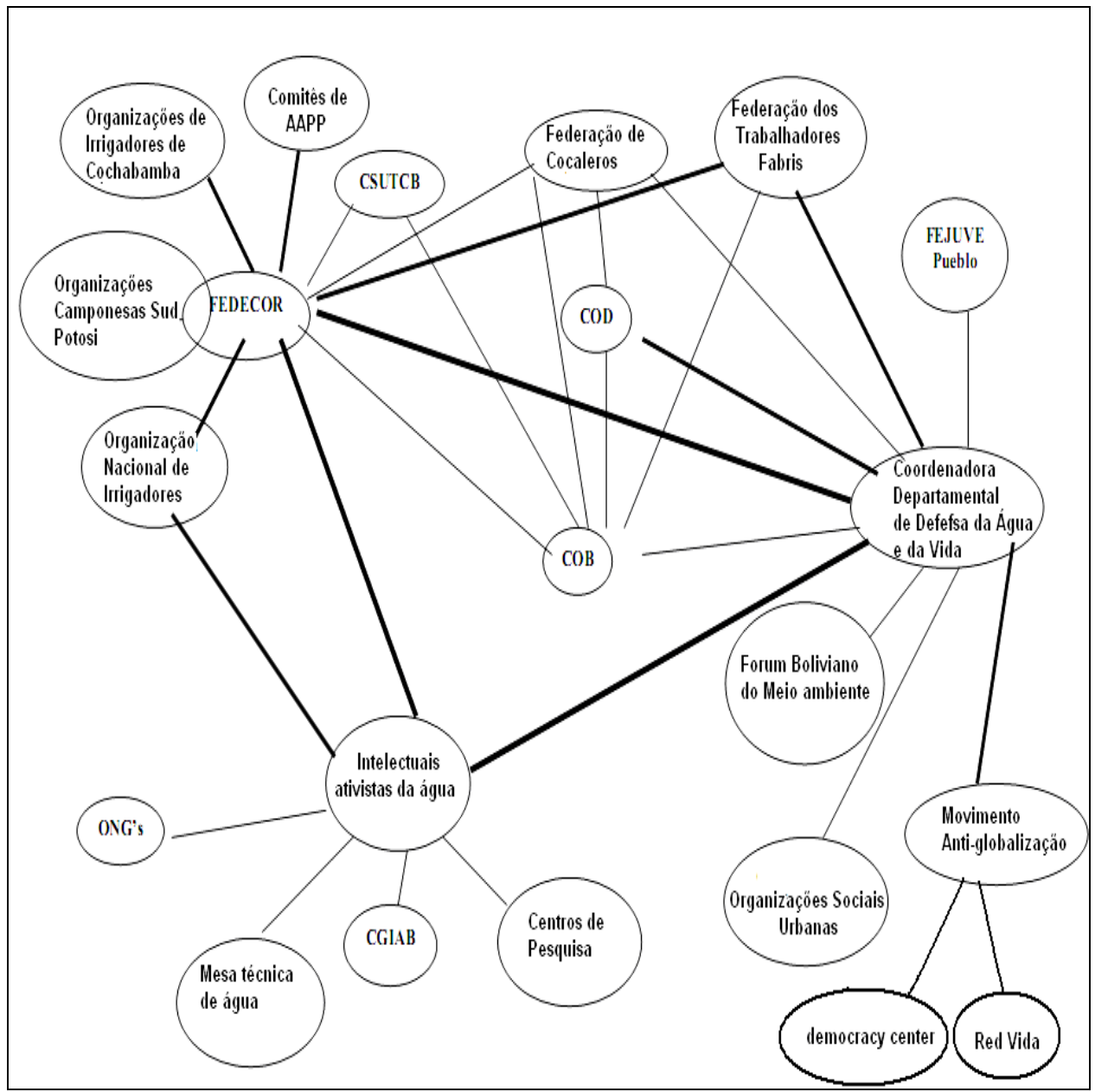

Esquema 14. Rede de movimentos sociais ligados à Coordinadora del Agua.

Fonte: Organizada pelo autor com base em Crespo e Fernández (2004, p. 329).

De outro lado, também houve a constituição de uma rede de empresas transnacionais, as quais se articularam como forma de flexibilizar a produção e os riscos oriundos do mercado. Esse foi o caso do consórcio nacional Aguas del Tunari, do qual Bechtel e Edison faziam parte. Mais que uma simples aliança comercial entre empresas internacionais, os vínculos entre essas instituições transnacionais parece ser bem mais profundo, como apontam alguns indícios.

A empresa Bechtel mantém fortes laços com a cúpula do governo norteamericano desde a década de 1970, quando George Schultz foi Secretário do 
Tesouro Norte-americano. Além disso, outros representantes da empresa, como Caspar Weinberger, W. Kenneth Davis, Riley Bechtel e Jack Sheehan, participaram diretamente da cúpula do governo norte-americano. O próprio presidente da companhia, Riley Bechtel, foi membro do Conselho de Exportação no governo de Geroge W. Bush Jr., em 2003. A Bechtel, que atua em mais de 50 países, graças a seus fortes vínculos com o governo dos Estados Unidos recebeu o contrato de reconstrução do Iraque e de New Orleans após o furacão Katrina. Faz-se importante destacar que, antes de se voltar para o setor de abastecimento de água na Bolívia, a Bechtel já participava da atividade de extração de gás e petróleo naquele país. Comentou-se na Bolívia que a empresa teria aceitado deixar Cochabamba em troca de outros benefícios na área de hidrocarbonetos (ALBÓ, 2006). ${ }^{231}$

Outro grupo que fazia parte do consórcio transnacional, Edison International, não somente possui forte vínculo com o governo norte-americano como também com o governo italiano. Em relação ao governo dos Estados Unidos, o presidente da Edison International, John Bryson, foi membro do Council on Foreign Relations (Conselho para Relações Exteriores). De acordo Geuens (2003, p. 84, tradução nossa), a função dessa instituição era "fornecer novas ideias para a política externa dos Estados Unidos". ${ }^{232}$ Ou seja, os próprios dirigentes da empresa também forneciam instruções acerca do que deveria ser feito em política exterior pela diplomacia norte-americana. Outro exemplo ilustrativo é o de Alberto Clo, antigo gerente do grupo Edison que, posteriormente, se tornou Ministro da Indústria e, em seguida, do Comércio Exterior italiano entre 1995 e 1996.

Ao analisar o complexo militar industrial norte-americano, Geuens (2003) apresentou várias indústrias que dele participavam, entre as quais se encontravam Bechtel e Edison. Durante o governo do presidente George W. Bush Jr., a Bechtel assinou um contrato para operar o Lawrence Livermore National Laboratory (Laboratório Nacional Lawrence Livermore), que incluía uma série de instalações de defesa, como o laboratório nuclear da base militar de Los Alamos. Interessante observar que outras empresas privadas que adquiriram estatais com sede em Cochabamba não apenas eram norte-americanas como possuíam, ainda, cadeira cativa nesse complexo militar industrial. A Duke Energy, que adquiriu a empresa

${ }^{231}$ ALBÓ, Xavier. Comunicação pessoal em entrevista concedida ao autor. El Alto, 22 de janeiro de 2006.

232 "[...] fournir de nouvelles idées pour la politique étrangère des Etats-Unis." 
Corani, também fazia parte desse complexo militar industrial norte-americano e seu presidente, Richard B. Priory, foi membro do Conselho Consultor sobre Energia do presidente George W. Bush Jr. (GEUENS, 2003).

Embora não haja nenhum documento ou prova cabal confirmando que a atuação das empresas transnacionais se deu a partir de um plano formulado desde o governo de George W. Bush Jr., há certa coincidência no horizonte temporal entre a iniciativa de construção das três bases militares norte-americanas no Chapare, além da aquisição via privatização das principais estatais (com sede em Cochabamba) por grupos privados norte-americanos fortemente ligados ao governo dos Estados Unidos. Das quatro principais estatais privatizadas na região, todas foram repassadas a grupos privados com origem norte-americana. Apesar de não se poder afirmar cabalmente que haja esse envolvimento, alguns indícios parecem apontar para a existência de uma estratégia traçada pela política externa dos Estados Unidos para que o complexo militar norte-americano tomasse conta da região, não somente por meio de um conflito de baixa intensidade (programa coca zero), mas também aproveitando a oportunidade concedida pela Lei $\mathrm{n}^{\circ} 1.544$ (BOLIVIA, 1994b).

Fazendo uma reflexão sobre a Guerra da Água, o sociólogo Ortego (2000, p. 18, tradução nossa) reiterou que:

Acrescentamos à complexidade dos conflitos que os fatores externos contribuíram para que este finalmente se tornasse imanejável. Esses fatores têm a ver com os processos de globalização por um lado, e com as intrigas locais. Entre esses fatores, cujos efeitos não são muito mensuráveis [...], podemos citar a generalização dos conflitos pela privatização da água que tem vivido a região nos últimos anos, a crise que tem afetado principalmente os setores mais pobres da sociedade, e os interesses ocultos de certos atores interessados em uma saída não negociada do conflito. ${ }^{233}$

Portanto, a partir da estruturação de tensões da escala global entre ONGs, movimentos sociais internacionais e empresas transnacionais, o conflito se tornou mais intenso e polarizado, adquirindo a forma de tensões multiescalares. Com a experiência acumulada pelas ONGs internacionais (como o Democracy Center) e as

233 "Añadimos a la ensalada del conflicto, los factores externos contribuyeron a que éste finalmente se hiciera inmanejable. Estos factores tienen que ver con los procesos de globalización por un lado, e con las intrigas locales. Entre estos factores, cuyos efectos no son muy medibles [...], podemos citar la generalización de los conflictos por la privatizacion del agua que ha vivido la region en los ultimos años, la crisis que ha afectado principalmente a los sectores mas pobres de la sociedad, y los intereses ocultos de ciertos actores interesados en una salida no negociada del conflicto." 
lutas coloniais indígenas, a resistência aos intentos de privatização se tornou mais intensa, estendendo-se a escalas e dimensões maiores. Não foi mera coincidência que logo após a saída de Aguas del Tunari de Cochabamba o movimento logo passou a visar a luta contra o neoliberalismo em âmbito nacional, em vez de se preocupar com a resolução da problemática gestão da água no Vale Central. Ademais, por meio desse exemplo, percebe-se a forte ingerência de atores estrangeiros em território nacional, principalmente dos Estados Unidos. Embora seja difícil comprovar cabalmente a presença de um plano de controle territorial da região, percebe-se forte vínculo entre os indícios e os fatos. 


\section{8 ÁGUA PURA OU ABIGARRADA?}

Ao longo desse extenso percurso esperamos finalmente haver chegado a um porto seguro, ainda que ele seja temporário. Cabe, então, indagar a respeito das águas passadas navegadas: eram puras ou abigarradas? Abigarrado significa uma conjunção de cores, um colorido com diversas cores confusas, representando o complexo. Ao lidarmos com a relação entre recursos hídricos e conflitos, resta-nos saber se a água foi um fator suficiente para engendrar o conflito ou houve uma complexidade de fatores engendrando-o. Ante o exposto, concluímos que:

a) Os conflitos são fenômenos complexos que podem ser mais bem compreendidos a partir dos conceitos da geografia, principalmente a partir do método regional e de uma apreciação multiescalar. Adicionalmente, a geopolítica pode complementar a reflexão sobre a relação entre recursos hídricos, principalmente a partir de uma geopolítica lato sensu, levando em conta também os conflitos entre Estados bem como entre comunidades e grupos humanos. Por outro lado, nem sempre conflitos violentos impactam mais fortemente os seres humanos, já que as relações de poder como aquelas vinculadas aos recursos hídricos podem ser mais mortíferas que os meios convencionais de violência. Ainda mais tendo em mente que essas relações de poder logram se camuflar no cotidiano. Sugerimos que a relação entre recursos hídricos e segurança seja refletida de forma mais abrangente, levando em conta que os conflitos e as relações de poder são momentos distintos de um mesmo fenômeno.

b) $\quad$ embate das diferentes territorialidades de vários atores na região do Vale Central de Cochabamba foi sobrepondo rivalidades de diversas escalas, assim como polarizando os interesses dos diversos protagonistas. Ressaltamos que essa sobreposição de rivalidades se deu sobretudo pela posição estratégica da região no contexto boliviano e sul-americano. Não obstante, ao mesmo tempo em que atores de outras escalas passaram a atuar no contexto regional, o equilíbrio precário do arranjo territorial na região começou a entrar em colapso, particularmente no que concerne à expansão das áreas urbanas em relação às comunidades camponesas e, por outro lado, polarizando ainda mais a diferença entre as três territorialidades rígidas. Porém, com a união entre o campo e os setores periurbanos, uma nova 
ordem territorial, mormente no que tange aos recursos hídricos, passou a favorecer a territorialidade camponesa indígena.

c) Embora assim tenha sido denominada, a Guerra da Água não pode ser considerada um conflito relacionado apenas aos recursos hídricos. Notamos que várias outras tensões foram se sobrepondo: a rivalidade entre o movimento altermundialista e os vetores do neoliberalismo; o conflito entre diferentes partidos, politizando a questão da gestão hídrica; a política econômica desenvolvida pelo Estado boliviano e a resistência dos diferentes movimentos sociais; a erradicação dos plantios de coca pelo governo central e pelo governo americano. Observamos que havia vários outros processos ocorrendo conjuntamente com as tensões relacionadas com a gestão hídrica. Naturalmente, devido ao contexto regional do Vale Central de Cochabamba, essas tensões acumuladas nas escalas maiores acabaram sendo liberadas por meio do mecanismo de válvula de escape proporcionado pelas características da região: forte tradição camponesa e falência na gestão hídrica e ordenamento territorial. Enquanto região de fronteira interna, Cochabamba está exposta a dois contrastes: o rural e o urbano, o ocidente e o oriente boliviano. Dessa forma, a questão hídrica foi um mecanismo liberador de tensões acumuladas, não somente por vetores da escala regional, mas fundamentalmente das escalas maiores.

d) Na escala temporal, verificamos que fatores conjunturais e estruturais também convergiram para o desencadeamento do conflito. Em primeiro lugar, apresentaram-se fatores estruturais, como a transformação do Vale Central pelas políticas territoriais do governo central e de outros atores, a política econômica implantada pelo governo em favor dos vetores da globalização, a forte presença estrangeira, na Bolívia como um todo e, especificamente, em Cochabamba, e o fracasso no aprovisionamento dos serviços básicos no Vale Central. Posteriormente, apresentaram-se os fatores conjunturais, tais como a falência da democracia pactuada, o fracasso das políticas de colonização no Chapare, o início da erradicação forçada da coca e a constituição de novas formas de resistência pelos movimentos sociais.

e) A Guerra da Água se apresentou como um ponto de inflexão entre diferentes fatores estruturados e estruturantes. Os fatores estruturantes, tais como as políticas territoriais e as novas formas de resistência pelos movimentos sociais, 
podem ser consideradas como as forças de construção de um novo contexto após a Guerra da Água. Esses fatores acabaram por estruturar diversos outros fenômenos, como a eleição do primeiro presidente boliviano indígena e a volta a um nacionalismo. Em adição a isso, se os vetores da globalização têm perdido espaço, as diferenças regionais criadas pelas políticas territoriais vêm se acentuando, plasmadas no eixo oriente Camba e ocidente Colla. Ainda que na escala nacional a Guerra da Água tenha significado vários avanços, na escala regional vimos, in loco, a triste realidade da incapacidade de gestão dos serviços de aprovisionamento de água potável e esgoto sanitário. Ganhou-se a guerra e perdeu-se a água... 


\section{REFERÊNCIAS}

ACSELRAD, Henri. As práticas espaciais e o campo dos conflitos ambientais. ACSELRAD, Henri. (Org.). Conflitos ambientais no Brasil. Rio de Janeiro: Relume Dumará, 2004, p. 13-36.

ADORNO, Theodor W.; HORKHEIMER, Max. Dialética do esclarecimento: fragmentos filosóficos. Tradução Guido Antonio de Almeida. reimpr. 2 ed. Rio de Janeiro: Jorge Zahar, 2006.

AGNEW, John; CORBRIDGE, Stuart. Mastering space: hegemony, territory and international political economy. London: Routledge, 1995.

ALENDA, Stéphanie. Bolívia: la erosión del pacto democrático. Revista Fuerzas Armadas y Sociedad, Santiago, año 18, no. 1-2, p. 3-22, 2004. Disponível em: <http://www.fasoc.cl/files/articulo/ART4112c9b126f28.pdf>. Acesso em: 12 maio 2009.

ALLAN, John A. Avoiding war over natural resources. In: FLEMING, S. (Ed.). War and water. Geneva: ICRC Publication Division, 1999. p. 251-255.

ALLAN, John A. Virtual water: a strategic resource. Ground Water, Westerville, v. 36, no. 4, p. 545-546, 1998.

ALLAN, John A. Virtual water: the water, food and trade nexus, useful concept or misleading metaphor? IWRA, Water International, Johannesburg, v. 28, no. 1, p. 411, 2003. Disponível em: <http://www.soas.ac.uk/waterissues/papers/file38394.pdf>. Acesso em: 30 out. 2008

ALONSO, Ângela; COSTA, Valeriano. Ciências sociais e meio ambiente no Brasil: um balanço bibliográfico. Revista Brasileira de Informação Bibliográfica em Ciências Sociais, São Paulo, v. 53, p. 35-78, 2002.

ALONSO, Ângela; COSTA, Valeriano. Por uma sociologia dos conflitos ambientais no Brasil. In: ALIMONDA, Hector. (Org.). Ecología política: naturaleza, sociedad y utopia. Buenos Aires: CLACSO, 2002, p.115-135. Disponível em:

<http://bibliotecavirtual.clacso.org.ar/ar/libros/ecologia/ecologia.html>. Acesso em: 20 abr. 2009.

ALVAREZ, Frederico Escobar. Participación ciudadana en los bloqueos de abril. Conflictos, Cochabamba, v. 3, no. 6, p. 12-13, 2000. 
ANDRADE, Everaldo de Oliveira. A revolução boliviana. São Paulo: Editora da UNESP, 2007.

ARENDT, Hanna. Da violência. Tradução Maria Claudia Drummond. Brasília, DF: Editora da Universidade de Brasília, 1985.

ASSIES, Willem. David versus Goliath in Cochabamba: water rights, neoliberalism, and the revival of social protest in Bolivia. Latin American Perspectives, Newbury Park, v. 30, no. 3, p. 14-36, 2003.

AYEB, Habib. L'eau au Proche-Orient: la guerre n'aura pas lieu. Paris : KarthalaCEDEJ, 1998.

BAECHLER, Günther. Violence through environmental discrimination. Dordrecht: Kluwer Academic, 1999.

BARBANTI JÚNIOR, Olympio. Conflitos socioambientais: teorias e práticas. In: ENCONTRO DA ASSOCIAÇÃO NACIONAL DE PÓS-GRADUAÇÃO E PESQUISA EM AMBIENTE E SOCIEDADE, 1., 2002, Indaiatuba. Anais... Indaiatuba: ANPPAS, 2002. Disponível em: <http://www.anppas.org.br/encontro_anual/encontro1/>. Acesso em: 10 fev. 2008.

BARBATO, Daniel Veja; CAPRIOLO, Ronald Peñarrieta. Facilitando procesos de diálogo sobre el problema de la invasión urbana en zonas agrícolas bajo riego, área perirubana de Cochabamba, Bolivia. In: ENCONTRO POR UMA NOVA CULTURA DA ÁGUA NA AMÉRICA LATINA, 2005, Fortaleza. Anais... Fortaleza: Associação Brasileira de Recursos Hídricos, Fundación Nueva Cultura del Água, 2005. Disponível em: <http://www.fnca.eu/fnca/america/docu/1708.pdf>. Acesso em: 10 set. 2009.

BARJA, Gover; URQUIOLA, Miguel. Capitalization, regulation and the poor access to basic services in Bolivia. Helsinki: World Institute for Development Economics Research, 2001. (Discussion Paper no. 2001/34). Disponível em: <http://website1. wider.unu.edu/publications/dps/dp2001-34.pdf >. Acesso em: 20 ago. 2009.

BARKAN, Steven; SNOWDEN, Lynne. Collective violence. Boston: Allyn and Bacon, 2001.

BARNETT, Jon. The meaning of environmental security: ecological politics and policy in the new security era. London: Zed Books, 2001. Disponível em: <http://books.google.com.br/books?id=jheOra9RUhlC\&pg=PA55\&lpg=PA55\&dq=it+s 
eems+that+the+broader+political+context+is+more+relevant+than+the+specific+inst ance+of+water+scarcity \&source=bl\&ots=C-

wtpZe7Y7\&sig=mKjL9VcaSNZE5meqEcura8WIvJE\&hl=pt-

BR\&ei=b7fCSpTbFNDEIAfimqDIBQ\&sa=X\&oi=book_result\&ct=result\&resnum $=1 \# v=$ onepage \&q=\&f=false>. Acesso em: 23 abr. 2009

BARRAGÁN, Júlio; CRESPO, Carmen; DONOSO, Guillermo; ESCOBAR, Jairo. Mercados e instituciones de aguas en Bolivia. La Paz: UDAPE, 1998.

BARRIOS MORÓN, Raúl. La elusiva paz de la democracia boliviana. In: ALBÓ, Xavier; BARRIOS, Raúl. (Coord.). Violencias encubiertas en Bolivia. Coca, vida cotidiana y comunicación. v. 1. La Paz: CIPCA, 1993. p. 143-208.

BAUMAN, Zygmunt. Comunidade: a busca por segurança no mundo atual. Tradução Plinio Dentzien. Rio de Janeiro: Jorge Zahar, 2001.

BAYLISS-SMITH, Tim; OWENS, Susan. O desafio ambiental. In: GREGORY, Derek; MARTIN, Ron; SMITH, Graham (Org.). Geografia humana: sociedade, espaço e ciência social. Tradução Mylan Isaack. Rio de Janeiro: Jorge Zahar, 1996. p. 125158.

BEAUJEU-GARNIER, Jacqueline. La géographie: méthodes et perspectives. Paris: Masson, 1971.

BEBBINGTON, Anthony. NGOs and uneven development: geographies of development intervention. Progress in Human Geography, London, v. 28, no. 6, p. 725-745, 2004.

BECK, Ulrich. Politik der Angst. Süddeutsche Zeitung, München, n. 169, p. 13, 25 Juli, 2005.

BECKER, Bertha Koiffmann. A geografia e o resgate da geopolítica. Revista Brasileira de Geografia, Rio de Janeiro, v. 50, n. especial, p. 99-125, 1988.

BECKER, Bertha Koiffmann. Inclusion of the Amazon in the geopolitics of water. In: ARAGÓN, Luiz E.; CLÜSENER -GODT, Miguel (Org.). Issue of local and global use of water from the Amazon. Montevideo: NAEA, UFPA, UNESCO, 2004. p. 143-166. Disponível em: <http://www.bvsde.paho.org/bvsacd/cd29/inclusion.pdf>. Acesso em: 13 set. 2008. 
BECKER, Bertha Koiffmann. O uso político do território: questões a partir de uma visão do terceiro mundo. In: BECKER, Bertha; COSTA, Rogério H. da; SILVEIRA, Carmen B. (Org.). Abordagens políticas da espacialidade. Rio de Janeiro: UFRJ, 1983. p. 1-8.

BETHEMONT, Jacques. Les grands fleuves. 3e. éd. Paris: Armand Colin, 1999.

BLACKBURN, Richard James. O vampiro da razão: um ensaio de filosofia da história. Tradução Raul Ficker. São Paulo: Editora da Unesp, 1992.

BLANES, José. Descentralización y participación popular en las comunidades aymaras de Bolivia. Reflexiones sobre el futuro de la modernización del Estado. Laz Paz: CEBEM, 1999. Disponível em:

$<$ http://www.iisec.ucb.edu.bo/projects/Pieb/archivos/Blanes-

DescentyComunAymaras.pdf>. Acesso em: 17 set. 2009.

BLANES, José. Bolivia: las áreas metropolitanas en perspectiva de desarrollo regional. Revista Eure, Santiago de Chile, v. 32, no. 95, p. 21-36, 2006. Disponível em: <http://www.scielo.cl/pdf/eure/v32n95/art02.pdf>. Acesso em: 12 dez. 2008.

BOLIVIA. Decreto Supremo no. 21.060, del 29 de agosto de 1985. Gaceta Oficial de Bolivia, La Paz, 29 agosto 1985.

BOLIVIA. Decreto Supremo no. 23.858, del 9 de septiembre de 1994. Reglamento de las Organizaciones Territoriales de Base. Gaceta Oficial de Bolivia, La Paz, 9 sept. 1994a.

BOLIVIA. Decreto Supremo no. 24.963, del 20 de febrero de 1998. Gaceta Oficial de Bolivia, La Paz, 16 marzo 1998.

BOLIVIA. Decreto ley no. 16.562, del 13 de junio de 1979. Decreto ley de control de sustancias peligrosas. Gaceta Oficial de Bolivia, La Paz, 13 jun. 1979.

BOLIVIA. Ley de 28 de noviembre de 1906. Ley de Dominio y Aprovechamiento de Aguas. Gaceta Oficial de Bolivia, La Paz, 28 nov. 1906.

BOLIVIA. Ley no. 1.544, del 21 de marzo de 1994. Ley de capitalización. Gaceta Oficial de Bolivia, La Paz, 21 marzo 1994b. Disponível em: <http://www.aguabolivia.org/legisaguasX/Leyes/LEYCAPITALIZACION.htm>. Acesso em: 29 jul. 2009. 
BOLIVIA. Ley no. 1.551, del 20 de abril de 1994. Ley de participación popular. Gaceta Oficial de Bolivia, La Paz, 20 abr. 1994c. Disponível em: <http://www.congreso.gov.bo/leyes/1551.htm>. Acesso em: 13 maio 2009.

BOLIVIA. Ley no. 1.600, del 28 de octubre de 1994. Ley del Sistema de Regulación Sectorial (SIRESE). Gaceta Oficial de Bolivia, La Paz, 28 oct. 1994d. Disponível em: <http://www.bvsde.paho.org/bvsacd/cd22/legislacion/ley_sirese.pdf>. Acesso em: 16 jun. 2008.

BOLIVIA. Ley no. 1.654, del 28 de julio de 1995. Ley de descentralización administrativa y reglamentos. Gaceta Oficial de Bolivia, La Paz, 28 jul. 1995. Disponível em: <http://www.oas.org/juridico/spanish/blv_res43.pdf>. Acesso em: 21 jul. 2009.

BOLIVIA. Ley no. 2.028, del 28 de octubre de 1999. Ley de municipalidades. Gaceta Oficial de Bolivia, La Paz, 28 oct. 1999a. Disponível em: $<$ http://www.sigma.gov.bo/PDF_ppto/fpr2005_ley2028.pdf>. Acesso em: 12 ago. 2009.

BOLIVIA. Ley no. 2.029, del 29 de octubre de 1999. Ley de servicios de agua potable y alcantarillado sanitario. Gaceta Oficial de Bolivia, La Paz, 29 oct. 1999b. Disponível em: <http://www.congreso.gov.bo/leyes/2029.htm>. Acesso em: 12 ago. 2009.

BOLIVIA. Ley no. 2.066, del 11 de abril de 2000. Ley de Servicios de Agua Potable y Alcantarillado Sanitario. Gaceta Oficial de Bolivia, La Paz, 11 abr. 2000. Disponível em: <http://www.aguabolivia.org/legisaguasX/Leyes/LEYAGUAPOTAB.htm>. Acesso em: 13 set. 2009.

BOLIVIA. Ley no. 2.235, del 31 de julio de 2001. Ley del dialogo nacional 2000. Gaceta Oficial de Bolivia, La Paz, 31 jul. 2001. Disponível em: <http://www.sigma.gov.bo/PDF_ppto/fpr2005_ley2235.pdf>. Acesso em: 21 jul. 2009.

BOSCOVICH, Nicolas. Pensamiento geopolítico brasileño: Travassos, Golbery, Meira Matos. Geopolítica, v. 34, p. 37-44, 1986.

BRAUDEL, Fernand. Gramática das civilizações. 3. ed. Tradução Antonio de Pádua Danesi. São Paulo: Martins Fontes, 2004.

BRAUDEL, Fernand. La méditerranée et le monde méditerraneén à l'époque de Philippe II. Paris: Armand Colin, 1976. 
BRECHER, Michael; WILKENFELD, Jonathan. A study of crisis. Ann Arbor: University of Michigan Press, 1997.

BROWN. Lester. Redefining national security. Worldwatch Paper, Washington, DC, no. $14,1977$.

BROWN, Neville. The geography of human conflict: approaches to survival. Eastbourne: Sussex Academic Press, 2008.

BUHAUG, Halvard; GATES, Scott. The geography of civil war. Journal of Peace Research, London, v. 39, no. 4, p. 417-433, 2002.

BUSTAMANTE, Rocio. La guerra del agua o la resistencia contra el intento de privatización y tarifación del agua en Cochabamba, Bolivia. Santiago: Global Water Partnership, South American Technical Advisory Committee, 2002.

CALOW, Roger; MacDONALD, Alan; NICOL, Alan; ROBINS, Nick; KEBEDE, S. The struggle for water: drought, water security and rural livelihoods. Keyworth: Natural Environment Research Council, 2002. (British Geological Survey, Groundwater Systems and Water Quality Programme, Commissioned Report CR/02/226N). Disponível em: <http://www.odi.org.uk/resources/download/2970.pdf>. Acesso em: 16 jun. 2008.

CAMACHO B., Natalia. El conflicto del agua según sus protagonistas. Conflictos, Cochabamba, v. 3, no. 6, p. 25-26, 2000.

CAMARGO, Alfredo José Cavalcanti Jordão de. Bolívia: a criação de um novo país a ascensão do poder político autóctone das civilizações pré-colombianas a Evo Morales. Brasília, DF: Fundação Alexandre de Gusmão, 2006.

CANGUILHEM, Georges. La connaissance de la vie. Paris: Librairie Philosophique J. Vrin, 1985.

CAPRA, Fritjof. O ponto de mutação: a ciência, a sociedade e a cultura emergente. Tradução Álvaro Cabral. São Paulo: Cultrix, 1982.

CECEÑA, Ana Ester. La guerra por el agua y por la vida. Buenos Aires: Ediciones Madres de Plaza de Mayo. (Colección En Movimiento).

CEDIB. Centro de Documentación e Información Bolivia. Datos de la gestión de los recursos naturales no renovables de Bolivia. La Paz, 2005. 
CEDIB. Centro de Documentación e Información Bolivia. La absurda guerra de la coca. In: ALBÓ, Xavier; BARRIOS, Raúl. (Coord.). Violencias encubiertas en Bolivia. Coca, vida cotidiana y comunicación. v. 2. La Paz: CIPCA, 1993. p. 177190.

CEDIB. Centro de Documentación e Información Bolivia. "30 dias" de noticias. Cochabamba, 2000.

CERES. La Guerra del Agua. Conflictos, Cochabamba, v. 3, no. 6, 2000.

CHILD, Jack. South American geopolitics and Antarctica. In: KELLY, Philip; CHILD, Jack. Geopolitics of the Southern Cone and Antarctica. Boulder: Lynne Rienner Publishers, 1988. p. 187-202.

CHRISTOFOLETTI, Antônio. Impactos no meio ambiente ocasionados pela urbanização no mundo tropical. In: SOUZA, Maria Adélia de; SANTOS, Milton; SCARLATO, Francisco Capuano; ARROYO, Mônica (Org.). Natureza e sociedade de hoje: uma leitura geográfica. São Paulo: Hucitec, Anpur, 1994. p. 127-138.

CIDADE, Lúcia Cony Faria. Visões de mundo, visões da natureza e a formação de paradigmas geográficos. Terra Livre, São Paulo, n. 17, p. 99-118, 2001. Disponível em:

<http://www.geoambiente.ufba.br/Arquivos\%20extras/Textos/Vis\%C3\%B5es\%20de \%20mundo\%20Vis\%C3\%B5es\%20de\%20Natureza.pdf>. Acesso em: 11 fev. 2008.

CLARK, Margareth L. Cooperation on ice: the potential of collaboration in the Southern Cone. In: KELLY, Philip; CHILD, Jack. Geopolitics of the Southern Cone and Antarctica. Boulder: Lynne Rienner Publishers, 1988. p. 203-213.

CLAUSEWITZ, Carl Philipp von. Da guerra: a arte da estratégia. Tradução Pilar Satierra. São Paulo: Tahyu, 2005.

CLAVAL, Paul. Espaço e poder. Tradução Waltemir Dutra. Rio de Janeiro: Zahar, 1979.

CLAVAL, Paul. Geographie humaine et économique contemporaine. Paris : Presses Universitaires de France, 1984.

CODAPO. Comité de Agua Potable de Barrios Unidos. Gestion de Água en la OTB Barrios Unidos. Cochabamba, 2006. 
COHEN, Saul Bernard. Geography and politics in a divided world. London: Methuen \& Company, 1964.

COLIN, Peter H. Dictionary of environment and ecology. $5^{\text {th }}$ ed. London: Bloomsbury, 2004.

COLLIER, Paul; HOEFLER, Anke. Über die Ökonomischen Ursachen von Bürgerkriegen. In: ALBRECHT, H. J.; ENTORF, H. (Org.). Kriminalität, Ökonomie und Europäischer Sozialstaat. Heidelberg: Physica Verlag, 2003. p. 241-270.

Disponível em: <http://www.bernhard-wieser.de/buergerkriege.html>. Acesso em: 22 set. 2009.

COLLINS, Randall. Conflict sociology: toward an explanatory science. New York: Academic Press, 1975.

CONDORETTY, Valentín Raúl Quinteros. Asentamientos humanos en el Parque Nacional Tunari: Trabajo de verano en Bolivia. Ginebra: Fundación Simón I. Patiño, 2003. Disponível em: <http://www.cesip.org/es/enlaces-

bdd/trabajos/bolivia/2003/quinteros_parquetunari.pdf>. Acesso em: 12 ago. 2009.

CONTI, José Bueno. A geografia física e as relações sociedade/natureza no mundo tropical. 2. ed. São Paulo: Humanitas-FFLCH, 2002.

COOLEY, John K. The war over water. Foreign Policy, Washington, DC, no. 54, p. 3-26, 1984.

CÓRDOVA, Eduardo. El conflicto municipal de 1992 en Cochabamba. No rebuznaron en balde el uno y el otro alcalde. In: CERES-FORHUM. Crisis en el desarrollo local. Conflictos políticos, desastres y protestas sociales en municipios de Cochabamba, compilador. Cochabamba, 2001. p. 3-38.

COSANDEY, Claude; ROBINSON, Mark. Hidrologie continentale. Paris: Armand Colin, 2000.

COSER, Lewis. The functions of social conflict. New York: The Free Press, 1956.

COSGROVE, William J. (Org.) Water security and peace. Paris: UNESCO, Green Cross International, 2003. (Technical Documents in Hydrology. 29).

COSTA, Wanderley Messias da. Geografia política e geopolítica: discursos sobre o território e o poder. 2. ed. rev. São Paulo: EDUSP, 2008. 
COTTLE, Patrícia; RUIZ, Carmen Beatriz. La violenta vida cotidiana. In: ALBÓ, Xavier; BARRIOS, Raúl. (Coord.). Violencias encubiertas en Bolivia. Coca, vida cotidiana y comunicación. v. 2. La Paz: CIPCA, 1993. p. 81-189.

COURIVAUD, Alix. Relaciones entre las organizaciones comunitarias de abastecimiento de agua con empresas municipales y el Estado en zonas periurbanas de América Latina. Aplicación al caso de Cochabamba. [s.I.]: NEGOWAT, 2005. (Documento de Trabajo, no. 7). Disponível em:

$<$ http://www.negowat.org/Docs4Web/Bolivia_pdf/07_Bolivia.pdf>. Acesso em: 7 ago. 2008.

COUTO E SILVA, Golbery do. Geopolítica do Brasil. Rio de Janeiro: José Olympio, 1967.

COX, Kevin R. Conflict, power, and politics in the city: a geographic view. New York: McGraw-Hill, 1970.

COX, Kevin R. Redefining "territory". Political Geography Quarterly, Oxford,v. 10, no. 1, p. 5-7, 1991.

CRESPO, Carlos. Continuidad y ruptura: la "guerra del agua" y los nuevos movimientos sociales en Bolivia. Observatorio Social de America Latina, Buenos Aires, v. 2, no. 9, p. 21-28, 2000a. Disponível em:

<http://bibliotecavirtual.clacso.org.ar/ar/libros/osal/osal2/bolivia.pdf>. Acesso em: 15 maio 2008.

CRESPO, Carlos. Los actores estatales el la "Guerra del Agua". Conflictos, Cochabamba, v. 3, no. 6, p. 10-11, 2000b.

CRESPO, Carlos; FERNÁNDEZ, Omar. Estado, movimientos sociales y recursos hídricos: presión social y negociación luego de la guerra del agua de Cochabamba. Cochabamba: CESU, UMSS, 2004.

CRESPO, Carlos; FERNÁNDEZ, Omar. Los campesinos regantes de Cochabamba en la guerra del agua: una experiencia de presión social y negociación. Cochabamba: CESU/FEDECOR, 2001.

CRESPO, Carlos; FERNÁNDEZ, Omar; PEREDO, Carmen. Los regantes de Cochabamba en la guerra del agua. Cochabamba: CESU, UMSS, 2004.

CRESPO, Carlos; HALKYER ORELLANA, René. Conflictos ambientales (dos casos: água y território). Cochabamba: CERES, 1999. 
CROSBY, Alfred. O imperialismo ecológico: a expansão biológica da Europa: 900 1900. Tradução José Augusto Ribeiro e Carlos Afonso Malferrari. 1. ed., São Paulo: Companhia das Letras, 1993.

CUBA, Jorge. Gestion de l'eau: I'eau privée enflamme la Bolivie. Le Courrier de I'UNESCO, Genève, v. 52, n. 12, p. 12-13, 2000.

CUNHA, Sandra Batista; GUERRA, Antônio José Teixeira. A questão ambiental: diferentes abordagens. Rio de Janeiro: Bertrand Brasil, 2003.

DALBY, Simon. Environmental security. Minneapolis: Minnesota University Press, 2002.

DAROCA OLLER, Santiago. La guerra del agua. Protesta y acción social en Cochabamba. Fernando Molina: Programa de Naciones Unidas para el Desarrollo (PNUD), 2001. (Cuadernos de Trabajo). Disponível em: <http://idh.pnud.bo/webportal/LinkClick.aspx?fileticket=mBOLxkPVhZQ=>. Acesso em: 7 ago. 2008.

DAVIES, James Chowning. Perspectivas biológicas do conflito humano. In: GURR, Ted Robert. Manual do conflito político. Tradução Inéa Fonseca. Brasília, DF: Editora da Universidade de Brasília, 1985. p. 35-87.

DE LA FUENTE, Manuel. La guerra por el agua en Cochabamba. Crónica de una dolorosa victoria.Documentos de Reflexión Académica, Cochabamba, no. 15, 2000. Disponível em:

<http://www.umss.edu.bo/Academia/Centros/Ceplag/AguaMDLF.PDF>. Acesso em: 13 ago. 2008.

DESCARTES, René. Discurso sobre o método para bem conduzir a própria razão e procurar a verdade nas ciências. 2. ed. Tradução Jacob Guinsburg e Bento Prado Júnior. São Paulo: Difel, 1973.

DEUDNEY, Daniel H. Bringing nature back in: geopolitical theory from the Greeks to the global era. In: DEUDNEY, Daniel H.; MATTHEW, Richard Anthony. Contested grounds: security and conflict in the new environmental politics. New York: State University of New York, 1999. p. 25-57.

DEUTSCH, Karl. Política e governo. Pensamento político. Tradução Maria José Matoso Miranda Mendes. 2. ed. Brasília, DF: UNB, 1983. 
DE VILLIERS, Marq. Water: the fate of our most precious resource. New York: Mariner Book, 2001.

DIAMOND, Jared. Collapse: how societies choose to fail or succed. New York: Viking Penguin, 2005.

DIAMOND, Jared. Guns, germs and steel. A short history of everybody for the last 13,000 years. New York: W. W. Norton and Company, 1999.

DIEGUES, Antônio Carlos. O mito moderno da natureza intocada. 3. ed. São Paulo: Hucitec, NUPAUB, 2001.

DOMINGUEZ, Idoia; JIMENEZ, Mónica. Actores, demandas y medidas. Conflictos, Cochabamba, v. 3, no. 6, p. 6-9, 2000.

DUNLAP, Riley E.; CATTON Jr., William R. Toward an ecological sociology: the development, current status, and probable future of environmental sociology. The Annals of the International Institute of Sociology, Paris, New Series, v. 3, p. 263284, 1992/93.

DUNKERLEY, James. Rebellion in the veins: political struggle in Bolivia 1952-1982. London: Verso, 1984.

ECKSTEIN, Harry. Abordagens teóricas para explicar a violência política coletiva. In: GURR, Ted Robert. Manual do conflito político. Tradução Inéa Fonseca. Brasília, DF: Editora da Universidade de Brasília, 1985. p. 159-271.

ELHANCE, Arun P. Hydropolitics in the third world: conflict and cooperation in international river basins. Washington, DC: United States Institute of Peace Press, 1999.

EPSAS arrastra la herencia de las gestiones privadas. La Razon, La Paz, julio 10, 2009. (Edición Digital). Disponível em: <http://www.larazon.com/versiones/20090710_006784/nota_257_842830.htm>. Acesso em: 22 set. 2009.

ESTY, Daniel C.; GOLDSTONE, Jack A.; GURR, Ted Robert; HARFF, Barbara; LEVY, Marc; DABELKO, Geoffrey D.; SURKO, Pamela T.; UNGER, Alan N. State Failure Task Force Report: phase II findings. Environmental Change \& Security Project Report, Washington, DC, v. 5, p. 49-72, 1999. Disponível em: <http://www.wilsoncenter.org/events/docs/phase2.pdf>. Acesso em: 7 ago. 2008. 
FAGAN, Brian M. Floods, famines and emperors: el Niño and the fate of nations. New York: Basic Books, 1999.

FALK, Richard. This endangered planet: prospects and proposals for human survival. New York: Random House, 1971.

FALKENMARK, Malin. Middle East hydropolitics: water scarcity and conflict in the Middle East. AMBIO, Lawrence, v. 18, no. 6, p. 350-352, 1989. Disponível em: <http://www.popline.org/docs/0974/074960.html>. Acesso em: 4 fev. 2008.

FAO. FOOD AND AGRICULTURE ORGANIZATION. New dimensions in water security: water, society and ecosystem services in the $21^{\text {st }}$ century. Rome, 2000.

FARTHING, Linda; KOHL, Benjamin. Conflicting agendas: the politics of development aid in drug-producing areas. Development Policy Review, London, v. 23, no. 2, p. 183-198, 2005.

FAZENDA, Ivani Catarina Arantes. Interdisciplinaridade: história, teoria e pesquisa. São Paulo: Papirus, 1994.

FEITELSON, Eran. Implications of shifts in the Israeli water discourse for IsraeliPalestinian water negotiations. Political Geography, Oxford, v. 21, no. 3, p. 293318, 2002.

FERREIRA, Aurélio Buarque de Holanda. Miniaurélio: o minidicionário da língua portuguesa. 6. ed. Curitiba: Positivo, 2004.

FLINT, Colin. Introduction to geopolitics. London: Routledge, 2006.

FLINT, Colin; TAYLOR, Peter J. Political geography : world-economy, nation-state and locality. 4.ed. London: Prentice Hall, 2000.

FONT, Joan Nogué ; RUFI, Joan Vicente. Geopolítica, identidad y globalization, Barcelona: Ariel Geografía, 2001.

FOUCAULT, Michel. Em defesa da sociedade. Tradução Maria Ermantina Galvão. São Paulo: Martins Fontes, 2005. 
FOUCAULT, Michel. Histoire de la sexualité: la volonté de savoir. v. I. Paris: Galimard, 1976.

FRASER,Leah. Related environment and security research. In: MATTHEW, Richard A.; FRASER, Leah. Global environmental change and human security: conceptual and theoretical issues. Irvine: Global Environmental Change and Human Security Program Office, University of California, 2002. p. 15-29. Disponível em: $<$ http://www.auswaertiges-amt.de/diplo/de/Aussenpolitik/ForumGF/17-GF/17-GFMatthew.pdf>. Acesso em: 15 mar. 2009.

FROMM, Erich. Violence. Tuebingen: The Literary Estate of Erich Fromm, 2004.

FUKS, Mário. Conflitos ambientais no Rio de Janeiro: ação e debate nas arenas públicas. Rio de Janeiro: UFRJ, 2001.

FUKUYAMA, Francis. O fim da história e o último homem. Tradução Aulyde S. Rodrigues. Rio de Janeiro: Rocco, 1992.

FUNDACIÓN MILENIO. Informe de Milenio sobre el acontecer político em Bolívia no. 3. La Paz, 2001.

GALEANO, Eduardo. As veias abertas da América Latina. 30. ed. Tradução Galeno de Freitas. Rio de Janeiro: Paz e Terra, 1990.

GALLAND, Franck. L'eau. Géopolitique, enjeux, stratégies. Paris: CNRS, 2008.

GALTUNG, Johan. A structural theory of imperialism. Ten years later. Millennium: Journal of International Studies, London, v. 9, no. 3, p. 181-196, 1980.

GALTUNG, Johan; JACOBSEN, Carl G.; BRAND-JACOBSEN, Kai Frithjof. Searching for peace: the road to transcend. $2^{\text {nd }}$ ed. London: Pluto, 2002.

GARCÍA, Alberto Orellana; GARCÍA, Fernando Yapur; QUITÓN, Luz Herbas. La "guerra del agua". Abril de 2000: La crisis de la política en Bolivia. La Paz: Fundación PIEB, 2003.

GEIGER, Pedro Pinchas. Regiões fronteira no Brasil. Anuário do Instituto de Geociências, Rio de Janeiro, v. 17, p. 53-64, 1994. 
GEOBOL. SERVICIO GEOLÓGICO DE BOLIVIA. Mapa geológico de Bolivia. La Paz, 1992.

GEOBOL. SERVICIO GEOLÓGICO DE BOLIVIA. Mapa geológico de lós valles de Cochabamba. La Paz, 1998.

GEORGE, Pierre. Os métodos da geografia. Tradução Liliana Lagana Fernandes. 2. ed. São Paulo:Difel, 1986.

GEUENS, Geoffrey. Tous pouvoirs confondus. Etat, capital et médias à l'ère de la mondialisation. Anvers: EPO, 2003.

GIBLIN, Béatrice. L'eau: une question géopolitique, en France aussi. Hérodote, Paris, n. 110, p. 9-28, 2003. Disponível em: <http://www.cairn.info/article.php?ID_ARTICLE=HER_110_0009>. Acesso em: 5 mar. 2009.

GIDDENS, Anthony. A constituição da sociedade. 2. ed. Tradução Álvaro Cabral. São Paulo: Martins Fontes, 2003.

GIDDENS, Anthony. Dualidade da estrutura. Agência e estrutura. Tradução Octávio Gameiro. 1. ed. Oiras: Celta Editora, 2000.

GIZEWSKI, Peter; HOMER-DIXON, Thomas F. The case of Pakistan. In: HOMERDIXON, Thomas F.; BLITT, Jessica (Ed.). Ecoviolence: links among environment, population, and security. Lanham: Rowman \& Littlefield Publisher, 1998. p. 147-200.

GLEDITSCH, Nils Petter. Armed conflict and the environment: a critique of the literature. Journal of Peace Research, London, v. 35, no. 3, p. 381-400, 1998.

GLEDITSCH, Nils Petter. Environmental conflict and the democratic peace. In: GLEDITSCH, Nils Petter (Org.). Conflict and the environment. Dordrecht: Kluwer, 1997. p. 91-106.

GLEDITSCH, Nils Petter. Resource and environmental conflict: the state-of-the-art. In: PETZOLD-BRADLEY, Eileen; CARIUS, Alexander; VINCZE, Arpád. (Ed.). Responding to environmental conflicts: implications for theory and practice. Dordrecht: Kluwer Academic Publishers, 1999. p. 53-66. (NATO Science Series, 2. Environmental Security, v. 78). Disponível em: $<$ http://books.google.com.br/books?id=U8EGXIWjx8sC\&pg=PA53\&lpg=PA53\&dq=R esponding+to+environmental+conflicts:+implications+for+theory+and+practice\&sourc e=bl\&ots=n6kSutSDCG\&sig=190bQ8NuBpMtd_GSqaQuvQuw-hM\&hl=pt- 
BR\&ei=wyS9SsOMH4fjIAe47uhd\&sa=X\&oi=book_result\&ct=result\&resnum=1\#v=one page \&q=\&f=false>. Acesso em: 11 set. 2009.

GLEDITSCH, Nils Petter; FURLONG, Kathryn; HEGRE, Havard; LACINA, Bethany; OWEN, Taylor. Conflict over shared rivers: resource scarcity or fuzzy boundaries. Political Geography, Oxford, v. 25, no. 4, p. 361-382, 2006.

GLEICK, Peter H. Water and conflict: fresh water resources and international security. International Security, Cambridge, v. 18, no. 1, p. 79-112, 1993.

GLEICK, Peter H. Water conflict chronology. Database on water and conflict (water brief). Oakland: Pacific Institute for Studies in Development, Environment, and Security, 2008. Disponível em: <http://www.worldwater.org/conflictchronology.pdf>. Acesso em: 31 maio 2009.

GOLDSTEIN, Daniel M. Flexible justice: neoliberal violence and 'self-help' security in Bolivia. Critique of Anthropology, London, v. 25, no. 4, p. 389-411, 2005.

GOLDSTEIN, Daniel M. The spectacular city: violence and performance in urban Bolivia. Durham: Duke University Press, 2004.

GOLDSTONE, Jack A.; GURR, Ted Robert; HARFF, Barbara; LEVY, Marc A.; MARSHALL, Monty G.; BATES, Robert H.; EPSTEIN, David L.; KAHL, Colin H.; SURKO, Pamela T.; ULFEDER, John C.; UNGER, Alan N.; CHRISTENSON, Matthew; DABELKO, Geoffrey D.; ESTY, Daniel C.; PARRIS, Thomas M. State Failure Task Force Report: phase III findings. McLean: Science Applications International Corporation, 2000. Disponível em:

$<$ http://www.cidcm.umd.edu/publications/publication.asp?pubType=paper\&id=9>. Acesso em: 25 ago. 2009.

GOMES, Paulo Cesar da Costa. Geografia e modernidade. Rio de Janeiro: Bertand Brasil, 1996.

GONÇALVES, Carlos Walter Porto. Os (des)caminhos do meio ambiente. São Paulo: Contexto, 1989.

GOTTMANN, Jean. La politique des états et leur géographie. Paris: Armand Colin, 1952

GOTTMANN, Jean. The evolution of the concept of territory. Social Science Information, London, v. 14, no. 3-4, p. 29-47, 1975. 
GREENBERG, James B.; PARK, Thomas K. Political ecology. Journal of Political Ecology, Tucson, v. 1, no. 1, p.1-12, 1994. Disponível em:

<http://jpe.library.arizona.edu/volume_1/FOREWARD.PDF>. Acesso em: 12 jul. 2009.

GRUENBERGER, Jenny. Conflictos ambientales en Bolivia: miradas, voces y sonidos. La Paz: FOBOMADE, OLCA, 1999.

GUGLIALMELLI, Juan Enrique. Corpus-Itaipu: Três batallas perdidas por la Argentina y ahora peligrosas perspectivas: el papel de sócio menor del Brasil. Estrategia, Buenos Aires, v. 61-62, p. 7-29, 1979-1980.

GURR, Ted Robert. Das conseqüências do conflito violento. In: GURR, Ted Robert. Manual do conflito político. Tradução Inéa Fonseca. Brasília, DF: Editora da Universidade de Brasília, 1985. p. 273-333.

GWP. GLOBAL WATER PARTNERSHIP. Towards water security: a framework for action. Stockholm: GWP, 2000.

HABERMAS, Jürgen. The legitimation crisis. London: Heinemann, 1980.

HAESBAERT, Rogério. O mito da desterritorialização. Do "fim dos territórios" à multiterritorialidade. 2. ed. Rio de Janeiro: Bertrand Brasil, 2006.

HAGMANN, Tobias. Confronting the concept of environmentally induced conflict. Peace, Conflict and Development, Bradford, no. 6, p. 1-22, 2005.

HANNIGAN, John A. Environmental sociology: a social constructionist perspective. London: Routledge, 1995.

HARTMANN, Betsy. Will the circle be unbroken? A critique of the project on environment, population and security. In: PELUSO, Nancy Lee; WATTS, Michael. (Ed.). Violent environments. Ithaca: Cornell University Press, 2001. p. 39-62.

HARTSHORNE, Richard. Perspectives on the nature of geography. Washington, DC: Association of American Geographers, 1966.

HARTSHORNE, Richard. The concepts of raison d'être and maturity of states. Annals of the Association of American Geographers, Washington, DC, v. 30, p. 59-60, 1940. 
HARTSHORNE, Richard. The functional approach in political geography. Annals of the Association of American Geographers, Washington, DC, v. 40, no. 2, p. 95130, 1950.

HARVEY, David. Justice, nature and the geography of difference. Oxford: Blackwell, 1996.

HAUGE, Wenche; ELLINGSEN, Tanja. Beyond environmental scarcity: causal pathways to conflict. Journal of Peace Research, London, v. 35, no. 3, p. 299-317, 1998.

HELFERICH, Christoph. História da filosofia. Tradução Luiz Sérgio Repa, Maria Estela Heider Cavalheiro e Rodnei do Nascimento. ed. São Paulo: Martins Fontes, 2006.

HERBAS CAMACHO, Gabriel F. Cochabamba y la nueva conciencia sobre el Agua. Cochabamba: FOBOMADE, 2001.

HERBAS, Monica; LIZÁRRAGA, Alberto. Conflicto político en el municipio de Puerto Villarroel. Ensayos Forhum, Cochabamba, no. 14, p. 39-58, 2001.

HERMANN, Jonathan G.; ROBIOU, Grace M. Water security research and policy: EPA's water security research and technical support action plan. Journal of Contemporary Water Research and Education, Carbondale, no. 129, p. 3-7, 2004. Disponível em: <http://www.ucowr.siu.edu/updates/129/Herrmann.pdf>. Acesso em: 6 abr. 2008.

HOEKSTRA, Arjen Y.; CHAPAGAIN, Ashok K. Water footprints of nations: water use by people as a function of their consumption pattern. Water Resources Management, v. 21, no. 1, p. 35-48, 2007. Disponível em: $<$ http://www.waterfootprint.org/Reports/Hoekstra_and_Chapagain_2007.pdf>. Acesso em: 13 jul. 2009.

HOEKSTRA, Arjen Y., HUNG, Pham Q. Globalization of water resources: international virtual water flows in relation to crop trade. Global Environmental Change, Guildford, no. 15, p. 45-56, 2005. Disponível em: <http://www.waterfootprint.org/Reports/Hoekstra_Hung_\%282005\%29.pdf>. Acesso em: 20 nov. 2008.

HOMER-DIXON, Thomas F. Environmental change and violent conflict. American Academy of Arts and Sciences, Cambridge, occasional paper, 1990. 
HOMER-DIXON, Thomas F. Environment, scarcity, and violence. Princeton: Princeton University Press, 1999.

HOMER-DIXON, Thomas. The ingenuity gap: can poor countries adapt to resource scarcity? Population and Development Review, New York, v. 21 no. 3, p. 587-612, 1995.

HOMER-DIXON, Thomas F.; BLITT, Jessica (Ed.). Introduction: A theoretical Overview. In: HOMER-DIXON, Thomas F.; BLITT, Jessica (Ed.). Ecoviolence: links among environment, population, and security. Lanham: Rowman \& Littlefield Publisher, 1998. p. 1-17.

HOWARD, Guy; BARTRAM, Jamie. Domestic water quantity, service level and health. Geneva: World Health Organization, 2003. Disponível em:

$<$ http://www.who.int/water_sanitation_health/diseases/WSH03.02.pdf>. Acesso em: 13 set 2008.

HOWARD, Philip; HOMER-DIXON, Thomas F. The case of Chiapas, Mexico. In: HOMER-DIXON, Thomas F.; BLITT, Jessica (Ed.). Ecoviolence: links among environment, population, and security. Lanham: Rowman \& Littlefield Publisher, 1998. p. 19-66.

INE. INSTITUTO NACIONAL DE ESTADÍSTICA. Censo nacional de población y vivienda. La Paz, 2001a.

INE. INSTITUTO NACIONAL DE ESTADÍSTICA. Censo sociodemografico por ciudades capitales. La Paz, 2001b.

INE. INSTITUTO NACIONAL DE ESTADÍSTICA. Cochabamba: Producto Interno Bruto, según actividad económica, 1988-2007. La Paz, 2007.

INE. INSTITUTO NACIONAL DE ESTADÍSTICA. Cochabamba: resultados departamentales. La Paz, 2002a. (Serie II, Resultados departamentales, 3).

INE. INSTITUTO NACIONAL DE ESTADÍSTICA. Departamento de Cochabamba. Estadísticas e indicadores sociodemográficos, productivos y financieros por município. La Paz, 2005.

INE. INSTITUTO NACIONAL DE ESTADÍSTICA. Encuesta nacional de cobertura. Censo nacional de población y vivienda. La Paz, 2002b. (Serie III, Metodologías y proyecciones, 2). 
INE. INSTITUTO NACIONAL DE ESTADÍSTICA. Mapa de pobreza 2001: Cochabamba. La Paz, 2001c.

IRIARTI, Gregório. Análisis crítico de la realidad: compendio de datos actualizados. 15. ed. Cochabamba: Kipus, 2005.

JACKSON, Robert H. Regional markets and agrarian transformation in Bolívia: Cochabamba 1539-1960. Albuquerque: University of New Mexico Press, 1994.

JETTÉ, Christian; ROJAS, Rafael. Cochabamba: pobreza, genero y medio ambiente. La Paz: Embajada Real de los Paises Bajos, 1998.

JOHNSTON, Ron J.; GREGORY, Derek; SMITH, David M. Dictionary of human geography. $4^{\text {th }}$ ed. Oxford: Blackwell Publishers, 1994.

JOLLIVET, Marcel; PAVÉ, Alain. O meio ambiente: questões e perspectivas para a pesquisa. In: VIEIRA, Paulo Freire; WEBER, José (Org.). Gestão de recursos naturais renováveis e desenvolvimento: novos desafios para a pesquisa ambiental. Tradução Anne Sophie de Pontbriand Vieira e Chistilla de Lassus. 3. ed. São Paulo: Cortez, 2002. p. 53-112.

JONES, Stephen. A unified field theory of political geography. Annals of the Association of American Geographers, Washington, DC, v. 49, no. 2, p. 111-123, 1954.

KAPLAN, Robert. À beira da anarquia: destruindo os sonhos da era pós-guerra fria. Tradução Carlos Henrique Trieschmann. São Paulo: Editora Futura, 2000.

KELLY, Kimberley; HOMER-DIXON, Thomas F. The case of Gaza. In: HOMERDIXON, Thomas F.; BLITT, Jessica (Ed.). Ecoviolence: links among environment, population, and security. Lanham: Rowman \& Littlefield Publisher, 1998. p. 67-108.

KELLY, Philip; P. Escalation of regional conflict: testing the shatterbelt concept. Political Geography Quarterly, Oxford, v. 5, no. 2, p. 161-180, 1986.

KLARE, Michael T. Resource wars: the new landscape of global conflict. New York: Owl Books, 2002.

$\mathrm{KOHL}$, Benjamin. Challenges to neoliberal hegemony in Bolivia. Antipode, v. 38, no. 2, p. 304-326, 2006. 
$\mathrm{KOHL}$, Benjamin. Privatization Bolivian style: a cautionary tale. International Journal of Urban and Regional Research, London, v. 28, no. 4, p. 893-908, 2004.

KOHL, Benjamin. Stabilizing neoliberalism in Bolívia: popular participation and privatization. Political Geography, Oxford, v. 21, no. 4, p. 449-472, 2002.

KOHL, Benjamin; FARTHING, Linda. The price of success. Bolivia's war against drugs and the poor. NACLA Report on the Americas, New York, v. 35, no. 1, p. 3551, 2001. Disponível em:

<http://www.temple.edu/gus/kohl/documents/Kohlfarthingcocanacla2001.pdf>. Acesso em: 5 out. 2009.

KRUSE, Thomas; RAMOS, Cecilia. Bolivia, water and privatisation: doubtful benefits, concrete threats. Montevideo: The Third World Institute, 2003.

KRUSE, Thomas; VARGAS, Humberto. Las victorias de abril. Una historia que aún no concluye. Ensayos Forhum, Cochabamba, n. 14, p. 73-87, 2001.

LACOSTE, Yves. A geografia : isso serve em primeiro lugar para fazer a guerra. Tradução Maria Cecília França. Campinas: Papirus, 1988.

LACOSTE, Yves. El agua. La lucha por la vida. Tradução Gloria Roset Arissó. Barcelona: Larouse, 2003. (Colección Larouse El Mundo Contemporáneo).

LACOSTE,Yves. Géopolitique de l'eau. Hérodote, Paris, n. 102, p. 3-18, 2001.

Lacoste, Yves. Países subdesenvolvidos. 9. ed. Tradução Diva Benevides Pinho. São Paulo: Difusão Européia do Livro, 1974.

LARSON, Brooke. Cochabamba 1550-1900. Colonialism and agrarian transformation in Bolívia. Durham: Duke University Press, 1998.

LASERNA, Roberto. 2000: conflictos sociales y movimientos políticos en Bolivia. Anuario Social y Político de América Latina y el Caribe, Caracas, no. 4, p. 61-74, 2000a. Disponível em: <http://www.nuso.org/upload/anexos/foro_418.pdf>. Acesso em: 14 ago. 2008.

LASERNA, Roberto. Cochabamba. La guerra contra el agua. Cuarto Intermedio, La Paz, no. 56, p. 36-49, 2000b. 
LASERNA, Roberto. Conflictos socio-laborales en Bolivia. Perspectiva de mediano plazo (1994-junio de 2005). In: LASERNA, Roberto; ORTEGO, Jesús; CHACÓN, Douglas. Conflictividad sociolaboral en Bolivia. Estudios y reflexiones. La Paz: Organización de los Estados Americanos, 2006. p. 78-113. (Programa Sistemas de Prevención y Resolución de Conflictos.). Disponível em:

<http://www.geocities.com/laserna_r/ConflictosSociolaborales.pdf>. Acesso em: 18 jun. 2008.

LASERNA, Roberto. La democracia en el ch'enko. La Paz: Fundación Milenio, 2004.

LASERNA, Roberto (Org.). Sostenibilidad y desarrollo humano. La calidad de vida en Cochabamba. Cochabamba: Los Amigos del Libro, CORDECO-PNUD, 1995.

LASSERRE, Frédéric; DESCROIX, Luc. Eaux et territoires. $2^{\mathrm{e}}$. éd. Quebec: Université du Quebec, 2005.

LAVAUD, Jean Pierre. Bolivie: la nation incertaine. Hérodote, Paris, n. 99, p. 161$181,2000$.

LE BILLON, Philippe. Fuelling war: natural resources and armed conflicts. New York: Oxford University Press, The International Institute for Strategic Studies, $2001 \mathrm{a}$.

LE BILLON, Philippe. The geography of "resource wars". FLINT, Colin. (Ed.). The geography of war and peace: from death camps to diplomats. New York: Oxford University Press, 2005. p. 217-241.

LE BILLON, Philippe. The political ecology of war: natural resources and armed conflicts. Political Geography, Oxford, v. 20, no. 5, p. 561-584, $2001 \mathrm{~b}$.

LEBRUN, Gérard. O que é poder. São Paulo: Brasiliense, 1981.

LECONTE, Jacques. L'eau. Paris: Presses Universitaires de France, 1998. (Collection Que sais-je?).

LEDO, Carmen. Inequality and social exclusion in the access to drinking water: the city of Cochabamba, Bolivia. In: TVEDT, Terje; COOPEY, Richard (Ed.). A history of water. The political economy of water. v. 2. London: IB Tauris, 2006. p. 59-100. 
LEDO GARCÍA, Maria del Carmen. Urbanisation and poverty in the cities of the national economic corridor in Bolivia. Case study: Cochabamba. Delft: Delft University Press, 2002.

LEDO GARCÍA, Maria del Carmen. Urbanization, productive strucuture and employment process in the national economic corridor of Bolivia. In: INTERNATIONAL CONGRESS OF THE LATIN AMERICAN STUDIES ASSOCIATION, 22., 2000, Miami. Proceedings... Miami: Latin American Studies Association, 2000. p. 1-25.

LEFF, Enrique. Epistemologia ambiental. 4. ed. São Paulo: Cortez, 2006.

LEFF, Enrique. Saber ambiental: sustentabilidade, racionalidade, complexidade, poder. Tradução Lúcia Mathilde Endlisch Ortth. Petrópolis, RJ: Vozes, 2001.

LE PRESTRE, Philippe. Ecopolítica internacional. Tradução Jacob Gorender. São Paulo: Editora SENAC, 2000.

LEVY, Mark. Time for a third wave of environment and security scholarship? In: WOODROW WILSON CENTER. Environmental change and security project report. Washington, DC, 1995. p. 44-46.

LIBISZEWSKI, Stephan. What is an environmental conflict? In: SPILLMAN, Kurt R.; BAECHLER, Günther. Environment and Conflicts Project. ENCOP Occasional Paper no. 1, Berne: Center for Security Studies, ETH/Zurich, Swiss Peace Foundation 1992.

LIDSKOG, Rolf. The re-naturalization of society? Environmental challenges for sociology. Current Sociology, London, v. 49, no. 1, p. 113-136, 2001.

LIETZMANN, Kurt M.; VEST, Gary D. Environment and security in an international context: Executive Summary Report. Brussels: NATO, 1999. (Final Report, no. 232). Disponível em: <http://www.wilsoncenter.org/topics/pubs/Report5Sect2-a.pdf>. Acesso em:9 jun. 2008.

LIPSET, Seymour Martin. Consensus and conflict: essays in political sociology. $2^{\text {nd }}$ print. New Brunswick: Transaction Publishers, 1990.

LITTLE, Paul. Os conflitos socioambientais: um campo de estudo e de ação política. In: BURSZTYN, Marcel (Org.) A difícil sustentabilidade: política energética e conflitos ambientais. Rio de Janeiro: Garamond, 2001, p. 107-122. Disponível em: $<$ http://books.google.com.br/books?id=z4HCHSBOtpEC\&pg=PA107\&lpg=PA107\&dq 
$=$ Os +conflitos+socioambientais: + um +campo+de+estudo+e+de+a\%C3\%A7\%C3\%A3 o+pol\%C3\%ADtica.\&source=bl\&ots=h1xB_4oEOt\&sig=Wj0dtrGE4dp1uymmRcfupJ2zxo\&hl=pt-BR\&ei $=1 \mathrm{H}-$

_SrunLOSB8Qa0luCwAQ\&sa $=X \&$ oi=book_result\&ct=result\&resnum $=1 \# v=$ onepage\& $\bar{q}=$ Os\%20conflitos\%20socioambientais\%3A $\% 20$ um\%20campo\%20de\%20estudo\%2 0e\%20de\%20a\%C3\%A7\%C3\%A3o\%20pol\%C3\%ADtica.\&f=false>. Acesso em: 30 ago. 2009.

LOË, Rob de. Allocation efficiency in the context of water security. In: The SciencePolicy Interface. Water and Climate Change, and the Energy-Water Nexus. Ottawa: PRI, Woodrow Wilson International Center for Scholars, 2007. Disponível em: <http://policyresearch.gc.ca/doclib/de-Loe_paper.pdf>. Acesso em: 30 jan. 2009.

LOPES, José Sérgio Leite; ANTONAZ, Diana; PRADO, Rosane; SOLVA, Gláucia (Org.). A ambientalização dos conflitos sociais: participação e controle público da poluição industrial. Rio de Janeiro: Relume Dumará, 2004.

LORES, Raul Juste. Pequim teme falta de tempo para mudar de fato. Folha de Esportes, São Paulo, Caderno Esportes, 2 mar. 2008. Disponível em: <http://www1.folha.uol.com.br/fsp/esporte/fk0203200817.htm>. Acesso em: 3 jun. 2008.

LOS BLOQUEOS se intensifican. Presencia, La Paz, 4 abr. 2000.

LOWI, Miriam R. Transboundary resource disputes and their resolution. In: DEUDNEY, Daniel H., MATTHEW, Richard A. Contested grounds: security and conflict in the new environmental poltics. Albany: State University of New York Press, 1999. p. 223-245.

LUJALA, Päivi. Classification of natural resources for conflict and growth research. In: European Consortium for Political Research Joint Session of Workshops. Edinburgh: ECPR, 2003. Disponível em: <http://www.essex.ac.uk/ECPR/events/jointsessions/paperarchive/edinburgh/ws9/Luj ala.pdf>. Acesso em: 15 mar. 2008.

LUJALA, Päivi; GLEDITSCH, Nils Petter; GILMORE, Elisabeth. A diamond curse? War and a lootable resource. Journal of Conflict Resolution, Newbury Park, v. 49, no. 4, p. 538-562, 2005.

LUKE, Timothy W. Toward a green geopolitics: politicizing ecology at the Worldwatch Institute. In: DODDS, Klaus; ATKINSON, David. (Ed.). Geopolitical traditions: a century of geopolitical thought. London: Routledge, 2000. p. 353-371. 
MALDONADO ROJAS, Gonzalo. $\mathbf{H}_{\mathbf{2}} \mathbf{O}$ : la guerra del agua. Testimonio desde la línea de fuego. La Paz: Fondo Editorial de los Diputados, 2004.

MALIK, Deepak. Sustainable water security in the Thar Desert, India: blending traditional wisdom with modern techniques. In: WATER ENGINEERING

DEVELOPMENT CENTRE (WEDC) INTERNATIONAL CONFERENCE, 33. 2008, Accra. Records... Accra: Engineering Development Centre (WEDC), 2008. p. 1-5.

MANAHAN, Stanley E. Environmental chemistry. $7^{\text {th }}$ ed. Boca Raton: CRC Press LLC, 2000.

MANN, Michael. The sources of social power. Cambridge: Cambridge University Press, 1986.

MARCONI, Marina de Andrade; LAKATOS, Eva Maria. Fundamentos de metodologia científica. 6. ed. São Paulo: Atlas, 2007.

MARCONI, Reinaldo. El drama de Chapare. La frustración del desarrollo alternativo. La Paz: CEDLA, 1998. Disponível em: <http://sala.clacso.org.ar/gsdl/cgibin/library?e=d-000-00---0cedla--00-0-0--0prompt-10---4-----0-11--1-es-50---20-about--00031-001-1-0utfZz-8-00\&cl=CL1.1\&d=HASH01fa43f3abf716e6eedc26ee \&x=1>. Acesso em: 3 jan. 2009.

MARTIN, Andre Roberto. Fronteiras e nações. São Paulo: Contexto, 1992.

MARVIN, Simon; LAURIE, Nina. An emerging logic of urban water management, Cochabamba, Bolívia. Urban Studies, Essex, v. 36, no. 2, p. 341-357, 1999.

MÁS bloqueos y no hay visos de solución. Los Tiempos, Cochabamba, 6 abr. 2000.

MATTHEW, Richard A. Environmental change and human security: concepts and definitions. In: MATTHEW, Richard A.; FRASER, Leah. Global environmental change and human security: conceptual and theoretical issues. Irvine: Global Environmental Change and Human Security Program Office, University of California, 2002a. p. 7-14. Disponível em: <http://www.auswaertigesamt.de/diplo/de/Aussenpolitik/ForumGF/17-GF/17-GF-Matthew.pdf>. Acesso em: 15 mar. 2009.

MATTHEW, Richard A. In defense of environment and security research.

Environmental Change \& Security Project Report, Washington, DC, no. 8, p. 109124, 2002b. Disponível em: 
<http://www.wilsoncenter.org/topics/pubs/Report_8_Matthew.pdf>. Acesso em: 15 mar. 2009.

MATTHEW, Richard A.; FRASER, Leah. Related environment and security research. In: MATTHEW, Richard A.; FRASER, Leah (Org.). Global environmental change and human security: conceptual and theoretical issues. Irvine: Global Environmental Change and Human Security Program Office, University of California Irvine, 2002. p. 15-29. Disponível em:

<http://www.gechs.uci.edu/gechsprdraffinal.pdf>. Acesso em: 15 mar. 2009.

MATURANA, Humberto R.; VARELA, Francisco J. A árvore do conhecimento. As bases biológicas da compreensão humana. Tradução Humberto Marioti e Lia Diskin. São Paulo: Palas Athena, 2001.

MAYORGA, René Antonio. Presidencialismo parlamentarizado y gobiernos de coalición en Bolivia. In: LANZARO, Jorge. (Org.). Tipos de presidencialismo y coaliciones politicas en América Latina. Buenos Aires: CLACSO, 2001, p. 101135. Disponível em:

$<$ http://bibliotecavirtual.clacso.org.ar/ar/libros/lanzaro/mayorga.pdf>. Acesso em: 18 fev. 2008.

MAZUREK, Hubert. Three pre-concepts regarding the internal migration in Bolivia. Revista de Humanidades y Ciências Sociales, Santa Cruz de la Sierra, v. 3, special edition, p. 1-15, 2007. Disponível em:

$<\mathrm{http}: / /$ socialsciences.scielo.org/pdf/s_rhcs/v3nse/scs_a02.pdf>. Acesso em: 23 mar. 2009.

McKENZIE, David; MOOKHERJEE, Dilip. The distributive impact of privatization in Latin America: evidence from four countries. Economía, Baltimore, v. 3, no. 2, p. 161-218, 2003.

McNEILL, John Robert. Something new under the sun: an environmental history of the twentieth century world. New York: W. W. Norton and Company, 2000.

MEDEIROS, Carmen. Civilizing the popular? The law of popular participation and the design of a new civil society in 1990s Bolívia. Critique of Anthropology, London, v. 21, n. 4, p. 401-425, 2001.

MEISSNER, Richard. Water as a source of political conflict and cooperation: a comparative analysis of the situation in the Middle East and Southern Africa. 1999. Dissertation (Master's Degree)-Department of Political Studies, Rand Afrikaans University, South Africa, 1999. 
MÉLANÇON, Simon. La guerre de l'eau de Cochabamba, Bolivie: un problème géopolitique et de territorialité. 2005. Dissertação (Mestrado em Ciências Geográficas)-Université Laval, Quebec, 2005.

MELLO, Leonel Itaussu de Almeida. Geopolítica do Brasil e a Bacia do Prata. Manaus: Editora da Universidade Federal do Amazonas, 1997.

MENDONÇA, Francisco Assis. Geografia física: ciência humana? 3. ed. São Paulo: Contexto, 1993.

MENDONÇA, Francisco de Assis. Geografia e meio ambiente. 3. ed. São Paulo: Contexto, 1998.

MENDONÇA, Francisco de Assis. Geografia socioambiental. Terra Livre, São Paulo, v. 1, n. 16, p. 113-132, 2001.

MERRET, S. Virtual water and the Kyoto consensus. A water forum contribution. IWRA, Water International, Johannesburg, v. 28, no. 4, p. 540-542, 2003.

MESA, José de; GISBERT, Teresa; MESA, Carlos Gisbert de. Historia de Bolivia. 5. ed. La Paz: Editorial Gisbert, 2003.

$\mathrm{MICH}$, Frederick C. (Ed.). Merriam-Webster's Collegiate Dictionary. $10^{\text {th }}$ ed. Springfield: Merriam-Webster, Incorporated, 1993.

MILARÉ, Edis. Direito do ambiente: doutrina - prática - jurisprudência - glossário. 2. ed. rev. e atual. São Paulo: Revista dos Tribunais, 2001.

MOLINA, Silvia. El rol de Bolivia en la integración sudamericana. In: Foro Boliviano sobre Medio Ambiente y Desarrollo (FOBOMADE). Geopolítica de los recursos naturales y acuerdos comerciales en Sudamerica. La Paz, 2005. p. 59-69. Disponível em: <observatorio.ddhh.bo.googlepages.com/FOBOMADERoldeBolivia.pdf>. Acesso em: 12 out. 2008.

MORAES, Antonio Carlos Robert. A gênese da geografia moderna. São Paulo: Hucitec, 1989.

MORAES, Antonio Carlos Robert. Geografia: pequena história crítica. 21. ed. São Paulo: Annablume, 2007. 
MORAES, Antonio Carlos Robert. Meio ambiente e ciências humanas. 4. ed. São Paulo: Annablume, 2005.

MORAES, Antonio Carlos Robert. O que é território? Revista Orientação, São Paulo, n. 5, p. 81, 1984.

MOREIRA, Ruy (Org.). Geografia. Teoria e crítica. Petrópolis, RJ: Vozes, 1982.

MORIN, Edgard. Da necessidade de um pensamento complexo. Tradução Jurema Machado da Silva. In: MARTINS, Francisco Menezes; SILVA, Jurema Machado da. Para navegar no século XXI. 3. ed. Porto Alegre: Sulina, EDIPUCRS, 2003. p. 1336. Disponível em: <http://books.google.com.br/books?id=8ol_Rd$\mathrm{d} 6 \mathrm{wC} \& \mathrm{dq}=$ para + navegar + no+s\%C3\%A9culo+xxi+\%E2\%80\%93+tecnologias +do+im agin $\% \mathrm{C} 3 \% \mathrm{~A} 1$ rio+e+cibercultura\&printsec=frontcover \&source=bl\&ots=04qLCUgglf $\&$ si $\mathrm{g}=\mathrm{ECITnpVUVTphly2Q-WhUkLC8RGc \& hl=pt-}$

$\mathrm{BR} \& \mathrm{ei}=0 \mathrm{JTjSt}$ iN8Ke8AauoYylBw\&sa=X\&oi=book_result\&ct=result\&resnum $=3 \&$ ved $=0 C B Q Q 6 A E w A g \# v=$ onepage $\& q=\& f=$ false $>$. Acesso em: 24 out. 2009.

MORIN, Edgard. Sobre la interdisciplinariedad. Tradução Josep Margarit Dalmazau. Zaragoza: Universidad de Zaragoza, 1995. p. 1-18. (Seminário Interdisciplinar).

MORIN, Edgard. O método. A natureza da natureza. v. I . 3. ed. Tradução Juremir Machado da Silva. Porto Alegre: Sulina, 2008.

MURRA, John Victor. The economic organization of the Inca State. 1956. Tese (Doutorado em Antropologia)-University of Chicago, Chicago, 1956.

MYERS, Norman. Ultimate security: the environmental basis of political stability. New York: W. W. Norton \& Company, 1993.

NASCIMENTO, Elimar Pinheiro do. Os conflitos na sociedade moderna: uma introdução conceitual. In: BURSZTYN, Marcel (Org.) A difícil sustentabilidade: política energética e conflitos ambientais. Rio de Janeiro: Garamond, 2001, p. 85105. Disponível em:

<http://books.google.com.br/books?id=z4HCHSBOtpEC\&pg=PA107\&lpg=PA107\&dq $=$ Os +conflitos +socioambientais: + um + campo+de+estudo+e+de+a\%C3\%A7\%C3\%A3 o+pol\%C3\%ADtica.\&source=bl\&ots=h1xB_4oEOt\&sig=Wj0dtrGE4dp1uymmRcfupJ2zxo\&hl=pt-BR\&ei=1H-

SrunLOSB8Qa0luCwAQ\&sa=X\&oi=book_result\&ct=result\&resnum $=1 \# \mathrm{v}=$ onepage \& q=Os\%20conflitos $\% 20$ socioambientais $\% 3 A \% 20$ um $\% 20$ campo\%20de $\% 20$ estudo\%2 0e\%20de\%20a\%C3\%A7\%C3\%A3o\%20pol\%C3\%ADtica.\&f=false>. Acesso em: 21 ago. 2009. 
NEUMANN-REDLIN, C. H. R.; RENNER, S.; TORREZ, J. Hidrogeología del Valle Central de Cochabamba, Bolivia. In: JOINT WORLD CONGRESS ON GROUNDWATER, 1., 2000, Fortaleza. Proceedings... Fortaleza: Cooperação Brasil-Canadá, 2000. p. 1-8. Disponível em:

<http://www.bgr.bund.de/nn_324630/EN/Themen/Wasser/Projektbeitraege_NIL/TZ_ Bolivia/cbba_hydro_fb_pdf,templateld=raw,property=publicationFile.pdf/cbba_h ydro_fb_pdf.pdf>. Acesso em: 5 set. 2009.

NICKSON, Andrew; VARGAS, Claudia. The limitations of water regulation: the failure of the Cochabamba concession in Bolivia. Bulletin of Latin American Research, Oxford, v. 21, no. 1, p. 99-120, 2002.

NICOLAS, Vincent; FERNÁNDEZ, Marcelo; FLORES, Elba. Modos originarios de resolución de conflictos en pueblos indígenas de Bolívia. La Paz: Fundación UNIR, Fundación PIEB, 2007. Disponível em:

<http://www.unirbolivia.org/index.php?option=com_content\&task=view\&id=225\&Itemi d=193>. Acesso em: 17 jun. 2009.

NIETZSCHE, Friedrich W. Vontade de potência. Tradução Mário Ferreira dos Santos. São Paulo: Escala, 2001.

ODUM, Eugene. Ecosystem theory In: PFAFFLIN, James R.; ZIEGLER, Edward N. Encyclopedia of environmental science and engineering. Boca Raton: Taylor and Francis, 2006. p. 260-270.

OKI, Taikan; KANAE, Shinjiro. Virtual water trade and world water resources. Water Science and Technology, Colchester, v. 49, no. 7, p. 203-209, 2004.

OLIVEIRA FILHO, José Jeremias. Patologia e regras metodológicas. Estudos Avançados, São Paulo, v. 9, n. 23, p. 263-268, 1995.

O'LOUGHLIN, John. The political geography of conflict: civil wars in the hegemonic shadow. In: FLINT, Colin. (Ed.). The geography of war and peace: from death camps to diplomats. New York: Oxford University Press, 2005. p. 85-110.

OPHULS, William; BOYAN Jr., Stephen A. Ecology and the politics of scarcity revisited: the unraveling of the American dream. Salt Lake City: W. H. Freeman \& Co, 1992.

OPSCHOOR, Johannes B. The concept of environmental security: a historical introduction. In: KOK, MARCEL T. J. (Org.). Environmental security and 
sustainable development. Bilthoven: Dutch National Research Program on Global Air Pollution and Climate Change, 1996.

ORELLANA AILLÓN, Lorgio. El proceso insurreccional de abril: estructuras materiales y superestructuras organizativas de los campesinos regantes en el Valle Central cochabambino. In: GIARRACCA, Norma; LEVY, Bettina. Ruralidades latinoamericanas: identidades y luchas sociales. Buenos Aires: CLACSO, 2004. p. 477-550. Disponível em:

<http://bibliotecavirtual.clacso.org.ar/ar/libros/ruralidad/Orellana.pdf>. Acesso em: 14 fev. 2008.

ORTEGO, Jesus. Factores determinantes del conflicto. Conflictos, Cochabamba, v. 3, no. 6, p. 14-19, 2000.

Ó'TUATHAIL, Gearoid. Critical geopolitics: the politics of writing global space. London: Routledge, 1996.

PAASI, Anssi. Region and place: regional identity in question. Progress in Human Geography, London, v. 27, no. 4, p. 475-485, 2003.

PACHECO, Mario Napoleón. Aguas del Illimani x SAMAPA de Abel Mamani. La Prensa, La Paz, marzo 3, 2005.

PARK, Robert E.; BURGESS, Ernest W. Introduction to the science of sociology. 2. ed. Chicago: The University of Chicago, 1924.

PASCAL, Blaise. Oevres completes. Paris: Hachette, 1887.

PEISER, Benny. From genocide to ecocide: the rape of Rapa Nui. Energy and Environment, Brentwood, v. 16, no. 3-4, p. 513-539, 2005. Disponível em: <http://www.staff.livjm.ac.uk/spsbpeis/EE\%2016-34_Peiser.pdf>. Acesso em: 18 jun. 2009.

PELUSO, Nancy Lee; WATTS, Michael. Violent environments. In: PELUSO, Nancy Lee; WATTS, Michael. (Ed.). Violent environments. Ithaca: Cornell University Press, 2001. p. 3-38.

PERCIVAL, Valerie; HOMER-DIXON, Thomas F. The case of South Africa. In: HOMER-DIXON, Thomas F.; BLITT, Jessica (Ed.). Ecoviolence: links among environment, population, and security. Lanham: Rowman \& Littlefield Publisher, 1998. p. 109-146. 
PEREDO BELTRÁN, Elizabeth. Las mujeres del Valle de Cochabamba: agua, privatización y conflicto. Berlin: Heinrich-Böll-Stiftung, 2004. (Global Issue Papers, no. 4). Disponível em:

<http://www.boell.de/downloads/internationalepolitik/GIP4_span.pdf>. Acesso em: 16 mar. 2009.

PEREIRA, Osny Duarte. Itaipu: prós e contras. Rio de Janeiro: Paz e Terra, 1974.

PERELMAN, Chaïm; OLBRECHTS-TYTECA, Lucie. Tratado de argumentação: a nova retórica. Tradução Maria Ermantina Galvão. 2. ed. São Paulo: Martins Fontes, 2005.

PERREAULT, Thomas. From the Guerra del Agua to the Guerra del Gas: resource governance, neoliberalism and popular protest in Bolivia. Antipode, Worcester, v. 38 , no. 1, p. 150-172, 2006.

PERROUX, François. L'économie du xxe siècle: ouvrages et articles. 3e. éd. augm. Grenoble: Presses Universitaires, 1991.

PFRIMER, Matheus; ROSEIRA, Antonio Marcos. Transformações territoriais na Bolívia: um novo triangulo estratégico? In: ENCONTRO LATINO AMERICANO DE GEÓGRAFOS, 12., 2009, Montevideo. Anais... Montevideo: Universidad de Montevideo, 2009. p. 1-15. Disponível em: $<$ http://egal2009.easyplanners.info/area01/1062_Hoffmann_Pfrimer_Matheus.doc>. Acesso em:

PIEROLA, Ramiro Rafael Rojas. Estado, territorialidades e etnias andinas: luta e pacto na construção da nação boliviana. 2006. 252 f. Tese (Doutorado em Planejamento Urbano e Regional)-Instituto de Pesquisa e Planejamento Urbano e Regional, Universidade Federal do Rio de Janeiro, Rio de Janeiro, 2006. Disponível em: <http://teses.ufrj.br/IPPUR_D/RamiroRafaelRojasPierola.pdf>. Acesso em: 21 jul. 2008.

PIRES DO RIO, Gisela A. Recursos hídricos e território: tensões e cooperação. In: ENCONTRO DA ASSOCIAÇÃO NACIONAL DE PESQUISA (ANPPAS), 3., 2006, Brasília. Anais... Brasilia: ANPPAS, 2006. p. 1-15. Disponível em: <http://www.anppas.org.br/encontro_anual/encontro3/GT13.html>. Acesso em: 17 mar. 2008.

PROGEO. Programa de Geografía. Mapas zona metropolitana Cochabamba. Cochabamba: Consejo Departamental de Competitividad, 2003. 1 CD-ROM. 
PRUDENCIO V. Augusto. Manejo integral del agua en el Valle de Cochabamba. Foro del agua de Cochabamba. Cochabamba: Asociación de Investigación y Desarrollo Andino-Amazónico, 1998. Disponível em: <http://www.condesan.org/memoria/CBBA0198.PDF>. Acesso em: 7 jun. 2009.

RAFFESTIN, Claude. Por uma geografia do poder. Tradução Maria Cecilia França. São Paulo: Ática, 1993.

RALEIGH, Clionadh; URDAL, Henrik. Climate change, environmental degradation and armed conflict. Political Geography, Oxford, v. 26, no. 6, p. 674-694, 2007.

RATZEL, Friedrich. Politische Geographie. 3. ed. Osnabrück: Otto Zeller Verlag, 1974.

RAVNBORG, Hellen Munk. From water "wars" to water "riots"? In: RAVNBORG, Hellen Munk (Org.). Water and conflict: conflict prevention and mitigation in water resources management. Copenhagen: Danish Institute for International Studies, 2004. p. $17-30$.

RAZONES de los campesinos. Opinión, Cochabamba, p. 7a, 7 abr 2000.

REALE, Giovanni, ANTISERI, Dario. História da filosofia. Do humanismo a Kant. v. II. 2. ed .São Paulo: Paulus, 1990.

RECLUS, Elisée. Du sentiment de la nature dans les sociétés modernes. Ecologie Politique: Science, Culture, Société, Paris, n. 5, p. 159-173, 1993.

REIGOTA, Marcos. Meio ambiente e representação social. 3. ed. São Paulo: Cortez, 1998.

RENNER, Michael. Fighting for survival. New York: W. W. Norton and Company, 1996.

REUBER, Paul. Raumbezogene politische Konflickte: geographische Konflicktforschung am Beispiel von Gemeindegebietsreformen. Stuttgart: Franz Steiner Verlag, 1999.

REX, John. Social conflict: a conceptual and theoretical analysis. London: Longman, 1981. 
REY, Alain. Le Robert micro. Dictionnaire de la langue française. Paris:

Dictionnaires Le Robert, 1998.

RIBEIRO, Wagner Costa. Meio ambiente: o natural e o produzido. Revista do Departamento de Geografia, São Paulo, n. 5, p. 29-32, 1991.

ROCHA, Maurício Santoro. A outra volta do bumerangue: estado, movimentos sociais e recursos naturais na Bolívia (1952-2006). In: ROCHA, Maurício Santoro; CÂMARA, Marcelo Argenta; SEGABINAZZI, Alessandro. Bolívia: de 1952 ao século XXI. Brasília: FUNAG/IPRI, 2006. p. 12-56.

RODRIGUES, Lysias Augusto. Geopolítica do Brasil. Rio de Janeiro: Biblioteca Militar, 1947.

ROSS, Michael. Oil, drugs, and diamonds. How do natural resources vary in their impact on civil war? In: BALLENTINE, Karen; SHERMAN, Jake. (Ed.). The political economy of armed conflict. Boulder: Lynne Rienner Publishers, 2003. p. 47-72. Disponível em: <http://www.sscnet.ucla.edu/polisci/faculty/ross/OilDrugs.pdf>. Acesso em: 12 maio 2008.

ROSS, Michael. What do we know about natural resources and civil war? Journal of Peace Research, London, v. 41, no. 3, p. 337-356, 2004. Disponível em: $<$ http://www.sscnet.ucla.edu/polisci/faculty/ross/whatdoweknow.pdf>. Acesso em: 24 ago. 2009.

SAAVEDRA, Carlos. Estimating spatial patterns of soil erosion and deposition in the Andean region using geo-information techniques: A case study in Cochabamba, Bolivia. 2005. 265 f. Tese (Doutorado)-Wageningen University, Enschede, 2005. Disponível em: <http://www.itc.nl/library/papers_2005/phd/saavedra.pdf>. Acesso em: 10 fev. 2008.

SACK, Robert D. Human territoriality: its theory and history. Cambridge: Cambridge University Press, 1986.

SALAZAR ORTUÑO, Fernando. El agua es vida, el agua es conflicto, el agua es poder. Disputa y conflicto por el acceso al agua en el Valle Central de Cochabamba. Cochabamba: [s.n.], 2000. Disponível em:

$<$ http://www.aguabolivia.org/comentarios/tema2/ciso.doc>. Acesso em: 15 mar. 2008.

SALAZAR ORTUÑO, Fernando. El Plan Dignidad y el militarismo en Bolivia. El caso del Trópico de Cochabamaba. In: SEOANE, José. Movimientos sociales y 
conflicto en América Latina. Buenos Aires: Consejo Latinoamericano de Ciencias Sociales, 2003. Disponível em:

<http://bibliotecavirtual.clacso.org.ar/ar/libros/osal/seoane/salazar.rtf>. Acesso em: 20 set. 2009.

SALAZAR ORTUÑO, Fernando. El rostro oculto del desarrollo alternativo: caso Trópico de Cochabamba - Bolivia, 1984-2002. Cochabamba: IESE, CLACSO, 2004. Disponível em: <http://168.96.200.17/ar/libros/bolivia/iese/salazar.pdf>. Acesso em: 19 out. 2009.

SANTILLI, Juliana. Socioambientalismo e novos direitos. Proteção juridica a diversidade biologicae cultura. São Paulo: Peirópolis, 2005.

SANTOS, Milton. A natureza do espaço: técnica e tempo, razão e emoção. 3. ed. São Paulo: Hucitec, 1999.

SANTOS, Milton. Da totalidade ao lugar. São Paulo: EDUSP, 2005.

SANTOS, Milton. Metamorfoses do espaço habitado. São Paulo: EDUSP, 2008.

SANTOS, Milton. Por uma geografia nova: da crítica da geografia a uma geografia crítica. 6. ed. São Paulo: EDUSP, 2004.

SARTRE, Jean Paul. Critique of dialectical reason: theory of practical ensembles. Tradução Alan Sheridan-Smith. London: Verso, 1976.

SCHAUBERGER, Viktor. Nature as teacher: new principles in the working of nature. Trandução Callum Coats.Dublin: Gateway Books, Gill \& Macmillan, 1998.

SCHEMENAUER, Robert S.; CERECEDA, Pilar. Fog collection's role in water planning for developing countries. Natural Resources Forum, New York, v. 18, no. 2, p. 91-100, 1994.

SCHILLING, Paulo R. O expansionismo brasileiro: a geopolítica do General Golbery e a diplomacia do Itamaraty. São Paulo: Global, 1981.

SCHNAIBERG, Alan. The environment: from surplus to scarcity. New York: Oxford University Press, 1987. Disponível em:

$<$ http://media.northwestern.edu/sociology/schnaiberg/1543029_environmentsociety/i ndex.html>. Acesso em: 24 jun. 2009. 
SCHULTZ, Bart; UHLENBROOK, Stefan. "Water security": what does it mean, what may it imply? In: UNESCO-IHE, Institute for Water Education. $\mathbf{5 0}$ years of wise water. Delft, 2007. p. 1-20. (Discussion Draft Paper for the session on Water Security). Disponível em: <http://www.unesco-

ihe.org/content/download/1011/11858/file/3.paper\%20water\%20Secur\%20Box\%20dr aft.pdf>. Acesso em: 9 jun. 2009.

SEABRA, Manoel F. G. Geografia(s)? Orientação, São Paulo, v. 5, p. 9-17, 1984.

SEMAPA. Plan maestro del Sistema de Abastecimiento de Agua Potable y Alcantarillado Sanitario para la ciudad de Cochabamba. Lineas maestras. Cochabamba, 2002.

SHULTZ, Jim. Bolivians win anti-privatization battle. NACLA Report on the Americas, New York, v. 33, n. 6, p. 44-47, 2000.

SILVA, Armando Corrêa da. As categorias como fundamentos do conhecimento geográfico. In: SANTOS, Milton; SOUZA, Maria Adélia de. (Coord.). O espaço interdisciplinar. São Paulo: Nobel, 1986. p. 25-37.

SILVA, Armando Corrêa da. Espaço fora do lugar. São Paulo: Hucitec, 1978.

SIMMEL, Georg. Conflict: conflict and the web of group affiliations. Glencoe: The Free Press, 1955.

SOLARES SERRANO, Humberto. Historia, espacio y sociedad: Cochabamba 1550-1950: formación, crisis y desarrollo de su proceso urbano. Cochabamba: CIDRE, 1990.

SOLDAL, Arild. The water war? Coca, structural adjustments and water in Cochabamba, Bolívia. Saarbrücken: Verlag Dr. Müller, 2008.

SOSSA, Erick V.; ONTIVEROS, Miguel. Diseño de una red hidrométrica para el Valle Central de Cochabamba. La Paz: Servicio Nacional de Meteorología e Hidrología, [2006?]. Disponível em:

<http://www.senamhi.gov.bo/meteorologia/publicaciones/resumen\%20Erick\%20Soss a.pdf> . Acesso em: 23 ago. 2009.

SOUZA, Marcelo José Lopes de. O território: sobre espaço e poder. Autonomia e desenvolvimento. In: CASTRO, Iná Elias de; GOMES, Paulo Cesar da Costa; CORREAA, Roberto Lobato. Geografia: conceitos e temas. 7. ed. Rio de Janeiro: Bertrand Brasil, 2005. p. 77-116. 
SOUZA, Marcelo Lopes de. "Território" da divergência (e da confusão): em torno das imprecisas fronteiras de um conceito fundamental. In: SAQUET, Marcos Aurélio; SPOSITO, Eliseu Savério. Território e territorialidades: teorias, processos e conflitos. São Paulo: Expressão Popular, 2009. p. 57-72.

SOYSA, Indra de. Paradise is a bazaar? Greed, creed, and governance in civil war, 1989-99. Journal of Peace Research, Oslo, v. 39, no. 4, p. 395-416, 2002.

SOYSA, Indra de; GLEDITSCH, Peter Nils. To cultivate peace: agriculture in a world of conflict. Oslo: International Peace Research Institute, 1999. (Prio Report 1/99). Disponível em: <http://www.isn.ethz.ch/isn/DigitalLibrary/Publications/Detail/?ord655=grp2\&ots591=0C54E3B3-1E9C-BE1E-2C24A6A8C7060233\&Ing=en\&id=37962 > . Acesso em: 15 maio 2009.

SOYSA, Indra de; WAGNER, Angelika. Global market, local mayhem? Foreign investment, trade openness, state capacity, and civil war, 1989-2000. In: ECPR. European Consortium for Political Research Sessions. Colchester, 2003. (Paper presented at the European Consortium for Political Research Sessions in Edinburgh).

STARR, Joyce R. Water wars. Foreign Policy, Washington, DC, no. 82, p. 17-36, 1991. Disponível em: <http://www.ciesin.org/docs/006-304/006-304.html>. Acesso em: 31 jul. 2009.

STOEHR, Jacob. Searching for truth and water: deconstructing Cochabamba's "water war". Lexington: Washington and Lee University, 2004. (Student's paper). Disponível em: <http://shepherd.wlu.edu/pdf/stoher423.pdf>. Acesso em: 9 set. 2008.

SUVELZA, Franz Xavier Barrios. El estado triterritorial. Una nueva descentralización para Bolivia. La Paz: FES-ILDIS, Plural Editores, 2002. Disponível em: <http://www.constituyentesoberana.org/3/docsanal/refconst/estado-tri-territorialsuvelza.pdf >. Acesso em: 12 jun. 2008.

TAINTER, Joseph A. Complexity, problem solving, and sustainable societies. In: COSTANZA, Robert; SEGURA, Olman; MARTINEZ-ALIER, Juan. (Ed.). Getting down to earth: practical applications of ecological economics. Washington, DC:Island Press, 1996. p. 61-76. Disponível em: <http://dieoff.org/page134.htm>. Acesso em: 30 jul. 2009.

TAINTER, Joseph A. The collapse of complex societies. New York: Cambridge University Press, 1988. 
TAPIA, Luis. La crisis política de Abril. Revista Del Observatorio Social de America Latina, Buenos Aires, v. 2, no. 9, p. 3-6, 2000. Disponível em: $<$ http://bibliotecavirtual.clacso.org.ar/ar/libros/osal/osal2/bolivia.pdf>. Acesso em: 11 ago. 2008.

THIELE, Rainer. The social impact of structural adjustment in Bolivia. Journal of International Development, Chichester, v. 15, no. 3, p. 299-319, 2003. Disponível em: <http://www.iisec.ucb.edu.bo/seminars/seminars2002/prspseminar/pwp08.pdf>. Acesso em: 23 jan. 2009.

THIENGO, Silvana C.; SANTOS, Sônia B.; FERNANDEZ, Monica A. Malacofauna límnica da área de influência do lago da usina hidrelétrica de Serra da Mesa, Goiás, Brasil. I. Estudo qualitativo. Revista Brasileira de Zoologia, Curitiba, v. 22, n. 4, p. 867-874, 2005.

TICONA, Esteban. La rebelión aymara y popular de octubre de 2003. Uma aproximación desde algunos barrios paceños de La Paz, Bolivia. In: DÁVALOS, Pablo (Org.). Pueblos indígenas, estado y democracia. 1. ed. Buenos Aires: CLACSO, 2005. p. 185-196.

TOMASONI, M. A.; TOMASONI, S. M. R. P. Ecologia, ética e ambientalismo: prefácio de suas ambigüidades. Revista da FAEEBA: Educação e Contemporaneidade, Salvador, v. 11, n. 18, p. 303-316, 2002.

TOSET, Hans Peter Wollebaek; GLEDISTCH, Nils Peter; HEGRE, Håvard. Shared rivers and interstate conflict. Political Geography, Oxford, v. 19, no. 8, p. 971-996, 2000.

TOSI, Jorge Luis. Geopolítica fluvial argentina. Buenos Aires: Ciudad Argentina, 1999.

TOURAINE, Alain. Os novos conflitos sociais. Para evitar mal-entendidos. Lua Nova, São Paulo, n. 17, p. 5-18, 1989.

TRAVASSOS, Mário. Projeção continental do Brasil. São Paulo: Companhia Editora Nacional, 1935.

TROLL, Carl. Geo-ecology of the mountainous regions of the Tropical Americas. Bonn: Dummler, 1968. 
TURTON, Anthony. Hydropolitics: the concept and its limitation. In: TURTON, Anthony; HENWOOD, Roland. (Ed.). Hydropolitics in the developing world. a Southern African perspective. Pretoria: African Water Issues Research Unit, 2002. p. 13-22.

TURTON, Anthony. Water wars: enduring myth or impending reality? In: SOLOMON, Hussein; TURTON, Anthony (Ed.). Water wars: enduring myth or impending reality? Pretoria: The African Centre for the Constructive Resolution of Disputes (ACCORD), 2000. p. 165-175. (Africa Dialogue Monograph Series, no. 2).

UITTO, Juha I.; WOLF, Aaron T. Water wars? Geographical perspectives: introduction. The Geographical Journal, London, v. 168, no. 4, p. 289-292, 2002.

UN-HABITAT. United Nations Human Settlements Programme. Water and sanitation in the world's cities: local action for global goals. London: Earthscan, 2003.

URQUIDI, Vivian Grace Fernández-Dávila. Heterogeneidade temporal e diversidade cultural: o movimento cocalero na Bolívia. 2001. 212 f. Tese (Doutorado em Sociologia)-Faculdade de Filosofia, Letras e Ciências Humanas, Universidade de São Paulo, São Paulo, 2001.

USEPA. U.S. ENVIRONMENTAL PROTECTION AGENCY. A water security handbook: planning for and responding to drinking water contamination threats and incidents. Washington, DC: Office of Ground Water and Drinking Water, 2006. (EPA Publication, no. 817-B-06-001). Disponível em:

$<$ http://www.epa.gov/safewater/watersecurity/pubs/water_security_handbook_rptb.pd $\mathrm{f}>$. Acesso em: 12 jun. 2008.

VARGAS, Monica. Integración de la Infraestructura Regional Sudamericana (IIRSA). Proyectos en Bolivia. In: Foro Boliviano sobre Medio Ambiente y Desarrollo (FOBOMADE). Geopolítica de los recursos naturales y acuerdos comerciales en Sudamerica. La Paz, 2005. p. 71-79. Disponível em: <observatorio.ddhh.bo.googlepages.com/FOBOMADEIIRSABolivia.pdf>. Acesso em: 11 set. 2008.

VEIGA, José Eli da. A emergência socioambiental. São Paulo: Senac, 2007.

VESENTINI, José William. A capital da geopolítica. 4. ed. São Paulo: Ática, 1996.

VIEHWEG, Theodor. Tópica e jurisprudência. Tradução Tércio Sampaio Ferraz Júnior. Brasília, DF: Departamento de Imprensa Nacional, 1979. 
VILA, Rafael Antonio Duarte. A Antártida no sistema internacional: análise das relações entre atores estatais e não-estatais com base na perspectiva da questão ambiental. São Paulo: Editora Hucitec, 2004.

VILAS, Carlos M. Lynchings and political conflict in the Andes. Latin American Perspectives, Newbury Park, v. 35, no. 5, p. 103-118, 2008.

VILLEGAS, Carlos Quiroga. Explotación de los recursos hidrocarburíferos en Bolivia. Problemas y Perspectivas. In: Foro Boliviano sobre Medio Ambiente y Desarrollo (FOBOMADE). Geopolítica de los recursos naturales y acuerdos comerciales en Sudamerica. La Paz, 2005. p. 133-140.

WCED. WORLD COMMISSION ON ENVIRONMENT AND DEVELOPMENT. Our common future: the World Commission on Environment and Development. Oslo, 1987.

WEBER, Max. Max Weber im Kontext: Gesammelte Schriften, Aufsaetze und Vortraege. Berlin: InfoSoftWare - Verlag, Vertrieb \& Entwicklung von CD-ROMAnwendungen, 1999.

WENDT, Alexander. Social theory of international politics. Cambridge: Cambridge University Press, 2006.

WESTING, Arthur (Ed.). Environmental warfare: a technical, legal and policy appraisal. London: Taylor and Francis, 1984.

WESTING, Arthur H. Global resources and international conflict: environmental factors in strategic policy and action. Oxford: Oxford University Press, 1986.

WHITEHEAD, Alfred North. The concept of nature. Cambridge: Cambridge University Press, 1920.

WHITTLESEY, Derwent. The earth and the state. New York: Henry Holt Company, 1944.

WITTFOGEL, Karl. Despotismo oriental. Un estudio comparativo del poder totalitario. Tradução Francisco Presedo. Madrid: Guadarrama, 1966. 
WOLF, Aaron T.; KRAMER, Annika; CARIUS, Alexander; DABELKO, Geoffrey D. Managing water conflict and cooperation. In: THE WORLDWATCH INSTITUTE. State of the world 2005: redefining global security. Washington, DC, 2005. p. 8095.

WOLF, Aaron T. The Transboundary Freshwater Dispute Database Project. IWRA, Water International, Johannesburg, v. 24, no. 2, p. 160-163, 1999a.

WOLF, Aaron T. Water wars and water reality: conflict and cooperation along international waterways. In: LONERGAN, Steve C. Environmental change, adaptation and human security. Dordrecht: Kluwer Academic, 1999b. p. 251-165.

WOLPERT, Julian. Departures from the usual environment in locational analysis. Annals of the Association of American Geographers, Washington, DC, v. 50, no. 2, p. 220-229, 1970.

WUTICH, Amber Yoder. The effects of urban water scarcity on sociability and in reciprocity in Cochabamba, Bolivia. 2006. 249 f. Tese (Doutorado em Filosofia)University of Florida, Gainesville, 2006. Disponível em: <http://etd.fcla.edu/UF/UFE0013898/wutich_a.pdf>. Acesso em: 14 out. 2008.

YANG, Hong; ZEHNDER, Alexander. "Virtual water": an unfolding concept in integrated water resources management. Water Resources Research, St. Louis, v. 43, p. 1-10, 2007.

ZIMMER, Daniel; RENAULT, Daniel. Virtual water in food production and global trade: review of methodological issues and preliminary results. In: HOEKSTRA, Arjen Y. (Ed.). Virtual water trade. Proceedings of the international expert meeting on virtual water trade. Delft: UNESCO-IHE, Institute for Water Education, 2003. p. 93107. (Value of Water Research Report Series no. 12). Disponível em: <http://www.waterfootprint.org/Reports/Report12.pdf>. Acesso em: 26 mar. 2009.

ZIMMERER, Karl S. Rescaling irrigation in Latin America: the cultural images and political ecology of water resources. Cultural Geographies, London, v. 7, no. 2, p. 150-175, 2000.

ZONDAG, Cornelius Henry. The Bolivian economy 1952-1965. The revolution and its aftermath. New York: Frederick A. Praeger, 1966.

ZUNES, Stephen. United States and Bolivia. The taming of a revolution, 1952-1957. Latin American Perspectives, Newbury Park, v. 28, no. 5, p. 33-49, 2001. 
APÊNDICES 


\section{APÊNDICE A Questionário aplicado aos membros da Coordinadora del Agua QUESTIONÁRIO \\ SEXO: $M() \quad F() \quad$ EDAD: AÑOS \\ TIEMPO QUE VIVE EN COCHABAMBA: AÑOS}

1. ¿Cómo cree que es el agua que consume?
a) Puro
b) limpio
c) contaminado
d) sucio
e) no sabe

2. ¿Qué cantidad de agua cree que Ud. utiliza en un mes
a) 1-100 Lts.
b) $100-1000$ Lts.
c) más de 1000 Lts.
d) no sabe

3. ¿Cree Ud. que la población aumentó en los últimos 10 años

$\begin{array}{lll}\text { a) } \mathrm{SI} & \text { b) } \mathrm{NO}\end{array}$ ¿ por que?

R: SI a) Por la relocalización minera c) crisis naturales en las zonas rurales

b) aumento de la tasa de natalidad

d) desarrollo industrial urbano

4. El crecimiento demográfico en Cochabamba ocasionó:

$\begin{array}{lll}\text { a) crecimiento económico } & \text { b)escasez de servicios } & \text { c) desempleo y pobreza }\end{array}$

5. ¿Cree Ud. que hay mala distribución de los recursos naturales en Cochabamba $i$
a) $\mathrm{SI}$
b) No
c) No sabe

6. ¿Quienes cree según Ud. son los más favorecidos con los recursos naturales:
a) los campesinos
b) los ricos
c) los hab. Del centro
d) las industrias

7. ¿Cuales serán las causas según Ud. de la escasez del agua en Cochabamba:
a) sequías naturales
b) crecimiento poblacional
c) mal uso
d) falta de políticas públicas
e) falta de inversiones extranjeras

8. ¿Cual es la fuente de donde UD. consume el agua:
a) Red de SEMAPA
b) Pozo privado
c) Pozo zonal
d) compra

9. ¿En abril de 2000 "la guerra del agua", Ud. participó porque:
a) le obligaron
b) creyó que era justo
c) no participó

10. En abril del 2000 "la guerra del agua", Ud. participó reclamando:
a) expulsión de "Aguas del Tund) ari"
b) el aumento de agua para su consumo
c) nuevas políticas de aguas
d) que se culmine el proyecto MISICUNI 


\section{APÊNDICE B Legendas das siglas na tabela que se segue com os resultados do questionário}

Sex $=$ Sexo $(1=$ Homem; 2 = Mulher $)$

Ida $=$ Idade em anos

Tem $=$ Tempo que vive em Cochabamba (em anos)

Agua $=$ sua opinião sobre a qualidade da água consumida (questão 1 )

Quant $=$ quantidade da água utilizada por mês (questão 2)

AumPop $=$ Acredita no aumento populacional nos últimios 10 anos. (questão 3-

primeira parte)

PorQ = Motivos para o aumento populacional, caso a resposta à questão 3- primeira parte tenha sido afirmativa

CrescDem $=$ Consequencias do crescimento demográfico em Cochabamba (questão 4)

Hamaldis = Crença na má distribuição dos recursos naturais em Cochabamba (questão 5)

Masfavor = Quem são os mais favorecidos com os recursos naturais (questão 6)

Causequi = Causas da escassez de água em Cochabamba (questão 7)

Fonteagua $=$ Qual é a fonte da água que consome (questão 8)

Partic $=$ Motivos da sua participação na Gerra da Água em 2000 (questão 9)

Recla $=$ Quais foram suas reinvindicações na Gerra da água em 2000 (questão 10) 


\section{APÊNDICE C Resultados obtidos após aplicação do questionário}

A Tabela abaixo ilustra os resultados obtidos através das respostas dos questionários:

\begin{tabular}{|c|c|c|c|c|c|c|c|c|c|c|c|c|c|}
\hline Sex & Ida & Tem & Água & Quant & AumPop & PorQ & CrescDem & Hamaldis & Masfavor & Causequi & Fonteagua & Partic & Reclam \\
\hline 1 & 60 & 60 & 2 & 2 & 1 & 3 & 3 & 2 & 2 & 1 & 3 & 3 & 1 \\
\hline 1 & 45 & 45 & 2 & 2 & 1 & 3 & 3 & 1 & 2 & 2 & 3 & 1 & 3 \\
\hline 2 & 19 & 19 & 2 & 2 & 1 & 2 & 3 & 1 & 2 & 1 & 3 & 2 & 1 \\
\hline 1 & 14 & 14 & 2 & 1 & 1 & 3 & 3 & 1 & 1 & 3 & 3 & 3 & 3 \\
\hline 2 & 21 & 12 & 3 & 3 & 1 & 3 & 3 & 1 & 4 & 4 & 3 & 3 & \\
\hline 1 & 76 & 16 & 4 & 4 & 2 & & & 3 & 3 & 5 & 3 & 3 & \\
\hline 1 & 24 & 20 & 4 & 3 & 1 & 2 & 2 & 2 & 1 & 3 & 3 & 2 & 1 \\
\hline 2 & 26 & 12 & 3 & 4 & 1 & 3 & 3 & 1 & 1 & 3 & 3 & 2 & 1 \\
\hline 2 & 74 & 13 & 3 & 4 & 2 & & 2 & 1 & 3 & 1 & 3 & 3 & \\
\hline 2 & 51 & 20 & 2 & 4 & 1 & 3 & 2 & 1 & 2 & 3 & 1 & 2 & 4 \\
\hline 2 & 18 & 18 & 2 & 2 & 1 & 2 & 3 & 1 & 1 & 3 & 3 & 3 & 1 \\
\hline 2 & 29 & 17 & 2 & 3 & 1 & 1 & 3 & 1 & 3 & 2 & 1 & 3 & \\
\hline \multirow[t]{2}{*}{2} & 39 & 24 & 2 & 3 & 1 & 2 & 2 & 3 & 2 & 2 & 1 & 3 & 4 \\
\hline & & & 2 & 1 & 1 & 1 & 3 & 1 & 2 & 2 & 1 & 2 & 1 \\
\hline 1 & 26 & 5 & 3 & 4 & 1 & 1 & 2 & 1 & 3 & 4 & 1 & 3 & \\
\hline 2 & 42 & 5 & 4 & 4 & 1 & 1 & 2 & 1 & 2 & 3 & 1 & 2 & 1 \\
\hline 2 & 50 & & 5 & 4 & 1 & 1 & 2 & 1 & 2 & 4 & 1 & 2 & 1 \\
\hline 2 & 30 & 30 & 1 & 3 & 1 & 1 & 1 & 1 & 2 & 4 & 3 & 2 & 1 \\
\hline 1 & 25 & 25 & 3 & 3 & 1 & 1 & 1 & 1 & 3 & 2 & 3 & 2 & 1 \\
\hline 1 & 32 & 18 & 5 & 1 & 1 & 2 & 3 & 1 & 4 & 1 & 3 & 2 & 3 \\
\hline 2 & 20 & 20 & 3 & 4 & 1 & 2 & 3 & 1 & 3 & 3 & 3 & 2 & 3 \\
\hline 1 & 23 & 23 & 3 & 4 & 1 & 1 & 2 & 1 & 3 & 3 & 3 & 2 & 1 \\
\hline 2 & 25 & 25 & 2 & 2 & 1 & & 2 & 1 & 3 & 4 & 3 & 2 & 1 \\
\hline 1 & 27 & 27 & 2 & 1 & 1 & 1 & 3 & 1 & 2 & 2 & 3 & 2 & 1 \\
\hline 1 & 20 & 20 & 2 & 2 & 1 & 2 & 2 & 1 & 4 & 3 & 3 & 3 & , \\
\hline 1 & 28 & 20 & 3 & 2 & 1 & 3 & 3 & 1 & 2 & 5 & 3 & 2 & 1 \\
\hline 2 & 29 & 4 & 3 & 2 & 1 & 3 & 2 & 1 & 2 & 4 & 3 & 1 & 1 \\
\hline 1 & 24 & 20 & 4 & 2 & 1 & 2 & 3 & 1 & 3 & 3 & 3 & 2 & 1 \\
\hline 2 & 40 & 40 & 2 & 3 & 1 & 3 & 3 & 1 & 4 & 5 & 3 & 2 & 3 \\
\hline 2 & 18 & 18 & 3 & 1 & 1 & 2 & 3 & 1 & 2 & 3 & 3 & 3 & 1 \\
\hline 2 & 26 & 26 & 2 & 1 & 1 & 1 & 2 & 1 & 3 & 2 & 3 & 2 & 1 \\
\hline \multirow[t]{2}{*}{2} & 47 & 47 & 1 & 2 & 1 & 3 & 3 & 1 & 3 & 1 & 3 & 2 & 1 \\
\hline & 25 & 25 & 2 & 2 & 1 & 1 & 2 & 1 & 4 & 1 & 3 & 2 & 1 \\
\hline 2 & 60 & 53 & 1 & 2 & 1 & 2 & 1 & 1 & 2 & 4 & 3 & 2 & 4 \\
\hline 2 & 30 & 30 & 2 & 2 & 1 & 3 & 3 & 1 & 2 & 1 & 2 & 2 & 1 \\
\hline 1 & 27 & 27 & 1 & 2 & 1 & 2 & 1 & 1 & 2 & 4 & 1 & 2 & 1 \\
\hline 1 & 29 & 29 & 2 & 2 & 1 & 1 & 3 & 1 & 2 & 3 & 1 & 2 & 1 \\
\hline 1 & 27 & 27 & 1 & 2 & 1 & 3 & 3 & 1 & 2 & 3 & 1 & 2 & 1 \\
\hline 1 & 28 & 28 & 3 & 3 & 1 & 1 & 3 & 1 & 2 & 1 & 1 & 2 & 1 \\
\hline 1 & 42 & 42 & 1 & 2 & 1 & 2 & 3 & 1 & 2 & 2 & 1 & 2 & 1 \\
\hline 1 & 23 & 22 & 5 & 4 & 1 & & 3 & 3 & 1 & 3 & 1 & 2 & 1 \\
\hline 1 & 23 & 6 & 5 & 4 & 1 & & 3 & 3 & 2 & 3 & 1 & 2 & 1 \\
\hline 1 & 30 & 30 & 5 & 4 & 1 & 4 & 1 & 1 & 4 & 4 & 1 & 2 & 1 \\
\hline 2 & 15 & 6 & 5 & 1 & 1 & 3 & 3 & 1 & 2 & 3 & 1 & 3 & 4 \\
\hline 1 & 23 & 23 & 1 & 4 & 1 & 2 & 2 & 1 & 2 & 3 & 1 & 2 & 1 \\
\hline \multirow[t]{2}{*}{1} & 29 & 29 & 1 & 4 & 1 & 2 & 2 & 1 & 2 & 3 & 1 & 2 & 1 \\
\hline & 24 & 24 & 2 & 1 & 1 & 2 & 3 & 1 & 2 & 3 & 1 & 2 & 1 \\
\hline
\end{tabular}




\section{Resultados obtidos após aplicação do questionário:}

Questão 1: Sua opinião sobre a qualidade da água consumida $54,1 \%$ - pura ou limpa

$29,5 \%$ - contaminada ou suja

$16,39 \%$ - não sabe

Questão 2 - Sobre a quantidade da água utilizada por mês

$57,7 \%$ - menos de $1000 \mathrm{~L} / \mathrm{mês}$

16,39 - mais de $1000 \mathrm{~L} / \mathrm{mês}$

$26,22 \%$ - não sabe

Questão 3: Se acredita no aumento populacional nos últimios 10 anos

$96,72 \%-\operatorname{Sim}$ $3,27 \%$ - Não

Por quê?

6 pessoas não responderam

$27,86 \%$ - pela relocalização mineira

$27,86 \%$ - pelo aumento da taxa de natalidade

$31,14 \%$ - crise natural ocorrida na zona rural

$3,27 \%$ - desenvolvimento industrial urbano

Questão 4: Sobre as consequencias do crescimento demográfico em Cochabamba $8,2 \%$ - crescimento econômico

$26,2 \%$ - escassez de serviços

$62,29 \%$ - desemprego e pobreza

Questão 5: Se acredita que há má distribuição dos recursos naturais em

Cochabamba

88,52\% - Sim

$26,22 \%-$ Não

$6,55 \%$ - Nao sabe

Questão 6: Quem são os mais favorecidos com os recursos naturais 
$8,19 \%$ - os camponeses

$55,73 \%$ - os ricos

$21,31 \%$ - os moradores do centro da cidade

$14,75 \%$ - as indústrias

Questão 7: Causas da escassez de água em Cochabamba

$18,03 \%$ - secas naturais

$21,31 \%$ - crescimento populacional

$36,06 \%$ - mal uso

$18,03 \%$ - falta de políticas públicas

$6,57 \%$ - falta de investimentos estrangeiros

Questão 8: Qual é a fonte da água que consome $45,9 \%$ - rede da SEMAPA

$4,91 \%$ - poço particular

$45,99 \%$ - poço regional

$3,27 \%$ - compra a água

Questão 9: Motivos da sua participação na Gerra da Água em 2000

$1,63 \%$ - não respondeu

$3,27 \%$ - por obrigação

$75,71 \%$ - por acreditar que era justo

19,67\% - não participou

Questão 10:Quais foram suas reinvindicações na Gerra da água em 2000

$11,47 \%$ - não responderam

$68,85 \%$ - a expulsão da empresa Águas del Tunari

$1,63 \%$ - aumento de água para seu consumo

$9,83 \%$ - novas políticas sobre a água

$6,55 \%$ - a conclusão do projeto MISICUNI 


\section{APÊNDICE D DVD - "La Guerra del Agua" na Bolívia}

